Universidad de Valladolid

Facultad de Filosofía y Letras

Departamento de Historia Moderna, Contemporánea y de América

Curso 1991-92

\title{
Católicos, política e información. \\ Diario Regional de Valladolid, \\ 1931-1980
}

Memoria para la obtención del grado de Doctor en Historia que presenta 
Para la defensa de los intereses católicos

Dirigida por el Doctor D. CELSO ALMUIÑA FERNÁNDEZ 
A mis padres 



\section{Índice}

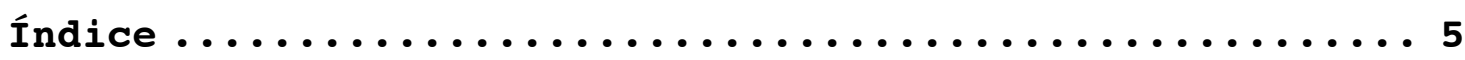

Agradecimientos ........................... 13

Introducción $\ldots \ldots \ldots \ldots \ldots \ldots \ldots \ldots \ldots \ldots \ldots \ldots \ldots \ldots \ldots \ldots \ldots \ldots \ldots \ldots$

Para la defensa de los intereses católicos .......... 33

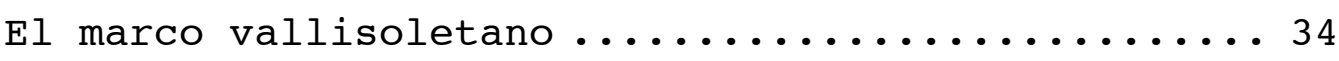

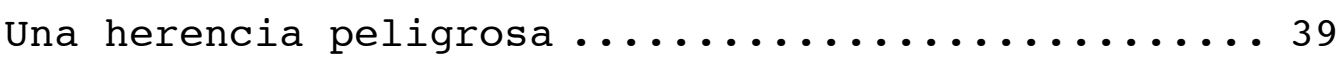

El apellido "católica" .................. 42

Prensa de masas y prensa de opinión ........4 46

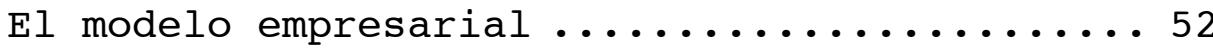

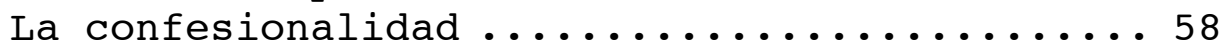

"Diario Regional, S.A.".................6 60

La Segunda República: periodismo de combate ........ 65

Un diario moribundo ................. 66

La vieja política ha muerto: iViva el Rey! ...... 72

La derecha que nunca existió ............ 78

Monarquía hoy, República mañana ............ 83

"Derecha Regional" ................... 83

El fracaso de una modernización política .... 90

Veintitrés mil votos para un periódico ...... 103

Entre victorias y revoluciones ............... 108

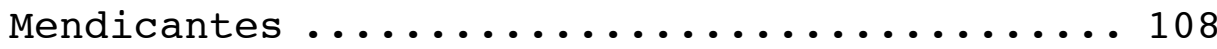

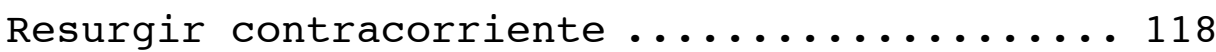

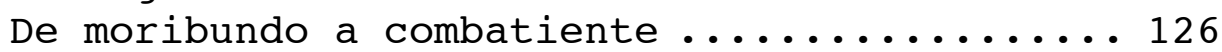

Lo que a todo católico importa saber

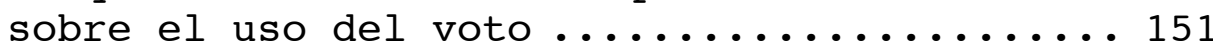

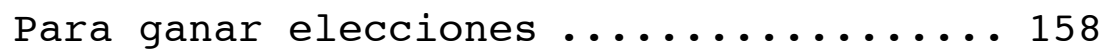

o reforma social, o revolución .......... 168

Fascistas, no; pero antifascistas,

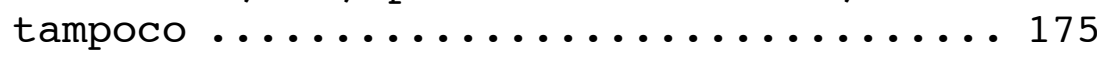

La modernización periodística ............. 184

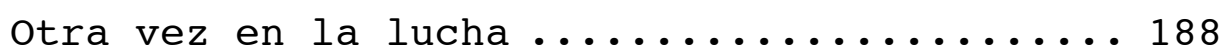


La guerra: sin Madrid y con fanatismo........... 203

Tristes días de entusiasmo...............204

El movimiento se demuestra muriendo....... 209

Provincias sin prensa de Madrid............ 216

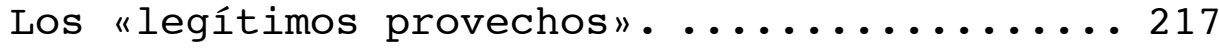

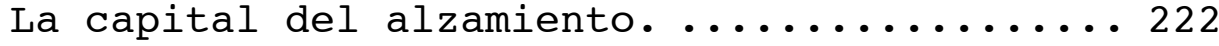

La nueva política muere por el

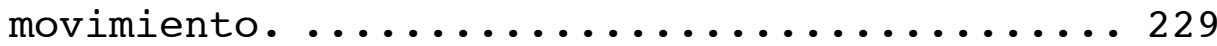

También la prensa liberal debe morir...... 238

Los años de "La Editorial Católica": redactores

líricos, fervor católico, y consignas............ 257

No toda la prensa española es católica ........ 258

Diario episcopal ..................... 272

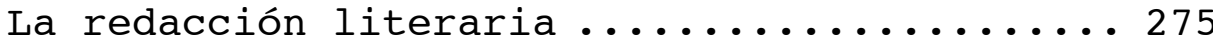

Portavoz oficioso de la jerarquía......... 292

Con Roma, pasando por Madrid ......... 294

En la Ciudad de la Gran Promesa ....... 299

Con permiso de la autoridad .............. 316

La destitución nonnata de Martín Abril ..... 317

Una tapadera de la oposición monárquica .... 320

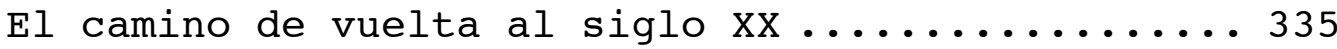

Periodismo es información, y "católico" sustantivo.... 343

Modernización empresarial, rumores, y el Opus

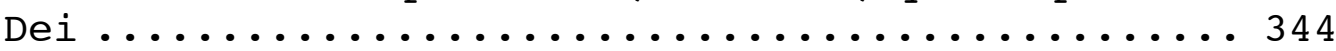

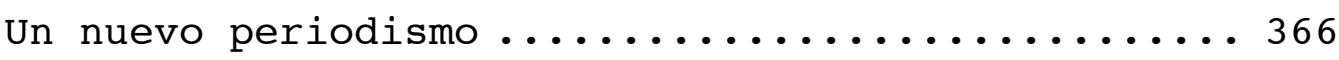

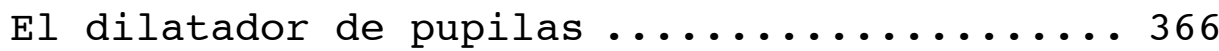

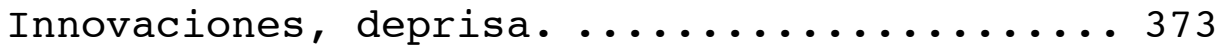

El nuevo periodismo no gusta a las

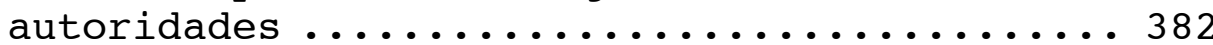

Las opiniones de Fernández Areal......... 392

Del "control rutinario" al Consejo de

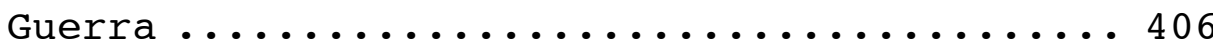

Un trabajador de la prensa ............441 
La sustantivación del catolicismo ...........4455

Debilitamiento, enajenación, y muerte de un diario.... 487

Siglas para una crisis: de "S.A.R.P.E." a "P.E.S.A.", y de "P.E.S.A." a "CINISA"........4 488

Periodismo débil y vista a la izquierda....... 510 La turbulenta y corta vida

$\mathrm{d}$ e 1 Independiente castellano.........5543

Con El Imparcial y contra todos............. 558

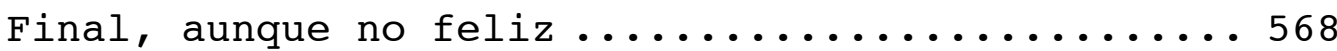

Conclusiones.......................... 575

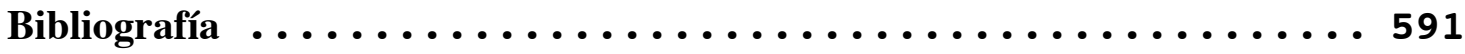

Obras de referencia: ................. 592

La prensa: .......................606

Los católicos y la política: ..............6623

Los católicos y la prensa: ...............6628

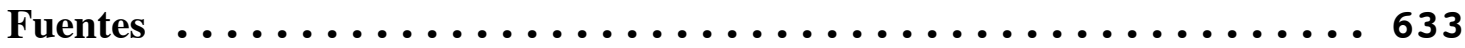

1. Escritas. Archivos y hemerotecas consultados: .........................6 634

2. Orales. entrevistas realizadas y contestaciones a cuestionarios : .............6 635

Apéndices ............................ 639

Apéndice 1.- Ficha descriptiva de Diario

Regional...........................6 640

Título, subtítulo y lemas .............6 640

Datación .........................6640

Suspensiones .......................6 649

Colección .......................... 650

Sede social: administración, redacción y

lugar de impresión. .................6651

Formato y características técnicas ........6 652

Impresor ...................... 658

Sistema de impresión ................. 658

Zonas de difusión .....................660 
Apéndice 2.- Estructura informativa.

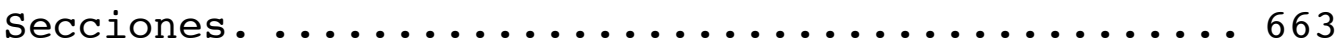

En 1931, con Oscar Pérez Solís y Rafael

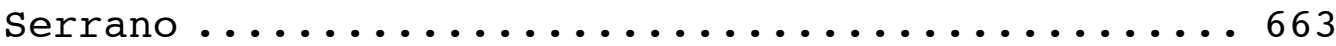

Con Felipe Salazar Urrizola (renovación 1931-

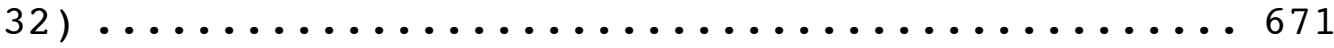

Con Ignacio Valverde (agosto de 1935) .........6679

A partir de 19 de julio de $1936 \ldots \ldots \ldots \ldots . \ldots . \ldots 64$

Con Francisco Javier Martín Abril (desde

marzo de 1939) ........................6 691

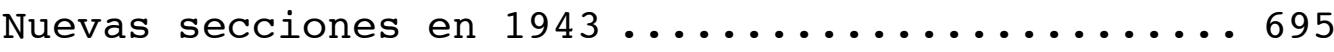

A partir del cambio de formato en noviembre

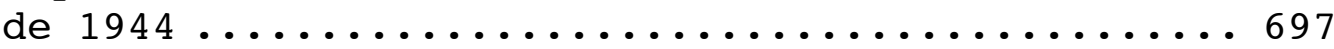

Con Manuel Santaella como subdirector(1949) .....700

Primeros cambios a partir de mayo de 1955 con

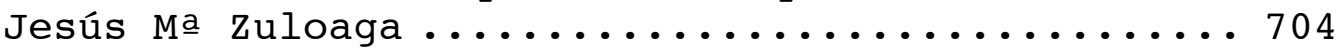

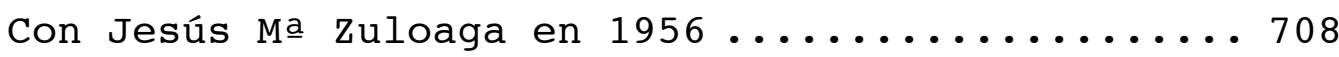

Esquema básico de la estructura informativa

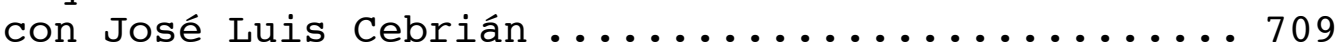

Con Manuel Fernández Areal (1959) ........... 712

Con José Tallón García(1965) .............. 717

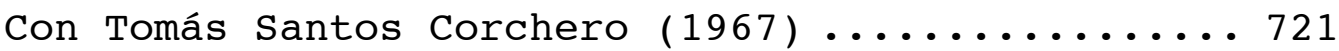

Durante la interinidad de Fernando de la

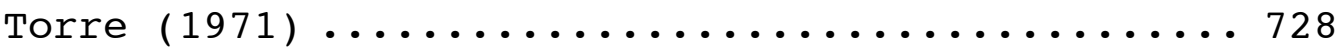

Con Esteban Greciet Aller (1972) ........... 730

Con Ignacio Bel Mallén (1974) .............. 734

Con Pedro Muñoz García (1977) .............. 738

Con Ma Aurora Viloria Nieto (1978) ........... 741

Apéndice 3.- Ficha analítica. La empresa

periodística "Diario Regional, S.A.".......... 744

Aspectos jurídicos ................. 744

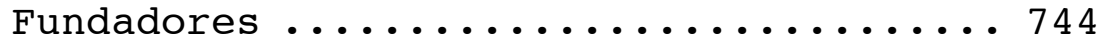

Estatutos fundacionales de "Diario

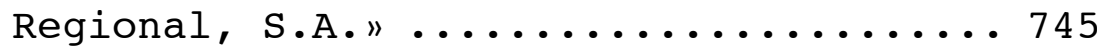

Propiedad, capital social y accionistas.... 762

En el momento de la fundación: ........762

"La Editorial Católica, S.A."

accionista mayoritario en 1941:.......765

Ampliación de capital en febrero de

1943 ...................... 766

Ampliación de capital de diciembre 


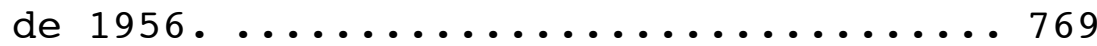

Ampliación de capital de 10 de

abril de 1965. S.A.R.P.E.

accionista mayoritario............ 781

Venta de S.A.R.P.E. a P.E.S.A.: 31

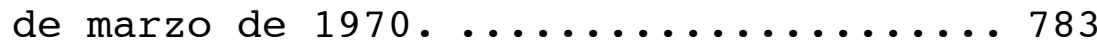

Venta de P.E.S.A. a CINISA: 31 de

mayo de $1971 \ldots \ldots \ldots \ldots \ldots \ldots \ldots . \ldots \ldots$

Reducción y ampliación de capital

de 9 de junio de 1972............. 784

Ampliación de capital de 19 de

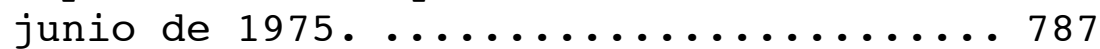

Venta de CINISA a Jerónimo Gallego

y Manuel Casado en julio de 1977 y

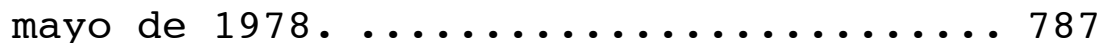

Venta de "Diario Regional, S.A." al

grupo de El Imparcial en noviembre

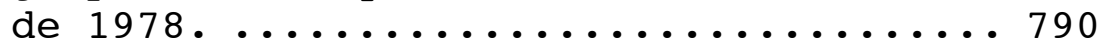

Venta de "Diario Regional, S.A." a

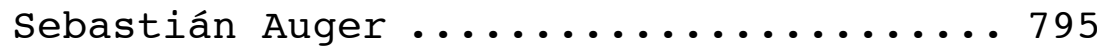

Consejos de Administración ............. 797

Primer consejo y presidentes del

mismo entre 1926 y 1943 ........... 797

Presidencias de Germán Adánez

194242-43 y Juan Misol 1943-45 .......799

Presidencia de Francisco de Luis

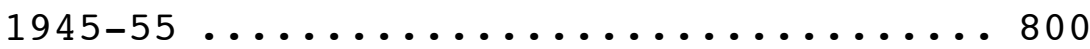

Presidencia de Víctor Jolín

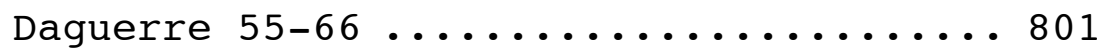

Consejo de administración en

diciembre de $1958 \ldots \ldots \ldots \ldots . \ldots . \ldots 82$

Consejo de administración en 1960 .... 802

Consejo de administración en

octubre de $1964 \ldots \ldots \ldots \ldots . \ldots . \ldots 3$

Consejo de administración en abril

de $1965 \ldots \ldots \ldots \ldots \ldots . \ldots . \ldots . \ldots 4$

Consejo de administración en marzo

de $1966 \ldots \ldots \ldots \ldots \ldots \ldots . \ldots . \ldots . \ldots 5$

Consejo de administración en agosto

de $1966 \ldots \ldots \ldots \ldots \ldots \ldots \ldots . \ldots . \ldots . \ldots 6$

Consejo de administración en marzo

de $1967 \ldots \ldots \ldots \ldots \ldots \ldots \ldots . \ldots . \ldots 8$

Consejo de administración en junio

de 1969. Presidencia de Francisco

Pérez de Los Cobos ................ 810

Consejo de administración en mayo

de 1971. Presidencia de Emilio

Fernández de Caso ................. 811

Consejo de administración en junio

de $1972 \ldots \ldots \ldots \ldots \ldots \ldots . \ldots . \ldots . \ldots 13$ 
Consejo de administración en junio

de $1974 \ldots \ldots \ldots \ldots \ldots \ldots \ldots . \ldots . \ldots 14$

Consejo de administración en julio

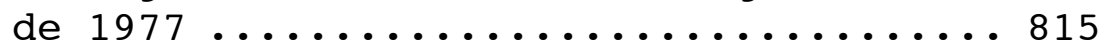

Consejo de administración en

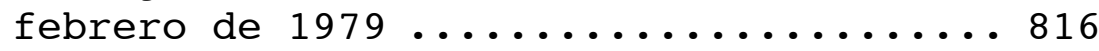

Entrada de Auger en la gestión de

Diario Regional ................ 817

Apéndice 4.- Aspectos económicos ............8 818

Tarifas de suscripción .............. 818

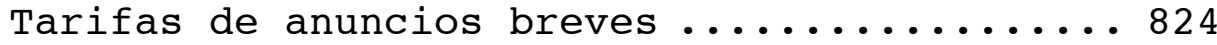

Tarifas de publicidad en 1970 y $1978 . \ldots . .829$

Producción facturada (1974-79)........... 837

Desglose de producción de publicidad en

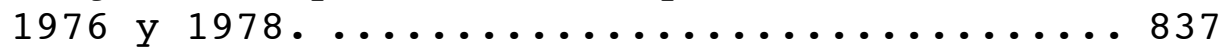

Balance de situación a 30 de junio de

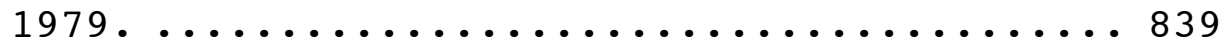

Apéndice 5.- Directores, redactores jefe y

equipos de redacción.................. 843

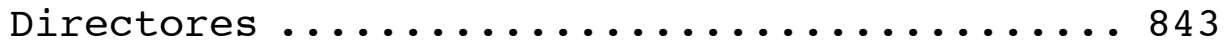

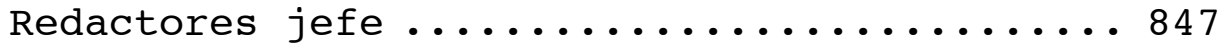

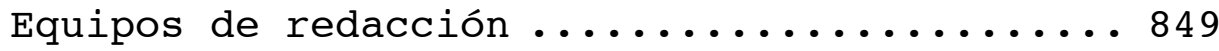


Apéndice 6.- Declaración programática de

Derecha Regional.................... 874

Apéndice 7.- Manifiesto electoral de Rafael

Serrano y Serrano en junio de 1931...........881

Apéndice 8.- editorial publicado por Diario

Regional al finalizar su suspensión, el 2 de

septiembre de 1932 ................... 885

Apéndice 9.- Manifiesto del Comité Electoral

de Unión de Derechas y texto de la

convocatoria socialista de una manifestación

de protesta, en marzo de 1933............... 890

Apéndice 10.- Editorial publicado en los

folios mecanografiados difundidos por el

periódico durante la huelga general de 7 de

octubre de 1934..................... 897

Apéndice 11.- Editorial publicado el primer

día después de la revolución de octubre de

1934 .............................. 899

Apéndice 12.- Editorial publicado en julio de

1937 definiendo la prensa católica española. ....9901

Apéndice 13.- Resumen de infracciones

cometidas por Diario Regional, desde el 1 de

junio de 1943 hasta octubre de 1944...........9905

Apéndice 14.- Carta del director general de

prensa, Tomás Cerro Corrochano al director de

Diario Regional Francisco Javier Martín

Abril, de 21 de agosto de 1946............... 914

Apéndice 15.- Carta de Francisco Javier

Martín Abril a Tomás Cerro, de 1 de

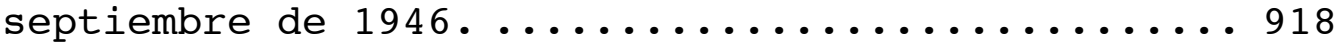

Apéndice 16: informe del delegado provincial

de Prensa al juez instructor de la causa de

José Luis Cebrián Boné, de 31 de mayo de

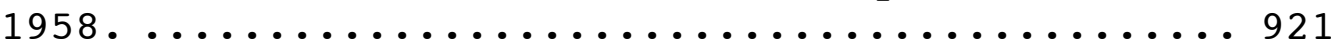

apéndice 17: oficio del director general de

Prensa al ministro de Información y Turismo

solicitando la destitución de José Luis

Cebrián Boné como director de Diario

Regional, de fecha 30 de septiembre de 1958.....9926

Apéndice 18: artículo publicado el 6 de

noviembre de 1964 que dio lugar al

procesamiento y Consejo de Guerra a Manuel

Fernández Areal. 
Introducción

Apéndice 19: artículo que como réplica al anterior se publicó en el periódico el 8 de noviembre de 1964, firmado con tres

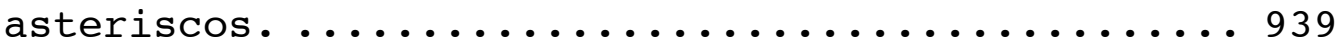




\title{
Agradecimientos
}

\author{
«El río en que me baño \\ es tradición y gracia»
}

Goethe

Hay favores que resulta imposible devolver. Para esos casos Don Quijote recomendaba pregonar lo más posible las mercedes recibidas, y como - por fortuna- es ese nuestro caso, antes que cualquier otra cosa, queremos comenzar agradeciendo a todos los que nos han prestado su ayuda, las molestias que tan generosamente se tomaron. La lista sería excesivamente extensa si pretendiéramos ser exhaustivos. No nos queda más remedio que limitar nuestra mención a unos pocos, de los que somos especialmente deudores. Sin ellos, este trabajo nunca hubiera visto la luz, o sería muy distinto. Así pues, conste nuestro reconocimiento en primer lugar al Doctor Celso Almuiña, director del trabajo; y junto a él a nuestros compañeros Ricardo M. Martín, José-Vidal Pelaz - a quienes debemos tantas y tan valiosas sugerencias- y Guillermo A. Pérez. Por lo mismo, debemos también gratitud al Doctor Elías González Posada, por tantos motivos que él bien conoce y, finalmente, a todos nuestros compañeros del Colegio Mayor Peñafiel, que han sabido soportar con paciencia nuestros defectos. 


\section{Introducción}


"Medio siglo de un periódico". La frase valdría como encabezamiento de un número conmemorativo, en un diario de esa edad. Podría parecer igualmente adecuada para sintetizar lo que intentamos exponer en este trabajo, y en cierto modo lo es. Pero, si cabe admitirla como descripción de la base objetiva de nuestro análisis, no agota su objeto formal. Somos historiadores y,como tales, estamos interesados -sobre todo- en el hombre, no en las cosas, que no tienen historia propiamente dicha. Cuando nos ocupamos de los avatares de la vida de un diario lo hacemos con la intención de comprender el comportamiento de cuantos tuvieron relación con él, y de ese modo ser capaces de narrar acertadamente su historia. El enriquecimiento de la conciencia histórica nos permite distanciarnos de la mentalidad del poeta que canta la gloria de sus antepasados -que nos perdonen los poetas por el atrevimiento de pasar por alto su genio-, y también la de quien se erige en juez de comportamientos ajenos. No es ésta nuestra intención, sino más bien tratar de comprender el pasado de modo que el presente nos resulte más inteligible.

Por otra parte, nuestra concepción del quehacer histórico dista un tanto de ciertas corrientes al uso en años pasados; tendencias que valoramos, aceptamos y aplaudimos en unos sentidos, mientras que nos distanciamos de ellas en otros. Estamos con Andreski en el rechazo de 
"las ciencias sociales como forma de brujería", y -con éldamos de lado también a esa especie de complejo que ha llevado a algunos a seguir en la tarea de escribir historia un método que es imitación del empleado por las ciencias experimentales. Probablemente ha sido la laudable intención de hacer más objetivo y válido su trabajo lo que ha desencadenado ese afán de citar estadísticas y series de datos. Pero no es menos probable que tal empeño haya dado como fruto escritos difícilmente legibles y -no pocas veces- escasamente clarificadores.

Así pues, a la vez que reivindicamos como criterios básicos para estimar la validez intelectual de un análisis histórico la solidez de las fuentes y el rigor en su tratamiento, sostenemos que la utilidad del estudio resultará proporcional a la claridad del lenguaje empleado, o -lo que es lo mismo- al grado de comunicabilidad que el autor alcance en la exposición de sus conclusiones. No estamos de acuerdo con quienes sostienen, abierta o solapadamente, que un cierto grado de esoterismo en la redacción redunda en aumento de la calidad científica de la obra.

Por eso, el índice del trabajo que presentamos difiere un tanto de los que son habituales en algunas de las tesis doctorales que nos son conocidas. Estamos convencidos de que forma parte del trabajo universitario la continua renovación y la búsqueda de nuevos caminos en 
la tarea de alcanzar un mejor conocimiento de la realidad, y nuestro modesto intento de contribuir a esa tarea pasa por intentar una reforma del planteamiento, con raíces y consecuencias metodológicas, que -nos consta- no pocos cultivadores de nuestra disciplina vienen reclamando últimamente.

Así pues, el cierre sobre sí mismo del análisis, la unidad de la hipótesis de trabajo, y su reflejo en la vertebración del texto, desempeñan un papel nada despreciable en el intento que nos mueve: poner al lector -con el menor disgusto posible- ante una explicación convincente de unos hechos, tal y como nosotros la hemos concebido. Somos conscientes de la limitación de esas premisas, y también de que éstas se basan en el abandono de toda pretensión de explicación completa, cerrada, con pretensiones de exahustividad, que otros han tenido por inspiración y por meta. Somos conscientes, decimos, y apostamos por esta forma de hacer. Estamos convencidos de que más que historia, hay historiadores, y esto, lejos de parecernos un desdoro "científico" de nuestra disciplina, nos parece indicio del alto grado de libertad creativa que -sin menoscabo del rigor debido- ésta no sólo permite, sino que demanda.

Hechas estas precisiones, prosigamos con la
descripción de los objetivos que nos hemos marcado.
Investigar sobre la historia de la prensa viene a ser


indagar sobre el modo en que los hombres percibieron parte de su vida, tratar de descubrir la conciencia que tuvieron de su tiempo aquellos que -al menos en teoría- hicieron gala de un mayor afán de conocer la actualidad y de transmitir a sus coetáneos sus impresiones en torno a ella. Por razones sociales, técnicas y culturales, en las sociedades contemporáneas ese tipo de personas deja testimonio escrito de sus juicios y ejerce un influjo especial sobre el mundo que le es propio. Ese empeño por dejar constancia pública y escrita de las novedades -a diario- es, en sí mismo, una novedad de la historia contemporánea, consecuencia y causa, a la vez, del modo de pensar y de vivir de los occidentales en los siglos más recientes. Ese deseo, además, convive con factores vitales de mayor antiguiedad, como son, por ejemplo, la religión y la política.

Pues bien, nuestro estudio se propone esclarecer cuál ha sido la actitud de los católicos ante este fenómeno de la vida contemporánea. Ése es el nervio del trabajo, la línea de fuerza de la tesis que defendemos. Para alcanzar esa meta hemos estudiado la vida de los que hicieron un diario católico vallisoletano entre los años 1931 y 1980 . La primera de las fechas viene determinada por los acontecimientos políticos que tuvieron lugar entonces, y que -como veremos- fueron causa de una profunda transformación en el diario que sirve de apoyo a nuestro estudio. La segunda, corresponde a la fecha de 
desaparición del diario, y no precisa, por tanto, mayor justificación.

La elección de semejante materia de estudio es fruto de una tradición académica, y somos, por tanto, deudores directos de quienes antes que nosotros abrieron un camino en el análisis de los medios de comunicación como objeto de interés histórico. Al describir en alguna ocasión esa tradición, el doctor Almuiña ha estableciendo tres generaciones de historiadores que han atendido a estas tareas en nuestra Universidad. Nosotros perteneceríamos a una tercera generación, y así, seríamos como nietos intelectuales de Palacio Atard y Enciso Recio, e hijos de Egido López, Palomares Ibáñez, y el propio Almuiña, entre otros. En la bibliografía se puede apreciar cómo han ido variando las orientaciones de esta "familia» y qué costumbres se han mantenido invariables. Por nuestra parte, sentimos el deber de agradecerles esta herencia, y nos gustaría hacerlo subrayando aquel pensamiento del poeta alemán:

Tenemos la buena fortuna de podernos dedicar al estudio del pasado, y deseamos no defraudar a quienes han confiado en nosotros para continuar una tarea que ellos hicieron fecunda. 
A diferencia de los investigadores que nos precedieron, contamos -según denota la misma bibliografíacon un buen número de estudios paralelos, que sirven de marco y apoyo a nuestra labor. Estudiar la prensa no es ya una novedad. Ahora bien, en dos sentidos al menos, nuestra tarea sí lo es: por un lado, la prensa vallisoletana de los años que nos ocupan no ha sido todavía estudiada; y por otro lado, la prensa católica, durante esta misma etapa, apenas ha sido objeto de investigaciones monográficas. Hemos de advertir, no obstante, que la orientación de nuestro trabajo difiere en buena medida de los que más abundan en relación con la prensa. En efecto, otros suelen poner el acento en el conocimiento del medio - medios en cuestión y de las transformaciones que experimentan. Nuestro punto de partida, la hipótesis de trabajo que nos guía, es otra.

Siendo España un país de tradición católica, nos interesa saber qué significara el catolicismo para los españoles de aquel periodo, por qué hubo gentes que quisieron hacer un periódico católico, y por qué ese diario se extinguió. Teniendo en cuenta que en los años ochenta el país sigue contando con católicos, pero no con diarios católicos, nuestra hipótesis podría expresarse del siguiente modo: algo ha cambiado en la actitud de los católicos ante la prensa diaria, y en ello radica la causa de la desaparición de los medios confesionales. Además, como quiera que las empresas de prensa son un fenómeno 
cabalmente mercantil con concomitancias ideológicas y de mentalidad, su relación con las convicciones religiosas entraña un interés singular; aún más, si se tiene presente que en el periodo que estudiamos las transformaciones económicas del país fueron muy notables, y generaron profundos cambios sobre los modos de vida, sin que dejaran de afectar -muy densamente- a los comportamientos de los españoles en materia religiosa.

Se trata, pues, de una hipótesis que pretende encontrar explicaciones para un fenómeno de alcance nacional -o mejor, para un problema humano-, a partir de un caso particular. En este sentido, la atención prestada a lo específicamente vallisoletano, por tener un carácter instrumental y no final, presentará un acento más o menos intenso según lo requiera la clarificación del entorno del diario, sin más pretensiones.

La historia de los medios de prensa es la historia de la sociedad que los produce y los consume, de ahí que en ningún momento hayamos olvidado la complejidad inherente al estudio que en su día decidimos emprender. El recorrido que realizaremos, a lo largo de cincuenta años, por la sociedad vallisoletana, no puede por menos que ser limitado y parcial. Huelga, pues, cualquier pretensión de entenderlo como exhaustivo. Pero a la vez, estimamos que la extensión del periodo considerado, y la especificidad de los protagonistas, nos permitirán atisbar algunas 
conclusiones sobre cuál haya sido y cómo evolucionara el comportamiento de los católicos castellanos en materia política e informativa.

Como ya sabemos -merced a los estudios que se han dedicado a esta cuestión-, España es un país de larga, dilatada tradición, en la que el catolicismo ha intervenido para vertebrar todo un proyecto de convivencia de tales proporciones, que en la edad Moderna probablemente la más intensa de nuestra historia- el catolicismo de los españoles resultaba ser una de las componentes fundantes de su idiosincrasia, contrapunto de lo que se tenía para otros países europeos, y savia que nutría muchas de las empresas de esos años. Como era característico de la época, el elemento religioso tenía una plasmación institucional: España era un país católico, y sus reyes eran la encarnación de ese catolicismo nacional.

El declive del dominio español coincidió con la irrupción de los movimientos que iban a dar lugar a la Ilustración, y posteriormente, a la Revolución Francesa y a toda la corte de revoluciones del siglo XIX. En la sociedad, eso venía a significar el retroceso de la sacralización, o, dicho de otra forma, el avance secularizador. Políticamente, significaba el fin de la Monarquía absoluta. Era la liquidación del Antiguo Régimen. 
El proceso dio lugar en nuestro país a un siglo convulso surcado de inercias y cambios que las más de las veces no convivieron pacíficamente. La fuerte ligazón entre religión y trono, que había sido característica de los "buenos tiempos" pasados, impulsó a muchos creyentes a entender los cambios sociales y las nuevas ideas políticas como fruto del debilitamiento católico en su país. Partiendo de ese axioma, concluyeron que, si querían defender sus ideas, deberían luchar por volver al pasado que era -a su entender- el único momento en que se había logrado una forma de convivencia coherente. Por su parte, otros católicos veían esos planteamientos carentes de sentido: los tiempos habían cambiado, y hacía falta consolidar estructuras políticas nuevas que permitieran el gobierno de una realidad nacional también nueva. Otros españoles -secundando en esto a los tradicionalistasoptaron por identificar creencias y pasado, y no dudaron en declararse enemigos de la religión en mayor o menor grado.

El siglo XX sorprendió a los peninsulares inmersos en esta discusión, y humillados por el doloroso fin que había tenido el imperio colonial. Cada vez era más evidente cómo habían cambiado las cosas. La derrota militar infligida por los estadounidenses revelaba que el nuevo orden de cosas dependía no tanto de resplandecientes tradiciones o grandiosos planteamientos, por "heroicos" y "gloriosos" 
que éstos fueran, cuanto de ese otro factor tan determinante llamado desarrollo industrial.

Ahora bien, los cambios que generó la industrialización del país fueron causa de una nueva e intensa secularización, que esta vez afectó a las clases más populares y no sólo a las élites políticas o intelectuales. De ahí se derivaba un doble problema: por un lado sería necesario reformar el sistema político para abrir cauces de participación a esas masas emergentes, en una coyuntura histórica en la que apenas se había conseguido asentar el liberalismo; por otro lado, se planteaba para la Iglesia un nuevo problema: la actuación en un nuevo mundo -las sociedades de masas- que aunque nacían en el seno de las sociedades europeas tradicionales, eran a un tiempo ajenas a ellas.

Los católicos que se habían situado en la línea tradicionalista no tardaron en ver en la acentuación de las tendencias secularizadoras una confirmación de sus temores. Esto contribuyó a que los partidarios de admitir los nuevos planteamientos estuvieran -más todavía- en exigua minoría, y así, las tendencias autoritarias entre los católicos españoles experimentaron un sensible crecimiento. Por su parte, los nacientes partidos de masas echaban mano del anticlericalismo liberal, cuando no del agnosticismo o del ateísmo, como bandera de los 
movimientos que promovían en favor de la libertad y emancipación de los ciudadanos.

En este contexto social ¿qué sucedía con la prensa católica? Ella pretendía ser -en la mente de sus promotores- una respuesta al avance desolador de la impiedad, que parecía amenazar con destruir España. Se había llegado ya al convencimiento de que era necesario combatir al enemigo con sus mismas armas, y los más activos se lanzaron a la arena de la opinión pública para defender sus convicciones y ganar adeptos. Era una cuestión de propaganda de corte religioso que discurría paralela a la batalla política que se libraba, y que reflejaba las fracturas existentes en el campo católico. Lo mismo que encontramos partidos tradicionalistas -en sentido lato-, encontramos periódicos del mismo signo. También aquí, los católicos que aceptaban los nuevos modos de vida y se atenían a ellos, eran pocos, y su prensa, escasa.

Nuestro punto de partida será, por tanto, el concepto de "prensa católica" que tenían los que profesan esa religión a la altura de los años treinta. Como veremos, ese concepto tiene unas consecuencias específicas en cuanto al tipo de periodismo que se hace y al de empresa que sirve de sostén a los medios católicos. A desintricar los pormenores de esa concepción -ejemplificados en los 
protagonistas directos de nuestra historia- dedicamos el primer capítulo.

Durante el periodo al que atiende el segundo, la Segunda República, el periódico constituyó fundamentalmente un instrumento de lucha política. Nos detendremos, entonces, en la descripción de la que hacen quienes lo promueven, puesto que ésa es la razón de ser del rotativo: sólo puede comprenderse el Diario Regional de esos años conociendo la actividad de la derecha confesional vallisoletana, y viceversa. La actitud de los católicos políticamente activos, sus estrategias, logros, y fracasos, además de las consecuencias que de todo ello se derivan en el mundo de la prensa, son los centros de atención que nos ocupan y sirven de guías en las respuestas que -para aquella etapa- podemos dar a nuestras preguntas.

La guerra civil supuso un paréntesis, que era simultaneamente espera y gestación de la nueva coyuntura que se esperaba alcanzar una vez que la contienda hubiera concluido. Se constituye así en un periodo de transición que merece una atención específica, $y$, por eso, le dedicamos un capítulo aparte en el que tendremos ocasión de descubrir, a través del discurso del diario, cómo las consecuencias de su comportamiento en los años de la República, se constituyen en raíces de actitudes que serán características del primer franquismo. 
Es en 1939 cuando nos adentraremos en la fase definitiva que nos conduce hacia la respuesta a nuestra pregunta. Las motivaciones políticas para el mantenimiento del periódico -en virtud de la confesionalidad del régimen de Franco, y de la uniformidad impuesta a la opinión- se atenuaron, cuando no desaparecieron, dando lugar a la anquilosis total de los planteamientos que fueran jugo vivificante de la prensa católica en los años del liberalismo. Estas circunstancias provocaron una auténtica crisis de identidad de los medios católicos que enfrentó en ocasiones a los católicos con un régimen que se servía de la religión para legitimarse. Fueron tiempos de paradojas que nos sirven para delimitar más claramente las disfunciones que lastran la vida de los medios de prensa confesionales. En nuestro periódico estos años -hasta 1955- resultaron ser los de "La Editorial Católica", tiempo que concluyó con el rotativo en trance de muerte, por razones que resultan no poco esclarecedoras en la tarea de responder a nuestra hipótesis.

A partir de 1955 entramos en un nuevo capítulo y en una etapa que puede calificarse de definitiva por lo que a nuestro intento se refiere. El alejamiento del modelo de prensa de opinión -básicamente política- que había venido gestándose, precipitó en el abandono de la línea opinante y en la acentuación de la información como esencia de la tarea periodística. Nos colocaremos así, de forma casi insensible, ante el problema de la actitud de los 
católicos ante la información, ahora sin añadidos. A las transformaciones internas del periódico, se sumaron las que afectaban a la actitud de los católicos en general -y de los católicos españoles en particular- ante la vida pública. La clarificación de posturas que pretendió el Concilio Vaticano II introdujo notables novedades y -como suele ocurrir en tiempos de cambio- no pocas situaciones confusas. Nos interesan más las primeras que las segundas, ya que en ellas $-y$ en sus "alrededores"- encontraremos la parte principal de las respuestas que venimos buscando.

El final, que abordamos en el último capítulo, podría calificarse como un epílogo en toda regla. Se trata de la extinción de un periódico de empresa que había sido católico, y dejó de serlo por voluntad expresa de periodistas católicos. Nosotros defendemos que, aunque ese fenómeno pueda parecer paradójico, en realidad, no lo fue.

Por desgracia, el ocaso del diario podría calificarse de catastrófico. Esto motivó que sus pertenencias fueran a parar a manos de acreedores; y que de los archivos de la empresa no quedara prácticamente nada: de hecho, tan sólo se han conservado algunas escrituras y un informe de los últimos años, en las oficinas de una empresa de artes gráficas que compartía los locales con el diario. Así pues, la reconstrucción de los hechos no se presentaba tarea fácil. Disponíamos -eso sí- de varias colecciones completas de los números editados. Desearíamos subrayar 
que es ésta una ventaja inherente a la prensa: se trata de una actividad cuyo producto final adquiere carácter de fuente histórica. Esto justifica que las páginas del periódico fuesen -en primera instancia- la fuente primordial.

La bibliografía sobre el periódico en sí se reducía a unos cuantos artículos de carácter rememorativo publicados por el propio diario, y alguna revista especializada, además de un breve artículo publicado por el profesor Almuiña. Todo con carácter más divulgativo que de investigación, y utilizando siempre como fuente el periódico mismo.

En cuanto a la bibliografía que más nos interesaba, la que tratara específicamente de las actitudes de los católicos ante la prensa, los estudios históricos no resultaban ser -como puede verse en la bibliografía que recogemos- muy abundantes. Si bien existen estudios relativos a la evolución de los partidos católicos, que tratan de rechazo sobre la prensa ligada a esos grupos, no hemos encontrado una conceptualización diacrónica de la "prensa católica». Todo lo más existen "biografías" de medios católicos concretos $-y$ no muchas para los años que abarcamos-, y publicaciones que recogen reflexiones de los protagonistas, contemporáneas a la historia misma. Es significativo que la única obra publicada en castellano con el título "La prensa católica" -la de Georges Hourdin- 
sea traducción de un libro francés, al que se añade como apostilla un epílogo descriptivo sobre la prensa católica en España. Este hecho, unido a su fecha de edición -1959venía a confirmarnos la oportunidad de las preguntas que nos habíamos formulado.

Como estudios especialmente orientadores en relación con el papel desempeñado por los católicos en los años que nos ocupan, señalaríamos básicamente los de los profesores Payne y Tusell. En nuestra opinión, sus obras han logrado recoger aportaciones anteriores, al tiempo que conseguían diseñar un marco interpretativo coherente, atractivo y clarificador.

Por lo que hace a las fuentes, aunque para el periodo de la Segunda República y la guerra civil la información hallada en archivos haya resultado escasísima, los estudios históricos que se ocupan de esos años nos permitían reconstruir algunos aspectos del entorno del diario, y con ello completar en esa etapa su peculiar fisonomía. Pero sucedió que, cuando entramos en el franquismo, el número de trabajos que pudieran resultarnos útiles resultó ser menos abundante. Afortunadamente, los archivos ofrecían ahora una mayor información. El afán de vigilancia de la prensa, demostrado por las autoridades franquistas, generó toneladas de documentación en las que es posible encontrar datos esclarecedores sobre la empresa, las redacciones, la censura, etc.. De este modo, 
para los años centrales del estudio, el apoyo en fuentes archivísticas -fundamentalmente, del Archivo General de la Administración, y del Archivo Provincial de Valladolidviene a ser el complemento documental que se añade al diario mismo. Además, la proximidad temporal de los hechos permitía el recurso a fuentes orales, y -a través de ellas- a algunos archivos privados singularmente ricos. Esto justifica que las entrevistas hayan llegado a ser una fuente de conocimientos nada despreciable para esa etapa. Siempre que recurrimos a ellas lo hacemos recogiendo testimonios de varios protagonistas de la misma época, sin dejar de contrastar sus aportaciones -cuando es posiblecon fuentes escritas. No olvidemos que los recuerdos personales son -por su misma naturaleza- subjetivos, y las más de las veces- imprecisos.

La última década objeto de nuestra atención es sobre la que menos documentación escrita hay depositada en los archivos, por razones obvias. Por este motivo hemos debido reconstruirla apoyándonos con mayor énfasis en el periódico mismo, y en testimonios orales, que suponen las fuentes predominantes para el último capítulo junto con aportes documentales procedentes de archivos privados.

No hemos podido contar con otros auxilios que son clásicos en este tipo de trabajos: el Archivo de Hacienda de Valladolid -que se encuentra en un estado lamentableno ofrece ningún dato sobre "Diario Regional, S.A.", y 
tampoco hemos conseguido localizar nada en el de Correos. Otro tanto hemos de decir del Archivo Diocesano, en el que los papeles que hacen relación a estos años no están aún disponibles. Resultó también infructuoso nuestro intento de consultar fondos procedentes de la Casa Social Católica, y -con disgusto- comprobamos que resulta imposible acceder al Archivo de Ya-«La Editorial Católica», que está prácticamente destruido.

Como no puede ser menos, la diferente disponibilidad de documentación y de apoyos historiográficos resultan un condicionante ineludible para el estudio, que recibe su unidad de la pregunta que nos formulamos como hipótesis interpretativa. No nos corresponde a nosotros juzgar si hemos conseguido responderla. En todo caso, el modesto fruto de ese empeño son las páginas que siguen. 


\section{Para la defensa de los intereses católicos}

«No vendemos, pues, papel; propagamos y defendemos ideas. No somos una empresa mercantil; ejercemos un apostolado.»

Diario Regional, 30 de mayo de 1935. 


\section{EL MARCO VALLISOLETANO}

El último siglo no había resultado ser el mejor de la historia de Valladolid, pero -así es el tiempo- a la altura de 1931 era el que más impronta había dejado en los aires de esta ciudad de Castilla. De hecho su carácter de capital de provincia tenía apenas un siglo y era ya probablemente el rasgo que mejor la definía. Cierto que a diferencia de otras villas de igual categoría administrativa, la del Pisuerga tenía, entre otras cosas, Universidad, Audiencia Territorial, Academia de Caballería, Arzobispo, Capitán General, y una flamante estación de ferrocarriles que -con sus talleres- era sin duda la mayor industria de la provincia; pero por encima de todo esto -vestigio del pasado la mayor parte-, el siglo del liberalismo había dejado su huella: la administración racional que los nuevos tiempos habían traído no miraba al pasado por glorioso que fuera, sino a la eficacia en el presente, y con ese rasero había que medir a la ciudad ${ }^{1}$. En este sentido el dato apuntado sobre

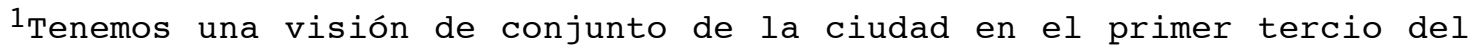
siglo en PALOMARES IBÁÑEZ, Jesús María, Valladolid 1900-1931, Ateneo de Valladolid, Valladolid, 1981; y en CARASA SOTO, Pedro "Modernización de la sociedad vallisoletana en el primer tercio del siglo XX", en Arquitecturas en Valladolid. Tradición y modernidad. 1900-1950, tomo I, págs. 9-29. Sobre la vida municipal cfr. GARCÍA DE LA RASILLA ORTEGA, Mạ del Carmen, El Ayuntamiento de Valladolid: política y gestión (1898-1936), Ayuntamiento de Valladolid, Valladolid, 1991. Para los aspectos sociales y políticos en el primer tercio de siglo, cfr. los siguientes trabajos publicados en la revista Investigaciones Históricas, Secretariado de Publicaciones de la
} 
el ferrocarril dice bastante: cuando la primera industria en una ciudad del interior resulta ser una auxiliar del transporte, algo no termina de ir bien en el mundo de la producción industrial. Es verdad que el final de la última centuria había conocido una cierta expansión de la economía vallisoletana; pero a partir de 1905 ese dinamismo había declinado para dejar sitio a un estancamiento que las fuerzas vivas reconocían como la mejor definición de la vida económica de Valladolid².

Universidad de Valladolid: en el no 1, 1979, págs. 231-262, "La Federación de Sindicatos Agrícolas Católicos de Valladolid", por Félix FERNÁNDEZ GORRINDO; en el no 4, 1983, págs. 431-457, 1983, "Los agricultores vallisoletanos y la legislación triguera de 1932", por Mạ Concepción MARCOS DEL OLMO; en el no 5, 1985, págs. 267-294, "Aproximación al regionalismo castellano durante la segunda República", por Jesús Mạ PALOMARES IBÁÑEZ; en el no 6, 1986, del mismo autor, págs. 169-186, "Líderes del socialismo castellano: Remigio Cabello, fundador de la agrupación socialista de Valladolid (18691936)", y págs. 187-214, "Repercusión del problema marroquí en la vida vallisoletana (1909-27)", por Ma del Carmen GARCÍA DE LA RASILLA ORTEGA; en el no 7, 1987, págs. 169-202, "Asociacionismo confesional en Valladolid. La Asociación Católica de Escuelas y Círculo de Obreros, 1881-1914", por Elena MAZA ZORRILLA; en el no 9, 1989, págs. 251-286, nuestro artículo en colaboración con Ricardo M. MARTÍN DE LA GUARDIA Y Guillermo A. PÉREZ SÁNCHEZ, "La sociedad castellana a comienzos del siglo XX: comportamientos ante el nacimiento, matrimonio y muerte"; en el no 10, 1990, págs. 9-39, "La evolución del empleo y del salario en el Ayuntamiento de Valladolid: 1875-1930. Análisis cuantitativo", por Guillermo A. PÉREZ SÁNCHEZ, y en las págs. 41-70, "Los seguros sociales: la pluralidad de cauces en el primer bienio republicano, 1931-33", por Elena MAZA ZORRILLA; en el no 11, 1991, págs. 199-227, "Los trabajos municipales de invierno del Ayuntamiento de Valladolid", por Guillermo A. PÉREZ SÁNCHEZ; y en el no 12, 1992, págs. 255-283, del mismo autor, "Los Talleres Principales de Reparación de la Compañía del Norte en Valladolid: un estudio de Historia Social (1861-1931)". Cfr. también PALOMARES IBÁÑEZ, Jesús María, El socialismo en Castilla. Partido y Sindicato en Valladolid durante el primer tercio del siglo $X X$, Universidad de Valladolid, Caja de Ahorros y M. de P. de Salamanca, Valladolid, 1988; y PRADO MOURA, Ángel de, El movimiento obrero en Valladolid durante la Segunda República, Junta de Castilla y León, Salamanca, 1985.

2 "La nota dominante del estado general de los negocios en toda la provincia de Valladolid es la paralización", "Estado general de los negocios y movimiento industrial y mercantil", en Boletín de la Cámara oficial de Comercio e Industria de Valladolid, no 58, año VI, junio de 1914, pág. 3. En los años siguientes las afirmaciones serán de carácter similar. Cfr. nuestro estudio "Los negocios y la actividad industrial $y$ mercantil en Valladolid vistos por sus protagonistas 
Quizá por eso la ciudad era poco más que el centro administrativo $y$ de servicios -sanitarios, legales $y$ comerciales- de su entorno rural; adornada, eso sí, por edificios que hablaban claro sobre glorias de otros tiempos, y por obras de ensanche, saneamiento, alumbrado, etc., que no eran menos explícitas sobre otras más recientes ${ }^{3}$.

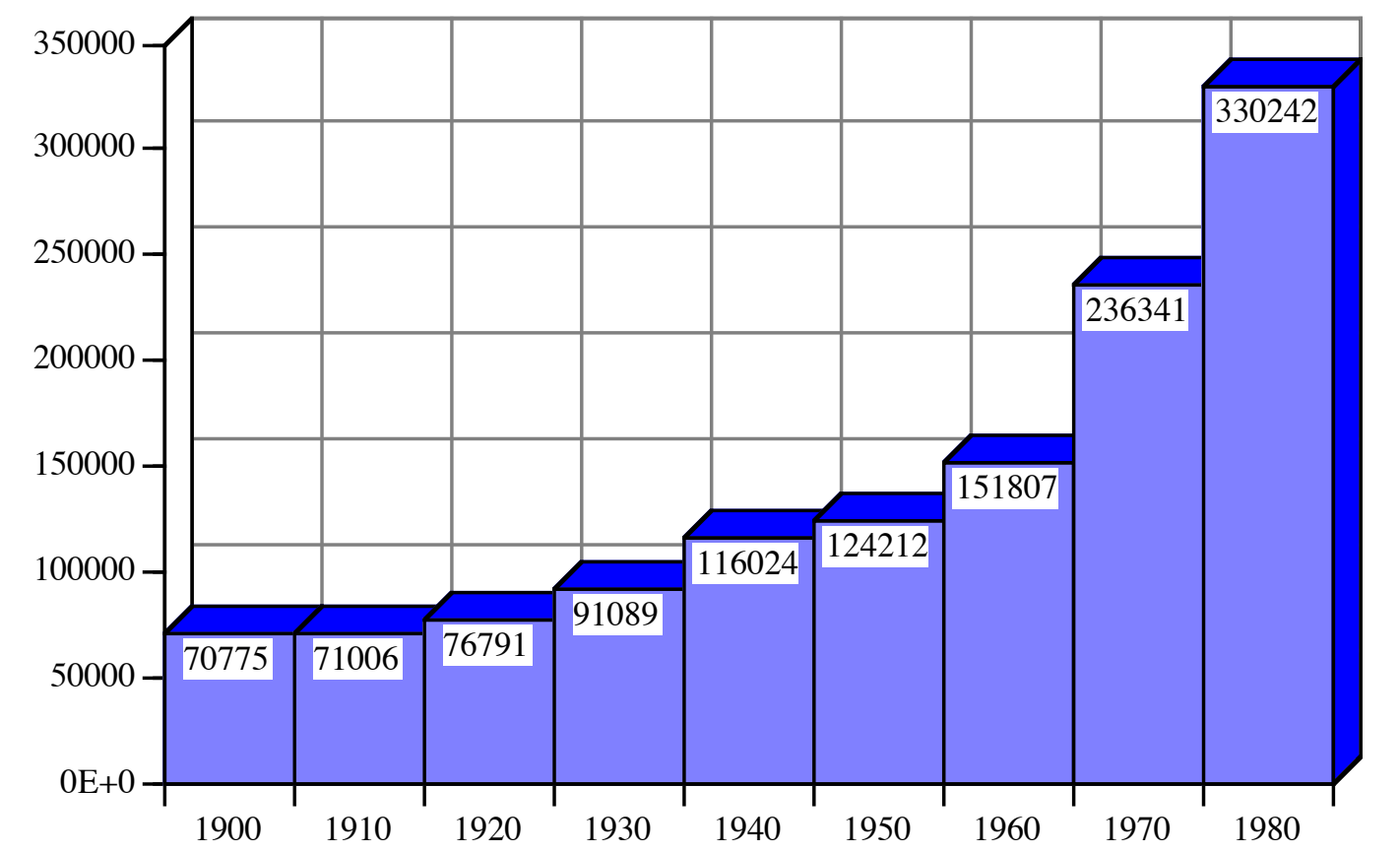

Gráfica 1.- Número de habitantes de Valladolid capital. Fuente: Censos de la Población de España.

Su número de habitantes se había convertido casi en una tradición en los primeros veinte años del siglo, tradición que comenzaba a romperse merced al modesto

(1913-27)" en Espacio, Tiempo y Forma, serie V, Hạ Contemporánea, t. 3, 1990, págs. 249-264.

${ }^{3}$ Para el desarrollo urbanístico de Valladolid, cfr. VIRGILI BLANQUET, María Antonia, Desarrollo urbanístico y arquitectónico de Valladolid, 1851-1936, Ayuntamiento de Valladolid, Valladolid, 1979; GARCíA FERNÁNDEZ, Jesús, Crecimiento y estructura urbana de Valladolid, Los libros de la frontera, Barcelona, 1974; SERRANO, Manuela, Proceso de desarrollo urbano de Valladolid, 1900-1965, tesis doctoral inédita. 
crecimiento de alrededor de 1.400 habitantes al año que había conocido la ciudad en "los felices veinte": el fruto eran las 91.000 almas que la llenaban ahora. Esto si miramos Valladolid desde el punto de vista de la demografía típica de las ciudades industriales, si nos ponemos en el lugar de un vallisoletano nacido en 1860, que desde sus setenta años vuelve la vista atrás, hemos de decir que en el tiempo que vive un hombre la ciudad ha duplicado con creces su población. Además, a estas alturas, la actividad de la mitad de los vallisoletanos activos eran los servicios, en los treinta últimos años el número de los que trabajaban en el sector secundario se había triplicado, y los agricultores habían pasado de diez, a uno por cada veinticinco trabajadores.

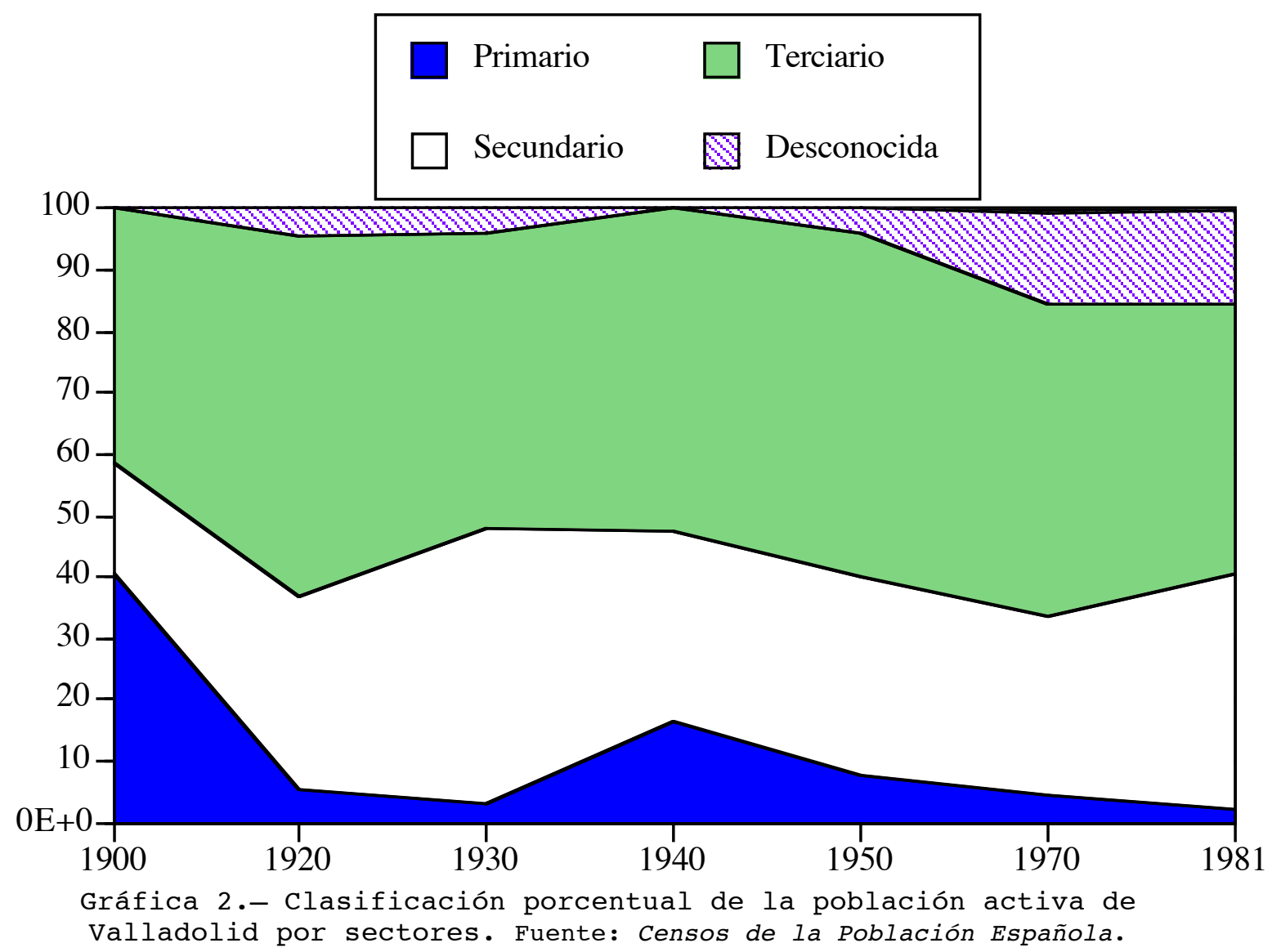


Estancamientos y cambios, tradición e innovación: son sustantivos imprescindibles para quien escriba la historia de cualquier parte y en cualquier tiempo. De la proporción en que se mezclen $y$ de la naturaleza de unos y otros depende el perfil histórico de la época. Pues bien, en el primer momento de nuestra historia, sobre un poso de estancamientos se verterán tal número de cambios y de tales características, que a punto estarán de convertirse en protagonistas exclusivos de la vida vallisoletana. El ritmo acelerado de la historia contemporánea irrumpía con fuerza en la Castilla centenaria.

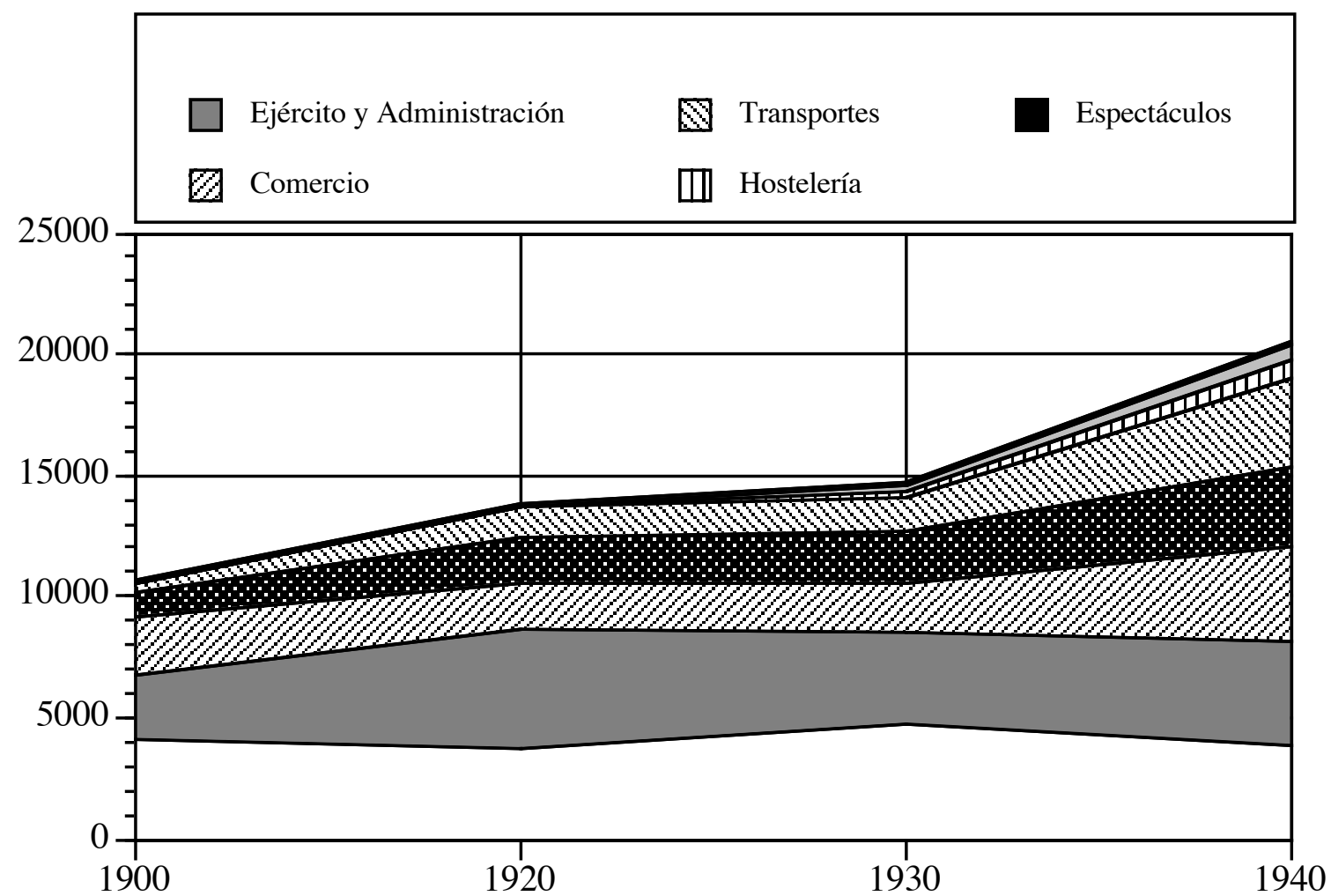

Gráfica 3.- Clasificación de la población vallisoletana del sector terciario. Fuente: Censos de la Población Española. 
UNA HERENCIA PELIGROSA

A esta ciudad había venido a parar tiempo atrás un abogado navarro -Justo Garrán-, que pese a ser descendiente de la nobleza isabelina4, y ser hijo de un alfonsino declarado, se sentía más próximo a las ideas tradicionalistas que a las liberales ${ }^{5}$ Licenciado en Derecho por Madrid, se inició en el ejercicio de la profesión en el despacho Maura-Gamazo. Hombre activo, de entre sus múltiples iniciativas ${ }^{6}$ una iba a tener especial

${ }^{4} \mathrm{Su}$ madre era hermana del conde de Espoz y Mina. La esposa de Justo Garrán -Catalina Mosso- era prima suya, y hermana del heredero del condado.

${ }^{5}$ Los datos más personales son fruto de la entrevista con su hija, María Garrán, mantenida el 27/10/1989 en Valladolid. A través de esta fuente hemos sabido que Justo Garrán, tras la muerte de su padre, quemó unos cuantos libros de éste $y$ de su abuelo por rechazar su carácter liberal.

${ }^{6}$ Francisco Javier Marín Abril hace un retrato elogioso del personaje con motivo de su muerte en 1942: "Don Justo Garrán era una figura célebre de nuestra ciudad con esa aureola de popularidad que da la inteligencia y el estilo. (...) su vida fue un constante sacrificio en bien de los pobres; de los pobres materiales o de los espirituales (...). Si don Justo Garrán fue un personaje político, lo fue guiado por el sentimiento religioso. (...) En su solapa siempre llevaba una insignia del Corazón de Jesús. Porque todas las cualidades de don Justo Garrán se compendiaban en un ardiente y militante catolicismo". "El señorío de don Justo Garrán", DR, 30/8/1942, pág. 1. Hombre culto, estaba suscrito a varias publicaciones inglesas, francesas e italianas, y hablaba con fluidez esos idiomas además del alemán y el catalán. Publicó tres libros sobre cuestiones políticas y filosóficas: Las regalías de la Corona, Sofismas y razones, y Sistema foral de Navarra; además de un folleto con sus intervenciones en las Cortes: Principales intervenciones en el Congreso, en materia religiosa. Fue diputado a Cortes durante la Restauración en 1918 por Valladolid y en 1922 por Tafalla (Navarra); fue también diputado foral de Navarra, participó en la asamblea fundacional del Partido Social Popular en 1922, fue miembro del Tribunal de Garantías Constitucionales en la II República, Presidente del Tribunal Tutelar de Menores de Pamplona durante el franquismo, etc. En Valladolid estaba vinculado a numerosas obras de caridad y en estrecha relación con la Casa Social Católica y las Conferencias de S. Vicente de Paúl. En 1932 acogió en su casa a varios jesuitas con motivo de la disolución de la Compañía; en 1936 se negó a permitir fusilamientos en su finca de las afueras de Valladolid 
relieve en su patria de adopción: el periódico que fundara en 1908 -tenía entonces cuarenta y un años- y que salía a la calle con el título de Diario Regional. En su opinión no era ésta la más pequeña de las numerosas obras benéficas que había emprendido en favor de sus paisanos ${ }^{7}$ : bien necesitaba estaba la ciudad de una prensa de segura orientación, católica sin ambages, vigilante frente a las perniciosas ideas liberales que infectaban el ambiente..., en fin: de "buena prensa". Dieciocho años de su vida dedicó al periódico Justo Garrán, y quizá hubiera dedicado más si no fuera porque consideraba que éste era una herencia peligrosa. El Diario era en su opinión un instrumento insustituible para la difusión de opinión sana en la ciudad, pero económicamente era una ruina. Así que si por un lado la ciudad no podía pasarse sin él, por otro le pareció temerario legarlo a su primogénito -un muchacho fogoso aficionado

a

la

y dio cobijo a algunos empleados suyos vinculados a grupos de izquierda para salvarlos de la persecución.

${ }^{7} \mathrm{Su}$ dedicación al periódico llegó a ser la tarea que más tiempo le absorbía. Significativamente no tenía mentalidad empresarial en su gestión, sino netamente benéfica como decimos. Seleccionaba la publicidad en función de criterios morales e ideológicos sin importarle las pérdidas que se generaban, y con su propio capital cubría los déficits y financiaba seguros de accidentes, enfermedad o vejez de los empleados del diario. Entrevista con María Garrán. 
política como su padre ${ }^{8}$ - cuando éste comenzaba a abrirse paso en la vida ${ }^{9}$.

${ }^{8}$ Licenciado en Derecho, era miembro de la Asociación Católica Nacional de Propagandistas (A.C.N. de P.), participó en la fundación de la Unión Patriótica en Valladolid, y más tarde ingresó en Falange Española.

${ }^{9}$ Para conocer al ambiente periodístico de la ciudad en los primeros años del siglo, puede verse ALMUIÑA FERNÁNDEZ, Celso, "Periódicos y periodistas", no 46 de Cuadernos Vallisoletanos, Obra Cultural de la Caja de Ahorros Popular, Valladolid, 1988. 30 págs.. En la ciudad convivieron durante el primer tercio de siglo los siguientes diarios: El Norte de Castilla, fundado en 1856, propiedad de César Silió y Santiago Alba desde 1893, y de orientación liberal; El Porvenir (19021918), diario católico; Diario Regional; y La Defensa (1911-1913) de orientación maurista. De periodicidad no diaria, pero con significación política, tenemos iAdelante!, órgano del partido socialista, que tuvo una primera época entre 1911 y 1918, y una segunda de 1931 a la guerra civil. Junto a él está otro semanario, portavoz de las Juntas de Ofensiva Nacional Sindicalista de Onésimo Redondo, y que se publicó desde 1931 con el título de Libertad, y de Igualdad cuando quiso burlar suspensiones. Éste semanario se convertirá en diario a partir de 1938, y sobre él está a punto de ver la luz una tesis doctoral elaborada por el profesor Ricardo MARTÍN DE LA GUARDIA.

Almuiña señala por un lado la preponderancia de El Norte, y por otro desmiente el anticlericalismo que se atribuye al órgano liberal de la ciudad desde los medios católicos. Significativamente, Justo Garrán comenzó trabajando en El Porvenir, que llegó a dirigir, y salió de él para fundar otro periódico, también católico, pero más alejado de las posturas del partido conservador, a las que El Porvenir se demostraba cada vez más próximo. Durante la primera etapa de Diario Regional, Garrán contó con la ayuda de dos periodistas para en su tarea de editar el periódico: Federico Santander y Eusebio Zuloaga. En general, puede decirse que el diario siguió una línea próxima al tradicionalismo -aunque Garrán no se declaró nunca carlista-, y consiguió vencer a sus adversarios más afines $-E l$ Porvenir y La Defensa- logrando de ese modo el monopolio en lo que se refiere a periodismo católico en la ciudad.

Otra visión del periodismo vallisoletano en el siglo $\mathrm{xx}$, hecha por protagonistas del mismo, puede verse en el número extra de La Estafeta Literaria, № 272-73, correspondiente a los días 17 y 31 de agosto de 1963, que se publicó con el título genérico de «Un mapa literario de la Tierra de Campos". En él, Leandro Pérez PÉREz GómEz, escribió una reseña sobre la vida del periódico titulado "Diario Regional. Periódico católico agrario de Valladolid" (págs. 28-29). Para los primeros años de la publicación, ésta era la definición que apuntaba el periodista vallisoletano: "Como Valladolid y su provincia, sobre todo ésta, ha sido y es una tierra eminentemente agrícola, la prosperidad de la agricultura ha sido, juntamente con la defensa de la religión y de la libertad, los temas y objetivos de las más intensas y tenaces campañas de Diario Regional, como las de propaganda y creación de los Sindicatos Agrícolas Católicos y la Federación Católica Agraria; los de política hidraúlica que por los años veinte inició el conde de Guadalhorce; los de establecimiento de la Confederación Hidrográfica del Duero...". En definitiva, según Leandro Pérez, un 
La solución adoptada fue recurrir a un conjunto de vallisoletanos que compartieran las motivaciones que le habían llevado a fundar Diario Regional : así nació el grupo de los fundadores de "Diario Regional, S.A.", que se harían cargo del periódico en diciembre de 1926 al fundar esta sociedad. Pero antes de ocuparnos de ellos y de su empresa conviene reparar en lo que significa todo esto. El propio fundador del periódico, el hombre que lo ha sacado adelante durante dieciocho años y que mejor lo conoce, está diciendo a gritos con su modo de actuar que Diario Regional es tan buena obra de caridad como negocio ruinoso, y esto es quizá la más clara definición del concepto de prensa católica que manejan estos hombres. Aquí está para nosotros una de las claves para comprender la historia del periódico.

EL APELLIDO "CATÓLICA"

El nacimiento de la prensa es contemporáneo a la aparición de la sociedad liberal laica y al comienzo del

portavoz del reformismo regeneracionista $y$ un apostol de las instituciones católico-sociales. Pueden verse también los artículos correspondientes a los otros dos diarios de la ciudad, a saber, "La escuela periodística de "El Norte de Castilla"", por Francisco UMBRAL (págs. 30-31), y "Periódico Castellano Revolucionario", por Narciso GARCÍA SÁNCHEZ (pág. 29) que versa sobre Libertad. El artículo citado de Leandro Pérez, resulta ser el único referido a Diario Regional señalado por Pedro ALTABELLA en su tesis doctoral Fuentes críticobibliográficas para la historia de la prensa provincial española, Editorial de la Universidad Complutense de Madrid, 1983, pág. 424. Finalmente, puede verse el resumen del periodismo de la ciudad que hace CARASA SOTO, Pedro, en op. cit., pág. 23. 
proceso de separación de Iglesia y Estado10, y esto por una razón bien sencilla: si bien antes las necesidades de comunicación e información ya existían, e incluso los medios para hacer que éstas fluyeran copiosamente, el control de los Estados no permitió ese flujo hasta que la libertad de expresión fue reconocida, al derrumbarse el Antiguo Régimen, como un derecho de los ciudadanos. En ese ambiente el nacimiento de una prensa católica tiene el carácter de creación de un instrumento de defensa frente a los ataques de la prensa liberal11. Los cristianos, privados ya del escudo oficial de protección de la censura, que en países como España estaba en buena parte en manos de la Iglesia, se ven necesitados de crear medios propios de difusión de ideas, que impugnen las acusaciones que desde los ambientes racionalistas se les imputan, que contrarresten la difusión de las doctrinas que están en la base de lo que se había dado en llamar "moderna civilización»12, o -de acuerdo con el esquema liberal- que

10 Cfr. ALBERT, Pierre, et TERROU, Fernand, Histoire de la presse, Presses Universitaires de France, Paris, 4 a edición puesta al día, 1970 , págs. 13 y ss.

${ }^{11}$ Cfr. para Francia la descripción de Georges HOURDIN en La prensa católica, Casal y Vall, Andorra, 1959, págs. 14 y ss. Para España el fenómeno es bien Claro: "El periodismo católico, surge en España en un instante decisivo de su historia, como réplica al procaz lenguaje empleado por la prensa liberal, aparecida a la sombra de las famosas Cortes doceañistas." TARIN IGLESIAS, José, "Un siglo y medio de prensa católica en España", apéndice de la edición española de la obra citada, pág. 123 .

12 Cfr. la Encíclica Quanta Cura, y el Syllabus que la acompañaba, publicados por Pío IX en 1864. Cfr. ANDRÉS GALLEGo, José, La política religiosa en España: 1868-1913, Editora Nacional, Madrid, 1975 y CUENCA TORIBIO, Manuel, Estudios sobre la Iglesia española del XIX, Rialp, Madrid, 1973. 
hagan presente la existencia de un sector de opinión que se adhiere a los planteamientos de su religión. La prensa era en efecto, en sus primeros pasos, un instrumento de divulgación más educativo que informativo13, y bajo este aspecto será subrayada su importancia en los medios católicos. Al fin $y$ al cabo, la Iglesia siempre ha entendido las tareas educativas como una de sus funciones propias. Pero al mismo tiempo para numerosos personajes del mundo de la cultura, católicos o no14, la prensa tenía a lo sumo un carácter degradado en cuanto instrumento de difusión de cultura: Rousseau, por ejemplo, la caracteriza como difusora de una pseudo-instrucción envanecedora de

13 TIMOTEO ÁLVAREZ, Jesús, Del viejo orden informativo. Introducción a la Historia de la Comunicación, la Información y la propaganda en Occidente, desde sus orígenes hasta 1880, Editorial Universidad Complutense, Madrid, 1985, págs. 83 y ss. Nunca perderá la prensa pese a todo es carácter de difusora de conocimientos: "Saber y hacer saber es la actividad principal y la finalidad específica de los periódicos" VOYENNE, La prensa en la sociedad contemporánea, Editora Nacional, Madrid, pág. 26.

14 "C'est qu'exprimait Rousseau en 1775 :

"Qu'est-ce qu'un livre périodique? Un ouvrage éphémère sans mérite et sans utilité dont la lecture négligée et méprisée des gens lettrés ne sert qu'à donner aux femmes et aux sots de la vanité sans instruction."

Et plus tard Diderot lui-même dans L'Enciclopédie:

“Tous ces papiers sont la pâutre des ignorants, la resource de ceux qui veulent parler et juger sans lire, le fléau et le dégoût de ceux qui travaillent. Ils n'ont jamais fait produire une bonne ligne à un bon esprit, ni empeché un mauvais auteur de faire un mauvais ouvrage."

Pour Voltaire, les gazzettes n'étaient que "le récit des bagatelles "." ALBERT, P., et TERROU, F., op. cit., pág. 14 .

MENÉNDEZ PELAYO por su parte, escribió: "Desfacedores de supersticiones comenzaban a ser, en tiempo de Montegón, los periodistas, mala y diabólica ralea, nacida para extender por el mundo la ligereza, la vanidad y el falso saber, para agitar estérilmente y consumir y entontecer a los pueblos, para halagar la pereza, privar a las gentes del racional y libre uso de sus facultades discursivas, para levantar del polvo y servir de escabel a osadas medianías y espíritus de fango, dignos de remover tal cloaca.", Historia de los heterodoxos españoles, tomo II, Biblioteca de Autores Cristianos, segunda edición, Madrid, 1967, pág. 523. 
mujeres y tontos. Ven en los papeles periódicos antes que nada la manifestación de una degeneración por comparación con la verdadera cultura, que se transmite en los libros.

Sea como fuere, entre los católicos, al menos algunos entendieron que no bastaba lamentarse cuando en la práctica esas publicaciones venían a ser, poco más o menos, prolongación de la escuela en un número de adultos cada vez mayor. A esto habrá que sumar más adelante los cambios inherentes a la implantación de los nuevos modos de vida que la revolución industrial trajo consigo, y entre ellos no es el menos importante el desarraigo de las tradiciones, la pérdida de la organicidad en las relaciones sociales, y la postergación de las creencias religiosas en el esquema de valores que va a predominar, la secularización de la sociedad, en síntesis ${ }^{15}$. La causa

\footnotetext{
${ }^{15}$ Puede verse una última interpretación de estas transformaciones en CASTILLO CASTILLO, José, Sociedad de público, discurso de apertura del curso 1990-91, Ediciones Universidad Complutense, Madrid, 1990. Otro análisis muy sugestivo en FUSI AIZPURÚA, Juan Pablo, "La Edad de las Masas (1870-1914)", en Historia Contemporánea, Revista del Departamento de Historia Contemporánea de la Universidad del País Vasco, no 4, Bilbao, 1990, págs. 261-272. Una visión clásica en MOSCOVICI, Serge, La era de las multitudes. Un tratado histórico de psicología de las masas, Fondo de Cultura Económica, México, 1985, págs. 25-57 y 231-261. VOYENNE ofrece el siguiente resumen: "Lo que diferencia a la sociedad de masas de las antiguas sociedades de vecindad es, pues: a) las misma existencia de vastas reuniones de individuos; b) su estado de vacuidad moral e intelectual, a causa de la doble acción de desarraigamiento y del trabajo no cualificado; c) la nivelación de sus condiciones de vida y de sus centros de interés; d) el hecho de que estos individuos se agrupen hasta el punto de ser aparentemente idénticos; e) la imposibilidad en que se encuentran de poder comunicar entre ellos a consecuencia de su alejamiento físico, pero sobre todo de su desorganización." op. cit., pág. 20.

Los graves problemas que trajeron consigo algunas de estas transformaciones, llevaron a denunciar el nuevo régimen de vida tanto a la Iglesia como a otros pensadores que fundamentarán las teorías socialistas. Cfr. por ejemplo la encíclica Rerum novarum, y cualquiera de los autores de la corriente "pesimista" de interpretación de la
} 
de este fenómeno podía ser en parte la propaganda indiferentista o contraria a lo sobrenatural difundida desde los ambientes intelectuales y más tarde desde los políticos, realizada en buena medida mediante la prensa; pero junto a ella habría que situar la dificultad que presentaban las estructuras eclesiásticas para adaptarse a las de un nuevo mundo, nacido con rapidez sorprendente, y que se imponía con una fuerza igualmente insólita; un nuevo mundo que requería nuevos modos de acción. Los más intrépidos pusieron manos a la obra: fundaron sus periódicos conscientes de que hacerlo era una obra de caridad inexcusable y un gasto necesario, no un negocio:

"Durante el siglo XIX, los periódicos [católicos] que hemos mencionado se fundaron con la ayuda de subvenciones y donativos, independientemente de toda otra preocupación comercial; servían de portavoz a una personalidad o a todo un equipo, a veces a los dos. Les permitía expresar su punto de vista cristiano o defender la doctrina de la Iglesia de manera algunas veces discutible. Comprendían de antemano que podían perder dinero y el déficit llegó por sí mismo. Participaban de la mentalidad de "obra de caridad". Estos periódicos se sostenían porque era necesario que el buen criterio fuera oído, porque se deseaban propagar ciertas ideas. No conseguían más que unos miles de lectores." 16

No hacían otra cosa que imitar a la primera prensa liberal.

Prensa de masas y prensa de opinión

Pero la dinámica social y económica, al alumbrar la sociedad de masas, llevó pronto a la prensa por otros

revolución industrial. Cfr. DEANE, Phyllis, La primera revolución industrial, Península, sexta edición, Barcelona, 1988, págs. 228 y ss..

16 HOURDIN, Georges, op. cit., pág. 35. 
derroteros, encaminándola hacia la información general, y dándole un cometido propio, diferente de la mera amplificación del rumor o de los conocimientos; en dos palabras, democratizándola e industrializándola17. Es en este momento cuando se plantea la diferenciación entre lo que será la prensa de masas y la prensa de opinión, dentro de la cual podemos situar a la católica. Esta última tenderá a seguir siendo una tribune agrandie, mientras que

${ }^{17} \mathrm{P}$. ALBERT y F. TERROU señalan como factores generadores de esta transformación los políticos y sociales en primer lugar y tras ellos los económicos y técnicos, cfr. op. cit., págs. 32 y ss. Cfr. un análisis concreto de la sociología del fenómeno en MURILLO, F., Estudios de sociología política, Tecnos, Madrid, 1966, pág. 100.

A. de TOCQUEVILLE ha descrito las necesidades sociales que laten bajo estos cambios como sigue: "Cuando los hombres no están ya ligados entre sí de una manera sólida y permanente, no se puede conseguir que un gran número actúe en común, a menos que se persuada a cada uno de aquellos cuya colaboración es necesaria de que su interés particular le obliga a unir voluntariamente sus esfuerzos a los esfuerzos de todos los demás. Eso no puede hacerse habitual y cómodamente más que con la ayuda de un periódico. Sólo un periódico puede llegar a depositar al mismo tiempo el mismo pensamiento en mil mentes." La democracia en América, Aguilar, Madrid, vol. II, págs. 152-153.

VOYENNE, por su parte, resume el cambio del siguiente modo:

"Hasta la aparición de los fenómenos de masificación, la prensa no era nada más que uno de los canales de intercambio social, y no el más extendido. En efecto, sus funciones se limitaban a dos: por un lado, amplificaba el rumor, sin, por lo tanto, anunciar las noticias (éstas eran conocidas mucho más rápidamente por otros caminos); por otro lado, a partir de la Revolución francesa, sirvió de portavoz de algunas individualidades que expresaban y formaban las corrientes de ideas de su época.

"Se puede ver que ni una ni otra de esas funciones tiene finalidad propia. Prolongan simplemente actividades preexistentes, aportándoles como mucho el prestigio de la inscripción. Benjamín Constant llamaba a la prensa política " la tribune agrandie "; en el mismo sentido se hubiera podido decir de otros periódicos que eran la continuación de la palabras de la portera, el eco de los salones, la hoja de anuncios del ministerio. Y esto se decía. Ninguno de ellos hacía nada que no hubiera existido antes y que no hubiera podido hacerse sin él.

"En la sociedad de masas, por el contrario, la prensa desempeña un papel específico. Es prácticamente la única fuerza que forma e informa la masa como tal. Es ella la que actualiza las imágenes latentes, magnetiza las corrientes, provoca las tomas de conciencia de estos millones de seres que son semejantes, y que sin ella no lo serían. Es el único vínculo no solamente entre vastas solidaridades planetarias, sino que incluso, frecuentemente, entre dos vecinos de escalera." op. cit., págs. 20-21. 
la otra, sin dejar de serlo, será sobre todo una nueva industria, un nuevo negocio, regido antes que nada por las leyes del mercado:

"El que quiere convencer debe presentar sus argumentos, hacer intervenir todos los recursos de su talento persuasivo, llevar al adversario a sus atrincheramientos, responder a las objeciones. Una parte de la prensa presenta en efecto estas características: son los periódicos a los que se les llama, precisamente, de opinión. Pero son poco numerosos y no alcanzan nada más que a una minoría de lectores compuesta, como lo hemos señalado, por convencidos de antemano. Esta prensa contribuye ampliamente a mantener el fervor pero no suscita cambios.

"En cuanto a los otros periódicos -los más numerosos, los más populares- es su misma potencia la que les impide proclamar sus convicciones $y$, frecuentemente, tenerlas. Se les llama "influyentes" sin duda por antífrasis. Sabemos, en efecto, que el desarrollo de un órgano de prensa está condicionado por sus posibilidades de satisfacer a la vez a individuos $y$ a grupos muy diferentes. Todo lo que podría dividir a este público es, por definición, ruinoso para el periódico. Los grandes periódicos se ven, por lo tanto, obligados a poner el acento sobre lo que une y callar lo que separa. (...) Los editoriales, los artículos de ideas y, de una manera general, todas las posiciones afirmadas, están casi ausentes en la gran prensa. Cuando se encuentra en ella opiniones sobre temas en controversia, es bajo la forma de alusiones ocultas o de citas de aspecto imparcial, inmediatamente equilibradas por una referencia a la opinión contraria." 18

Lógicamente ese modelo -sin duda creador de opinión también ${ }^{19}$ - no se impondrá absolutamente ni ipso facto, al

${ }^{18}$ VOYenNe, Bernard, op. cit., pág. 156.

19 "Se dirá que la ausencia de opinión no existe y que abstenerse significa incluso tener una. Ciertamente, siempre es posible descubrir en un periódico, cualquiera que sea, una tendencia general. Pero en los órganos de gran difusión ésta se manifiesta de una manera esencialmente negativa. Todo su esfuerzo va dirigido a no sorprender, a no inmiscuirse en las certidumbres adquiridas de sus lectores. Es una actitud, sin ninguna duda. No es propia, se reconocerá para suscitar cambios. Lejos de modificar las posiciones previas de su público, esta prensa recibe por el contrario, su reflejo y su garantía. No tiene el poder de modificar las clasificaciones fundamentales de las que es solamente el producto. Este es el sentido de la humorada que se atribuye a Villemessant: "iYo soy su jefe, tengo que seguirles!". Ibid. pág. 156. Más adelante habremos de ocuparnos de cómo proceden este tipo de publicaciones para modificar la opinión 
contrario, junto a él seguirá existiendo otra prensa que tiene por objetivo no tanto ofrecer productos informativos capaces de venderse masivamente, como proporcionar la información que estima más conveniente a priori, sea cual sea la demanda, es decir, convencer: la que Voyenne llama prensa de opinión. Dentro de este grupo están la prensa de partido, cualquiera que sea la ideología que lo inspira, y la prensa católica, que difunde doctrina y opinión inspiradas en el mensaje de la Iglesia partiendo del esquema de obra de caridad, con la consiguiente dificultad para adaptarse a un entorno que no la considera tal en absoluto.

En España, el escaso grado de modernización y democratización alcanzado por la sociedad durante el XIX propicia la pervivencia e incluso el predominio del segundo tipo de prensa descrito, la prensa de partido o si se prefiere- de opinión o de combate ${ }^{20}$. Conviene no

pública, o al menos intentarlo; procedimientos por otro lado bien conocidos.

20 "(..) a la prensa de combate de los dos primeros tercios del siglo diecinueve iban reemplazándola periódicos con un nuevo espíritu: el espíritu de empresa." MORI, Arturo, La prensa española de nuestro tiempo, Ediciones Mensaje, México, 1943, pág. 13. Cfr. ALMUIÑA FERNÁNDEZ, Celso, La prensa vallisoletana durante el siglo XIX (18081894), tomo I, Servicio de publicaciones de la Diputación provincial de Valladolid, Valladolid, 1977, págs. 279 y 283. El mismo autor ha descrito así el proceso de nacimiento y conformación de una prensa católica española durante el siglo XIX: "Serán los liberales los que primero recurran a la prensa como instrumento de toma de contacto y captación de la opinión pública. Y esto es lógico si se tiene en cuenta que se trata de una nueva ideología que trata de desalojar el campo y sustituir al anterior, amén de por su mayor preocupación esencial por las bases ya que proclama al pueblo como soberano y en último término refrendador de cualquier decisión. Se trata de una cosmosociología frente a una cosmoteología que si no desprecia al menos ignora el parecer popular. De ahí que los defensores del viejo orden recurran más tarde y a regañadientes al campo de la opinión 
perder de vista este contexto para no atribuir en exclusiva a los presupuestos de la prensa católica la causalidad de sus propias características: como cualesquiera otros, con independencia de su credo, los católicos españoles son primeramente hijos de su tiempo y de su tierra y, después, católicos. Además, hay que recordar que el atraso español es especialmente patente en la sociedad y economía castellana en general y vallisoletana en particular, que -como vimos- están a lo más a medio camino entre una antiguorregimental, predominantemente agraria, y otra contemporánea, industrial: una sociedad que por consiguiente no demanda una prensa de masas ${ }^{21}$.

Hecha esta precisión, continuemos con las características generales que definen a la prensa que nos

pública. Se niegan a convertir al pueblo, al simple número, en supremo árbitro y juez de la disputa." "Clericalismo y anticlericalismo a través de la prensa española decimonona", en La cuestión social en la Iglesia española contemporánea, Biblioteca "La Ciudad de Dios", Real Monasterio del Escorial, 1981, pág. 127.

21 «Del mismo modo que existen retrasos económicos, técnicos o culturales, se constata lo que podría llamarse "retrasos de prensa". En algunas sociedades, incluso industrializadas, los contactos personales o de pequeños grupos siguen siendo importantes y aseguran, paralelamente a la prensa y a veces mejor que ella, funciones sociales idénticas. Se comunican unos a otros las noticias del día, se discuten los aspectos políticos, se cuentan historias graciosas. Las costumbres sociales arraigadas mantienen lugares permanentes de intercambio: la plaza pública, el café o, simplemente, el portal de las casas. Se hace allí, a horas fijas, una especie de periódico hablado. ¿Para qué comprar el otro que es mucho menos interesante?" VOYENNE, op. cit., págs. 110-111. Sobre la convivencia de medios de comunicación típicos de sociedades simples con los característicos de las complejas, pueden verse ALMUIÑA FERNÁNDEZ, op. cit. tomo I, págs. 51 y ss. y passim; SOLÍs, Ramón, El Cádiz de las Cortes. La vida en la ciudad en los años de 1810 a 1813, Instituto de Estudios Políticos, Madrid, 1958, págs. 269, 363, y 457 y ss.; y GIL NOVALES, Alberto, Las sociedades patrióticas (1820-1823). Las libertades de expresión y de reunión en el origen de los partidos políticos, Tecnos, Madrid, 1975, passim. 
ocupa. La segunda deriva directamente de la que acabamos de ver: si este tipo de publicaciones no está dirigida a la masa social, se dirige a un grupo concreto, a saber: el integrado por los católicos. Esta afirmación resulta paradójica para España. En efecto, la pregunta surge de inmediato ise puede distinguir en un país de tradición católica, en el que prácticamente toda la población es -al menos nominalmente- católica, un grupo que se caracterice por practicar esta religión? La respuesta global debería ser "no", pero hay algo que permite contestar "sí": se puede definir un grupo católico en la sociedad española desde el momento en que hay otro grupo que se define por su enemiga contra la Iglesia. Las características de este grupo, genéricamente anticlerical, habían evolucionado a lo largo del siglo XIX hasta llegar a ser a finales de éste $\mathrm{y}$ principios del $\mathrm{xx}$ las descritas por Payne:

"A diferencia del anticlericalismo anterior, que a menudo derivaba de la rivalidad política o económica, o de la crítica de los defectos personales y culturales de los clérigos, el anticlericalismo antirreligioso era ideológico por su origen y categórico por naturaleza. Se oponía a las creencias religiosas y a su influencia en la sociedad, y se proponía reducirlas o eliminarlas. Esto debía conseguirse, primero, suprimiendo todos los privilegios de la Iglesia, y en segundo lugar poniendo fuera de la ley al clero o, en casos extremos, liquidándolo físicamente. Era la consecuencia de la dimensión radical del liberalismo moderno $y$ de las filosofías materialistas revolucionarias, en particular en atmósferas sociales y culturales que no habían entrado en una plena laicización moderna» 22

${ }^{22}$ PAYNE, Stanley G., El catolicismo español, Planeta, Barcelona, 1984, págs. 161-162. En cuanto al apoyo social conseguido por esta tendencia, después de ser incubada por la propaganda liberal más radical durante todo el siglo, el mismo autor señala: "En aquel momento [en 1868], el radicalismo español había avanzado ideológicamente y disponía de un apoyo social mayor que en épocas anteriores. En sus elementos más extremistas, el anticlericalismo dejaba el lugar a la antirreligión. Medio siglo antes, se miraba a la 
Esto forzaba sin lugar a dudas la existencia de un movimiento defensivo, pero -como tendremos ocasión de verno garantizaba la coherencia del sector católico, lo que para la prensa católica resultaba una dificultad, ya que la difusión de este tipo de medios se ve tanto más favorecida cuanto más particularizado esté el grupo social al que se dirige 23 .

\section{El modelo empresarial}

De estas características generales se deriva un modelo empresarial también propio, que distingue la empresa de prensa de masas de la católica de forma paralela a como las distingue su finalidad. En un primer

religión como el baluarte de un orden institucional anacrónico, cuya estructura debía modernizarse. La nueva generación de radicales, ya no meros liberales, sino republicanos federales y democráticos, de tendencia racionalista utópica, consideraban la religión como un mal fundamental que debía reprimirse $y$, de ser posible, extirparse por completo. Por eso, en muchas ciudades, las juntas revolucionarias emprendieron, a fin de 1868, una vigorosa persecución, restringiendo la libertad de acción de los obispos y del clero, a veces cerrando o saqueando las iglesias $y$ hasta atacando físicamente a los sacerdotes.", pág. 124 .

23"(...) una comunidad fuertemente particularizada se cierra en sí misma, tiene pocos contactos con los otros que no comprende y que no la comprenden. Ahí se desarrolla, en efecto, una prensa, pero sirve solamente para el uso interior y continúa siendo artesanal mientras que la sociedad ya no lo es." VOYENNE, op. cit., págs. 110-111.

Para Bélgica tenemos una descripción de ese proceso general, particularizado para el caso católico: "Certains catholiques ont voulu une presse particulière pour le peuple et ont organisé une presse spécialement pour la masse laborieuse jusqu'en 1914, en fonction de son émancipation, de l'Eglise et du parti catholique." GÉRIN, Paul, Presse Populaire Catholique et Presse Démocrate Chrétienne en Wallonie et à Bruxelles (1830-1914), Editions Nauwelaerts, Louvain, Paris, 1975, pág. III. El autor distingue en esta obra los dos tipos de prensa que cita en el título, el uno -la popular- no acepta los planteamientos sociales liberales $y$ está orientado a un sector restringido con ánimo de preservarlo de las influencias externas; mientras que el otro -la prensa demócrata cristiana, acepta el hecho de la sociedad liberal y tiende a hacer presentes en ella a los católicos y sus intereses. Cfr. especialmente págs. 261-263. 
momento bastaba el entusiasmo de una sola persona para sacar a la calle una publicación periódica, que no era más que el canal de difusión de las ideas del editor, ya que "Las ideas liberales se han extendido en una época en la que técnicamente hablando, no era más difícil ni costoso fundar un periódico que alquilar una sala de de reunión (...) •"24 La creciente complejidad característica de las sociedades industriales, con la extensión de la instrucción y del sufragio, reclamará luego otro tipo de planteamientos empresariales ${ }^{25}$. Al igual que en otros ámbitos de la actividad económica habrá que recurrir primero a las empresas familiares para allegar más capital, y más tarde a las sociedades mercantiles hasta llegar a las sociedades anónimas, a la vez que el trabajo se especializa y las plantillas se amplían. Se configura así una nueva "industria de síntesis que tiene por objeto el acopio, la elaboración, el acondicionamiento y la venta

${ }^{24}$ Cfr. ALMUIÑA, op. cit., tomo II, págs. 724-725; TUSELL, Javier, Oligarquía y caciquismo en Andalucía (1890-1923), Planeta, Barcelona, 1976, pág. 358; TIMOTEO ÁLVAREZ, Jesús, y otros, Historia de los Medios de Comunicación en España. Periodismo, Imagen y Publicidad (1900-1990), Ariel, Barcelona, 1989, págs. 41-49; LEÓN CORREA, Francisco Javier, León en el último tercio del siglo XIX. Prensa y corrientes de opinión (1868-1898), Diputación Provincial de León, León, 1988; y VOYENNE, Bernard, La Prensa en la Sociedad Contemporánea, pág. 200 .

25 "Desde la segunda mitad del siglo XIX, la escolarización y el sufragio universal han llevado a la prensa, que había alcanzado hasta entonces categorías restringidas de la población, la casi totalidad del público de los países avanzados. Métodos apropiados de producción y de venta permitieron responder a las necesidades de esta clientela muy amplia e incluso ir por delante de ella. (...)" VorenNe, op. cit., pág. 20. Pueden verse ejemplos concretos en las monografías de ALMUIÑA y LEÓN que hemos citado, y también, para la prensa nacional, en IGLESIAS, Francisco, Historia de una empresa periodística. Prensa Española. Editora de "ABC" $y$ "Blanco $y$ Negro" (1891-1978), Prensa Española, Madrid, 1980 , págs. 66 y ss. y passim. 
de las noticias así como de sus comentarios»26. Pues bien, justamente esa definición de prensa o, mejor dicho, de empresa de prensa, resulta inaplicable en buena medida a nuestro periódico. Veamos por qué.

Debemos tener presentes en primer lugar las peculiaridades que en general presentan en su organización las empresas que tienen un carácter ideológico, pero nos interesan más las que dentro de ese conjunto caracterizan a las empresas periodísticas católicas. Como Hourdin señala para Francia

"Todos los periódicos [católicos hasta 1870] eran considerados por quienes los publicaban como una especie de cátedra que les permitía exponer sus opiniones. Por el contrario, la calidad y cualidad de la información, es decir, la rapidez y seguridad de su difusión, eran dejadas en segundo lugar. Ciertamente que en el siglo XIX hubo grandes periodistas cristianos, a quienes un público adicto inspiraba el medio de expresión. Sin embargo, hablando con propiedad, no hubo prensa católica, en el sentido de que no existía un grupo comercial dedicado a la solución del problema técnico que entraña la publicación regular de diarios y otros periódicos. "La Casa de la Buena Prensa en 1873 distingue por vez primera los presupuestos del problema y se propone resolverlos. Los cristianos descubren entonces lo que significa una empresa comercial de prensa» 27

Para España el proceso es el mismo28. Se planteaba por tanto la necesidad paradójica de dotar a una obra de caridad, deficitaria por definición, de una estructura empresarial. La solución que se alcanza es distinta según los casos, pero lo más común es que se trate de soluciones clericales; es decir, no son hombres del mundo de la

26 Ibid., pág. 30 .

${ }^{27}$ HOURDIN, G., op. cit., págs. 33-34.

${ }^{28}$ Cfr. J. TARIN IGLESIAS, ibid., págs. 123-129. 
empresa los que asumen la tarea de la publicación de los medios católicos, sino que han de ser los organismos eclesiásticos con más experiencia en la promoción de obras de caridad, las órdenes religiosas, las encargadas de promover ahora empresas editoras de periódicos ${ }^{29}$. Lógicamente, el tipo de empresa que se alcanza por este camino es por completo característica, hasta el punto de que sus canales de distribución serán distintos de los habituales para el resto de la prensa -se distribuirá sobre todo por suscripción, no por venta al número-, carecerá de intereses comerciales y tendrá un comportamiento anormal ante la publicidad. Se trata por lo general de publicaciones no diarias, revistas, de tirada limitada,muchas veces gratuitas, que tiene más carácter de boletín que de órgano informativo.

Este esquema -que tuvo y tiene éxito para
determinadas publicaciones ${ }^{30}-\quad$ resultaba claramente

29 "[La buena prensa] Fue fundada con un cierto contenido apostólico y en un especial clima de acción algo tumultuoso. Es imposible separar su fundación de las grandes peregrinaciones populares que, a partir de 1872, los PP. Ricard y Bailly organizaron hacia todos los lugares importantes para un espíritu cristiano. Con estas peregrinaciones los religiosas Asuncionistas querían ayudar a las gentes sencillas que permanecían fieles a encontrar de nuevo las sendas de su piedad católica, a sentirse numerosos y solidarios y a manifestar públicamente su fe. En su peregrinar hacia los santuarios de Francia dieron además con dos ideas: la promesa nacional de construir en la colina de Montmartre una gran basílica redonda y blanca dedicada al Sagrado Corazón y la publicación de un periódico económiconHOURDIN, G., op. cit., pág. 38 .

${ }^{30}$ En 1887 se publican 118 revistas religiosas, en 1900, 103 -el número de diarios católicos rondaba los 20 a principios de siglo-, y en 1920, 339. Cfr. TARIN IgLESIAS, J., op. cit., pág. 136. Para la actualidad cfr. CAPUANO, Carlo, La stampa cattolica in Italia, Sellenio editore, Palermo, 1982, que se ocupa exclusivamente de este tipo de prensa católica. 
inadecuado cuando lo que se intentaba era influir en el ámbito de la opinión política. El medio por antonomasia para actuar en ese terreno es el diario, y, además, ahí no cabía ya la gestión directa por parte de institutos religiosos,obligados a mantenerse al margen de opciones políticas concretas. Los diarios católicos heredan la inspiración empresarial de la prensa católica que hemos descrito, pero se ven obligados a adoptar otra forma empresarial, en todo semejante a los diarios que apoyan a un determinado personaje político. Al igual que los líderes políticos locales adquieren o fundan su periódico, distintos prohombres católicos -como Justo Garrán- cargan sobre sus hombros y pagan de su bolsillo el órgano correspondiente con el fin de defender los intereses católicos en la vida política. Pero otra vez hay que decir que la fórmula no era del todo válida, pues si bien en algunos aspectos se trataba de fenómenos semejantes, también estaba claro, al menos en teoría, que los católicos por el hecho de serlo no estaban obligados antes al contrario- a apoyar a un candidato concreto. Así pues, la definición es siempre un problema para el diario católico, de forma análoga a como lo es para el partido político "católico". La diferencia estriba en que mientras que los partidos no se denominarán católicos de ordinario, y la jerarquía recordará que no existe una opción política única para los fieles, los periódicos sí, y esto con el apoyo y la certificación de la jerarquía eclesiástica. La comparación entre uno y otro fenómeno resulta interesante, 
y nos ocuparemos de ella pocas líneas más abajo. Antes de hacerlo queremos extraer dos conclusiones del análisis de los modelos empresariales que acabamos de hacer.

La primera se refiere a la financiación de la prensa católica. Una prensa que ha de mantenerse con independencia de los gustos de sus potenciales compradores, precisa una financiación ajena al mercado, que va a ser por lo general aportación de católicos hacendados. De esta forma, la prensa confesional queda liberada de la mediatización que supone la opinión más común, para atarse a la opinión de quienes la financian: su fidelidad a la doctrina de la Iglesia será la de sus propietarios, y lo mismo hay que decir de su interpretación -más o menos acertada- de esa doctrina.

La segunda se refiere a la caracterización profesional de los que elaboran esta prensa. El oficio de periodista está en sus comienzos. Pocos hombres hay que vivan exclusivamente del periodismo, y difícilmente pueden contribuir a mejorar los sueldos de éstos empresas que sobreviven gracias a donativos. Empezando por el director, que muchas veces es también el propietario y financiador de la publicación, hay que decir que a los que trabajan en la prensa -más todavía en provincias- se les puede llamar periodistas después de llamarlos por el nombre de su otra y fundamental ocupación. En la España de los años veinte podemos decir que el periodismo es un subempleo, segundo 
empleo, afición u obligación de conciencia más que una profesión ${ }^{31}$.

\section{La confesionalidad}

Como dijimos unas líneas más arriba, existe un cierto paralelismo entre partidos católicos y prensa católica de opinión. La cuestión central, motivo de frecuentes debates entre los católicos -sobre todo para organizaciones políticas o sociales- viene a ser la confesionalidad del partido. Tal polémica no se presenta tan acusada para las publicaciones, debido a que en este caso los criterios para identificar como confesional un medio están mejor delimitados. Partiendo de las diversas definiciones de confesionalismo ${ }^{32}$ hemos elaborado las siguientes notas:

\footnotetext{
${ }^{31}$ Para la situación profesional de los periodistas de provincias en el siglo XIX cfr. ALMUIÑA, op. cit., págs. 105-112.

${ }^{32}$ Una primera definición contemporánea del concepto la encontramos en un artículo de Salvador Minguijón publicado en 1921, en el que distingue la simple inspiración católica del confesionalismo en las obras sociales: "(...) la confesionalidad tiene dos fines, cristianizar y unificar. Ha de manifestarse, por consiguiente, en dos modos de actividad: de un lado la regeneración de las almas como dice L'Osservatore Romano, y la tendencia hacia una concepción más pura y más religiosa de la vida social; de otro lado, la disciplina y la sumisión a la autoridad de la Iglesia." Salvador MINGUIJON, "En torno a la confesionalidad", El Debate, 30/9/1921.

Oscar ALZAGA enumera cuatro acepciones distintas: "Cuatro criterios, al menos, se han empleado para definir una organización cultural, sindical o política como confesional, a saber: a) el empleo de los términos "cristiano" o "católico" en la denominación del movimiento; b) su inspiración en la doctrina social de la Iglesia; c)ser necesario para afiliarse profesar la religión católica; d) estar sometida la organización a las directrices de la jerarquía eclesiástica.", La primera democracia cristiana en España, Ariel, Barcelona, 1973, pág. 208.

Finalmente, Juan Ma GUASCH aporta tres acepciones para el concepto: "Por nuestra parte creemos que confesionalismo puede entenderse del siguiente modo: a) confesar la fe cristiana en la vida personal; b) el reconocimiento que el Estado hace en sus normas y en su funcionamiento de la ley de Dios; c) entender que hay en cada caso
} 
El periódico está a medio camino entre la institución de tipo educativo y el partido político. Por esta razón le son aplicables por parte de la Iglesia los criterios que sigue en uno y otro caso, dependiendo sobre todo de los contenidos de la publicación.

En el caso de los diarios, orientados a la opinión política, cuanto mayor sea su espíritu de combate, más próximos están a un medio político. En este sentido la Iglesia no los reconoce como medios propios, sólo considera tales los Boletines Oficiales de las diócesis u otros medios similares. Del espíritu que informa al diario depende que intente o no monopolizar la opinión católica identificándola con la suya.

El modo de garantizar al mismo tiempo la corrección doctrinal de la publicación y la independencia de la Iglesia es el ejercicio de la censura eclesiástica. Este instrumento, experimentado ya en la vigilancia ejercida sobre la publicación de libros, es de carácter voluntario y se orienta a la revisión de los contenidos que afectan a cuestiones de fe y costumbres, sin intervenir para nada en cuestiones de orientación política o técnicas, de las que la Iglesia como tal se desentiende.

En el caso concreto de la España de la Restauración, la diferenciación con respecto a los periódicos políticos

\footnotetext{
una fórmula o solución que se adapta "hic et nunc ", a los principios éticos del cristianismo.

"Así como las dos primeras opciones son plenamente positivas, la tercera supone una restricción del pluralismo. Dentro del respeto a los preceptos morales, cabe en las cosas contingentes una multitud de opciones que no es lícito restringir." "El Debate" y la crisis de la Restauración (1910-1923), Eunsa, Pamplona, 1986, pág. 300, nota 1.
} 
liberales y liberal-conservadores hace que los órganos de opinión que reclaman la denominación de católicos sean casi siempre próximos a las corrientes políticas tradicionalistas. Los problemas que pueden surgir en este sentido son por consiguiente reducibles al de la compatibilidad de las distintas tendencias políticas con las enseñanzas de la Iglesia.

Con esto tenemos esbozada la idea de qué es un periódico católico en el primer tercio del siglo. Vamos a fijarnos con detalle en el que nos ocupa.

"Diario Regional, S.A."

La única sociedad anónima creada en Valladolid en $1926^{33}$ tenía por objeto hacerse cargo de un negocio ruinoso. Ya conocemos los porqués de cada uno de los adjetivos. Los fundadores de la misma son un grupo de dos empresarios y diez profesionales de la ciudad: seis abogados, dos ingenieros, un notario y un médico ${ }^{34}$, una

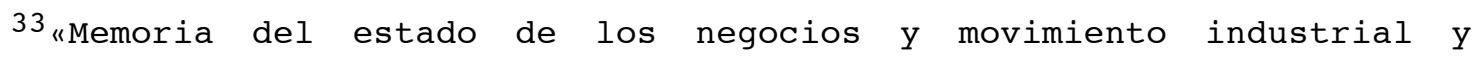
mercantil, en la provincia de Valladolid, durante el año 1926", en Boletín de la Cámara oficial de Comercio e Industria de Valladolid, no 134, año XIX, noviembre de 1927, pág. 11.

${ }^{34}$ Constantino Mateo González, propietario; José Jalón Semprún, abogado; Gregorio Merino Pinedo, propietario; Pascual Pinilla Jiménez, ingeniero; Joaquín Pérez Agote, abogado; Angel María Llamas Zapatero, ingeniero; Rafael Serrano y Serrano, notario; Guillermo Gil de Reboleño, abogado del Cuerpo Jurídico Militar; Manuel Sánchez Belloso, abogado; Antonio Gimeno Bayón, abogado; José María Rodríguez Villamil, abogado; Antonio Miguel Romón, médico. Se señala también como fundador a Romualdo Galindo Zorita, del que no conocemos la profesión y que tampoco figura en los órganos de gobierno de la sociedad en lo sucesivo. "Notaría de D Ignacio Martín de los Ríos. Oficial Letrado excedente del Consejo de Estado. № 1.227 de 14 de diciembre de 1926 . 3 a copia de la escritura de constitución de la sociedad "Diario 
buena síntesis de fuerzas vivas del catolicismo militante en una capital de provincia como valladolid, de los cuales, al menos siete participaron activamente en política en partidos de derecha.

La empresa se funda con un capital social de 500.000 ptas $^{35}$, de las que se ponen en circulación en el momento de la fundación 250.000. Por lo que se refiere a la suscripción de acciones, nuestra única fuente es el listado nominativo de 1959 del que, con las oportunas reservas ${ }^{36}$ podemos deducir:

1.- El capital social estaba muy repartido: hay numerosos accionistas que poseen una sola acción de 100 o de 500 ptas y ninguno posee más de un $2 \%$ del capital social, a no ser que consideremos como un todo las acciones que están en manos de la familia Garrán, en cuyo caso ésta controlaría el $4,8 \%$, lo que no cambia mucho las cosas.

2.- El grupo de los fundadores suscribe un 10\% del capital aproximadamente.

Regional, S.A." otorgada ante el Notario DON EMILIO IGLESIAS MAGADÁN", Archivo Privado de "Gráficas Andrés Martín, S.A.", en adelante A.P.G.A.M.. No firma el acta fundacional, pero se señala como fundador a Romualdo Galindo Zorita.

${ }^{35} \mathrm{Mil}$ acciones de la serie A de 100 ptas cada una y ochocientas de la serie B de 500 ptas cada una. Cfr. art. 6 de los "Estatutos" de la sociedad, recogidos en el apéndice 3 .

${ }^{36}$ Vid. en el apéndice 3, apartado "Propiedad, capital social y accionistas", subapartado "Ampliación de capital de diciembre de 1956" la relación de accionistas en 1959. En el mismo apéndice, en el subapartado "En el momento de la fundación" hacemos las observaciones oportunas y formulamos las hipótesis en que se basan las afirmaciones hechas en el texto. 
3.- Las suscripciones de personas o entidades eclesiásticas -Arzobispo de Valladolid, Obispo de Segovia, Religiosas Reparadoras, Colegio de Lourdes, etc.- suman poco más de 7.000 ptas. Si le sumamos las 10.000 de la Casa Social Católica, este grupo que podemos llamar "Católico institucional" aporta un 3,5\% del capital.

4.- La impresión que causa el reparto del capital es más de suscripción benéfica que de reparto de poder económico: nos parece verosímil la explicación de que se formaran lotes que irían de las 10.000 a las 100 ptas escalonándose prácticamente de 500 en 500 , de los que se hacen cargo diversas personas o entidades según su capacidad económica.

El modelo de empresa periodística definido en los estatutos ${ }^{37}$ de la sociedad se inspira en buena medida en el adoptado por $E I$ Debate, $y$, por lo que se refiere a la orientación el artículo 4 no deja lugar a dudas:

"El criterio doctrinal de Diario Regional y de las demás publicaciones que la sociedad emprendiere, será de completa independencia, pero informada siempre en las normas $y$ enseñanzas de la Iglesia Católica, declaradas por las Autoridades Legítimas a las que la sociedad se somete y somete también a la dependencia profesional del periódico.

"Un consejo de redacción será el encargado de mantener siempre este espíritu en las publicaciones de la Sociedad."

Los órganos de gobierno de la sociedad son la Junta General de accionistas, el Consejo de Administración, el Gerente y el Consejo de Redacción. Los tres primeros tienen las facultades acostumbradas en este tipo de sociedades, el cuarto se compone de cinco miembros que -

${ }^{37}$ Vid. apéndice 3 . 
como vimos- velan por la adecuada orientación del periódico. A sus reuniones pueden asistir cuando el Consejo lo estime conveniente el Director del periódico, y el censor del mismo que haya designado el Prelado, ambos con voz pero sin voto (art. 28). La importancia atribuida a este órgano, así como a la orientación del diario se pone de manifiesto en las disposiciones sobre modificación de los estatutos: ésta podrá hacerse en la forma que la Junta General acuerde, salvo en el caso de que la modificación se refiera a lo dispuesto en los artículos 4 y 28, para lo que se requerirá la reunión de las cuatro quintas partes del capital y la misma fracción de los accionistas. Es decir, es prácticamente imposible.

De esta forma quedaba listo para su uso el que se quería fuera defensor de los intereses católicos en Valladolid. De cómo se entendió esa misión y de sus frutos efectivos tratan las siguientes páginas. 



\section{La Segunda República: periodismo de combate}

«Necesitamos el asenso de la opinión pública y a ella nos dirigimos solicitando de todos aquellos hombres de buena voluntad que compartan nuestro ideario, vengan a la lid dispuestos a cumplir sus deberes de Católicos y de patriotas.

La quietud es incompatible con la actualidad; se requiere energía, movimiento, lucha, calor en la idea, y ello sólo se consigue con la prensa.» Diario Regional, 17 de noviembre de 1931. 


\section{UN DIARIO MORIBUNDO}

Resulta fácil definir el Diario Regional de los años treinta: el órgano de opinión de la derecha católica vallisoletana. Su estructura formal está en función de esta finalidad y es por tanto la de un órgano de opinión más que de información. Su vida se identificaba con la del grupo de opinión al que servía, y los efectos que tuvo el fracaso de la Dictadura, que era también el de la "sana regeneración" preconizada por muchos de estos hombres, colocaron al periódico al borde de la desaparición. Así lo describen ellos mismos un año más tarde:

\footnotetext{
"Acaecimientos de todos conocidos y que acaso sea inoportuno rememorar, pero a los cuales no fue ajena la masa de opinión que al parecer coincidía en ideología con la que con orgullo y como verdadera gloria sustenta DIARIO REGIONAL, engendraron en él, primero una vida lánguida, después una serie de vacilaciones con marcada indecisión y desorientación y por último un peligro de desaparición por inanición derivada no tanto de la falta de medios materiales como de la decadencia espiritual." 38
}

Esta desmayada empresa ofrecía al comprador a principios de 1931, por el módico precio de diez céntimos, un gran pliego de papel de 82 por 57,2 centímetros, doblado en dos, que contenía una hoja central de mitad de ancho los diarios, o bien otro pliego idéntico los

38 "Nuestras reformas. La evolución de "Diario Regional".", editorial, 5/6/1932, pág. 1 . 
domingos $^{39}$.El espacio de cada página se distribuía en siete columnas de 5 centímetros de ancho. No había otras ilustraciones que las de algunos reclamos publicitarios especialmente los domingos-, y las fotografías eran un extraordinario reservado al Papa en su onomástica o a la "encantadora señorita" elegida reina en el festival de la prensa celebrado cada año.

La maquetación era bastante precaria: frecuentemente un artículo encabezado por un titular a dos columnas se distribuía en cuatro distintas con tres alturas diferentes, y eso cuando no terminaba en una página distinta. El tamaño de los tipos empleados en los titulares era casi siempre el mismo: en nada se diferencian formalmente la cabecera de la crónica de la Casa Real y la de un artículo de opinión o un editorial. Por último la defectuosa composición, con unos tipos más altos que otros y pequeñas manchas aquí y allá, dejaba ver que la maquinaria estaba tan deteriorada como el espíritu de la empresa.

${ }^{39} \mathrm{Vid}$. en el apéndice 1 la evolución exacta del número de páginas. 


En cuanto a la
distribución de las
secciones 40 , nada rígida,
normalmente la primera
página estaba dedicada a
la información política
nacional y a la escasa
internacional que se
ofrecía, mientras que en
la última se concentraba
la local. En estas dos
encontramos también los
editoriales, que son
frecuentemente

sustituidos

por

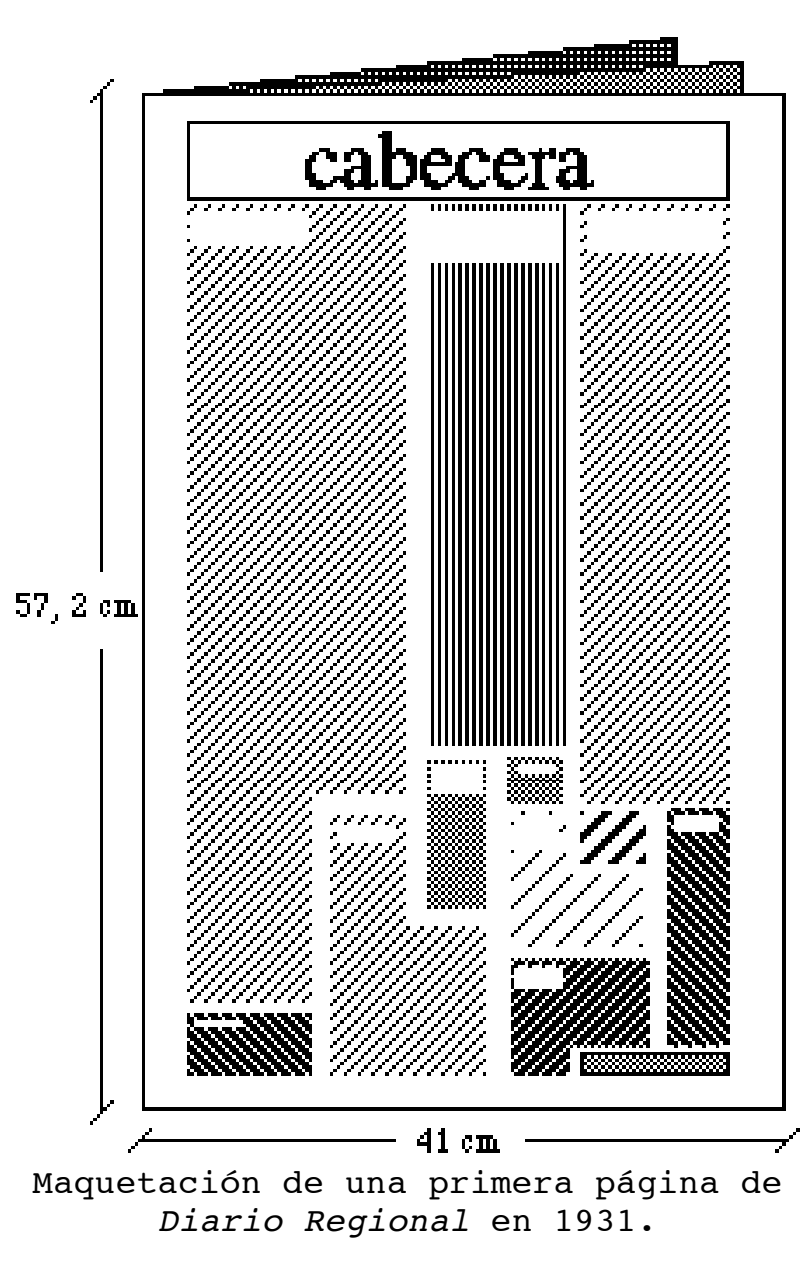

Maquetación de una primera página de Diario Regional en 1931 .

artículos de fondo firmados. En las centrales aparecían invariablemente la agenda local, "La vida católica" información y comentarios religiosos- y la “Información agrícola y mercantil". Junto a ellas se publicaban según los días un comentario de política internacional, deportes, toros, teatro, crítica de libros, agenda de espectáculos, la breve información provincial y regional, que atiende al resto de las capitales castellanas y a una veintena larga de pueblos de la provincia, y el folletón

\footnotetext{
${ }^{40}$ Puede verse en el apéndice 2 la relación detallada de las distintas secciones y sus principales características.
} 
cuando lo haya41. La publicidad era escasa; sólo cuando el periódico alcanzaba las ocho páginas había una dedicada por entero a ella: "Creaciones Publicitas", obra de la que será agencia de publicidad del periódico hasta junio de 1932; el resto de los días dos o tres anuncios y poco más de una decena de "Anuncios breves" son todos los reclamos comerciales publicados. Pero había otros -también económicos, pero de carácter bien distinto- en los que el periódico pone mayor empeño: las suscripciones. Diariamente se da cuenta de la cuantía de la recaudación para el motivo de que se trate. Las finalidades de las colectas en 1931 dibujan los trazos más gruesos del perfil del diario.

En enero tenemos tres cuestaciones, una "A favor de la Guardia Civil y de las víctimas que murieron en el cumplimiento de su deber durante el intento revolucionarion, para la que se ha constituido una comisión gestora ajena al periódico. Desde el diario se recomienda a esa comisión que se recojan donativos no sólo en los bancos sino también en periódicos, ya que "El público está más acostumbrado a ir a ellos", afirmación bien significativa. La segunda tiene por finalidad un "Homenaje al sr. Arzobispo: suscripción para edificar la iglesia parroquial de San Juan". La tercera se pone en

\footnotetext{
${ }^{41}$ En 1931 se publicarán dos folletones: en mayo "Así es Moscou (Nueve años en el país de los soviets)", por José Douillet, cónsul de Bélgica en Rusia, y en octubre "Los piratas del Halifax" de Julio Verne. Cfr. apéndice 2 .
} 
marcha "En favor de unos artistas": se trata de actores de teatro que se encuentran en una situación difícil y que acuden a Diario Regional por recomendación del Gobernador civil para que el periódico inicie una suscripción en su favor. En mayo comienza otra "Por los obreros parados", en colaboración con una iniciativa del alcalde socialista, Landrove; y en noviembre otra más "para la total renovación de Diario Regional ". Por motivos que no hace falta aclarar no se publican los resultados de esta última cuestación, que -como veremos- adopta una forma sui generis.

En cuanto a la información, el periódico ofrece la que le llega, no hay reporterismo42. La internacional y nacional -servida por las agencias43-viene desde Madrid normalmente en los trenes correo, y, por lo que se refiere a Valladolid, las reseñas de los actos culturales,

\footnotetext{
${ }^{42}$ Ciertamente, son de elaboración propia las crónicas teatrales, crítica taurina, deportiva y bibliográfica o los sucesos, pero esto no supone una tarea de "descubrimiento" de la noticia sino solamente el seguimiento rutinario de la vida de la ciudad. Significativamente la mayor parte de estas secciones no llevan firma: la labor del redactor es anónima.

${ }^{43}$ No se cita nunca la agencia de noticias que es fuente de las mismas. Hay dos que son características del periódico: la "Agencia Internacional Arco", agencia de colaboraciones para la que trabajan buena parte de las firmas que aparecen en el periódico, y la agencia "Fides" especializada en noticias relativas a la vida de los católicos en otros países, especialmente en tierras de misión.

Además de las noticias de agencia son frecuentes las informaciones especializadas extraídas de otras publicaciones: El Financiero para temas económicos, diversas revistas católicas españolas, otros periódicos de la misma tendencia, publicaciones francesas sobre temas agrarios, y alguna vez sobre temas políticos relacionados con la actualidad española, etc. También es frecuente que reproduzcan algún editorial de otros periódicos, además de los retazos que ofrecen de ordinario en la sección "Para el curioso lector".
} 
políticos, benéficos o recreativos, propios de la ciudad, tiene las más de las veces el sabor del resumen elaborado por los protagonistas u organizadores de los mismos, con el inevitable latiguillo "el señor $Z$. fue muy aplaudido", - la sobrecarga de adjetivos correspondiente ${ }^{44}$. Solamente las crónicas deportivas, taurinas o teatrales y las cuestiones políticas locales o nacionales son vivamente comentadas por iniciativa propia.

Así las cosas, prácticamente todo el dinamismo del periódico depende de la pujanza de su orientación política y la tensión que rodee las cuestiones abordadas: ahí están las claves de su capacidad de comentar o formar opinión, que es lo original y propio de nuestro diario, tarea que se aborda en los diversos artículos de fondo de carácter editorial o firmados ${ }^{45}$. Veremos en las páginas siguientes cómo las transformaciones políticas de 1931 propiciaron una reanimación del periódico que afectó primero a su misma estructura formal -no serán extraños lo titulares a toda plana antes muy raros-, después a su director, y al fin a toda la empresa: desde la maquinaria al Consejo de

\footnotetext{
${ }^{44}$ En este sentido el periódico resulta una buena fuente para conocer el dinamismo de las distintas asociaciones, especialmente vinculadas a la Iglesia: Sindicatos Católicos, Casa Social Católica, Juventudes obreras Católicas, Acción Católica, etc.

${ }^{45}$ No hay comentarios elaborados por redactores, todos son del director - de los colaboradores. Entre los comentaristas de la política nacional predominan en estos meses las firmas de hombres vinculados al Grupo de la Democracia Cristiana: Severino Aznar, Manuel Siurot, Salvador Minguijón; y las de los propios consejeros de la empresa editora.
} 
administración; un difícil proceso cuyo término se anuncia con sones de gloria en junio de 1932:

"Habrá periódico; es decir, ya lo hay, y si antaño hubo quien
creyó próximo su fin, hoy DIARIO REGIONAL, orgulloso de su
ideología, puede exclamar: "surrexit: hic est". "Resucitó:
aquí está"." 46 Estas palabras u otras parecidas van a ser el estribillo de la historia que queremos relatar, historia que en sus primeros momentos es, como dijimos, la historia del portavoz de la derecha católica vallisoletana.

\section{LA VIEJA POLÍtica ha MUERTO: iVIVA EL REy!}

Así se puede resumir la actitud de Diario Regional a comienzos del año 1931. La idea se repite una vez y otra con distintas palabras y matices, pero siempre con tonos de urgencia ante la necesidad de que nuevos hombres con un nuevo estilo acudan a la palestra política representando a las derechas. La tarea no admite demoras porque los "auténticos problemas" de España los económicos y sociales- sólo serán atendidos cuando la política sea colocada en su lugar por hombres honrados 47 . La enfermedad de España es la distorsión introducida en la vida nacional por una política sobredimensionada y corrupta, a la que algunos oponen insensatamente sus afanes revolucionarios. Los sucesos de Jaca han sido elocuentes en este sentido:

\footnotetext{
46 «Nuestras reformas...", DR, loc. cit..

${ }^{47} \mathrm{DR}$, 29/1/1931, pág. 1, editorial: "La España artificial y la verdadera".
} 
"La República que se nos iba a venir encima"-como rezaba el titular del editorial de Diario Regional el 14 de enero-, socialista, anticatólica, ha sido reprimida por la fuerza una vez, pero eso no basta. Esa revolución frustrada acabará por llegar si las gentes de orden no se unen para solucionar eficazmente los problemas que aquejan a España. Para ello deben despertar de su perezoso letargo, movilizarse para actuar si no quieren padecer ${ }^{48}$.

De este modo, pese a la reiterada afirmación de que la política no es lo más importante, prácticamente todo lo que es opinión en el periódico girará en torno a este problema, que por su urgente demanda de soluciones se antepone a todos los demás. El Rey, o mejor, la Monarquía, se convierte en la bandera del movimiento antirrevolucionario que se preconiza49. Se pretende evitar

\footnotetext{
${ }^{48} \mathrm{El}$ editorial citado resume las ideas vertidas por Fermín Galán en su folleto Nueva creación, que son interpretadas como el programa que se hubiera aplicado de triunfar la sublevación de Jaca. El editorialista concluye: "Ello impone (...)a todos los hombres interesados en conservar aquello que el vandalismo revolucionario quiere destruir, el deber ineludible y apremiante de formar un haz nacional de voluntades, de esfuerzos y de contrapropaganda para conjurar un peligro que está latente y palpitante en el ambiente que nos rodea."

${ }^{49} \mathrm{El} 23$ de enero de 1931, un recuadro en negrita proclama en la primera página de DR:

"iVIVA EL REY!"

"Ni alabarderos ni cortesanos, ni escuderos del Trono ni idólatras de la Monarquía, ese vítor quiere decir que, si hay quienes hacen alarde de valentía vitoreando a la República -y no nos interesa saber si son valientes o lo fingen-, no queremos caer en la cobardía de callar nuestra fe monárquica, de proclamarla arrogantemente, con denuedo, frente al silencio pusilánime de unos y la jactancia estridente de otros.

"No creemos eterna ninguna forma de gobierno; no creemos tampoco que sean la misma sustancia Patria y Monarquía. Sobre la Monarquía, la Patria. Pero no acertamos a ver en la República la felicidad de nuestra nación. Por el bien de ella, queremos que continúe la Monarquía. Y el Rey es su encarnación, con lo que, gritando “iviva el
} 
una ruptura, una revolución, la República, y eso significa que la meta es conservar la Monarquía. Para conseguirlo, el periódico desata una campaña por la unidad de la derecha vallisoletana, que se inspira por un lado en las ideas de su director -Oscar Pérez Solís-, y por otro en las de los hombres que componen los Consejos de Administración y Redacción del periódico.

La peculiar biografía de Pérez Solís ${ }^{50}$ tiene fiel reflejo en sus actividades periodísticas. Comenzaron éstas en Valladolid hacia 1909, en el órgano que el Partido Socialista editaba en la ciudad -Adelante-, y tuvieron su continuación en Bilbao con la fundación del primer diario de tendencia comunista que hubo en España -Las Noticias-, en agosto de 1921, cuando era secretario del Partido Comunista vizcaíno. Él mismo fue el director del diario,

Rey!", decimos que en la Monarquía hallamos la salud de la Patria. Por patriotas, gritamos "iviva el Rey!"”

${ }^{50}$ Nacido en Asturias el 24/8/1882, a los quince años ingresó en la Academia de Artillería para seguir la carrera militar. Destinado a Canarias se adhirió allí a las ideas anarquistas, que cambió por las socialistas cuando entró en contacto con hombres de esta tendencia al ser destinado a Valladolid. Abandona entonces la carrera militar para dedicarse a actividades políticas dentro del P.S.O.E., por el que llegará a ser concejal primero y diputado provincial más tarde. Como consecuencia de la represión de la huelga general de 1917 debe exiliarse en Portugal. A principios de los veinte se integrará en el recién creado Partido Comunista, donde ocupa diversos cargos. Después de ser herido en enfrentamientos con la policía en Bilbao, es encarcelado. En prisión recibe las visitas del jesuita $P$. Gafo que consigue reintegrarlo a la fe, decisión que Pérez solís hace pública en una carta dirigida a $E I$ Debate. A partir de ese momento se dedica a la publicística y al periodismo hasta llegar a ser director de DR en 1930, cargo que dejará, como veremos, en junio de 1931. Sus colaboraciones seguirán apareciendo con frecuencia en DR, y -después de la guerra- en Libertad, siendo galardonado con el premio Francisco Franco de periodismo. Desempeñó también algunos cargos políticos durante el franquismo. Falleció en Valladolid el 26/10/1951.Cfr. DR, 28/8/1938, pág. 6, últ. y 28/10/51, págs. 1 y 2 . 
al mismo tiempo que dirigía la revista comunista La Bandera Roja en la misma ciudad. Más adelante fue redactor de La Antorcha, "Organo del Partido comunista de España. Sección española de la Tercera Internacional»51. Era el tiempo en que estaba con "los de allá", como los llama ahora, antes de volver al catolicismo de la mano del $\mathrm{P}$. Gafo, y a Valladolid, donde retoma las actividades publicísticas y es nombrado director de Diario Regional en 1930. El conocimiento de la política de izquierdas tiene importancia en su argumentación, que gira en torno a dos ejes: a) la denuncia de la irresponsabilidad, apatía y desunión de los elementos de derechas vallisoletanos, en contraste con el comportamiento de los revolucionarios: activos, unidos, comprometidos, capaces de sacrificios ${ }^{52}$. Primero veladamente, y luego con toda claridad expondrá estas ideas al mismo tiempo que reclama en el terreno práctico la formación de una coalición de derechas en la que no estén los viejos caciques sino nuevos hombres

\footnotetext{
${ }^{51}$ Las Noticias no encontró suficientes lectores y en enero de 1923 sucumbió ante una huelga de tipógrafos. Cfr. SANCHEZ TABERNERO, Alfonso, El Correo Español-El Pueblo Vasco y su entorno informativo (1910-1985), Servicio de Publicaciones de la Universidad de Navarra, Pamplona, 1989, pág. 34, y GómEz APARICIO, Pedro, Historia del periodismo español T. IV. De la Dictadura a la Guerra Civil, Madrid, Editora Nacional, 1981, págs. 372-373.

52 "(...) no puedo callar que he encontrado “aquí" menos idealistas que "allá". Menos idealismo y, por consiguiente, menos abnegación, menos espíritu de sacrificio. (...) Unos [católicos] cruzados de brazos, cómodamente abstenidos, suicidamente apartados de la acción; otros, abrazados a la sutil teoría del "mal menor", yendo a engrosar la comparsa de grupos políticos que la Nación detesta y cuya caída, que puede ser trágica, tal vez arrastre muchas cosas nuestras; la mayoría, fiándolo todo a la fidelidad de unos fusiles." "Los que dicen amar a Dios, pero sirven al diablon, DR, 12/2/1931, pág. 1 .
} 
dispuestos a hacer una política nueva53: hay que movilizar a la gran masa silenciosa si se quieren evitar las falsas soluciones dictadas por el radicalismo ciego -revolución y dictadura-, "Dos amenazas antagónicas, pero coincidentes en dar a nuestro país un tono de pueblo balcánico o de república centro-americana." 54

b) a esa acción política deberá unirse una intensa y eficaz acción social, -"la cuestión más importante, quizá, hoy dían- que pasa por la toma de conciencia de los empresarios católicos de sus deberes, según se ha puesto de manifiesto en las encíclicas sociales de los distintos Papas $^{55}$ El concepto de propiedad hace referencia a exigencias sociales ${ }^{56}$ y, además, no hay auténtica democracia sino dictadura de una minoría mientras no se

${ }^{53}$ Entre los numerosos textos que podrían citarse, recogemos uno que pretende ser la declaración programática de la actitud política del periódico, el editorial de 15/2/1931 titulado "Vamos a edificar": "España está en crisis -en la crisis más grave de su vida política y social desde hace muchos años- y de cómo esta crisis se desenlace depende el inmediato porvenir de la Patria (...). No pretendemos [con nuestra acción política] un simple revoco de fachada, ni tampoco nos contentaremos con apuntalar las viejas paredes agrietadas. (...) Hay que romper con el pasado porque ya no nos vale. (...) Sólo podemos aprovechar la base imperecedera de los grandes principios generales que forman la razón de ser de nuestra conciencia católica."

54Oscar Pérez Solís, "Soñar despierto", DR, 28/1/1931, pág. 2 .

55 Este era en resumen el contenido del editorial "Que Dios les ilumine" publicado el 1/1/1931 (pág. 1). Cfr. también la reseña del folleto titulado Manual del católico militante, publicado por el semanario La Cruz (ibid. pág. 3 ).

${ }^{56}$ En la página dedicada a cuestiones sociales el 17/5/1931 (pág. 4) se publicaron dos artículos recogidos de la revista del mismo título, uno de Gregorio Amor - "Trabajo y riqueza"- y otro de Pérez Solís -"El caso de un cura de aldea"- en torno a estas cuestiones. El último incidía en la cuestión de la promoción de un cierto colectivismo por parte de los sectores católicos. 
generalice una conciencia ciudadana y ésta es imposible para algunos por su penuria económica; por eso hay que atender a la redistribución de la riqueza, no olvidarse de ello como hizo la Monarquía: las clases adineradas y conservadoras, si realmente son patriotas y cristianas deben ayudar y sacrificarse en este terreno ${ }^{57}$

Junto a esto, en la preparación de las elecciones a Cortes que se esperaban para marzo de 1931, será lugar común en los editoriales la afirmación de la independencia política de Diario Regional respecto a cualquier candidato concreto. Pero los deseos formulados por el periódico eran difíciles de plasmar en realidades prácticas. Una organización política no se improvisa en unas semanas por más que se afirme que hay una mayoría católica que la apoyaría. Al fin y al cabo las razones de la crisis que aquejaba a la política española hundían sus raíces precisamente en esta desmovilización política y en la falsificación electorera que la suplantaba. La responsabilidad de tal estado de cosas concernía a todos, pero de manera muy especial a las derechas. De poco valía cargar las tintas sobre las culpas de los viejos caciques y sus infames modos políticos; el pecado de omisión se iba a manifestar pronto igualmente grave, y -como en el dicho, cargado de penitencia.

57 DR, 3/6/1931 editorial "Un problema de nacionalidad" pág. 1. 


\section{La derecha que nunca existió}

Diario Regional dio cabida en sus páginas a diferentes iniciativas que aparecieron en el campo de las derechas: los manifiestos del Conde de Gamazo58, del Partido Nacional Agrario59 y del Centro Constitucional60, y -sobre todo- dio cumplida cuenta de las gestiones del Comité para la unidad o coalición de las derechas, que era el único que formalmente contaba con el apoyo del periódico. Se trataba de evitar todo lo que separara en aras de configurar la derecha modelo: movilizada y unida.

A pesar de las frecuentes declaraciones de imparcialidad, el apoyo al Comité se hará especialmente ferviente cuando es un "amigo de Diario Regional" el designado como candidato, manifestándose así a las claras el carácter de tribuna de un grupo de opinión que vimos como característica general para el periódico; grupo que tenía bastante que ver con la promoción de una candidatura única de derechas: en el Comité están dos miembros del Consejo de Administración de "Diario Regional, S.A."61. La

5814/1/1931, págs. 3 y 4 íntegras.

5928/2/1931, pág. 2; 25/3/1931, pág. 1; 27/3/1931, pág. 6, últ..

607/3/1931, pág. 6, últ.; 10/3/1931, pág. 1; 15/3/1931, pág. 1; 26/3/1931, pág. 4. Significativamente, al partido de Cambó se le había alabado pero se ponían reparos a su catalanismo y a su industrialismo, opuestos a los intereses de la Castilla agrícola. Vid. "El nuevo partido centrista", editorial, 28/2/1931, pág. 6, últ..

${ }^{61}$ Es el caso de la candidatura de Guillermo Gil de Reboleño, miembro del Consejo de Administración de "Diario Regional, S.A.". Inicialmente 
identificación con el Comité llevará a rechazar la publicidad de candidaturas monárquicas independientes ${ }^{62}$, a endurecer las críticas al viejo partido conservador de Bugallal y a los liberales albistas, en los que viene a personificarse la "vieja política"63, y a conocer el sabor del fracaso, que no fue otra cosa la historia del Comité citado ${ }^{64}$.

se anuncia que ha sido designado candidato por el comité, pero luego él mismo renunciará por no haber unanimidad en su designación. Todo parece indicar que las noticias aparecidas en el periódico eran parte de la campaña de lanzamiento de su candidatura. En el Comité están los consejeros Constantino Mateo y Pascual Pinilla. Cfr. DR 3/2/1931, pág. 6, últ.; 4/2/1931, pág. 1; 6/2/1931, pág. 1 .

${ }^{62} \mathrm{Cfr}$. DR, 25/3/1931, pág. 1.

63 "Acábese de una vez", DR, editorial, 15/2/1931, pág. 1: "Toda esa gente ávida de expeler despechos y saciar rencores, de lograr el desquite de 1923 -no de enmendar su negra historia anterior al golpe de Estado, olvidada por muchos de los que ahora les jalean como defensores de la soberanía nacional y de las libertades públicas, tantas veces escarnecidas por todos ellos, de don José Sánchez Guerra a don Santiago Alba-, es la que ha torpedeado la vida del gobierno Berenguer para colocar a la Corona en un trance de los más arduos que don Alfonso XIII ha tenido que afrontar." El repertorio es amplísimo, como ejemplos cfr. "Los sembradores de obstáculos", editorial, 4/1/1931, pág. 1, col 1-2; "Política local", ibid., pág. 8, últ., col 1-2; "¿Para quién trabajan?", editorial, 12/2/1931. La oposición al albismo se recrudece con el nombramiento como gobernador civil de Alfredo Queipo de Llano a principios del mes de marzo. DR denuncia una reunión suya con elementos albistas a la que asisten Federico Santander, Leopoldo Stampa y Enrique Gavilán, los "rabadanes del albismo" (13/3/1931, pág. 6), y se queja de que el nombramiento del nuevo Gobernador civil no tenga otro fin que facilitar apoyos a Santiago Alba en las elecciones: esto es retroceder a lo peor de la vieja política ("Como antes de 1923", editorial, 3/3/1931, pág. 1, col 1-3). Como veremos habrá una tregua cuando se forme la coalición monárquica para las elecciones municipales.

${ }^{64}$ Después de anunciarse el 3 de febrero la candidatura de Gil de Reboleño y Zaera -gamacista- a las elecciones, al día siguiente se hace público el resumen de los trabajos del Comité: "(...) El Comité de coalición electoral de las derechas -único con poderes para proclamar los candidatos de éstas- sólo ha confirmado la designación de don Francisco Zaera como representante del sector gamacista. (...) [y hace saber] 1․ Que integrado por los elementos no afiliados a los partidos políticos, por elementos bugallistas, y por mauristas gamacistas (...) comenzó las gestiones para lograr la coalición con bases escritas y categóricamente aceptadas por todos y cada uno de sus componentes. 20 . Para ampliar la coalición, intentaron atraer a los agrarios, que no 
Esto significaba un duro golpe para la vía seguida por algunos consejeros del periódico -Mateo, Pinilla y Gil de Reboleño sobre todo-, y favoreció la concesión de espacio a las iniciativas de Pérez Solís, secundadas por otros miembros del Consejo, siempre con el telón de fondo de las llamadas a la unidad -desde ahora de "todos los monárquicos" y no sólo de los elementos de derechas- para hacer frente a la amenaza revolucionaria y sostener la Monarquía65. Pérez Solís había demostrado una especial simpatía por el movimiento agrario, basándose en su carácter "apolítico" (!), de solución técnica o corporativa a los problemas ${ }^{66}$. Es una de las muchas paradojas que encontramos en el transcurso de esta batalla política librada con instrumentos precarios, mal definidos, muchas veces mal gobernados, que se mueven más por miedo al contrincante político que por imperativo de las propias convicciones. Desde el Partido Nacional

han aceptado (...) 30. Un candidato liberal-conservador, sin conocimiento ni consentimiento del Comité presentó su candidatura y se desentendió del compromiso adquirido." Sigue una carta aclarando la postura de Gil de Reboleño que ya reseñamos, y finalmente hay un comentario editorial de DR que alaba la actitud de éste señor para terminar lamentando una vez más "el triste espectáculo que están dando las derechas vallisoletanas."; 4/2/1931, pág. 1 .

65 "Hay que establecer el contacto", DR, recuadro en negrita en primera página, 19/2/1931. En este tipo de proclamas son constantes las identificaciones república-revolución, citándose muchas veces el ejemplo soviético como modelo de lo que puede ser una República en España.

66 "Continúa el tradicional divorcio entre los partidos políticos y la nación (...). No es extraño, por consiguiente, que vayan produciéndose en España movimientos de opinión -como el de los agrarios, por ejemplo-, que tienden a prescindir de los partidos políticos.",DR, 29/1/1931, pág. 1, editorial. Cfr. también "Lo que importa a la mayoría de Españan, editorial, 28/2/1931, pág. 1 . 
Agrario -como se le llamaba- se llegará a proponer a Pérez Solís que sea candidato por esta formación, proposición que éste rechaza aduciendo un aislamiento político voluntario67 que poco más tarde iba a abandonar. Pero, ¿Qué caminos -al margen de la derecha ideal inexistenteofrecía la derecha española en 1931? Siguiendo el esquema de Eugen Weber ${ }^{68}$, y particularizando para el caso de la España de 1931 tendríamos: 1a , la derecha de resistencia, los conservadores integrados en el sistema; $2 \underline{a}, 1 \mathrm{l}$ derecha descontenta, escindida del grupo anterior, que busca modificar el sistema, representada básicamente por el maurismo. Dentro de ella, como los profesores Tusell y Avilés han puesto de manifiesto, hay dos corrientes: la democrática o de los cristianos sociales, que evolucionan hacia la democracia cristiana, y los que evolucionan hacia el corporativismo o el nacionalismo autoritario, y que se han alineado generalmente dentro de la Unión Patriótica69; 3a , la derecha reaccionaria, tradicionalistas e integristas ${ }^{70} ; 4 \underline{a}, 1 a$ derecha radical, integrada por

${ }^{67}$ Oscar Pérez Solís, "Contestación a un ofrecimiento. De ninguna de las maneras", DR, 21/1/1931, pág. 1 .

68 ROGGER, Hans; WEBER, Eugen, The European Right. A historial Profile, Berkeley, Los Angeles, University of California Press, 1965.

69TUSELL, Javier, y AVILES, Juan, La derecha española contemporánea. Sus orígenes: el maurismo, Espasa, Madrid, 1986, pág. 226. Es interesante notar que como señalan estos autores "(...) la otra derivación del maurismo, popularista y social católica, estaba representada por EI Debate, al menos en [1921]."

${ }^{70}$ Además de las diferentes facciones en que se había dividido el viejo carlismo, hay que considerar la Unión Monárquica Nacional, fundada en abril de 1930. Algunos de sus teóricos -Pemán, Pradera- escribirán frecuentemente en las páginas de DR más adelante. 
revolucionarios de derechas, de tipo nacionalista o fascista, que está ahora en gestación ${ }^{71}$.

Diario Regional rechazaba de plano la primera y se mantenía alejado de la cuarta. Por tradición debería seguir la corriente tradicionalista o la corporativoautoritaria, por otra parte cada vez más próximas, pero la presencia de Pérez Solís y el influjo que ejercía el ejemplo de El Debate hizo que durante unos meses el periódico apoyara tesis próximas a las demócrata cristianas, e incluso que se convirtiera en portavoz de un embrionario movimiento de este signo impulsado por el director del periódico.

La proximidad a los sectores católico-sociales de la derecha española no era ajena a la tradición del periódico. Justo Garrán y Nicolás Santos de otto -ex director y ahora colaborador asiduo de Diario Regionalhabían participado en diciembre de 1922 en el congreso fundacional del Partido Social Popular. Santos de Otto había sido además -cuando residía en Zaragoza- miembro del

\footnotetext{
${ }^{71}$ Cabe considerar integrantes de este grupo algunos sectores de la U.M.N., aunque su reaccionarismo limita esta clasificación. Junto a ellos está el Partido Nacionalista Español de Albiñana, fundado por las mismas fechas que la U.M.N., que tiene caracteres fascistas más netos en su milicia de legionarios, pero que en su ideología se basa más bien en formas de cultura tradicional, especialmente en la religión. Cfr. para un análisis de estos movimientos PAYNE, Stanley G., El régimen de Franco 1936-75, Alianza Editorial, Madrid, 1987, págs. 43-44.
} 
Grupo promotor nacional de este partido ${ }^{72}$. Pero la etapa crítica del P.S.P. llegó precisamente durante la Dictadura, y todo parece indicar que Garrán evolucionó hacia el corporativismo, dada su adhesión al Dictador ${ }^{73}$, mientras que Santos de otto seguía próximo al catolicismo social. Era suficiente como para "tolerar" que Pérez Solís se sirviera del periódico como tribuna de sus ideas. Más adelante veremos porqué decimos tolerar y no aplaudir.

\section{MONARQUía hoy, REPÚblica mañana}

\section{"Derecha Regional»}

Ajeno a la tradición maurista, y apremiado por la necesidad de movilizar a la derecha católica vallisoletana para evitar un desastre electoral, Pérez Solís abandonó su "espléndido aislamiento" político con la fundación de un nuevo partido que llevó el nombre de Derecha Regional, y que tuvo su sede en el edificio del propio periódico ${ }^{74}$. La inspiración en el partido de Luis Lucia Derecha Regional Valenciana parece clara, y está avalada por la atención informativa que se prestaba a éste en Diario Regional.

72AlzAgA, Oscar, La primera Democracia Cristiana en España, págs. 147 y 201 .

$73_{\mathrm{Es}}$ suficientemente significativo que fuera uno de los pocos que acudieron a recibir el cadáver del Dictador a Hendaya. Por otro lado DR no se recataba en sus alabanzas al Dictador en el aniversario de su muerte, cfr. el editorial de $17 / 3 / 1931$ en que se le atribuye entre otros el mérito de haber acabado con la "vieja política".

${ }^{74}$ Se señala siempre que es la sede provisional, pero la corta vida del partido hará que nunca tenga otra. 
Cuestión distinta son las semejanzas en los programas. Derecha Regional expone su declaración de principios en las páginas de nuestro periódico el cuatro de marzo de 193175. Su contenido -fue redactado por Oscar Pérez Solís ${ }^{76}$ - es un buen resumen de las argumentaciones que con más frecuencia se hacen en los editoriales del periódico. El partido se funda porque al avance de la revolución es preciso oponer, antes que la fuerza, una acción social y política que la derecha no asume. La finalidad de la nueva organización es llevar los principios de la doctrina social católica a la vida pública, ya que el orden se concibe no como ausencia de conflictos, sino como "resultante de un fuerte anhelo de justicia social que, cumpliéndose por vías de pacíficos acuerdos, vaya reduciendo antagonismos de intereses, creando colaboraciones sociales cada día más amplias y suprimiendo privilegios (...)." En cuanto al régimen se declaran indiferentes aunque reconocen la conveniencia del monárquico para España en ese momento concreto, pero supeditando siempre la cuestión a la decisión que democráticamente tome la nación soberana. Nacidos en Valladolid, aspiran a defender los intereses de la región castellano-leonesa, especialmente los agrarios.

\footnotetext{
75 "La Derecha Regional. Declaración general de sus principios y finalidades", pág. 1. Lo recogemos íntegro en el apéndice 6 .

${ }^{76}$ Cfr. Oscar Pérez Solís, "Principios y tácticas. Religión y Orden.", DR, 15/5/1931, pág. 2; "Patria y Familia», DR, 26/5/1931, pág. 2 .
} 
Si comparamos estos planteamientos con los de Derecha Regional Valenciana podemos obtener conclusiones esclarecedoras. Como puntos comunes entre los dos tenemos su orientación demócrata cristiana, en el sentido de que como señala el profesor Tusell "(...) demócratas de inspiración cristiana en lo político, trataban al mismo tiempo de cumplir un programa social de carácter reformista (...)"77, y su regionalismo. Pero estos rasgos están matizados por las diferentes realidades políticas y sociales de Castilla y de Valencia en el momento. Así, mientras la incipiente democracia cristiana de Lucia tiene ya una tradición política de raíz maurista, la que se quiere crear en Valladolid nace alejada de los herederos más directos de este partido en nuestra ciudad, cuestión sobre la que abundaremos más adelante. En segundo lugar, mientras que los dirigentes de la primera huyen de los "dilemas equivocados" -entre izquierda y derecha, revolución y contrarrevolución, socialismo o cristianismo, República y Monarquía78-, la Derecha Regional de Valladolid nace de la anquilosis de la derecha tradicional y de la necesidad de hacer frente a una izquierda activa que se califica muchas veces de revolucionaria, aunque

\footnotetext{
77TUSELl, Javier, Historia de la Democracia Cristiana en España.Tomo I: Los antecedentes. La CEDA y la segunda República, Edicusa, Madrid, 1974, pág. 16. Cfr. también VALLS, Rafael, La Derecha Regional Valenciana (1930-1936), Edicions Alfons el Magnanim, Institució Valenciana d'Estudis i Investigació, col. Estudios Universitarios, no 51 .

${ }^{78} \mathrm{Cfr}$. ibid. págs. 323-324.
} 
sólo sea para incentivar la reacción de los elementos derechistas desmovilizados. En tercer lugar, $y$ es a nuestro entender un punto de fundamental importancia, mientras que en la sociedad valenciana se puede robustecer un regionalismo que ya existe, en la castellana habría que crearlo. Un regionalismo moderno no puede basarse en exclusiva sobre una tradición cultural, necesita todavía más de unos intereses económicos avanzados, y estos faltan en Castilla79. A lo más encontramos aquí intereses proteccionistas comunes, y eso dibuja en todo caso un regionalismo defensivo y contradictorio, que precisa antes que nada de la ayuda del gobierno central para conseguir aranceles que favorezcan su arcaica economía. Valencia en cambio tenía unos intereses -agrícolas en su origen, como los de Castilla- integrados ya en una economía moderna ${ }^{80}$. "Hemos de prestar atención vivísima a los problemas generales de la región castellano-leonesa, cuya

\footnotetext{
${ }^{79}$ Puede verse un análisis pormenorizado de la actuación de los diputados castellanos en las Cortes de la República, y los intereses que defienden, en ALMUIÑA FERNÁNDEZ, Celso, "Castilla ante el nacionalismo en la II República, a través de los debates parlamentarios", en Las Cortes de Castilla y León, 1188-1988. Actas de la Tercera Etapa del Congreso Científico sobre la Historia de las Cortes de Castilla y León, Volumen II, Cortes de Castilla y León, Valladolid, 1990, págs. 321-385.

80 "El autonomismo de Derecha Regional [Valenciana] abarcaba varios aspectos: robustecimiento de las diputaciones mancomunadas, dotadas de "una hacienda propia y bien dotada"; Universidad regional; obras públicas; política sanitaria y benéfica..., etc. Los límites del regionalismo valenciano no eran por tanto, excesivamente precisos, aunque, desde luego, presuponían la existencia de un Estatuto. En todo caso, el origen del mismo, no solamente radicaba en el reconocimiento de una tradición cultural valenciana, sino también en la defensa de unos intereses económicos: los naranjeros. Cuando Lucia escribía los que luego habían de ser los principios de la Derecha Regional, había comenzado ya la crisis económica que afectaría grandemente al comercio mundial durante la década de los treinta." Ibid. pág. 154.
} 
personalidad -en lo económico y cultural, sobre todo- hay que afirmar y robustecer para que tenga en el conjunto nacional la influencia que le corresponde y recoja los provechos a que tiene natural derecho, tan olvidado hace mucho tiempon, leemos en el manifiesto de Derecha Regional. Los verbos que hemos subrayado son suficientemente significativos. Finalmente, como última diferencia entre los dos grupos, hay que señalar que el énfasis confesional no es tan fuerte en el partido valenciano como en el vallisoletano.

Decíamos que es ilustrativa la comparación porque nos pone delante de las dificultades más notables que ofrece la estructura social y económica de Valladolid para que enraíce en ella un movimiento de tipo demócrata cristiano, y más en general un movimiento de modernización política. A esto hay que añadirle otros factores de carácter práctico y no menos importantes. Salta a la vista que intentar crear un movimiento político prescindiendo de todo lo anterior es un intento desesperado de hacer algo, pero con escasas posibilidades de éxito. Los hombres de Derecha Regional se verán pronto en la necesidad de defenderse frente a la lógica acusación de que la creación de su partido es superflua cuando ya existe el partido centrista de Cambó, en el que se han alineado la mayoría de los antiguos mauristas vallisoletanos. La respuesta que dan, que ellos son netamente derechistas, no de centro, y que su partido nace de abajo a arriba, como consecuencia 
de una acción ciudadana y no de la actividad de algún cacique de la vieja política81, no deja de ser endeble en la práctica si se considera que la unidad de la derecha se sigue proclamando como la más alta aspiración.

El desarrollo de los acontecimientos explica en cierta medida este empeño. Pocos días más tarde -el siete de marzo- se constituía en Valladolid el partido Centro Constitucional. Sus manifiestos tendrán cabida en Diario Regional, pero se señalarán cuidadosamente las diferencias y semejanzas entre éste $y$ Derecha Regional: los dos coinciden en su "defensa del orden, afirmación de la fe monárquica y propósito de dar preferencia a los problemas económicos y sociales sobre los puramente políticos", pero se diferencian en que el Centro desdibuja el perfil de la derecha cuando más necesitada está ésta de definiciones claras:

"(...) para la Derecha Regional, todo el eje de su pensamiento y de su actuación presente y futura descansa sobre una afirmación de religiosidad, que ha de informar todos sus actos, sin perderla nunca de vista. Es lo que mejor puede definir -acaso lo único que puede caracterizar bien- a un partido de derecha." 82

81 "La Derecha Regional. Puntos sobre íes.", DR, 6/3/1931, pág. 6, últ., $\operatorname{col} 1-2$.

82 «El centro y la derecha. Semejanzas y diferencias", DR, 8/3/1931, pág. 1. Los entrefilets con propaganda de Derecha Regional que se insertan en DR siguen esta línea argumental: "¿Quiere usted una acción netamente de derecha? Afíliese a la DERECHA REGIONAL"; "No basta llamarse hombre de derecha. Hay que serlo. Incorpórese a la DERECHA REGIONAL"; "O con la derecha o contra ella. iFuera equívocos! iNo los hay en DERECHA REGIONAL!"; "Quien dice que es de derecha, si no es inconsecuente, tiene que estar en la DERECHA REGIONAL" 
El centro -insistían- no pone esto por delante. Además, el Centro Constitucional se edifica sobre un absurdo culto mesiánico a Maura y Cambó, con el agravante de que Cambó representa los intereses industrialistas catalanes, opuestos a los de Castilla83.

Esta polémica duró apenas diez días, ya que, al fin, los elementos de derechas -las élites, claro está- se movilizaron para volver a intentar formar una coalición, esta vez de todos los elementos monárquicos. Primero fueron los elementos católicos los que buscaron aclarar posturas en una reunión mantenida en la Casa Social Católica el quince de marzo84. Pocos días más tarde una reunión convocada por el alcalde, Federico Santander, a la que concurrieron elementos del albismo, del partido liberal conservador, del Centro Constitucional, y del grupo de católicos movilizados, alcanzó su objetivo unificador ${ }^{85}$. El realismo de los viejos modos se había

${ }^{83} \mathrm{Cfr}$. ibid. y más arriba nota 23.

84 "Hoy domingo, a las doce de la mañana, se celebrará en la Casa Social Católica una reunión de cuantos elementos de la derecha no pertenecientes a ningún partido político organizado deseen conocer las gestiones realizadas para formar en Valladolid una coalición monárquica que intervenga en la próxima lucha electoral.

"La reunión tendrá también por objeto organizar, con el mencionado fin, a los elementos indicados, por lo que se encarece la asistencia al acto." DR, 15/3/1931, pág. 1 .

${ }^{85}$ Se reúnen en el Teatro Calderón: Leopoldo Stampa, Enrique Gavilán, Luis A. Conde, Luis Silió, Antonio Infante, Francisco Zaera, Valentín Arévalo, Manuel Carnicer, Antonio Gimeno Bayón, Rafael Serrano, José Mạ Rodríguez Villamil. Cfr. DR, 15/3/1931, pág. 1; y 21/3/1931, pág. 6. "Es lo más probable que los 28 candidatos de la coalición monárquica -cuyos nombres no tardarán mucho en conocerse- se distribuyan, por sus filiaciones políticas, del modo siguiente: 15 albistas, siete centristas, tres liberales-conservadores y tres 
impuesto; en Diario Regional se escribía: "(...) nos ponemos incondicionalmente a las órdenes de la coalición monárquica, que pasa a ser localmente nuestra única bandera política»86. Esto aplazaba el debate sobre cuál debía ser la derecha que se construyera: lo primero era salvar la Monarquía. Derecha Regional se unió a la coalición y presentó tres candidatos a las elecciones ${ }^{87}$.

\section{El fracaso de una modernización política}

En los veinte días siguientes se derrochó entusiasmo y falta de realismo. En la Casa Social Católica tuvo lugar un acto sobre los deberes políticos de los católicos organizado por Derecha Regional que sería el último acto público promovido por el partido. Diario Regional titulaba su primera página a toda plana el doce de abril: "La campaña electoral. Informes oficiales permiten augurar enorme triunfo a las candidaturas monárquicas en toda España." El martes siguiente -catorce de abril- el

católicos." La proporción pactada dice bastante del peso que se reconocía a cada sector en la vida política vallisoletana. En la coalición se marginó a los elementos de la U.M.N., lo que motivó alguna pequeña protesta como la aparecida en DR, firmada por NEU el 24/3/1931, pág. 1 .

${ }^{86}$ Ibid.En efecto, a partir de entonces no se detectan en DR las habituales críticas a la vieja política, el albismo, etc. Menos aún algún asomo de polémica dentro de la derecha.

${ }^{87}$ Manuel Julio Rebollo, ferroviario; Francisco Calvo, agricultor; y Jesús Rivero Ramos, comerciante. Ninguno de ellos había pertenecido a un partido político, y se procuró que profesionalmente correspondieran al modelo de bases movilizadas que se propugnaba. Cfr. DR, 25/3/1931, pág. 1, col 5-6. 
editorial iba encabezado por una frase de acento trágico: "La guerra civil, no", $y$ en él se podía leer:

"Fieles en todo momento a la verdad, por doloroso que nos sea decirla, hemos de reconocer, sin ambages ni rodeos, que la jornada del domingo último implica una grave derrota de la Monarquía. (...) Hemos defendido la Monarquía y la defendemos aún (...) [porque] la República, en el estado actual de nuestro país, entraña, para éste riesgos que puede evitarle la Monarquía; pero nuestra convicción, por fundada que la creamos, jamás la anteponemos al mandato de la voluntad nacional, por muy equivocado que lo creamos. Porque hay una soberanía que acataremos siempre: la soberanía de la Nación. (...)

"Hablan unos de dictadura; otros de revolución, y ambas serían la guerra civil. Rechazamos la una y la otra. Si ha de caer la Monarquía, que caiga en la paz de España; si la República no ha de venir, que la paz de España no se resienta por ello."

Comenzaba así un interesante periodo caracterizado por la lucha entablada en las páginas del periódico entre los partidarios de no transigir con el cambio de régimen y los que lo aceptaban y proponían organizarse para actuar dentro de la nueva legalidad. Derecha Regional -que había obtenido una concejalía88- desapareció en medio de este tormentoso proceso, pero las ideas que la inspiraban fueron expuestas repetidas veces en los editoriales de los meses de abril, mayo y parte de junio; fue precisamente ahora cuando se produjo de modo más neto un acercamiento a las posturas demócratas de inspiración cristiana

\footnotetext{
${ }^{88}$ Los resultados fueron:

Izquierda liberal......11 Alianza Republicana ....... 11

Centro Constitucional....3 Socialistas ............. 10

Liberales Conservadores... 3 Radicales Socialistas ....... 5

Derecha Regional......... (Rivero Ramos)

MONÁRQUICOS ........... $18 \quad$ REPUBLICANOS ........... 26

El nuevo alcalde será Federico Landrove, del P.S.O.E.. Cfr. DR, 14/4/1931, pág. 1 .
} 
El primer punto en litigio fue la aceptación de los resultados electorales $y$ de su significación ${ }^{89}$. Varios editoriales se consagraron a poner de manifiesto la necesidad de acatar por católicos y patriotas la voluntad nacional90 por encima de personalismos $u$ opiniones de partido, postura que tendrá que defender frente a las ironías de $E l$ Norte de Castilla 91 y a las protestas de

${ }^{89}$ Una carta al director decía: "(...) recojo frases del diario de su digna dirección en el día de hoy, lazadas doblemente contra católicos y monárquicos." A lo que Pérez Solís contesta: "Las elecciones del domingo último habrán sido todo lo municipales que usted quiera; pero han puesto de relieve una realidad abrumadora que solamente los ciegos - los apasionados pueden negar o desconocer: la mayoría de la Nación se ha pronunciado contra la Monarquía (...) .

"Acatar esa voluntad no es sentar plaza de republicano; es sencillamente, conducirse como español sumiso a la soberanía de la Nación, soberanía superior -salvo para quien se sienta absolutista y no se dé cuenta del siglo en que vivimos- a la Monarquía y a la República.", DR, 19/4/1931, pág. 8 últ..

90 El más significativo se publicó casi inmediatamente después de las elecciones. Tras reconocer la evidencia del triunfo republicano, a pesar de que albergaban hasta el último momento la esperanza de alcanzar una mayoría monárquica, reiteran su sometimiento a la voluntad nacional. Su programa de acción ahora lo resumen así: "No fuimos cortesanos del Rey y no lo seremos de la República. Pero, si con el Rey practicábamos el acatamiento a la autoridad en ejercicio, con la República lo practicaremos también. Y, sin renunciar a ninguno de los principios religiosos y sociales que son la esencia de nuestro credo y el nervio de nuestra acción en la vida pública; resueltos a defenderles, dentro de la ley, por cuantos medios ponga ésta a nuestro alcance; decididos a coadyuvar, dentro de la República, con cuantos españoles acepten aquellos principios, para que el nuevo régimen no implique una negación de ellos, saludamos con emoción a la Monarquía caída -en la que no veíamos a un hombre, sino a un régimen secular de España- y abrimos paso con respeto a la República naciente, pidiendo a Dios que España haya acertado en este momento trascendental de su historia" (15/4/1931, pág. 1). Cfr. también entre otros el artículo firmado por Pérez Solís "Ni monárquico ni republicano, español nada más" (29/4/1931, pág. 6, últ.).

91 El editorial "Historias añejas" (19/4/1931, pág. 8, últ.) responde a un suelto de $E I$ Norte de Castilla, en el que éste mostraba su extrañeza por que "(...) un gobierno republicano reciba mayor acatamiento de las derechas españolas que los gobiernos liberales del antiguo régimen, para los que no había sino encíclicas condenatorias.", a lo que DR contesta: "Despacio, colega, y fuera 
lectores y colaboradores de Diario Regional 92. Con este motivo se fustigó de nuevo a los sectores católicos por su incapacidad para moverse en el campo político democrático con agilidad, y esperarlo todo de la acción del Estado o del empleo de la fuerza93. Sólo "quien se sienta

habilidades (...), los católicos españoles, con excepciones bien notorias, y a nuestro parecer muy sensibles, prestan acatamiento a la República como antes lo prestaban a la Monarquía, no por los principios ideológicos de ésa ni de aquélla, sino porque antes la Monarquía era, como lo es ahora la República, el poder constituído. "Pero acatar la República no supone adhesión incondicional -ni para los propios republicanos- a todos los gobiernos que la República tenga. (...)

"Bajo la República, es muy posible que tengamos que combatir actos de sus gobiernos, así en aquella cuestión primordial para nosotros [la cuestión religiosa] como en otras varias; pero ello no ha de menoscabar el acatamiento al poder público, no porque sea republicano, como tampoco le acatábamos antes porque fuera monárquico, sino por ser el poder público de la Nación.

"Por otra parte, harto sabido es que los gobiernos liberales de la Monarquía (...) jugaban al anticlericalismo con fines que no tenían nada de serios y para disimular, con fáciles estrépitos populacheros, su carencia de aptitud para gobernar dignamente a España".

92 El director se queja por las cartas que recibe de lectores que amenazan con dejar de apoyar a DR a causa de su línea de acatamiento de la República. Atribuye esas actitudes a la preponderancia de los personalismos en la derecha. Declara que políticamente sólo estaba en contra de los gobiernos corruptos de la vieja política que han sido los que han echado abajo a la Monarquía, y a ese tipo de gobiernos quizá los apoyaron antes los que ahora lloran por la Monarquía caída.Cfr. DR, 29/4/1931, pág. 6 últ..Cfr. también "La discusión de ahora. Una carta y una respuestan, 1/5/1931, pág. 1 .

930scar Pérez Solís, en el artículo titulado "Religión y Monarquía" (DR, 30/4/1931, pág. 6, últ.) escribe: "Evidentemente en nuestro tiempos, la República, no en sí misma, sino por el uso que de ella pueden hacer los hombres, puede tener un sentido de amenaza contra la Religión. Pero esto, que no debe hacernos olvidar cómo bajo la Monarquía, incluso en las usual y tradicionalmente llamadas católicas, ha tenido la Religión que soportar días de prueba, no arguye que haya una incompatibilidad de principio entre la República y la Religión.

"(...) tengo la sospecha de que, a la sombra de creer inseparables la religión y la Monarquía han dormitado lamentablemente muchas conciencias católicas en nuestra nación. Sólo Dios sabe el número de católicos verdaderamente militantes que hasta ahora ha habido en España. Recostados cómodamente en la autoridad del Estado oficialmente católico, quizá no sean pocos los fieles que han atendido más a lo externo y ritual de su fe que a al edificación interior y a la preocupación vehemente y constante por los destinos, la prosperidad y la gloria de su Iglesia. (...) iCuánto tiene que hacer la Iglesia en catequesis, en caridad, en el terreno social, en su propio 
absolutista y no se dé cuenta del siglo en que vivimos» ${ }^{94}$ puede pretender que después de las elecciones pasadas se plantee la lucha política en términos de elección entre Monarquía y República: ese es un falso dilema "antipatriótico y peligroso"95. Lo que procede ahora es aceptar sin reparos el nuevo régimen ${ }^{96}$, ceder cuanto sea necesario, organizarse, formar una verdadera democracia

sostenimiento, y qué poco le han ayudado los muchos, muchísimos católicos, quién sabe si la mayoría!"

${ }^{94} \mathrm{Cfr}$. más arriba nota 52.

95Así titulan el segundo editorial el 16/4/1931 (pág. 1).Tratan de demostrar en él que la actitud de pánico de algunos conservadores ante una República que comienza a vivir "felizmente" con "un acentuado sentido de orden" es antipatriótica $y$ peligrosa, $y$ hacen un llamamiento a una colaboración responsable con el nuevo régimen. Al mismo tiempo, en el primer editorial, advertían de la necesidad de que las nuevas autoridades no atentaran contra las convicciones de los católicos: "¿llegará la naciente República a ser el régimen que menos separe entre sí a los españoles? Vivamente lo deseamos. Y, como es notorio que esta concordia civil, en el grado máximo posible, ha de exigir sacrificios a todos, estemos todos dispuestos a realizarlos hasta el límite que, traspuesto, puede implicar una claudicación de la conciencia en sus deberes sagrados. Con lo que francamente, lealmente, queremos significar, en primer término, lo penoso que sería para la España católica -la mayoría aún, de seguro, en nuestro país- ver marchar a la República por derroteros que dificultasen el patriótico afán de quienes, no siendo republicanos, aspiran a que la república sea patrimonio y amor de todos los españoles."16/4/1931, pág. 1 .

${ }^{96}$ Esa disposición se había puesto de manifiesto desde el primer momento. En la información sobre la proclamación de la República en Valladolid, se describe el momento en que se izan la bandera republicana y el Pendón de Castilla en el Ayuntamiento como "un momento emocionante e histórico" ("La República en Valladolid", DR, 15/4/1931, pág. 1). Más adelante se llegará incluso a criticar la postura que mantiene El Debate sobre el particular: "Las posiciones dudosas, inciertas, ambiguas no serán bien vistas ni por los monárquicos ni por los republicanos. ¿Monarquía? ¿República? Hay que optar por una de las dos (...) nos parece demasiado borroso, demasiado gris, eso de que no se debe contraer compromiso alguno ni de traer de nuevo la Monarquía ni de consolidar la República." ("Un editorial de El Debate ", editorial, DR, 23/4/1931, pág. 1). Y en otro editorial se impugnará también la postura de $A B C$ insistiendo en que, contra lo que dice el rotativo madrileño, no se trata ya de discutir si República o Monarquía sino qué República queremos ("Una apelación al buen sentido" editorial, 9/5/1931, pág. 1). Cfr. también el artículo de Oscar Pérez Solís "Principios y táctica. El punto de partida", DR, 9/5/1931, pág. 2 . 
cristiana dentro de la legalidad del nuevo régimen ${ }^{97}$, que no es sinónimo de revolución ${ }^{98}$, aunque podría llegar a serlo si los sectores derechistas siguen aferrados a los viejos modos $y$ se niegan a colaborar99. Entonces los sectores radicales de la izquierda podrán hacer bascular la República hacia la revolución, desbordando a los

97 Tenemos un resumen de la táctica política propuesta por Pérez Solís en un artículo que -con su firma- se publicó en el lugar del editorial con el título "Como en tiempos de Fabio Cuntáctor" (DR, 31/5/1931, pág. 1). En él compara la defensa de los intereses católicos con la defensa de Roma ante el avance imparable de Aníbal y sostiene que el curso de la revolución que vive España depende del comportamiento de los conservadores. La República "ha nacido en ocasión bien poco propicia para facilitar [su] normal desarrollon: la herencia de los últimos años de Monarquía son "una honda perturbación del espíritu público, agravada en los últimos años de la Dictadura (...), con la agravante del legado en encrespadas cuestiones -la económica y la social a la cabeza de todas- (...)." La exaltación de los sectores revolucionarios comunistas y anarcosindicalistas, tradicionales enemigos de los socialistas que ahora colaboran en el gobierno, hacen necesario que "la masa de opinión que piensa moderadamente [se decida] a apoyar activamente, no pasiva ni cicateramente y con reservas mentales, al poder público.(...) [La táctica de la derecha] consiste en retroceder ordenadamente -no en huir- sin dejar de dar la cara al enemigo, sacrificando las posiciones avanzadas a que se había llegado ayer $y$ que hoy son insostenibles por peligrosas; retroceder combatiendo hasta que el ímpetu contrario se desgaste y haya posibilidad de ocupar posiciones firmes y ventajosas que permitan dar por terminado el retroceso y estabilicen el frente. (...) táctica de sacrificios $y$ poco brillante, pero que evita los desastres, las desbandadas $y$ los fáciles triunfos del enemigo." Un artículo de Salvador Minguijón publicado poco antes hacía ver la oportunidad histórica que se ofrecía a los católicos españoles: " (...) si los católicos españoles lo quieren verdaderamente con fe y con energía, podrán ofrecer a Europa por primera vez el espectáculo de una verdadera Democracia cristiana ordenada hacia el porvenir y con un programa de reformas sociales que construirían al fin la sociedad moderna sobre el terreno del Evangelio." ("Una nueva era", DR, $22 / 5 / 1931$, pág. 1).

98 "Confusiones perjudiciales», por Alfa, DR, 22/5/1931, pág. 2 .

${ }^{99} \mathrm{En}$ torno a este problema giran una serie de artículos de José Mạ Rodríguez Villamil publicados los días 19, 21 y 22 de marzo en DR. La argumentación se apoya en las normas dadas por la jerarquía a los católicos franceses al proclamarse la tercera República en el país vecino. 
elementos izquierdistas moderados, como se ha entrevisto en los sucesos del once de mayo ${ }^{100}$.

El fin de la acción política de los católicos es conseguir que los principios cristianos informen la vida social, pero eso hay que obtenerlo por medios legales y especialmente con una intensa acción social. Para ello no se precisa un régimen $u$ otro, sino un programa y una voluntad de acción; la solución de los problemas del país depende más de la movilización de los católicos y de su influencia en la vida pública que del régimen político que se dé al país. Basta que las autoridades respeten la libertad de la Iglesia -que puede perfectamente, incluso ventajosamente, vivir separada del Estado- $y$ que los

${ }^{100} \mathrm{El}$ editorial publicado con motivo éstos decía: "Ahora y siempre hemos sostenido que defender el orden no puede consistir en implantar ni en bordear siquiera el despotismo, que, en resumidas cuentas, es acumulador de desórdenes a corto o a largo plazo; pero hemos dicho siempre y volvemos a decir ahora que, como el orden es la salud de la Patria, no caben flojeras en su sostén.". Tras señalar como ejemplo la represión de la revolución comunista por los socialistas en la Alemania de Weimar continúan: "No somos enemigos de la República. Desde el 14 de abril, esa ha sido la cantinela de los paladines del nuevo régimen, como si no hubiera para la República, ien estos tiempos!, una terrible asechanza por su izquierda; como si no existiera en todo el mundo una conspiración anárquica contra la sociedad que Monarquías y Repúblicas deben defender; como si los frailes y las monjas fueran endriagos feroces, y niños traviesos los adeptos de la Acracia y del soviet.

"Piedad, más que indignación, hay que sentir de las turbas a quienes se ha señalado el convento y el hábito clerical como sus más infames enemigos. Surge del corazón cristiano la divina súplica que fue hecha en el Calvario: "iPerdónalos, Señor, que no saben lo que hacen!" Pero mediten bien su tremenda responsabilidad quienes, debiendo hacerse cargo de ella, han empujado moralmente esas turbas contra las casas de religión (...); cuando hayan ardido todos los conventos ¿Qué arderá entonces? (...)." ("Cuando hayan ardido todos los conventos", DR, 12/5/1931, pág. 1). 
católicos propongan y realicen programas coherentes que demuestren 10 adecuado de sus planteamientos ${ }^{101}$.

$\mathrm{Ni}$ siquiera los brotes de anticlericalismo alejaron al periódico de esta postura, aunque fueron recibidos con consternación, y -junto con las medidas discriminatorias en materia de enseñanza- señalados como una injusticia que no se debía consentir si se pretendía que el régimen republicano fuera para todos y se consolidase102. No hace falta destacar la novedad que esto suponía en el discurso católico español con respecto a la cosa pública.

${ }^{101}$ Esta postura -puesta de manifiesto en textos recogidos más arribacontinuará siendo defendida por otros autores y en la línea editorial de DR más adelante. Cfr. por ejemplo el editorial titulado "Violencias ineficaces" (DR, 16/6/1931, pág. 1) en que se protesta contra las violencias de los grupos extremistas, especialmente las que tienen un matiz antirreligioso, $y$ se insiste en que el problema de las relaciones Iglesia Estado "No creemos que ofrezca serias dificultades si se respetan los sentimientos de la inmensa mayoría del país. Bien está la libertad de cultos si no se merma la de la Iglesia. También es aceptable la separación de la Iglesia y el Estado, siempre que no se prive a al Iglesia de lo que le pertenece por derecho propio." . En la misma línea Salvador Minguijón afirmará que no hay miedo a la separación de Iglesia y Estado, ya que al contrario de lo que piensan algunos, se derivarán de ello grandes bienes ("Iglesia y Estado", DR, 19/6/1931, pág. 1).

${ }^{102}$ Véase más arriba la cita del editorial publicado con motivo de la quema de conventos (nota 63). Buena parte del sectarismo republicano es atribuido a los prejuicios anticlericales de los socialistas españoles, llamativos si se comparan con la actitud que ante la cuestión religiosa mantienen los socialistas de otros países. Un editorial propone el ejemplo de los socialistas alemanes, que defienden a los católicos de la política antirreligiosa, y concluye que los españoles tacharían de reaccionarios a sus correligionarios germanos por este modo de proceder ("iReaccionarios!", DR, 19/3/1931, pág. 1, col 1-2.). Los comentarios de las hostilidades abiertas contra los católicos por parte de determinados republicanos -especialmente alguna prensa (cfr. por ejemplo "Nerones republicanos", por Viriato, DR, 10/6/1931, pág. 6, últ.)- tienen un tono de lamento que evita la réplica violenta. Lo ordinario es que se razone sobre la conveniencia que tiene para el régimen mismo evitar rupturas con los católicos (cfr. "Un enemigo común", por M.H. -Miguel Hoyos- DR, 29/4/1931, pág. 6, últ.). 
Pero semejante cambio distaba mucho de ser generalmente aceptado en su totalidad. Pronto encontraremos coletillas de Pérez Solís que subrayan lo personal de este tipo de opiniones ${ }^{103}$, y paralelamente, un debate enconado en torno a estas mismas cuestiones cuando se esté definiendo el programa de la naciente Acción Nacional: será otra vez la práctica política la que haga variar el rumbo editorial de Diario Regional. El director del periódico -que no estaba solo en la cuestión del acatamiento del régimen ${ }^{104}$ - terminó por salir de la recién nacida Acción Nacional105. Esta conducta, junto con las

103 Así ocurre especialmente con las reiteradas llamadas que hace a la declaración de adhesión a la República por parte de la derecha, único medio en su opinión de "centrar la República": "ésta es una opinión personal, personalísima, mía." ( A caballo sobre la tapia. Una postura incómoda y arriesgada", DR, 16/5/1931, pág. 1) .

104 José Mạ Rodríguez Villamil, uno de los socios fundadores de "Diario Regional, S.A." estaba en la misma línea (Cfr. más arriba nota 62), y lo mismo cabe decir de la mayor parte de los hombres del antiguo Centro Constitucional, empezando por sebastián Criado del Rey, teniente de alcalde del nuevo Ayuntamiento y protagonista de una polémica esclarecedora sobre el particular que acabó con la salida de éste y de Pérez Solís de la recién creada Acción Nacional.

${ }^{105}$ En la Junta General de Acción Nacional celebrada el 27/5/1931 se nombra un comité encargado de las gestiones relacionadas con las próximas elecciones, integrado por "los señores Pinilla, Semprún, Pérez Solís, Llorente, Varona y Redondo (0.)". Pérez Solís, que no asistió a la junta, "por no estar conforme con los acuerdos adoptados en la reunión, y muy especialmente con la orientación política marcada, se considera desligado de todo vínculo con Acción Nacional (DR, 28/5/1931, pág. 2). Al día siguiente DR publica una carta de Criado del Rey, que había sido elegido vocal de la Junta de Gobierno de Acción Nacional, en la que hace público que decide abandonar la asociación por la profesión de monarquismo que se ha hecho. Esta postura fue defendida de manera especial por onésimo Redondo, Planas, Luciano de la Calzada "y algún otro". Criado explica en su carta las razones de su postura, que consiste en olvidar la defensa de la Monarquía "(...) no limitándonos a acatar la República, sino haciendo firme y decidida intención de defenderla, porque, si ella cae, no será para dejar paso a la Monarquía, sino para que en nuestro solar hispano establezca Rusia la primera de las sucursales que está pensando 
opiniones sobre la organización del Estado que Pérez Solís mantuvo en una serie de artículos sobre la autonomía de Castilla -se mostraba partidario de una organización federal, y esto para algunos sectores derechistas era tan grave o más que la quema de conventos ${ }^{106}$ - vino a colmar el vaso.

A principios de junio, con una derecha mal organizada en vísperas de unas elecciones de importancia trascendental, las diferencias entre el director $y$ el

abrir." Es interesante además hacer notar que, como él señala, no asistieron a la junta "la casi totalidad de los elementos que integraron el disuelto Centro Constitucional" -los mauristas-, y esto le colocaba en una violenta situación, ya que su entrada como vocal en la Junta de gobierno de Acción Nacional da a entender que se produjo como representante de los componentes de esa ya extinta fuerza política. Finalmente se dirige también a sus electores para aclarar los motivos que le impiden dimitir de su cargo de concejal -fue elegido como monárquico- como sería su deseo ( $E$ l señor Criado del Rey explica por qué se aparta de Acción Nacional. Carta abierta", DR, 29/5/1931, pág. 6 últ.).

${ }^{106}$ Una pequeña reseña publicada por $\operatorname{DR}(15 / 5 / 1931$, pág. 6, últ.), había dado cuenta del nacimiento de una nueva asociación denominada "Centro Regional Castellano", que tenía como fines "exaltar el culto al deber; acatamiento de los Poderes públicos constituídos, y defender el orden en sus manifestaciones de Religión, Patria, Trabajo y Propiedad". Aceptando la invitación de los dirigentes de Acción Nacional, se integraba en esta asociación. Todo parece indicar que "Centro Regional Castellano" es heredera de la Derecha Regional de Pérez Solís; de hecho ese mismo día DR publicaba (pág. 2) un artículo suyo titulado "Principios y tácticas. Religión y orden" que pretendía precisar esos conceptos, $y$ en el que se volvía sobre ideas ya expuestas en el manifiesto fundacional de Derecha Regional. Ya hemos visto cómo luego saldrá de Acción Nacional por no aceptar ésta la premisa de adhesión a la República.

Por lo que se refiere al regionalismo, después de una reunión de fuerzas vivas en la Diputación para tratar de esta cuestión en la que él participa (DR, 30/5/1931, pág. 6 últ.), publicará una serie de cuatro artículos con el título "El Estatuto de Castilla" en los que analiza la personalidad de la región, las provincias que comprende, y el marco político general en que se debe afrontar la cuestión: según Pérez Solís el Estado español va a ser federal porque así se decidió en el Pacto de San Sebastián, y por tanto ahora "Lo patriótico, lo español, es ir resueltamente al federalismo." (DR, 7/6/1931, pág. 8, últ.). El resto de los artículos son publicados los días 3,5 y 6 de junio también en última página. 
Consejo de Redacción del periódico -identificado con Acción Nacional- hicieron insostenible la situación. Se decidió darle una nueva orientación, que se consideraba más apta para aglutinar a los elementos de derecha: Diario Regional no debía ser el expositor de debates sobre las nuevas ideas de su director, sino el condensador de la opinión más común entre las élites del catolicismo políticamente activo de Valladolid, es decir, las de Acción Nacional. Se acepta el monarquismo como dato político positivo, aunque silenciado, y se lucha contra la revolución, en un esfuerzo de "salvación nacional" frente a la peligrosa política republicana. Datos había más que de sobra para calificarla así. En cuanto al republicanismo, la propaganda de Acción Nacional, tras la ruidosa salida de ella de Pérez Solís y Criado del Rey, se ocupará de recordar que los que lo sostienen caben también en la asociación ${ }^{107}$.

En un primer momento se anunció que Pérez Solís se tomaba un tiempo para sí y dejaba momentáneamente la dirección del periódico: había solicitado un mes de licencia temporal al Consejo de Redacción para poder atender mejor sus múltiples quehaceres -"de índole política algunos"-, permiso que se le había concedido108. Dos semanas más tarde se publicó una carta de Pérez Solís dirigida al director interino, Rafael serrano, que en

\footnotetext{
${ }^{107} \mathrm{Cfr}$. recuadro en negrita en primera página 30/5/1931.

${ }^{108} \mathrm{DR}$, 5/6/1931, pág. 6, últ..
} 
resumen decía: 1․- Desde la proclamación de la República y aún más desde los preliminares de la presente campaña electoral las discrepancias entre el Consejo de Redacción y él habían aumentado paulatinamente. 20.- Esas discrepancias, "manifestadas de forma cordial", llegaron a tal punto que decidió primero pedir una licencia temporal, y más tarde presentar espontáneamente la dimisión. 3‥Esto no empañaba su afecto hacia los hombres de Diario Regional, a los que quedaba profundamente agradecido. Tras la carta, una nota de la redacción lamentaba la pérdida de "un maestro de la pluma como él", e insistía en que las discrepancias entre Consejo y director venían de los preparativos de la campaña. "La definición del periódico con motivo del histórico suceso del 14 de abril, de cuyo enjuiciamiento nos sentimos orgullosos, obra conjunta suya es y del Consejo que la aprobó, afrontando el estado pasional de aquellos días»109.

Terminaba así un capítulo decisivo de la historia política de la derecha vallisoletana en la segunda República. La postura triunfante significaba el predominio del miedo al contrario sobre la confianza en encontrar en las propias ideas soluciones válidas para la mayoría. El viraje suponía en cierta forma la aceptación de que la convivencia sólo era posible una vez impuesto uno de los

10921/6/1931, pág. 8, últ., "La dirección de Diario Regional. Una carta de don Oscar Pérez Solís." 
modelos en lizal10, y esto era la negación de los principios modernizadores tal como se han entendido en occidente en los tiempos modernos. Por eso nos parece que se puede decir que la historia de estos meses es la crónica del fracaso de la modernización de la derecha vallisoletana. No podemos entrar en detalles sobre las causas del mismo, pero sí al menos citar dos que saltan a la vista: lo precario de los proyectos de Pérez Solís, y el profundo desánimo que cunde en los sectores católicos ante el rumbo que ven tomar a la República.

Ésa fue la cuestión abordada en el primer editorial del nuevo equipo director, que reconocía que los vallisoletanos se movían entre el pesimismo y el entusiasmo respecto a Acción Nacional; que no estaban en la Asociación "todos los que lógicamente debieran estar en ella", e incluso que lo que se hacía podía resultar "(...) insuficiente para lograr el fin inmediato de ganar en las elecciones próximas los puestos que se desean (...)"; pero pese a esto, se trataba del movimiento de derecha con mayor éxito en muchos años, y, lo que era más importante,

${ }^{110}$ Un índice de hasta qué punto esto es así es el tratamiento que se da a los adversarios políticos en las páginas del periódico. Hasta este momento se facilitaba información sobre la actuación de los grupos socialistas sin limitarla en exclusiva a las actuaciones sectarias o violentas, como será práctica común desde ahora. Así, por ejemplo, se publicaba el manifiesto del P.S.O.E. ("Del otro lado. Un manifiesto electoral", DR, 31/3/1931, pág. 8, últ.) o se decía del alcalde socialista de Valladolid: "Tenemos al señor Landrove de hombre ecuánime, sincero y competente (...)", al tiempo que se recogían declaraciones o cartas suyas ("Cuestiones municipales. Una nota de la alcaldía", DR, 19/4/1931, pág. 2) . 
podía ser el germen del futuro gran partido católico español:

"Porque lo que nosotros vislumbramos en la penumbra de 10 porvenir, es la diferenciación, cada vez más honda entre los partidos de la izquierda y de los de la extrema derecha, hasta el punto de que, al aire a que van las cosas, pensamos en que ha de llegar día en que bajo la inevitable policromía de matices y la diversidad de motes, no habrá en rigor, más que dos verdaderos y divergentes partidos: el de los que en lo religioso profesan íntegramente el dogma católico, en lo ético la moral vivificada por la religión, $y$ en lo social el programa cuyas líneas directrices se contienen en las encíclicas de León XIII y Pío XI principalmente, aplicado este programa sin subterfugios ni atenuaciones; $y$ el partido de los que consideran la religión como un asunto puramente privado y la Iglesia como una institución subalterna que sólo puede admitirse a título de supeditada y dependiente de la soberanía democrática." 111

\section{Veintitrés mil votos para un periódico}

Diario Regional quedaba así identificado con Acción Nacional de Valladolid, que en este momento no era más que el fruto de la apresurada actividad política desplegada por los miembros de la A.C.N. de P. de la ciudad112. Su manifiesto apareció dos veces en las páginas del

111 «Lo presente y lo futuro», editorial, DR, 6/6/1931, pág. 1 .

112Así había nacido en Madrid: "Acción Nacional nació en la redacción de El Debate y tomó cuerpo en un retiro de la A.C.N. de P. en Chamartín de la Rosa el día 26 de abril de 1931, a los catorce días de la República." GONZÁLEz RUIZ, Nicolás, y MARTín MARTÍnEz, Isidoro, Seglares en la historia del catolicismo español, Rayca, Madrid, 1968, pág. 155-156. Puede verse un pequeño resumen de los comienzos en Valladolid en MONTERO, José Ramón La C.E.D.A.. El catolicismo social y político en la II República, ediciones de la Revista del Trabajo, Madrid, tomo I, págs. 385-386. La primera Junta directiva en Valladolid fue la siguiente: Presidente, Rafael Alonso Lasheras; Tesorero: Manuel Sánchez Belloso (socio fundador de "Diario Regional, S.A."); Secretario: Francisco Ercilla Ortega; Vocales Sebastián Criado del Rey y Miguel Prado de la Cuesta (cfr. DR, 26/5/1931, pág. 1). 
periódicol13, junto con aclaraciones encaminadas a atraer a todos los elementos derechistas -apelando a su catolicismo- con independencia de sus tendencias políticasi14. A las dificultades que para la puesta en práctica de este plan hemos descrito en el epígrafe anterior había que sumar otra de mayor peso: la negativa de los agrarios a unirse a esta peculiar coalición que afirmaba no ser partido políticol15. Esta sería la causa

113 "Al servicio de España", DR, 8/5/1931, pág. 1; "Acción Nacional", DR, 22/5/1931, pág. 6, últ.. Había sido publicado por El Debate el día 7 del mismo mes.

${ }^{114} \mathrm{En}$ el manifiesto fundacional se marcaban dos objetivos principales: hacer frente a la revolución social de tipo soviético, anticristiana, que según ellos estaba en marcha, y a los separatismos que amenazaban romper España. En un suelto aclaratorio aparecido dos días más tarde con el título de "Acción Nacional" (DR, 10/5/1931, pág. 1) declaraban no ser ni monárquicos ni republicanos. Se caracterizaba el movimiento como una hermandad en la que se unen todos los españoles que "no quieren ver arrollada su fe, ni dividida su patria, ni imperante el desorden, ni descompuesta la familia, ni envilecido el trabajo, ni esclavizada la propiedad(...) No es un partido (...), su verdadera fisonomía es la de una coalición antirrevolucionaria." Contrasta la definición con la solicitud de dar programas positivos y no ser "anti" que se hacía en DR días antes (Cfr. por ejemplo "Los programas negativos", por Alfa, 15/5/1931, pág. 1). Por otro lado, la negación "no es un partido", tiene claras resonancias primorriveristas e indica la peculiar actitud ante la política de este sector católico, actitud que llegará a ser la predominante.

${ }^{115}$ La situación política desde el punto de vista de los dirigentes de Acción Nacional está resumida en el editorial de DR "En Valladolid. Panorama político de la provincia." (2/6/1931, pág. 8, últ.): nunca ha estado más clara la diferencia entre derechas e izquierdas, los partidos intermedios [el albista, podríamos leer] están descompuestos. En la derecha están Acción Nacional... y los agrarios, que por su pasividad han perdido hasta ahora mucho de lo que tenían en el campo. "La superioridad de las izquierdas sobre las derechas, en el momento actual $y$ por lo que se refiere a valladolid, es innegable y abrumadora", en la capital estarán como el 12 de abril poco más o menos, pero en el campo, lo que no tengan los agrarios -y poco tienen ahora- será para republicanos y socialistas. Los cuatro de la mayoría serán para la coalición de izquierda, la minoría puede ser para la derecha, y aún eso no está claro debido al mal entendimiento de Acción Nacional y agrarios, ya que a pesar de todo lo bueno que tiene Acción Nacional, sola no podrá contrarrestar "el alejamiento de ella de importantes núcleos rurales que la habrían apoyado si [el Partido Nacional Agrario] no se hubiera empeñado incomprensiblemente en 
principal del retraso de la campaña electoral de Acción Nacional, iniciada en teoría el treinta y uno de mayo, pero sin candidatos concretos hasta el veinte de junio, cuando Diario Regional anuncie la presentación de Rafael Serrano como derechista independiente ${ }^{116}$.

Su manifiesto fue una mezcla de confesionalismo tradicional, indefinición política e ingenuidad, que dejaba patente su inexperiencia: entre las propuestas más concretas estaban la imitación del sistema político entonces vigente en Uruguay, y la solución de los problemas sociales de Castilla mediante el desarrollo de la Confederación Sindical Hidrográfica del Duerol17. Además del esfuerzo realizado desde el periódico, se repartieron por la provincia ciento cincuenta mil candidaturas con su nombre y con los de los agrarios. Éstos, por el contrario,

sostener a estas alturas la indeterminación de su color político." Para la polémica con los agrarios cfr. además DR, 19/5/1931, pág. 6, últ., y 30/5/1931, pág. 6, últ..

$116 \mathrm{El} 30 / 5 / 1931$ un recuadro a tres columnas en primera página anuncia la decisión de presentar una candidatura cerrada de Acción Nacional en las próximas elecciones, proyecto que no se ejecutará. No obstante, se pone en marcha un comité de propaganda que dará algunos mítines pidiendo el voto para los elementos "de orden". Entre los oradores están Luciano de la Calzada, Antonio Gimeno Bayón (socio fundador de "Diario Regional, S.A."), Tomás Cerro, Luis Zulueta y Rafael Martín Lázaro. El 20/6/1931 (pág. 1) se notifica la presentación de Serrano y Serrano como candidato a las elecciones, "requerido insistentemente por valiosos elementos de un amplio sector de las derechas vallisoletanas", pero sin identificarlo como candidato de Acción Nacional. En ese momento Serrano era director en funciones del periódico y presidente de su Consejo de Administración.

${ }^{117}$ Lo recogemos íntegro en el apéndice 7. 
pedían el voto para la candidatura agraria íntegra, sin recomendar uno ni otro nombre para completarla118.

La breve campaña -nueve días-, fue vivida con la conciencia de la superioridad de la izquierda. Serrano obtuvo 22.879 votos: algo menos de tres mil lo separaron de la consecución de un acta119. Como era de rigor Diario Regional ponderó la desaparición "como tipos anticuados, [de] los "muñidores" y "agentes electoreros", las "coacciones" y demás elementos "persuasivos" para conquistar votos", al mismo tiempo que destacaba el brillante resultado de su candidato. Recriminó de nuevo a los agrarios por su actitud, vaticinó la desaparición del partido si no se unían a "la causa del orden", y cargó las tintas en la crítica al candidato de Derecha Liberal Republicana que se había llevado los pocos votos "que

118 "En Valladolid. Nuestra candidatura triunfa en la capital (...)", DR, 30/6/1931, pág. 1 .

${ }^{119}$ Los resultados para los nueve más votados fueron:

Derechistas indepen-

capital total

dientes.............. Rafael Serrano y Serrano... 4.511......22.879

Antonio Royo Villanova....5.513......28.046

Agrarios............. Pedro Martín Martín......4.319......25.713

Mariano Valdés García..... 3.693......20.650

Derecha L. Republicana... José Serrano Pacheco....... 893.......4.797

Republicano-socialistas.. Isidoro Vergara Castrillón 11.549......35.943

Remigio Cabello Toral.... 10.299.........30.718

Vicente Sol Sánchez...... 10.609.......29.662

Luis Araquistain Quevedo.. 10.698........30.160

Censo de la provincia 76.154, votaron, 60.129.

Cfr. DR, 30/6/1931, art. cit. y 3/7/1931, pág. 1 .

Para las cuestiones electorales cfr. MARCOS DEL OLMO, Mạ Concepción Sociología electoral en Castilla-León durante la Segunda República, tesis doctoral inédita, Valladolid, 1990.. 
hubiera necesitado el señor serrano y Serrano para triunfar.»120

La lección que se extraía de los resultados era la necesidad de seguir trabajando en la misma línea de formación de un partido único católico: "El único porvenir está en unirse en torno a la derecha social de Rafael Serrano", se leía en el editorial del primero de juliol21. Unos días más tarde, siguiendo las indicaciones de Angel Herrera122, se acordaba consolidar Acción Nacional de Valladolid $y$ se nombraba una nueva Junta con Rafael Serrano como presidente y Nicolás Santos de Otto como vicepresidente, lo que a su vez confirmaba la definición del periódico como portavoz del "no-partido" -si se nos permite la expresión- en la ciudad del Pisuerga123.

${ }^{120} \mathrm{Cfr}$. ibid.

121 «Enseñanzas de la contienda electoral», pág. 1 .

122 "Unos comentarios de D. Angel Herrera sobre las elecciones", DR, 1/7/1931, pág. 2 .

123Presidente, Rafael Serrano y Serrano; vicepresidente, Nicolás Santos de Otto; secretario, Francisco Ercilla Ortega; vicesecretario, Jesús Salgado Aguirre; tesorero, Eustasio Abril Carnero; vicetesorero, Julio Francia Manjón; vocales: Luciano de la Calzada, Carlos Soto Sanz y Federico Calvo Lebrero. ("Acción Nacional. La asamblea de ayer" DR, 8/7/1931, pág. 1). 


\section{ENTRE VICTORIAS Y REVOLUCIONES}

\section{Mendicantes}

Seguir adelante con la publicación no resultó tarea fácil. Hasta tal punto apretaron las dificultades y cundió el desaliento, que en octubre se llegó a decidir cerrar el periódico. Pero cuando se comunicó la decisión a los más allegados, algunos manifestaron su desacuerdo con la medida: antes que cerrar, ellos se encargarían de sacar adelante Diario Regional costara lo que costase ${ }^{124}$. Comenzó entonces una campaña para sacar a flote el periódico, que recibiría su refrendo oficial en la Junta General extraordinaria de accionistas celebrada el 15 de noviembre, a la que se invitó a los suscriptores ${ }^{125}$. Obtenido este apoyo, dos días después de la Junta la primera página de "la hoja" -como llamaban despectivamente al periódico los hombres de El Norte - se dedicaba casi íntegramente a la causa de la prensa católica. Un manifiesto titulado "A la opinión pública" anunciaba la constitución de una comisión

"(...) que con plenos poderes proyectará la renovación total del órgano de prensa de que dispone y henos aquí a quienes tal

\footnotetext{
124 "El fruto de una santa misa. Del 15 de abril de 1931 al 29 de noviembre de 1933", por Felipe Salazar, DR, 29/11/1933, pág. 2 .

${ }^{125} \mathrm{En}$ los anuncios de la Junta publicados por el periódico se leía: "(...)Se ruega muy encarecidamente la asistencia de todos los accionistas y se invita también a quienes solamente sean suscriptores, pues a todos interesa el asunto.

"Como la resolución que pueda adoptarse es de suma transcendencia, el Consejo espera la mayor concurrencia." DR, 21/10/1931, pág. 1 .
} 
función se ha conferido, si no en plan de periodistas, para lo que, aun constituyendo un verdadero honor nos faltan las debidas aptitudes, por lo menos transformados en inspiradores de un periódico. Y eso es precisamente lo que la comisión se propone; hacer un periódico moderno, dotado del más perfecto material y que sepa o acierte a recoger en sus páginas el sentir de los elementos netamente Católicos y de todos aquellos que por su afinidad de ideas, militen en el campo político llamado de las derechas."

Los firmantes eran Rafael Serrano, Emiliano Cardeñoso, José María osset y Felipe Salazar. Este último, abogado y ex-militar -había pedido la baja en el ejército de forma un tanto estruendosa ante la política azañista126_ , se iba a convertir en el nuevo director de Diario Regional.

Esta comisión solicitaba el apoyo no sólo moral sino también económico de los vallisoletanos. Según decían, ya habían recibido la donación de un taller de fotograbado y aportaciones relativamente cuantiosas de numerario, y desde ese momento se ponía en marcha una suscripción "para la total renovación de Diario Regional ", a la que se daba carácter de cruzada por la salvación de España:

"Sigue abierta la suscripción de acciones y la admisión de donativos, dedicados a la adquisición del material de imprenta

126 "Se anunció la trituración del Ejército; llegó el momento de sacrificar mi carrera y un buen día pasé a la categoría de ciudadano (...).

"Para colofón y recuerdo seguramente perdurable de mi entrañable amor a España y al honor de sus instituciones armadas, a las que con tanto orgullo pertenecí, me va a quedar seguramente un proceso y una probable condena que la tendré merecida: me exalté y debo reparación que estoy presto a dar. Así lo requiere la justicia."

Felipe Salazar, art. cit. en DR, 29/11/1933.

Cfr. también el telegrama del gobernador civil de Valladolid al ministro de la Gobernación, no 597, de fecha 12/8/1932, en el Archivo Histórico Nacional (A.H.N.), Sección Ministerio de Gobernación. Subsecretaría. Sección de Orden Público. Leg. 18-A, expediente no 12, documento 20 . 
de este periódico iCatólicos! iHombres amantes del orden! iGentes de la derecha! iCooperad al triunfo de vuestro ideal! iTodo por España!"127.

Esta actitud pedigüeña del periódico pasa por el reconocimiento de las propias deficiencias, lo que confiere un tono de cantinela de mendigo a los reclamos de ayuda, que será característico del periódico hasta 1935. Es bien significativa esta forma de proceder: el periódico tenía enfrente a un diario bien dotado de medios informativos $y$ materiales, de mayor raigambre y mayores tiradas, mejor periódico en definitiva, pero inspirado por los grupos liberales de la ciudad que eran vistos desde nuestro diario como los responsables de buena parte de los males que afligían al país. Era el representante de la prensa de negocio, la indiferente, católica sólo para lo que le interesa, primer eslabón de la cadena que acaba en el comunismo ${ }^{128}$, pero -para escándalo de los promotores de la "buena prensa»129- preferida mayoritariamente por los católicos.

${ }^{127}$ Recuadro a tres columnas y con grandes tipos en la última página de DR, $20 / 11 / 1931$.

128 "La prensa del liberalismo condenado por la Iglesia, nos ha engendrado a la España socialista, como ésta traerá a la comunista; y mientras tanto los católicos, propietarios y elementos de orden, contribuyendo con el anuncio, la esquela y la suscripción al fomento de la Prensa liberal." DR, recuadro en última página, 26/11/1931.

${ }^{129} \mathrm{En}$ torno a este asunto gira la argumentación de los artículos publicados en 1931 con motivo del día de la prensa católica, que este año se celebro el 5 de julio por disposición del arzobispo, en los que se llama "Roedores de la Prensa católica" a los católicos que se dedican a criticarla, sea por sus deficiencias técnicas, sea por las divergencias de opinión con esos medios confesionales. Son dos artículos tomados de El Buen Pastor : "Ante el Día de la Prensa Católica. Horrible estrago ¿Qué hacemos con la buena prensa?", y "Roedores de la Prensa católica. Desacuerdo. iBonito marco para 
Este era el primer frente en que había que combatir: atraer a los católicos a la que se autodenomina "su" prensa. Era la traslación al ámbito de las tareas informativas de la mentalidad de partido único católico, de sobra conocida en las luchas políticas propias del liberalismo. Si esto había planteado ya con la Monarquía serios debates -hasta el punto de que desde Roma se había tenido que descalificar cualquier intento de monopolizar políticamente a los católicosicon, las nuevas circunstancias políticas hacían variar los términos del problema, y aportaban nuevos argumentos en favor de la tesis unificadora, ya que -como señala Payne- lo que se produjo "Más bien que una lucha entre la tradición y el liberalismo, fue una de las más importantes guerras del siglo $\mathrm{xx}$ entre revolución y contrarrevolución. No la indujo el anticlericalismo, sino el desarrollo de poderosas masas revolucionarias a las que las fuerzas conservadoras decidieron enfrentarse antes de que fuese demasiado tarde."131 A medida que pasaba el tiempo y los hechos confirmaban los temores, esa era la razón de mayor peso que Diario Regional podía esgrimir en su favor:

semejante cuadro!", en DR, 3/7/1931, pág. 3, y 5/7/1931, pág. 4, respectivamente.

${ }^{130}$ Cfr. GUASCH BORRAT, Juan María, "El Debate" y la crisis de la Restauración, (1910-1923), Eunsa, Pamplona, 1986, págs. 23-32.

${ }^{131}$ PAYNE, Stanley G., El catolicismo español, pág. 193. 
revolución que oprime nuestras conciencias y nos niega el fuero de la libertad»132

"iVallisoletanos! No leais los periódicos que después de habernos traído la revolución se han quedado a caballo sobre la tapia, tanteando de que lado les será más "conveniente" caer» 133

Tendremos ocasión de ahondar en este punto -uno de los centrales en la historia de estos años- cuando analicemos los contenidos de las opiniones políticas del periódico. Baste con añadir ahora que el 19 de noviembre cambiaba la cabecera del periódico: se añadía bajo el título el lema "Religión. Patria. Orden. Trabajo." de Acción Nacional, que será el del periódico hasta que deban retirarlo, ya durante el franquismo.

Por el momento los promotores del diario tenían que empeñarse en una doble tarea de mejora de elementos materiales y de publicidad, que permitiera hacer bueno su propósito de hacer resurgir la publicación. Una de las primeras campañas que se emprendieron consistió en publicar trabajos que hicieran patente cuál era la importancia de la prensa, comenzando por citas de documentos papales, de otros autores, o del mismo periódico que tocaban la cuestión, y que aparecerán casi a diario a modo de gacetillas ${ }^{134}$. En alguno de los artículos

\footnotetext{
${ }^{132} \mathrm{DR}$, recuadro en primera página el 10/2/1932.

${ }^{133}$ Idem el $11 / 2 / 1932$.

${ }^{134}$ Los más repetidos son tres textos de León XIII, Pío IX y Pío X, que insisten sobre la importancia de que se publiquen periódicos con criterio católico, Diario Regional por su parte añadía reflexiones del tenor siguiente:
} 
publicados se alcanzaba en la práctica una mitificación de la prensa, o mejor de la propaganda, fácilmente explicable si se considera que estamos en los primeros momentos del empleo de ésta de forma masiva, por lo mismo que estamos en el primer momento en que la opinión pesa definitivamente en la elección de los destinos del país. En este ambiente, llegaba a atribuirse a la prensa un poder absoluto en la vida de las sociedades: bastaba volver la vista a lo ocurrido recientemente en España, según podía leerse en una de estas colaboraciones:

"Nosotros seguimos en nuestro tema de que quien derribó a la Monarquía fue la Prensa; y quien hizo y ganó las elecciones fue la Prensa, y la que viene ganando todas las batallas en que decida la opinión es indefectiblemente la Prensa y siempre la Prensa, $y$ que mientras no contrarrestemos la acción demoledora de cierta prensa y sus propagandas con un contradiluvio de Prensa sana y cristiana, serán estériles todos nuestros esfuerzos y habremos de contar nuestras derrotas por el número de batallas."135

La actitud de los católicos en tales circunstancias no podía ser un tranquilo e inconsciente laisser

"El verdadero termómetro que señala con seguridad los grados de calor de las convicciones religiosas de un pueblo es la Prensa. Y en España, desgraciadamente, predominan por su número los periódicos hostiles a la Iglesia Católica y los que, sin ser hostiles, la miran con indiferencia. Es que hay gente de un catolicismo confuso, convencional, fragmentario, y esa gente es la que sostiene con su óbolo esa Prensa.

"iAsí suceden los acontecimientos que suceden en España!"

"El denso ambiente de sectarismo callejero que se respira en España, es producto principalísimo de la prensa groseramente impía y anticatólica. Para desvanecer y purificar ese ambiente no vale la prensa neutra; es indispensable, absolutamente indispensable, una prensa católica fuerte $y$ extendida por todas partes. Ello exige sacrificios, y cada cual ante Dios y la propia conciencia debe pensar hasta dónde puede sacrificarse o se le puede exigir el sacrificio." DR, 14/11/1931, pág. 6, últ.

135 "La grande obra", por José Dueso, C.M.F., DR, 3/12/1931, pág. 6, últ. . 
faire liberal, como había venido siendo hasta ahora. Si se quería un país católico hacía falta una opinión católica. El mejor ejemplo estaba en la conducta de los socialistas o de los laicistas, que no regateaban esfuerzos en la propaganda de sus ideas ${ }^{136}$ iCuánto tenían que aprender los católicos de los obreros!:

"Los obreros, que han sido previsores y abnegados, desprendiéndose de parte de su necesario jornal para formar y sostener grandes asociaciones con la correspondiente propaganda, han recogido su fruto. Las clases acomodadas, que, imprevisoras y egoístas, han querido disfrutar aisladamente de sus pocos o muchos bienes, sin gastar en asociaciones y campañas, están recogiendo el suyo ¿Rectificarán su suicida equivocación? "137

De este modo, al intento de unificación de los católicos bajo una misma bandera se unía el empeño de hacerles conscientes de la necesidad de una intensa movilización que supliera las deficiencias que -al menos en el terreno de la propaganda- presentaban sus modos apostólicos hasta la fecha. Una mezcla explosiva, muy de la época.

Que el camino emprendido no llevaba fácilmente a la meta lo comprobamos al ver que un año más tarde este tipo de argumentos se sigue repitiendo138, que en 1933 se

${ }^{136}$ Este era en resumen la argumentación vertida en uno de las gacetillas que proponía como ejemplos el trabajo de Pablo Iglesias y de la Institución Libre de Enseñanza. DR, 18/10/1931, pág. 1.

${ }^{137}$ Recuadro en última página, 23/10/1931. En la misma línea estarán otras gacetillas como la aparecida el 25//10/1931, pág. 1; o el artículo firmado por "Viriato" "Para las clases conservadoras. Una gran verdad que les dice "El Socialista"", DR, 8/11/1931, pág. 1.

${ }^{138} \mathrm{DR}, 3 / 9 / 1932$, pág. 1: "si los católicos, ante lo que está pasando, no se deciden a abstenerse de comprar la prensa francamente mala o neutra, tienen mucho que temer para lo porvenir. "No se pueden hacer ciertos equilibrios." 
publican reclamos como "Diario Regional necesita mejorar sus elementos materiales»139, ${ }^{139}$ el siguiente ruego: "Simpatizante de DIARIO REGIONAL: ¿Nos ha encontrado usted un nuevo lector?"; que en 1934 Oscar Pérez Solís puede preguntar todavía de quién es la culpa de que el diario no sea tan buen periódico como católicol40; y que en 1935 continúe el tono mendicante:

"Suscriptor o lector de "Diario Regional" Mira lo que puedes hacer por tu periódico, sin sacrificio mayor, en este año que comenzamos:

"Si no lo eres, hazte suscriptor; te resultará más económico.

"Si ya lo eres, haz a otro amigo; por lo menos a uno.

"Abona tu suscripción por adelantado; ello no desequilibrará tu situación económica, y al periódico le reportas un beneficio considerable.

"Paga tu suscripción en nuestras oficinas siempre que tengas ocasión; considera el ahorro que ello supone para tu periódico.

"Si eres comerciante, industrial o labrador, y si no lo eres, siempre que tengas motivo para ello, anúnciate en tu periódico.

"Siempre que hayas de hacer alguna compra o instalación, por insignificante que sea, $y$ en igualdad de condiciones, da preferencia a las casas que se anuncien en tu periódico, y haz constar que has visto su anuncio en el mismo.

"Facilítale cuantos datos y noticias merezcan publicarse.

"De ello, si representa sacrificio, te verás compensado automáticamente, pues harás que tu periódico prospere y mejore, gracias a tu ayuda." ${ }^{141}$

11/10/1932, pág. 1: "El católico de mediana posición que quiera cumplir los deberes para con su prensa, debe suscribirse al diario católico de la localidad y abonar, según sus medios, una o más suscripciones, para hacer llegar el periódico a lugares de reunión de las clases modestas."

16/10/1932, pág. 1: "El católico que pudiendo, no ayuda a la prensa católica, es, por lo menos un inconsecuente.

"El católico que favorece a la prensa enemiga y sectaria, es, francamente, un traidor."

Cfr. también los artículos de Oscar Pérez Solís "Triste, muy triste. El arma de la prensa enmohecida y mellada" (DR, 17/11/1932, pág. 1), y "Los ricos y nuestra prensa" (DR, 8/1/1933, pág. 1).

${ }^{139}$ Recuadro anunciando la celebración del "Día de la Prensa Católica" el 20/6/1933, pág. 1.

140 "¿̇e quién es la culpa?», DR, 29/6/1935, pág. 1.

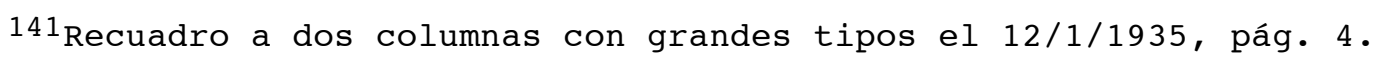


Estamos ante el problema de siempre: por un lado la prensa católica se considera una obra de beneficencia poco menos que eclesiástica-, y por otro se concreta en unas empresas periodísticas que deben competir con sus iguales, editores -quizá también católicos, como es el caso de Valladolid- de otros periódicos.

La tarea de promoción de la "buena prensa" había llevado en España a la creación de la Junta Nacional de Prensa Católica, que se reorganizó en 1934, después de que Angel Herrera ocupara la presidencia de la Junta Nacional de Acción Católica. Desde esta fecha tenía concretamente por misiones el cuidado de la organización del "Día de la Prensa Católica", la agencia "Prensa Asociada" y la obra de los "Legionarios de la Prensa"142. En provincias esto quedaba reducido al primer punto, del que se cuidaba en cada diócesis la Junta de Acción Católica correspondiente. El provecho que de aquí se seguía para un periódico como Diario Regional era la posibilidad de recibir informaciones de una agencia de inspiración cristiana, y quizás alguna ayuda económica en efectivo cuya cuantía sería, en todo caso, a todas luces insuficiente para cubrir sus necesidades ${ }^{143}$. Resultaba así que la

142Cfr. DR, 9/2/1934, pág. 2.

${ }^{143}$ En el día de la prensa católica, que se celebraba con el lema "Oración, Propaganda, Limosna", se realizaba una colecta cuyos frutos se distribuían como sigue: obras de prensa diocesanas, 60\%; Dinero de San Pedro -donativo para el Vaticano-, 10\%; Tesoro de la Buena Prensa, 20\%, organización de la jornada del año siguiente, 10\%. De 1916 a 1934 se habían recaudado a favor de la prensa católica en toda España 
dinamización de la actividad de los católicos que se estaba operando a través de la Acción Católica, en la práctica era ineficaz para los órganos de opinión más afines a la Iglesia. Los días de colecta podían servir para las misiones, pero eso era porque se contaba con vocaciones de misioneros y seminarios para formarlos; pero aplicando el mismo esquema a la prensa lo único que se tenía era la recaudación a palo seco. De aquí había nacido la idea de Herrera Oria de crear una Escuela de Periodismo de inspiración católica, y de aquí también nos parece que arranca la mentalidad de servicio paraeclesiástico que se atribuye al periodismo por parte de los que se forman en ella. Sin embargo, las dificultades de articulación que conlleva esta traslación de esquemas son patentes: los periódicos católicos, por más católicos que sean, no son de la Iglesia como institución, ni de los católicos en conjunto, son de quienes los hacen, y no entender esto así plantea serios problemas, tanto de concepto como prácticos; y además, al periodismo no cabe catalogarlo como una vocación sobrenatural.

En nuestra opinión, aquí está precisamente una de las causas de las disfunciones de buena parte de la prensa católica en estos años, ya que la idea que prevalece entre

3.113.452, 75 ptas., lo que hace una media anual de poco más de 160.000 ptas., que debían repartirse entre las distintas diócesis y dentro de ellas entre las publicaciones que existieran, por lo general numerosas, $y$ de periodicidad no diaria. "El día de la prensa católica", por Félix, Obispo de Tortosa, Presidente de la Junta Nacional de Prensa Católica, DR, 15/6/1935, pág. 6, últ.. 
sus realizadores es que por ser católica, es de la Iglesia y el deber de su sostenimiento afecta a todos los católicos españoles. El defecto de éstos que desde el periódico se criticará tantas veces -su falta de sentido de responsabilidad respecto a las obras de la Iglesia-, tenía una manifestación paralela en el comportamiento de estos católicos más "comprometidos": en última instancia remitían a la Jerarquía o a la Iglesia en su conjunto la solución de los problemas de envergadura que a ellos se les planteaban.

No obstante, como ahora veremos, las campañas del periódico dieron sus frutos: no se cerró, al contrario, mejoró la calidad de la publicación y su difusión. Pero de ello eran también responsables otros factores que trataremos de analizar. Por lo que respecta a la línea mendicante, que continuará igual en las instancias eclesiásticas, el periódico la abandona con la llegada a la dirección -en agosto de 1935- de Ignacio Valverde, un periodista profesional formado en la Escuela de El Debate.

\section{Resurgir contracorriente}

Antes de ver en concreto cómo salió Diario Regional de la campaña por su total renovación, conviene detenerse a considerar en qué estado se encontraba el sector social al que dirigía sus llamadas: los católicos vallisoletanos. La preocupación inicial ante la 
proclamación de la República había aumentado con la quema de conventos de mayo y con los resultados de las elecciones de junio. Las nuevas Cortes habían emprendido su tarea constituyente con un sesgo anticlerical, y la propaganda de la prensa izquierdista en el mismo sentido tenía tonos cada vez más violentos. La conclusión que cabía extraer daba título a un artículo de Pérez Solís que se publicaba en el lugar del editorial el 15 de octubre: "Aprestémonos a la defensa»144.

Ante esto, lo que predominaba entre los católicos era el miedo. Pocos había que se atrevieran a reaccionar frente a tal estado de cosas. Hasta las actividades de la Acción Católica -en pleno proceso de reorganización en estos años-, experimentaron una recesión, casi un colapso, en palabras de sus dirigentes, en 1931 y buena parte del año siguiente ${ }^{145}$. Dejando a un lado las actividades puramente políticas -de pobres resultados hasta el momento-, puede decirse que el único indicio de movilización de los católicos era el que se producía en torno a Diario Regional en el mes de octubre; y junto a él, las iniciativas de formar una asociación de familias de religiosos que protestara por los atentados de mayo -

${ }^{144} \mathrm{En}$ él lamentaba que no se hubiera sabido aprovechar "aquel movimiento nacional de abril, el más formidable de la historia nacional de España", y que se estuviera haciendo una política sectaria.

145 "La Acción Católica de Valladolid avanza considerablemente», DR, 14/6/1936, pág. 5 . 
que recibió un jarro de agua fría con la contestación que Alcalá Zamora dio a sus reclamaciones ${ }^{146}-$, y la de presentar un recurso contencioso administrativo contra el decreto de disolución de los jesuitas ${ }^{147}$.

Este predominio del miedo es también apreciable en la atribución de los males que se padecen a enemigos míticos : ante todo al comunismo148, y, junto a él, aunque de forma menos generalizada, a la masonería149, y al judaísmo150. Se

146 Atribuyó a la actitud de las derechas la quema de conventos. "Dice el jefe del Gobierno...", editorial, DR, 21/8/1931, pág. 1 .

147 "Ante la disolución de la Compañía de Jesús", DR, 28/1/1932, pág.1. En estos días fueron frecuentes los artículos protestando por la medida.

${ }^{148} \mathrm{El}$ comunismo junto con el anarquismo son identificados como las dos fuerzas revolucionarias por antonomasia, cuando se habla de revolución se quiere decir sobre todo revolución soviética. Este peligro, que con el tiempo llegará a ser real, es exagerado en los primeros meses de la República en algunas informaciones. Es significativo que se llegue a afirmar que son el catolicismo y el socialismo las dos fuerzas de contención que se oponen al avance del comunismo en Europa: "Dos grandes sectores sienten la inquietud de aniquilar y anular el "peligro comunista" que se cierne sobre Europa occidental: el catolicismo y el socialismo." La diferencia entre uno y otro está en el materialismo, que hace al socialismo netamente descristianizador; por eso precisamente urge una acción social por parte de los católicos ( "El peligro socialista", por “Neu", DR, 19/6/1931, pág. 1).

${ }^{149} \mathrm{Al}$ principio son sobre todo colaboradores de Diario Regional los que insisten en este punto: Nicolás Santos de Otto, Albiñana, y otros dos que firman con pseudónimo: "P.P." y "Alfa". El propio periódico, ante los conatos revolucionarios de junio de 1931 señalaba en un editorial - "Las fuerzas secretas de la revolución»- que éstas eran la masonería y el comunismo (5/6/1931, pág. 1); y con motivo de la crónica del asalto sufrido por El Heraldo Alavés, que había sido, además multado por un artículo sobre la masonería que publicaba ese día, se preguntaba "¿Pero es que hay también una ley de defensa de la masonería?" (20/2/1932).

${ }^{150}$ Este tipo de acusación está restringida a Albiñana, que por sistema califica de judío masónico liberal todo lo que tenga que ver con el liberalismo, y a otro colaborador del periódico que firma "S. de P.", que publica los siguientes artículos sobre el tema: "Plan y medios de acción de los judíos. El capitalismo y la prensa", 13/9/1932, pág.1; "Los judíos y el socialismo" I y II, 21/9/1932, pág. 1, y 25/9/1932, 
presentaban tan tenebrosos y poderosos que paralizaron a casi todos..., y provocaron una fuerte movilización femenina:

"Nos organizamos en días en que el miedo se había
apoderado de los españoles hasta el punto de temblar las
mismas columnas que parecían desafiar todas las
tempestades."151

Así describen las protagonistas de esa movilización el ambiente que rodeó la fundación de la Liga Anticomunista Femenina, más tarde Liga Anticomunista Española. No sabemos exactamente cuando se creó; la primera referencia de la misma que hemos encontrado es de noviembre de 1932, pero por el relato que hacen de sus actividades es posible que la fundación pueda datarse a finales de 1931. El caso es que su actividad es, en nuestra opinión, clave para entender la marcha de la derecha católica vallisoletana y de su prensa en estos años. Vale la pena recoger por extenso algunas citas de su historia, contada por ellas mismas, por lo clarificadora que resulta:

\begin{abstract}
"Hicimos nuestro trabajo por modos nuevos, en silencio, huyendo siempre de la publicidad (...). Recorrimos casa por casa y piso por piso toda la ciudad, e hicimos de ese modo más de quince mil visitas (...). Recorrimos toda la provincia de un cabo a otro (...). En nuestros ficheros llegamos a contar hasta sesenta y cuatro mil mujeres de la ciudad y del campo.

"Al ponernos en contacto con el pueblo, pudimos darnos bien cuenta de su estado material y moral. La incultura, el desconocimiento de las verdades fundamentales de la vida, el egoísmo, el abandono de la vida cristiana, la miseria... Esto por un lado. Por otro una propaganda fiera llevada a cabo con medios poderosos y muy abundantes, contra la religión, la familia, la sociedad. Hicimos estadísticas de la prensa que se lee en cada pueblo de la provincia, y en cada bar y barbería de la ciudad; recogimos folletos de propaganda, anotamos los
\end{abstract}

pág. 3, respectivamente; y "El peligro judío en España", 20/10/1933, pág. 3 .

151 «Liga Anticomunista Española», DR, 6/11/1934, pág. 1 . 


\begin{abstract}
mítines tenidos en cada pueblo; ponderamos las condiciones de las personas más influyentes en cada pueblo (...). El alma se partía al saber que cerca de nosotros existen pueblos donde los niños sin bautizar se cuentan por docenas; que en el mismo Valladolid, en los barrios más populosos, que representan la mayor parte de la ciudad, el pueblo vive a una distancia inmensa de la Iglesia." 152
\end{abstract}

Una vez conocida de cerca la realidad, pusieron en marcha un programa de propaganda que incluía conferencias, difusión de folletos y hojas volanderas por la ciudad y los pueblos -varios centenares de millares-, campañas para el abandono de suscripciones a la prensa de signo contrario, suscripciones a la prensa católica -«(...) sólo por nuestra oficina, por lo tanto sin contar con los que directamente se entendían con Madrid, se pagaban mensualmente hasta más de doce mil periódicos»-, difusión de prensa católica en bares y barberías de la ciudad, apertura de un kiosko en un barrio populoso de la ciudad estaba proyectado abrir más-, fundación de bibliotecas "con que satisfacer el ansia de saber que encontramos en muchas partes", organización de dos casas de ejercicios por la de las chicas pasaron quinientas jóvenes de noventa y cuatro pueblos de la provincia-, envíos de hatillos para recién nacidos y niños pobres, etc. Las asociadas pagaban cuotas mensuales de diez o veinticinco céntimos, excepto las que voluntariamente aportaban más. Se organizaban por comités, cuya actuación, especialmente en los pueblos, califican de decisiva. Es decir, reprodujeron fielmente, y seguramente mejoraron, la estructura y actividad de las

\footnotetext{
152 Ibid.
} 
células de activistas de un partido de izquierdas de la época, con resultados particularmente eficaces en los ambientes rurales:

"Del efecto de nuestras visitas a los pueblos ningún testimonio más elocuente que el de la hoja infame de los marxistas de Valladolid. En ella se decía, hablando de "esas señoras, o lo que sean", siempre fueron muy educados los que escribían esa hoja, que "no hay manera de contrarrestar el confusionismo que siembran por esos pueblos". Ese confusionismo era la verdad sobre el marxismo $y$ sus dirigentes." 153

Éstas, y otras reacciones que no es posible detectar, hicieron posible un resurgir católico, que irá creciendo con los años e informando la vida de los vallisoletanos. Hemos mencionado ya el proceso de reorganización de la Acción Católica, que se había puesto en marcha en Valladolid en 1929 con la constitución de la Junta Diocesana, y que culmina en 1934, cuando estén ya organizadas sus cuatro agrupaciones ${ }^{154}$. Diario Regional, en su número extraordinario de 14 de junio de 1936 dedicado a la Exposición Mundial de Prensa Católica, que se celebraba en Roma por esas fechas, dedica dos páginas a la historia de esta remodelación, en las que se ofrecen datos abundantes sobre el desarrollo de las actividades de las

153 Ibid. El artículo es un manifiesto de despedida a las asociadas. La Liga desaparece siguiendo instrucciones del obispo, ya que la Acción Católica, plenamente organizada en la diócesis en estas fechas, se hará cargo de las actividades que hasta ahora desarrollaba la Liga. Firma el comunicado la Junta directiva: Cándida Pintó, presidenta; Pilar Madurga de Llamas, vicepresidenta; María Carrillo de Albornoz de Monedero, secretaria; Luisa Laporta de Igea, vicesecretaria; Rafaela Torre de Romón, tesorera.

${ }^{154}$ Mujeres Católicas, Asociación Católica de Padres de Familia, Juventud Femenina de A.C., y Juventud Masculina de A.C.. 
cuatro agrupaciones en los últimos seis años. Era, según el periódico, el mejor índice de cómo se había fortalecido y desarrollado el catolicismo vallisoletano, ya que, en efecto, desde finales de 1932, el crecimiento del número de miembros y de actividades había sido constante ${ }^{155}$.

Hasta donde nos es posible analizar cuestiones que afectan a las conciencias, cabe decir que esto era consecuencia de cómo se secundó el empeño que el arzobispo -Remigio Gandásegui- había puesto en el desarrollo de la Acción Católica. Pero nos interesa más lo que significaba en relación con el periódico. Por estos años se suscitó una polémica en torno a la Acción Católica y al uso que Herrera hacía de ella para cuestiones partidistas que dice bastante sobre esta cuestión ${ }^{156}$ :

\section{Miembros de la Acción Católica en Valladolid}

\footnotetext{
$\begin{array}{rrrrrrr}1929 & 1930 & 1931 & 1932 & 1933 & 1934 & 1935\end{array}$

Actividades de la A.C....... ... $6 \ldots \ldots 3 \ldots \ldots 4 \ldots \ldots 7 \ldots \ldots 15 \ldots \ldots 18$

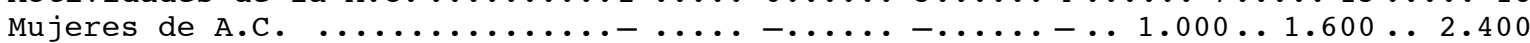

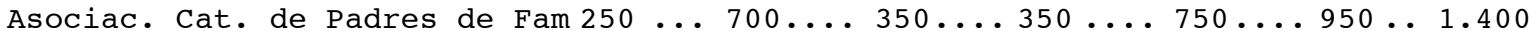
Juventudes Femeninas de A.C. (Asociadas) -............. 1.000..1.800..4.300 Juventudes Femeninas de A.C. (Aspirantes)-............. 100...500 . 1.200 Juventudes Masculinas de A.C. (Asociados)-.............600... $1.100 \ldots 1.300$ Juventudes Masculinas de A.C. (Aspirantes) .................. 100 ...4400 .....................600

Tarjeta de Acción Católica........................... 1.500..6.000 Los datos son aproximados.

156 «Pero la única y verdadera causa [de las críticas de algunos católicos a la Ación Católica] era la convicción profunda de que el presidente de la misma, Herrera, actuaba en la vida pública poniendo el prestigio de la Acción Católica al servicio de una política de partido y usando medios económicos que su personalidad le procuraba para el incremento y apoyo de determinadas organizaciones de prensa, agencias informativas, cursos de conferencias, publicaciones, etc., todo ello usado de forma tendenciosa y partidista (...)." CÁRCEL ORTí, Vicente, La persecución religiosa en España durante la segunda República (1931-1939), Rialp, Madrid, 1990, pág. 78 .
} 
"Con respecto a la actuación política del presidente Herrera, que fue la crítica más insistente que le dirigieron los católicos de otras tendencias, hay que decir que era una realidad indiscutible aunque el interesado trataba de disimularla. Su periódico El Debate era considerado el órgano de Acción Popular y existía una relación tan íntima y profunda entre el diario y el partido que los adversarios decían que Acción Popular era un instrumento político de El Debate. Este periódico, publicado bajo la inspiración de los obispos aunque como órgano oficial de Acción Católica, era considerado un instrumento de partido, clara y públicamente definido como órgano de Acción Popular, y con él la agencia Logos, que vivía bajo su protección, así como otros periódicos de provincias. Toda esta organización de prensa estuvo siempre inspirada por Herrera y en contacto permanente con los órganos centrales de Acción Católica." 157

Esto es aplicable a Diario Regional 158, con la particularidad de que al tratarse de un ámbito provincial, más restringido, la actividad en expansión de la Acción Católica, unida a la actividad política desplegada por los hombres próximos a la A.C.N. de P. en la ciudad, favorece, por encima de la media nacional, el éxito de las campañas que el periódico realice en pro de la unificación política de los católicos en torno a Acción Popular.

Por otro lado, el anticlericalismo desplegado por los partidos de izquierda forzaba una postura beligerante entre los católicos, a medida que se sobreponían al temor que les había dominado. Esto prestigiaba la actuación de Diario Regional, a quien correspondía ahora ser periódico

${ }^{157}$ Ibid. págs. $79-80$.

${ }^{158}$ Aunque en el periódico no se hace referencia a contactos con hombres de El Debate por estos años, cuando un redactor veterano hace una breve reseña de su historia años más tarde, escribe refiriéndose a los años 1933-1936: "Para el más favorable desarrollo de la empresa, D.R. se puso en relación con "La Editorial Católica", a la que pidió ayuda y consejo, que le fueron prestados oportunamente.", "Cincuenta y ocho años de historia. Aquellos hombres de fe que no volvieron la cara", DR, 20/3/1966, pág. 4 . 
de la oposición, abogado de las causas perdidas, y que por si fuera poco- fue denunciado en varias ocasiones, suspendido, apedreado, y vio encarcelado por dos veces a su director. Estaba haciendo méritos para recibir un apoyo cada vez mayor, y al fin iba a tenerlo.

\section{De moribundo a combatiente}

El 5 de junio de 1932 tuvo lugar otra Junta General extraordinaria de accionistas, que esta vez tenía por finalidad escuchar el balance que el Consejo de Administración hacía, de la labor de renovación que se le encomendara ocho meses atrás.

Los frutos de su gestión se habían dejado ver en las páginas del periódico un mes antes. Primero una de ellas, luego dos, y por fin -el 7 de mayo- todas, habían ido mostrando lo que se podía hacer con la maquinaria importada de EE. UU. que se había adquirido159: una impresión más pulcra, con los tipos perfectamente alineados, y pequeñas mejoras aquí y allá que servían para decorar las cabeceras de las nuevas secciones que iban apareciendo. El número del 5 de junio tenía tres fotografías a tres columnas en la portada, que mostraban las nuevas instalaciones, desde el despacho del director hasta los talleres, y servían de ensayo para el empleo del taller de fotograbado, más usado desde ahora, aunque 
todavía las fotografías publicadas tuvieran un carácter más decorativo que informativo ${ }^{160}$.

La maquetación mejoró, aunque al desorden que antes era habitual, le sucedió un orden excesivamente rígido -en las primeras páginas sobre todo-, que dejaba bastante que desear por lo que se refiere a la relación entre asignación de espacios e importancia concedida a las informaciones. En primera página se colocaban casi sin excepción dos artículos de fondo flanqueando la información más destacada del día, de ordinario nacional. Con Maquetación de una primera página de Diario Regional en 1932. cierta frecuencia los

\footnotetext{
${ }^{160}$ Detrás de todas estas reformas estaba el consejo de los hombres de Herrera, y la colaboración económica de muchas personas: "Ofrecimientos valiosísimos llegaron hasta los que en nombre de una idea suplicaron. Vino después un aliento vivificador para continuar el camino emprendido, y material ayuda para orillar los obstáculos que en él se encontrasen. Les confortaron prudentes consejos y acertadas orientaciones de las primeras figuras de la Iglesia, y al fin, la ayuda económica largamente prestada y la orientación fija de los principios de Patria, Orden, Trabajo y sobre todo el de Religión, por los que habíamos tanto propugnado, cerró el ciclo de las posibilidades para dar paso a las realidades." "Nuestras reformas. La evolución de “Diario Regional".", editorial, DR, 5/6/1932, pág. 1 .
} 
tipos de los artículos de opinión iban en negrita o bastardilla, y en general se buscó dar un aire más variado al aspecto de los textos. La última página se reservaba, como hasta ahora, para las cuestiones locales, los recortes de otros periódicos, una viñeta de humor, gacetillas, los versos de rigor, cuyo título -"A ripio tendidon- era de por sí clarificador, y breves comentarios políticos editoriales que son quizá lo más característico de la redacción de esta etapa. En efecto, tanto la información sobre el Gobierno Civil, como sobre el Ayuntamiento o la Diputación, que antes eran escuetas crónicas, van ahora precedidas de entradillas que aplauden, critican o ironizan sobre lo que se relata. Salazar hace diariamente una sección - "Brotes del día»-, que suele ser el comentario del diario agravio detectado en la vida política local o nacional: un comentario anticlerical de un diputado o de tal o cual periódico, la actuación del Ayuntamiento, la multa o suspensión de un periódico derechista, etc.

Esa acentuación de la opinión se acompañó de una mayor acometividad en la denuncia de problemas locales, que iban desde los defectos del abastecimiento de aguas a los precios del suministro eléctrico, la necesidad de urbanizar los barrios, de construir un edificio nuevo para la Audiencia, o de aumentar las inversiones municipales para paliar el paro obrero. Es decir, la información es 
mucho más incisiva, propia de quien se encuentra en la oposición.

En cuanto al resto de la estructura informativa, nuevas secciones mejoraban el periódico, sin sacarlo de su línea de diario de opinión. Eran sobre todo firmas nuevas las que habían aparecido, e irían apareciendo en el curso de estos años. Entre las más prestigiosas estaban José Calvo Sotelo161, Francisco Casares ${ }^{162}$, José María Gil Robles ${ }^{163}$, Enrique Herrera Orial64, Mariano Marfill165, el Marqués de Lozoya, José María Pemán166, Víctor Pradera, Federico Salmón ${ }^{167}$, José María Albiñana168 además de las ya conocidas de Salvador Minguijón, Severino Aznar, Manuel Siurot, etc. Un plantel que cubría el espectro del Grupo de la Democracia Cristiana, Acción Popular, Renovación

\footnotetext{
${ }^{161}$ Desde octubre de 1932 publica una columna con el título "Problemas del día».

${ }^{162}$ Sus colaboraciones, que llegan a través de la Agencia Internacional Arco, serán más frecuentes -hasta convertirse en la crónica política diaria del periódico- en el primer semestre de 1935.

${ }^{163}$ Desde enero de 1932.

${ }^{164}$ Especializado en temas de educación, lleva adelante diversas campañas para la defensa de la enseñanza católica.

${ }^{165}$ Comentarios sobre economía.

${ }^{166} \mathrm{Su}$ columna se titula "Crónicas de Pemán", y comienza a publicarse en marzo de 1932 .

${ }^{167}$ Sus crónicas se interrumpen mientras desempeña el cargo de ministro.

${ }^{168}$ Desde enero de 1932 escribe una columna titulada "Palique de los jueves", que se interrumpe con su ingreso en prisión. Cuando más tarde sea desterrado enviará esporádicamente algunas colaboraciones.
} 
Española, Partido Tradicionalista, y Partido Nacionalista, queriendo confirmar el carácter de derechista independiente que reclamaba para sí el periódico, calificación que -como veremos- no se ajustaba a la realidad. A éstos hay que sumar un buen número de colaboradores vallisoletanos ${ }^{169}$, muchos de ellos puramente ocasionales, y entre los que destaca -tanto por su

${ }^{169}$ Los colaboradores más frecuentes eran: Aguirre Ceballos, J. G., redactor jefe de El Financiero (Crónica financiera); Alfa (política tras la proclamación de la República); Ayala, Emilio (temas de economía agrícola); Aznar, Severino (política); Criado del Rey, Sebastián (política); Cruz, Juan de la ("Temas sociales"); de P. (política, temas de apostolado social); Echenique, J. M. (política); "El Magistral de Burgos" (cuestiones religiosas); Gil Mariscal, Fernando (cuestiones agrarias); Goyau, Jorge, de la Academia Francesa (sobre temas religiosos en el extranjero); Herrera, Enrique (política y educación); Hoyos, Miguel (política tras la proclamación de la República); Huerta, Manuel H. (Temas médicos); Jaira (desde Madrid); Mateos, José Mạ (deportes); Miñara, Emilio (temas de economía agrícola); Minguijón, Salvador (política); Mir, Raúl M. (cuestiones agrarias).; Nadal, Joaquín Mạ de ("Crónicas catalanas", política).; Nagore, Daniel (temas de economía agrícola); Neu (política tras la proclamación de la República); Nieto García, José (temas de economía agrícola); Olascoaga, Ramón de (economía); Palacio, José Mạ (cuestiones agrarias); Perero, Mariano, maestro de Quintanilla de abajo (temas literarios y bibliografía)Rivero, Jesús (deportes); Royo Villanova, Ricardo (Temas médicos); San Germán, Z . (mercados aragoneses); Sánchez, Lisardo (temas de economía agrícola); Siurot, Manuel (comentarios con intención política); Revesz, Andrés ("Juan de Vacz", "Política internacional"); Viriato (política);

Tras la renovación de 1931-32 tenemos los siguientes colaboradores:; "P.P."; "S. de P."; Albiñana, José María ("El palique de los jueves", hasta su encarcelamiento, después "En mi confinamiento"); Arévalo Cantalapiedra, Gregorio, pseudónimo "Juan del Pueblo».; Argente, Baldomero (Agencia Internacional Arco); Arrarás, Joaquín (1934); Aznar, Severino; Bermúdez Cañete, Antonio; Calvo Sotelo, José (desde octubre de 1932 "Problemas del día"); Casares, Francisco (Agencia Internacional Arco), desde enero de 1935 ("Temas del momento"); "Cayo Graco"; Cruz, Juan de la (temas sociales); Gil Robles, José María (desde enero de 1932, política); Herrera Oria, Enrique (temas de educación); Herrero García, Miguel; Juan del Agro (temas agrícolas); Marfil, Mariano (Temas económicos, 1934); Marqués de Lozoya; Marsillach, Adolfo (Agencia Internacional Arco); Martín Villapecellín, José; Minguijón, Salvador; Muro, Carlos (desde mayo de 1935); Pemán, José María ("Crónicas de Pemán" desde marzo de 1932); Pérez Solís, Oscar; Pradera, Víctor (Comentarios políticos); Rico Ruano, Pedro (temas agrícolas); Salmón Amorín, Federico; Siurot, Manuel; Villarino y Campero, Ramiro (Agencia Internacional Arco). 
asiduidad, como porque sus fondos iban normalmente en primera página- Oscar Pérez Solís.

Apoyándose en buena medida en colaboraciones, se introdujo otra novedad mayor en la estructura del periódico: las "páginas". Se trataba de secciones semanales -unas más regulares que otras-, que normalmente cubrían en efecto una página completa, aunque pueden también ser más breves: "Página femenina»170, "Página católica»171, "Página médica»172, "Página jocista»173, "Página de radio»174, "Página escolar»175, y "Letras, Historia, Arte»176. A la carga informativa que éstas ${ }^{170}$ Se publica desde junio de 1932 .

171Aparece el 22/1/1933, según se aclara en la presentación, con el fin de "aminorar los estragos del laicismo oficial, que pretende privar al pueblo de las enseñanzas religiosas", DR, 22/1/1933, pág. 4.

${ }^{172}$ Se publica por primera vez el 15/3/1933. Sale normalmente los sábados,con colaboraciones de distintos médicos de la ciudad de carácter divulgativo.

173 Comienza a publicarse el 21/5/1933, y es la más regular de todas. La elaboraba el centro de la J.O.C. (Juventud Obrera Católica) en Valladolid. Dirigía la publicación Ignacio Ruiz Gómez, secretario de la J.O.C. de Valladolid y empleado de banca (cfr. DR, 15/8/1937, pág. 4). Tiene una especial relevancia ya que los jocistas se encargaban también de su difusión por España y diversos puntos de América Latina (cfr. DR, 19/5/1935, pág. 5).

${ }^{174}$ Lanzada el 5/7/1933, es la más irregular como tal página, aunque la información sobre temas radiofónicos se hará cada vez más importante, como tendremos ocasión de apuntar más abajo, hasta el punto de que hay un redactor -José María Martín Liébana, que firma normalmente "Parásitos"- especializado en la misma.

${ }^{175}$ Comienza su publicación el 6/12/1933, dirigida por la Federación de Estudiantes Católicos.

${ }^{176}$ Página literaria que aparece por primera vez el 29/4/1934 y que se publica normalmente los domingos. En algunos momentos la página se completa con artículos sobre otros asuntos, y lleva entonces el título de "Miscelánea". 
aportaban, hay que añadir la que supone el mayor cuidado de la información internacional, que aunque deja todavía bastante que desear, va cobrando cada vez más importancia177. Lo mismo hay que decir de los deportes, que a partir de septiembre de 1932 ocupan normalmente una página completa los martes.

Por lo que se refiere a las secciones ocasionales, al margen de las que son propias de tiempos de elecciones, su misma aparición dice bastante de la vida del periódico. A finales de 1931 se publican una serie de artículos con el título "Labor cultural, moral y benéfica de las órdenes religiosas". Tras la suspensión, de la que nos ocuparemos en breve, aparecen "Después del 10 de agosto", crónicas de lo sucedido mientras el periódico no se pudo publicar, y "Los deportados a Villa Cisneros", que informa sobre la suerte que corren los condenados por su implicación en el intento de golpe de Sanjurjo. Por esas mismas fechas se publica ocasionalmente una breve crónica titulada "Justicia de lo alto", que relata desgracias ocurridas a elementos anticlericales, o bien actos hostiles a la Iglesia que han terminado en fracaso. Entre los folletones publicados están ${ }^{178}$ uno sobre la Reforma Agraria, obra de

${ }^{177}$ La mayor novedad en este aspecto fue la aparición de una crónica de periodicidad indefinida, titulada "Desde Nueva York", que firma Marcial Rossell, y que tiene la misma carga de opinión que las ya conocidas del Conde de Sarto y Andrés Revesz ("Juan de Vacz").

${ }^{178}$ En julio de 1931 se había publicado en 16 entregas, en el lugar del editorial (!), un serial titulado un serial titulado "El anteproyecto 
un notario palentino, en mayo de 1932; "El programa agrario de la CEDA", en diciembre y enero de 1933-34; y una novela moralizante de febrero a mayo de 1934179. Desde principios de 1933, se anuncian en primera página los días de "colecta ordinaria pro culto y clero" para el sostenimiento de la Iglesia. En el mes de abril del mismo año se emprende una suscripción para sufragar los gastos ocasionados por el asalto izquierdista a la Casa Social Católica y Diario Regional. En enero de 1934 comienza una suscripción por los obreros católicos parados, bien significativa si la comparamos con la que se hizo en 1931 para todos los parados, sin distinciones. En abril aparece casi a diario una sección titulada "Del ambiente revolucionarion, en octubre una suscripción en favor de los soldados vallisoletanos en el frente -Asturias- y otra para la compra de camas y de material sanitario para las mismas tropas. Finalmente, de noviembre de 1934 hasta abril de 1935, se publica "Pasada la sublevación", con informaciones sobre la revolución de octubre y sus consecuencias.

En cuanto a la publicidad, el hecho más significativo es el paso a la gestión directa de la misma desde la administración del periódico, en junio de 1932, sin la mediación que hasta ahora ejercía la agencia "Publicitas".

de Constitución. Examen del artículo 8.- La Iglesia y el Estado. I", firmado por "Tarquini", que luego se venderá como folleto.

${ }^{179}$ Layeta. El triunfo de la gracia, por "Raquel”, Editorial Librería y Tipografía Católica S.A. de Barcelona. 
La medida resulta coherente si tenemos en cuenta que la misma agencia gestionaba la publicidad de El Norte de Castilla, y es lógico que desviara hacia ese medio, de mayor difusión, la parte del león de los contratos que consiguiera. Esta es una constante del periodismo vallisoletano. Si Diario Regional quería aumentar sus ingresos por publicidad, no le quedaba más remedio que realizar gestiones él mismo para conseguir que crecieran. Parece que la gestión tuvo cierto éxito: el espacio dedicado a la publicidad aumentó, aunque siguiera representando una muy escasa proporción dentro del total. Los continuos apuros económicos que se traslucen tras el reiterado recurso a los donativos, $y$ en el ruego a los suscriptores de que hagan economías, confirman que no se avanzó demasiado180.

No obstante, en estos años encontramos ya indicios de mejoras en la gestión. Del 14 al 22 de agosto de 1933 Diario Regional se ve obligado a faltar a su cita con los lectores por vacaciones de sus empleados ${ }^{181}$. Pero en abril

${ }^{180}$ La rescisión del contrato con "Publicitas" se produjo al mismo tiempo que otra medida encaminada a la obtención de fondos: la oferta de acciones de "Diario Regional, S.A." por valor de 110.000 ptas. (Cfr. DR, 26/6/1932, pág. 1). En diversas ocasiones se pedirá a los suscriptores que abonen sus cuotas directamente en las oficinas o que la giren, para evitar gastos al periódico. Con motivo de la suspensión del periódico, publicarán una nota en la que advierten que durante la misma se siguieron pagando los sueldos, pidiendo a los lectores que compartan el sacrificio (DR, 7/9/1932, pág. 1).

${ }^{181}$ Cfr. anuncio en primera página el 12/8/1933. La medida se debía a la aplicación de la base décima del trabajo de prensa, aprobado por el jurado mixto en $21 / 2 / 1933$. 
habían dado los primeros signos de dinamismo comercial: la organización de una carrera ciclista, y de un concurso, dirigido a las modistas de la ciudad; en agosto organizan otro de mayor envergadura -esta vez de escaparates-; y al año siguiente conseguirán que las vacaciones de sus empleados sólo provoquen la reducción de la publicación a cuatro páginas en los primeros días de agosto. No deja de ser sorprendente, después de todo esto, que ante el forzoso aumento del precio de los periódicos ${ }^{182}$, que califican de abuso del legislador, declaren que no son una empresa mercantil, sino un apostolado. Pero, sin duda, esa era la mentalidad de los editores, y una muestra de ello es su deseo de llegar a quienes menos medios económicos tienen, y las causas del mismo.

Cuando se anunció la decisión de renovar el periódico, en noviembre de 1931, el suelto que aparecía en el lugar del editorial bajo el título "Prensa católica", advertía lo siguiente:

"La conciencia española que comienza a revivir (...) requiere un altavoz que lleve el eco de la doctrina católica sobre los graves problemas nacionales a las más apartadas soledades de Castilla. Es menester un periódico, que sepa interpretar fielmente el pensamiento de la Iglesia, para que de una vez nos pongamos en camino de atraer a las masas proletarias, que hoy por hoy, no nos pertenecen. (...)

"Otro escollo que debe salvar cuanto antes el periódico católico es la preterición en que tiene los problemas proletarios, las cuestiones sociales. El obrero se contenta con un periódico de escasa información, como lo estamos viendo en alguno de los diarios de Madrid (...). Pero exige que se le dediquen algunas páginas semanales a tratar sus intereses de clase (...). Se tiende a la idea de que los periódicos

${ }^{182} \mathrm{E} 11 / 6 / 1935$ pasó de 10 a 15 céntimos. 
derechistas son de la clase conservadora, por el escaso interés que se toman en el estudio de los problemas atinentes al trabajador. iTal vez sea verdadera esta suposición! Y de ahí el desprecio con que miran a la publicación católica."183

Ya vimos los medios que pusieron para conseguir esto las mujeres de la Liga Anticomunista. Diario Regional por su parte insistía en el deber de los católicos de aportar ayudas económicas para esta tarea184, y aumentó -del modo que más adelante veremos- su atención a las cuestiones sociales, hasta el punto de que hubo de responder a quienes tachaban su conducta de demagógica185, o -fue el caso de El Norte - de aproximarse a los socialistas ${ }^{186}$. La postura adoptada era, pues, difícil de conjugar con una mentalidad "típica" de negociante.

Las dificultades económicas no fueron, sin embargo, las que resultaron más pesadas para la empresa y los periodistas. Otra cuestión va a ser motivo de frecuentes reclamaciones, sobre todo hasta 1933: la libertad de prensa. La situación que se produjo con la aprobación de

${ }^{183}$ El artículo está firmado por A. de Ibaseta, DR, 17/11/1931, pág. 1.

184 «El católico de mediana posición que quiera cumplir los deberes para con su prensa, debe suscribirse al diario católico de la localidad y abonar, según sus medios, una o más suscripciones, para hacer llegar el periódico a lugares de reunión de las clases modestas.", DR, recuadro en primera página el 11/10/1932.

${ }^{185}$ Este era el tema abordado en un artículo de Salvador Minguijón, que con el título de "Alarma inmotivada" calificaba así la de los que piensan $-y$ escriben en $A B C$ : Alcalá Galiano y Goicoechea por ejemploque los cristianos sociales han caído en la demagogia y son un peligro por atacar la propiedad. Rebatía también en él, las críticas a Giménez Fernández por su labor en Agricultura, que Minguijón alaba. DR, 15/5/1935, pág. 1

186 "Diario Regional está donde estaba» editorial, 12/11/1933, pág. 1. 
la "Ley de defensa de la República»187 resultaba incómoda para el periódico, que llegaría a afirmar que así era imposible oponerse al Gobierno188. Las sanciones impuestas a la prensa derechista enseñaron al periódico lo que significaba el control de la prensa en manos de un poder adverso, y por ende el valor de la libertad. Desde agosto de 1931 comienzan a denunciarse las suspensiones de periódicos desafectos al Gobierno ${ }^{189}$, que se acompañan de una pregunta que será inseparable de ellas ¿Por qué no se castiga de igual forma a la prensa "impíamente revolucionarian? ${ }^{190}$ De este modo se reconocía que no se postulaba una omnímoda libertad, sino una libertad regulada. Realmente eso era lo que tenían, sólo que desde la posición que ahora les correspondía, no les parecía el régimen ideal para el buen funcionamiento de la prensa. Por otra parte, tenían razón en ironizar sobre los aplausos que las publicaciones izquierdistas dedicaban al

${ }^{187}$ Las garantías establecidas en materia de prensa en el artículo 34 de la Constitución quedaron inoperantes con esta ley, de carácter constitucional. Cfr. GÓMEZ-REINo, Enrique, Aproximación histórica al derecho de la imprenta y de la prensa en España, Instituto de Estudios Administrativos, Madrid, 1977, págs. 181 y ss.

188 «Ante el grave momento político», editorial, DR, 20/7/1931, pág. 1.

189 "Suspensión de periódicos. Al árbol verde y el árbol seco.", editorial, 23/8/1931, pág. 1 .

${ }^{190}$ No se destacarán, o se silenciarán, cuando se produzcan, las sanciones a la prensa comunista o anarquista, como en febrero de 1932. 
sistema de prensa vigente, ciertamente la libertad ahora era sobre todo "para ellos" ${ }^{191}$.

A las protestas y reclamaciones de libertad -que llevaron al periódico a adherirse a la Liga para la defensa de la libertad de Prensa creada en Madrid192-, se unió pronto la solicitud de ayuda económica para los periódicos católicos suspendidos, especialmente para El Debate ${ }^{193}$. En Valladolid el diario había denunciado el secuestro del semanario Libertad 194 que dirigía Onésimo Redondo, de la revista Defensa Estudiantil 195, y de las hojas de propaganda de las J.O.N.S.196. Si de momento Diario Regional no dio motivos a la autoridad gubernativa

191 "La libertad de prensa es una realidad», DR, 20/2/1932, pág. 6, últ.. "Cinismo sin lógica", DR, 3/9/1932, pág. 6, últ.. En éste último se recoge un artículo de Heraldo de Madrid que critica la censura que el régimen de Carmona impone en Portugal, sobre los periódicos y las noticias llegadas de España, para evitar la atracción que produciría el régimen de libertades que reina en España. Hacía sólo dos días que había cesado la suspensión de Diario Regional, y permanecían todavía suspendidos en España casi un centenar de periódicos.

${ }^{192}$ Fundada por dieciséis diarios de Madrid de distintas tendencias, los coaligados publicaron un manifiesto el 14/2/1932, que fue firmado por todos los periódicos de Madrid, excepto Luz, El Liberal, y El Socialista. "Por la libertad de prensa", DR, 14/2/1932, pág. 1. Cfr. también GÓMEZ APARICIO, Pedro, Historia del periodismo..., tomo IV, pág. 269; y SANCHEZ TABERNERO, Alfonso, El Correo Español..., pág. 152.

193 "Nuevos sacrificios. Ante la suspensión de periódicos católicos.", DR, 19/2/1932, pág. 6, últ..

194 "La autoridad gubernativa y la libertad de prensa.", editorial, 10/2/1932, pág. 1. El día anterior se había publicado una carta de Onésimo Redondo quejándose de la recogida del semanario.

${ }^{195} \mathrm{DR}, 21 / 4 / 1932$, pág. 6, últ..

196 "Juntas de Ofensiva Nacional Sindicalista J.O.N.S.. Cierre del domicilio social", DR, 21/4/1932, pág. 8, últ.. 
para denunciarlo, sí que los encontró el Ayuntamiento, que consideró injurioso el comentario sobre la gestión de la Electra -la compañía abastecedora de Electricidad- que Salazar hizo en el periódico el 8 de marzo197. Un mes más tarde el mismo Salazar fue detenido en virtud de una denuncia presentada ante el Gobernador Civil, con ocasión de los disturbios ocurridos en Valladolid en protesta contra el Estatuto de Cataluña. La denuncia se demostró falsa y fue puesto enseguida en libertad198, pero el periódico fue objeto de nuevo de una denuncia, esta vez por el fiscal, con motivo del editorial del 11 de mayo, en que se pedían responsabilidades penales por la forma en que habían intervenido los Guardias de Asalto, actuación que -según ellos- era la raíz del resto de los incidentes, en los que hubo un muerto y varios heridos. Ante la nueva denuncia, el periódico escribía:

"El pueblo vallisoletano, árbitro soberano, nos ayuda con su asistencia, llegando a tiradas inverosímiles. Sigan, sigan, pues, los perseguidores en su empeño, que al propio tiempo que triunfa la Justicia, nos proporcionan un brillante éxito, no sólo moral, sino económico." 199

197 El artículo denunciado era el "Brotes del día" de la fecha, que con el título "Se abarata el precio del flúido eléctrico", daba cuenta de la baja de las tarifas en Madrid, y comentaba: "Aquí los socialistas $y$ sus afines, que se han pasado largos años lanzando denuestos contra la Electra Vallisoletana, al ocupar el poder, no solo no han hecho absolutamente nada para llevar a la práctica aquello, por cuya consecución tanto propugnaron, sino que por el contrario parece que están en plena luna de miel con la poderosa empresa. En Valladolid paga el vecindario más cara la luz que en parte alguna de España (...)". Pág. 1 .

${ }^{198} \mathrm{DR}, 12 / 5 / 1932$, pág. 1.

199 "DIARIO REGIONAL es otra vez denunciado", editorial, 14/5/1932, pág. 1 . 
El 15 de junio se comunicaba la revocación del auto de procesamiento correspondiente a la primera denuncia200, y dos meses más tarde -el 10 de agosto, con motivo del frustrado golpe de Estado de Sanjurjo- llegaba la suspensión; el 12 el registro del periódico y del domicilio del director, y el 13 su ingreso en prisión, donde permaneció hasta el día 20, que fue puesto en libertad por falta de cargos $^{201}$. El siguiente número de

200 "Triunfo de la Justicia.", DR, 15/6/1932, pág. 6, últ.

${ }^{201} \mathrm{En}$ el telegrama dirigido por el gobernador civil de Valladolid al ministro de la Gobernación, se relataban así los pormenores de la suspensión del periódico:

"Representación de todos los partidos republicanos y socialistas me piden decreto encarcelamiento Onésimo Redondo y Felipe Salazar, Directores respectivamente "Libertad" $y$ "Diario Regional" por juzgarles comprometidos complot últimos sucesos. Fundan su creencia en campaña violenta contra Régimen actual y vaticinios ocurrencias acusados, retardando diario tirada para dar cabida relato sucesos ocurridos en Madrid cuya perpetración conocían en conciliábulos últimos días con militares retirados y en convinción (sic) de que han intentado aquí, sin éxito, pronunciamiento militar. Ambos periódicos fueron ayer por mí suspendidos, clausurado imprenta del segundo. Para Redondo se ha pedido aplicación Ley Defensa República y Salazar es comandante acogido ley de retiro. He solicitado Juzgado mandamiento para registro pero temo que todo sea infructuoso; y respecto detención decídase en consecuencia. Salúdole."

Telegrama no 597. De Valladolid, a las 3. 12/8/1932. A.H.N., Sección Ministerio de Gobernación. Subsecretaría. Sección Orden Público. Leg. 18-A, exp. no 12 , doc. 20 . Esa misma noche, otro telegrama relataba las incidencias del

día:

"Por motivos indicados en el telegrama 148, he ordenado la detención de Felipe Salazar, Director de Diario Regional y de Onésimo Redondo Ortega, director de "La Libertad" (sic) que ha desaparecido ignorándose su paradero y al que en registro practicado se le ha encontrado una carta con membrete Junta de Ofensiva Nacional Sindicalista. Avenida de Dato 7, Madrid y firmado por Ledesma, de la que se deduce la participación de Redondo en el complot para el movimiento pasado y que se señalaba hacia el 20 de este mes. La carta original la paso al Juzgado; copia de la misma le remito a V.E. Salvo orden en contrario ordenaré ingreso salazar en la cárcel a disposición de V.E."

Telegrama de 13/8/1932, a las 0.55. Ibid.

Cfr. también "Durante nuestra suspensión», DR, 2/9/1932, pág. 8, últ. 
Diario Regional veía la luz el día 2 de septiembre 202 . El primer párrafo del editorial de ese día -a tres columnas y con grandes tipos- estaba dedicado a la libertad de prensa:

"Al reanudar hoy su publicación DIARIO REGIONAL, que, al
mismo tiempo que otros muchos periódicos madrileños y
provincianos -casi todos ellos católicos o de significación
derechista- quedó gubernativamente suspendido desde el día 10
de Agosto, nos vemos obligados a salir a la calle poniendo
sordina a cuanto en razón y justicia podríamos decir y
atemperándonos a unas circunstancias en que la fuerza manda y
tenemos la libertad encadenada."203

A continuación lamentaban el intento de golpe, y protestaban por el daño económico que se les había hecho. Rechazaban de firme el cargo que formalmente había sido causa de la suspensión -«(...) campañas tendenciosas hechas contra el régimen»-, retando a cualquiera para que señalara ataques al sistema político vigente en las páginas del periódico. Pero lo más interesante estaba en otro punto:

"Digamos ahora que es, por cierto, bien acerba la realidad a que hemos venido a parar; pero la tenemos bien merecida, ya que quiénes más, quiénes menos, hemos contribuido a prepararla y a traerla -nos referimos a la situación religiosa y moral del país- a fuerza de un liberalismo estúpido que acaba indefectiblemente por matar a toda institución o sociedad que le toma como principio, base y norma de gobierno. (...)

202 La decisión de permitir su reaparición fue comunicada por el gobernador civil de la provincia al ministro de la Gobernación el 28/8/1932:

"Participo a V.E. en cumplimiento su orden que atendidas circunstancias de firmeza espíritu republicano no hallo inconveniente en que V.E. autorice reaparición periódico "Diario Regional". Le saludo."

A.H.N., Sección Ministerio de Gobernación. Subsecretaría. Sección de Orden Público. Telegrama oficial no 1421, de Valladolid a las 11 . Leg. 49-A, $\mathrm{n}$ ㅇ 34, doc. $\mathrm{n}$ 으 53 .

${ }^{203}$ Reproducimos completo este editorial en el apéndice 8 . 
"Con Monarquía o con República, estamos en el mismo puesto, del que jamás hemos descendido para subirnos a la trasera de ninguna carroza triunfal, ni para colocarnos al sol que más calienta. No todos pueden decir esto. Y es que nosotros no hacemos campañas por politica de partido, ni por sostener ningún caciquismo, ni por ambición, ni por ansia de medro personal, ni para engañar al pueblo. No está en eso la finalidad de DIARIO REGIONAL."

La batalla con El Norte de Castilla se enconaba, y con ella el rechazo formal de los principios liberales. En la última página había una nota de agradecimiento para los lectores que se habían abstenido de comprar otra prensa mientras duró la suspensión, que contenía duros calificativos para el colega ${ }^{204}$. De este modo, el endurecimiento de la represión unificaba las dos batallas, la antirrevolucionaria y la antiliberal.

Los meses siguientes, se volverá una y otra vez sobre la cuestión de la reaparición de los periódicos todavía suspendidos 205 , y de las demás trabas impuestas a los medios de información católicos o derechistas ${ }^{206}$. Esporádicamente aparecerá una información que con el

204 "(...) esos determinados periódicos no inspiran la menor confianza ni por la calidad de su información, ni por su apasionada tendencia politica; ni siquiera ofrecen el aliciente de su porte literario, bajuno y plebeyo.

"Ese es el deber y la acción plausible y eficaz que han de realizar los católicos españoles: abstenerse de comprar y leer la Prensa hostil y sectaria, que nada respeta, ni aun la desgracia y el dolor de los vencidos."

${ }^{205}$ Cfr. por ejemplo "Datos para la historia. La libertad de prensa en España", DR, 18/9/1932.

${ }^{206} \mathrm{En}$ un aviso titulado "A nuestros lectores", 20/9/1932, pág. 1, se informa de que la agencia Logos sigue intervenida por un delegado del Gobierno "el cual asiste a las operaciones previas de la información transmitida a los periódicos", lo que provoca deficiencias en las informaciones. Cinco días más tarde otro suelto insiste sobre el mismo tema. 
título "Periódicos que reaparecen" da la lista de los títulos a los que se levanta la suspensión. Con motivo de la visita de Azaña a Valladolid el 13 de noviembre de 1932, se insertó en la primera página un recuadro con grandes tipos que bajo el título "La visita del jefe del Gobierno a Valladolid. Nuestro saludo y lo que pedimos", además de saludarle y agradecer la visita, solicitaba:

"(...) [que] sea levantada la suspensión de “ABC" y de los
demás periódicos que sufren la misma situación harto
prolongada, gravosa y vejatoria. Con ello el señor Azaña no
hará más que servir constitucionalmente a la justicia, al
derecho y a la libertad de prensa.
"Asimismo nos permitimos recordar al señor Azaña que el
Centro Escolar Vallisoletano de la Inmaculada y San Luis
Gonzaga y el de la Federación de Estudiantes Católicos llevan
cerrados cerca de un año. El señor Azaña dejaría entre la
clase escolar buen recuerdo de su visita a Valladolid si
ordenara la reapertura de ambos centros de carácter
exclusivamente cultural. (...)"

En marzo de 1933, la difusión del manifiesto del Comité Electoral de Unión de Derechas, que había sido publicado por Diario Regional el día 19, fue ocasión para que la violencia se desatara de nuevo. El domingo 26 hubo enfrentamientos entre los derechistas que difundían el manifiesto y elementos socialistas. Al día siguiente, la manifestación convocada por la Casa del Pueblo, con el lema "Viva la República. Muera el fascismo", terminó con el asalto y saqueo de la Casa Social Católica, y con un intento frustrado de asalto al periódico, que no se libró de ser apedreado207. Los destrozos fueron considerables, y

${ }^{207}$ Recogemos en el apéndice 9 los textos del manifiesto de las derechas y la hoja volandera que convocaba a la manifestación. 
el agravio moral mayor todavía 208 , pero lo que más dolió fue la pasividad con que se condujeron las autoridades ante los hechos. El día 26 se habían practicado algunas detenciones -de derechistas-, y el Gobernador Civil se personó en el periódico después de los sucesos; pero durante los mismos, las fuerzas de orden permanecieron pasivas. La lección que se extraía era la siguiente:

\footnotetext{
«Malas, malas jornadas para Valladolid las de estos días; son algo tristísimo; pero algo bien claro habrá llegado como resultado de ellas a la conciencia de los hombres de bien y es la necesidad de agruparse para la mutua defensa, pues caso de verse agredidos, ya no pueden esperar nada del apoyo que debe prestar la autoridad." 209
}

Es un buen índice del grado de crispación y de deterioro institucional que se respiraba. Pocos días más tarde comenzaba la suscripción para la reparación de los daños en los dos edificios, y Diario Regional publicaba un editorial agradeciendo las muestras de adhesión, celebrando la vuelta de la tranquilidad, y pidiendo que se les respetara "como nosotros respetamos el derecho o las inclinaciones y tendencias de otros, aun cuando no estén

Sobre el ambiente de agitación y violencia que se vivía, puede verse ALMUIÑA FERNÁNDEZ, Celso, "Introducción: la Universidad de Valladolid dentro del marco de la universidad española contemporánea", en Historia de la Universidad de Valladolid, vol. II, pág. 399-400. Al parecer gran parte de la violencia desatada partió de elementos de la asociación izquierdista de universitarios, la Federación Universitaria Española -FUE.- enfrentados desde tiempo atrás con la de los estudiantes católicos, la Federación de Estudiantes Católicos -FEC-.

${ }^{208}$ Se produjeron profanaciones de imágenes religiosas, cuyos restos se arrojaron contra el periódico. La reacción del obispo se retrasó prudentemente una semana, tras la cual se convocaron actos de desagravio público: "Voz del Prelado. Alocución sobre los desagravios al Sagrado Corazón de Jesús por el ultraje inferido en su Imagen Sagrada, arrastrada por las calles de Valladolid", DR, 5/4/1933, pág. 6 , últ..

${ }^{209} \mathrm{DR}, 28 / 3 / 1933$, pág. 1, editorial. 
comprendidas bajo ningún derecho, ya que para nosotros, éste no puede estar al mismo tiempo en posiciones contrarias» 210 .

Por fin, dos meses más tarde, llegaría la última denuncia de esta etapa, motivada por la publicación de una carta al director ${ }^{211}$, en la que dos fontaneros municipales denunciaban su despido -irregular, en su opinión- y el contrato por favoritismo de obreros socialistas venidos de fuera de Valladolid, así como diversos actos de violencia de que habían sido objeto. El periódico comentaba:

\footnotetext{
"Bien está y lo aplaudimos, el celo del señor fiscal, el de las restantes autoridades y el de los agentes de Vigilancia [que se han personado para retirar los ejemplares del número denunciado] para que las leyes se cumplan, y si alguien las conculca sufra las consecuencias; pero, todo ese celo por y ante presunto delito, sobre el que los Tribunales dirán en su día la última palabra, pudo y debió emplearse también para perseguir y exigir el castigo de los autores de otros delitos, no presuntos, sino reales y tristemente efectivos." 212
}

Pero las dificultades no echaron para atrás a estos hombres. Poco después se afrontaba un proyecto más ambicioso para el periódico. El impulso y la ayuda que se recibían de Madrid habían aumentado desde que Angel Herrera había sido nombrado presidente de la Junta Nacional de Acción Católica, en los primeros meses de 1933. En junio pronunció en Valladolid una conferencia sobre la Acción Católica, en la que insistió sobre la

210 "Después de unos sucesos. A guisa de epílogo.", editorial, DR, 31/3/1933, pág. 1 .

211 «Como viene y sin comentarios», DR, 4/5/1933, pág. 8, últ.

212 "DIARIO REGIONAL, denunciado.", 6/5/1933, pág. 8, últ. 
necesidad de que Diario Regional hiciera honor a su nombre:

"Es cierto que tenéis en Valladolid un periódico católico;
pero que no responde hoy a las necesidades de la vida
presente. No se me ocultan los sacrificios que llevais
realizados y la labor benemérita de los que en él trabajan y
colaboran; pero es necesario, como os digo, llegar a
constituir el verdadero diario regional que sea el periódico
de gran circulación por toda la región castellana, que sea el
portavoz de nuestras ideas en todos los pueblos y que tenga,
como los fundados en Granada y en Badajoz, la supremacía de
todo buen rotativo moderno, bien ordenado, bien orientado y
que pueda trabajar fecundamente en toda la extensión de la
meseta del Duero."213

La sugerencia fue recogida con entusiasmo por Salazar, que se dirigía a los lectores el día de la prensa católica, prometiendo hacer del periódico un gran rotativo regional si se le prestaba ayuda económica "como en el campo contrario»214. Anunciaba el comienzo de una nueva campaña con este fin, que no llegó a organizarse, quizá por la proximidad de las elecciones, quizá por falta de acuerdo entres quienes debían promoverla. Pero de todo ello hay una conclusión cierta: el periódico crecía, su entierro, por el momento, podía esperar.

En noviembre, tras el éxito electoral de las derechas, Felipe Salazar dio por terminada su estancia al frente del periódico. En el artículo que escribe como

213 «En el Teatro de Calderón. Interesante conferencia de don Angel Herrera Oria, sobre acción católica», DR, 27/6/1933, pág. 8, últ.. 214 «Las armas actuales», DR, 29/6/1933, pág. 4. 
despedida215, además de hacer un repaso de las dificultades que encontró en su tarea por parte de los adversarios naturales del periódico, levantaba el velo que cubría las dificultades que había encontrado también en "los de dentro": envidias, suspicacias, zancadillas²16. Es la única referencia que encontramos a disensiones internas entre los católicos vallisoletanos, que no debieron ser pocas. Si algo había conseguido Salazar era consolidar, por encima de todas ellas, un instrumento combativo, de propaganda en favor de la unidad política. La fórmula se demostraría eficaz: a la altura de 1933 la opinión política defendida por Diario Regional obtenía ya más votos que la que propugnaba El Norte de Castilla, hasta ahora dueño tradicional de la política local. "Mi misión está cumplida", decía el ex-militar y ahora ex-periodista, y no le faltaba razón. La etapa de su dirección, si no había sido brillante en algunos aspectos -su estilo no era nada depurado, como él mismo reconoce, y debió inventar más de una palabra-, sí había conseguido dejar al periódico mucho más arriba de donde lo encontró, o, a lo menos, mucho más batallador:

\footnotetext{
«Es posible que en nuestro DIARIO REGIONAL (...) se maltrate la gramática, $y$ ello es posible porque no es una hoja literaria, $\mathrm{ni}$ su redacción se compone, precisamente, de académicos de la lengua ni prestigiosos estilistas. Nuestro
}

\footnotetext{
215 «El fruto de...", DR, 29/11/1933, pág. 2.

${ }^{216}$ La última había sido la difusión del rumor -que llegó a publicarse en un semanario local- de que la empresa quería despedirlo, pero que él no se marchaba "por bemoles". Cfr. ibid..
} 
periódico es un periódico de lucha, con ideas bien definidas y lenguaje claro." 217

Le sucedió al frente de la publicación el que era redactor jefe desde 1912, Ricardo Martínez y Fernández. Valen para la época de su gestión las características señaladas hasta aquí para años anteriores, ya que puede decirse que su labor fue sobre todo conservar lo que heredaba. Los tiempos -con la C.E.D.A. pesando en el Gobierno- se prestaban a ello, aunque no faltaron batallas que librar, como veremos al hablar de los contenidos políticos, o del comportamiento ante la revolución de 1934. En lo periodístico lo más destacable fue quizá el cambio de actitud ante la libertad de prensa, la generalización de la radio como medio de comunicación, y el encono del enfrentamiento con $E l$ Norte -o lo que es lo mismo, con los albistas convertidos en radicales-.

Por lo que hace a lo primero, las nuevas circunstancias políticas permitían que no fuera necesario clamar por la libertad, y cuando llegó la limitación de la misma, con motivo de la revolución de 1934, el periódico será el primero en pedir la represión de la propaganda revolucionaria218. Finalmente, en 1935, además de las crónicas parlamentarias correspondientes, se dedicó algún

217 "A "El Norte de Castilla". Algo más de dos palabras.", DR, 7/9/1933, pág. 6, últ..

218 "Un enemigo interior que no tiene derecho a vivir.", editorial, DR, 10/6/1934. El periódico apoya la ampliación de la censura previa ante las llamadas a la revolución de algunos medios como El Socialista. 
fondo a la defensa del proyecto de Ley de Prensa de la C.E.D.A. ${ }^{219}$, con cuya orientación se identificaban ${ }^{220}$.

El momento de mayor tensión de estos años llegaría el 5 de octubre de 1934. El día 6, con motivo de la huelga general que se ha declarado en Valladolid, no sale el periódico. El 7, aunque tampoco se pudiera publicar, se difundió un "suplemento de Diario Regional ": cinco folios mecanografiados, con un breve editorial - "Por España»221_, y las informaciones más importantes sobre los sucesos de esos días en Cataluña, Asturias, Madrid y Valladolid. Algunos días después, el redactor especializado en temas de radio -José María Martín Liébana- publicaba un artículo titulado "La radio al servicio de la Patria. Revolución radiada.", en el que manifestaba su alegría por el general reconocimiento que, con motivo de los últimos acontecimientos, se hacía de la importancia de este medio de comunicación. La historia de la primera emisora de radio vallisoletana se remontaba a mayo de $1933^{222}$. Por entonces existía ya una asociación de radioyentes

219 "Ante el proyecto de ley de prensa ¿Hasta dónde llegará su trascendencia?", DR, 30/1/1935, pág. 1. "La libertad de la prensa", por Salvador Minguijón, DR, 20/7/1935, pág. 1.

220 Sobre la génesis y contenidos del proyecto de ley cfr. FERNANDEZ AREAL, Manuel, El control..., págs. 135 y ss.

${ }^{221}$ Lo reproducimos íntegro en el apéndice 10.

222 "La emisora de Radio Valladolid. Ya hay un proyecto firme para crear Radio Castilla», DR, 14/5/1933, pág. 2. 
vallisoletanos, con unos quinientos socios 223, y la publicidad sobre aparatos de radio comenzaba a aparecer en las páginas del periódico. En septiembre, Radio Castilla de Burgos obtuvo el permiso municipal para instalar una emisora en la ciudad224, que en marzo de 1935 se transformará en Radio Valladolid, con el consiguiente cambio de programación y de orientación ${ }^{225}$.

El rápido crecimiento de la prensa había preocupado a los medios escritos, que pedían una nueva regulación legal, que les protegiera de lo que consideraban competencia desleal: la emisión de informativos, incluso los lunes, la publicidad sin tasa, o la retransmisión en directo de acontecimientos deportivos ${ }^{226}$. Diario Regional lamentaba además "la perniciosa tendencia informativa de Radio Prensa, de Madrid»227, y tuvo que abrir un nuevo frente en sus batallas periodísticas, contra la propaganda radiada que él estimaba

223Cfr. DR, 5/7/1933, pág. 4. El periódico prestaba una cuidadosa atención a los temas de radio en la sección correspondiente: programaciones, calidad de las emisiones, problemas técnicos, etc.

224 «El Ayuntamiento emitió el último sábado dictamen favorable a Radio Castilla de Burgos para instalar una emisora de radio en el Hotel Francia de nuestra ciudad", DR, 6/9/1933, pág. 5. La autorización definitiva llegará pocos días más tarde: DR, 27/9/1933, pág. 5 .

${ }^{225}$ Cfr. la entrevista con el director, Jesús Varona, en DR, 29/3/1935, pág. 2 .

226 "La radio y la prensa", por D. Lagunilla, DR, 15/6/1934.

${ }^{227}$ Hasta junio de 1935 Radio Valladolid emitía los informativos de esa emisora. Cfr. DR, 8/6/1935, pág. 1 . 
revolucionaria, defendiéndose de las críticas que se le hacían desde ese medio 228.

En cuanto al último punto, las luchas políticas que le enfrentaban a El Norte, hay que enmarcarlo en el conjunto de la definición ideológica del periódico.

\section{Lo que a todo católico importa saber sobre el uso del voto}

Paralelo al proceso de renovación de Diario Regional discurría el de consolidación de Acción Nacional en Valladolid. En los primeros meses después de las elecciones de 1931, el diario fijaba su atención en uno u otro político, como si se preguntara de dónde le llegaría el auxilio229. Eran los momentos de miedo y desconcierto, de los que ya hemos hablado. Acción Nacional apenas si pasaba de ser un proyecto, cuyos primeros pasos habían terminado en fracaso. Por si fuera poco, recibirá un desplante de Royo Villanova, el derechista más votado en

${ }^{228} \mathrm{La}$ polémica más señalada tuvo lugar con motivo del acto que la J.A.P. (Juventudes de Acción Popular) organizó en Medina del Campo en junio de 1935. Desde la radio se criticó la campaña propagandística del periódico sobre el mismo, a lo que el periódico contestó con el editorial "La propaganda política", DR, 6/6/1935, pág. 1 .

${ }^{229}$ Se mantenía ahora una actitud prudente en las críticas, que sólo eran duras para los azañistas o los socialistas. Así, se encuentran alabanzas en el periódico para Ortega y Gasset -19/11/1931, pág. 1-; la noticia de la fundación del partido Conservador de la República de Miguel Maura se da a toda plana en primera página, y se le dedican nueve columnas en las páginas interiores -12/1/1932-; se publican elogios para Lerroux, como en el editorial de 16/12/1931, titulado "Ya hay una oposición republicana", o en todo caso se pone en duda si se deben depositar en él esperanzas -23/2/1932, pág. 6, últ.-; algo que un año más tarde será inconcebible. 
la provincia, en el artículo que éste publicó en El Norte para justificar su permanencia en las Cortes cuando -en octubre del treinta y uno- se produjo la retirada de los agrarios. Royo agradecía el apoyo de los albistas que lo animaron a presentarse a las elecciones, pero ni mencionaba a Acción Nacional ni a los agrarios como colaboradores de su éxito. Rafael Serrano, por Acción Nacional en Castilla -que así se denominaba ahora la agrupación-, contestó en Diario Regional con otra versión:

"La coalición que dio el triunfo al señor Royo en las elecciones del 28 de junio, no tenía otras fuerzas organizadas que las del Partido Agrario y las de Acción Nacional; los elementos que sacaron al señor Royo de su casa y le apoyaron también, en parte residuos del antiguo albismo, eran fuerzas dispersas y escasas, pudiendo afirmar cualquiera persona, que el éxito del señor Royo (...) le (sic) debe precisamente a quienes no le sacaron de su casa y le apoyaron resueltamente con sus votos.

"Acción Nacional, por su parte, imprimió y repartió profusamente, por toda la provincia, candidaturas con su nombre, sin trato de reciprocidad, como es notorio." 230

Los mejores aliados que iba a encontrar Acción Nacional, aunque parezca paradójico, serían el anticlericalismo y los brotes revolucionarios. El periódico echará en cara a las derechas su pasividad hasta El Socialista está asombrado231-, y lanzará llamadas a una movilización general en defensa de la religión. Ese era el fondo de los llamamientos que se publicaban en el diario convocando al mitin revisionista que se celebraría

230 "La actitud del señor Royo. contestación de Acción Nacional.", por Rafael Serrano, DR, 20/10/1931, pág. 6, últ..

231 "Para las clases conservadoras. Una gran verdad que les dice "El Socialista"", por "Viriato", DR, 8/11/1931, pág. 1 . 
en Palencia el día 8 de noviembre 232 , y que sería el primer éxito de Acción Nacional en Castilla233. Todo el problema era ahora tratar de acaparar la oposición al socialismo, a la que en diciembre de este año se había sumado también $E l$ Norte de Castilla 234, y luchar por la unidad de los elementos de derecha.

El siguiente gran mitin estaba anunciado para el 5 de mayo de 1932. Se preparó con la misma profusión de anuncios en el periódico desde semanas antes, y fue prohibido el día 2. Acción Nacional calificó la medida como "el máximo abuso de la más antijurídica ley (la de Defensa de la República)"235. A renglón seguido comenzó una campaña desaforada en las páginas del periódico contra el

${ }^{232}$ Estaba organizado por las minorías parlamentarias agraria y vasconavarra. En Valladolid lo promovía y gestionaba las asistencias Acción Nacional. Los recuadros con tipos en negrita que publicaba el periódico tenían el tono siguiente: "Mujeres católicas: si queréis conservar la integridad del clásico hogar español evitando la desmembración de la familia, posible al calor del divorcio que la Constitución implanta (...), laborar cuanto vuestro celo os sugiera dentro de las normas legales en pro de la tarea revisionista de la Constitución (...)."; "Católicos: si queréis evitar que vuestras creencias religiosas sean desconocidas, menoscabadas y pisoteadas..."; "Agricultores castellanos: si queréis que vuestras tradiciones de familia, propiedad, orden, justicia, pacífica producción y trabajo honrado no se interrumpan..."; "Españoles: por la fe y las creencias, por la santidad de la familia española, por la enseñanza católica de nuestros hijos, por la defensa de la propiedad...". En todos los anuncios se insistía en el respeto a la República y a la actuación dentro de la legalidad vigente.

${ }^{233} \mathrm{El} 10 / 11 / 1931$ se dedican tres páginas completas a la crónica.

${ }^{234} \mathrm{En}$ ese mes se desató una polémica entre los dos periódicos con este motivo a raíz de una colaboración publicada por Diario Regional que llamaba la atención sobre el viraje político de su colega.

235DR, 4/5/1932, pág. 4, últ.. Se esperaba que asistieran al mitin 25.000 personas. 
Estatuto de Cataluña, que iba a encontrar un eco considerable. En Palencia se celebró una asamblea regional para protestar contra el Estatuto, a la que asistieron representantes de casi todas las provincias, menos de Valladolid 236 , donde el Ayuntamiento y la Comisión Gestora de la Diputación se habían declarado contrarios a la misma. El día 8 había tenido lugar una manifestación contra el Estatuto que acabó con una intervención de los Guardias de Asalto que ocasionó heridos graves. Los días 10 y 11 continuaron los disturbios, que terminaron por ocasionar -en una carga de los de Asalto- la muerte de un joven en la Plaza Mayor.

En estos incidentes el periódico estaba en el ojo del huracán -ya mencionamos la detención de su director y la denuncia del editorial del día 11- con el consiguiente beneficio publicitario. Todo esto reflejaba el crecimiento de un movimiento de oposición a las izquierdas gobernantes, pero eso no equivalía a tener una derecha unida ni, mucho menos, homogénea. Si repasamos los nombres de algunos de los oradores de los mítines de Acción Nacional en la provincia durante este tiempo, encontramos a hombres por lo general jóvenes, que tendrán-dentro del periodo republicano- destinos políticos dispares: Luciano de la Calzada, Antonio Gimeno Bayón, Rafael Martín Lázaro,

236 Asistieron los alcaldes de Palencia, Burgos, Santander, Salamanca y Zamora, tres diputados por Burgos y uno por León. Cfr. DR, 8/5/1932, pág. 5. De Valladolid acudió el presidente de la Cámara de la Propiedad Urbana. 
Tomás Cerro, Antonio Valentín, Mariano Escudero de Solís, Onésimo Redondo y Javier Martínez de Bedoya. Y si nos fijamos en los oradores previstos para el mitin abortado tenemos casi lo mismo: José María Pemán, Dimas de Madariaga, José María Valiente, Pedro Sáinz Rodríguez, Joaquín Reuniza y José María Gil Robles. Transcurrido poco tiempo, algunos de ellos siguen en Acción Nacional, pero otros estarán en Renovación Española, las Juntas de Ofensiva Nacional Sindicalista (J.O.N.S.), o el Partido Nacionalista.

Este proceso de constitución de grupos políticos era lógico si tenemos en cuenta que la vieja política, como tantas veces se había dicho, había muerto. Los restos que aún pervivían tenían sus días contados. Esto planteaba graves problemas para el sector de $E l$ Norte, no tantos al Diario, que crecía en su actividad política al mismo tiempo que los nuevos grupos emergentes; pero no era, desde luego, algo que favoreciera la unidad. En febrero se había constituido en Valladolid el Bloque Agrario Castellano 237 -que venía a ser una reagrupación de viejos caciques para defender intereses agrícolas-, en marzo en Partido Nacionalista Español de Albiñana238, en mayo el

\footnotetext{
${ }^{237} \mathrm{DR}, 25 / 2 / 1934$, pág. 6, últ.. ${ }^{238} \mathrm{DR}, 30 / 3 / 1932$, pág. 6., últ..
} 
Partido Tradicionalista ${ }^{239}$, y Onésimo estaba ya organizando sus J.O.N.S.

Todos ellos se presentaban como la solución a la política sectaria del momento, y los tradicionalistas reclamaban también para sí el voto de los ciudadanos en cuanto católicos. Diario Regional, o lo que es lo mismo, Acción Nacional, dirigía llamadas a la unidad especialmente a los agrarios, que no en vano eran el grupo con más posibilidades reales de captar votos 240 . La actividad de la agrupación en este año, además del gran mitin nonnato, se centró en los actos de propaganda, especialmente numerosos en los pueblos, donde se fueron creando comités locales, $y$ en los contactos con otras entidades de derechas. La creciente actividad llevó a un cambio de sede en noviembre 241 , y a la organización de dos actos de propaganda el 3 de diciembre, cuyo éxito fue saludado con entusiasmo como el signo del resurgir de la derecha ${ }^{242}$. En el editorial del día 6 se respondía a las

239DR, 6/5/1932, pág. 6, últ.. Justo Garrán presidirá el mitin del partido que se celebrará en Valladolid en febrero del año siguiente. Cfr. DR, 28/2/1933, pág. 2 .

240 "Un acto importante. Constitución del “Bloque Agrario".", DR, 12/4/1932, pág. 8, últ.

$241 \mathrm{Al}$ acto inaugural asistieron representantes de la Liga Anticomunista Femenina, Centro Tradicionalista y Bloque Agrario. Cfr. DR, 6/11/1932, pág. 8, últ..

${ }^{242}$ Los actos se convocaron con el lema "Por la Religión, la Patria y la Libertad". Royo Villanova pronunció una conferencia en la sede de Acción Nacional pidiendo la unión "bajo una sola idea, la defensa de la libertad religiosa $y$ de la integridad de la Patrial. El acercamiento de Royo había pasado por un homenaje al diputado, que 
señales de alarma de la izquierda reafirmando el propósito de "seguir avanzando, siempre con honradez" hasta conquistar de nuevo el poder político243.

A fines de año tuvo lugar la elección de la nueva Junta de Gobierno de Acción Nacional, y la aprobación, un tanto controvertida, de la constitución de una Juventud de Acción Popular, decisión que no se pondrá en práctica hasta enero de $1934^{244}$. La controversia quizá tenía relación con el problema general del radicalismo político de las juventudes en la segunda República, que en la derecha de Valladolid se iba a manifestar en el éxito de la formación que fundara Onésimo Redondo, las J.O.N.S., especialmente entre los universitarios. Las Juntas permanecerán unidas a Acción Popular en 1932, para separarse más tarde por desacuerdo con la postura confesional, separación que supuso un duro golpe para los

Diario Regional había impulsado para agradecer su actuación en las Cortes con motivo del debate sobre el Estatuto de Cataluña. Cfr. DR, 4/12/1932, pág. 1 .

243 "¿Qué a dónde van las derechas? iA donde pueden ir con pleno derecho!", DR, 6/12/1932, pág. 1 .

244Cfr. DR, "Acción Popular en Castilla", 23/12/1932, pág. 6, últ., e "Importante manifiesto. Juventud de Acción Popular Agraria", 25/1/1934, pág. 8, últ. El primer presidente era José María Valentín, y el secretario Francisco Javier Martín Abril, futuro director del periódico.

Por lo que respecta a los cargos de Acción Popular en Castilla en 1932, Serrano había abandonado la presidencia, que fue ocupada hasta diciembre por el notario Francisco Mañueco, mientras que aquél permanecía como vicepresidente en funciones. La junta elegida en diciembre estaba compuesta por: Félix Igea, médico; Luis Ruiz de Huidobro, abogado; Santos Rodríguez Pardo, comerciante; Teodoro Martín y Faustino Herranz, obreros; Francisco Pérez, empleado y Luciano de la Calzada, licenciado en Historia. 
cuadros de Acción Nacional, del que se recuperará gracias a la acción de Luciano de la Calzada245.

Si por un lado las derechas avanzaban, y su autodefinición se iba clarificando con el repudio de Lerroux y de Miguel Maura246, por otro, las diferencias internas de los distintos grupos persistían e incluso se acentuaban frente a cuestiones como la actitud ante el régimen, los problemas sociales, el parlamentarismo, la violencia, o el fascismo.

Para ganar ELECCiOnes

De ser posible, el periódico hubiera pasado por encima de todas esas diferencias. Si algo le preocupaba, por encima de todo, era ver fuera del Gobierno a quienes entonces lo ocupaban, que cesara la persecución religiosa, todo lo demás era secundario, matices por los que no valía la pena discutir. Una curiosa forma de hacer política, que se supone que es, precisamente, la tarea a la que concierne dilucidar todos esos debates. Pero -con la finalidad mencionada como norte-, se procuraba por todos los medios evitar una definición política que distanciara de nadie. Por eso las campañas más características del periódico son las que llaman a la unidad de la derecha

245Cfr. MONTERO, José Ramón, La CEDA..., tomo I, págs. 385-386.

246 Cfr. "El caso Lerroux", por Baldomero Argente, DR, 27/10/1932, pág. 1, $\mathrm{Y}$ "El discurso de Miguel Maura", por José Calvo Sotelo, DR, 22/1/1933, pág. 2 . 
ante las elecciones. En cuanto se llega a la formación de la C.E.D.A., Diario Regional se apresura a publicar un editorial resaltando el hecho y su significado:

\begin{abstract}
"(...) Lo esencial es Dios y la Patria. (...) Otro objetivo importantísimo es la cuestión social (...). La CONFEDERACION DE DERECHAS AUTONOMAS está en marcha. Dios lo quiere y ha de ayudarlas si saben merecerlo, ¿Adoptaremos nosotros [los vallisoletanos] locamente una conducta pareja a la que ha iniciado el Congreso habido en Madrid?"247
\end{abstract}

El día 19 publicaba en primera página el manifiesto del Comité Electoral de Unión de Derechas de Valladolid, firmado por representantes del Comité Femenino -la Liga Anticomunista-, Acción Nacional en Castilla, Centro Tradicionalista y Juntas de Ofensiva Nacional Sindicalista, a los que más tarde se unirá Renovación Española: un manifiesto confesional, antimarxista y de repudio de la política liberal.

Las elecciones a los ayuntamientos formados en 1931 por el artículo 29, y las de vocales del Tribunal de Garantías Constitucionales, sirvieron de ensayo para lo que serían las elecciones a Cortes. El resultado de las primeras - Aplastante triunfo de las candidaturas antigubernamentales»248-, se celebró como preludio de una victoria próxima. Con motivo de las segundas se desarrolló una intensa campaña a favor de los vocales de la C.E.D.A.

\footnotetext{
247 "A las derechas vallisoletanas", editorial, DR, 9/3/1933, pág. 8, últ..

${ }^{248}$ Titulares a 7 columnas en la primera página, DR, 25/4/1933.
} 
-a los que se refieren siempre como "agrarios"- que también terminó con éxito, y con un duro ataque a los concejales albistas del Ayuntamiento de la capital, al que respondió $E l$ Norte de Castilla con no menos dureza249. Era el primer acto de una nueva batalla entre los dos periódicos, que iba a ser una constante en los próximos años: el ascenso de un periódico pasaba necesariamente por hacer mella en el campo del otro, más todavía en estos momentos en que periodismo y combate político iban juntos.

El recrudecimiento de las hostilidades llegó con la noticia de que Santiago Alba había decidido apoyar al Partido Radical. "La conversión de don Santiago Alba" titulaba Diario Regional un editorial dedicado a comentar el hecho, en el que se leía:

"(...) [No es una conversión cualquiera la de] quien, como él, tanto influyó en el aspecto que la política tuvo en Valladolid, dominando la ciudad en todos los órdenes y en todos los sentidos, no pudiendo en ella darse un solo paso en cualquier dirección sin toparse con Alba y con los albistas (...).

"Aquí, entre nosotros, el acontecimiento será memorable para los fastos de la política local. Felicitaciones sinceras, horizontes que se abren, posibilidades que se acercan, figuras ya conocidas y casi esfumadas que adquirirán brillo, reflejo, sí, pero brillo al fin; hombres que se definirán, publicaciones que cesarán de hacer equilibrios y bajarán de la albardilla para disfrutar de las caricias del sol político en el lado de la tapia más y mejor bañado y, sobre todo, ya sin confusiones ni eufemismos. (...) Ya está cerca; y preparémonos a ver muchas cosas de antaño y probablemente nuevos rumbos, nuevas cosas y nuevos republicanos." 250

249 "Los concejales albistas elegidos por los monárquicos, votan contra los agrarios. Traición.", DR, 5/9/1933, pág. 6, últ. y "A "El Norte de Castilla". Algo más de dos palabras.", DR, 7/9/1933, pág. 6, últ.

250 "La conversión de don Santiago Alba.", DR, 18/10/1933, pág. 1 . 
Después de los revolucionarios, éstos iban a ser los enemigos.

Aliados por fin con los agrarios, se lanzó la campaña a favor de "Nuestra candidatura": la "Candidatura Agraria de Derechas", que -insistirán machaconamente-, debe votarse "sin tachar un solo nombre, (...) íntegra, absolutamente íntegra (...)."251. La componían dos agrarios Antonio Royo Villanova y Pedro Martín Martín-, y dos hombre de Acción Popular Agraria252 -Luciano de la Calzada y Blas Cantalapiedra253-. Al mismo tiempo, se desplegaba una campaña contra los radicales, a los que se identificaba con la masonería: su victoria no sería más que el "laicismo a fuego lento"

"Es preferible la agresión cruel, despiadada, que hemos padecido en dos años de persecución salvaje y que produce la natural reacción salvadora, a la garantía enervante de que van a despellejarnos poco a poco, pidiéndonos perdón, con la sonrisa en los labios, a cada tira que se nos arranque. Esta es la táctica del partido radical." 254

251 «En plena campaña electoral. Nuestra candidatura», editorial, DR, 31/10/1933, pág. 8, últ.

${ }^{252}$ La nueva denominación era una indicación expresa de Gil Robles. Cfr. MONTERO, op. cit., ibid..

${ }^{253}$ De éste se indicaba que era "independiente de todo grupo político".

254Cfr. DR, 9/11/1933, pág. 1. Otros textos decían: "Los radicales obedecen y cumplen ante todo los mandatos de la Masonería internacional."; "Los diputados radicales apoyaron al Gobierno en Casas Viejas."; "En su último mitin electoral ha dicho Lerroux, jefe del partido radical, que respetará todas, absolutamente todas las leyes votadas por las Cortes constituyentes." 
Por estos días se publicó el editorial cuyo título da nombre a este apartado. En él, apoyándose en citas de Pío $\mathrm{X}$, de la pastoral de mayo de los obispos españoles, y textos de obispos alemanes en el siglo XIX, concluyen que no es moralmente lícito a un católico votar al Partido Republicano Radical o a Miguel Maura, ya que éstos han permanecido pasivos ante la acción revolucionaria, y no han defendido la libertad de la Iglesia, ni garantizado el carácter cristiano de la enseñanza255.

El tono no era el de una campaña electoral ordinaria, era el de un combate por la supervivencia. Del mitin de Gil Robles en Valladolid se había destacado en los titulares la siguiente frase: "Para nosotros la democracia no es un fin sino un medio, $y$ si los izquierdistas pretenden saltar sobre la democracia porque el triunfo sea nuestro, nosotros saltaremos sobre la democracia y sobre ellos."256 Venciera quien venciera, parece claro que ya entonces pocas posibilidades quedaban de que alguien deseara la vigencia de una democracia liberal: el sistema había sido el gran perdedor de los primeros años de República. En Diario Regional se habían evitado los ataques editoriales contra el parlamentarismo, aunque no habían faltado los de colaboradores como Calvo Sotelo o, sobre todo, Víctor Pradera; pero cuando -por fin- en

255 "Lo que a todo católico importa saber sobre el uso del voto", editorial, DR, 15/11/1933, pág. 1 .

256 DR, 3/11/1933, pág. 1 . 
febrero de 1934, publique dos editoriales definiendo lo que entiende por un programa de derechas, en resumen dirá que consiste en: 1.- regionalismo sin separatismo; 2.- ni autoritarismo ni democracia liberal: tradición española de autonomía municipal y corporaciones de productores; 3.tradicionalismo español: la libertad de los Austrias, los Reyes Católicos y Felipe II, frente a imposiciones francesas de Borbones y liberales; 4.- dictaduras, sólo excepcionalmente y nunca prolongadas - "la democracia liberal no es más que una dictadura disfrazada de comités políticos»-; 5.- elecciones: serían de tipo presidencialista; 6.- Cortes corporativas; 7.- referéndum como modo de consulta popular habitual. En tres palabras, "Estado democrático corporativo" 257 .

La alegría por la victoria de noviembre de 1933 -los cuatro puestos de la mayoría fueron para la candidatura

257 "Un programa español» I y II, editoriales, 1/2/1934, pág. 1 y 2/2/1934, pág. 2, respectivamente. 
del periódico ${ }^{258}$ - se vio enturbiada poco después por otras declaraciones de Royo Villanova -esta vez a $A B C-$, que parecía empeñado en aguar todas las fiestas de Acción Popular Agraria: afirmaba que con su prestigio se había convertido en "remolcador de dos candidatos agrarios de nombre desconocido". Royo rectificó, y Diario Regional pudo hacer callar a El Norte de Castilla, que ya estaba comenzando a hablar de las divisiones en el campo contrario259. El periódico se colocó en la línea de Gil Robles, defendiendo la necesidad de acatar la República, de colaborar con el Gobierno; ceder y conformarse con los logros que poco a poco pudieran obtenerse. Era su postura de siempre, por las razones de siempre:

"Nadie, maliciosamente, crea que hacemos sacrificio de afanes monárquicos o de aficiones fascistas. No, nada de eso. Sacrificamos todas las naturales ansias de ver compensadas las

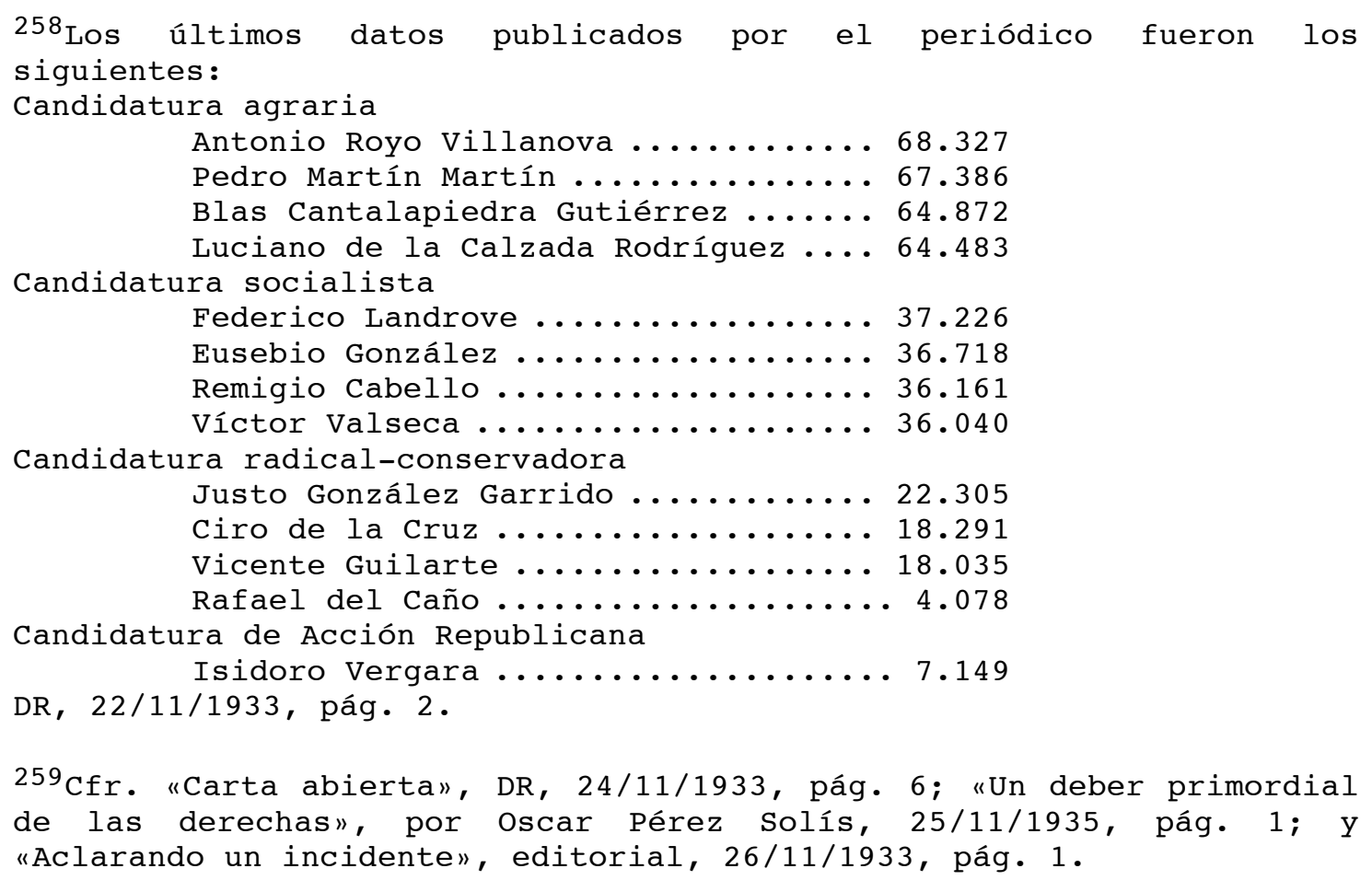


amarguras que como católicos y españoles llevamos sufridas desde abril de $1931 . " 260$

Las posiciones radicales se abandonaron en aras de un entendimiento que ayudara a serenar los ánimos y gobernar el país, al tiempo que se esperaba la revocación de la legislación anticlerical, y se pedía que se conservara lo que de bueno había hecho el bienio azañista en materia social, mejorándolo cuanto fuera necesario. Hasta se llegó a alabar y apoyar una propuesta de Santiago Alba261.

Los mismos motivos que empujaban a la concordia motivaron un progresivo distanciamiento de los radicales, agentes de la masonería, como se dirá repetidas veces ${ }^{262}$, y por tanto enemigos de la Iglesia. Pero lo que sembró de nuevo el desánimo y provocó un cierto desconcierto, fue la revolución de octubre del treinta y cuatro. Los comentarios que se publicaron con ese motivo dibujan por un lado la solución "nacional" al problema como la única

260 "El camino está bien indicado", editorial, 7/2/1934, pág. 1.

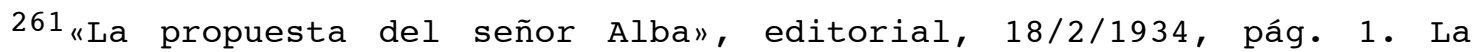
iniciativa de Alba consistía en elaborar un elenco de temas que Las Cortes debían abordar como cuestiones básicas. El periódico la aplaudía, aunque dudaba de su viabilidad por la división interna de los radicales.

Sobre las relaciones de Alba con el Partido Radical cfr. RUIZ MANJón, Octavio, El Partido Republicano Radical, 1908-1936, Tebas, Madrid, 1976, especialmente págs. 529-553.

262 "Una espina en el Gobierno", editorial sobre Martínez Barrio y su "política masónica", DR, 9/2/1934, pág. 1; "Un Gobierno más...", editorial lamentando que Martínez Barrio no corte con las presiones de la masonería, 16/6/1932, pág. 1; "El rumbo que sigue el régimen", editorial sobre el mismo tema. Además de estos editoriales, aparecen otros artículos sobre la masonería en general. Cfr. para este asunto nuestro estudio "La Masonería en la prensa confesional en Castilla durante la Segunda República y la guerra civil: Diario Regional de Valladolid 1931-39", en Masonería, revolución y reacción, tomo I, Instituto de Cultura Juan Gil Albert, Alicante, 1990, págs. 391-409. 
posible 263, y por otro llaman a los ciudadanos de derecha a prepararse para una defensa armada de sus posiciones. Por lo significativo de los textos recogemos algunos con cierta amplitud:

"La derrota de la revolución, es el vencimiento de unas fuerzas políticas -en primer término el partido socialista- y de una fracción mal aconsejada del proletariado; pero no debe ser convertida en una victoria de otras fuerzas políticas y de otros sectores sociales, cualesquiera que hayan sido sus esfuerzos $y$ sus méritos, indudables, para conseguir ese triunfo. La hora es demasiado grave para deformar el sentido nacional que tiene y desviarle hacia fines de partido $o$ de clase. (...)

"Hay que interpretar la revolución como una crisis dolorosa, pero saludable, que pone término a una España confusa y desquiciada y determina el comienzo de una España neta, orgánica. El pasado no debe volver; pero hay que asegurar un porvenir firme. "España -dice la Constitución- es una república de trabajadores de todas clases que se organiza en un régimen de libertad y justicia". Es preciso que de una vez lo sea." 264

"(...) [la revolución] ha sido vencida pero no aplastada. (...) La paz material está lograda, pero hay que convertirla en paz moral. (...) Son muchos los caminos que conducen a este fin, uno primero es aprestarse a la defensa (...), hemos llegado a unos días en que ser ciudadano tiene que equivaler a ser militar. (...) [Hay que crear] un frente patriótico, esto es, sin más política que la de España, inerme en la paz, combatiente en la guerra, que participe con la fuerza armada del Estado en el honor y los gloriosos peligros de impedir la degradación y la muerte de la Patria."265

Llegarán después las quejas por el modo en que se lleva la represión -el periódico pedía que fuera ejemplar para los jefes ${ }^{266}$, para concluir que la revolución no se

263 "Vive y vivirá España», editorial, 9/10/1934, pág. 1. Lo reproducimos íntegro en el apéndice 11 .

264 "La victoria de España", editorial, 16/10/1934, pág. 1.

265 «Un frente patriótico», editorial, 21/10/1934, pág. 1.

${ }^{266}$ Cfr. por ejemplo el editorial "iA la cabeza, a la cabeza!", DR, 11/10/1934, pág. 1 . 
ha liquidado, y que el sectarismo continuaba: hay que proceder de otra forma si se quiere "reconquistar lo que, en momentos de vesania sectaria se ha arrebatado con todo derecho a la inmensa mayoría del país»267.

Las señales de ruptura con los radicales se dieron incluso en la política local. En marzo de 1935, la minoría de Acción Popular Agraria abandonó el Ayuntamiento por desacuerdo con la política y los modos de los radicalesalbistas ${ }^{268}$; y en abril estalló el escándalo de un desfalco en la Diputación. Diario Regional se ocupó con detalle de la cuestión a pesar de las amenazas recibidas en el periódico 269 , y de que El Norte de Castilla calificara sus informaciones de sucia maniobra política270. En el centro mismo del turbio asunto estaba el jefe del Partido Radical en Valladolid -Ciro de la Cruz-, que se suicidó a los pocos días de descubrirse la sustracción de fondos. Diario

267 "Es necesario otro ritmo", editorial, 15/3/1935, pág. 1.

268Cfr. DR, 31/3/1935, pág. 8, últ., y 5/4/1935, pág. 8, últ.. Las críticas a la gestión municipal, -dominada por los albistas desde que, con motivo de la revolución, fuera suspendido el Ayuntamiento salido de las elecciones de 1931-, eran muy frecuentes en el periódico. Cuando después de las elecciones de febrero de 1936 sea repuesto el Ayuntamiento socialista, la revisión de los acuerdos del equipo anterior dará en varios asuntos la razón a Diario Regional, que se dirige entonces a $E l$ Norte preguntándole si sigue pensando que su actitud anterior era cerrilismo. Cfr. DR, 4/3/1936, pág. 1. Los concejales de Acción Popular Agraria eran Julio Cano, Julio Martín, Ambrosio Pérez, Javier González Sarriá, Amando Valentín, Mariano Escudero de Solís, Francisco Pérez López, Manuel Pascual Espinosa, Luis Ruiz de Huidobro y Buitrago, y Gonzalo García Ganges.

${ }^{269}$ Cfr. DR, 26/5/1935, pág. 2 .

270 «De la Diputación Provincial», editorial, DR, 8/5/1935, pág. 1. 
Regional evitó el ensañamiento con sus contrincantes políticos por este motivo: ni una sola vez aparecieron en los titulares los vínculos que unían a los protagonistas con el Partido Radical, que sólo se mencionaron de pasada en el texto 271 .

En diciembre de 1935, después de los escándalos nacionales en que se vio envuelto el Partido Radical, el desencanto dejó paso a la preparación de una nueva batalla: "se formará un frente nacional contra la revolución»272. El nuevo director -Ignacio Valverdecomenzaba su carrera en tiempos difíciles.

O REFORMA SOCIAL, O REVOLUCIÓN

Hemos mencionado ya varias veces la actitud del periódico ante los problemas sociales, que son su segunda preocupación después de la legislación anticlerical. Javier Tusell ha puesto de relieve la transformación que

$271_{\mathrm{El}} 28 / 4 / 1935$ se da la primera noticia del desfalco, que rondaba el millón de pesetas. Ciro de la Cruz era el oficial de Depositaría de la Diputación, y el Depositario era León del Río Ortega, que al comienzo del proceso está internado en un sanatorio psiquiátrico. El periódico pedirá varias veces que se aclaren la responsabilidades, sin hacer recaer toda la culpa sobre de la cruz, aprovechando que ya está muerto. Sospechaban que del Río era también responsable del delito, y que su supuesta perturbación mental no era más que una treta.

272 Titulares a 7 columnas el 17/12/1935, pág. 3. Sobre la crisis en el seno del Partido Radical y la posición adoptada por Santiago Alba, que pensó llegado el momento de hacerse con la jefatura del partido para reorganizarlo, cfr. RUIZ-MANJÓN CABEZA, Octavio, op. cit. págs. 510 y loc. cit.. Pueden verse en la misma obra el papel desempeñado por los hermanos del Río Ortega en la historia del partido. 
en este sentido se produjo en el grupo que inspiraba Angel Herrera:

"Aunque desde luego antes de la República no era el más avanzado en el terreno social dentro del catolicismo, con el advenimiento de la segunda República se dio cuenta de la absoluta trascendencia de esta temática. Pretendiendo como pretendía poner al catolicismo español a nivel del europeo, no tiene nada de particular que concediera una gran importancia a la labor de propaganda social, hasta ahora enteca y reducida prácticamente al mínimo, aparte de retrasada en cuanto a sus procedimientos $" 273$

Sin embargo, estas intenciones no pudieron menos que verse afectadas por el desarrollo de los acontecimientos políticos, y, pese a que se avanzó, todavía en 1933 Pérez Solís podía escribir que "(...) las derechas españolas han sido el gran archivo de las mejores intenciones en lo que respecta a la política social católica; pero no han pasado de ahí (...)."274 A esto trataban de poner remedio los que entendían que el partido católico que había de formarse debía ser un gran partido social. La asamblea de Acción Popular de 1933 incorporó a su programa esa sugerencia, lo que saludaba un colaborador del periódico como "la resurrección del espíritu del prematuramente extinto Partido Social Popular» ${ }^{275}$. El resumen del programa social era la sustitución del régimen del salario por el contrato de sociedad; una más justa distribución de la riqueza, aumentando todo lo posible el número de propietarios -lo

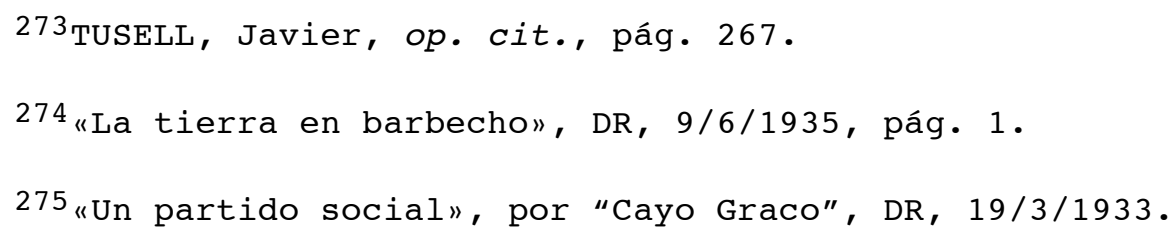


que requería continuar con repartos de tierras-; la implantación gradual de la participación en los beneficios y dominio de la gestión de las empresas; salario mínimo, y sobresalario familiar276. El ejemplo para ese partido social estaba claro: Derecha Regional Valenciana ${ }^{277}$.

Hacía falta ahora comprobar si la derecha continuaría con sus funciones de archivera o iría más allá. Las advertencias negativas que encontramos en el periódico al respecto, indican que continuaba en su línea tradicional. En mayo, un suelto llamaba la atención sobre una estadística significativa: incluso por lo que hace a la más estricta actuación política, en tiempos tan difíciles como se viven, la derecha gasta más dinero en fiestas que el que emplea en ayudar a sus partidos ${ }^{278}$.

Lo que sí es apreciable en el periódico, es una mayor acometividad por parte del sector católico más consciente de la necesidad de las reformas sociales. Un proceso paralelo a la modernización política, que -como tantos

276Cfr. ibid.. Eran las ideas defendidas desde tiempo atrás por Severino Aznar y su Grupo de la Democracia Cristiana.

277 "No llegan a dos las veces que he tenido ocasión de escribir a don José María Gadea Vidal, distinguida personalidad de la burguesía trabajadora levantina y militante benemérito de esa admirable organización católica que es la Derecha Regional Valenciana, modelo que no sé cómo no están apresurándose a imitar las entidades católicas de orientación similar en nuestra España.", "Fray ejemplo. Todo un católico verdad (sic )", por Oscar Pérez Solís, DR, 1/3/1933, pág. 1. En el artículo se glosan algunas ideas del libro Orientaciones para la reforma social agraria, publicado por Gadea.

278 "Indiscreciones en voz alta", por "Light", DR, 3/5/1933, pág. 1. 
otros durante la República- acabaría por truncarse. Desde 1931 encontramos artículos que llaman a una mayor preocupación por los obreros, especialmente por los $\operatorname{parados}^{279}$, o que se quejan de la táctica obstruccionista en las Cortes ante una Ley de Reforma Agraria que se reconoce necesaria280. Más adelante se achaca a la dejadez y falta de sentido social de la burguesía católica el fracaso de los sindicatos de igual apellido ${ }^{281}$, actitud que la convertía en una de las causas de la revolución ${ }^{282}$; se denuncian casos concretos de empresarios que por su conducta difícilmente pueden ser tenidos por católicos ${ }^{283}$,

279 "¿Puede tener solución el problema del paro en el campo?", por M. García del Olmo, DR, 13/6/1931, pág. 2. El autor insistía en que el obrero es mucho más sufrido que exigente, y proponía algunas soluciones para el paro estacional, que según sus cálculos eran rentables: "Tal vez estableciendo el jornal fijo anual, abonando semanalmente el salario, estableciendo también el seguro de inutilidad, muerte, etc., y un tanto por ciento de los beneficios, como estímulo." Otro artículo de "Cayo Graco", "Obreros y libertad" ponía como condición necesaria para evitar la revolución el aumento de la preocupación por los obreros, ya que, según él, estaban en un error quienes suponían que bastaba con el apoyo de la clase media. Cfr. más adelante la serie de artículos sobre el tema publicada por Oscar Pérez Solís en diciembre de 1933 y enero de 1934, con el título "El paro forzoso y las derechas". El primero se publicó en DR, 24/12/1933, pág. 1 .

280 "Sobre la Reforma Agraria", por "Cayo Graco", DR, 8/5/1932, pág. 8, últ.. La tesis del autor es que si la Ley es mala, mucho peor sería desitir de hacer una reforma, que no puede esperar más, aunque los propietarios ciegamente no la quieran ahora. Cfr. también "El laboreo forzoso", por "Juan del Agro", DR, 24/1/1933, pág. 7.

281 "Lo que no es accidental», por Oscar Pérez Solís, DR, 29/1/1933, pág. 1 .

282 "Los revolucionarios de arriba", del mismo autor, DR, 9/9/1933, pág. 6, últ..

283 "Justicia, sí; lucha de clases, no. ¿Católico?", articulo publicado en la "Página jocista", DR, 30/7/1933, pág. 4. Cfr. también las denuncias de casos concretos de abusos de patronos en Valladolid, en la misma sección de DR, 14/7/1935, pág. 5. 
se pide que la Iglesia decrete penas para los católicos irresponsables en estas materias ${ }^{284} ;$ se advierte que no basta con oponerse sin más al marxismo285, que no pueden equipararse las críticas al marxismo y al capitalismo ${ }^{286}$, que socialismo y cristianismo son incompatibles ${ }^{287} ;$ se apoya la labor de Giménez Fernández en Agricultura288, y se fustiga la actitud paternalista de algunos ${ }^{289}$. En

284 "La Asamblea de Vitoria. El comienzo de un camino", por Oscar Pérez Solís, DR, 12/9/1933, pág. 6, últ.. Entre otras cosas decía: "A mi parecer ya va siendo hora de que la acción social católica sepa hacerse respetar e imponerse con energía. (...) A los obreros católicos se les puede y debe pedir moderación; por una compensación elemental, a los patronos católicos hay que exigirles obediencia a la doctrina social de la Iglesia. Hay que acabar con los catolicismos a medias y a gusto del consumidor. o se es o no se es. (...) La cuestión es vidriosa pero hay que abordarla de frente y de una vez."

285 "No basta atacar negativamente al marxismo", por Federico Salmón, DR, 9/5/1933, pág. 1 .

${ }^{286} \mathrm{Es}$ un índice de hasta dónde habían llegado las críticas al mismo por parte de algunos católicos sociales. Cfr. "La moral y el espíritu de lucro", por Mariano Marfil, DR, 29/7/1934, pág. 1. Cfr. también "¿Es anticristiano el capitalismo?", por Oscar Pérez Solís, DR, 1/5/1934, pág. 1 .

287 "Sofismas de los socialistas", editorial, DR, 23/6/1931, pág. 8, últ.; "Católicos y socialistas", editorial, 20/9/1933, pág. 1. Este es también el núcleo argumental de una serie de cuatro artículos, publicados a fines de julio y principios de agosto de 1931, con el título "La encíclica "Quadragesimo anno" y el socialismo", firmados por "I.S.". Otros dos de contenidos similares se publicarán en abril de 1932, firmados por E. Torkal. Parece claro que estos artículos respondían a intentos de algunos sectores socialistas de atraerse a los católicos, cfr. "El socialismo peligroso", por S. de P., 16/7/1935, pág. 1 .

${ }^{288}$ Cfr. por ejemplo los editoriales de 23/11/1934, que defiende la conveniencia de que los yunteros extremeños permanezcan en las tierras que se les dieron, y de 8/12/1935, que califica de aplicación de la doctrina católica las medidas que contribuyan a aumentar el número de propietarios.

289 "Más justicia aunque haya menos caridad", dentro de la "Página jocistan, DR, 2/2/1936, pág. 5. Los autores comparan la movilización para atender a los damnificados por las inundaciones ocurridas en Valladolid en ese mes, y la que se tiene ante "esa continua catástrofe que es la justicia social." 
Valladolid se promueve la construcción de viviendas baratas para obreros ${ }^{290}$, se realizan las colectas para los parados que ya mencionamos, y el periódico se adhiere a una iniciativa ciudadana contra el paro, que -bien miradasignificaba el reconocimiento práctico de la necesidad de una atención pública de las necesidades sociales ${ }^{291}$.

Sin embargo, en conjunto, si se deja al margen esta minoría, el empuje en las cuestiones sociales era secundario para la derecha católica. De ahí que los resultados prácticos fueran pobres: un sindicalismo escasamente eficaz en general, y -pese a la afiliación

290 "En favor de los obreros católicos parados", DR, 2/1/1934, pág. 1. El periódico dedicará a esta cuestión un editorial diario en primera página durante dos meses. A finales de febrero cesa el comentario editorial, y los resultados de la suscripción pasan a última página. La cuantía de los donativos fue notablemente mayor que la que era normal en este tipo de iniciativas: sólo en los dos primeros meses se recaudaron cerca de 40.000 ptas. La campaña tenía tonos apremiantes, y a veces un tanto ingenuos. Por ejemplo, en el primer editorial, en el que se lanzaba la idea de la construcción de esas viviendas, se sugería que bastaría vender los coches que se ven a la puerta de los mítines derechistas para solucionar el problema de la vivienda de los obreros católicos. La campaña logró su finalidad, y a finales de mayo de 1935 comenzaban las obras.

291Cfr. "El problema del paro obrero. Manifiesto", DR, 7/2/1934, pág. 3. Ante la imposibilidad de remediar el problema del paro con las inversiones municipales, se recurrió a una acción ciudadana que significaba el establecimiento de un impuesto especial voluntario, que la corporación municipal invertiría en obras de interés público para las que se contrataría a los parados. La cuantía establecida era un día de haber para los trabajadores por cuenta ajena, o las ganancias de un día para profesiones liberales o comerciantes. No sabemos qué resultado tuvo la iniciativa. La apoyaban casi todas las entidades públicas de la ciudad: el Ayuntamiento, la Diputación, las Cámaras de Comercio e Industria y de la Propiedad Urbana, la Asociación Patronal de Comercio e Industria, la Asociación Libre de Defensa de la Propiedad, el Círculo Mercantil, la Asociación Patronal de la Construcción, el Colegio de Agentes Comerciales, la Asociación de Dependientes de Comercio e Industria, la banca local, el Banco de la Propiedad, los Servicios Hidráulicos del Duero, la Sociedad de Albañiles, la Federación Local de Sociedades Obreras, y la Federación de Sindicatos Católicos. 
alcanzada- prácticamente inútil en Castilla ${ }^{292}$. La articulación de una acción social moderna y efectiva hubiera precisado el concurso de muchas energías, y los más prefirieron consagrarlas a otras causas que les parecían más urgentes. Sólo cuando parece que las cuestiones políticas están encauzadas, o se advierte que si no se presta atención a lo social, poco se podrá hacer en política, se ponen en primer término los problemas sociales ${ }^{293}$. En el periódico pesan más, por ejemplo, las críticas a la Reforma Agraria -por su carácter socializante, los criterios de clase que la inspiran, o los errores técnicos que tiene- que las alabanzas ${ }^{294}$. Y,

292La máxima movilización conseguida en Castilla, "La Confederación Nacional Católico Agraria fue, por ejemplo, calificada en las páginas de Renovación social como un "gigante anémico", porque sus federaciones provinciales llevaban una vida prácticamente independiente y caótica.", TUSELL, Javier, op. cit., pág. 135. Puede verse en este mismo autor la historia del desarrollo del Instituto Social Obrero (I.S.O.), el Frente Nacional del Trabajo (F.N.T.), y la Confederación Española de Sindicatos obreros (C.E.S.O.). Todas estas iniciativas son seguidas con interés en el periódico, que será portavoz suyo en Valladolid.

${ }^{293}$ Esto es manifiesto después de la revolución de octubre de 1934. Como han advertido los profesores Elorza y Tusell, el motor para la constitución de una central sindical de tipo cristiano fue esta revolución. Cfr. TUSELL, op. cit., pág. 276. En el primer semestre de 1935 se procede en Valladolid a la constitución de la Federación Provincial de Sindicatos Católicos. Cuando ésta se consigue, el periódico dedica varios editoriales a comentar el tema. Cfr. por ejemplo, "Es el momento de resolver la cuestión social", 20/8/1935, pág. 1 .

${ }^{294} \mathrm{Cfr}$. la serie de seis artículos de Nicolás Santos de Otto sobre el tema en septiembre de 1931, centrada en aspectos técnico jurídicos. Más adelante, las críticas más repetidas serán que no se hacen nuevos propietarios, sino que se hace propietario al Estado, que las expropiaciones son pura y simplemente confiscaciones, y que la Ley de Términos es inaplicable en Castilla sin graves perjuicios para los pequeños propietarios. Cfr. "Antinomias. El Estado frente al patrono. El Estado como patrono", editorial, 20/4/1932; "La cuestión social en el campo", por Oscar Pérez Solís, 5/10/1932, pág.1, que atribuye a la 
cuando la C.E.D.A. esté en el Gobierno, parece que el mayor empeño es demostrar a los agricultores castellanos que se están defendiendo sus intereses ${ }^{295}$. Por una razón u otra, los problemas sociales tendían a relegarse a segundo término. Sólo estaban en el primero cuando iban del brazo del tema estrella de estos años: el enfrentamiento con la revolución.

FASCISTAS, NO; PERO ANTIFASCISTAS, TAMPOCO

En uno de los mejores análisis sobre Acción Nacional que publicó Diario Regional se leía:

"La Acción Nacional (...) era una masa social políticamente amorfa, $y$ en estos días se ha transformado en un partido político francamente diferenciado. De ella se han desprendido, como de la nebulosa cósmica los astros, primero el partido tradicionalista, luego el monárquico de Goicoechea. Todavía habrá más desprendimientos. (...) En la ebullición precipitada, un poco atolondrada e inconsciente que se advierte hoy en el alma de España, asoma ya, y va dibujando sus contornos, una organización fascista. Será (...) una reacción defensiva contra la agresividad violenta del comunismo. Si desapareciera el comunismo en España (...) no se explicaría y no tendríamos fascismo. Pero el comunismo (...) sube como la espuma, y tendremos fascismo y éste suscitará un nuevo desprendimiento de las masas refugiadas en un principio por instinto de conservación en la improvisada tienda de campaña de Acción Popular." 296

política de clase el fracaso de la reforma; "De mal en peor. La Reforma Agrarian, por Baldomero Argente, 1/3/1933, pág. 1, etc.

295 A ello contribuía también la crisis del mercado del trigo que se inicia en 1934 y se agudiza en los años siguientes. La información sobre esta cuestión será destacada y abundante en las páginas del periódico. Cfr. por ejemplo "Buscando solución al angustioso problema del trigo", 29/1/1935, pág. 1, "Asamblea triguera en Medina del Campo", 1/5/1935, pág. 8, últ.; "El complicado problema triguero", 19/5/1935, pág. 1, etc.

296 «Un partido social», 19/3/1933, loc. cit.. 
Por otro lado, la afirmación de Payne de que "en la mayor parte de Europa, el antifascismo precedió al fascismo y fue más fuerte que él»297 iba a verse confirmada en Valladolid de diversas formas. El 24 de mayo -hablando del mitin agrario que se iba a celebrar en la ciudad el día 25-, publicaba El Socialista un artículo titulado "Movilización fascista en Valladolid". Como sabemos, Diario Regional venía anunciándolo desde semanas atrás. El acto fue finalmente suspendido por orden del ministro de la Gobernación, el mismo día 24, ante la amenaza de huelga general que habían hecho pública los socialistas vallisoletanos:

"Ni Valladolid ni ninguna otra ciudad de España puede ser el cuartel general o el campo de maniobras de un movimiento que [la República] precisa aplastar en flor; el fascista. Si la República comete errores, los rectificaremos los socialistas. Si el Estado se cruza de brazos como ante el mitin retador de Valladolid, los trabajadores sabrán sustituir al Estado y señalarle sus deberes. La huelga general anunciada tiene ese sentido." 298

La respuesta de Diario Regional afirmaba que "la primera mentira y la primera infamia era afirmar que el movimiento agrario es un movimiento fascista $y$ una maniobra monárquica»299. Tenían razón, pero, ¿cuál había

${ }^{297}$ PAYNE, Stanley G., El catolicismo español, págs. 203-204: "Esto era también cierto para España, donde, en 1933 la mayoría de la izquierda, imitando modelos extranjeros, juzgaba los acontecimientos políticos por analogía con países como Italia, Alemania y Austria. Como no había ningún movimiento fascista español importante, se atribuyó ese papel a la C.E.D.A., que surgía como principal adversario de la izquierda."

${ }^{298}$ El Socialista, art. cit..

299 "España no tolerará por mucho tiempo la tiranía socialista", editorial, DR, 25/5/1933, pág. 1 . 
sido la actitud del periódico ante el fascismo? Las primeras referencias que encontramos en estos años son de febrero de 1931: críticas al partido hitleriano, como se le llama entonces ${ }^{300}$; y una colaboración rememorando la firma de los pactos de Letrán entre Mussolini y el Vaticano, en la que se trata con un tono de moderada admiración la figura del dictador italiano, al que se reprochan algunas opiniones suyas sobre la Iglesia de corte temporalista-imperialista ${ }^{301}$.

Ese punto de vista contrasta con el que vamos a encontrar en el verano de 1931. El 10 de junio, un artículo titulado "Fascismo y catolicismo", hace una dura crítica de las teorías fascistas:

"El Estado fascista por su tendencia absorbente y su interpretación unilateral del derecho, es la más acabada expresión del absolutismo del Estado moderno, punto en el que coincide $y$ se confunde con el Estado comunista. El individuo es parte ordenada de una organización dirigida por el Estado. Una organización tal repugna el libre albedrío, y la libre expresión de la conciencia colectiva que es precisamente la más elevada y pura manifestación de la doctrina católica."302

300 "¿A dónde vamos con esta nueva moral?", por El Magistral de Burgos, DR, 6/2/1931, pág. 3. Critica la "moral de fuerza" defendida por algunos médicos del partido nacional-socialista, que proponen acabar con los desechos de guerra, y poner los medios para tener una Alemania fuerte "eugenésica". "Las complicaciones políticas y económicas de Alemania", por Andrés Revesz -“Juan de Vacz"-, DR, 7/2/1931, pág. 6, últ..Describe el comportamiento violento de los hitlerianos y la oposición socialista, demócrata y católica. Los católicos alemanes, situados más al centro, evitan la derecha extrema. Poco más tarde, otro artículo del mismo autor - "El movimiento nacional-socialista»definía el nazismo como una "curiosa mezcla de ultranacionalismo y de ideas comunistas", DR, 9/4/1931, pág. 2 .

301 «Fecha memorable», por Jesús Requejo, DR, 11/2/1931, pág. 3.

${ }^{302}$ Por J. Lozano Castresoy, DR, 10/6/1931, pág. 6, últ.. 
Dos días después una crónica internacional abundaba en la misma argumentación, equiparándolo al comunismo, afirmando que el fascismo es "una religión, con una divinidad; la patrian, y que -lo mismo que a Maurras- la religión le interesaba sólo como fuerza social, sin importarle su origen sobrenatural303. La causa de estos comentarios quedaba clara cuando un mes más tarde otra colaboración reproducía algunos párrafos de la encíclica de Pío XI sobre el fascismo: el Papa hablaba de "persecución" de la Iglesia bajo el régimen de Mussolini304. El periódico no hizo ningún comentario al respecto.

Pese a la afición del diario a las citas papales, esta encíclica no se volverá a mencionar; y aunque el periódico nunca apoye al fascismo en un editorial, sí publicará crónicas o colaboraciones que hablen bien de

303 "Las desavenencias entre el Vaticano y el fascismo. Una vez más se evidencian la universalidad de la Iglesia y el sentido pagano del Estado moderno", por Conde de Sarto, DR, 12/6/1931, pág. 6, últ.. En cuanto a las diferencias concretas entre fascistas y católicos en Italia, la crónica continuaba: "Por ahora los acontecimientos de Italia se reducen a escaramuzas de la estudiantina bullanguera fascista con los estudiantes católicos y a los atropellos a las personas y locales de las instituciones de la Acción Católica. (...)

$" Y$ en el terreno político no hay que olvidarse que el Partido católico italiano dirigido por Astuzo (sic) y desaprobado por el Pontífice, para no poner obstáculos a la entonces labor patriótica del fascismo, es quizá el partido político más fuerte de Italia y que hoy muchos partidos de oposición se sumarían a él, aunque no sea más que por ir en contra del fascismo.",

304 "La Encíclica de Pío XI sobre el fascismo", por Jorge Goyau, DR, 22/7/1931, pág. 6, últ.. Se trataba de la encíclica Non abbiamo bisogno, cuya causa inmediata había sido la prohibición de la Acción Católica por el Estado fascista. Se publicó en París para suavizar su efecto, y de este modo evitar a los católicos italianos -especialmente a los funcionarios, que habían jurado fidelidad al fascismo- las consecuencias de un enfrentamiento directo con el régimen. 
él305. Por lo que se refiere a los nazis, la actitud de rechazo se mantendrá siempre, hasta extremos que podían resultar sorprendentes para un derechista español en 1932:

"Ante la doble amenaza fascista y comunista [en Alemania], el socialismo se ha convertido en un elemento de orden, y a los católicos y conservadores no les repugna colaborar con ellos. En la política nunca se puede decir: "fuente, de tu agua no beberé"." 306

Aunque no faltó la excepción: José María Albiñana, a quien Ramiro de Maeztu había citado en un artículo en $A B C$-«me ha dispensado el honor de compararme con Hitler»-, publicó una colaboración en la que alababa al jefe del partido nazi, y reconocía que, si se le financiara convenientemente, él podría hacer algo parecido en España 307 .

En 1933, con el ascenso de Hitler al poder, el tema del fascismo será abordado con más frecuencia: varios colaboradores -Calvo Sotelo y Pemán entre otros- se proclamarán favorables a una solución fascista, que

305 "Crónica internacional. Los prodigios del fascismo en el campo", por Conde de Sarto, DR, 2/3/1932, pág. 2. "Diez años de régimen fascista", por "Juan de Vacz", DR, 19/10/1932, pág. 8, últ.: "Llegará el día en que italiano y fascista sean tan sinónimos como lo son hoy italiano y católico. Mussolini ha creado realmente un país y un pueblo nuevos."

306 "Política Internacional. Elecciones en Prusia ¿Tomará Hitler el poder?", por "Juan de Vacz", DR, 23/4/1932, pág. 6, últ..

307 "El Camarada Hitler», DR, 1/5/1932, pág. 6, últ.. El artículo, con el peculiar estilo del autor, era una diatriba contra los adinerados españoles, a los que advertía: "El que espere que lo defiendan "de gorra" sufrirá el justísimo castigo de barrer las calles bajo el látigo soviético." 
entienden como nacionalismo antimarxista ${ }^{308}$; mientras que otros -Salvador Minguijón ${ }^{309}$, Oscar Pérez Solís310, los autores de la información internacional311, etc.- se manifiestan contrarios. En años sucesivos las informaciones sobre Alemania irán siendo cada vez más contrarias al nacional-socialismo312, mientras que se

${ }^{308}$ Calvo Sotelo, en su "Problemas del día" de 26/2/1933 pide la creación de un frente antimarxista, como en Italia o Alemania. Poco más tarde el mismo autor escribía: "Por eso brota el fascismo. Que dice al obrero: "tú no tienes que luchar contra el patrono; es el Estado quien tiene que disciplinar al patrono y al obrero asegurando a todos paz y justicia". iAh! Sin el marxismo no existiría el fascismo. ¿Habrá que felicitarse de la recrudescencia marxista que atosiga a España en estos tristes meses?", "El cincuentenario de Carlos Marx", DR, 26/3/1933, pág. 1 .

José María Pemán pensaba que la actitud de los socialistas españoles empujaba al país hacia una solución como el fascismo, que él identificaba como un "movimiento nacionalista de promoción del bien común". "Socialismo y fascismo", DR, 25/3/1933, pág. 1.

Como prueba de la confusión reinante, otro colaborador-Miguel Herrero García-, se mostraba conforme con seguir el camino fascista siempre que significara -como a él le parecía entender- la renovación de la educación sobre la base de la patria y de la tradición católica (!). "Bajo el signo hitleriano", DR, 21/3/1933, pág. 1 .

309 "El problema del fascismo", DR, 8/4/1933, pág. 1. En su opinión un régimen fascista destruiría la labor de los católicos en la vida pública que poco a poco se iba haciendo. En cuanto a su porvenir en España, decía: "Que el fascismo venga o no venga -nosotros deseamos que no venga- depende de dos cosas: la una es la conducta de sus enemigos; la otra es la ruta que sigan los destinos del mundo."

310 "Acerca del fascismo", DR, 16/3/1933, pág. 1. En su opinión es cuando menos- difícilmente compatibilizable con los planteamientos católicos.

${ }^{311}$ Cfr. por ejemplo las crónicas del Conde de Sarto "El porvenir del hitlerismo", DR, 25/3/1933, pág. 1; y "iTriunfará el hitlerismo en Austria?", DR, 1/6/1933, pág. 1, en que se insiste en la exaltación racista del nacionalismo nazi.

${ }^{312}$ Cfr. "Barruntos de guerra civil religiosa", por Gottfried Uhlmann, que describe el enfrentamiento abierto entre nazis y católicos que se vive en Baviera, DR, 27/2/1935, pág.2; y "El neo-paganismo alemán", por Conde de Sarto, DR, 7/8/1935, pág. 3 . 
advierte una creciente simpatía hacia el fascismo italiano 313 .

Del protagonismo de la propaganda izquierdista en este asunto, son índice el título y los contenidos del editorial que Diario Regional publicó con motivo del intento de asalto a sus instalaciones - "Ante un manifiesto socialista. El peor y más intolerable fascismo"314-, que demuestra cómo, por esas fechas, se había conseguido que el calificativo fascista, fuera uno de los más ignominiosos que podían lanzarse sobre alguien. Y fue precisamente esa propaganda la que motivó la primera declaración editorial del diario al respecto, que -como vimos- fue de rechazo del fascismo. Fundada la Falange, el periódico volvió a declarar que no era partidario del fascismo, "por varias razones", que no detallan315. Parece claro que una de ellas era el rechazo formal de la violencia que el periódico había hecho en varias

${ }^{313} \mathrm{En}$ el verano de 1935 se publica un reportaje laudatorio para Mussolini: "A. Zacchea. Intimo colaborador del Duce durante muchos años. Mis recuerdos de Mussolini. Su vida en mi hotel. Los primeros pasos del fascismo", DR, 19/7/1935, pág. 6, últ..

314DR, 29/3/1933, pág. 1: "Estamos, pues, bajo la amenaza de una mano negra, de un fascismo intolerante, despótico, despiadado, sañudo, terriblemente sectario."

315 "Los fomentadores del fascismo", Editorial, DR, 12/1/1934, pág. 1. Una vez más insistían en que los fomentadores del fascismo eran las izquierdas con sus desaforados ataques a un peligro que no existía. 
ocasiones, lo mismo que su aceptación del régimen constituido 316 .

El acto de unificación de Falange y las J.O.N.S., que tuvo lugar en Valladolid el 4 de marzo de 1934, así como los incidentes que se produjeron con ese motivo-que se saldaron de nuevo con un muerto-, propiciaron la declaración formal del periódico al respecto. Se dedicaron tres editoriales a la cuestión, en los que ponían de relieve la simpatía con que veían al nuevo partido. El que se publicó antes de los incidentes decía:

"No ocultemos, en fin, que el fascismo es una valiosa aportación a los esfuerzos, no privativos de él, ciertamente, que del seno de la cultura europea parten en guerra contra sistemas caducos o disolventes que, si prevalecieran, la destruirían. (...) La sociedad del materialismo, del liberalismo y del capitalismo está en pie solamente por un milagro de equilibrio." 317

El editorial del martes siguiente culpaba a los socialistas y a su actitud violenta de la expansión del fascismo, y -en el del miércoles-, renunciaban a publicar la crítica a los discursos del mitin de Falange y las

${ }^{316} \mathrm{La}$ denuncia de la violencia está presente desde los primeros momentos, incluso aludiendo a los dos bandos, aunque el periódico no destacará actos de violencia de derechistas hasta noviembre de 1935. Cfr. "Fortiter in re, suaviter in modo", DR, 26/8/1931, pág. 6, últ..Es también significativo que un escritor como José María Pemán, que -como hemos visto- se declaraba partidario de un fascismo sui generis, publicara un artículo contra la guerra, en el que afirmaba que si los católicos se habían dejado arrebatar todos los ideales generosos en el último medio siglo -liberalismo, internacionalismo, obrerismo...-, esperaba que no ocurriera igual con el pacifismo, que hubiera "desertores de conciencia" católicos. Cfr. "Contra la guerra", DR, 30/12/1932, pág. 1 .

317 "Ante el fascismo", editorial, DR, 4/3/1934, pág. 1. 
J.O.N.S. que habían anunciado. El motivo era evitar confusiones, ya que, si no eran fascistas, tampoco antifascistas ${ }^{318}$. En cambio, a finales de 1935, los redactores de la "Página jocista" abordaron la cuestión para pronunciarse resueltamente contra el fascismo:

\footnotetext{
"La familia antes que la nación: ese es el orden. (...)

"Veamos lo que pasa en Italia, Alemania y Rusia. Estos tres dictadores: Mussolini, Hitler y Estalin, organizan en sus países la intervención del Estado en la enseñanza, en provecho de la nación y con grave detrimento de la familia." 319
}

Hasta las elecciones de 1936 no se volverá a tocar el tema. Durante la campaña electoral se informará de los principales actos de propaganda falangista, sin destacarlos ni comentar nada a favor ni en contra. En un editorial volverán a insistir en que, si bien la candidatura falangista también es antirrevolucionaria, hay diferencias políticas que la separan de Acción Popular. No les llamarán a la unidad, ni criticarán su presentación de candidatos; es decir, les dispensaron el único trato de favor que el periódico concedía a los grupos políticos afines que no representaban un serio peligro para su estrategia ${ }^{320}$.

318 "Después de unos sucesos lamentables. Sectarismo, intolerancia, brutalidad", 6/3/1934, pág. 1. "Fascistas, no; pero antifascistas, tampoco", 7/3/1934, pág. 1

319 "iPor qué somos antifascistas!", DR, 10/11/1935, pág. 6 .

${ }^{320} \mathrm{Cfr}$. la reseña del mitin del mitin de Primo de Rivera, Ruiz de Alda y Onésimo Redondo, y el comentario editorial en DR, 14/1/1936, págs. 4 y 8, últ., respectivamente. Otros partidos a los que se concederá el mismo trato son el Nacionalista, el Agrario -debilitado y casi deshecho por esas fechas- y el Tradicionalista. 


\section{LA MODERNIZACIÓN PERIODÍSTICA}

Los frutos de la Escuela de Periodismo de El Debate llegaron a Valladolid, en agosto de 1935, con Ignacio Valverde. Ricardo Martínez dejó la dirección en manos de su nuevo jefe, veintiún años más joven que él, y tuvo ocasión de ver -por primera vez en su vida- los efectos de la formación teórica en materia periodística. Desde las secciones a la maquetación, pasando por los reclamos publicitarios, casi todo iba a cambiar en el periódico. No sabemos qué opinaría el veterano redactor jefe de esto, pero sí sabemos lo que opinaba el nuevo director, que tardó apenas un mes en dar a conocer su idea sobre lo que debe ser el periodismo:

" "Los periodistas deben salir de las Universidades". (...) si un abogado no lo puede ser sin los estudios indispensables, creemos que tampoco se puede llegar sin la adecuada preparación a la profesión periodística. (...) día llegará en que [en España] sea necesaria la implantación de las Facultades de Periodismo, como ocurre ya en Estados Unidos. (...)

"De este modo es muy posible que la prensa de nuestra nación no caiga en esa libertad desenfrenada, próxima a la anarquía, en la que el periodista se considera un ser totalmente irresponsable; $\mathrm{ni}$ en esa sumisión total y absoluta a un poder tiránico y abusivo. (...) [y si cayera], que una justa Ley de Prensa, nos salve de la tiranía o de la irresponsabilidad." 321

321 "La profesión periodística", editorial, 17/9/1935, pág. 1. La frase entrecomillada está tomada de un discurso en la reunión anual del Instituto de periodistas de Londres, del que se toma ocasión para el editorial. 
Las lecciones de Angel

Herrera estaban bien

asimiladas.

Del

aprovechamiento de otras asignaturas daba cuenta el periódico mismo ${ }^{322}$. Los editoriales -con su nuevo formato a una columna, la primera y a veces también la última de la primera plana-, se hicieron más incisivos, y se aumentó y dinamizó la información local e

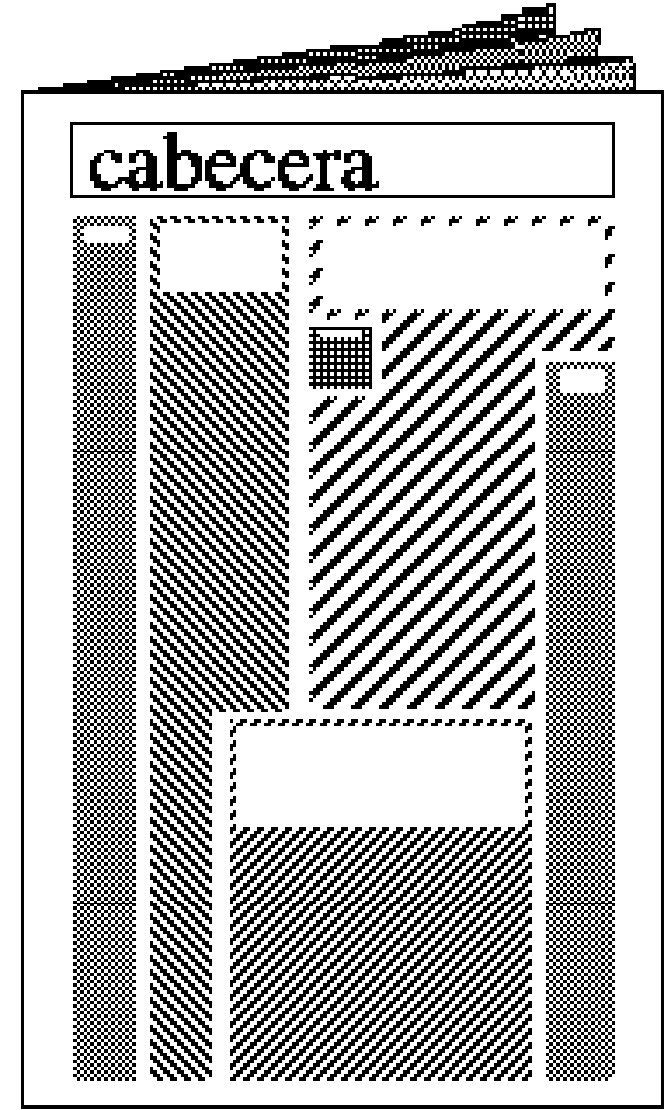

Maquetación de una primera página de Diario Regional a finales de 1935 . internacional. En la maquetación se dejó sentir la mayor importancia concedida a la titulación, tanto en la redacción, como en la elección de los tipos, lo que dio mayor fuerza a las horizontales en el diseño. Desaparecieron las cabeceras fijas a modo de secciones de la primera página, con lo que ésta adquirió más aires de novedad informativa, y se incrementó la importancia concedida a la información internacional. Paralelamente, la local -que traslucía un reporterismo creciente- llenaba por entero la última página, bajo la cabecera "La vida en la ciudad": un breve editorial abordaba un tema local, mientras que una crónica

${ }^{322} \mathrm{Cfr}$. en el apéndice 2 la relación de secciones con este director. 
-también escueta- hacía el resumen de lo más destacado de la vida vallisoletana el día anterior, ya fuera el calor, la fiesta patronal de los dependientes de comercio, o una huelga general, que de todo hubo.

Las corresponsalías destacadas eran ahora las de Madrid, Lisboa y París, a las que se añadía de vez en cuando alguna crónica desde Ginebra. Las de los pueblos, en cambio, dejaron de ir fijas bajo la cabecera "Información provincial y regional", para aparecer sueltas, de forma más esporádica, cuando hubiera sucesos destacados. La opinión, destacada normalmente en negrita, pasó a la tercera página, que comenzó así a tener personalidad propia, mientras que la segunda hacía acopio de avisos e información rutinaria. La publicidad fue en aumento, hasta alcanzar un volumen notable en febrero de 1936 con motivo de las elecciones. Por entonces el periódico tenía habitualmente ocho páginas, $y$, en junio del mismo año, era ya normal que tuviera doce algunos días.

Si el carácter opinante de la publicación seguía siendo una nota destacada, estaba claro que la información mejoraba notablemente. Cesaron los "editoriales-homilía" que antes eran habituales en las fiestas religiosas, y aparecieron los primeros reportajes publicitarios e informativos, de una o dos páginas, que eran anunciados desde días antes, con el reclamo de las plumas que los elaborarían. Se realizaron encuestas sobre los temas que 
más interesaban en la ciudad ${ }^{323}$, y campañas de tono apremiante reivindicando mejoras locales ${ }^{324}$. Los reclamos de ayuda para el periódico desaparecieron, lo mismo que las citas papales sobre la importancia de la prensa católica. Ahora el estilo era diferente: pequeñas gacetillas daban cuenta del éxito de una información dada como primicia, del de tal o cual nueva sección, o de la pizarra que se colocaba en el exterior de la sede del periódico con las últimas noticias. Se había terminado el pedir limosna, ahora se pedía que quienes reproducían los trabajos publicados en Diario Regional tuvieran la delicadeza de citarlo, o se decía a los agricultores castellanos:

"Diario Regional defiende los intereses de los labradores. Publica crónicas e informaciones de todos los pueblos. Suscríbase usted a Diario Regional y verá en él las noticias del pueblo en que usted vive y sus intereses defendidos." 325

La mayor carga informativa desplazó el centro de atención de los debates teóricos a otros más prácticos, de

${ }^{323} \mathrm{En}$ agosto de 1935 se publicaron las respuestas de diversos personajes de la provincia a una encuesta del periódico sobre los remedios al problema triguero, y en septiembre se hizo lo mismo con respecto a la primera Feria de Muestras de Valladolid.

${ }^{324}$ Estas campañas las lanzaba casi siempre Valverde en la sección "Temas locales". Nada más incorporarse comenzará una sobre la mendicidad, que llevará a pedir la construcción de un albergue para los numerosos mendigos que deambulan por valladolid; otra sobre la necesidad de crear escuelas de formación profesional para los campesinos; otra sobre la caótica organización del tráfico en la ciudad, etc..

325DR, 25/9/1935, pág. 4. En este número se publicaba un reportaje de dos páginas sobre Villalón y la Federación de Sindicatos Agrícolas Católicos. 
forma que la cuestión triguera, que era el problema por antonomasia de la región y de la provincia, fue desde entonces objeto de numerosas crónicas, artículos de opinión y editoriales ${ }^{326}$, lo mismo que lo era habitualmente en El Norte de Castilla. Era el lógico punto de confluencia para los medios de información vallisoletanos.

\section{Otra vez en la lucha}

Si las mejoras introducidas por Valverde aumentaban la competencia con El Norte en lo puramente informativo, en lo político el choque entre los dos se acentuó con motivo de las elecciones. Valladolid fue el escenario del primer mitin de la campaña de Acción Popular, que -más que nunca- era una llamada a la unidad de las derechas. En el editorial dedicado a comentarlo se daba el primer varapalo a los radicales-albistas:

"Ayer hubo en el Calderón la más genuina representación de una política caduca, típicamente vallisoletana. Ni un aplauso tributó esta representación a Gil Robles. Mucho cuidado, cuando llegue el momento de la unión, con estos elementos que bajo una capa de falso derechismo irán en busca del medro

${ }^{326}$ Cfr. "Que la cooperativa de Medina del Campo sea sustituída por la Sección Agronómica para la retirada del trigo" un escrito de Luciano de la Calzada, 28/9/1935, pág. 1 y 3. "Los discursos de los señores Calzada y Cantalapiedra en la sesión de Cortes del 4 de octubre. La rectificación de la sesión nocturna del martes.", 8/10/1935, pág. 5. "Las importaciones de trigo del bienio" editorial, 19/10/1935, pág. 1. "La libertad de contratación de trigos" editorial, 12/11/1935, pág. 1. "El trigo, las izquierdas y las derechas" por P. (comentarista habitual de temas de mercados agrícolas), 17/11/1935, pág. 7. "Hay que realizar el movimiento triguero nacional", 22/12/1935, pág. 10 completa. "La libertad de circulación de trigo. Que el Estado intervenga en las fábricas de harinas. Conclusiones de la asamblea triguera", 28/12/1935, pág. 1 . 
personal de siempre. Unión. Unión de todas las derechas en una nueva cruzada de Religión y de Patria."327

La decoración preparada para el mitin da idea de la orientación que tomaba la derecha: carteles con la palabra "iJEFE!" en los antepalcos, y un gran cartel en el antepecho de los palcos, con las frases "Los trescientos son pocos", "Contra la revolución y sus cómplices", "Todo el poder para el JEFE»328. Este estilo, habitual en las juventudes, era la primera vez que se empleaba de modo generalizado.

El planteamiento que se hace de la contienda es el de una "campaña antirrevolucionaria". La revolución ha triunfado, había afirmado Gil Robles cuando se le cerró el paso en la crisis ministerial de diciembre; Martínez Barrio aseguraba en un mitin que aunque las derechas obtuvieran 300 diputados, no se les entregaría el poder; los socialistas habían dado una muestra de su programa en el mes de octubre del año anterior ${ }^{329}$. La conclusión del

327 "Un llamamiento, unos votos $y$ una unión", editorial, DR, $20 / 12 / 1935$, pág. 1 .

328 "Doce mil personas escuchan el primer discurso de Gil Robles", crónica del mitin, a seis columnas, en primera página, DR, 20/12/1935, pág. 1 .

${ }^{329}$ Durante la campaña aparecía en las páginas del periódico un recuadro con el siguiente texto: "iElectores de la provincia de Valladolid! Largo Caballero ha dicho: si triunfan las derechas, Revolución; si no triunfan, Revolución desde el Gobierno.

"iDerechistas! sois suficientes para imponer el orden y para demostrar en las urnas que en Valladolid están en inmensa mayoría los antirrevolucionarios. "Votad la candidatura de derechas."

Cfr. por ejemplo DR, 31/1/1936, pág. 8, últ.. 
periódico, expuesta en el editorial del día de Navidad de 1935, reflejaba una ruptura insalvable:

"La revolución ha triunfado. (...) Por ello es necesario, absolutamente indispensable, que se forme de modo compacto el frente nacional antirrevolucionario no sólo para rescatar los valores religiosos, morales, familiares, sociales, $y$ aun materiales, que hemos perdido, sino para defender los que todavía nos quedan y que podemos perder. (...)

"Hay que formar el frente nacional ampliamente contra la revolución, que es masonería, marxismo y separatismo, y sus cómplices. Y hay que desalojar a los enemigos de España de todas las posiciones que ocupan en los puestos de mando, organismos, corporaciones y dependencias del Estado. (...) Y esta debe ser la decisión enérgica, inexorable y unánime de las derechas sin el menor empacho de legalidad, porque está visto que hay legalidades que matan, o, por lo menos, ayudan a dejar morir." 330

El 17 de enero se anunciaba en el editorial la constitución de una candidatura de derechas de Valladolid: se trataba de tres candidatos de Acción Popular ${ }^{331}$, que invitaban al resto de los partidos a presentar otro candidato más, para completar la lista que lucharía por los cuatro puestos de la mayoría en la provincia. Dos días más tarde el periódico daba muestras de seria preocupación ante las noticias de que Renovación Española, el Partido Agrario y el Partido Tradicionalista habían decidido presentar candidaturas propias. No eran todas las

330 "La campaña antirrevolucionaria", editorial, DR, 25/12/1935, pág. 1. Como elementos del frente antirrevolucionario se mencionaban: "Acción Popular, Bloque Nacional, Renovación Española, Derecha Regional Valenciana, Partido Tradicionalista, Partido Nacionalista Español, etc.."

331 "Candidatura de derechas de Valladolid", editorial, DR, 17/1/1936, pág. 1. Los candidatos eran Luciano de la Calzada, Germán Adánez y Amando Valentín. Royo Villanova había decidido separarse del Partido Agrario y retirarse de la política, cfr. DR, 18/12/1935, pág. 5 . 
derechistas: se anunciaban más. Para Diario Regional eso era caminar derechamente a la derrota o a algo peor ${ }^{332}$.

Negociaciones posteriores hicieron que Renovación Española renunciara a la candidatura propia e incorporara un candidato a la de Acción Popular, que se autodenominaba candidatura antirrevolucionaria de Valladolid ${ }^{333}$. El mismo día que daba la noticia, el periódico señalaba en en editorial que esa era la candidatura que se debía votar, y refiriéndose a El Norte, empeñado también en la campaña antirrevolucionaria, agregaba:

\footnotetext{
"Es lamentable que esa "unión e inteligencia entre todas las fuerzas del bloque antirrevolucionario", que, según decía hace pocos días "El Norte de Castilla", es la que él venía propugnando desde el primer momento, se malogre, con su cooperación, por pequeñeces partidistas, que para nada debían contar ante la gravedad de las circunstancias políticas actuales.» 334
}

La valoración que los partidos derechistas vallisoletanos hacían de sus propias fuerzas, se puso de manifiesto con el acuerdo alcanzado poco después: la candidatura de derechas para la mayoría sería la de Acción Popular y

332 "Las elecciones y los partidos de derecha de Valladolid", editorial, DR, 19/1/1936, pág. 1 .

333 "El conde de Gamazo, Juan Antonio Gamazo Abarca, completa la candidatura de Acción Popular Agraria por Valladolid", DR, 26/1/1936, pág. 1. "Manifiesto de los candidatos contrarrevolucionarios de Valladolid. Al cuerpo electoral de la provincia de Valladolid", Luciano de la Calzada Rodríguez, Germán Adánez Horcajuelo, Amando Valentín Aguilar, Juan Antonio Gamazo Abarca. Este último, conde de Gamazo, publicaba al día siguiente su manifiesto particular, en el que hacía profesión de fe monárquica, "Manifiesto de don Juan Antonio Gamazo", DR, 2/2/1936, pág. 1.

334 "La candidatura que se debe votar", editorial, DR, 1/2/1936, pág. 1 . 
Renovación española, pero se lucharía por un quinto puesto, para el que el resto de los partidos designaría un candidato. Hasta ahí todos de acuerdo; lo que no se consiguió pactar fue el nombre de ese candidato. Al final se proclamaron para la elección los cuatro de la mayoría, más un centrista -que se retiró enseguida-, un agrario, un nacionalista, un conservador, dos falangistas $y$ un albista. El diario católico cargó con fuerza contra el partido radical, que era el que a su entender podía menguar el éxito de su candidatura; sobre todo, si se hacía caso a la campaña orquestada desde El Norte que invitaba a tachar uno de los cuatro nombres de la candidatura de su competidor -Luciano de la Calzada-, y a poner en su lugar al candidato radical ${ }^{335}$.

En los numerosos "editoriales de elecciones" que Diario Regional publicó en estos días -hasta seis por número-, no falta uno diario consagrado a descalificar la actitud de los radicales-albistas, que son, según el periódico, los culpables de que no se llegara a un acuerdo sobre el quinto candidato, y los que podían hacer que no triunfara la candidatura contrarrevolucionaria. Con la retirada del candidato republicano conservador y del nacionalista se simplificaron algo las cosas, pero el núcleo de la discusión siguió intacto.

335 "Después de la proclamación de candidatos", editorial, DR, 12/2/1936, pág. 1 . 
La

candidatura

antirrevolucionaria

obtuvo

holgadamente los cuatro puestos de la mayoría en la provincia, pero en Valladolid capital obtuvo menos votos que la del Frente Popular336. En el primer editorial publicado después de las elecciones, el periódico responsabilizaba del hecho a El Norte de Castilla y a los radicales-albistas ${ }^{337}$. Realmente la contribución de éstos al hecho no había sido grande, el número de votos del candidato radical era muy pequeño.

Frente Popular(38,7\%)

$$
\text { Falange }(0,5 \%) \quad \text { Agrario(2,0\%) }
$$

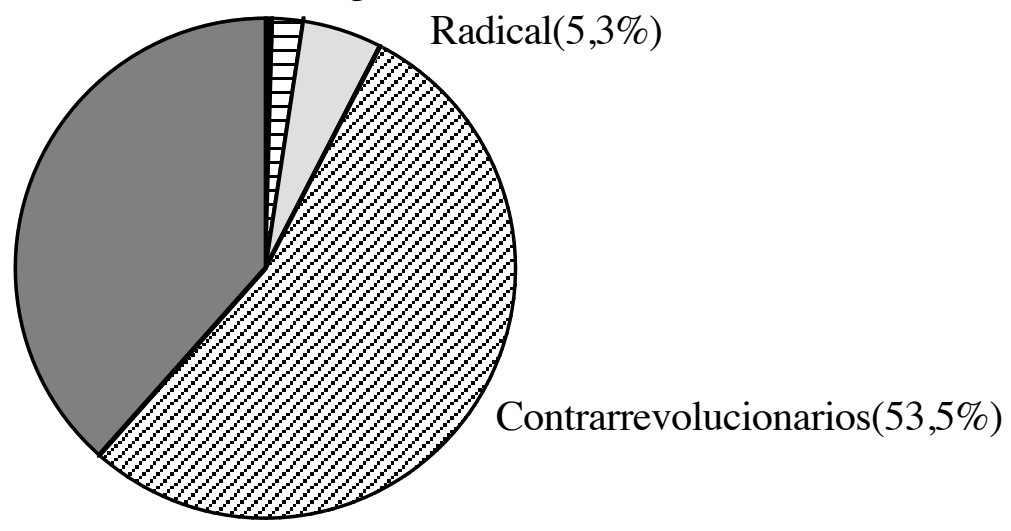

336 CAPITAL TOTAL PROVINCIA

Contrarrevolucionarios Amando Valentín ...... 17.092 ....68.226

Luciano de la Calzada .. 16.978...667.234 Juan Antonio Gamazo ... 17.306 ....665.614 Germán Adánez .......617.170....66.256

Izquierda Republicana Isidoro Vergara ......20.688...449.177 Socialista Federico Landrove ....20.263 ....48.698 Eusebio González .....20.313 ....44.976 Álvaro Díaz Quiñones ...20.178 ....447.860

Unión Republicana Radical

Partido Agrario

Falange E. de las JONS 490 Joaquín Álvarez Taladriz $4.091 \ldots \ldots 26.315$ Juan Antonio Llorente ... 1.026 .....9.843 Onésimo Redondo ........ $736 \ldots . .5543$ José $\mathrm{A} \quad \mathrm{n}$ t $\circ \mathrm{n}$ i $\mathrm{o}$ Primo de Rivera 2.723

40\% necesario: 51.888. No hay segunda vuelta. DR, 18/2/1936, y 21/2/1936, pág. 2 .

337 "Villanía ciudadana», editorial, DR, 18/2/1936, pág. 1 . 
Al día siguiente se hacía un diagnóstico más certero: los que no votaron, $y$ los que lo hicieron "a palo seco" por el candidato radical, eran los "cómplices de la revolución". Se destacaba que la abstención abundaba sobre todo en "los distritos en que vive mayor número de personas de orden $\circ$ de derechas $\circ$ adineradas 0 conservadoras» ${ }^{338}$, un hecho bien significativo que -unido a los resultados del resto de la provincia- dibujaban claramente el panorama de la opinión vallisoletana: el sector social que había sido el apoyo del sistema anterior abandonaba a su suerte a la estridente e incontrolable «nueva política», una amplia mayoría provincial se pronunciaba contra la revolución, y otra buena parte de los electores, por la revolución.

Diario Regional había vencido su batalla particular con El Norte. Pero -por tratarse de una batalla políticaera una victoria pírrica. Sólo hay política cuando se puede gobernar una sociedad; si la sociedad se rompe, no queda lugar en ella para la política. Ese será el peligro que trate de evitar el periódico. Después de los momentos iniciales de incertidumbre -en los que daba por vencedoras a las derechas, "aunque no como se esperaba" ${ }^{33}-$, se insistirá en el clima de normalidad, se pasarán por alto

\footnotetext{
338 "Cómplices de la revolución" y "Los otros grandes cómplices", editoriales, DR, 19/2/1932, pág. 1 .

${ }^{339} \mathrm{Cfr} . \mathrm{DR}, 18 / 2 / 1936$, pág. 2 .
} 
algunos incidentes ${ }^{340}$, y se alabará el discurso de Azaña, para destacar que ahora lo principal es que el Gobierno gobierne341. Se aceptó a regañadientes el Gobierno de la izquierda, manteniendo un tono de moderación en las críticas ${ }^{342}$, buscando al mismo tiempo argumentos para el optimismo que animaran a continuar en la lucha: digan lo que digan las urnas o el sufragio mentiroso; la realidad es que la mayoría de España es católica, por eso hay que seguir luchando343. Desde el primer momento se destacaron los buenos resultados electorales obtenidos en Valladolid y en toda la región ${ }^{344}$. Pronto se hablará de ella como del núcleo de resistencia "para volver a dar a España el sabor y el olor de la Patria tradicional y eterna»345.

${ }^{340}$ En la crónica local se resaltaba que, después de unos días de cierta paralización en espera de los resultados definitivos, los vallisoletanos habían dado muestras de ciudadanía con su serenidad al conocer la solución adoptada. "Normalidad ciudadana", DR, 22/8/1936, pág. 8, últ.. En la misma página se describía el día anterior: manifestaciones continuas, estandartes rojos, puños en alto, tensión, "pero sólo un incidente". "El día 21 de febrero en Valladolid", Ibid..

341 «a gobernación, obra principal», editorial, DR, 22/2/1936, pág. 1 .

${ }^{342} \mathrm{El} 3$ de marzo, ante las gestiones del ministro de Educación para limitar la enseñanza religiosa, piden en un editorial "prudencia y respeto". Ante las amenazas socialistas de -si no se cumple su programa- entregar todo el poder a la clase trabajadora, el periódico respondió insistiendo en la necesidad de "profundas acciones de carácter social", Editorial sin título, DR, 29/2/1936, pág. 1.

343 "De nuevo en la lucha", editorial, DR, 25/2/1936, pág. 1. "La mayoría no es de ellos", editorial, DR, 28/2/1936, pág. 1 .

344 "Castilla-León, núcleo central de la nacionalidad española", editorial, 19/2/1936, pág. 1 : la región se ha mantenido sin bandazos por la derecha, a ella corresponde "la reconquista espiritual de España, sin otras armas que las de su ejemplo, su consecuencia, su patriotismo y su lealtad". "Tenemos cuatro diputados", editorial, DR, 29/2/1936, pág. 1 .

345 «Significación política de Castilla», DR, 12/3/1936, pág. 1 . 
Paralela a esa línea que podemos llamar moderada o expectante, discurría otra más pesimista, que recordaba que "el triunfo de las izquierdas es la revolución, es la repetición de lo de octubre", y que no había motivos para suponer que los republicanos de izquierda iban a detenerla, después de que no lo habían conseguido los de derechas :

\footnotetext{
"Más lógica sería la actitud de estar preparados para la revolución que se consideraba inevitable para el caso de triunfo de las izquierdas y de sus aliados. Las izquierdas y sus aliados han vencido. Siguen unidos. Y los socialistas y los comunistas anuncian sus propósitos de hacer la revolución definitiva, la que, de una vez, conduzca al régimen soviético. En esto hay que reconocerles una claridad absoluta. (...) Lo lógico es que las derechas sigan pensando que viene la revolución. Y que viene a pasos agigantados." 346
}

El periódico, no obstante, siguió en su línea de evitar hacer llamadas a un enfrentamiento directo con el gobierno; pero poco a poco el desánimo ante la marcha del país iba siendo cada vez más manifiesto. Con él crecía la desconfianza en las soluciones políticas dentro del sistema: Acción Popular, como el resto de los partidos de la derecha, ante el ambiente de guerra civil, renunció

346 "Las derechas, Azaña y la revolución", por Francisco Casares, 14/3/1936, pág. 4. Era frecuente que la prensa socialista diera la razón a estas argumentaciones. El 14 de abril, con motivo del aniversario de la República Claridad decía en un editorial: "Sin octubre de 1934 no hubiera advenido el triunfo electoral de febrero de 1936. No lo olviden los republicanos, y, recordándolo, no olviden tampoco que en octubre de 1934 se comenzó a hacer lo que en abril de 1931 no se hizo. Y lo que hay que continuar haciendo. Pero a fondo, metiendo el bisturí del poder en la entraña de la sociedad monárquica y teocrática, y no sólo en la ley escrita y no ejecutada, ni en bellas piezas oratorias." 
primero a participar en las elecciones municipales que se anunciaron 347, y más tarde en las presidenciales:

"Las garantías constitucionales han permanecido y
permanecen suspendidas; la censura de Prensa está en todo su
vigor; la seguridad personal por la calle, y hasta en la
propia casa, nadie la garantiza; el asalto a los centros
políticos, con la consiguiente desaparición de ficheros, ha
estado a la orden del día; los encarcelamientos de elementos
de derecha son abundantísimos; en los pueblos no funcionan los
Ayuntamientos de elección popular, sino en aquellos en que la
elección fue favorable para los que hoy integran el Frente
Popular; en fin, la propia situación de ánimo de los que el 16
de febrero triunfaron, y tantas y tantas cosas más, han
obligado a los partidos políticos [de derecha] a no
presentarse a las elecciones de hoy."348

Las noticias de las alteraciones del orden público en la región -atentados, asaltos, bombas, robos sacrílegos, incendios de templos- y en la ciudad ${ }^{349}$, son continuas; y las huellas de la censura cada vez ocupan más espacio en las columnas del periódico. A finales de marzo hay editoriales enteros tachados, y de ahora en adelante es raro el día en que no se suprima alguna frase o algún titular350. El 6 de mayo no sale el periódico como

347 "El partido Acción Popular ha acordado no ir a la próxima lucha electoral para las elecciones de concejales. Basa su acuerdo en la ilegalidad de la convocatoria, en que no hay garantías de independencia y en que existe un verdadero ambiente de guerra civil.", "Abstención electoral", editorial, 31/3/1936, pág. 1 .

348 "Ante las elecciones de hoy", DR, 26/4/1936, pág. 1 .

${ }^{349} \mathrm{Cfr}$. por ejemplo, "Temas locales. Bajo el imperio del bandidaje", DR, 31/3/1936, pág. 8, últ., y "Barbarie callejera», en la misma sección, DR, 22/4/1936, pág. 8, últ.. En los dos casos se denuncian sobre todo los cacheos y dentenciones efectuados por grupos que se autodenominan "guardias cívicos". El periódico insiste en que eso no se puede achacar a ideas políticas de ninguna clase, y que es puro y simple bandidaje.

${ }^{350}$ Una reclamación frecuente es la unificación de criterios en la censura, que no se permita publicar algo a unos medios y a otros no. Cfr. "Bajo la censura", editorial, DR, 15/4/1936, pág. 1; y "Anomalías 
consecuencia de la huelga general declarada en la ciudad. Los titulares del día siguiente recogían una frase de Madariaga: "Por debajo del Estado gobernante hay un Estado de subversión"; el editorial era una nueva llamada a las autoridades para que salieran de la pasividad ${ }^{351}$

En la información local continuaron las campañas sobre temas como la localización del recinto de la Feria de Muestras, las consecuencias de las inundaciones de febrero, o el paro obrero, a las que se añadía la continua reclamación de que se pusiera orden en la calle y se liberaran los presos políticos. En mayo se retomó una campaña sobre el regionalismo castellano que la revolución de 1934 había interrumpido: era momento de pensar en el Estatuto de Castilla352. Sólo se publicó un artículo en contra, firmado por Onésimo Redondo353.

En esas circunstancias, el número extraordinario preparado por el periódico con motivo de la Exposición Mundial de Prensa Católica354 -era la aportación de Diario

de la censura", editorial, DR, 22/5/1936, pág. 1. En junio de 1936 se publican los acuerdos de la Federación de Empresas periodísticas, que contienen reivindicaciones similares: que se garantice la seguridad de los periódicos, que se indemnice a los asaltados, que se suavice la censura y se unifiquen sus criterios. DR, 4/6/1936, pág. 1. Cfr. también ALMUIÑA FERNÁNDEZ, Celso, "Castilla ante el nacionalismo...", en op. cit..

351 "Lo que no debe repetirse", 7/5/1936, pág. 1 .

352 «El Estatuto castellano-leonés», editorial, DR, 21/5/1936, pág. 1.

353 "Sobre Estatuto castellano-leonés. Mi voto en contra», DR, 27/5/1936, pág. 1 y 3 .

${ }^{354}$ Se celebró en Roma de la primavera al otoño de 1936. 
Regional a la exposición-, quedó un tanto fuera de sitio. El contenido se ocupaba de "dos cosas fundamentales de Valladolid: las actividades católicas de nuestra ciudad y Diócesis, y la preocupación agrícola»355. Las palabras del Arzobispo que se publicaban eran una llamada a seguir trabajando en los medios de prensa como un medio más de evangelización, para hacer frente no sólo "a los demoledores elementos de la prensa impía", sino también "a esa prensa industrialista cuyo único fin es el negocio, al que subordina y sacrifica todos sus medios de publicidad» 356 .

Cuatro días después de publicarse el extraordinario la violencia volvía a adueñarse de Valladolid. La noche del jueves 18 unos individuos derechistas habían abierto fuego contra los parroquianos de dos cantinas de la ciudad. De resultas de los disparos hubo un muerto y seis heridos. A partir de las doce de la noche, en protesta contra los atentados, la C.N.T. y la U.G.T. convocaron la huelga general. Los huelguistas se hicieron con la ciudad, en la que llegó a haber dificultades para el aprovisionamiento de alimentos. Los trenes quedaron paralizados, $y$, pese a los salvoconductos que facilitaban los sindicatos organizadores, hizo falta que el diputado socialista Federico Landrove se colocara en la máquina de

355Editorial sin título, DR, 14/6/1936, pág. 1 .

356 "El Papa y la Prensa Católica», por Remigio Gandásegui, Arzobispo de Valladolid, Ibid., págs. 1 y 2. 
los convoyes para que los piquetes permitieran su salida de la ciudad. Hubo cuatro heridos por arma de fuego -esta vez disparaban los izquierdistas-, y resultó muerto un sindicalista católico. El gobernador civil fue sustituido por el de Zamora, y en la Casa del Pueblo se acordó poner fin a la huelga en la madrugada del día 20357. En el número del día 21 -los días 19 y 20 no salió el periódico-, el editorial llevaba por título unas palabras del alcalde socialista, García Quintana: "Deben cesar las violencias". Lamentaban que se hubiera llegado a una situación de guerra civil en la ciudad, $y$ se pedía a todos tranquilidad. La responsabilidad principal se atribuía a los que habían llenado de violencia el ambiente, a las izquierdas, pero se insistía en que más que exigir responsabilidades era momento de hacer caso a las palabras del alcalde.

El mes de julio trajo una intensificación de la censura. El cincuenta por ciento de la información política aparecía tachada, y apenas había una página en que no aparecieran manchones o ristras de "Lea usted Diario Regional". El 14 de julio, con motivo del asesinato de Calvo Sotelo se llamaba a las derechas a abandonar el Parlamento. La ruptura estaba consumada. Del sistema nada se podía esperar, así que se apelaba al tribunal de Dios:

${ }^{357} \mathrm{Cfr}$. el relato de los hechos en la última página de DR, 21/6/1931. 
"Pero ¿y las derechas parlamentarias? ¿No creen llegada la hora de adoptar una actitud enérgica, decisiva, tajante? Ante el cadáver del señor Calvo sotelo ino habrán llegado al convencimiento pleno y evidente de que están de más en el actual Parlamento.

"Más todavía, es posible que a las derechas españolas ni siquiera les sea dado ver cumplida en los culpables toda la justicia que debiera cumplirse. Aquí no cabe más que esperar a que caiga sobre quienes deba caer la justicia de Dios, que esperamos -por algo somos providencialistas- habrá de caer cuando menos lo pensemos, quizá los unos y los otros.

"Mas, por encima de todo, es para nosotros ineludible condensar nuestra indignación y nuestras ansias de justicia en una protesta honda, encendida y fulminante, no sólo contra los autores del horrendo asesinato del señor Calvo Sotelo, sino contra un ambiente y una situación que hace posibles tamaños crímenes en España."358

La situación de guerra civil era ya un hecho. Sólo hacía falta que uno de los dos bandos abriera las hostilidades en gran escala. El periódico no pedía abiertamente un levantamiento militar, pero entre líneas, como luego reconocerán, toda su esperanza se cifraba en que se repitiera -en el sentido que él la había interpretado- la actuación de los militares en 1934 .

358 "Ante el cadáver de Calvo Sotelo", editorial, DR, 14/7/1936, pág. 1. 



\title{
La guerra: sin Madrid y con fanatismo
}

\author{
«La prensa española de hoy no es todavía la prensa que ansiamos \\ y que el nuevo Estado, seguramente, acabará de modelar, \\ para mayor eficacia de estos auténticos órganos de unánimes estados de opinión.»
}

Diario Regional, 21 de julio de 1937.

«Del mismo modo que la guerra civil esfumó la personalidad pura del periodista liberal, esfumó también la personalidad pura del periodista reaccionario»

Arturo Mori. 
TRistes días de entusiasmo.

"Ya no es delito gritar iVIVA ESPAÑA!

"El Frente Popular se ha derrumbado bajo el peso de sus propias iniquidades.

"La sangre de Calvo Sotelo, mártir de España, ha librado de sus enemigos a la Patria.

"Las fuerzas gubernativas y del Ejército, entusiásticamente compenetradas con el pueblo. "iViva España, Arriba España, España sobre todas las cosas, y sobre España, Dios!"

Con estos titulares a toda plana, salió a la calle Diario Regional en la mañana del domingo 19 de julio de 1936. La tarde anterior, los Guardias de Asalto de la ciudad habían desobedecido la orden de salir de Valladolid, $y$ a eso de las siete patrullaban en una furgoneta por las calles del centro, dando vivas a España y entonando el himno de la Falange. Las fuerzas de la Guardia de Seguridad y de la Guardia Civil se unieron a los de Asalto, y junto con jóvenes de los partidos de derecha -Falange, Acción Popular, Renovación Española y Tradicionalistas-, establecieron controles en las calles. La ciudad estaba tomada a las ocho de la tarde. A las ocho y media se oyeron disparos en torno a la sede de la C.N.T., y algunas explosiones. Los tiroteos continuaron durante la tarde y se hicieron más intensos después de las diez, principalmente en la Plaza Mayor y la del Campillo. Avanzada la noche, tres compañías de soldados salieron a 
la calle y se hicieron con la situación. En los barrios céntricos, los enfrentamientos dejaron paso a las aclamaciones que desde las casas se lanzaban a las tropas. De fondo sonaban todavía algunos disparos aislados.

El tiroteo definitivo había tenido lugar en la División, cuando el general Saliquet había acudido para deponer pistola en mano al general Molero. Sus ayudantes abrieron fuego. Resultó muerto un joven abogado, afiliado a Renovación Española, que acompañaba a Saliquet, y heridos Molero y dos de sus ayudantes. El Gobernador Civil salía de la ciudad a las dos de la mañana, los presos políticos fueron puestos en libertad, y Saliquet declaró el estado de guerra a última hora de la madrugada. El bando terminaba así:

"POR ULTIMO: Espero la colaboración activa de todas las personas patrióticas, amantes del orden y de la paz, que suspiraban por este movimiento, sin necesidad de que sean requeridas especialmente para ello, ya que siendo, sin duda, estas personas la mayoría, por comodidad, falta de valor cívico o por carencia de un aglutinante que aúne los esfuerzos de todos, hemos sido dominados hasta ahora por unas minorías audaces sujetas a órdenes de internacionales de índole varia, pero todas igualmente antiespañolas. Por esto termino con un sólo clamor que deseo sea sentido por todos los corazones y repetido por todas las voluntades. iVIVA ESPAÑA! 359

\footnotetext{
359 "Bando. Don Andrés Saliquet Zumeta, General de División y jefe de las fuerzas de la Séptima División", DR, 19/7/1936, pág. 1. El resto de los datos están también extraídos de la crónica de los sucesos que se hace en el periódico en las páginas 6 y 7 . Puede verse también el relato de los hechos que hace Hugh THOMAS en La guerra civil española, edición corregida y aumentada, tomo 1, Grijalbo, Barcelona, 1976, págs. 265-266. El autor basa su relato en el que hace Juan de ITURRALDE en El catolicismo y la cruzada de Franco, vol. II, Bayona, 1955, págs. 107 y ss.. Para otros aspectos, como la situación de la Falange en Valladolid antes y después del levantamiento militar, véase RIDRUEJo, Dionisio, Con fuego $y$ con raíces. Casi unas memorias, Planeta, Barcelona, 1976, págs. 64-82.
} 
Luciano de la Calzada y los jefes de Renovación Española y Falange apoyaron desde el primer momento el movimiento, "secundado por la mayor parte del pueblo vallisoletano". El ambiente del día siguiente fue de fiesta en la mayor parte de la ciudad: la gente salió a la calle, hubo desfile con banda, una manifestación de mujeres, y vivas a España y a Diario Regional. El ambiente de otros barrios era justamente el contrario, tal y como el periódico lo dejaba entrever:

"Esta mañana también, los números de nuestra edición del domingo, que no pudieron repartirse a domicilio porque todavía en algunos barrios la envenenada pobre gente exmarxista agredía cobardemente a los ciudadanos indefensos, fueron vencidos por los disciplinados "balillas" -ya les daremos un nombre español- siendo recibido nuestro periódico al grito de iVIVA LA PRENSA HONRADA! (...) »360

Se daba cuenta de los muertos $y$ heridos ${ }^{361}$, y un editorial criticaba -sin descender a detalles- las violencias de los derechistas y las ejecuciones:

"Cuando las izquierdas cometían excesos que, además de inútiles, demostraban instintos de perversidad $y$ de ensañamiento feroz, lo censurábamos duramente, y todas las personas sensatas sentían justa indignación. Hemos mantenido y mantendremos siempre la misma actitud. Hemos sido y somos partidarios de la justicia aplicada con serenidad, porque de otra manera, no es justicia. ¿Para qué los excesos si siempre son inútiles?

"Es más fácil convencer con palabras y, sobre todo, con hechos. Razones, verdades y justicia, siempre. Otra cosa, no. ¿Que las izquierdas no procedían así? Exacto. Y precisamente por eso hay que hacer lo contrario. Será la mejor manera de acertar.

"En todas las horas $y$ en todos los momentos hemos

360 "El aspecto de Valladolid después del triunfo", DR, 21/7/1936, pág. 3 .

361 «El movimiento triunfante en Valladolid», DR, 21/7/1936, págs. 1, 2 y 6 . 
mantenido con igual firmeza nuestras convicciones, aun a costa de todos los riesgos. Nuestra actitud será siempre la misma, y estamos seguros de que habrá unanimidad en compartirla» 362

Lástima que no cumplieran tan buenos propósitos. Es posible que la censura impidiera la publicación de las denuncias que hubieran debido hacer de los crímenes que por entonces se cometieron ${ }^{363}$, pero no hay ninguna evidencia de que lucharan contra esa grave situación con el denuedo del que habían hecho gala en los últimos años. Contrasta, en efecto, la actitud ante las violencias de ahora, con la que se había adoptado ante hechos análogos en años anteriores, cuando la denuncia de los mismos se afrontaba aun a riesgo de multas, pedreas o suspensiones. Algo importante había muerto, y sólo así puede explicarse que fuera posible la guerra.

Esta palabra, guerra, no aparece en ninguno de los comunicados militares, es más, un mensaje radiofónico del

362 "Justicia y serenidad", editorial, DR, 21/7/1936, pág. 6, últ..

${ }^{363}$ No sabemos el número de ejecuciones que tuvieron lugar en Valladolid durante la guerra. THOMAS, siguiendo a ITURRALDE, cita la actuación de una "patrulla del amanecer" formada por falangistas, que fusilaba cuarenta personas diarias, y señala a Onésimo Redondo como uno de los protagonistas de estos hechos (op. cit., págs. 287-288). Poco más adelante considera desautorizada la versión de ITURRALDE, según la cual el número de muertos en Valladolid fueron "más de $1.600 "$, para dar por buena la noticia dada por "un "diputado católico" y por el director del Colegio Inglés de Valladolid al difunto Bernard Malley", de que el número de muertos fueron 9.000 (op. cit., pág. 291). En conclusión, no disponemos de ningún estudio bien documentado sobre la represión en Valladolid. Sea como fuere, se puede afirmar con seguridad -cfr. por ejemplo el testimonio de María Garrán que se cita en la nota 3 del primer capítulo- que tuvieron lugar numerosas ejecuciones incontroladas de elementos izquierdistas y militares que no se sumaron al movimiento. Lo notorio de estos hechos, y la proximidad de los redactores del periódico a los autores de los crímenes hace imposible la disculpa de su actitud, sólo explicable por clima de miedo, odio y venganza que se impuso, al menos en los primeros momentos. 
general Franco -del que se tacharon unas líneas-, apremiaba a tomar posiciones ante un desenlace que se preveía próximo364, y otro de los publicados terminaba con vivas a España y a la República ${ }^{365}$. No ocurría así en otros casos. En su alocución radiofónica de la noche del domingo 19, Onésimo Redondo hablaba de un nuevo Estado y afirmaba: «Estamos totalmente entregados a la guerra, ya no habrá paz mientras el triunfo no sea completo". ${ }^{366}$

La actitud de Diario Regional era también manifiestamente beligerante. Junto al editorial que pedía justicia y serenidad había otro dedicado a escarnecer a El

${ }^{364} \mathrm{El}$ mensaje afirmaba que "Andalucía, Valencia, Aragón, Burgos, Valladolid, Coruña, Asturias, con sus fuerzas de orden público, están estrechamente unidas a nosotros. La gloriosa Marina española, con sus bases, con todo entusiasmo se unió al movimiento. [siguen seis líneas tachadas ]

"Si alguno por ignorancia se mantiene alejado del movimiento salvador, poco tiempo le queda para entrar en el camino de la Patria. (...)

"El movimiento es arrollador $y$ no hay fuerza humana para contenerlo."

"Copia del radiograma enviado por el Excmo. Sr. General Franco, Jefe de las Fuerzas Militares Españolas, en la mañana del domingo", DR, 21/7/1936, pág. 1. Se publicó con grandes tipos.

365 "Radiograma del general Franco al jefe de la base naval de Cádiz", DR, 21/7/1936, pág. 1 .

${ }^{366} \mathrm{El}$ discurso comenzaba con un ataque a la mentira -el medio marxista por antonomasia- que Madrid seguía radiando, y continuaba asegurando el triunfo del movimiento: frente al Ejército nada se puede poner, $y$ "junto al Ejército está la Falange Española de las J.O.N.S.(...). Todo ha caído, derechas e izquierdas, sólo la Falange permanece invariable". La patria, que no quiere ser colonia de Rusia, si quiere lograr algo definitivo, debe proletarizarse, hacer que el sentimiento patriótico llegue a todos los obreros. Amenazaba a los capitalistas, que hoy con fácil entusiasmo levantaban el brazo, si en el futuro seguían ocupándose de su "incorregible egoísmo, de su solo interés sin volver la cabeza a los lados ni atrás para contemplar la estela de hambre, escasez, y dolor que los sigue y los cerca (...). El Estado nacional-sindicalista viene sobre todo a redimir al proletariado". "Alocución del jefe de las J.O.N.S. en Valladolid, Onésimo Redondo", DR, 21/7/193, pág. 2 . 
Norte de Castilla :

"Con la tibieza y recato que siempre han sido su lema en los momentos críticos y difíciles, se creyó relevado de poner a contribución de la causa que está salvando al país su influencia, escribiendo entre otras ambigüedades que "hoy podemos escribir libres de esta traba, y esta misma libertad nos impone moderación en el juicio". [No es extraño que haga esto] quien estimó la publicación de la muerte del teniente "rojo" Castillo en el mismo plano de interés que la del eximio español don José Calvo Sotelo, está bien conocido como órgano acomodaticio a las circunstancias que, por rara casualidad, se amoldan siempre a su negocio. (...)

"El colega local, que un día fue albista, otro lerrouxista, más tarde y cuando así convenía izquierdista y mañana será falangista si los propios falangistas no lo remedian, que si lo remediarán." 367

Terminaban haciendo una advertencia: los viejos liberales coqueteaban hasta ahora con los izquierdistas; estos días ya se les ha visto en la División y en el Gobierno Civil. "iOjo con ellos!, hemos de advertir. Ellos y su periódico serán hoy de la nueva y gloriosa situación como ayer hicieron el amor a los izquierdistas y antes a todos los que habían llegado al poder." Prometían hablar más de la cuestión, y esta vez -como tendremos ocasión de vercumplieron escrupulosamente su palabra.

\section{El movimiento se demuestra muriendo.}

Para el periódico estaba claro que el movimiento no era otra cosa que la ejecución de una sentencia divina, vengadora de la iniquidad de los izquierdistas ${ }^{368}$, y que

367 "Dos periódicos de Valladolid», DR, 21/7/1936, pág. 6, últ..

${ }^{368}$ En el editorial del día 19 recordaban las frases del que habían publicado con motivo del asesinato de Calvo Sotelo: "Y efectivamente, pasados cuatro días desde la muerte del señor Calvo Sotelo, cuando ni los unos ni los otros lo pensábamos la justicia de Dios se ha hecho patente y la sangre de aquel insigne mártir del deber patrio ha tenido 
por tanto daba a los planteamientos políticos de la derecha la razón que las urnas le habían negado: la verdadera España era la suya, donde terminaba su ideología, comenzaba el extranjero.

La realidad era menos escatológica: una conspiración militar había cuajado en un levantamiento que contaba con fuerte apoyo popular en una parte importante del país. En los lugares donde no triunfaba, la victoria sobre el alzamiento significaba el comienzo de la revolución ${ }^{369}$. En la zona donde había tenido éxito, había diferencias entre los planteamientos de los militares, los de los políticos y los de la gente común, pero ni siquiera se mencionaban. Lo importante era el rechazo de la política republicana, tal como venía siendo desde febrero, del peligro revolucionario, y el deseo de un nuevo estado de cosas.

En las comunicaciones de los militares que se publican, se habla de orden y patriotismo; advierten que devolverán al pueblo los resortes del poder en cuanto "la violencia, el fraude y el crimen" hayan sido detenidos, que «nada tienen que temer ni las legítimas autonomías regionales $\mathrm{ni}$ las conquistas intangibles de las clases

su eficacia...

"(..) por fin el fuego del patriotismo ha encendido los corazones de todos los buenos españoles, que llevaban cinco meses devorando con paciencia incomprensible toda injusticia, toda iniquidad, todo vejamen, todo agravio, todo insulto, toda humillación. Pero, gracias a Dios -repitámoslo muy alto, gracias a Dios- la infamante opresión ha terminado $y$ los poderes tenebrosos del Frente popular se han derrumbado al grito de iviva España! (...)"

${ }^{369} \mathrm{Cfr}$. THOMAS, op. cit., tomo 1, pág. 273. 
trabajadoras»370, que "el movimiento no se hace para favorecer a ninguna clase privilegiada, sino para proteger a los obreros, hacer resurgir la economía nacional y beneficiar a la clase media, tan abandonada de los gobiernos anteriores" ${ }^{371}$. $\mathrm{Ni}$ una palabra sobre la cuestión religiosa en los primeros días, esa no era la motivación primordial de los sublevados:

\begin{abstract}
"La rebelión militar que desencadenó la guerra civil española fue organizada casi exclusivamente por algunos sectores de oficiales del ejército. Representaba una reacción nacionalista y derechista frente a las fuerzas revolucionarias y a la política kerenskiana del gobierno republicano. Se proponía instaurar un régimen más autoritario y conservador dominado por los militares. La religión no tuvo ningún papel oficial en esa empresa. Algunos de los activistas militares no sentían ningún interés por la defensa del catolicismo, mientras que otros se mostraban renuentes a complicar aún más la situación, dando a su movimiento un tono religioso. Los rebeldes esperaban un apoyo extenso de las clases medias y no deseaban provocar el antagonismo de los anticlericales moderados. Por eso, sus primeras declaraciones, en los comienzos del conflicto, no hicieron ninguna referencia a la cuestión religiosa.

"Más aún, el jefe de la Junta de Defensa Nacional, la de los rebeldes, formada el 23 de julio de 1936, era el general Miguel Cabanellas, bien conocido como liberal moderado y masón. Sólo cuatro de los diez miembros de la junta habían sido con anterioridad partidarios políticos activos del catolicismo." 372
\end{abstract}

El día 11 de agosto, cuando ya se puede hablar de

370Cfr. "Bando del General Gobernador", DR, 21/7/1936, pág. 3; "Proclamas de los generales que dirigen el gran movimiento nacional", DR, 22/7/1936, pág. 2 .

371 «El general Franco envía un abrazo para la Guardia Civil», DR, 23/7/1936, pág. 1 .

372PAYNE, El catolicismo..., pág. 217. El mismo autor señala la intención del general Mola, el que planeó la rebelión, de seguir el ejemplo del régimen dictatorial de portugal y mantener la separación de la Iglesia y el Estado, aunque siempre con la presunción de que un gobierno militar de derechas se mostraría mucho más solícito hacia los intereses católicos que la República de izquierdas (págs. 212-213). 
frentes de guerra, Valladolid ha sido bombardeado373, y las esquelas de los vallisoletanos muertos en la sierra de Madrid llenan más de una página del periódico diariamente, se publican unas declaraciones de Franco a Radio Club Portugués que provocaron el desconcierto, e ilustran sobre la ausencia de propósitos definidos entre los jefes militares :

"España es y será republicana. Ni la bandera ni el régimen
deben cambiarse. Lo unico que se cambiará será el
bandolerismo, que hasta hace pocos días ha imperado, por una
era de paz, de trabajo y de bienestar. Las ideas que
representamos no tienen ni colores ni matices políticos.
J.O.N.s., Acción Popular y Requetés, fuerzas distintas, que
ahora van unidas, representan, con nosotros, a todas las
fuerzas de España. No hay que pensar ni en regímenes nuevos ni
en monarquías, sólo hay que pensar en Dios y en España"374

Al día siguiente el periódico afirmaba que lo publicado "seguramente está muy lejos del pensamiento del general Franco", y alegando que la entrevista la había realizado un extranjero, no se responsabilizaban de la exactitud del párrafo que reproducimos ${ }^{375}$.

Por otro lado, los partidos políticos que habían sobrevivido lo hacían más bien como milicias, y, al menos

${ }^{373} \mathrm{El}$ primer bombardeo de los tres que sufriría la ciudad tuvo lugar el 3 de agosto y causó siete muertos. El hecho provocó la publicación de un editorial sobre el bombardeo de las ciudades: "El bombardeo de ciudades abiertas", DR, 8/8/1936, pág. 6, últ..

374 "Interesantísimas declaraciones del general Franco", DR, 11/8/1936, pág. 1. El periódico había publicado pocos días antes un artículo sobre la recuperación de la bandera bicolor por iniciativa popular, pero no se izó en el Ayuntamiento hasta el 14 de agosto. Cfr. "Arriba la bandera nacional", DR, 27/7/1936, pág. 1, y "Se iza en el balcón del Ayuntamiento la verdadera bandera española", 15/8/1936, pág. 1.

375 "Sobre unas declaraciones del general Franco", DR, 12/8/1936, pág. 1 . 
en Valladolid, los falangistas pretendían tener el monopolio, lo que provocó algún roce con el periódico. El primer día que aparecen las "suscripciones patrióticas" para sostener a los milicianos, se citan como tales los de las Juventudes de Falange Española, de Acción Popular, de Renovación Española, Tradicionalistas, y Voluntarios de España ${ }^{376}$. Al día siguiente aparece un solo rótulo: "Suscripción para las Juventudes de Falange Española de las J.O.N.S.", con una nota de la redacción: "Lo recaudado en Diario Regional, según advertimos en nuestro número de ayer, creemos que se debe destinar a todas las fuerzas, al menos a todas las organizaciones civiles, que intervienen en el movimiento."377 La presencia de Onésimo Redondo primero, y su temprana muerte después ${ }^{378}$, contribuyeron sin duda a prestigiar su movimiento, mucho más apto que la J.A.P. para las actividades que ahora se desarrollaban. Pese a todo, el periódico daba discretamente -apenas veinte líneas a una columna- la salida de Luciano de la Calzada para el frente y de un centenar de milicianos de la J.A.P. para Ávila379.

Por lo que se refiere a las creencias religiosas, que

${ }^{376} \mathrm{Cfr}$. solicitud de donativos en DR, 21/7/1936, pág. 3

${ }^{377} \mathrm{DR}, 22 / 7 / 1936$, pág. 1 .

${ }^{378} \mathrm{Su}$ asesinato camino del frente el 24 de julio constituyó un acontecimiento en la ciudad. Desde entonces el periódico se referirá a él como "el caudillo de Castilla".

379 «El diputado señor Calzada marcha al frente», DR, 30/7/1936, pág. 6 , últ. 
tantas pasiones desataron en uno y otro bando, resulta claro que para muchos fue el principal motivo para apoyar el movimiento. $\mathrm{Ni}$ que decir tiene que para Diario Regional así era, pero también lo fue para otros que estaban lejos del periódico en materia política. La dura persecución desatada en la zona republicana380 contribuyó a acentuar ese convencimiento de que lo que se llevaba a cabo era una lucha en defensa de la religión, aspecto que los militares no tardaron en incorporar a su programa. Por lo que se refiere a declaraciones oficiales de la jerarquía, en Valladolid la única que se produjo fue una instrucción del arzobispado -el Arzobispo estaba en zona republicana- que mandaba a los sacerdotes decir en las misas la oración Pro pace, pro re gravi, el 30 de julio ${ }^{381}$. Pocos días más tarde, el periódico publicó una carta de los obispos de Vitoria y Pamplona que reprobaba la actuación de los nacionalistas vascos, en la que afirmaban que "nadie, para defender su ideal, puede aliarse con el comunismo»382. La siguiente declaración oficial aparecida en Diario Regional, fueron las palabras que Pío XI dirigió a un grupo de españoles en septiembre. Se publicó primero

\footnotetext{
380 "La persecución de la Iglesia Católica fue la mayor jamás vista en la Europa occidental, incluso en los momentos más duros de la Revolución francesa. El número de los eclesiásticos asesinados -unos 7.000- era proporcionalmente igual al de las matanzas comunistas en Rusia, teniendo en cuenta las diferencias de población (...)", PAYNE, op. cit., pág. 214 .

381 "Circular del arzobispado de Valladolid», DR, 30/7/1936, pág. 6, últ..

382 "Los obispos de Vitoria y Pamplona condenan la actuación de los nacionalistas vascos", DR, 9/8/1936, pág. 5.
} 
un resumen de la alocución el día 17, y dos días después el texto completo de la misma. El Papa lamentaba la persecución y la guerra, especialmente dolorosa por ser entre compatriotas, advertía del peligro de los movimientos revolucionarios que proliferaban en el mundo, rechazaba la acusación de que fueran los principios católicos los causantes de la situación, y terminaba deseando la conversión de los perseguidores. El tono de la alocución contrastaba con el que era habitual en el periódico -ajeno a criterios de caridad o comprensión-, y con los titulares que encabezaban la noticia, que se centraban en la descripción de los agravios recibidos ${ }^{383}$.

El papel del catolicismo en la definición del movimiento salía, pues, de la calle, y sólo después fue reconocido oficialmente. En definitiva, como lo describe Payne:

"Según cruzaban las líneas las noticias de la explosiva revolución que se estaba produciendo en la zona del Frente Popular y de las atrocidades masivas que allí se cometían, el apoyo católico creció de forma aplastante. En sí mismo, esto no es sorprendente; sólo hubiera sido extraordinario el

${ }^{383}$ Sobre la guerra decía: "La guerra es siempre, aun en la hipótesis, triste, terrible e inhumana. El hombre busca a el hombre para matar al mayor número posible de semejantes. Para hacerles daño con los medios cada vez más mortíferos."; y sobre los enemigos: "¿Qué decir de los otros, que son y serán siempre nuestros hijos, aunque en las cosas y en las personas que nos son más caras hayan empleado procedimientos crueles (...)? No podemos dudar un solo instante lo que debemos hacer: amarles, y orar por ellos (...). Orar para que estén con nosotros cuando, en un porvenir próximo -tenemos de ello plena confianza en Dios- el iris de la paz se eleve en el hermoso suelo español (...)." Los titulares eran: "La revolución española puede servir de enseñanza a todos los pueblos, dice el Papa", DR, 17/9/1936, pág.1; y "El Papa habla de las cosas de España ante 500 sacerdotes, religiosos y seglares españoles. Las matanzas, profanaciones y carnicerías que se ejecutan en España son como una visión apocalíptica", DR, 19/9/1935, pág. 1 . 
resultado opuesto. Como se vio después, el apoyo católico, en términos de respaldo político, voluntarios para el ejército, ayuda económica y, quizá lo más importante, motivación espiritual y legitimación cultural, se convirtió en el pilar interior más importante del movimiento nacionalista."384

En ese proceso de apoyo, tendrá especial importancia la interpretación del papel del catolicismo en la vida pública que era característico de los hombres que en su actuación política decían representar los intereses católicos .

Toda esta mezcla de factores de uno y otro tipo hacían de hecho indefinible al movimiento. Será a lo largo de la guerra cuando se vaya perfilando la solución a los interrogantes planteados. De momento aquello era "el movimiento salvador", $y$ esto bastaba para que muchos perdieran su vida en los frentes para defenderlo, y otros en la retaguardia por no apoyarlo. Impresiona hojear un periódico en el que unas páginas se dedican a hacer ejercicios de lenguaje, para mejorar cada día la retórica de exaltación patriótica y de humillación del adversario, mientras otras están llenas de esquelas de jóvenes que morían "por España", "por Dios y por España", "luchando contra los enemigos de Dios y de su Patrian, o, si eran militares, "en cumplimiento de su deber y en defensa de España» •

Provincias Sin prensa de Madrid.

${ }^{384}$ PAYNe, Stanley G., El régimen de Franco 1936-75, Alianza Editorial, Madrid, 1987, pág. 210 . 


\section{Los "legítimos provechos".}

La publicación de una gran cantidad de esquelas indica una gran difusión del periódico. En cierta forma estaban "recogiendo los legítimos provechos de su acción y de su constancia»385, pero también debían el aumento de su difusión a la geografía dibujada por la reacción ante el alzamiento. De las ciudades donde había triunfado, Valladolid era una de las mayores; estaba además en el centro geográfico de la zona norte adicta al movimiento, y era también el centro tradicional de la única región que junto con Galicia-, se había colocado entera del lado de los militares sublevados. A todo esto había que sumar un factor importante: la división del país era un singular experimento de geografía informativa, que permitía comprobar qué ocurre en provincias cuando falta la prensa nacional, la de Madrid; si bien es cierto que un momento como el que se vivía provoca una aumento anormal de la demanda de prensa; las guerras venden periódicos en la retaguardia, y hacen lectores a combatientes que nunca lo fueron, que llenan con el periódico muchas horas muertas en la trinchera386. Además Diario Regional, que era el

385 "Una carta de don Justo Garrán a Diario Regional», DR, 2/1/1937, pág. 1 .

${ }^{386} \mathrm{El}$ periódico era vehículo de información para el conocimiento de las nuevas normas, los numerosos avisos oficiales, noticias de desaparecidos - cfr. en el apéndice 2 las observaciones a la sección "radiogramas recibidos"-, etc. Una de las iniciativas puestas en marcha consistía en sufragar los gastos de suscripción para el envío de ejemplares del periódico a los frentes: "Seguimos recibiendo suscripciones para nuestro periódico, para enviar por cuenta de los 
periódico derechista por antonomasia de la ciudad, se había colocado decididamente, desde el primer momento, a favor de la causa que triunfaba en su entorno, lo que no podía reportarle sino beneficios. El resultado de todo esto lo describía con cierto asombro, y una característica falta de objetividad, el propio periódico:

"Desde que se inició el movimiento salvador de España, nuestro periódico alcanza el valor que su lucha constante por los más altos valores patrios tenía deparado.

"Primero fuimos citados, por servir de fiel y valiosa fuente de información, por Radio Club Portugués; después fueron las radios de Milán y de Burgos. Una nube de demandas de los pueblos de las provincias limítrofes, y de las más apartadas, donde estamos repartiendo nuestro periódico por muchos millares. Altas [de suscripciones], por cientos. La "radio fantasma" de Madrid hace referencia a nosotros en sus emisiones...

"Y en Valladolid, los simpáticos balillas, voceando a todo pulmón Diario Regional, han sido seguramente los que más nos han ayudado en nuestra labor expansiva.

"Pero lo que no había sucedido nunca, ni en Valladolid ni en España, y que es lo que más demuestra el interés por nuestro periódico, es que los voceadores, los vendedores todos de Prensa de Valladolid, están dando en estos días el espectáculo de organizarse en turno para arrebatarse nuestros ejemplares. Desde las 8 de la noche del día anterior puede vérseles ante nuestro periódico cogiendo vez para ser los primeros en ser despachados al día siguiente y salir a la calle. iY eso que no se limitan los pedidos!

"Todo esto conforta nuestro ánimo y nos hace comprender que el público asiste comprensivamente a nuestra obra y a nuestra labor diaria, $y$ que, en definitiva, no se deja arrastrar por los que adoptan las oportunas posturas de cada momento, sino por los que siempre se han esforzado por la defensa de un mismo ideal." 387

que nos las encargan como donativo a los frentes.

"Ayer nos ha pagado un trimestre de suscripción a un ejemplar don Sebastián García Guerra, de ésta.

"Asimismo, la noticia que dábamos ayer, de habernos encargado la Federación de Sindicatos Agrícolas Católicos de villalón una suscripción durante el mes de febrero a diez ejemplares, hoy queda ampliada en el sentido de que dicho organismo nos ordena la entrega de treinta ejemplares más durante dicho mes.

"Estas suscripciones son distribuidas de acuerdo con la oficina de Prensa y Propaganda del Cuerpo de Ejército de la División Reforzada de Madrid."

"Más suscripciones de Diario Regional para el frente", DR, 5/2/1937, pág. 1 .

387 "El interés por DIARIO REGIONAL", editorial, DR, 15/8/1936, pág. 6, 
La gacetilla que anunciaba los lugares de venta de Diario Regional fuera de Valladolid, que por lo raquítica no se publicaba desde 1931, volvió a aparecer de vez en cuando, llenando -para satisfacción de sus editores- más de cien líneas de una columna: se mencionaban casi todas las provincias del sector norte de la zona nacional, y multitud de pueblos de la provincia de Valladolid y de las limítrofes ${ }^{388}$. Por lo que a difusión se refiere, el diario se encontraba en el mejor momento de su historia.

Las informaciones publicadas eran las facilitadas por los militares, las que el periódico podía conseguir directamente, y las radiadas por la emisora Radio club Portugués, fuente de la mayor parte de las novedades de esos días. Las agencias, como todos los instrumentos de información de ámbito nacional, habían enmudecido. El redactor especialista en taquigrafía -Gerardo Serrano- iba

últ..

${ }^{388} \mathrm{En}$ agosto de 1936 se señalaban como puntos de venta: Medina, Palencia, Peñafiel, Rioseco, Villalón, La Bañeza, Arévalo, León, Burgos, Aranda de Duero, Cuellar, Segovia, Salamanca, Nava del Rey, Mota del Marqués, Villafranca del Bierzo, Tudela de Duero. A continuación indicaban que "puede encontrarse también en": Arrabal de Portillo, Bercero, Cubillas de Santa Marta, Laguna de Duero, Pozoantiguo, Sardón de Duero, Traspinedo, Tordesillas, Vecilla de Valderaduey, Villada (Palencia), La Seca, Aguilar de Campos, Rubí de Bracamonte, Torrecilla de la orden, Olmedo, Alaejos, Villarcayo (Burgos), Esquevillas, Castrojeriz, Valencia de don Juan (León), Valdestillas, Valoria la buena, Pesquera de Duero, Casasola de Arión, Campaspero, Cabezón, Matapozuelos, La Rúa (Orense), Villanubla, Magaz (Palencia), Dueñas (Palencia), Torquemada (Palencia), Villabrágima, Zamora y Toro.

En septiembre de 1936 se añaden a la lista los siguientes lugares: Villarramiel (Palencia), Iscar, Boadilla del Campo, Villavicencio de los Caballeros, Fuente Olmedo, Barco de Valdeorras (León), Cabezón de Valderaduey, Cogeces del Monte, San Miguel del Arroyo, Pozaldez, Barruelo (Palencia) y Revenga de Campos (Palencia). 
a tener abundante trabajo en estos años, en los que la radio se convirtió en la fuente de información por antonomasia. La calidad del papel empeoró ostensiblemente a primeros de agosto, para dar un nuevo cambio a peor a mediados del mismo mes, y llegar a la reducción por racionamiento en octubre de $1936^{389}$ : el periódico tendrá un día a la semana cuatro páginas, y el resto seis. Estos amantes de la tradición tuvieron, por una vez, quejas de una legislación apoyada en el pasado: a los que preguntan la por la razón de que Diario Regional dé menos páginas que otros periódicos hay que recordarles que

\begin{abstract}
"(...) el decreto ordena la reducción del cincuenta por ciento sobre la superficie utilizada en los siete primeros días del año 1935. Entonces Diario Regional (...) no gozaba del favor oficial ni del favor de esa masa de lectores que va siempre tras la situación del momento y esto se traducía en la menor superficie de sus ediciones. Por el contrario, los periódicos poco escrupulosos en cuanto a ideas, que a todo hacían y que elogiaban a manos llenas a los izquierdistas, estaban en auge y tiraban abundante cantidad de páginas." 390
\end{abstract}

En los primeros meses hasta un tercio de la superficie impresa estaba ocupada por la "Sección necrológica" -noticias de las bajas en el frente y esquelas-, $y$ el listado de donativos para las "Suscripciones patrióticas", que llegó a ocupar una página completa y es muestra del fuerte apoyo civil que se prestó al movimiento.

\footnotetext{
${ }^{389} \mathrm{Cfr} . \mathrm{DR}, 9 / 10 / 1936$, pág. 1

390 «Nuestra reducción de papel», DR, 13/1/1937, pág. 1.
} 
En la primera página, los editoriales a una columna desaparecieron imperativo por del sensacionalismo. Todos los días había titulares que ocupaban el tercio superior de las siete columnas. A dos columnas aparecía un editorial, $y$, con el mismo formato, otro artículo de fondo firmado por Falange Española de las J.O.N.S.. Hasta febrero de 1938, en el tercio inferior de las columnas centrales, aparecía la transcripción de la alocución radiofónica diaria del general Queipo de Llano, de la que se eliminaban púdicamente las blasfemias y palabras malsonantes. A partir de diciembre de 1936, por orden de la Dirección General de Prensa y Propaganda, el artículo de fondo cedía su sitio a los partes de los Cuarteles Generales del Generalísimo y del Ejército, a los que había que añadir como coletilla cuantas órdenes de carácter oficial se recibieran. Muchas de éstas llegaban por radio, y da idea de la tosquedad propagandística de los incipientes organismos oficiales la forma en que se 
avisaba de esto y del comienzo de una campaña contra la propaganda enemiga:

"La Dirección general de Prensa y Propaganda ordena: (...)

"30.- En todas las radio emisiones en que se vaya a comunicar noticias oficiales se hará sonar previamente, el Himno de la Legión "soy valiente y leal legionario", terminándose con cualquiera de los Himnos de Falange y Requetés.

"CONTRA LA DIFAMACIÓN ROJA

"En vista del recrudecimiento de la campaña de difamación y calumnias que se hace contra España en el mundo entero, se esforzarán todos nuestros medios de propaganda y difusión en rebatirla, demostrando al mundo con realidades la perversidad comunista en sus horrendos crímenes, asesinatos, incendios, robos, saqueos y devastaciones. Para ello nos bastará demostrar que nuestra actuación, enérgica y arrolladora, lo es en los combates; pero no es, $\mathrm{ni}$ lo ha sido en forma alguna, criminal ni abusiva, ni aun tan siquiera con los enemigos que están en nuestras manos.

"La prensa publicará, constantemente, un entrefilet que diga "Vigilad todos el espionaje enemigo, detened y denunciad a los traidores." "391

\section{La capital del alzamiento.}

La última página siguió manteniendo el rótulo de "La vida en la capital». En la sección "Temas locales" Valverde continuó con sus campañas, que ahora giraban en torno a la necesidad de perseguir el encarecimiento

${ }^{391} \mathrm{El}$ resto de la orden, decía: "1‥- Serán publicados en la Prensa, desde ahora en adelante, los partes de los Cuarteles Generales del Generalísimo y los del Ejército, en el lugar del artículo de fondo, y a continuación de éstos toda la publicidad, informaciones, artículos órdenes y avisos que remitan esta Dirección de Prensa y Propaganda y las autoridades locales militares y civiles, y cuantos con carácter oficial, se difundan por Radio salamanca y sus retransmisoras o radios regionales, en cuanto a órdenes o noticias de las autoridades de la región. Aquellos periódicos que, por su alejamiento en distancia, reciban con retraso las expresadas publicaciones oficiales, las insertarán aunque lleguen retrasadas.

"2‥-En lo sucesivo, y consignados a la Dirección de Prensa y Propaganda (Salamanca), remitirán por ahora, los periódicos y toda clase de publicaciones, dos ejemplares, utilizando el medio más rápido de transporte a su alcance.

$\mathrm{DR}, 4 / 12 / 1936$, pág. 1 . 
abusivo y el fraude en la comercialización de los productos básicos o en los alquileres ${ }^{392}$, lo mismo que el enchufismo y las recomendaciones ${ }^{393}$; en la necesidad de cambiar el nombre de algunas calles -Fermín Galán, Pablo Iglesias, avenida de la República-394, de desterrar los nombres extranjeros -llegó a proponer que a la tortilla francesa se la llamara portuguesa-395, de proceder ordenadamente y evitando las denuncias falsas en la tarea de depuración que se consideraba imprescindible 396 , de afinar en la censura cinematográfica y en la moralidad callejera397, etc. Pero, en lo local, la campaña por

${ }^{392}$ Esta campaña se inicia pocos días después del alzamiento -cfr. "Temas locales», 28/7/1936, pág. 6, últ.-, vuelve a intensificarse en mayo de 1937, y de nuevo en mayo de 1938. Las denuncias sobre cuestiones de vivienda tienen a veces nombre y apellidos como en el caso de el alquiler abusivo que pretende imponer "un capitalista a un ferroviario afectado por los bombardeos". Cfr. "No nos parece tolerable", DR, 16/8/1936, pág. 6, últ.

${ }^{393}$ En un editorial se afirmaba que deberían -con mayor razón en tiempo de guerra- ser declaradas delito, DR, 5/11/1936, pág. 1 .

${ }^{394} \mathrm{DR}, 30 / 7 / 1936$, pág. 6, últ.

395 "Hay que desterrar los nombres franceses», DR, 25/9/1936.

396 "Depuraciones y difamación», DR, 12/8/1936, pág. 6, últ.. Corría el rumor de que había una lista de "los que fueron protectores de los rojos". Valverde pedía que se hiciera pública y se verificara, y a esos "se les expulse", pero no arbitrariamente ni de forma clandestina. Veremos más adelante las referencias a las depuraciones cuando nos ocupemos de la campaña contra El Norte.

${ }^{397}$ Por lo que se refiere a la censura cinematográfica, la primera referencia fue un elogio de su puesta en marcha: "Hora era ya de que se pusiera, por fuerza de la autoridad, un dique a la libre circulación de tanta propaganda inmoral, subversiva, y a veces antipatriótica, diariamente realizada desde la pantalla cinematográfica.", "La censura cinematográfica», DR, 1/3/1937, pág. 4, últ.. En otras ocasiones insistirán en que la censura debe atender no sólo a cuestiones políticas sino también morales, cfr. por ejemplo 13/6/1937, pág. 6, últ., y "Cine y películas», DR, 7/1/1938, pág. 6, últ. . 
excelencia fue la que se dedicó a pedir el engrandecimiento de la ciudad.

Las primeras reclamaciones en este sentido fueron la vuelta de la Academia de Caballería a la ciudad y la construcción de un aeropuerto ${ }^{398}$-ambas fácilmente aceptables por las autoridades militares-, a las que siguió la solicitud de que el Tribunal Supremo tuviera su sede en Valladolid ${ }^{399}$. Pero el que sería uno de los lemas básicos de la campaña llegará de un colaborador del periódico. Wenceslao González Oliveros, catedrático de la Universidad de Salamanca400, escribió un artículo en el que tras considerar los méritos hechos por la ciudad, sugería que Valladolid debería ser declarada "capital del alzamiento", de momento sin mayúsculas ${ }^{401}$. La campaña del periódico consiguió que la Diputación cursara una

La cuestión de las costumbres se aborda primero para alabar la labor del nuevo jefe de policía de la ciudad -DR, 22/10/1936, pág. 6, últ.-. En julio de 1937 será el tema más frecuente, para pedir que sea vigilado con más seriedad: si el ambiente de la playa de San Sebastián, por ejemplo, va a ser como está siendo, más vale no engañarse hablando de nueva España.

${ }^{398}$ Cfr. DR 2 y 5/9/1936, págs. 6, últ. y 1 respectivamente.

399 "El Tribunal Supremo, en Valladolid», DR, 29/11/1931, pág. 6, últ.. En diciembre de 1938 el Tribunal Supremo se instaló en Valladolid, lo que permitió al periódico tributarse un gratificante autoaplauso, DR, 23/12/1938, pág. 6, últ..

400En 1939 será nombrado Gobernador Civil de Barcelona. Su hermano, Germán González Oliveros, era sacerdote, Deán de la Catedral de Valladolid, y fue censor eclesiástico de Diario Regional.

401 «Valladolid, capital del alzamiento», por Germán González Oliveros, DR, 11/10/1936, pág. 3 . 
solicitud en este sentido al Jefe del Estado402, e hizo nacer -en vista del éxito- una nueva campaña en un sentido similar. Su lema sería "por un Valladolid rico". Este fue el título del primer editorial dedicado a la cuestión, que abogaba por no dejar pasar una ocasión como la que se presentaba, de transformar comercial e industrialmente la ciudad ${ }^{403}$. Esta vez la reacción de las autoridades no fue tan rápida, y el periódico presionó con un estilo más agresivo: Burgos, Salamanca y Sevilla tienen organismos oficiales, sellos con sus nombres y monumentos; Navarra, Zaragoza y la Coruña atraen la industria que huye: Valladolid no tiene nada porque sus "fuerzas vivas" duermen ${ }^{404}$.

Es notable cómo la campaña pone en evidencia tanto la escasa acometividad de los empresarios vallisoletanos, como la mentalidad -también típica de la ciudad- que lo fía todo a las concesiones del Estado, y que estaba en la base de los celos de Cataluña que desde tiempo atrás eran endémicos. Se consiguió que Ayuntamiento y Diputación constituyeran una "comisión propulsora" de los intereses de Valladolid405, pero poco más. En Diario Regional los

\footnotetext{
402 "La Diputación acuerda interesar al Jefe del Estado que se dé a Valladolid el título de "Capital del Alzamiento"", DR, 28/11/1936, pág. 6, últ.. La campaña continuará en la sección "temas locales", especialmente durante el mes de enero de 1937.

403 "Por un Valladolid rico», DR, 11/12/1936, pág. 6, últ..

404 «Por un Valladolid rico», DR, 7/1/1937, pág. 1.

405 «Una comisión propulsora», DR, 9/1/1937, pág. 6, últ..
} 
artículos se sucedieron, haciendo hincapié en que se asistía al momento culminante de la historia de la ciudad406, y colocando una y otra vez la frase "por un Valladolid rico" como cabecera de los "Temas locales". En junio de 1937 se reorganizó la comisión, y es significativo que en ella, el representante de la prensa local fuera Francisco de Cossío, el director de El Norte de Castilla : no se cambia en dos días la estructura social de una ciudad. Diario Regional podía decir lo que quisiera sobre los viejos liberales, pero las élites de la ciudad eran las que siempre lo habían sido407. Así las cosas, el periódico no volvió a insistir sobre el particular, limitándose a publicar alguna colaboración de González Oliveros sobre la capitalidad del alzamiento merecida por la ciudad merced a su identificación con la Falange408-, e insistiendo él mismo en que Valladolid había cambiado totalmente y ahora tenía un nuevo destino:

"En el porvenir le espera a Valladolid una tarea primordial. Cuna de la Falange, alma de Castilla, crisol de

406 "España, una, grande y libre por Valladolid», editorial, DR, 29/1/1937, pág. 1 .

${ }^{407} \mathrm{La}$ composición de la comisión era la siguiente: Presidente: Alcalde, Luis Funoll Mauro; Vocales: Arturo López Argüello, Banca de la Propiedad; Isaías Bobo Díez, Cámara de la Propiedad Urbana; Fernando de Andrés Bueno, Sociedad de Fondistas; Francisco de Cossío, Prensa local; Julio Martín Álvarez, Diputación Provincial; Angel Chamorro, Cámara de Comercio; Jefe de Arquitectos de la Delegación de Hacienda.

Las cuestiones que se abordaban eran las mejoras en materia económica en general, de alojamiento, instalaciones, vivienda y hoteles.

"Nueva reunión de "fuerzas vivas"», DR, 29/6/1937, pág. 4, últ..

408 "Valladolid, capital del Alzamiento, ha sido una con la Falange", por Wenceslao González Oliveros, DR, 4/3/1938 pág. 1 . 
España, Valladolid tiene que dar pauta en cuanto a Revolución Nacional se refiere." 409

Con el tiempo se vería lo poco efectiva que resulta la retórica en lo que a economía se refiere.

Esta sucesión de campañas, con el tono de reclamación o denuncia apremiante que era característico de Valverde, podía mantenerse por la identificación ideológica del periódico con las autoridades, y porque éstas no tenían todavía iniciativas en esas materias. Pero también se pudo ver, ya durante la guerra, un anticipo de lo que sería el régimen de prensa durante el franquismo: el 22 de marzo de 1938, el "Temas locales" del día instaba a que se resolviera el problema del alojamiento de los combatientes. Al día siguiente, en la misma sección se aclaraba que ttal y como les comunicaba la autoridad militar-, el problema estaba ya resuelto.

Las campañas por el enriquecimiento de Valladolid desembocaron en un proyecto de urbanización de la ciudad del que el periódico se ocupará por lo menudo, aprovechando la ocasión para dar doctrina política: era el momento de emprender esa urgente tarea, que unas veces el liberalismo y otras el marxismo, se habían encargado de frenar410. "No ha habido jamás un movimiento general en favor de la capital", afirmaban en el primer artículo del

\footnotetext{
409 "La capital del Alzamiento", editorial, DR, 15/7/1938, pág. 1. 410 «El proyecto de urbanización», editorial, DR, 9/12/1938, pág. 1.
} 
serial dedicado al problema: todo lo que se había hecho en medio siglo era pavimentar las calles y mejorar el saneamiento411. El plan de urbanización debía detener la extensión de la ciudad a base de chamizos -como hasta ahora era normal-, y el caos constructivo. "A comentar este plan con la mejor buena fe $y$ objetividad van encaminados los propósitos de Diario Regional». Pese a la advertencia previa, pocos días más tarde -después de haberse mostrado contrarios a algunos proyectos-, se verán obligados a aclarar que su propósito no era dividir la opinión sino comentar, sugerir... . Era el comienzo de los nuevos tiempos para la prensa, que algo debían a las campañas laudatorias de la ley de prensa que el mismo periódico había hecho.

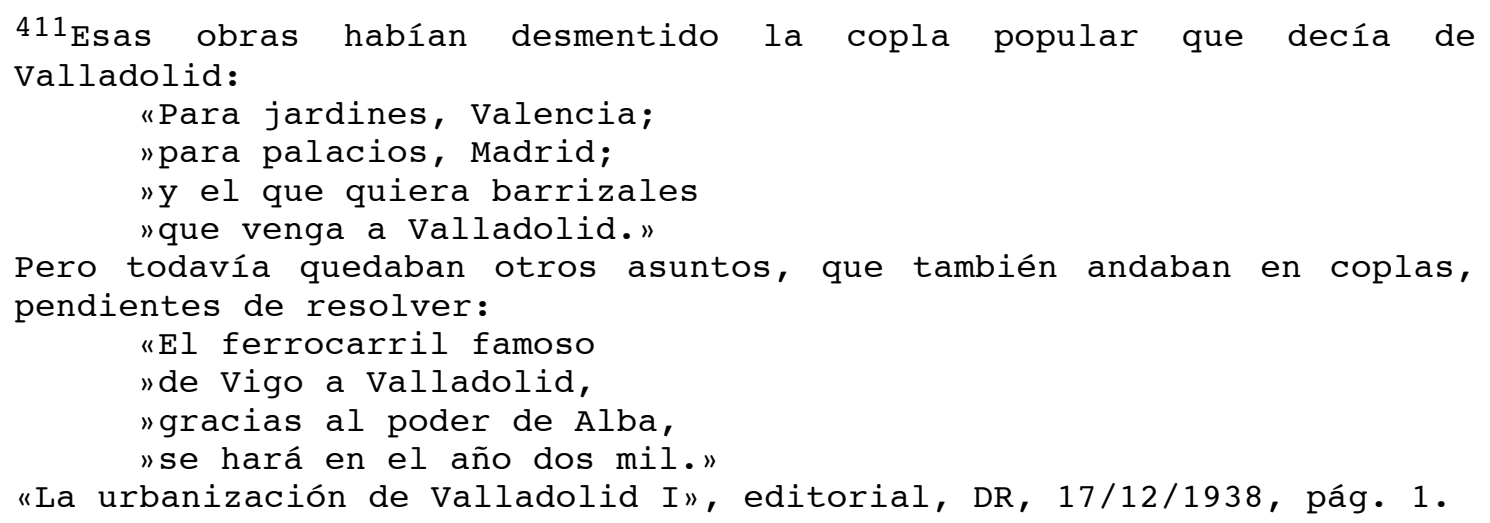




\section{La nueva política muere por el movimiento.}

De todos modos, no eran éstos los primeros sacrificios de opiniones que se ofrecían en el altar del movimiento nacional, otros mayores se habían hecho en materia política 0 sindical412. Diario Regional había dejado constancia en sus páginas de cómo se desarticulaba toda la estructura política que había ayudado a levantar en los años de la República. Seguramente esto no le supuso un gran sacrificio. Al fin $y$ al cabo ellos eran los primeros en afirmar que el sistema parlamentario y el de partidos no contribuían más que al desgobierno de la nación ${ }^{413}$. Se había organizado Acción Popular como algo que no quería ser un partido, que acabó siéndolo como mal menor frente a la revolución, pero no por deseos de contribuir al arraigo de un sistema democrático en el país414. Pocos había en España -en la derecha y en la izquierda- que quisieran semejante cosa. La muerte del sistema de partidos era motivo de alegría.

${ }^{412} \mathrm{El}$ anuncio de la prohibición de toda actividad política o sindical apareció en la primera página del periódico el 25/9/1936.

413Afirmarán que por culpa de los partidos, que sólo buscan su interés, "desde hace cerca de treinta años España no ha vivido más periodo de tranquilidad, trabajo y bienestar, que el de los siete años de la dictadura del glorioso general Primo de Rivera". "Algo sobre los partidos", editorial, DR, 4/9/1936. Cfr. también "Actuación de los partidos políticos", editorial, DR, 4/11/1936, pág. 1

414 "Acción Popular" quiso ser desde que nació, un amplísimo movimiento nacional. (...) aspiraba a juntar, si posible fuera, a todos los españoles dignos de tan glorioso nombre. (...) La estructura política de España, que al nacer como colectividad, nos encontramos ya hecha, nos obligó a constituirnos con las características externas de un partido. En realidad era un aliento superior el que vivificaba 
Ahora, eliminada la revolución, ¿qué mejor que vencer en la misma jornada al liberalismo?, de esta forma se podría construir la auténtica España, la católica, la de Isabel y Fernando, la de Felipe II... Esa era la España eterna. Y por fuerza había de serlo en los planteamientos de estos hombres; de otra forma sólo a locura cabría atribuir la intención de implantar en su tiempo un sistema político que había caducado trescientos años antes. Era necesario sacralizar ese sistema, atribuirle las características que tienen las realidades sobrenaturales, la atemporalidad, la universalidad, la inmutabilidad. Y de esta forma, para el servicio de una causa política del siglo $\mathrm{xx}$, se convirtió en un mito la religión que había acabado con los mitos paganos en los comienzos de nuestra era: entre los católicos significados como tales en la política, triunfó el tradicionalismo.

La despedida de los partidos iba acompañada de manifestaciones de adhesión al movimiento nacional415, que a partir de la unificación pasará a escribirse con mayúsculas. En febrero de 1937 se publicó una carta de José María Gil Robles a Luciano de la Calzada que preparaba a los afiliados y milicias para la desaparición

nuestra obra y un noble afán de superación de los moldes estrechos de partido, lo que inspiraba el esfuerzo de nuestras masas." Carta de José María Gil Robles a Luciano de la Calzada, fechada en Lisboa, el 17 de enero de 1937. DR, 5/2/1937, pág. 1.

$415 \mathrm{El}$ primero fue el del Partido Nacionalista Español. Asesinado Albiñana en la zona del Frente Popular, decidían unirse a la Comunión Tradicionalista. Hacían profesión de monarquismo y de adhesión a Franco. "Manifiesto del Partido Nacionalista Español. A la opinión pública», DR, 10/1/1937, pág. 2 . 
de Acción Popular:

"El Movimiento iniciado el 17 de julio marca un nuevo rumbo a la Patria. Después de él, una vez consolidada la victoria, deberán desaparecer los partidos políticos -tengan o no ese nombre- para integrar un solo y amplísimo movimiento nacional. Cuando llegue ese instante venturoso, "Acción Popular", lejos de ser obstáculo o un tropiezo, se enorgullecerá en dar las máximas facilidades. ¿Cómo podría ser de otro modo, si ello significa la realización de una de sus aspiraciones supremas?

"Entre tanto, seríamos unos insensatos o unos miserables, si a la vista del sacrificio inmenso que España hace para redimirse, pretendiéramos desarrollar la más leve actividad política y partidista. "Acción Popular" hoy no es más que una milicia." 416

Días antes de la unificación, uno de los raros artículos de fondo firmados por la Secretaría de Prensa de la J.A.P., aparecía en el periódico con un título revelador: "iFascismo!". En él alababan la decisión de Mussolini de que el Evangelio entrara a formar parte de los programas oficiales de enseñanza en Italia:

"Se equivocaban los que suponían que el fascismo podía, llegado el caso, desconocer a la Iglesia, ignorar sus normas, para conseguir un totalitarismo absoluto. No es eso posible. Mussolini marca el camino.

"El nuevo Estado Español no lo necesitaba: naciendo de un movimiento de indudable fondo religioso, los azares de la guerra sirven de crisol que va purificando las creencias religiosas de este pueblo (...)

"Por eso España volverá a ser el brazo derecho del mundo católico." 417

Seguramente no se buscaba desautorizar la voz del Papa, que era uno de los que -según ellos- se habían equivocado, pero resulta irónico que profeticen que quien

${ }^{416} \mathrm{DR}$, loc. cit..

417DR, 17/4/1937, pág. 4, últ.. Otros partidos que publicaban artículos de fondo antes de la unificación eran la Comunión Tradicionalista y Renovación Española. Estos artículos no iban en la primera página, lugar que estaba reservado para el de Falange. 
escribe estas cosas, y prohibe la difusión de la encíclica de condena del nazismo publicada por estas fechas ${ }^{418}$, pronto será "el brazo derecho del mundo católico". Diez días más tarde se publicaba otra carta de Gil Robles, en la que el ex-Jefe bendecía la muerte de Acción Popular419. Aún faltaba un mes para el sexto aniversario de su fundación.

El mismo día que se publicaba esa carta, se definió el "saludo nacional" -brazo en alto y mano extendida-, que era también denominado, en los entrefilets de propaganda, "el saludo de todos los buenos españoles". Una semana antes se publicaba en lugar destacado la primera fotografía de Hitler, con ocasión de felicitarle por su cumpleaños. Desde ahora, esta fecha, junto con la de su "exaltación" al poder, y el aniversario de la marcha fascista sobre Roma, formarán parte del calendario de efemérides dignas de la primera página420. De los dos

418Cfr. GÓMEz PÉREZ, Rafael, El franquismo $y$ la Iglesia, Rialp, Madrid, 1986 , pág. 72 ..

419 "(...) es preciso que Acción Popular muera. Bendita muerte que ha de contribuir a que crezca vigoroso un germen de nueva vida. En el nombre sagrado de España ha pedido el Jefe del Estado la unión de todos sus hijos. Acudid a su llamamiento (...)". "Don José María Gil Robles cancela las actividades políticas de Acción Popular. Una carta a Don Luciano de la Calzada", DR, 27/4/1937, pág. 1 .

420 "(...) España puede celebrar por primera vez esta fecha. No ya puede, sino que debe celebrarla y la celebrará. No en vano Alemania participa de un régimen nacional, anticomunista, como aquel que se ha implantado en España y que los españoles se esfuerzan en hacer llegar a aquellas regiones de la patria que yacen bajo la salvaje tiranía moscovita." "Hoy cumple Hitler cuarenta y ocho años", DR, 20/4/1937. Cfr. también "Benito Mussolini, vencedor del comunismo en Italia. Creador del imperio Italo-Etíope. DUCE de todos los italianos", DR, 28/10/1937, pág. 1.Nunca se mencionarán en titulares las tropas 
jerarcas se destacará siempre su anticomunismo y su amistad con España, y al mismo tiempo se recordará que el Movimiento no es ni fascista ni nazi, sino "español»421. Al tiempo que se aplaudía a los dictadores de otros países, hubo que ocuparse de la reeducación de los españoles en lo que a vítores se refiere, $y$ es que en estos momentos en que todo eran aclamaciones entusiastas de la enfervorizada e incluso delirante multitud, hasta las manifestaciones de disidencia vestían ese ropaje:

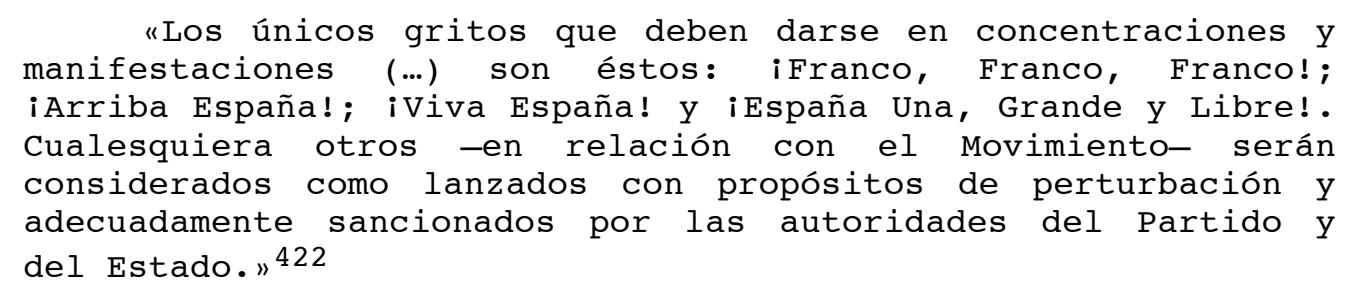

Sólo alcanzó la disidencia tonos más broncos en el caso de las mujeres. La Sección Femenina de la F.E.T. de las J.O.N.S. de Valladolid tuvo que ser disuelta, y sus asociadas debieron pedir permiso para reingresar, si es que no formaban parte de la lista de aquellas que fueron definitivamente expulsadas ${ }^{423}$.

Por parte de las organizaciones católicas, el periódico se hizo eco de dos conflictos en relación con

alemanas o italianas hasta que no llegue el momento de su repatriación en los últimos meses de la guerra.

${ }^{421}$ Cfr. por ejemplo la definición del nuevo Estado como Socialnacionalista, en el artículo de Vicente Gay "Sentido político y social del nuevo Estado", DR, 23/2/1937, pág. 1 .

422 "Nota de la Jefatura Provincial de F.E.T. y de las J.O.N.S. de Valladolid", DR, 29/10/1937, pág. 1 .

423DR, 25/11/1937, pág. 1 . 
las unificaciones. El primero se refería a los sindicatos católicos, y el segundo a las Asociaciones de Estudiantes Católicos. En relación al primero, hubo un toma y daca entre la Confederación Española de Sindicatos Obreros C.E.S.O.-, que sostenía que había libertad sindical, y la Central Obrera Nacional-Sindicalista -C.O.N.-S.-, partidaria del sindicato único424. A estas discrepancias se sumó la Delegación Provincial Carlista de Corporaciones y Gremios, que también hizo públicos sus proyectos de instauración de un régimen corporativo425. Al fin todo se resolvió con una nueva unificación, "unánimemente aplaudida"426. Para dejar constancia de su desaparición la C.E.S.O. empleó una esquela:

"Rogad a Dios en caridad por el alma de los Mártires de la Confederación Española de Sindicatos Obreros. Asesinados en la zona roja y muertos como vivieron, en lucha contra el marxismo, por los ideales de la sindicación cristiana. La unión Provincial de Sindicatos Obreros Católicos de Valladolid (C.E.S.O.) al terminar en su misión sindical aislada, para continuarla en unión $y$ hermandad con otros productores españoles en la C.N.-S., rinde un homenaje..." 427

Era la misma argucia que empleaban, por ejemplo, los

${ }^{424}$ Cfr. noticias del congreso de la C.E.S.O. en Burgos, en la "Página jocista", DR, 13/9/1936, pág. 4, y los artículos de las dos centrales publicados los días 13/9/1936, pág. 2; 15/91936, pág. 1; y 18/9/1936, pág. 6, últ..

425 "Obra nacional corporativa», DR, 20/11/1936, pág. 1; "No somos corporativos, somos sindicalistas", DR, 22/11/1936, pág. 2 .

426 "Hacia la unidad sindical. A los obreros y empleados de Valladolid Y su provincia", DR, 29/5/1937, pág. 6, últ.. "En la asamblea de la C.E.S.O. se aplaudió unánimemente la unificación con la C.O.N.-S.", DR, 3/9/1937, pág. 6, últ..

${ }^{427} \mathrm{DR}, 15 / 10 / 1938$, pág. 2 . 
Tradicionalistas, con sus misas "por los mártires de la Tradición", para marcar las diferencias con respecto a los otros grupos ${ }^{428}$.

Mayor resistencia se mostró ante la orden de unificar todas las asociaciones de estudiantes en el S.E.U.. Primero se publicó un artículo que pretendía demostrar que aunque éste fuera la única asociación profesional estudiantil de derecho público, las asociaciones de estudiantes católicos podrían seguir existiendo como asociaciones de derecho privado429; y un mes más tarde -a siete columnas- una carta pastoral del Primado, cardenal Gomá, a los estudiantes católicos, en la que afirmaba que "las asociaciones de estudiantes católicos son uno de los más poderosos medios para la santificación de las almas y la difusión de las sanas doctrinas» 430 .

Pero si había roces, lo habitual era el acuerdo y el aplauso. Siempre que se podía, se daba noticia del apoyo que los católicos de otros países prestaban a la causa del movimiento, y se descalificaba a los que lo criticaban ${ }^{43}$.

\footnotetext{
428 «Mártires de la Tradición. Mañana se celebra una misa en San Felipe Neri», DR, 9/3/1938, pág. 1 .

429 "El S.E.U. Y las asociaciones de estudiantes católicos", por Angel S. Lumbreras, DR, 11/3/1938, pág. 4 . 
En todo caso se procuraba moderar el sentimiento nacionalista, recordando la necesidad de la unión con Roma432; prevenir contra el odio y llamar al perdón ${ }^{433}$; y acentuar el sentido religioso de la guerra. Eso fue lo que se pretendió con el fallido intento de celebrar un "Día del Cruzado", que se hacía coincidir con la fiesta de la Inmaculada Concepción. La iniciativa contaba con la aprobación del Primado, y su finalidad era "avivar la espiritualidad católica de los que luchan", y "ofrecer una reparación por los sacrilegios cometidos en la zona roja especialmente en las imágenes de Cristo Crucificado". Los donativos recogidos ese día estarían destinados a donar a cada combatiente un crucifijo:

\begin{abstract}
"Se nos dirá que no salimos de una fiesta de este carácter y ya entramos en otra. Así es, y ojalá siempre sea así. De esta manera estará permanentemente avivado en todos el espíritu patriótico, de generosidad material y espiritual para nuestros soldados, que todo lo merecen. De este modo viviremos desvelados, en un santo y dulce desvelo, por nuestros combatientes que por nosotros y por España luchan con esfuerzo inigualado. Nadie, pues, debe en conciencia retraerse de estas fiestas, tan íntimas y consoladoras." 434
\end{abstract}

pág. 1; "Una maniobra de Maritain y sus secuaces", editorial, 24/6/1938, pág. 1; y "L'Osservatore Romano" condena un libro que calumnia a España", 22/1/1939, pág. 1, sobre Les grands cimitières sous la lune.

432 "Lo que debemos al Papa", DR, 13/2/1938, pág. 5 y 6. Recoge la pastoral del cardenal Gomá que insiste en que no puede haber catolicidad sin unión con el Vaticano.

433 "Y porque la caridad nos manda hacer el bien a nuestros enemigos, hagámoslo arrancando de nuestro pecho todo rencor y pidiendo a Dios que, si la confusión y la derrota de ellos ha de ser condición del triunfo de la causa de España, les abra antes los ojos y los convierta y no consienta que se pierda uno solo de ellos", "La cuaresma en España", DR, 3/3/1938, pág. 1 .

434 "El “Día del Cruzado" en Valladolid”, DR, 1/12/1938, pág. 6, últ.. Se celebraban por entonces el día del Alzamiento, el del Caudillo, el día de la Unificación, que conmemoraba la creación de la F.E.T. de las 
A pesar del recargadísimo estilo, $y$ de la temeraria llamada a las conciencias, no parece que se consiguiese el objetivo. El día 8 todo lo que habrá es un anuncio a dos columnas de la misa del arzobispo en la catedral, y el correspondiente "Temas locales" dedicado a comentar los actos.

El sector al que el periódico representaba estaba dispuesto a olvidar todos sus esfuerzos por hacer una nueva política siempre que, en contrapartida, se arrancara de cuajo cualquier residuo de liberalismo y se hiciera del catolicismo, oficial e institucionalmente, el núcleo articulador de la vida nacional. Lo decían bien claramente en el editorial publicado con motivo de la muerte de Unamuno, en el que lamentaban que incluso "periodistas que están colaborando en el actual movimiento nacional y que escriben hasta en periódicos católicos" hubieran alabado a un escritor como el fallecido, que había hecho más mal que bien a la cultura y la sociedad española:

"(...) hay un sentido liberal hondamente arraigado en muchos espíritus, los cuales piensan con pensamiento liberal, juzgan con criterio liberal y exaltan los valores apócrifos del campo liberal. Lo cual quiere también decir que es preciso restaurar en España la ideología recta y netamente católica, que dirija, encauce y oriente el pensamiento, el criterio, los juicios y las apreciaciones de muchos que no saben pensar, juzgar y

J.O.N.S., a los que había que añadir otras conmemoraciones del estilo del "día del periodista caído". A todo esto se sumaban los días de plato único, los días sin postre, etc. Muchas de estas celebraciones habían nacido de modo espontáneo, o, al menos, habían encontrado en un primer momento eco natural en una población que, en efecto, estaba entusiasmada con la causa que defendía. En los momentos finales de la guerra se observa ya un cansancio lógico que se intentará combatir con la retórica militarista, o sacro-militar, que ejemplifica el párrafo que reproducimos. Esa llamada a la permanente vigilia será constante durante el franquismo, cuando los fervores iniciales estén ya bien lejos. 
apreciar en católico a las personas y los hechos. Si esto no hacemos ¿qué nueva España vamos a construir?»435

\section{También la prensa liberal debe morir.}

La campaña más constante del periódico en estos años, fue también la que menos sentido cristiano demostraba; una auténtica lección de fanatismo.

Comenzó el 19 de julio, con aquel editorial titulado "Dos periódicos de Valladolid", que advertía sobre la tibieza con que El Norte de Castilla había dado cuenta de los acontecimientos. A partir de entonces iba a seguir tres líneas que tenían como punto de unión el ataque no sólo al liberalismo, sino a los hombres que lo defendían, y a su medio de expresión en Valladolid. La primera de ellas consistía en denostar la labor realizada por éstos en la historia de España. Para hacerla más efectiva, se definió a la masonería como el representante más caracterizado del liberalismo, identificando así los nombres de masón y de liberal, y convirtiéndolos en adjetivos ${ }^{436}$. Cualquier insulto que se dirigiera a estas

435 "Necesidad de catolizar la ideología», editorial, DR, 9/1/1937, pág. 1 .

436Cfr. entre otros, "Los masones", editorial, 12/9/1936; "Los anarquistas de ayer. El liberalismo y la masonería, tiranos de España durante el siglo XIX", por "Prospicio", de El Diario Vasco, DR, 16/12/1937, pág. 1; "El liberalismo y la masonería", por "Cleimo", DR, 23/3/1938, pág. 3, "El liberalismo y la Iglesia", del mismo autor, 22/4/1938, pág. 1; "Liberalismo, masonería, judaísmo", editorial, 29/9/1938, pág. 1; "Para los que lo saben y para los que lo ignoran", editorial, 4/12/1938, pág. 1. Se realizaron también campañas contra el Rotary Club y la Liga de los Derechos del Hombre, como asociaciones afines a la masonería. 
gentes resultaba desde entonces moderado: eran los malvados, los idiotas, los vividores, los criminales, los enemigos de España, de las más sagradas tradiciones y de la Iglesia, los aliados del marxismo, los culpables de la guerra...437. Tan intensa fue la campaña contra la masonería y el liberalismo, que esos calificativos se convertirán en un modo de censura preventiva contra los estados de opinión antifranquistas: teorías liberales y masónicas eran las que hablaban de negociaciones de paz con el Gobierno del Frente Popular, de mediación o de perdón; las que sostenían que ganada la guerra bastaba con el arrepentimiento de los equivocados, que no era necesario juzgar y castigar a los enemigos. Masones y liberales eran los que con su crítica a las autoridades del nuevo Estado sembraban la desmoralización y el desconcierto, los que no se mostraban entusiasmados con la nueva España que se estaba construyendo, los que minaban el prestigio del Caudillo para la paz ${ }^{48}$. Los masones, que primero se habían

437Cfr. "Los que llevaban a España a la ignominia y la muerte. Malvados, idiotas y vividores", editorial, DR, 8/9/1936, pág. 1; editorial de 13/1/1937, pág. 1; "La masonería, destructora de España", editorial, 11/12/1936, pág. 1; "La masonería trajo la revolución", 2/12/1936, pág. 4, últ., comentando un folleto de Tusquets; "La Masonería contra España", por Marcial Rossell, 4/11/1936, pág. 3; "La masonería y la instauración de la República", 24/12/1936, pág. 1; "La masonería decretó la muerte de Calvo Sotelo", 3/12/1936, pág. 3; "La ofensiva de la masonería", tomado de o Seculo de Lisboa, 29/1/1937, pág. 3; se publicaban entre otros los entrefilets:

"En el nuevo diccionario de España, masón significará asesino de la Patria."

"El peor traidor es el que disfraza su traición bajo el velo de una secta masónica."

Vid. 2/5/1937, pág. 3, y 8/6/1937, pág. 1 .

438 "Atención al disco masónico", tomado de Libertad, DR, 23/9/1937, pág. 1; "Consignas masónicas", editorial, 7/6/1938, pág. 1; "Teoría 
declarado enteramente contrarios al movimiento, ahora intentaban infiltrarse en el nuevo régimen. Ellos eran el peor enemigo: el marxismo había dado la cara en los frentes, y se le había podido vencer, la masonería laboraba en sus antros, conformándose con sobrevivir, para dar la batalla desde dentro cuando llegara su momento439.

La segunda línea argumental era menos mítica, ya que no se refería a un enemigo genérico sino concreto: los hombres de la vieja política, los viejos caciques $y$ liberales -particularmente los vallisoletanos- que ahora apoyaban al régimen. No se podía tolerar que esos advenedizos se apropiaran de unos ideales que nunca habían defendido:

"Lo peor que podría ocurrir en este movimiento salvador de la Patria es que se diese el mismo trato a quienes han dedicado toda su vida a la defensa de los mismos ideales españolistas, $y$ a los que hasta el 18 de julio simpatizaban con los enemigos de España. (...) Sería amarga decepción que así

\footnotetext{
liberal y masónica", editorial, 26/3/1939, pág. 1; "Prevenidos contra la masonerían, 2/6/1938, pág. 5; los titulares a toda plana de la primera página del 14/10/1938 decían: "La victoria total será el fin de nuestra guerra. Contra el liberalismo, España. Contra la masonería y el judaísmo, España. Contra el bolchevismo, España. Nuestra salvación está en la victoria. Nuestra derrota sería la mediación. Contra la mediación se alza el clamor unánime de todos los españoles". Como entrefilets aparecieron los siguientes textos: "La última maniobra de la Masonería, que ve perdida la guerra, es minar el prestigio del Caudillo para la paz. "Quien se presta a ella es reo de traición al Estado." "Los masones siempre andan en las alcantarillas de la sociedad para socavar los derechos del hombre"

Vid. 26/6/1937, pág. 1, y 11/12/1937, pág. 1.

439 "La Masonería española declara estar entera, total, y absolutamente con el "frente popular"", DR, 6/12/1936; "La Masonería quiere infiltrarse en los organismos públicos españoles", 10/3/1937, pág. 3; "El peligro masónico", editorial, 1/12/1937, pág. 1; "Los tres enemigos de España: liberalismo, masonería y marxismo", editorial, 6/7/1938, pág. 1 .
} 
ocurriese.» 440

Esos "patriotas del 19 de julio"441 que no habían arriesgado nada por vencer la revolución, pretendían ahora beneficiarse de la sangre heroicamente vertida en los frentes para lo de siempre, para que sus negocios no sufrieran menoscabo. Su comportamiento, que querían hacer pasar por una lección de convivencia, no era otra cosa que la astuta versatilidad con que disfrazaban sus egoístas intereses ${ }^{442}$.

La tercera vía de argumentación se refería a los periódicos liberales, y se concretaba frecuentemente en el ataque al colega local ${ }^{443}$. Media un abismo entre la postura hostil que antes encontrábamos en el periódico, que se quejaba de la actitud de los liberales por parecerle que no ponían empeño en la defensa de los intereses católicos,

440 «El mismo trato, no», editorial, DR, 9/9/1936, pág. 1.

${ }^{441}$ Cfr. el editorial de 15/9/1936, pág. 1.

${ }^{442}$ Cfr. el editorial citado "Dos periódicos..."; "Partidos y caciques", editorial, DR, 21/8/1936, pág. 1; "Convivencia y versatilidad", editorial, 7/11/1936; "Una cruzada contra los advenedizos y los oportunistas", por Gregorio Arévalo, 13/11/1936, pág. 1; "Los antiguos caciques esperan", editorial, 19/6/1938, pág. 1; "Los de la conducta turbian, editorial, DR, 20/11/1938, pág. 1. Esa lejanía de la mitificación fue también patente cuando se abordó el tema de la masonería en la ciudad; Diario Regional hizo una campaña para que se publicaran las litas de los masones vallisoletanos, al periódico llegaron varias listas diferentes, lo que atribuyeron a una maniobra masónica. No consiguieron que se hicieran públicas las listas: "Unas listas", DR, 6/9/1936, pág. 6, últ., "Maniobra masónica", 16/9/1936, pág. 6, últ., "La lista de los masones vallisoletanos", 10/10/1936, pág. 6, últ.

${ }^{443}$ Sólo se particularizó un ataque en el mismo sentido contra la agencia "Fabra". "La labor de una agencia informativa", DR, 26/11/1937, pág. 1 . 
y la que encontraremos ahora:

"El periódico liberal es injurioso a Dios, destructor de la Patria, y ser su admirador es admirar a la blasfemia, a la destrucción de la sociedad» 444

La radicalización de las posturas tradicionalistas había sido un importante ingrediente para llegar a afirmaciones como ésta: del mismo modo que se aspiraba a eliminar al adversario político, ya que en el nuevo Estado no había lugar para el pluralismo, el periódico católico de Valladolid creyó llegada la hora de eliminar a su competidor liberal. Lo que no había hecho la ley de la oferta y la demanda -según ellos, abolida en la nueva España445- debía hacerlo la autoridad en aras de la pureza ideológica y de la justicia. Eso es lo que decían, pero, por la forma en que se llevó a cabo la campaña, nos parece que el afán de revancha desempeñó también un importante papel. El mismo periódico que había declarado en 1933 que no era fascista, daba cuenta en 1936 de haber rechazado una colaboración porque su autor, que había colaborado con El Norte, había escrito en 1933 un artículo que era "una diatriba contra el nobilísimo saludo del brazo en alto»446.

444 «El liberalismo y la Prensa, sus crímenes», editorial, DR, 18/6/1938, pág. 1 .

445Con motivo de la promulgación del Fuero del Trabajo publican un editorial titulado "Ley inhumana y cruel", adjetivos que se aplican a la de oferta y demanda. Aunque se dice en otro contexto, la afirmación ilustra sobre el grado de exaltación retórica al que se llegaba, que si en lo socioeconómico era fuerte, lo era aún más en lo ideológico. Cfr. DR, 16/3/1938, pág. 1 .

${ }^{446} \mathrm{DR}, 16 / 9 / 1936$, pág. 1. El colaborador frustrado era Teófilo Ortega. 
El 4 de marzo de marzo de 1937 reproducirán los comentarios editoriales de Diario Regional y de El Norte de Castilla con motivo de los sucesos de la misma fecha en 1934, para que se pudiera comparar cómo trataban a la Falange unos $y$ otros tres años antes ${ }^{447}$. A los que afirmaban que había que alegrarse de que quienes simpatizaban con el izquierdismo, se acercaran ahora al movimiento, se les contestó en un editorial que, si bien el arrepentimiento es siempre respetable, consideraban más que dudoso que ese arrepentimiento fuera sincero; y añadían que "sería desalentador y desmoralizador llegar a la conclusión de que los antecedentes de los hombres no sirven para nada»448. Por eso -repetirán una y otra vezhay que revisar la conducta anterior al 18 de julio, para hacer justicia al historial de personas y periódicos. Del mismo modo que se depuran maestros y funcionarnos, deben ser depuradas las publicaciones:

"Entre los elementos más culpables de haber provocado la guerra civil española hay dos: la masonería y los periódicos liberales, a los que todavía no se ha exigido toda la responsabilidad en que incurrieron. (...)

"Ciertamente, ya lo hemos dicho en otras ocasiones, sin la ayuda tácita o expresa de los periódicos liberales españoles, el marxismo no hubiera adquirido en España el incremento que logró, y habría quedado reducido a límites de muy escasa importancia; pero muchos periódicos liberales $-y$ al hablar de periódicos liberales nos referimos a sus empresas e inspiradores- acogían con fruición en sus columnas la propaganda marxista y la colaboración izquierdista, y, con ello, estas ideas nefastas y disolventes encontraron ancho campo para su difusión. Y gratuitamente, por añadidura.

"Con la ruda sinceridad que hemos empleado siempre que se

447 "El 4 de marzo de 1934 en Valladolid", editorial, DR, 4/3/1937, pág. 1 .

448 "Convivencia y versatilidad», editorial, DR, 7/11/1936, pág. 1. 
ha tratado de defender los ideales fundamentales en toda sociedad civilizada, hemos de declarar que seguimos considerando como sospechosos a cuantos elementos, sin ser francamente izquierdistas o marxistas, contribuyeron a la difusión de estas ideas hasta el mismo 18 de julio, y no han hecho, posteriormente, retractación pública de su conducta anterior. Los consideramos sospechosos, sea cual sea la posición que ahora hayan adoptado, porque estamos seguros de que, con su acostumbrada sinuosidad, si las circunstancias variasen, alegarían que se les había obligado a defender ideas que nunca sintieron.

"Está en vigor el Decreto número 108 de la Junta de Defensa Nacional, $y$ se aplica a los funcionarios sospechosos por su conducta anterior y posterior al 18 de julio. ¿Por qué sólo a los funcionarios? Por analogía, debe aplicarse también a otros elementos que son culpables en grado sumo por haber contribuido grandemente a fomentar el marxismo con todas sus consecuencias. Desde luego, si hubiera dependido de esos elementos no hubiera estallado el Movimiento Nacional de salvación. Y, si no procede aplicar este Decreto, puede dictarse una disposición pertinente a las responsabilidades que se deben exigir. Todo menos dejar que se adquiera el convencimiento de que los antecedentes no sirven para nada. Los antecedentes deben ser tenidos en cuenta en todos los casos, porque, de lo contrario llegaríamos a la anárquica conclusión de que los sacrificios y la consecuencia en las convicciones no tienen ningún valor o tienen el mismo que las conductas tortuosas y las habilidades cotizables." 449

Un mes más tarde publicaron otro editorial dedicado a ponderar la importancia de los periódicos católicos, en el que se leía -además de que sin ellos no hubiera triunfado el movimiento-, que sólo ellos eran la auténtica prensa, por ser ajenos a todo interés económico; llegando a afirmar que "un hombre o un periódico que se venden por unas monedas son, además de despreciables, seguros traidores»450. Es decir, que ganarse la vida con el periodismo era una ignominia. Lo más asombroso es que esto lo escribía un periodista profesional. A nuestro parecer,

449 "El Decreto 108", editorial, DR, 9/6/1937, pág. 1. Cfr. también el editorial sobre la depuración de maestros y funcionarios, 17/9/1936, pág. 1; y "Revisión de conductas", editorial, 24/1/1937, pág. 1, y el

450 "Significación del periódico católico", editorial, DR, 9/7/1937, pág. 1. Lo reproducimos íntegro en el apéndice 12 . 
la raíz del desenfoque es la que ya señalamos más arriba: al considerar el periodismo "un apostolado", y el periódico católico una obra de beneficencia paraeclesiástica, se mira mal a quienes se ganan la vida con un negocio de prensa, presuponiendo que los intereses económicos hacen bastarda su empresa. Una deformación conceptual que entra en directa contradicción con la vida misma de las empresas de prensa autodenominadas católicas, que se han demostrado tan necesitadas de dinero como sus colegas, fueran éstas del signo que fueran. Pero -lo que a nuestro juicio es todavía peor-, se entiende que por el hecho de llamarse católica, una empresa recibe alguna suerte de sanción sobrenatural que le confiere una eficacia infalible y la eleva por encima de las de su especie. Algo así como si se transformara en un sacramento, que -como es sabido-, según enseña la Iglesia Católica, tiene en sí mismo eficacia, por haber sido instituido por Jesucristo.

Otra proposición extraída del mismo texto aclara todavía más las cosas: "Suprímanse los valores morales y espirituales, y todo lo demás carecerá de importancian. Es decir, la calidad profesional del trabajo no merece consideración alguna. ¿Cómo se había llegado a este espiritualismo? Quizá por exageración en el rechazo del materialismo, pero quizá también porque se era incapaz de hacer periódicos que fueran mejores que los que no se llamaban católicos, o eran francamente anticatólicos. Bien 
está -lo contrario no tendría sentido- que un creyente considere que su religión es la verdadera, pero no por eso parece autorizado a concluir que sus actividades en todos los órdenes son superiores a las que desarrollen el resto de los mortales que no compartan su credo. Pudiera ser que la cómoda postura de los católicos españoles, colocados tradicionalmente al abrigo de un poder público favorable a sus postulados, les hubiera hecho olvidar algunas importantes verdades naturales -como que la perfección de una obra humana no depende de causas sobrenaturales-, y otras históricas no menos importantes, como, por ejemplo, que si occidente era cristiano no lo era sólo por la virtud de la doctrina en sí, sino gracias al trabajo de evangelización de apóstoles de la causa, que habían sabido ser mejores que los que predicaban otras. Al fin $y$ al cabo, no parece contrario a ningún dogma de la Iglesia la solicitud de que, si tan nobles ideales defienden, 10 hagan con medios igualmente aptos materialmente, humanamente convincentes. Sin embargo, fuera por lo que fuere, por aquellos años, los periodistas católicos de nuestra historia no opinaban así.

La carga de la argumentación, como hemos visto, era muy otra: que a cada periódico se le tratara según sus antecedentes ideológicos. Fue de nuevo expuesta -corregida y aumentada- en otro editorial titulado "Problemas 
nacionales"451, que reprodujeron y comentaron El Noticiero de Zaragoza, El Diario Montañés de Santander, El Castellano de Burgos y El Defensor de Córdoba, entre otros periódicos. Es pena que la campaña más resonante de las alentadas por el periódico fuera precisamente ésta, pero el ambiente que se respiraba favorecía sin duda que así fuera.

El siguiente fondo sobre la cuestión llevó a que algunos acusaran al periódico de fanatismo452. No era para menos. Afirmaban en él que bastaba el sentido común para percatarse de la necesidad de las depuraciones, según se desprendía del siguiente apodíctico razonamiento: los hombres medianamente cultos no cambian de manera de pensar por un hecho externo que se produce en el medio ambiente, por importante que éste sea. Como corolario del principio sacralizador de las opiniones políticas, la afirmación es perfecta; y cumple también todos los requisitos para ser definida con propiedad como un fanatismo. El calificativo no ofendía a los hombres de Diario Regional, siempre y cuando se interpretara de la siguiente forma:

\footnotetext{
"Fanáticos, en buena hora, si por fanatismo se entiende intransigencia total, absoluta, con todo lo que no sea auténticamente cristiano y español."453
}

\footnotetext{
${ }^{451} \mathrm{DR}, 25 / 11 / 1937$, pág. 1 . 


\section{El periódico recibió cartas apoyando su postura, que}

le animaron a continuar su campaña454. Lo hicieron con gusto, dejando para la historia textos capaces de sonrojar

a cualquiera, como el siguiente:

"(...) volvemos hoy sobre el mismo tema para pedir de nuevo que se nos forme este expediente, que se depure nuestra actuación y que luego se nos sentencie según lo que del expediente formado resulte.(...) Todos tenemos nuestra historia; todos contribuimos a formar lo que se llamaba la "opinión"(...). Y nos parece indigno, y creemos faltar al concepto de la grave responsabilidad que a los periódicos nos corresponde, no ponernos a la disposición de las autoridades del Estado Español para que ellas revisen nuestra obra y la sancionen. Todos los periódicos, para vivir digna y tranquilamente en la nueva España, debemos pedir que se revise nuestra obra, como se ha revisado y se está revisando la de un maestro, la de un catedrático, la de una persona que haya desempeñado una función pública e influyente en cualquier sector de la vida nacional. Es tan claro todo esto que lo que nos sorprende es que no esté ya hecho.

"Y así no se darían los casos que se están dando.(...) Es inconcebible que hombres que hicieron periódicos que en cada ciudad eran órganos de las izquierdas puedan ahora seguir haciendo el mismo periódico en sentido nacional (...) y que esto se les consienta.

"Es hora de responsabilidades, como ninguna en la historia, porque lo que está sucediendo en España no tiene tampoco comparación posible a lo largo de los siglos. Digámoslo con las palabras de un colega que hoy se publica tan orondo, como si los antecedentes no avergonzaran o enorgullecieran a los hombres. Con esta advertencia: que donde el periódico del que tomamos estos párrafos decía Dictadura hemos de decir nosotros República y donde se pone Gobierno provisional hemos de leer Gobierno Nacional de España. Decía así:

"“...La Dictadura se caracterizó por hacer de las persecuciones piedra de escándalo. El Gobierno provisional se halla ahora en trance de no perseguir, sino de enjuiciar... Es evidente que existen grandes responsabilidades impunes y sería lamentable que los casos evidentes perdiesen la oportunidad del enjuiciamiento por el tiempo gastado en analizar los dudosos. No se trata ahora de venganza, sino de justicia, y, para estos efectos, la serenidad, la moderación y el desapasionamiento son condiciones ineludibles para que la acción enjuiciadora sea eficaz y sirva, al mismo tiempo, al interés público. Ello es lo más distinto al poder teatral. Las responsabilidades que el país espera ver exigidas no han de ser efectos brillantes, sino hechos estrictos". "Como esto se escribió en los primeros días de mayo de 1931, para quienes este periódico pedía responsabilidades era

454 "Los que están con nosotros", editorial, DR, 13/1/1938. 
para las gloriosas figuras de la Dictadura, algunas de las cuales están de nuevo, afortunadamente, al frente de los destinos de España. Esto sea dicho de paso." 455

La promulgación de la ley de Prensa en abril de 1938 brindó una ocasión de oro para volver a insistir sobre el particular. Se dedicaron ocho editoriales a comentar la ley, cuya promulgación, como se decía en el primero, no podía ser para Diario Regional más que motivo de satisfacción, ya que ellos habían defendido siempre la necesidad de un instrumento legal como ése para el bien del periodismo español. Además, la definición de prensa dada en el preámbulo - "una institución nacional»terminaba de hacer coincidir la mentalidad del legislador con la que les era propia ${ }^{456}$. Bueno es saber que esta ley tan vituperada en años venideros- llenó de contento a más de uno de los que entonces ejercían la profesión periodística; de este modo, en lugar de atribuir de modo

455 "El expediente a la prensa», editorial, DR, 21/1/1938, pág. 1. La manipulación del texto de El Norte de Castilla resulta evidente. Éste pedía que se exigieran responsabilidades a los políticos, que, por los cargos que habían desempeñado, tenían responsabilidad ejecutiva; mientras que ahora, se querían pedir responsabilidades por las opiniones que se habían sostenido, cosa a todas luces de naturaleza bien distinta. Era otra de las consecuencias de la atribución de características sagradas al Estado: lo que se pide es una especie de juicio final en el que las autoridades políticas hacen el papel de Dios.

Esta forma de proceder constituye un claro precedente del comportamiento que se observará en la postguerra cuando se instruya la llamada "Causa General". Disponemos ya de un análisis del efecto de ese proceso de depuración en la prensa -concretamente en la prensa vasca-, en ALMUIÑA FERNÁNDEZ, Celso, "Proceso a la Prensa Vasca (193639). La Inquisición franquista y la formación de la Causa General", en Comunicación, cultura y política durante la II República y la guerra civil, Departamento de Cultura de la Diputación Foral de Bizkaia, Servicio Editorial Universidad del País Vasco, Bilbao, 1990. Tomo I, págs. 46-80.

456 «La Ley de Prensa», 27/4/1938, pág. 1. 
exclusivo su espíritu a perversas e inexplicables intenciones fascistas -como parece que hacen algunos autores-, podemos razonar su génesis dentro de la mentalidad de la época sin forzar para nada las explicaciones.

Todos los comentarios que se hicieron a la ley eran un canto a la anulación de la libertad en un régimen socializante. La nueva ley dignificaba a la prensa porque impedía que pudiera estar al servicio de los particulares, y la convertía en un servicio al Estado457. Además, se preocupaba del periodista, que no sólo era elevado a la categoría de apóstol, sino que veía cómo el Estado disponía que estuviera bien pagado, y que su formación académica fuera la adecuada para los llamados a tan alta misión ${ }^{458}$. A esta serie de aciertos, se sumaba la disposición que ponía en manos del Estado la determinación del número y extensión de los periódicos; sabia medida que terminaría con uno de los problemas del periodismo

457 "Se acabaron los periódicos nacidos para servir a un señor, a un hombre de negocios o a un politicastro turbio que, como político, pueda poner los intereses personales por cima de aquellos otros sagrados intereses de la Patria. Se acabó la Prensa a pesar de la cual llegó el glorioso 18 de julio. Se acabaron las redacciones que albergaban seres turbios, servidores de todos los señores, a trueque de vivir bien. Lo primero que hay que hacer es acabar con todo eso. Y luego, reconstruir la Prensa nacional. bien dotada materialmente, con personas capacitadas para hacer periódicos, con una dirección de la absoluta garantía del Estado. Y hacer la Prensa bajo el concepto indiscutible y único de que ésta es servidora fiel de España, de su Estado y de su Gobierno." . "La Prensa, al servicio de España", editorial, DR, 28/4/1938, pág. 1 .

${ }^{458}$ Cfr. "Dignidad del periodista español», editorial, DR, 30/4/1938, pág. 1 . 
español, a saber: el excesivo número de periódicos que se publican, causa de que muchos de ellos no puedan vivir decorosamente. Diario Regional no sólo aplaudía la medida, sino que daba a la autoridad el criterio justo para aplicarla:

"Lo importante para llegar a [la regulación] es el criterio que se haya de seguir. Y aquí hemos de recordar nuestros artículos de etapas anteriores en los que reiteradamente, y con unánime aplauso, hemos pedido que se depure la responsabilidad de todos los periódicos a lo largo de su vida, siquiera la de los últimos quince años, y se proceda en consecuencia con cada uno. (...) No es concebible que sigan en pie redacciones en que se conspiró contra España un día tras otro y se hizo mofa de las ideas hoy triunfantes." 459

Por si alguien no tenía claro todavía a qué prensa se referían, se dedicó un nuevo editorial a definir con precisión el perfil de la prensa que debía desaparecer:

"Promulgada la ley de Prensa no tienen razón de ser los periódicos independientes. Es más desde el glorioso 18 de julio de 1936 no hay razón para que esta clase de prensa subsista. (...)

"Prensa independiente -en la mayor parte de los casos- es igual que prensa liberal, republicana, socializante. Es la Prensa que hacía las campañas difamatorias contra el general Primo de Rivera y sus hombres; lanzaba insolentes insultos contra lo más sagrado de nuestra Patria; encumbraba, con insolencia intolerable a todas las figurillas de políticos mezquinos; admitía la colaboración de los prohombres rojos; despreciaba cínicamente a aquellos primeros grupos de la Falange que se batían por España en todo momento. En una palabra, es la Prensa que no fue suspendida el 10 de agosto por Azaña; es la que ha hecho a la Patria más daño que los periódicos francamente socialistas.

"Pero la prensa independiente (...) sigue ostentando su ejecutoria en las ediciones de cada día. Como si no hubiera pasado nada. Como si la ley de Prensa no definiera acertadísimamente que ya no hay más servicio que el de España ni opción posible que la de servir al Estado NacionalSindicalista, sin independencias ni cosa que lo valga (...)."460

\footnotetext{
459 "Un criterio adecuado", editorial, DR, 4/5/1938

460 "Prensa independiente», editorial, DR, 20/5/1938, pág. 1 .
} 
$\mathrm{Ni}$ podemos ni queremos entrar a juzgar las intenciones que motivaron esta campaña, que duró todavía un año más ${ }^{461}$. No obstante, hay que decir que por su tono y contenidos fue gravemente injusta, repulsiva y descalificadora de sus autores. Gracias a ella y a otras parecidas, se consiguió que una parte de los católicos españoles escribieran sus nombres en la lista de los enemigos de las libertades públicas. Payne ha resumido su actitud política de forma acertada:

"Durante la primera parte del siglo $\mathrm{xx}$, el catolicismo español se había aferrado a su cultura conservadora y no había desempeñado ningún papel destacado en los movimientos por la renovación de la Iglesia en su conjunto. Pero demostró una modesta capacidad de responder a nuevas situaciones políticas $y$ sociales, $y$, en 1931, sus dirigentes se mostraron más dispuestos a coexistir con la República que los republicanos a coexistir con la Iglesia. La ocasión para una separación justa y equitativa de la Iglesia y el Estado fue desaprovechada por

${ }^{461}$ A finales de 1938 seguían siendo frecuentes los editoriales que glosaban la tesis de "la conversión imposible" al hablar de los liberales; y en la reseña que se publicó al dar noticia del la muerte -fue asesinado en Madrid- de Federico Santander, se decía: "Comenzó su actividad periodística en Diario Regional, en el que desempeñó con insuperable acierto el cargo de redactor-jefe, (...). siendo hombre sinceramente católico, cometió una equivocación inexplicable, dada su clara inteligencia, y, con gran consternación de las personas que le admiraban y querían, se separó de Diario Regional para ingresar en "El Norte de Castilla" y afiliarse a un partido de tristes recuerdos. Su carácter rotundamente independiente se avenía mal con los escalafones de los partidos políticos, $y$ su entereza le impedía soportar humillaciones. Por eso, sin duda, no logró ocupar los puestos que merecía. No sentía avidez de altos cargos políticos, ni sabía mendigarlos, y únicamente desempeñó los de concejal y alcalde de Valladolid.

"Fue lo contrario de un hombre acomodaticio, y el día 14 de abril de 1931, una vez proclamada la República, abandonó la dirección de "El Norte de Castilla", porque sus convicciones de monárquico, mantenidas dignamente hasta el momento de ser asesinado, le impedían continuar en ella.(...)

"Con gran dolor por verle descentrado, combatimos lealmente su equivocada actuación política; pero siempre vimos en él al caballero dignísimo que el día 14 de abril de 1931 se negó a servir con su pluma a un régimen funesto para España, porque no era un cínico explotador de regímenes triunfales a los que había combatido."

"Don Federico Santander fue asesinado en Madrid", DR, 15/4/1939, pág. 1. Cfr. también "Eso está bien", editorial, DR, 8/10/1938, pág. 1 . 
el gobierno, y la confrontación que esto trajo, con la parcial persecución de la Iglesia, reavivó el espíritu militante y adversario de muchos de los fieles. En 1936, el tono y las actitudes del catolicismo español eran mucho más conservadores y hasta reaccionarios, con un espíritu de restauración religiosa muy receptivo respecto al movimiento político de los militares en rebelión. El general Franco, jefe del nuevo régimen militar, se aprovechó de esto para restablecer una simbiosis parcial entre la Iglesia y el Estado. El resultante "nacionalcatolicismo" del régimen franquista produjo, por lo menos durante un decenio, la más notable restauración tradicionalista, religiosa y cultural que se haya visto en el siglo XX en cualquier país europeo." 462

Ignacio Valverde, llamado a ocupar puestos más importantes en la prensa nacional, dejó el periódico un mes antes de que terminara oficialmente la contienda ${ }^{463}$. No cabe duda de que un hombre con sus ideas estaba predestinado para ocupar un puesto destacado en los órganos de control de prensa de la nueva España. Se le hizo justicia: fue jefe de información de la agencia "Cifra", y -cuando falleció en diciembre de 1958desempeñaba el cargo de jefe de la Sección de Prensa Nacional del Ministerio de Información y Turismo. Las consecuencias de la puesta en práctica de sus teorías -que le permitieron trabajar, sin escrúpulo alguno, como Colaborador de El Norte de Castilla desde 1950464_, no iban a deparar una época de esplendor al periodismo español.

Diario Regional había reproducido íntegro el contenido de unas hojas que, con el título de El Alcázar,

462PAYNe, S.G., El catolicismo..., pág. 217.

${ }^{463}$ Cfr. "La dirección de Diario Regional", DR, 7/3/1939, pág. 1.

${ }^{464} \mathrm{Cfr}$. SÁNChez SÁNCHez, José Francisco, Miguel Delibes, periodista, Destino, Barcelona, 1989, pág. 72 . 
se difundían, a modo de boletín informativo, en el alcázar de Toledo mientras duró su asedio. Poco más tarde, un artículo de Manuel Casares comentaba el estilo de aquellas páginas; su contenido puede servir de contrapunto al ambiente dominante en estos años:

\footnotetext{
"Con sus sesenta renglones diarios, "El Alcázar" llenaba y superaba las necesidades de aquella población heroica. Nada de frases hueras ni altisonantes, ni de citas de erudición barata, ni apelaciones pedantes al Espasa, ni vanidades de escritor relamido. "El Alcázar" contenía lo único que el lector busca para mantener la sublime moral de aquella catacumba, lo único imprescindible en un diario. "El Alcázar" contenía "noticias". "Noticias del avance de nuestras fuerzas, noticias de la guerra, noticias del levantamiento en otras provincias, noticias que abrían la puerta a la esperanza de la próxima liberación. Noticias y nada más que noticias. Noticias de léxico llano y sencillo. Noticias sin adjetivos. Noticias en su prístina pureza.

"Qué gran lección de periodismo nos dio a todos los profesionales ese imponderable redactor de "El Alcázar" de Toledo." 465
}

Hubo maestros del periodismo con más éxito que este "imponderable redactor". Su lección se perdió en el olvido; y, terminada la guerra, el periodismo español, guiado por las autoridades del nuevo Estado, emprendió el camino de la identificación de información y propaganda, en el que las noticias que no sean lecciones -de lo que estime oportuno quien gobierna- serán consideradas un mal Y, por tanto, no publicables. $Y$ es que, en la nueva España, el mal estaría prohibido. Del combate con la utopía comunista salió vencedora la utopía tradicionalista, que se disponía a construir su propio

465 "El diario del Alcázar. Una magnífica lección de periodismo», DR, 21/5/1938, pág. 3 . 
La guerra: sin Madrid y con fanatismo

paraíso en suelo ibérico.

$-255-$ 



\title{
Los años de «La Editorial Católica»: redactores líricos, fervor católico, y consignas.
}

\author{
«Personalmente entiendo que quienes estamos en la misma línea en que hemos estado \\ siempre, \\ somos quienes pensamos que es un grave deber de conciencia para los católicos colaborar \\ con la máxima lealtad y con el máximo espíritu de sacrificio \\ con un régimen a quien muchos debemos la vida, \\ a quien España no podrá agradecer bastante su liberación del caos rojo \\ y la neutralidad en que ha sabido conservarla durante la guerra mundial, \\ cuyas instituciones están basadas en los más puros principios cristianos \\ y dentro del cual podemos desarrollar una labor de apostolado \\ que no hubiéramos podido soñar nunca.
}

Si dentro de veinticinco años el panorama religioso y moral de nuestro país no ha cambiado radicalmente, no es al régimen político a quien debemos culpar, sino a nuestra profunda incapacidad.»

Carta de Tomás Cerro Corrochano, Director General de Prensa, a Francisco Javier Martín Abril, Director de Diario Regional. 21 de agosto de 1946. 
Los años de "La Editorial Católica": redactores líricos, fervor católico, y consignas.

No TODA LA PRENSA ESPAÑOLA ES CATÓLICA

Terminada la guerra había sonado la hora de "ganar la paz». Sabemos ya lo que esto significaba para Diario Regional: construir una España católica. Era preciso pasar de la retórica de exaltación patriótico-religiosa a los hechos, o mejor dicho, sumar a la primera los segundos, ya que la retórica era un elemento importante de construcción: si el lenguaje siempre lo es en cualquier actividad humana, en este caso precedía las más de las veces a cualquier otra cuestión, en un característico proceso -típico de los regímenes totalitarios- de agigantamiento del papel de la propaganda. Y aquí se planteaba un problema, que no por conocido era menos difícil de resolver: en un Estado que se declara oficialmente católico, ¿se puede decir que todo lo que él promueve es también católico? En el caso concreto de la prensa, ¿toda la prensa reconocida por el Estado es católica? La estrecha alianza entre trono y altar volvía a poner sobre el tapete un problema de los siglos pasados, que -en lo que a nosotros nos interesa más- podríamos denominar una "querella de investiduras" de los medios de prensa. 
Los años de "La Editorial Católica": redactores líricos, fervor católico, y consignas.

Muy pronto se levantó la voz del cardenal Segura para advertir que no toda la prensa española era católica, sino sólo "aquella Prensa que está sometida a la autoridad de los Prelados de la santa Iglesia, quienes, por los medios establecidos en las leyes eclesiásticas, se cuidan de vigilar por la pureza de su doctrina y de la moral de sus enseñanzas e informaciones»466. El periódico recogió la argumentación del purpurado, de momento sólo como condimento de la que había sido por tres años su insistencia favorita, descrita con detalle en el capítulo precedente 467 . Esa herencia de Ignacio Valverde se iba a perder muy pronto, ya que el Estado se encargaría -como se le había pedido repetidas veces- no de suprimir, pero sí de configurar a su gusto los periódicos, fueran del tipo

466 "La verdadera Prensa Católica», editorial, DR 22/6/1939, pág. 1. Cfr. la información en que se apoya el editorial: "La prensa católica, combatida por sus enemigos $y$ menospreciada por los que se llaman amigos. Los impíos, si la compran, es para impugnarla; en cambio hay católicos que leen con avidez la prensa liberal. Una alocución pastoral de S.E. Revdma., el Cardenal Segura y Sáez con motivo del "Día de la Prensa Católica"", DR, 21/6/1939, pág. 1.

467En un editorial de 24/6/1939, titulado "Diferencias", insistían: "UNOS PERIÓDICOS DEFENDIERON A ESPAÑA Y CREARON EL AMBIENTE NECESARIO PARA EL GLORIOSO MOVIMIENTO NACIONAL. OTROS, NO. SON DIFERENCIAS HISTÓRICAS." Pero esta argumentación no volverá a parecer en adelante, será la postura de la jerarquía católica, defendiendo la necesidad de una prensa de la Iglesia, la que ocupe su lugar. Martín Abril resumía así su opinión sobre la cuestión: "Ese gran poder de la prensa hizo necesaria la creación del periódico católico, aquél que había de defender a pulso $y$ frente a todos los regímenes los postulados inmutables de la doctrina del Crucificado. Estos periódicos católicos, por lo que a España se refiere, constituyeron una firme avanzadilla del Movimiento Nacional. El paréntesis de la guerra se abrió con los gritos de Dios y España. Porque mal se concibe la integridad de la patria española, sin una Cruz dominando con sus brazos extendidos todo el paisaje nacional. (...) La que hoy renace a impulsos del Caudillo como fruto de los mártires por cuya pureza y santidad seguirá luchando la Prensa Católica que al estar al servicio de la Religión lo está también al de España.", "El gran poder de la prensa", DR, 29/6/1939, pág. 1 . 
Los años de "La Editorial Católica": redactores líricos, fervor católico, y consignas.

que fueran. El Norte de Castilla, por ejemplo, cambiaría de director y perdería su lema de "diario independiente", lo mismo que Diario Regional abandonaba en 1940 el suyo de "Religión. Patria. Orden. Trabajo»; la diferencia estaba en que éste último lo sustituiría por otro: "Diario católico". El apoyo mutuo entre el régimen y el catolicismo hacía posible que este lema fuera consentido por las autoridades, aunque no sin cierto recelo. Diversas voces se levantaban para afirmar lo contrario de lo que había dicho Segura: que no hacía falta alguna la prensa católica en un régimen como el franquista. Pero los obispos -que en su mayoría se adherían casi sin reservas al régimen- se mostraban guardianes celosos de algunas instituciones católicas, que no estaban dispuestos a dejar absorber por las estatales. El modelo tradicionalista lleva consigo estas paradojas, de forma que -como afirma Tusell- "la España [de Franco], por lo menos hasta los años sesenta, fue un país en que los obispos hablaban como si fueran políticos, pero el Jefe del Estado, parecía de vez en cuando ejercer de obispo."468 De momento, la polémica se saldó con el consentimiento de que existiera una prensa católica diferenciada, si bien sometida a la censura estatal. La unión de trono y altar que se preconizaba permitía que la situación se aceptara como normal.

468TUSELL, Javier, La España de Franco. El poder, la oposición y la política exterior durante el franquismo, Historia 16, Madrid, 1989, pág. 16 
Los años de "La Editorial Católica": redactores líricos, fervor católico, y consignas.

Los obispos no volvieron a hablar sobre esta cuestión hasta que -como veremos más adelante-, un discurso del Papa, con motivo del Congreso Internacional de Prensa Católica, forzó una reorientación de la misma. Pero sí insistieron en este punto los hombres de la A.C.N. de P., que eran los más caracterizados representantes del catolicismo oficial, y -en estos años- los más inmediatos promotores de la prensa católica española. Un artículo de Fernando Martín-Sánchez, el presidente de la asociación, distinguía, siguiendo al cardenal Cerejeira, tres clases de prensa católica: la oficial, órganos dirigidos inmediatamente por la jerarquía católica; la oficiosa, que "es órgano de los católicos pero no propiamente de la autoridad Eclesiástican; y la independiente que -en palabras del cardenal- "es aquella que no tiene ni pretende tener la cualidad de órgano de los católicos, sino que en su actuación procede por su libre iniciativa, en nombre de una persona, de un grupo, de un partido, o de un régimen, permaneciendo fiel a la Iglesia en todo lo que se refiere a la doctrina y disciplina, sin depender directamente del magisterio de la Iglesia". Ya hemos visto los problemas que presenta la definición de prensa católica oficiosa. Es importante ahora tener presente lo que añade Martín-Sánchez:

"Pero la más esencial es la Prensa Católica oficiosa (...) Claro está que la Prensa Católica oficiosa no puede reducirse a semanarios y revistas solamente. Necesita de grandes diarios que den noticias de todas las actividades, porque la mejor apologética es la información de la verdad. El Cardenal Cerejeira sale al paso de quienes quisieran limitar la Prensa 
Los años de "La Editorial Católica": redactores líricos, fervor católico, y consignas.

Católica a publicaciones de poca importancia, dedicadas sólo a materias de devoción. "No se piense -dice- que la Prensa católica oficiosa ha de convertirse en Prensa edificante o de desinteresada cultura abstracta. Correspondería esta prensa, en el equivocado pensar de algunos, a una concepción de católicos desterrados del presente, tránsfugas de las luchas humanas y ciudadanos disminuidos. Por el contrario, esta Prensa existe para tomar parte en la disputa sobre las soluciones concretas, con afirmaciones católicas. A las interrogaciones de cada hora, ella da una respuesta derivada del magisterio de la Iglesia. Sitúase en la misma cumbre de la vida social, para juzgar y orientar las actividades cívicas en el sentido de los deberes para con Dios, la Patria y la Humanidad" . " 469

Se insistía así en un punto importante: no se puede aislar a los católicos del mundo en que viven, por la sencilla razón de que son tan ciudadanos como los demás hombres. Pero al mismo tiempo se hacía una afirmación que era difícilmente compatible con ésta: al considerar posible una prensa de opinión católica oficiosa, se negaba el pluralismo entre los católicos, en materias reconocidas como opinables por la jerarquía -"las interrogaciones de cada hora" raras veces admiten una única solución desde la ortodoxia dogmática y moral-. Esto, en un mundo como el contemporáneo, que mantiene el pluralismo como uno de los postulados básicos de la convivencia, haría muy difícil que los católicos pudieran integrarse pacíficamente en este tipo sociedades, ya que su influencia en ese caso, tendería a eliminar las diferencias de opinión, y de rechazo, la sociedad misma. La teoría, sin embargo, puede resultar aceptable para quienes consideren que los

469 "El "Día de la Prensa Católica"”, DR, 29/6/1943, pág. 1. Los entrecomillados internos en el texto son palabras del cardenal portugués Cerejeira, en la inauguración de la "Exposición de la Prensa Católica Contemporánea" de Portugal, en 1934. 
Los años de "La Editorial Católica": redactores líricos, fervor católico, y consignas.

católicos deben formar un grupo de opinión homogéneo en todos los órdenes, $y$, por tanto, que deben construir sociedades de opinión limitada, autoritarias. Era el caso de Sánchez-Juliá, de muchos de sus colaboradores, y -en general- de los que se adherían a la mentalidad política triunfante en España, sólo que unos reclamaban como principio inspirador del Estado autoritario su peculiar interpretación de los principios católicos, y otros los postulados fascistas, más o menos corregidos, y siempre aderezados con las oportunas dosis de catolicismo. Por otra parte, no debemos olvidar que para Herrera Oria "el periodismo [es] la más alta escuela de política»470, y cuando este grupo de opinión habla de prensa católica -lo vimos para la segunda República- está hablando de política católica.

Se trataba, pues, de crear una red de periódicos diarios que sirvieran de apoyo para la construcción de ese Estado católico que se deseaba. No deja de ser un empeño paradójico, ya que se trata de utilizar un medio característico de las sociedades pluralistas para eliminar el pluralismo; de conseguir que unos medios de opinión fueran de tal naturaleza, que eliminaran la opinión de cualquier otro signo, o lo que es lo mismo, la opinión en general. La identificación entre el tipo de sociedad al que se llegaría por este camino, y una de Antiguo Régimen

${ }^{470}$ Cfr. la reseña de una conferencia suya en DR, 11/5/1951, pág. 5. 
Los años de "La Editorial Católica": redactores líricos, fervor católico, y consignas.

-la famosa España eterna- resulta clara. Si para los reyes la prensa era un privilegio real, para estos hombres era un privilegio ideológico, del que eran sujetos el Estado católico y su caudillo, y -como delegados de ellos-, los católicos a los que la jerarquía concediera el título de representantes oficiosos de su religión. En cambio, los medios prácticos para conseguir esto, no podían ser merced al desarrollo tecnológico- los que se empleaban en el Antiguo Régimen. El modelo para la consecución de una prensa homogénea en una sociedad moderna es el desarrollado por los regímenes totalitarios: la prensa es un servicio del Estado, $y$ sus agentes, soldadosfuncionarios al servicio de la causa, cualquiera que sea ésta: el comunismo, el fascismo, o -como se pretendía en España- el nacional-catolicismo ${ }^{41}$.

Tal era la opinión triunfante en nuestro país cuando la suerte de las armas quitó la razón a las potencias fascistas, brindando a los españoles la oportunidad de hacer gala de su capacidad de resistencia numantina. A las críticas al régimen se contestaba que éste era sobre todo anti-bolchevique; pero si bien es cierto que esa había

471Mussolini lo expresaba de la siguiente forma: "En un régimen totalitario, como ha de serlo necesariamente un régimen nacido de una revolución triunfante, la prensa es un elemento del régimen, una fuerza al servicio del Estado (...). He aquí por qué toda la prensa italiana es fascista. (10 de octubre de 1928)"

"Los periodistas italianos deben considerarse como soldados que han sido encargados de los puestos de vanguardia del frente fascista y que tienen a su disposición un arma más potente y más peligrosa que las demás. ( 31 de octubre de 1933)"

Cfr. VOYENNE, op. cit. págs. 188-189. 
Los años de "La Editorial Católica": redactores líricos, fervor católico, y consignas.

sido la tónica dominante de las informaciones durante la guerra, también lo era que no habían escatimado ni los ataques a la "plutocracia anglosajona" y al capital judío -el de los EE.UU.-, ni las informaciones sobre la acentuación del anticatolicismo y de la propaganda comunista en norteamérica472.

Pero no todos los católicos españoles pensaban que la única forma de mantener al país fiel a la religión, pasara por tenerlo ayuno de libertades. El fin de la guerra dio ocasión para que algunos solicitaran la modificación de la ley de Prensa, en aras de la concesión de una legítima libertad. Era el caso del ministro de Exteriores, Martín Artajo, un cualificado representante del catolicismo oficial, que en 1945 -según decía en una carta al cardenal Tedeschini- llegó a estar convencido de que se daría un nuevo estatuto a la prensa. Su primer proyecto fue vetado por Carrero Blanco. Un año más tarde fracasaría un nuevo intento en el mismo sentido ${ }^{473}$.

472Cfr. "La única solución posible", editorial, DR 1/4/1941, pág. 1; "Europa contra Rusia", por Angel de Pablos, DR, 24/6/1941, pág. 1; "Hoy hace dos años se abandonó toda solución pacífica en Europa", editorial, DR, 3/9/1941; "En los EE.UU. se acentúa el anticatolicismo", DR, 5/10/1941, pág. 1; "Actividades comunistas en las escuelas de Nueva York", noticia de EFE, DR, 5/12/1941, pág. 1.

473Cfr. SINOVA, Justino, La censura de Prensa durante el franquismo (1936-1951), Espasa Calpe, Madrid, 1989, págs. 118, 119 y 121 . La mejor descripción del proceso de elaboración de proyectos y los consiguientes fracasos en TUSELL, Franco y los católicos, la política interior española entre 1945 y 1957, Alianza Editorial, Madrid, 1984 ,págs. 188-192. 
Los años de "La Editorial Católica": redactores líricos, fervor católico, y consignas.

Por otro lado, tampoco todos los católicos eran españoles. En 1950, con motivo del Congreso Internacional de Periodistas Católicos, los que se autodenominaban brazo derecho de la Iglesia, iban a escuchar de su cabeza unas palabras que confirmaban las críticas que correligionarios suyos de otros países venían haciéndoles. Pío XII se expresó de la siguiente forma:

"Allí donde no haya ninguna manifestación de la opinión pública, y, sobre todo, donde sea preciso comprobar la total inexistencia de la misma, sea cual fuere la razón de su silencio o de su ausencia, habrá que ver en ello un vicio, una deformidad, una enfermedad de la vida social.

"Dejemos aparte, evidentemente, el caso en que calla la opinión pública en un mundo del cual está desterrada incluso la justa libertad y en el que solamente se puede hacer oir la opinión de los partidos en el Poder, la de los jefes o los dictadores. Ahogar la de los ciudadanos, reducirla al silencio forzoso es, a los ojos de todo cristiano, un atentado al derecho natural del hombre, una violación del orden moral del mundo tal como Dios lo ha establecido.

"(...) En verdad, habíamos esperado que las duras experiencias pasadas habrían servido al menos de lección para liberar definitivamente a la sociedad de una tiranía tan escandalosa y para poner fin a un ultraje tan humillante para los periodistas y para sus lectores. Sí; lo habíamos esperado tan vivamente como vosotros y nuestra decepción no es menos amarga que la vuestra." 474

\section{El embajador ante la Santa Sede escribió a Martín}

Artajo que "en modo alguno el Padre Santo ha tenido en mente una referencia a España o a otros países católicos»475. Tamaña interpretación fue aceptada por el

474 "Mensaje de Su Santidad al Congreso de la Prensa en Roma", DR, 23/2/1950, págs. 1 y 5. El Papa hablaba también de la necesidad de combatir con criterios adecuados las corrientes de opinión escépticas, ajenas a toda apreciación con sentido sobrenatural; precisaba que la misión de los periodistas era servir a la opinión, no formarla; y afirmaba que el periódico católico debía resistir a las tendencias inmorales aunque esto le supusiera un sacrificio económico.

${ }^{475}$ Cfr. TUSELL, Franco y los católicos..., págs. 205-207. 
Los años de "La Editorial Católica": redactores líricos, fervor católico, y consignas.

Gobierno, que un año más tarde endurecería su línea de control de la prensa con la creación del Ministerio de Información y Turismo, al frente del cual se colocó a Gabriel Arias Salgado.

En cambio, el cardenal primado -Plá y Deniel- publicó una pastoral en junio, con motivo del "Día de la Prensa Católica" en que afirmaba el derecho de la Iglesia a tener su propia prensa, y reclamaba la vigencia efectiva del Fuero de los Españoles:

"(...) es sumamente deplorable que no se quiera reconocer que entre las libertades de perdición, el desenfrenado libertinaje de la prensa (...) y el estatal totalitarismo de la prensa, existe un justo medio de una responsable libertad de Prensa, propia de una sociedad cristiana y civilizada, que es el que defiende el cristiano Fuero de los Españoles, que no es un programa académico para que rija en futuras generaciones, sino una ley declarada básica en la ley de sucesión a la Jefatura del Estado." 476

Hacía así su aparición una de las reivindicaciones del episcopado que será continua -siempre en tono moderadodurante estos años: la suavización de la censura. Por otro lado, el Primado señalaba que el criterio para distinguir la auténtica prensa católica no cabía darlo a priori sino que se hacían dignos de ese calificativo los medios que

476 "A la Iglesia -proclama el Primado- le asiste el derecho de tener su propia prensa. Y el grado de catolicismo en los periódicos no ha de apreciarse "a priori", sino de hecho. Entre el libertinaje periodístico y el totalitarismo estatal existe el justo medio de una responsable libertad", DR, 24/6/1950, págs. 1 y 5. El artículo del Fuero de los Españoles que se cita es el no 12, que dice: "Todo español podrá expresar libremente sus ideas mientras no atente a los principios fundamentales del Estado". El artículo 35 del mismo Fuero establecía que el 12 era uno de los artículos que "podrá ser suspendido temporalmente por el Gobierno, total o parcialmente mediante Decreto-ley, que taxativamente determine el alcance y duración de la medida." 
Los años de "La Editorial Católica": redactores líricos, fervor católico, y consignas.

con su comportamiento demostraban adherirse a los criterios doctrinales $y$ morales de la Iglesia. El catolicismo de un medio depende no tanto de declaraciones de principios como de la "formación religiosa y del catolicismo práctico de sus redactores. Por ello, el reciente Congreso Internacional de Roma, fue denominado no de periódicos católicos, sino de periodistas católicos." Era una matización significativa, y ciertamente importante, pero no se insistió tanto en ella como en la cuestión de la fidelidad a las directrices concretas de la jerarquía, quizá porque éste era un aspecto más práctico y fácilmente apreciable que el grado de catolicismo efectivo de los periodistas.

En septiembre de 1950 la Conferencia de Metropolitanos españoles hizo públicas las normas fundamentales que debían observar los periódicos que quisieran ser tenidos por católicos. En resumen se señalaban seis puntos: 1․-Todo católico debe considerar que estas orientaciones son fruto del afán positivo de preservar de un daño a los fieles. 20.- "Al hablar o escribir sobre libros dogmática o moralmente reprobables, han de proceder con justicia, sí, pero con caridad hacia sus oyentes o lectores, expresándose de modo que éstos entiendan fácilmente dónde se encubre el veneno, los errores, y los peligros para la moral." 3‥- No se debe elogiar lo que de positivo tienen las obras no recomendables en conjunto, según la máxima de Pío XI, “No 
Los años de "La Editorial Católica": redactores líricos, fervor católico, y consignas.

escribir jamás ni una sola palabra que implique recomendación del vicio o menosprecio de la virtud". 4‥Las impugnaciones de las obras deben hacerse de forma que no sirvan de propaganda para lo que se reprueba. 50.Podrán publicarse las carteleras de espectáculos, excepto las de los locales que se dedican siempre a espectáculos inmorales. En la prensa católica debe ponerse a continuación la calificación moral. 6․- En la prensa católica, además, a) no debe publicarse ningún anuncio que contenga un texto o grabado inmoral. b) "En ningún caso se publicarán anuncios ni reclamos de espectáculos inmorales." c) Sólo si es cierta la moralidad de un espectáculo, podrá anunciarse con reclamo. d) Si la moralidad es dudosa, se hará constar así, y no se publicará reclamo. e) No basta saber que hay censura civil, ya que ésta no sirve como criterio en la guía de las conciencias ${ }^{47}$.

Se pretendía así salir al paso de algunos evidentes defectos de la prensa católica española -los veremos luego ejemplificados en Diario Regional -, y de un ambiente que poco a poco se iba distanciando de las normas morales del catolicismo, en un característico proceso de secularización $y$ de incremento del materialismo: dos problemas ante los que la censura iba a demostrarse totalmente ineficaz. En octubre declararon acatar los seis

${ }^{477} \mathrm{Cfr}$. "Seis puntos fundamentales", DR, 16/9/1950, pág. 3. 
Los años de "La Editorial Católica": redactores líricos, fervor católico, y consignas.

puntos veintinueve diarios españoles, entre los que se encontraba Diario Regional ${ }^{478}$. Al anunciar que así lo hacían, simplificaban todavía más las normas de definición del periódico católico: según decían, la aceptación significaba dejar "de anunciar y publicar propaganda de obras literarias, teatrales o cinematográficas de carácter heterodoxo o inmoral", cuestión que, por importante que fuera, era quizá el aspecto más superficial de los que cabía considerar a la hora de definir una publicación como católica: no hay más que reparar en que algo parecido hacía la prensa comunista.

Este tipo de disquisiciones se iban a revelar poco eficaces. En los años finales de la etapa que consideramos en este capítulo, el órgano oficial de información de la Iglesia española, reconocía que "hoy por hoy carecemos de un criterio indiscutible y tajante que nos permita trazar una línea de separación en la gama casi continua que va desde la prensa española de criterios doctrinal y moralmente laxos hasta el periódico de actitud netamente

478Ya, de Madrid; El Correo Catalán, de Barcelona; La Gaceta del Norte y El Correo Español, de Bilbao; El Pensamiento Navarro y Diario de Navarra; El Correo de Galicia, de Santiago; El Faro de Vigo; El Diario Montañés, de Santander; Región, de Oviedo; El Progreso, de Lugo; El Diario Vasco, de San Sebastián; El Noticiero, de Zaragoza; Diario de León; Diario Palentino; Diario Regional; La Gaceta Regional, de Salamanca; Nueva Rioja, de Logroño;Extremadura, de Cáceres; Hoy, de Badajoz; Ideal, de Granada; La Verdad, de Murcia; El Correo de Andalucía, de Sevilla; Ayer, de Jerez; El Correo de Zamora y El Correo de Mallorca. Cfr. "El sacrificio de ser periódico católico" por Luis Sanz, colaborador de "Logos", DR, 14/11/1950, pág. 5. En 1957, en el folleto titulado La Prensa de la Iglesia en España, publicado por la Oficina General de Información y Estadística de la Iglesia en España (O.G.I.E.I.), se señalaban 34 periódicos diarios que acataban esas normas. 
Los años de "La Editorial Católica": redactores líricos, fervor católico, y consignas.

apostólica»479. Este desconcierto conceptual derivaba de la patente inutilidad de las categorías que se manejaban. El concepto de prensa católica que se había venido usando hasta el momento, estaba ya obsoleto. Pronto haría falta discurrir -y actuar- de otra forma, si se quería salir de este punto muerto. En cierta forma esto era consecuencia lógica del reflejo que tenía en la prensa la evolución de la sociedad española, que -por mucho que se dijera que era la de la España eterna- a medida que se modernizaba, de modo especial en los medios urbanos, se iba acercando a lo que conocemos como sociedad de masas y sociedad de consumo. Sabemos ya que en este tipo de sociedades la prensa de opinión -sobre todo la diaria- es cuando más residual, y la prensa católica se había definido y realizado como una prensa de opinión. A este importante factor había que sumar otro que era consecuencia del régimen político: su control de la prensa ahogaba la opinión en los medios, y pretendía hacer oficial una “opinión católica", artificial y sui generis. Con esos presupuestos, aun contando con que en el país existía una mayoría católica, pedir manifestaciones de vitalidad a la opinión católica era pedir lo imposible.

Hasta aquí las ideas básicas sobre la prensa católica que se manejaron en estos años. Veamos ahora cuáles fueron

479O.G.I.E.I., op. cit., pág. 11 . 
Los años de "La Editorial Católica": redactores líricos, fervor católico, $y$ consignas.

las realidades prácticas, qué era y cómo se hacía el diario católico de Valladolid.

\section{DIARIO EPISCOPAL}

La práctica totalidad de la redacción de Diario Regional se había formado en un periodismo que era esencialmente beligerante frente al liberalismo. Finalizada la guerra en el órgano tradicionalmente liberal de la ciudad -por obra y gracia de la ley de Prensa- no quedaba ni rastro de liberalismo. Junto a él estaba ahora un nuevo diario -Libertad-, que se definía como órgano del Movimiento. Ese Movimiento, y el régimen por él instaurado, se declaraban oficialmente católicos. Sin nadie que combatir ¿a qué debía dedicarse el diario católico? No sabemos si los redactores se hicieron nunca esta pregunta, pero sí conocemos la respuesta que dieron de hecho: se debían seguir combatiendo los residuos de liberalismo que aún aparecieran, cantar las alabanzas del catolicísimo régimen $y$ de sus representantes, lanzar denuestos contra sus enemigos -todos extranjeros, o en el extranjero-, y, finalmente, y como nota diferenciadora con respecto a los demás periódicos, preocuparse de difundir las enseñanzas de la jerarquía católica. Esa única nota diferenciadora irá cobrando cada vez más fuerza. En un proceso lógico, el diario católico, privado de sus matices políticos, se iba pareciendo más al resto de la prensa católica, la no diaria y también la más difundida. El 
Los años de "La Editorial Católica": redactores líricos, fervor católico, y consignas.

periódico será el canal de difusión de las enseñanzas papales y de las iniciativas del arzobispo de Valladolid, e irá adquiriendo tonalidades que le hacen catalogable como publicación de caridad o de espiritualidad: llegará un momento en que -sin que esto desentonara lo más mínimo de la línea habitual del periódico- casi todos los editoriales que publique estén tomados de Ecclesia, una revista de Acción Católica que -de hecho- era fundamentalmente para eclesiásticos. En cuanto que órgano de opinión, realmente poco lo distanciaba de las publicaciones católicas no diarias, y en cuanto a la información -si dejamos a un lado secciones como las notas de sociedad, la agenda diaria, los deportes y la crónica municipal- todo dependía de la información que le sirvieran las agencias, o lo que es lo mismo, de lo que pudiera pagar.

La difusión al final de la guerra era más o menos la misma que antes de que estallara el conflicto480, e incluso menor, merced a la aparición de Libertad como diario. El papel se encarecía casi tanto como escaseaba, y era necesario renovar la redacción. No es extraño que ante este panorama, la endeble estructura empresarial que servía de soporte al periódico se viniera abajo; y esta

$480 \mathrm{Cfr}$. más adelante los datos que tenemos para 1945. Por otro lado cabe deducir que así era porque ya no aparecían listados de lugares de venta, salvo algunas raras veces, en que se señalaban tres kioscos de Madrid. La escasa información sobre los pueblos de la provincia hace también suponer que su difusión en éstos no era muy amplia. 
Los años de "La Editorial Católica": redactores líricos, fervor católico, y consignas.

vez no bastó con el apoyo de algunos vallisoletanos entusiastas de la causa: fue necesario recurrir a la cadena de prensa católica más fuerte del país para salvar el periódico. Diario Regional no se incorporó propiamente a la cadena - Diario Regional, S.A." seguía siendo la empresa editora-, pero "La Editorial Católica" pasó a ser el accionista mayoritario, y nuestro periódico, uno de los que aparecían en el membrete del papel timbrado oficial que utilizaban todos los diarios del grupo. En 1942 se aprobó una ampliación de capital de 500.000 ptas. con lo que el capital social pasó a ser de un millón. "La Editorial Católica" suscribió íntegramente las acciones emitidas, que, sumadas a las que compró a otros accionistas -222.500 ptas. en acciones de las series A y B-, la convirtieron en propietaria del $72,3 \%$ del capital social481. El nuevo presidente del Consejo de Administración fue Germán Adánez, un notario al que ya conocemos como diputado electo por Acción Popular en Valladolid en los comicios de 1936. Junto a él encontramos a otros profesionales de la ciudad, vinculados como él a la Acción Católica y a la A.C.N. de P., y a Francisco de

481 «Escritura pública de aumento de capital y emisión de acciones de "Diario Regional S.A." que autorizó el notario que fue de Valladolid Don Luis Rodríguez de Huidobro el día 19 de febrero de 1943. Autorizada por Francisco Fernández-Prida. Abogado-Notario. Año de 1943. № 114". A.P.G.A.M.. "Copia de la escritura de adaptación de los Estatutos Sociales de "Diario Regional, S.A." otorgada por don Mariano Escudero de Solís, como Consejero-Delegado de dicha Entidad. Valladolid a 23 de febrero de 1955. Ante D. Salvador Escribano y Escribano, Abogado y Notario", A.P.G.A.M.. Vid. también en el Registro Mercantil de Valladolid las anotaciones 2 a y 3 a de la hoja no 597. Cfr. en el apéndice 3, apartado "Propiedad, capital social y accionistas" los datos pormenorizados. 
Los años de "La Editorial Católica": redactores líricos, fervor católico, y consignas.

Luis, consejero delegado de "La Editorial Católica", que será también presidente del consejo del diario vallisoletano en los cincuenta.

\section{La redacción literaria}

Al frente del periódico, Francisco Javier Martín Abril había tomado el relevo de Ignacio Valverde. El nuevo director era sobre todo un escritor -inclinado a la poesía- y un católico activo: miembro de la A.C.N. de P., había ejercido también el cargo de secretario de las Juventudes de Acción Popular de Valladolid. Además de colaborar esporádicamente en Diario Regional, había sido y volvería a serlo- director de la emisora Radio Valladolid, y estaba emparentado con el presidente de la empresa editora del periódico en 1939, Eustasio Abril. Va a ser el director que más años esté al frente del periódico: desde 1939 hasta 1952. Su estilo tiene una fuerte carga literaria que él mismo describía así:

"La literatura... o la amenidad. Necesitan, efectivamente, los periódicos abrir unos cuantos boquetes a la liberación de los lectores, para que éstos no se atosiguen de noticias tremendas, obscuras o insulsas. El lector de periódicos -iy quién, que es, no lee periódicos?- agradece esas maravillosas válvulas de escape de los artículos literarios, de las notas críticas, de los pasatiempos. He aquí las pausas gratas, los rinconcillos apacibles, los refugios divertidos, las lagunas soleadas, que interrumpirán, amablemente el plomo -abrumador, a veces- del paisaje periodístico.

"El artículo literario es al periódico lo que el cuadro a la pared. (...)

"iLiteratura breve y deleitable para los periódicos! Nada de originales largos y eruditos. Este cansancio que pesa ahora sobre las espaldas de la humanidad del siglo Xx, necesita ser 
Los años de "La Editorial Católica": redactores líricos, fervor católico, y consignas.

aliviado por la fuentecilla, por la brisa azul, por el manojo de flores, por la paz de las cosas dulces y pequeñas." 482

Se trataba de un estilo muy distinto al que hasta entonces era ordinario. Orientado hacia el comentario de los más variados aspectos de la vida ordinaria más que hacia las noticias ${ }^{483}$, tenía por lector ideal un grupo social muy concreto, como se desprende del texto que acabamos de citar: los que ya eran lectores de periódicos, que -pese a lo que dice Martín Abril-, no eran, ni mucho menos, todos los vallisoletanos ${ }^{484}$. Ciertamente, también publicó algún artículo de carácter político, glosando campañas concretas de las autoridades, o alabando en general al régimen en días significados ${ }^{485}$; pero muy pronto 482 "La literatura en los periódicos", DR, 10/4/1949, pág. 8, últ..

483Basta repasar los títulos de algunos de los artículos que publicó en estos años para hacerse una idea cabal de sus preferencias: "iiCartero!!", "Violetas en otoño", "iSerenoo!", "Limpiabotas", "Niebla", "Árboles de la ciudad", "El hombre del hielo", "Elogio del botijo", "El coche de la Central", "Los días largos", "Paseos del domingo", "La cristianización de la cuaresma", "Objetos perdidos", "El primer almendro en flor", "La primavera en la calle", "Tarde de marzo en las afueras", "Adiós al antiguo templete del Campo Grande", "Puestecillos callejeros", "Ciegos", "Escaparates".

${ }^{484} \mathrm{Esa}$ imagen, que realmente correspondía al hombre de clase media acomodada, era el estereotipo de ciudadano para Martín Abril, como lo demuestra otra frase suya de 1939: "El periódico es el único alimento espiritual de muchas personas. No se concibe hoy el desayuno de un hombre sin que tenga a la vera su "diario" predilecto." "El gran poder de la prensa", DR, 29/6/1939, pág. 1 .

${ }^{485}$ Puede servir como ejemplo de este tipo de escritos el siguiente texto: "Se inicia una campaña en favor de los pueblos de Castilla. Bien lo necesitan. Se pretende cambiar el tono pardo de las casas de adobe por el blanco alegre de la cal. Así nuestro paisaje tendrá también pueblecitos blancos que pondrán una nota de claridad en el sinfín uniforme de la llanura.(...)

"La Nueva España se preocupa ya activamente de sus problemas. Ahora se trata de cambiar la faz de algunas aldeas castellanas. Después vendrá la solución de otras necesidades. Hay que llevar a los pueblos de Castilla las ventajas de la civilización. Es preciso dotar 
Los años de "La Editorial Católica": redactores líricos, fervor católico, y consignas.

se advierte que delegó esas tareas en otros redactores. En 1942 se le concedió el premio Mariano de Cavia. Con ese motivo, un redactor -Ángel de Pablos- definía a Martín Abril como un poeta486, definición que debe considerarse acertada. Lo cierto es que no era el único periodista vallisoletano al que cabía encuadrar en esa categoría. Pedro Sánchez Merlo, otro periodista vallisoletano de la época, que fue durante muchos años presidente de la Asociación de la Prensa de la ciudad, nos decía en una entrevista, que por estos años "se habían hecho con los periódicos los redactores líricos". Francisco de Cossío, el ex-director de El Norte de Castilla, había recibido el premio Fastenrath de la Real Academia por su novela Manolo, netamente profalangista ${ }^{487}$; Nicomedes Sanz, otro redactor del diario decano era también escritor; Ángel de Pablos y Félix Antonio González, que serán redactores de

a la vivienda castellana de las indispensables condiciones de higiene y comodidad. Castilla, que siempre lo dio todo con el mismo desinterés, tiene derecho a ello. "Regresamos del campo. Los chopos y los hilos del telégrafo extienden las rectas de sus sombras, lentamente, como si tuvieran temor de confundirse con la noche. La aldea está lejos. No hay figuras en el paisaje. También nosotros, ahora, necesitamos una capa para apretar en sus pliegues el sonoro tic-tac de nuestro corazón." "Pueblos de Castilla", DR, 4/2/1941.

${ }^{486}$ Cfr. "Francisco Javier Martín Abril, premio Mariano de Cavia 1942", DR, 19/4/1942, pág. 1; "Francisco Javier Martín Abril: el hombre y el escritor" por "la redacción de Diario Regional", 21/4/1942, pág. 1; "Martín Abril, poeta" por Angel de Pablos, 22/4/1942, pág. 1; "Homenaje íntimo de Diario Regional a su director", 3/5/1942, pág. 4 últ. .

${ }^{487}$ Es significativo que con motivo de la concesión de este premio Martín Abril publicara un artículo alabar la obra del director del tantas veces denostado diario rival. Con la marcha de valverde, y el cambio de orientación de El Norte, la situación se había modificado considerablemente. Cfr. "El estilo de Francisco de Cossío" por Francisco Javier Martín Abril, DR, 5/4/1941, pág. 1. 
Los años de "La Editorial Católica": redactores líricos, fervor católico, y consignas.

Diario Regional en estos años, también cultivaban la poesía, y así podríamos seguir ampliando la lista. Es un fenómeno curioso, que puede interpretarse como resultado de la intensa exaltación sentimental, de tonos épicos, propia del momento, y del rechazo de los planteamientos liberales, que llevaría aparejado también un cierto menosprecio de los criterios de eficacia o racionalistas; algo así como un movimiento pendular que alejaría de lo que había sido tónica habitual en la ajetreada década de los treinta. En el fondo, un modo de huida de la deprimente realidad de postguerra, paralelo al gusto por la novela rosa que se cultivó en estos años. La exaltación del régimen demandaba una idealización del presente que se conseguía a través del lenguaje. Es lógico que los papeles periódicos $-y$ en esto recordaban también los siglos pasados- se concibieran como el lugar para estampar unos cuantos avisos junto a romances o sus equivalentes: épicos en el caso de editoriales y comentarios que cantan las gestas del caudillo y sus huestes; líricos para todo lo demás .

Esta mentalidad tenía sin duda consecuencias en la dirección del periódico: la forma mentis del poeta no es la más adecuada para gestionar una empresa periodística, y -todavía más en un periódico de provincias-, el director había de ejercer funciones de periodista, de empresario, y también -por el régimen de control estatal- de funcionario. Si Martín Abril era sobre todo un escritor, 
Los años de "La Editorial Católica": redactores líricos, fervor católico, y consignas.

en las otras facetas su trabajo dejaba algo que desear. Así le pareció a la Subsecretaría de Educación Nacional, que -como veremos con detalle más adelante- decidió destituirlo en 1944. Una razón parecida empujó a la empresa a buscar nuevos redactores que se ocuparan de los cometidos que el director no podía asumir. Martín Abril era un buen representante oficial del periódico, un buen garante de su ortodoxia católica, un buen articulista en su estilo; pero se hacía necesario un maquetador, y redactores con espíritu reportero y capacidad para comentar los variopintos asuntos que los órganos oficiales estimaban dignos de glosa. Los nuevos hombres que se incorporaron para cubrir esas lagunas fueron Ángel de Pablos y Luis Calabia. Éste último fue redactor jefe de Diario Regional hasta 1945, y de Pablos fue fichado por el colega en 1944 para ejercer las mismas funciones en $E l$ Norte de Castilla ${ }^{488}$. De Pablos firmaba los fondos de tono oficialista, y Calabia era el que reunía más características de reportero. Junto a ellos estaban otros veteranos redactores, capaces de comentar con su estilo de siempre la actualidad de la ciudad en el arte, el teatro,

${ }^{488} \mathrm{El}$ colega tenía unas razones parecidas a las que hemos expuesto para Diario Regional después de que se le hubiera impuesto como director a Gabriel Herrero tras la deposición de Cossío. Cfr. SÁNCHEZ SÁNCHEZ, José Francisco, Miguel Delibes periodista, pág. 53. Diario Regional dio la noticia de la siguiente forma: "Nuevo redactor-jefe de El Norte de Castilla» "En virtud del nombramiento decretado por el Delegado Nacional de Prensa, anteayer tomó posesión del cargo de redactor-jefe de El Norte de Castilla don Angel de Pablos chapado, que hasta el mismo día ha pertenecido a la redacción de Diario Regional.", 19/2/1944, pág. 1 . 
Los años de "La Editorial Católica": redactores líricos, fervor católico, y consignas.

o el cine -Leandro Pérez ${ }^{489}$-; en los deportes -Miguel Montalvo490-; de rehacer las informaciones de agencia Gerardo Serrano491_; de atender la información religiosa Antolín Gutiérrez ${ }^{492}-$, o de encargarse del resto de las tareas rutinarias, desde pulir una nota de sociedad, hasta componer la lista de viajeros o los horarios de trenes Mariano Benito Pardo493, Francisco de Raimundo ${ }^{494}$. Como escribe uno de ellos, las canas eran los cabellos más abundantes en la redacción ${ }^{495}$, y es fácilmente apreciable

${ }^{489}$ Firmaba normalmente como “LE-PE". Ingresó como redactor en 1922. Cfr. en el apéndice 5, apartado "Equipos de redacción" la fecha exacta. Los datos sobre las fechas de ingreso en la redacción están tomados de la "Plantilla-escalafón del personal de esta empresa [Diario Regional S.A.].- Artículos 47 y 48 de la Orden del Ministerio de Trabajo de fecha 14 de julio de 1950, B.O.E. del 2 de agosto del mismo año" Sindicato Provincial del Papel, Prensa y Artes Gráficas. Fechado el 10 de octubre de 1950. Archivo Histórico Provincial y Universitario de Valladolid, A.H.P.U.V., Sección A.I.S.S., legajo 4.694. El resto de la información está extraída del propio periódico y del Anuario de la Prensa española. Año III, vol. I.- Diarios, Ministerio de Información y Turismo, Dirección General de Prensa, Madrid, 1953-1954, pág. 40.

490Era redactor del periódico desde 1936. Atendía también a otras cuestiones de información local.

491Firmaba -las raras veces que lo hacía- con su segundo apellido, Fernández. Comenzó a ejercer el periodismo en el diario maurista de Valladolid La Defensa, y en los años veinte pasó a Diario Regional. Era funcionario municipal. Cfr. su nota necrológica "Don Gerardo Serrano Fernández. Ha muerto un gran periodista", DR, 20/3/1962, pág. 13; y el artículo de Francisco Mendizábal elogiando su figura "In memoriam" ", 21/3/1962, pág. 3 .

${ }^{492}$ Era sacerdote y utilizaba el pseudónimo “C. de Myriam". Entró a formar parte de la redacción en 1938 .

493 Redactor del periódico desde 1910; se encargaba también de la crítica taurina.

${ }^{494}$ Redactor del periódico desde 1926.

495 "Croniquilla de antaño. Aquellos antiguos locales", por "Fernández" -Gerardo Serrano-, DR, 1/11/1944, pág. 8. 
Los años de "La Editorial Católica": redactores líricos, fervor católico, y consignas.

la consiguiente falta de dinamismo en el periódico que hacían. Ayudaban también a ello la situación por la que atravesaba la prensa española en general. Con el papel -de pésima calidad- racionado, el periódico era una simple hoja en 1940, y sólo tenía cuatro páginas los domingos y algunos martes. A partir de septiembre de 1941 volverá a tener cuatro los diarios y seis los festivos ${ }^{496}$, hasta que cambie de formato en 1944, como luego veremos. La maquetación volvió a ser tortuosa y elemental, como antaño, atendiendo más al ahorro de espacio que a cualquier otro criterio.

Gracias al control estatal disponemos de un peculiar testimonio: la opinión de los funcionarios de la Delegación Nacional de Prensa sobre el periódico, tanto sobre sus contenidos como sobre su factura técnica. Esos comentarios eran elaborados en Madrid por inspectores que

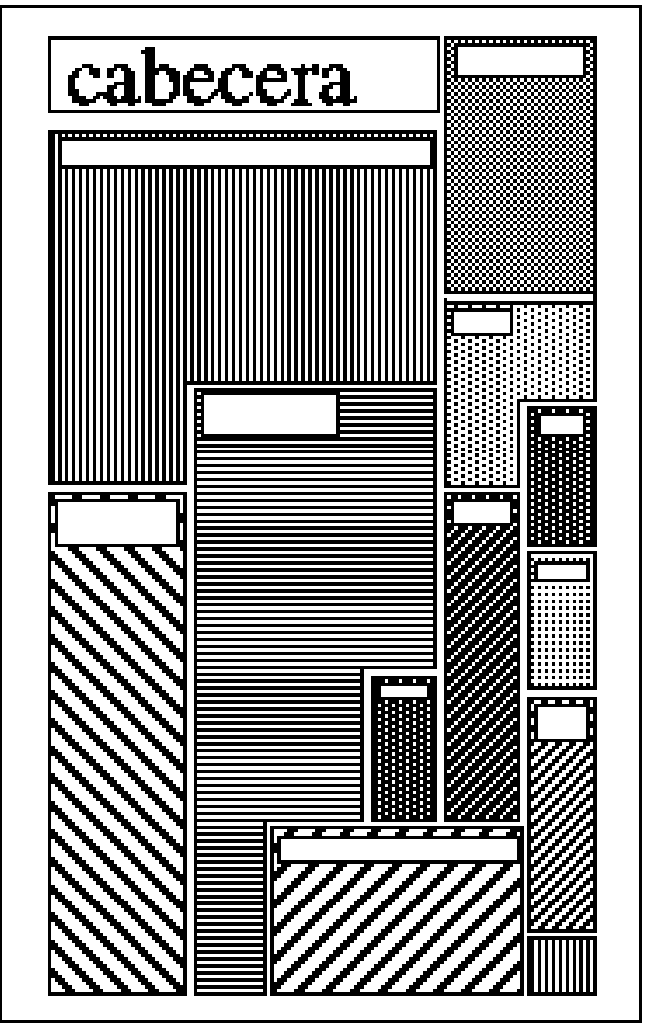

Maquetación de una primera página de revisaban todos o la Diario Regional en 1941.

${ }^{496} \mathrm{Cfr}$. en el apéndice 1 la estadística completa. 
Los años de "La Editorial Católica": redactores líricos, fervor católico, y consignas.

mayoría de los periódicos del país elaborando un breve informe que atendía a la calidad de los mismos en los siguientes aspectos: 1.- política: editorial y comentarios; 2.- información: secciones fijas, reportajes, colaboraciones, y corresponsales; 3.- recreativa: deportes, teatros, efemérides...; 4.- técnica; y 5.cumplimiento de consignas. A todo esto se añadía en algunas ocasiones un juicio global sobre la publicación, y siempre, al final de la "hoja de inspección» -como denominaban su informe- señalaban cuales eran a su juicio los mejores y los peores periódicos entre los revisados. De las "hojas de inspección que hemos consultado pueden destacarse los siguientes juicios: el periódico apenas tenía colaboraciones si no eran de agencia, era frecuente que no publicara editorial497, se publicaba en dos hojas sueltas cuando tenía cuatro páginas, lo que hacía muy incómoda su lectura498, la primera página presentaba una "confección desordenada: excepto una todas las noticias van a una columna", las páginas interiores eran "vulgares", y la última era con frecuencia "todo plomo", o "confección en bloques. La titulación poco vibrante y

497 "Hoja de inspección" no 162, correspondiente el número de 21/6/1942. Archivo General de la Administración del Estado (A.G.A.), sección Cultura, caja 280.

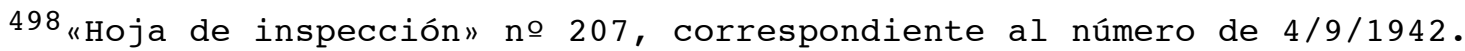
ibid. 
Los años de "La Editorial Católica": redactores líricos, fervor católico, y consignas.

expresiva»499, solía cumplir bien las consignas, pero algunos días podía ocurrir los siguiente:

\footnotetext{
«POLITICA.

Las apreciaciones que hacen son certeras; $y$ el comentario sobre la falta de calor en el cumplimiento de consignas, esclarecedor por lo que respecta a la mentalidad del organismo oficial: estaban convencidos de que la opinión dirigida que fabricaran en sus laboratorios, podía ser una natural y fragante realidad, que mejorara la opinión natural, o cuando menos, se le igualara. En esto sí que se comportaban como hombres del siglo $\mathrm{Xx}$.

Las secciones -como puede verse en el apéndice 2apenas si habían experimentado variaciones distintas de la mera extinción. Desaparecieron todas las "páginas" específicas, y la última plana dedicada a la vida en la ciudad -característica de Valverde- y aparecieron los

499 "Hoja de inspección" no 255, correspondiente al número de 24/10/1942. A.G.A., sección Cultura, caja 279.

500 "Hoja de inspección" no 206, correspondiente al número de 3/9/1942. A.G.A., sección Cultura, caja 280 . 
Los años de "La Editorial Católica": redactores líricos, fervor católico, y consignas.

artículos diarios de Martín Abril dedicados a los temas ya descritos. La información municipal se denominaba ahora "Valladolid al día". Adquirirá un mayor dinamismo cuando Calabia o de Pablos comiencen a hacer "Intereses vallisoletanos", una subsección de frecuente carácter reivindicativo. Durante estos años, como es lógico, la sección por antonomasia era la de internacional, con noticias sobre la guerra procedentes de la agencia "Efe", o de la alemana "DRV". Los cambios en la empresa trajeron sobre todo más información de agencia -de "Logos", claro está-, que se concentraba en crónicas desde distintas partes del mundo: Berlín, Roma, Lisboa, Tokio, Washington, etc. La importancia que se les concedía quedó clara cuando se les consagró íntegra la última página, bajo la cabecera "crónicas internacionales", y parte de la primera, donde solía insertarse la que resultara más interesante.

Pese a esa primera ayuda desde Madrid, el periódico llevaba una vida lánguida501; sin embargo, en ese auxilio se cifraban todas las esperanzas. Tal como era costumbre en el periódico, cuando salió del peligro de muerte, se

${ }^{501} \mathrm{si}$ tomamos como índice los anuncios por palabras, en 1940-41 publicaban alrededor entre 15 y 20 diarios. En 1943 se redujo a la mitad la tarifa y aumentaron hasta situarse entre 40 y cincuenta en cada número, para luego volver a descender, pese a que en el verano de 1944 se lanzó una oferta especial por la cual se podía publicar un anuncio en todos los diarios de la cadena. Cfr. DR, 1/8/1944, pág. 1. El precio de estos anuncios era veinte veces mayor que el de los ordinarios. 
Los años de "La Editorial Católica": redactores líricos, fervor católico, y consignas.

anunció que comenzaba una nueva etapa502. Para reanimarlo se contrató a Félix Antonio González, un joven periodista que sucedería a Calabia en la jefatura de la redacción 503. La marcha de De Pablos a El Norte significó un incremento de la competencia, y pocos meses más tarde se tomó una decisión atrevida: cambiar el formato del periódico. El primero de noviembre de 1944 salió a la calle el nuevo Diario Regional. Había perdido dieciséis centímetros de altura y unos diez de anchura. Cambió también la cabecera, y pasó a tener seis páginas los diarios, y doce los martes y domingos. En gasto de papel, esto significaba un consumo más bajo los diarios - -16\%-, y más alto domingos y martes - +12\%-. El resultado final era más o menos el mismo que antes: el consumo de papel se reducía en conjunto un 5\%504.

$502 \mathrm{En} \mathrm{la} \mathrm{información} \mathrm{sobre} \mathrm{las} \mathrm{juntas} \mathrm{generales} \mathrm{de} \mathrm{accionistas}$ ordinaria y extraordinaria celebradas en marzo de 1943, se decía: "(...) transcurrieron en medio de gran entusiasmo, tanto por las referencias de la marcha de nuestra Entidad en el pasado ejercicio, como por los acuerdos tomados en orden a su progreso para el porvenir. "Asistió a los actos don Francisco de Luis Díaz, consejero delegado de La Editorial Católica, que recibió el homenaje cordialísimo de los accionistas por su constante denuedo en conseguir que Diario Regional cuente con los medios y recursos que le sean indispensables para la plena consecución de su cometido.

"Al dar a conocer a nuestros lectores esta brevísima referencia, sentimos la alegría de expresar que se inicia una nueva etapa en nuestra colaboración al servicio de Dios y España."

"Junta general ordinaria y extraordinaria. Una nueva etapa", DR, 31/3/1943, pág. 1 .

${ }^{503}$ Cuando estaba a punto de licenciarse en Historia entró en Diario Regional como crítico de pintura y música. Poco tiempo después -a finales de 1943- pasó a ser redactor jefe a los 21 años de edad.A lo largo de sus diez años de trabajo en el periódico resultó un apoyo fundamental, tanto para suplir a Martín Abril en las tareas que éste no atendía, como para apoyar las reformas que más tarde introducirá Santaella. Cfr. entrevista con Félix Antonio González.

${ }^{504}$ Pueden verse en al apéndice 1 los datos pormenorizados. 
Los años de "La Editorial

fervor católico, y consignas.

Pero la novedad más llamativa era el diseño, sobre todo de la primera página: no había textos ni titulares, sólo fotografías con sus correspondientes pies y cabeceras. Era una portada más propia de una revista gráfica que de un diario. La maquinaria en que se imprimía había cambiado también: se abandonaron las viejas rotoplanas por una rotativa. La transformación técnica coincidió con un forzoso cambio de domicilio que había llevado las oficinas del periódico del número 86 al 33 de la céntrica calle de Santiago505. Los efectos de la ayuda de "La Editorial Católica», al menos en lo material, eran bien patentes. De todos modos

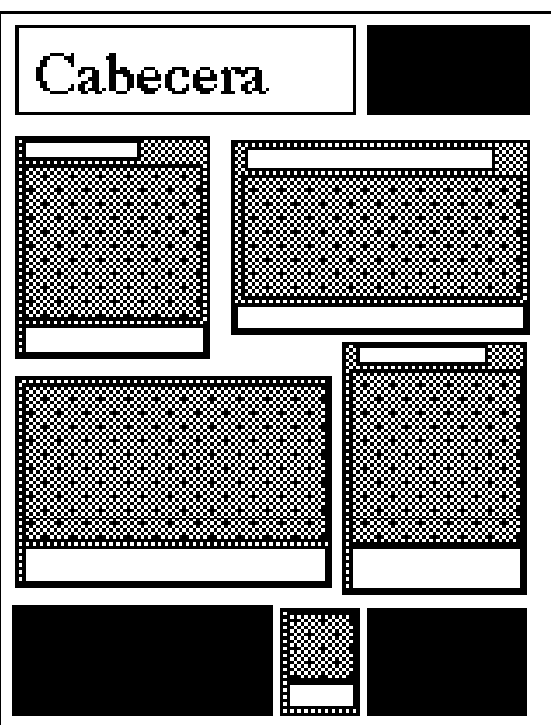

Fublicidal \%otogritis

Caheors y pies de foto Maquetación de una primera página de Diario Regional con el nuevo formato de noviembre de 1944 .

hizo falta poco tiempo para

darse cuenta de que el nuevo diseño no era un éxito. Un mes más tarde volvían a aparecer titulares con tipos

${ }^{505} \mathrm{El}$ derribo de su antiguo edificio cogió por sorpresa en el mes de febrero al periódico, tan amigo de comentar proyectos urbanísticos, y fue motivo de chuflas por parte de sus detractores. Cfr. DR, 20/2/1944, pág. 1. En el mes de junio ya se había adquirido un nuevo edificio para instalar la redacción, administración y talleres, DR, 9/6/1944, pág. 1 . 
Los años de "La Editorial Católica": redactores líricos, fervor católico, y consignas.

ordinarios en la primera página506, y, antes de que hubiera transcurrido un año, el periódico volvía, el 15 de julio de 1945 a su formato anterior.

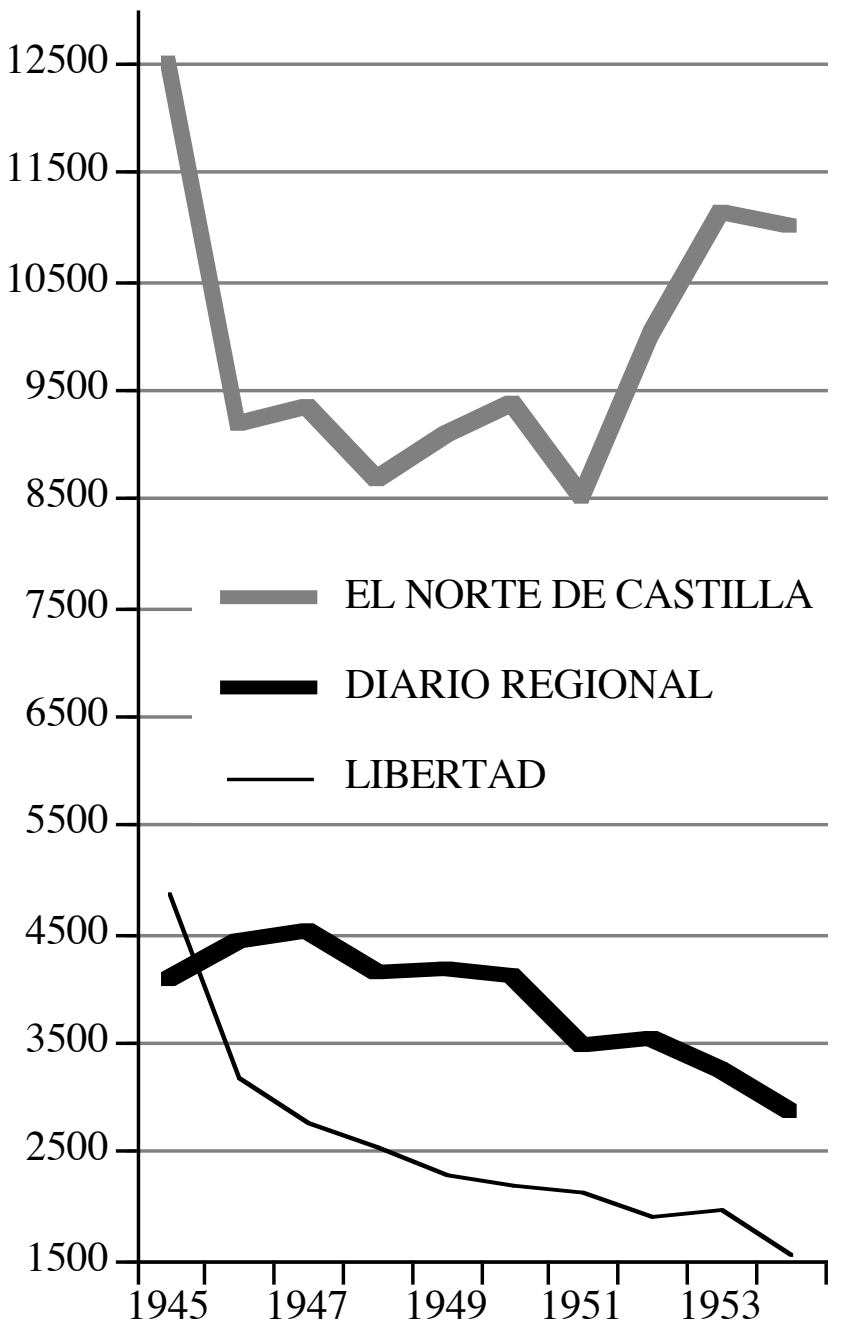

Gráfica 4.- Difusión estimada para los diarios de Valladolid, 19451954507 .

506El primero, muy del tiempo, rezaba así: "En España no hay agentes de la Gestapo", DR, 5/12/1944, pág. 1 .

507Fuente: aportaciones a la Institución San Isidoro, Cfr. NIETO TAMARGO, Alfonso, La empresa periodística en España, Ediciones Universidad de Navarra, Pamplona, 1973, cuadro 20.

En conversación mantenida con Félix Antonio González las apreciaciones de éste diferían notablemente de los datos aportados por Nieto. González afirma que cuando El Norte tenía unas tiradas de 11.000 ejemplares aproximadamente, Diario Regional rondaba los 8.000. Según estos datos, sería uno de los mejores momentos del periódico, al que se había llegado gracias al impulso dado por el propio Félix Antonio González y a las reformas introducidas por santaella. No obstante, González confirma la pésima situación del diario, al menos 
Los años de "La Editorial Católica": redactores líricos, fervor católico, y consignas.

Al margen de cuestiones técnicas, el periódico estaba ahora caracterizado por una absoluta atonía en la opinión. Los editoriales eran muy raros, $y$ en todo caso hay que decir que se había incrementado la atención a las informaciones de la vida social -sobre todo de las clases más acomodadas- y literaria de la ciudad, al tiempo que se seguían recogiendo en las páginas del rotativo directrices e iniciativas del arzobispo, campañas de Acción Católica, y editoriales-homilía en las fiestas religiosas. Las iniciativas parecían provenir más que nada de la gerencia, al frente de la cual estaba Luis Iglesias Veiga desde el cambio de empresa, y de los redactores jóvenes que se irían incorporando a la plantilla ${ }^{508}$ : concursos ${ }^{509}$,

en lo que se refiere a tiradas, en 1954. La explicación que aporta para este bajón incide sobre todo en el carácter del nuevo director: si Santaella era sin discusión un excelente profesional, tenía una manera de ser que le hacía difícilmente soportable para el resto de la plantilla. Esto, a la larga, acababa por generar problemas humanos que no podían menos que repercutir en la marcha del rotativo. De alguna forma, Félix Antonio González servía para detener algunas de las brusquedades de Santaella, y su marcha a El Norte en 1953, además de privar de un periodista activo y experto a Diario Regional, supuso un empeoramiento de las relaciones humanas en la plantilla.

Otra interpretación distinta es la que aporta Jerónimo Gallego. Según él, -que corrobora los problemas que generaba el carácter de Santaella, y su gran valía profesional- todos los esfuerzos realizados -y fueron muchos, intensos $y$ variados- no conseguían levantar la tirada si no era de 2.700 a 2.900 ejemplares o cifras similares. La razón en su opinión, y el propio Santaella así se lo hizo ver, no era otra que la absoluta preponderancia de El Norte de Castilla en las preferencias de los lectores vallisoletanos.

Sea como fuere, nos parece que la evolución de las ventas del periódico puede ser interpretada en esquema como una caída que termina por llevar a una situación desastrosa a la altura de 1954, tal como reconoce la propia empresa en los documentos que citamos más adelante.

${ }^{508}$ Cfr. Registro Mercantil de Valladolid, inscripción 3ạ. hoja 597.

509 A través de uno de ellos, celebrado en los meses de abril y mayo de 1950, podemos hacernos una idea de la difusión del periódico: en una semana se presentaron unos 12.000 boletos de concursantes -unos 2.000 por día-, y en otra unos 17.000 , lo que supone al menos una difusión 
Los años de "La Editorial Católica": redactores líricos, fervor católico, y consignas.

patrocinio de un equipo en la vuelta ciclista a España en 1947, etc. Martín Abril, mientras tanto, era galardonado con la encomienda de la orden del mérito civil en 1947, y publicaba otro libro -Cancionero- en 1949.

La difusión, disminuía progresivamente, como se puede apreciar en la gráfica 4. De nuevo se volvieron a tomar medidas: Félix Antonio González pasó a redactor jefe en 1943, lo que supuso un aumento de la acometividad en la información local; en 1949 vino de Madrid Manuel Santaella, un joven que había trabajado en la redacción de Ya. Será primero subdirector para sustituir finalmente a Martín Abril en la dirección en 1952, sin que éste abandonara la redacción ${ }^{510}$. Se contrataron además en 1949 los servicios de José Luis Pérez Herrero, y de Jerónimo Gallego. Este último, miembro de la A.C.N. de P., había dirigido la revista de "los Luises" -Valor y Fe- mientras cursaba los estudios de Derecho y se iba a convertir en

de unos 3.000 ejemplares diarios. Los datos que tenemos a través de las aportaciones a la Institución San Isidoro, señalan para este año una difusión media de 4.100 ejemplares.

Este tipo de concursos fueron iniciativa de Jerónimo Gallego, que empezó a trabajar como colaborador hacia 1948, y que se convertirá en uno de los redactores más activos con la llegada de Manuel Santaella a la dirección.

510 En la práctica Santaella pasó a ejercer las funciones de director desde el primer momento, ya que Martín Abril, que solía retirarse pronto a casa, apenas si llevaba la dirección efectiva del rotativo, y desde luego no en lo que se refiere a las cuestiones técnicas, cierre, etc. La acogida que se dispensó a santaella por parte de la redacción no fue en un primer momento muy amistosa, pero con el tiempo terminaría por ser respetado y admirado por todos, pese a que tuviera un carácter bronco. El motivo fue que se terminó imponiendo la valía periodística del andaluz venido de Madrid: un hombre trabajador, que dedicaba cuando menos dieciocho horas al periódico, con grandes inquietudes culturales, $y$ empeñado en cuerpo y alma en levantar a Diario Regional.

Entrevistas con Félix Antonio González y Jerónimo Gallego. 
Los años de "La Editorial Católica": redactores líricos, fervor católico, y consignas.

uno de los apoyos fundamentales para santaella en su empeño por levantar el periódico511.

La llegada de Santaella a la dirección no se realizó sin dificultad. Él mismo lo relata así:

"(...) ocurrió en Diario Regional algo curioso: primero, yo fui dirigido por [Francisco Javier Martín Abril]; luego, él fue dirigido por mí. Sin reservas. Con una lealtad total y absoluta y sin que fuera indispensable sino una conversación un poco agria para poner las cosas en su punto. (...) Naturalmente, no se empuja en la "cola" sin suscitar gruñidos y protestas." 512

Su tarea puede resumirse como el intento de transformar el periódico en un órgano informativo, de hacer un periodismo más despierto, a la búsqueda de la noticia, en lugar del que era habitual en los redactores veteranos, acostumbrados a trabajar en la elaboración rutinaria de lo que llegara a la redacción ${ }^{513}$. Para llevarla a término se

511 "Plantilla del personal..." Sindicato Provincial del Papel, Prensa y Artes Gráficas -Valladolid. A.H.P.U.V., Sección A.I.S.S., caja 4.694. "Nota de los productores que Diario Regional S.A. de Valladolid entrega a la Delegación de Sindicatos del Papel Prensa y Artes gráficas" de fecha 16 de septiembre de 1949. Ibid., caja 4.693. "Plantilla-escalafón del personal de esta empresa [Diario Regional S.A.].- Artículos 47 y 48 de la Orden del Ministerio de Trabajo de fecha 14 de julio de 1950, B.O.E. del 2 de agosto del mismo año" Sindicato Provincial del Papel, Prensa y Artes Gráficas. Fechado el 10 de octubre de 1950. Ibid., caja 4.694. Entrevista con Jerónimo Gallego.

512 "Carta abierta a un joven timonel", por Manuel Santaella, DR, 20/3/1966, pág. 17 .

${ }^{513}$ Una muestra de ese estilo la tenemos en una queja de Martín Abril que nos dibuja los perfiles básicos de las redacciones de la época. Es también uno de los pocos exabruptos del escritor que se conservan impresos: "¿Cuántos avisos, comunicados, notas y reseñas llegan todos los días a los periódicos, confeccionados por individuos que no son periodistas, que no están dentro de nuestro oficio? Se trata de cuartillas absurdas, escritas quizá por los dos lados y redactadas con un enrevesamiento que no tiene arreglo. 
Los años de "La Editorial Católica": redactores líricos, fervor católico, y consignas.

apoyó sobre todo en Félix Antonio González, el redactor jefe, y en los redactores jóvenes, que -paradójicamenteno eran redactores oficialmente, seguramente por carecer de carnet, y que figuraban en todo caso como colaboradores fijos: Rafael Andreu de la Cruz, Cirilo Muñoz López Palomo -"Carlos Zeda", que había comenzado como tipógrafo en La Editorial Católica-, Félix González Ferrández, o el propio Jerónimo Gallego, que consiguió el título de periodista en uno de los cursillos intensivos, en 1949. Ellos eran los encargados de hacer los "interviews", como entonces se decía, de dar aliciente a una crónica deportiva, al comentario de un proyecto municipal, etc. Junto a éstos, un nuevo redactor, Enrique Santos, cuidará la confección del periódico, junto al redactor jefe. Pero su esfuerzo no fue suficiente para hacer remontar la línea descendente de ventas del periódico514. Probablemente, una de las razones

"La nota se ha cocinado en una reunión de señores graves, de respetables damas, o en una asamblea o junta general, en el domicilio del secretario de tal entidad benéfica o en casa de la presidenta de cual institución de caridad. Y así está ella. Los interesados penetrarán en la Redacción del periódico, preguntarán por el director y, después de un largo exordio de palabras gastadas, sacarán la cuartilla que quieren publicar. Es inútil que pretendamos convencer a estas personas de que la nota no es de recibo. Ellas quieren que se publique precisamente esa nota, y no otra similar pero bien redactada y peinada. No es difícil que la cuartilla en cuestión comience de esta manera: "En el día de ayer -aquí la fecha que sea- a las veinte horas, tuvo lugar en (...). Y luego esas frases redundantes, esos elogios casi familiares... Pero ¿cómo quieren ustedes que el periódico se someta a sus caprichos? (...).

"El periodismo tiene sus exigencias, sus secretos, su técnica, su gracia y su garbo. El periodismo deben hacerlo los periodistas, no los aficionados que permanecen fuera."

"El periodismo para los periodistas", DR, 20/2/1949, pág. 6, últ.. $\mathrm{Si}$ bien captaba ya la insuficiencia de ese tipo de periodismo, es de notar que su concepción del periodismo se limita a un estilo literario: no se abandonaba el concepto sedentario de la profesión.

${ }^{514}$ Cfr. más arriba -nota 42- la interpretación que hace de estos hechos Félix Antonio González. 
Los años de "La Editorial Católica": redactores líricos, fervor católico, y consignas.

por las que esto fue así no estaba en la vida misma de Diario Regional sino en la de su colega. Fernando Altés Villanueva, alma de la empresa editora de El Norte de Castilla, iba a demostrar en estos años su capacidad de reacción. Miguel Delibes, que ya trabajaba para el periódico, y que había recibido en 1947 el premio Nadal, comenzará a hacer los editoriales en 1952. En 1953 llevan a su redacción a Félix Antonio González, por esas mismas fechas rehacen la red de corresponsales en los pueblos, contratan nuevos colaboradores -Ignacio Valverde fue uno de ellos- y aumentan el número de páginas del periódico de 8-10 a 10-12. Miguel Delibes era ya nominalmente el subdirector, y realmente el director de la publicación. La envejecida redacción de El Norte cobró nuevos bríos, y con ella el periódico515: el efecto de todo esto en las ventas está a la vista en la gráfica 4 y no precisa comentarios. La marcha ascendente del negocio y la actitud abandonista de "La Editorial Católica" con respecto a Diario Regional llevaron a Altés a pensar primero en contratar a Martín Abril y, después, en comprar al colega. Poco faltó para que alcanzara su propósito516.

Portavoz oficioso de la jerarquía.

515SÁnCHEZ SÁNCHEZ, José Francisco, op. cit., págs. 53, 72, 85, 95 y 98 .

${ }^{516}$ Cfr. ibid. págs. 103 y 106 
Los años de "La Editorial Católica": redactores líricos, fervor católico, y consignas.

Los cambios de los últimos años iban haciendo que el peso de la información en el periódico modificara un tanto su carácter de periódico-de-opinión-católica. No obstante, como veremos ahora, ese rasgo seguía siendo esencial en Diario Regional todavía en 1954, y era el que mejor lo definía para el resto de la etapa que abarcamos en este capítulo. Como ya adelantamos, los elementos constitutivos de esa opinión no podían ser ya las cuestiones políticas, que habían sido asumidas en exclusiva por el aparato estatal. Se trataba ahora de colaborar con la autoridad eclesiástica difundiendo sus enseñanzas y secundando sus iniciativas. Era la aplicación a su actividad propia de la idea sobre la misión de los "seglares", a quienes el periódico definía como "(...) aquellos que, respondiendo al llamamiento de la jerarquía se han alineado tras de ella con el propósito de colaborar más de cerca e intensamente en la misión salvadora de la Iglesia»517. Podemos distinguir dos tipos de campañas bien distintas dentro de este mismo género: las que se refieren a enseñanzas del Papa, y las que atienden a indicaciones de los obispos españoles, y -más en concreto- del arzobispo de Valladolid.

517DR, 19/9/1951, editorial preparando el Congreso Mundial de Apostolado Seglar. 
Los años de "La Editorial Católica": redactores líricos, fervor católico, y consignas.

CON ROMA, PASANDO POR MADRID

El conjunto de las informaciones que se ocupan de las enseñanzas del Papa nos interesan sobre todo porque constituyen el contrapunto del nacional-catolicismo que imperaba en España oficialmente en estos años. Bastaría con retrotraernos al discurso de Pío XII a los periodistas católicos que citamos más arriba para demostrarlo, pero hay otros aspectos que merecen que se les preste atención. Quizá el primero sea advertir que el apoyo a las enseñanzas papales no se dio pacíficamente en estos años. Es de sobra conocida la prohibición de la encíclica que condenaba el nazismo en 1937 -hay que esperar al final de la guerra para que se mencione el documento en las páginas del periódico518- y la mutilación del mensaje papal con motivo del fin de la guerra519. En 1944 se publicó un editorial tomado de Ecclesia que se defendía de los que acusaban a la publicación de una excesiva unión con el Papa: el eje de la argumentación era el derecho que asistía a la cabeza de la Iglesia a pronunciarse sobre las cuestiones que estimara oportuno para la guía de los católicos, sin exceptuar -como pretendían algunosaquellos problemas que afectaban también al poder

518Cfr. "El Papa relata el terror nacionalsocialista contra los representantes de la Iglesia Católica. Miles de religiosos fueron inmolados en los campos de concentración alemanes" DR, 3/6/1945, págs. 4 y 5 .

519Cfr. Gómez PÉREz, Rafael, op. cit., Rialp, Madrid, 1986, págs. 7273 . 
Los años de "La Editorial Católica": redactores líricos, fervor católico, y consignas.

temporal520. Es la única referencia al laicismo que encontraremos. El resto de los problemas en la aceptación e interpretación de mensajes papales llegará precisamente por el otro extremo: del clericalismo, que lleva a confundir vida civil y eclesiástica.

El asunto que acaparó la mayoría de las declaraciones papales en los primeros años de este periodo fue la paz. Las llamadas de Pío XII a evitar el conflicto primero, y a ponerle fin cuanto antes, después, se publicaban en primera página dando lugar a mezclas paradójicas: un día se publicaba un artículo titulado "El belicismo judaico no logrará desencadenar la guerra", y dos días más tarde, en el mismo lugar, otro encabezado por la frase "El Papa excita a todos a implorar a Dios para que nos preserve de nuevos conflictos"521. Con el comienzo de la guerra los titulares pro-Eje iban de la mano con las campañas de oración por la paz que organizaba la Acción Católica, secundando peticiones del $\mathrm{Papa}^{522}$; o se recogía la noticia de la condena del pontífice de la invasión de Holanda y Bélgica, y se afirmaba en un editorial que "la violencia es la negación de todo derecho (...) únicamente en legítima

\footnotetext{
520 "Vaticanismo", editorial, DR, 20/2/1944, págs. 1 y 3 .

${ }^{52}{ }^{1} \mathrm{DR}, 18 / 8 / 1939, \mathrm{y} 20 / 8 / 1936$, respectivamente, ambos en primera página.

522 "Oraciones por la paz", editorial, DR, 12/6/1940. Ese mismo día España abandonaba la neutralidad para declararse no beligerante.
} 
Los años de "La Editorial Católica": redactores líricos, fervor católico, y consignas.

defensa es legítimo el empleo de la fuerzan523, para publicar luego titulares a toda plana anunciando que "La guerra seguirá hasta que el Eje la termine. Alemania ha dado la libertad al continente europeo»524.

En definitiva, se trataba de mantener un difícil equilibrio que sólo podía resolverse apelando al anticomunismo. Eso es lo que se hacía en el editorial de primero de abril de 1941, con la siguiente argumentación: "una de las finalidades esenciales y concretas de la guerra civil (...) fue la de exterminar el comunismo internacional", hoy estamos en la misma postura -la única que la Iglesia apoya- deseando la paz, la justicia, el honor, la libertad, como ha dicho recientemente el Papa, contra el sovietismo, que es la negación absoluta del espíritu. El colmo de la esquizofrenia informativa se alcanzó posiblemente un 26 de diciembre de 1941. En la mitad superior de la primera página los titulares a siete columnas eran:

"Conmovedor y sensacional mensaje del Papa. La paz es una empresa universal en la que debe cooperar la humanidad entera. Premisas esenciales para una paz justa y duradera"

523 "La invasión de Bélgica es condenada, el Papa expresó su condolencia a los reyes de Bélgica, Holanda y Luxemburgo. Y ruega a Dios que los tres países recobren pronto su independencial, DR, 12/5/1940, pág. 1 «En estas horas de angustia», editorial, DR, $10 / 4 / 1940$.

${ }^{524} \mathrm{DR}, 9 / 11 / 1940$, pág. 1 . 
Los años de "La Editorial Católica": redactores líricos, fervor católico, y consignas.

Debajo, en la misma página, y a cinco columnas, otros titulares decían:

"Von Ribbentrop habla para España. Los países del Eje
lucharán hasta librar al mundo de la plutocracia y del
comunismo"

Los problemas de conciencia que esto pudiera plantear a algunos, se resolvían por el método que podríamos denominar de la "interpretación correcta de las palabras del Papa", en un editorial publicado unos días más tarde: estaba claro -se advertía- lo que quería decir Pío XII: la auténtica paz sólo se alcanza a través de los valores del espíritu, por tanto es preciso acabar con el soviet, sí, pero también con los otros materialismos, que acaban llevando también al comunismo525.

Se llegó a alcanzar una gran maestría en el manejo de la "correcta interpretación", habilidad que permitía escuchar -y alabar- cualquier declaración por contraria a los planteamientos políticos del régimen que pudiera parecer. El mensaje de Navidad del Pontífice en 1944 estuvo dedicado a la convivencia social. El periódico dedicó toda la primera página a informar sobre el mismo, bajo los siguientes titulares: "El Papa fija las normas que deben regular una sana democracia»526. Contra su costumbre, Diario Regional no insertó ningún comentario,

\footnotetext{
525 "Creadores del comunismo", editorial, DR, 31/12/1942, pág. 1 . ${ }^{526} \mathrm{DR}, 30 / 12 / 1944$, pág. 1.
} 
Los años de "La Editorial Católica": redactores líricos, fervor católico, y consignas.

es de suponer que en virtud del desconcierto y de alguna indicación oficial. Diez días más tarde se hizo pública la exégesis oficial en un editorial, que, después de hacer algunos alambicados razonamientos, concluía:

"(...) por estas anteriores palabras pontificias cae por su misma base el sistema político del sufragio universal absoluto o sin restricciones." 527

Al día siguiente el periódico pudo publicar ya un comentario al mensaje papal, que es un ejemplo de cómo se pueden escribir setenta líneas sin decir nada528.

Las informaciones sobre el Vaticano se multiplicaron con motivo del avance aliado en tierras italianas. El temor -tristemente confirmado- de posibles bombardeos de la ciudad, motivaron la reiteración de editoriales que condenaban los horrores de la guerra, y especialmente el castigo de centros no militares. La prensa extranjera -con razón- criticaba que esas denuncias se hicieran ahora, cuando ya era tarde, y antes se hubiera guardado silencio. Diario Regional reprodujo la contestación del ya a las críticas. En ella se afirmaba que mentían los medios extranjeros: desde el primer momento habían dado cabida en sus páginas a los llamamientos del Papa a la paz ${ }^{529}$.

\footnotetext{
527 «El Mensaje Orientador», DR, 10/1/1945, pág. 1 .

528 «El Papa y la sana democracia», DR, 11/1/1945, pág. 8, últ..

${ }^{529}$ Cfr. "Los bombardeos de ciudades abiertas", "El horror estéril", y "Una posición cristiana", editoriales tomados de Ya, DR, 26/5/1943 y $29 / 5 / 1943$.
} 
Los años de "La Editorial Católica": redactores líricos, fervor católico, y consignas.

Ciertamente, la prensa católica española no había dado una lección de coherencia, pero tampoco de catolicidad, en el sentido de universalidad, aunque ahora utilizara al Papa para justificarse.

En la Ciudad de la Gran Promesa

Por lo que hace a las campañas que podríamos denominar diocesanas, lo primero que conviene tener en cuenta es su elevado número, consecuencia directa del empuje evangelizador de estos años $y$ del intenso fervor religioso con que se vivieron. El arzobispo de Valladolid entre 1938 y 1953 fue Mons. Antonio García y García, y su personalidad tiene bastante que ver con la fisonomía del periódico en ese mismo periodo. Como contestación al telegrama de felicitación por su nombramiento que le envió Diario Regional, García y García contestó enviando una bendición para el periódico:

"para que Diario Regional sea, no sólo un gran periódico técnicamente, sino foco potentísimo de luz purísima en este amanecer glorioso de nuestra Patria» 530

Con motivo del fin de la guerra, publicó una pastoral, en la que hacía notar a los fieles que no bastaba con dar vítores, sino que era necesario "continuar la Cruzadan:

530 "El Arzobispo de Valladolid bendice a Diario Regional», DR, 24/2/1938, pág. 1 . 
Los años de "La Editorial Católica": redactores líricos, fervor católico, y consignas.

«Es necesario, con necesidad absoluta, que el Movimiento Nacional no pierda su carácter de Cruzada patriótica y religiosa, quedando reducido a explosiones fragmentarias con influencias perniciosas laicas, racionalistas, marxistas, masónicas, liberalescas." 531

Para completar un esbozo de su semblanza, basta quizá reproducir lo que el periódico publicaba con motivo de su muerte:

"Sus quince años de episcopado quedarán vinculados a obras trascendentales de la Archidiócesis: el Santuario Nacional de la Gran Promesa, el magno proyecto del Alcázar de Cristo Rey, el impulso de la Acción Católica en sus diferentes ramas, el florecimiento del seminario, el apoyo a las Asociaciones piadosas, la fundación del Carmelo de Cristo Rey, la dirección y ayuda en pro del secretariado de caridad y de las viviendas de la Constructora Benéfica "San Pedro Regalado"..." 532

Fue un hombre convencido de que el régimen de Franco era el mejor sistema político para España, y no se recató de hacer declaraciones de apoyo al mismo, ni de reconvenir a los que hablaban de vuelta a la democracia -que él, como tantos otros, identificaba con la situación de 1931-533, ni de indicar expresamente que se votara sí a la ley sucesoria534. Sus declaraciones llenaron en numerosas ocasiones las siete columnas de la primera página de Diario Regional, $y$ sus fotografías, junto con las de Franco, fueron las más frecuentes en el periódico. La gran

531 «Documento arzobispal. iLa guerra ha terminado! Demos gracias a Dios", DR, 3/4/1939, pág. 4, últ..

532 «El Arzobispo Don Antonio García», editorial, DR, 16/5/1953, pág. 3 .

533 "Importante exhortación pastoral del Arzobispo de Valladolid. El Alzamiento Nacional fue legítimo, justísimo para la defensa de la Religión y de la Patria», DR, 15/1/1947, pág. 1.

534 "Procede votar favorablemente la ley sucesoria. Según nuestra conciencia de ciudadano español y de Arzobispo", DR, 6/7/1947, pág. 1. 
Los años de "La Editorial Católica": redactores líricos, fervor católico, y consignas.

diferencia entre su enfoque $y$ el oficial fue que mientras el régimen se gloriaba de haber construido una España católica, el prelado vallisoletano $-y$ con él nuestro periódico- solía hacer hincapié en las conductas incompatibles con el catolicismo que todavía se detectaban en los españoles: afán de riquezas, frivolidad, orientaciones intelectuales poco cristianas, etc. Sus denuncias en este sentido no carecieron de valor: en 1942 pronunció un discurso en que fustigaba la conducta de los ricos en un momento en que "hay personas que se mueren de hambre" -algo que la censura no permitía publicar-, y se refirió a una revista de propaganda alemana en términos igualmente duros:

\footnotetext{
"(...) me veré obligado a condenar la revista Signal de seguir con el doble daño de la impudicia de frecuentes grabados y de orientación pagana de la juventud» 535
}

Una de sus labores predilectas resume buena parte de su actividad. Se trata de la obra "Pan y Catecismo", que se proponía impulsar las labores de caridad y de difusión de la doctrina católica en los barrios, objeto preferente de su atención durante todo su mandato. Año tras año aparecerá información en el periódico -que abandonaba en estos casos los tonos líricos- sobre la obra mencionada y

535 "Posiciones doctrinales", DR, 14/4/1942, pág. 1. Diario Regional dejó de publicar desde entonces publicidad de la revista. 
Los años de "La Editorial Católica": redactores líricos, fervor católico, y consignas.

sobre las campañas de caridad $^{536}$, llamando la atención de los vallisoletanos sobre la miseria reinante:

"Valladolid es una ciudad de extensos barrios. Pero nos referimos aquí al significado triste de la palabra "barrio". Al hablar de los barrios nos vamos con la imaginación a esas zonas miserables de la ciudad donde viven inhumanamente miles de personas, de hermanos nuestros, sin que a ellos llegue la civilización, en el sentido amplio y hermoso del vocablo.

"Se acaban las calles asfaltadas, las casas confortables o limpias, y comienza el polvo o el barro, las basuras, el mal olor, las casuchas infectas. Alguna pequeña huerta acá o allá, como un trozo de alegre naturaleza entre tapias en ruina y paredes desconchadas." 537

"Digámoslo claramente. Las clases obrera y media no pueden vivir. Materialmente, no pueden vivir. Sufren hambre. Sin atenuaciones, sufren las torturas del hambre con toda su triste secuela de enfermedades, pesimismo y desesperación. Y no hay más que un remedio. Uno sólo. La intervención enérgica, y ya inaplazable, del Gobierno para que sea una realidad inmediata el abaratamiento de la vida."538

Este tipo de campañas, que iban acompañadas de frecuentes acusaciones de enriquecimiento injusto de acaparadores y comerciantes inmorales, y de llamadas a la austeridad, acabaron cuajando en la promoción de viviendas baratas en la ciudad, en la organización de misiones en los barrios obreros, en el apoyo a numerosas obras de beneficencia, $y$ en la celebración de actos informativos sobre los deberes sociales de los católicos ${ }^{539}$. No hace

536Cfr. por ejemplo "Pan y Catecismo. Cruzada de caridad", DR, 12/10/1941, pág. 1; "La obra Pan y Catecismo", DR, 20/12/1942, pág. 3, íntegra; y "La exposición catequística "Pan y Catecismo". Habla el Prelado", DR, 3/11/1945, pág. 1, editorial que define perfectamente a DR como portavoz del arzobispo.

537 "La conquista de los barrios», editorial, DR, 3/3/1942, pág.1.

538 "El grito de los hambrientos", editorial, 18/4/1942.

${ }^{539}$ Cfr. entre otros, "Acaparadores y especuladores, reos de lesa patria", editorial, 27/10/1939, pág. 1. "Comensales y danzantes", 
Los años de "La Editorial Católica": redactores líricos,

fervor católico, y consignas.

falta insistir en la semejanza de algunos de esos comportamientos con los de la Iglesia en el Antiguo Régimen.

Unida en ocasiones a la denuncia de inmoralidades en los negocios iba la que reclamaba mejoras en la moralidad pública. Fue el caso de la que se denominó "Justicia y castidad", que comenzó en septiembre de 1941 con la publicación de los Decretos del II Concilio Provincial de Valladolid, celebrado en 1930540, que condenaban la usura, y exponían criterios morales concretos sobre la codicia de bienes materiales, la modestia en el vestir, la moralidad de los espectáculos, etc. El periódico los comentó en varios editoriales que clamaban contra el egoísmo, la

editorial pidiendo austeridad y criticando los bailes ostentosos, "desmoralizadores en el orden social", 5/1/1940, pág. 1. "Campaña eficaz", editorial sobre la labor de la J.O.C. en los barrios: mejoras materiales y doctrina católica, 23/2/1940, pág. 1."Amor al prójimo", editorial, sobre los deberes sociales de las clases acomodadas, 12/2/1941, pág. 1. "La austeridad frente al lujo", editorial, 15/2/1941, pág. 1. "Realidad agobiadora", editorial sobre la necesidad de mejoras materiales como requisito previo para la evangelización de los sectores sociales deprimidos, 10/3/1942, pág. 1. "Obreros católicos", editorial con motivo de la conclusión de tandas de ejercicios espirituales a los que han asistido más de mil obreros, DR, 22/3/1942, pág. 1. "El señor Arzobispo habló ayer ante cerca de 3.000 ferroviarios vallisoletanos. Con la alocución del prelado se cerró brillantemente el ciclo de conferencias católico-sociales", 14/11/1943, pág. 2. "Doctrina social de la Iglesia", editorial con motivo de las Jornadas Sociales que se habían desarrollado en Valladolid, 12/12/1948, pág. 1. "Un barrio entero va a ser construido por los Hombres de la Acción Católica", DR, 26/6/1951, pág. 6 . "Primera adjudicación de viviendas de Acción Católica", 8/1/1952, pág. 1. "Ricos y pobres", editorial, glosando unas palabras de Pío XII llamando a la moderación en los gastos festivos, DR, 16/5/1953, pág. 1. "Viviendas para los humildes", editorial, 14/5/1953, pág. 1. En 1951 surgió la iniciativa del "Banco de los pobres" que publicará informaciones tres veces por semana en el periódico, cfr. el balance de su actividad en el año 1953 en DR, 31/12/1953, pág. 11. El alma de muchas de estas actividades era el futuro cardenal Marcelo González.

${ }^{540} \mathrm{DR}, 14,16,18,20,21$ y $24 / 9 / 1941$. 
Los años de "La Editorial Católica": redactores líricos, fervor católico, y consignas.

sensualidad, y la "ola de paganismo corrosivo" que invadía la sociedad, a la vez que llamaba a seguir dócilmente las indicaciones de los obispos ${ }^{541}$.

La cuestión de la moralidad había sido ya abordada por el periódico en un editorial del verano de 1939, en el que llamaba la atención sobre la insuficiencia de cumplir las leyes positivas del nuevo Estado: había que atenerse a la ley moral -más amplia- que le servía de sustento y razón de ser542. El verano siguiente, una pastoral del arzobispo insistía en el mismo tema543, y desde entonces sobre todo en los meses centrales del año y en tiempos de ferias- se publicarán editoriales que reclamen el destierro de bailes extranjeros e indecentes, de modas absurdas - Esas que ahora llaman Gildas»-, de los espectáculos considerados deshonestos, del gamberrismo o de la blasfemia544. A pesar de que se hubiera dicho que no

541Cfr. "Los buscadores de placer", editorial, 18/9/1941, pág. 1; "Campaña sanitaria moral", editorial, 20/9/1941, pág. 1.

542 «La ley moral», editorial, DR, 9/8/1939, pág. 1 .

543 "Las normas de la moral cristiana hay que guardarlas con rigor y exactitud. Una circular del señor arzobispo sobre la modestia, especialmente de las mujeres", DR, 13/7/1940, págs. 1 y 2;

544Cfr. por ejemplo, "Tareas de la paz", editorial, 19/8/1939. "Anacronismo ignominioso", editorial contra la celebración del carnaval, 16/1/1940, pág. 1. "La mala lengua", editorial, 6/2/1941. "La moralidad pública", editorial, 28/5/1941. "El llamado imperativo de la moda", editorial, 13/6/1941. "Se prohiben los baños públicos sin las prendas adecuadas. Los bañistas fuera del agua se vestirán con albornoces", 17/7/1941, pág. 1. "Contra los blasfemos", editorial, 15/4/1942, pág. 1. "Enérgica circular del Gobernador Civil. Reprimirá la inmoralidad, la blasfemia y el alcoholismo", 25/9/1942, pág. 1. "Buenas costumbres", editorial, 21/10/1942, pág. 1. "Espectáculos", 21/2/1943, pág. 1. "Audacias de la moda", editorial, 24/7/1943, pág. 
Los años de "La Editorial Católica": redactores líricos, fervor católico, y consignas.

bastaba la intervención del Estado, lo cierto es que de él se esperaba la actuación oportuna para conseguir esos fines:

"Recabamos la intervención de las autoridades competentes de un Estado que inspira sus decisiones en la Religión de Cristo, para que borren de nuestro panorama social tales muestras de paganismo." 545

"En alguna población de España se ha llegado a censurar rigurosamente la letra de todas las canciones, chistes, comentarios, diálogos y demás propaganda que había de hacerse en barracas y lugares de diversión." 546

La construcción de la España Católica precisaba además la depuración de las publicaciones, y ése fue otro terreno en el que se insistió reiteradas veces, pidiendo que los libros fueran "católicos y españoles" de verdad: autores como Unamuno, Dumas, Ortega y Gasset, Nietzsche, etc., motivaron diversos editoriales recordando que estaban en el Índice de Libros Prohibidos, y señalando la incompatibilidad de sus opiniones con las de la doctrina católica547. El modo de hacer estas críticas constituía a

1. "La ofensiva del pudor", por Angel de Pablos, 25/7/1943, pág. 1. "Medidas contra el gamberrismo", editorial, 6/5/1944, pág. 1. "Los niños que blasfeman", editorial, 6/5/1944, pág. 1. "Protestamos", editorial, 12/9/1947, pág. 1. "Esas que ahora llaman Gildas", editorial, 19/5/1948, pág. 4, últ..Como contrapunto, una vez más, apareció en 1951 una información de Roma en que Pío XII pedía a los jóvenes de Acción Católica que vivieran la modestia cristiana sin gazmoñería, defecto en el que indudablemente cayó el periódico más de una vez. Cfr. "Pío XII preconiza un acercamiento entre las clases sociales", DR, 3/7/1951, pág. 3. En los años cincuenta el problema comenzaba a tener ya otro signo, como es apreciable en el editorial tomado de Ecclesia "Inmoralidad y turismo", DR, 19/9/1951, pág. 5.

545 «Espectáculos sin basura», editorial, DR, 4/12/1943.

546 "Las ferias a la vista", editorial, DR, 23/8/1942, pág. 1.

${ }^{547}$ Dejando a un lado las críticas de libros, pueden verse, entre otros, los siguientes editoriales: "Los libros y el nuevo Estado", 
Los años de "La Editorial Católica": redactores líricos, fervor católico, y consignas.

veces una auténtica propaganda para las obras reprobadas, y dejaba bastante que desear en cuanto a la distinción entre corrección de doctrinas erróneas y de personas equivocadas, defectos que los obispos trataron expresamente de corregir con las normas sobre calificación moral de las publicaciones que elaboraron en 1950. Además, lo habitual es que el periódico pidiera, como de costumbre, que fueran las autoridades del Estado las que impusieran el criterio católico en el material impreso que se ponía a la venta, a pesar de que algunos libros de exaltación falangista fueran reprobados por los obispos ${ }^{548}$. Los siguientes párrafos pueden servir para ejemplificar el tono de las campañas en los primeros años cuarenta:

"(...) los libros que más circularon en España durante la segunda mitad del siglo XIX y comienzos del XX, fueron los acatólicos o francamente contrarios al catolicismo (...) Mientras tanto, la auténtica literatura nacional -Pereda, Menéndez y Pelayo, Vázquez de Mella, Nocedal, Tamayo- llevaba una vida precaria por no disponer de las públicas plataformas que eran ocupadas por los otros.

editorial, DR, 12/8/1939. "retornos peligrosos", editorial: manifiesta extrañeza ante las alabanzas de algunos a una película basada en La dama de las camelias, que está en el índice; 9/11/1939, pág. 1. "Libros", editorial, 30/1/1941, pág. 1. "El peligro de los llamados "intelectuales" " editorial censurando a los hombres de la "generación del 98", 15/1/1942, pág. 1. "Por una cultura española", editorial, 22/2/1942, pág. 1. "La figura de Jesucristo y un libro de Baroja", editorial, 25/3/1942, pág. 1. "Condenación de un libro de Unamuno", editorial, DR, 27/3/1942, pág. 1. "Almas enfermas", editorial censurando a Unamuno, 30/1/1944, pág. 1. "Huella espiritual de la letra impresa", editorial, 3/2/1944, pág. 1. "Exaltación del libro español", editorial, 17/3/1944. "Todavía, Nietzsche", editorial, 4/7/1944, pág. 1. "Ética y estética", editorial reprobando la obra de Eca de Queiróz, 17/2/1945, pág. 1. "Anatole France está en el Índice", editorial, 12/1/1946, pág. 1. "Tenemos que vernos las caras, señor ortega", editorial, 8/5/1946, pág. 1 .

548 "El Sr. Arzobispo Primado denuncia la novela "La fiel infantería" como nociva para la juventud. Está salpicada de expresiones indecorosas y muchos pasajes contribuyen a debilitar al fe y la moralidad de las costumbres", DR, 20/1/1944, pág. 1 . 
Los años de "La Editorial Católica": redactores líricos, fervor católico, y consignas.

"He ahí un aspecto de la "Fiesta del Libro", digno de una especial atención. Hagamos literatura nacional y ensalcemos el libro bueno en su más profundo sentido. Pasaron los tiempos del liberalismo en que cualquier mercancía intelectual gozaba de la libre circulación. Hay que acotar, definitivamente, el libro antiespañol. Los sentimentalismos más o menos trágicos y filosóficos, no interesan a la nueva Patria española. Toda función de policía, en este sentido, será digna del mayor elogio. Limpiemos el polvo a nuestros ricos códices, y saquemos al sol de la hora actual el tesoro ingente de nuestra literatura del Siglo de Oro. Cerremos la puerta al "ensayista" sospechoso, al novelista sensual, al escritor escéptico, y abramos de par en par las ventanas de la conciencia nacional española para que por ellas penetre en nuestra inteligencia y en nuestro corazón, el amor, la bondad y la belleza de las plumas que sepan captar y cantar la vena inagotable de lo profundamente hispano." 549

Es palmaria la acentuación de la línea tradicionalista. Pero ese camino iba a encontrar serias dificultades en una nueva modalidad de difusión de comportamientos y mentalidades, que es probablemente la más importante del siglo xx, junto con la música: el cine. En ese terreno no cabía recurrir a los clásicos del Siglo de oro. Si se quería un "cine católico" había que hacerlo. La solución era la de siempre: por un lado censurar, por otro, reclamar la difusión del cine "auténticamente español»550. Realmente, con censura y todo, lo más que pudo

549 "El libro y la conciencia nacional», editorial, DR, 23/4/1940, pág. 1. El año siguiente el editorial era de alabanza para la fiesta del libro, no sabemos si por imperativo oficial, o porque las normas de censura habían alcanzado los objetivos propuestos por el periódico, aunque esto último fue poco más o menos así; cfr. "La fiesta del libro en Valladolid se celebra con certero tono espiritual", editorial, DR, $24 / 4 / 1941$, pág. 1 .

550 "Un paso decisivo en el cine nacional", editorial sobre "Raza", 30/1/1941, pág. 1. "La Asociación Católica de Padres de Familia, cimiento de una patria sana. El señor Martín Abril contesta a las preguntas del cuestionario formulado", el director del periódico señalaba como uno de los medios más importantes en la educación de los hijos la difusión del buen cine, DR, 24/12/1941, pág. 1. "Trascendencia moral y social del cine", editorial, 12/4/1942, pág. 1. "La batalla del cine", editorial, 28/1/1948, pág. 1. "Espectáculos", editorial: "el cine español está todavía muy lejos de un estilo hacia el que es 
Los años de "La Editorial Católica": redactores líricos,

fervor católico, y consignas.

hacerse fue publicar la calificación moral de las proyecciones.

Muchas de estas campañas no eran más que el reflejo en el periódico de las actividades de las distintas ramas de la Acción Católica, de cuyas actividades más relevantes daba cuenta el periódico puntualmente551. De ahí también que no fuera extraño encontrar editoriales que eran auténticos textos de espiritualidad, en los que a veces se encontraban en mezcla abigarrada ideas de Padres de la Iglesia y de los políticos del momento: animaban a hacer ejercicios espirituales, hablaban de la primacía de los deberes familiares sobre las actividades de la Acción Católica, ponderaban la necesidad del sacrificio, recalcaban que la vida interior era lo fundamental para construir España, o llamaban a la conversión en la

preciso caminar sin desmayos", 21/2/1943, pág. 1. En los años cincuenta seguirán publicando editoriales sobre el cine-sin hacer ya referencias al cine español- en los que es patente la preocupación ante el influjo de este medio.

${ }^{551} \mathrm{La}$ sede de la Acción Católica se instaló en 1951 en el mismo edificio de Diario Regional, y se dedicó por algún tiempo una sección - "Pase usted sin llamar"-a comentar con detalle actividades de la institución y diversas iniciativas en torno a ella. En el artículo de presentación de la sección, que firmaba "Banderín", se decía: "Vamos a ver si nos entendemos, queridos amigos. Este nuevo rinconcillo del periódico pretende recoger los afanes y las preocupaciones de un gran movimiento espiritual que existe en Valladolid. Aquí mismo, en el edificio de Diario Regional, está abierta, para todos los hombres de buena voluntad, la casa de Acción Católica." Pedían opiniones para hacer más dinámica la actividad de la Acción Católica. Publicarán reseñas de ejercicios espirituales y de otras actividades de Acción Católica. "Pase usted sin llamar. ibuenos días amigos!", DR, 13/9/1951, pág. 1. Nos parece clara la semejanza del texto citado la con los que son habitales en publicaciones del estilo de las hojas parroquiales o los boletines de alumnos de los colegios. Cfr. también "Una nueva etapa de la Acción Católica de Valladolid", DR, 26/1/1951, pág. 1 . 
Los años de "La Editorial Católica": redactores líricos, fervor católico, y consignas.

cuaresma. Significativamente, en alguna ocasión se denominó a la conversión "depuración espiritual", cerrando así el ciclo de ida y vuelta de términos religiosos a la política y viceversa552. No parece exagerado decir que algunas veces el periódico, más que un órgano de información, se podía definir como una publicación devota. El ambiente de la ciudad lo hacía posible, y también el nuevo régimen político, según decían:

"El Nuevo Estado hace posible tales expresiones de vida religiosa, antes cortapisadas por Gobiernos antiespañoles y sectarios (...). No podemos descansar. Valladolid debe seguir creciendo en vida espiritual." 553

Aunque no faltaban tampoco elementos reticentes entre los vallisoletanos ante este auge de la religiosidad

"Pero frente a esta magnífica "riada" de fervor, sigue su marcha el batallón del paganismo con sus llamativas banderas de frivolidad $y$ de pecado. Estamos seguros de que muchas personas reciben con desagrado estos ciclos de refinada espiritualidad y penitencia que la Iglesia establece para el logro de sus fines divinos. Son los eternos representantes de las fuerzas del mal, que incluso se quejan de algunas limitaciones que el Estado nacido con la Cruzada pueda imponer a su "estilo" liberal y torcido. iQué mermado es el ideal de algunas gentes! Toda su moral se reduce a eso que se llama "moral externa o social", y que sólo rechaza -quizá por un

552 cfr por ejemplo: "Depuración espiritual", editorial, 8/2/1940, pág. 1. "Fortaleza espiritual", editorial, 9/2/1941. "Tiempo de sacrificio", editorial, 26/2/1941, pág. 1. "Amor a la liturgia", editorial, 31/3/1942, pág. 1. "El ejemplo de un Rey", editorial sobre Alfonso II el Casto y la virtud de la pureza, 6/9/1942, pág. 1. "La jerarquía de los deberes", editorial, 17/11/1942, pág. 1. "La devoción al Corazón de María y la paz", editorial, 9/1/1944. "La ciencia del alma", editorial, 15/3/1944, pág. 1 .

553 "Resurgimiento de la vida espiritual en nuestra ciudad", editorial, DR, 1/2/1942, pág. 1 . 
Los años de "La Editorial Católica": redactores líricos, fervor católico, y consignas.

bien parecer- el robo a mano armada o el crimen vulgar. Y de estas personas, hay muchas." 554

Pero por más que se incensara al Estado, sin duda había mucho de auténtica religiosidad detrás de estos comportamientos. Dejando al margen las manifestaciones exteriores que hoy nos pueden parecer aparatosísimas procesiones de 15.000 personas, misas multitudinarias en las calles varias veces al año, proliferación de estandartes555-, y comportamientos hipócritas que sin duda existieron, la religiosidad imperante no puede atribuirse solamente a la presión social ambiente, y así lo reconocen los que vivieron esos años ${ }^{56}$. Otra cosa es que este intento de resacralizar la sociedad fuera o no acertado. Sobre ese punto, como es sabido, la opinión de los

554 "La cuaresma y el ambiente de la ciudad", editorial, DR, 19/2/1942, pág. 1 .

${ }^{555}$ Sobre las manifestaciones exteriores y su valoración puede verse "El año religioso en Valladolid" por León Espinel del Campo, DR, 2/1/1944, pág. 2 .

556Cfr. GÓMEZ PÉREZ, Rafael, op. cit., págs. 227-228. PAYNE, en El catolicismo español hace las siguientes apreciaciones: "Aunque Gomá bien pudo tener razón acerca de la ausencia de profundidad espiritual, la primera década después de la guerra civil vio un notable resurgimiento de la mayor parte de los aspectos de la vida religiosa. Aumentó la asistencia a misa, se reconstruyeron muchísimos edificios religiosos y subieron todos los índices de la práctica religiosa. En 1942, una nueva serie de "misiones populares" de evangelización en masa estaba en plena acción, y seguiría así durante más de un decenio. En número absoluto de personas nominalmente afectadas, bien pudo ser el mayor ejercicio evangelizador del siglo XX en todo el mundo. En las grandes ciudades industriales, como Barcelona, se veía a veces un cuarto de millón de personas en la calle durante esas campañas misioneras aunque sus efectos duraderos no fueron probablemente mucho mayores que los de los bautismos en masa de san Francisco Javier en Asia, a fines del siglo XVI. Se ampliaron los seminarios en todo el país, si bien apenas aumentó el número de seminaristas hasta alrededor de 1945; ya por entonces la nueva aculturación religiosa había tenido tiempo de formar nuevas vocaciones entre los jóvenes.". Pág. 231. 
Los años de "La Editorial Católica": redactores líricos, fervor católico, y consignas.

católicos no era unánime, y la Iglesia -oficialmenteinsistió poco más tarde en otros modos de hacer presente a Dios entre los hombres, distintos del toque de campana. Pero de momento, el pensamiento de muchos de estos católicos estaba puesto en una solución bien distinta que era una vuelta al pasado, o -como ellos mismos decían- el camino hacia una nueva Edad Media557.

Las campañas más llamativas y persistentes que sostuvo el periódico secundando al arzobispo -dejando a un lado las proseminario, que aparecían cada año en torno al 19 de marzo, "Día del Seminario"- están relacionadas con las construcciones: la catedral y el Santuario Nacional de la Gran Promesa, o Alcázar de Cristo Rey, fueron los objetivos de esas campañas. La primera estaba relacionada con una afirmación que suena a chanza, pero que fue publicada como titular de gruesos tipos en el periódico: «Hace 416 años que comenzaron las obras de la Catedral de Valladolid y aún están sin terminar»558. El proyecto para concluir las obras de la catedral fue galardonado con el Premio Nacional de Arquitectura en 1943559. El periódico recogió la noticia y la incluyó en sus campañas por la

${ }^{557} \mathrm{Cfr}$. el contenido de la conferencia pronunciada por Nicolás González Ruiz en la inauguración de la nueva sede de la Acción Católica en 1951, DR, 26/1/1951, pág. 1.

${ }^{558} \mathrm{DR}, 14 / 3 / 1943$, pág. 6 últ..

559 "Valladolid debe conocer los proyectos premiados en el C.N. de Arquitectura", editorial, 4/2/1943, pág. 1. Se trataba de completar el crucero de la catedral y construir un nuevo palacio arzobispal entre la iglesia de la Antigua y la catedral. 
Los años de "La Editorial Católica": redactores líricos, fervor católico, y consignas.

mejora urbanística de la ciudad-junto con el proyecto del Alcázar-, como uno de los objetivos preferentes que el municipio debía atender. Pero 416 años son una larga tradición: no se consiguió vencer la inercia centenaria que hacía escépticos a muchos respecto al ambicioso proyecto, aunque se insistiera más de una vez en la atención que debía prestársele y en su viabilidad ${ }^{560}$.

La campaña por el Santuario Nacional de la Gran Promesa, después Alcázar de Cristo Rey, fue más intensa y estuvo también más cargada de significado. La magna obra que se proyectaba tenía por base la creencia en unas revelaciones privadas de tipo sobrenatural, que habría recibido siglos antes el P. Hoyos, y que hablaban de un reinado del Corazón de Jesús en España, país al que el Redentor miraría con especial predilección. El reinado del Corazón de Jesús era, pues, el eje de devoción en torno al cual se articulaba toda la obra. Esta idea la conectaba el arzobispo con la construcción de una España católica, identificando de alguna forma el reinado de Cristo y la consolidación de lo que entonces se estaba realizando en nuestro país en el ámbito religioso, en el social y en el político -confundidos en uno en la idea tradicionalista-. En la mente del prelado, la obra era de gran trascendencia para todos los católicos españoles: era el monumento que debían erigir en conmemoración de la gesta de la guerra

560 "La terminación de la catedral no es una utopía", editorial, 9/5/1944, pág. 1 . 
Los años de "La Editorial Católica": redactores líricos, fervor católico, y consignas.

civil, que había librado al país del fin de su tradición católica bajo una dictadura comunista561. El Santuario Nacional de la Gran Promesa recibiría las "actas de los mártires de la Cruzada", y sería lugar de peregrinación para todos los españoles, centro de espiritualidad y devoción que dejara perpetua memoria de los destinos providenciales de la patria, a la vez que preservaba los valores de la fe católica, de los que Valladolid debía ser un foco de irradiación ${ }^{562}$. En 1941 se inauguró el Santuario, en medio de populosas manifestaciones de devoción ${ }^{563}$. Con el tiempo, a este fin, se le añadió el de ser punto de encuentro de todos los países hispanos; entre sus objetivos estaría "el estrechamiento y consolidación definitiva de la relación de concordia e intereses con las repúblicas americanas de habla española", marcados también por ese sello de predilección divina, y partícipes del mismo destino de la madre patria564.

En 1944 se modificó en lo material la idea inicial, que pasó a ser un gran monumento a los Sagrados

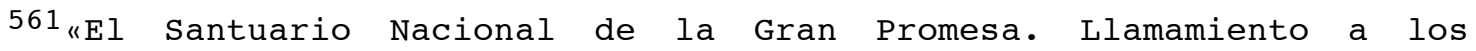
católicos españoles por el Excmo. y Revmo. Sr. Dr. D. Antonio García y García, Arzobispo de Valladolid", DR, 30/6/1939, págs. 1, 3 y 5.

562 «El Santuario Nacional de la Gran Promesa en el porvenir de la ciudad", DR, 8/7/1943, pág. 2 .

563 "Anteayer fue consagrado en Santuario Nacional de la Gran Promesa", DR, 17/6/1941, pág. 1. las informaciones sobre el acontecimiento se prodigaron durante toda la semana, cfr. "Solemnísima inauguración...", 21/6/1941, pág. 1 .

564 "Las obras del Santuario Nacional de la Gran Promesa", editorial, 14/11/1943, pág. 1 .
} 
Los años de "La Editorial Católica": redactores líricos, fervor católico, y consignas.

Corazones ${ }^{565}$. Cuando se consiguieron los terrenos, comenzó a llamarse a Valladolid "Ciudad de la Gran Promesa"566. Se engrandeció el proyecto arquitectónico, del que se llegó a hacer una maqueta que se expuso a principios de los cincuenta en Valladolid y Madrid para asombro de propios y extraños 567 . Tenía unas proporciones gigantescas y era de gusto cuando menos dudoso, o al menos, así nos lo parece a nosotros: 14.000 metros cuadrados; una torre de 125 metros de altura, con un faro en su cima que arrojaría rayos de luz a más de 50 kilómetros de distancia; 372 habitaciones; un patio capaz para 8.000 personas... Y todo esto en el centro de Valladolid568. Desde un punto de vista sí era fundamental el proyecto para el urbanismo de la ciudad: de realizarse la obra, el resto de ella sería la sombra del Alcázar.

565 "A base del Santuario Nacional de la gran Promesa se proyecta levantar un monumento gigantesco a los sagrados corazones de Jesús y de María. La torre de la fachada de acceso se elevará a cien metros de altura. Una entrevista con el señor Palacios, arquitecto autor del proyecto", DR, 1/1/1944, págs. 3, 4 y 7 .

566 "Ayer se firmó la escritura de cesión al Arzobispo de los terrenos contiguos al Santuario. La obra hispano-americana del templo de la Gran Promesa, en marcha", DR, 14/4/1945, pág. 6, últ.. "Valladolid, ciudad de la Gran Promesa", editorial, 21/4/1945, pág. 6, últ.. "Bienvenido sea el Jefe del Estado a la Ciudad de la Gran Promesa", editorial con motivo de una visita de Franco, DR, 20/5/1945, pág. 1. En las informaciones sobre la visita el periódico destacaba sobre todo la visita al Santuario.

567 "La maqueta de la magna obra ha despertado asombro y admiración al ser expuesta en Madrid", DR, 1/5/1953, pág. 6, últ.

568 "el Alcázar de Cristo Rey ocupará 14.000 metros cuadrados", DR, 26/10/1951, págs. 1 y 2. "El reinado de Cristo, la fórmula más eficaz contra el comunismo (Sr. Arzobispo) (...) En el acto de clausura de la Exposición de planos del futuro Alcázar de Cristo Rey", DR, 26/10/1951, págs. 1 y 5. 
Los años de "La Editorial Católica": redactores líricos, fervor católico, y consignas.

Si en el proyecto del Santuario se logró interesar al Ayuntamiento, hubo más dificultades cuando se trató ya del Alcázar569. Franco hizo personalmente un donativo570; llegaron algunas peregrinaciones -realmente de paso hacia Santiago de Compostela-, y se celebraron actos solemnes con ocasión de la entrega de las "actas de mártires" para depositar en el "altar de Cristo Rey": periodistas caídos, sacerdotes y religiosos caídos, etc.571. El arzobispo aclaró que estos actos no tenían su razón de ser en el rencor o el afán de venganza, sino, al contrario, que eran ocasión de reconocimiento del heroísmo de otros católicos en defensa de sus ideales, y siembra de comprensión para el futuro572. Se comenzaron las obras, que corrieron la misma suerte que las de la catedral cuatro siglos antes, esta vez no tanto por ausencia del arquitecto, sino por

569 "Un acuerdo municipal en favor del Santuario", DR, 23/5/1943, pág. 2. "El Municipio debe atención preferente al Santuario", editorial, DR, 29/3/1946, pág. 4, últ..

570 «El Generalísimo ofrece la custodia para el Santuario Nacional de la Gran Promesa», DR, 27/10/1939, pág. 1.

571 «El Arzobispo de Valladolid coloca la primera piedra del Monumento Hispánico a los Sagrados Corazones. El Director General de Prensa, en nombre del Ministro de Educación, entregó el Álbum de los Periodistas Mártires y pronunció un discurso", DR, 29/6/1948, págs. 1 y 4. "Las víctimas gloriosas", editorial con motivo de la entrega al Santuario de la relación de sacerdotes y religiosos muertos violentamente en la guerra civil, DR, 11/4/1950, pág. 1. "Álbumes de excautivos", DR, 16/6/1951, pág. 1: fueron depositados "cuatro álbumes con los nombres de 44.000 asesinados por Dios y por España en el altar de Jesucristo Rey de los Mártires y Monumento de la Victoria».

572 "Monumento de amor, de expiación y de rogativa" fue una de las definiciones que dio de él el arzobispo. "El Alcázar de Cristo Rey reclama la atención de todos los buenos católicos", DR, 5/2/1952, pág. 3 . 
Los años de "La Editorial Católica": redactores líricos, fervor católico, y consignas.

falta de fondos ${ }^{573}$. El periódico reavivó la campaña para allegarlos, pero de nada sirvió574: al final la obra quedaría inconclusa y el proyecto del gran Alcázar de Cristo Rey -pese a que el rector del Santuario realizó un documental cinematográfico sobre él para promocionarlomurió con su promotor ${ }^{575}$. Su recuerdo es, en nuestra opinión, un elemento valioso para caracterizar la mentalidad de la época.

\section{CON PERMISO DE LA AUTORIDAD}

Si decimos que el periódico fue portavoz del arzobispo, no debe olvidarse que esa apreciación se hace para diferenciarlo de otros medios, ya que la característica esencial de toda la prensa española en esos años es que es portavoz de las autoridades políticas. El régimen de consignas en esta etapa ha sido estudiado con detalle por Justino Sinova, y descrito por Miguel Delibes y Fernández Areal576. No nos interesa, pues, analizarlo con

573 "Las obras del Alcázar de Cristo Rey están suspendidas temporalmente, por dificultades económicas", DR, 1/5/1953, pág. 6, últ..

574 "La realidad más importante", por Mariano Escudero de Solís, DR, 1/5/1953, pág. 6, últ.. "El Santuario Nacional de la Gran Promesa, foco inextinguible de vitalidad religiosa", DR, 10/9/1953, pág. 8, últ.. Aseguraban que en cuanto se resolvieran las dificultades económicas del momento, estaría terminada la obra en dos años.

575 "Un espléndido documental cinematográfico sobre el Santuario de la Gran Promesa. Ha sido realizado bajo la dirección de D. Emilio Álvarez [rector] y será exhibido públicamente", DR, 2/2/1954, pág. 1 .

576SINOVA, op. cit., passim, DELIBES, Miguel, La censura de prensa en los años 40 (y otros ensayos), Ámbito, Valladolid, 1985, FERNÁNDEZ AREAL, Manuel, "Cuarenta años de censura en la España de Franco", en 
Los años de "La Editorial Católica": redactores líricos, fervor católico, y consignas.

detalle, ni fijarnos en los editoriales inspirados por el ministerio que se publicaron. Vamos a fijarnos únicamente en los conflictos que se produjeron, que son ilustrativos sobre el funcionamiento de los órganos de poder del régimen.

\section{La destitución nonnata de Martín Abril}

Cuando hablamos de la opinión que el periódico merecía en la Delegación General de Prensa, reflejada en las hojas de inspección, mencionamos ya el disgusto que producía la ausencia de editoriales o comentarios. El Ministerio no se conformaba con la identificación con el régimen, por sincera que fuera, quería además que la prensa fuera dinámica, de opinión encendida, y técnicamente bien hecha: lo contrario era un desprestigio para un sistema que -por perfecto- debía ser también perfecto en sus frutos.

En este sentido, Diario Regional no era un modelo de lozanía. De junio de 1943 a octubre de 1944 se le había advertido por los siguientes motivos: 14 veces por no publicar editorial, 26 veces por deficiencias técnicas, 10 veces por deficiencias valorativas, 6 veces por

opinión, números 32 (14-20/5/1977) y 33 (21-27/5/1977), págs. 65-72 y 69-75 respectivamente. Del mismo autor $E l$ control de la prensa en España, Guadiana de ediciones, Madrid, 1973; y La libertad de prensa en España (1938-1971), Editorial Cuadernos para el Diálogo, Madrid, 1971. Puede verse también nuestro estudio "El régimen de consignas de prensa durante el franquismo análisis de una fuente" publicado en Actas del I Congreso de Jóvenes Historiadores y Geógrafos, ADES, Madrid 1990, tomo II, págs. 739-747. 
Los años de "La Editorial Católica": redactores líricos, fervor católico, y consignas.

desenfoques en informaciones de política nacional, y 14 por el mismo motivo en política extranjera. Además, en 4 ocasiones no había cumplido las consignas que se le habían enviado, y se había hecho merecedor de 3 apercibimientos severos. No había publicado nada el día de los caídos de ese año, ni tampoco con motivo de la muerte de José Antonio; el 18 de julio de 1944 "Se distingue entre los periódicos que peor hacen el extraordinario, que prácticamente no existió»; y no había destacado varios discursos del Caudillo y sus ministros. En consecuencia, su director había sido sancionado una vez con un día de haber y otra con siete días de haber; se le había anotado en el expediente una "nota desfavorable y un apercibimiento severon; y -por fin- colmada ya la paciencia de sus atentos inspectores, se le había abierto expediente por faltas graves el 4 de septiembre de $1944^{577}$.

El Juez Instructor del expediente decretó la suspensión provisional de Martín Abril como director de la publicación, sentencia que fue oficialmente comunicada al interesado por la Delegación Provincial el 12 de

${ }^{577} \mathrm{Cfr}$. en el apéndice 13 la relación completa de advertencias y sanciones en "Oficios de deficiencias cometidas por "El Diario Regional" (sic) de Valladolid, desde el día 1-6-43 hasta la fecha", A.G.A., Sección Cultura, caja 66.627. Conviene notar que las signaturas de este archivo para la sección de Cultura presentan una anomalía. Parte de la documentación está numerada según la notación del archivo, mientras que la mayoría de los documentos conservan la signatura que se les dio en el archivo del extinto Ministerio de Información y Turismo. Por ese motivo, hay algunos números -los más bajos- duplicados. Los números más altos corresponden a la signatura del M.I.T. . 
Los años de "La Editorial Católica": redactores líricos, fervor católico, y consignas.

septiembre de 1944. El delegado provincial, Antolín de Santiago Juárez, nos ha dejado un relato pormenorizado de lo que a continuación ocurrió, que es un buen ejemplo de cómo se desarrollaba entonces la vida política de Valladolid, y la de su prensa católica:

"(...) al día siguiente de tal notificación y con motivo de la sesión de clausura del Congreso Carmelitano Hispanoportugués, celebrada en acto público solemne con asistencia de altas autoridades del Estado y numerosísimo público, el excelentísimo señor Arzobispo de esta diócesis, doctor don Antonio García y García, pronunció un discurso en el que después de dedicar encendidos elogios al señor Martín Abril, dijo que era "excelente padre de familia, católico cien por cien y periodista sin tacha", para terminar diciendo en tono de gran soberbia que aplaudía de corazón al señor Martín Abril y subrayando que estos aplausos "son los del Prelado".

"Estas palabras, dichas en tono de soberbia y con perfecta intención, recalcándolas, fueron pronunciadas teniendo conocimiento desde el día anterior del cese de don Francisco Javier Martín Abril y, al parecer, de acuerdo previo con la dirección de "Diario Regional".

"Complementan esta información las manifestaciones escuchadas en la sacristía de una iglesia al Notario eclesiástico de esta diócesis, don Alfonso Abia Zorita expulsado hace algún tiempo de Falange $y$ declarado antifalangista- según las cuales, las palabras del Prelado conociendo como conocía la suspensión del director de "Diario Regional"- constituían un acto de gran valor."578

El documento es tan gráfico que sobran los comentarios. La reacción de Madrid no es menos aleccionadora:

"4-9-44.- Con esta fecha se le abre expediente por las GRAVES FALTAS COMETIDAS. Y se da por terminado con fecha 18 de septiembre, con amable benevolencia." 579

578oficio del delegado provincial de la Vicesecretaría de Educación Popular de F.E.T. y de las J.O.N.S. en Valladolid al camarada delegado nacional de prensa. Valladolid, 16/9/1944. A.G.A., Sección cultura, caja 66.627 .

579 "Oficios de deficiencias cometidas...", pág. 3, A.G.A., Sección Cultura, loc. cit. 
Los años de "La Editorial Católica": redactores líricos, fervor católico, y consignas.

Las autoridades de Madrid no dudaron: el enfrentamiento con un obispo era un precio demasiado alto por llevar adelante la decisión de uno de sus jueces de prensa.

\section{Una tapadera de la oposición monárquica}

El expediente señala nuevos incumplimientos de consignas por parte de Diario Regional unos días más tarde, pero de momento Madrid iba a guardar silencio, aunque el periódico -como es patente en la colección del mismo- siguiera en la misma línea. El siguiente conflicto con las autoridades políticas llegaría dos años más tarde, y tendría por protagonista a una autoridad diferente de los vigilantes oficiales de la prensa, aunque éstos, como no podía ser menos, terminaran por intervenir.

El fin de la guerra motivó un reajuste político del régimen que se plasmó en la promulgación del Fuero de los Españoles y el cambio de Gobierno de 18 de julio de 1945, que significaban el fin del predomino profascista y el comienzo de un neotradicionalismo católico como línea oficial580. Por lo que hace a la prensa, esto supuso además de los intentos de Martín Artajo de darle un nuevo estatuto-, el fin del control falangista. Los órganos estatales que se ocupaban de ella pasaron de la Secretaría General del Movimiento al Ministerio de Educación

${ }^{580} \mathrm{Cfr}$. PAYNE, El régimen..., págs. 361 y ss.. 
Los años de "La Editorial Católica": redactores líricos, fervor católico, y consignas.

Nacional; más en concreto, a la Subsecretaría de Educación Popular. Al frente de la misma y de la Dirección General de Prensa se colocó a dos católicos oficiales: Luis Ortiz y Tomás Cerro. Los dos eran miembros de la A.C.N. de P. Y procedían de $E l$ Debate. La consecuencia práctica del cambio fue la promulgación de una orden que atenuaba la censura, que no llegó a aplicarse 581 . Fernández Areal sostiene que, al contrario, el número de órdenes y consignas aumentó más todavía ${ }^{582}$. De hecho, al mismo tiempo que se publicó la orden, al periódico llegó un oficio de la Delegación Provincial que advertía que la suavización de la censura anunciada, mientras no se reglamentara pormenorizadamente, no significaba que nada hubiera cambiado 583 .

${ }^{581}$ Orden de 23 de marzo de 1946. Cfr. SINOVA, op. cit., págs. 116-118. 582FERNÁNDEZ AREAL, Manuel, La libertad de prensa en España (1938-71), Editorial Cuadernos para el Diálogo, Madrid, 1971, pág. 40.

583Oficio de la Delegación Provincial de la Subsecretaría de Educación Popular en Valladolid al director de Diario Regional fechada el 28/3/1946. A.P.M.F.A.. Es también significativa la siguiente comunicación enviada por el mismo organismo al director del periódico con fecha 24/9/1946, y que se conserva en el mismo archivo:

«El Ilmo. Sr. Director General de Prensa, con fecha 23 de abril del actual, me dice lo siguiente:

"Para evitar reclamaciones de muy diversa índole; pero basadas siempre en definitiva en la simulación de corresponsalía, $O$ en la utilización incorrecta de otras fuentes de información, esta Dirección General de Prensa pone en conocimiento que, en lo sucesivo, será prohibida inexorablemente toda noticia en la que no se dé alguna de las siguientes condiciones:

"1a Referirse a la población misma en que cada periódico se publique y de que, por tanto, puedan sus propios redactores tener información directa.

"2 a Haber sido facilitada por Agencias españolas o extranjeras reconocidas.

"3a a Proceder de los corresponsales propios del periódico, bien entendido que estos han de ser verdaderamente tales, es decir periodistas, debidamente autorizados para el ejercicio 
Los años de "La Editorial Católica": redactores líricos, fervor católico, y consignas.

Pero tradicionalmente se había animado a los periódicos a opinar sobre cuestiones municipales, dejando en ese aspecto un cierto margen para las críticas, al que Diario Regional se acogía con frecuencia, cuidándose muy mucho, eso sí, de aclarar que se ocupaban de ellas con afán constructivo y sin ánimo de herir susceptibilidades ${ }^{584}$. En 1942 se criticó la lentitud en la construcción de viviendas protegidas, el defectuoso abastecimiento de agua de la ciudad, la falta de planificación en las tareas de pavimentación, el descuido del parque del Campo Grande, la inexistencia de planes de inversión en la Diputación, etc ${ }^{585}$. El tono a veces fue un tanto agresivo, como lo demuestra este párrafo de un editorial dedicado al urbanismo:

de su profesión, y con residencia, también reglamentariamente autorizada, en el lugar donde se diga remitida la crónica. "En ese caso y en el anterior deberá aparecer con toda claridad el nombre de la Agencia o corresponsal, antes o después del texto informativo.

"4 a Es lícito publicar textos de otros periódicos nacionales o extranjeros, siempre que se haga constar con toda precisión la procedencia, $y$ se disponga de los originales correspondientes.

"La Dirección General de Prensa exigirá la comprobación de este último extremo siempre que lo crea necesario.

"5 a Se prohiben las noticias captadas por Radio, salvo el caso en que el periódico que las inserte tenga autorización expresa para utilizarlas en las Emisoras propietarias de dichas noticias. En este caso deberán consignarse siempre terminantemente la Emisora y la Emisión.

"Cuantas normas se establecen en este oficio, tienden exclusivamente a evitar que sean utilizados el trabajo y propiedad ajenos (...)"

584Cfr. "La provincia y el municipio", editorial, DR, 16/6/1942, pág. 6, últ. "La importancia de lo municipal", editorial, DR, 5/7/1942, pág. 1. El periódico organizó en esos meses una campaña sobre el urbanismo de la ciudad.

${ }^{585}$ Cfr. "Los jardines del Campo Grande», editorial, DR, 4/8/1942, pág. 1, "Del Municipio. Lo más urgente", id. pág. 4, últ.. "¿Qué sucede?", editorial, 8/9/1942, pág. 1 . 
Los años de "La Editorial Católica": redactores líricos, fervor católico, y consignas.

"Y todo ha sido imprevisión, transigencia con las dificultades adversas, falta de ánimo de superación, falso afán conformista, defecto de inteligencia, mediocridad que resalta en la pobretonería de nuestras construcciones, que han podido eludir lo que son requisitos técnicos incumplidos porque tampoco se han exigido (...) . "586

En abril de 1946 volvieron sobre la cuestión urbanística con el mismo ímpetu de siempre, y en concreto manifestándose claramente contrarios al plan de reforma del Campo Grande587, y ahora sí que estalló la tormenta. El gobernador civil, Tomás Romojaro, consideró tendenciosa e inexacta la información literaria y gráfica que publicó el periódico en su número de 7 de julio, e impuso una multa de 5.000 ptas. a Martín Abril. Éste interpuso recurso de alzada ante el Ministro de Gobernación, al mismo tiempo que publicaba en el periódico -los días 10 y 14 de juliolas oportunas rectificaciones ${ }^{588}$. En esas estábamos cuando el número de 18 de julio de 1946 vino a complicarlo todo.

Con motivo del fasto era costumbre publicar un extraordinario, y si no, al menos, una portada a la altura de lo que se conmemoraba. En el número correspondiente de Diario Regional, apareció un titular a tres columnas "Hoy, 18 de julio»-, y bajo él una fotografía de Franco a dos, en cuyo pie se decía que él era "el General rebelde

\footnotetext{
586 «La defensa de nuestros intereses», DR, 4/9/1942, pág. 4, últ..

587 "La urbanización de la ciudad. Realidad de un problema», DR, $7 / 4 / 1946$, pág. 8, últ..

${ }^{588}$ Cfr. recurso de alzada presentado por Francisco Javier Martín Abril ante el ministro de la Gobernación. 22/7/1946. A.P.M.F.A..
} 
Los años de "La Editorial Católica": redactores líricos, fervor católico, y consignas.

que se alzó en Marruecos, supo ganar la guerra (...) y nos trajo la paz. (...) el General de la guerra ha dirigido los destinos pacíficos del pueblo español». A la derecha de la fotografía se anunciaban cuatro reportajes interiores:

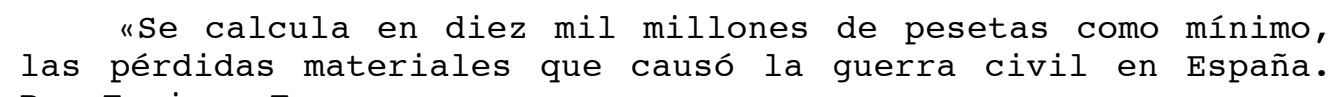

Por Enrique Torres."

"La Iglesia española advirtió siempre contra el simplismo político. Por Jesús Iribarren."

"El 18 de julio visto desde el extranjero. Por Luis Mira."

"Lo que la República no dio al obrero y mucho más se le está proporcionando por el nuevo Estado. Por Amado Fernández Heras."

El número pasó la censura de la Delegación Provincial como era de rigor. Pero al día siguiente El Norte de Castilla y Libertad arremetían en dos sueltos de tono duro contra los que demostraban tibieza ante el nuevo régimen. No citaban a nadie en concreto, pero no era ningún secreto a quién se referían.

El 20 de julio Martín Abril escribía una carta al director general de Prensa, Tomás Cerro, relatándole lo ocurrido, haciéndole ver que a él le parecía muy adecuado el número del 18 de julio, y poniéndole al corriente también de la multa que le había impuesto el gobernador civil. Cerro le contestó a vuelta de correo con una carta también personal, pidiéndole el número del 18 de julio y los artículos que habían sido motivo de la sanción 
Los años de "La Editorial Católica": redactores líricos, fervor católico, y consignas.

gubernativa589. Pocos días más tarde, el delegado provincial, Antolín de Santiago, le puso al corriente de la "excesiva frialdad e indiferencia" que el periódico católico había demostrado, y de la dureza con que le habían impugnado los otros diarios vallisoletanos ${ }^{590}$. Con la misma fecha, el gobernador civil oficiaba al subsecretario de Educación Nacional en los siguientes términos :

«Excmo. Señor :

"Tengo el honor de poner en su conocimiento que el periódico de esta Ciudad "Diario Regional" viene haciendo sistemáticamente una oposición, más o menos encubierta, a nuestro Régimen, que ha culminado en el número del día 18 de julio, que para dicho periódico no ha significado más que el Alzamiento de un General rebelde.

"Esta actitud está perfectamente en consonancia con la forma de ser y actuar de quienes tienen la verdadera dirección del periódico, que no es el Director precisamente pues este realiza su cometido tan en precario que ni siquiera aparece por la Redacción del diario cuando éste se compone. La verdadera dirección la tiene el Consejero-Delegado Sr. Escudero ayudado por el Sr. Huidobro, Secretario del Consejo de Administración, ambos como el Presidente de dicho Consejo firmantes del manifiesto de Don Juan de Borbón.

"Esta incomprensible actitud de unos malvados que se pasan la vida reptando de unos partidos políticos a otros, ha resultado premiada por la Dirección General de Prensa con un aumento del cupo del papel del $71 \%$, al mismo tiempo que el del periódico del Movimiento quedaba reducido a su mitad.

"Es verdaderamente lamentable que, Prensa Católica, para la que son todos nuestros respetos, tenga su diario, en una Ciudad verdaderamente católica como esta de Valladolid, en manos de semejantes personas, sin prestigio moral ni intelectual de ninguna clase $y$ que únicamente muestran sus creencias religiosas, por demás dudosas, con el fin de conseguir escalar en política." 591

${ }^{589}$ Las dos se conservan en A.P.M.F.A..

590 oficio del delegado provincial al director general de Prensa. 22/7/1946. A.G.A., Sección Cultura, caja 66.627 .

5910ficio del gobernador civil de Valladolid al subsecretario de educación nacional. Ibid. Los subrayados en el documento son del destinatario del oficio. 
Los años de "La Editorial Católica": redactores líricos, fervor católico, y consignas.

Ya veremos el efecto que el oficio produjo en Madrid.

Por el momento, Cerro contestó Santiago Juárez haciéndole ver la responsabilidad que le cabía en los hechos: no debía haber permitido los ataques de los otros periódicos ya que -le decía- "De cuanto la censura autoriza ahí, es usted personalmente responsable. (...) Si la censura se dejó sorprender o entendió que la actitud del periódico era correcta, una vez éste en la calle el responsable de su contenido es quien lo autorizó». Después de pedirle que amonestara al director de Diario Regional para evitar que en el futuro se repitieran comportamientos como el que les ocupaba, le recriminaba por la lentitud con que había procedido a la hora de informar592. Con la misma fecha, el director general escribía a Martín Abril una sentida carta. En ella le informaba del "muy áspero" oficio que el subsecretario había recibido del gobernador, así como de las instrucciones que había dado al delegado provincial que acabamos de resumir. Continuaba luego $-y$ esto es lo más interesante del documento- dándole su opinión sobre el asunto. El centro de su argumentación, es el que sirve de entradilla a este capítulo: era absurdo que los católicos se opusieran al régimen de Franco, y si él-como director del periódico- le daba motivos para pensar que actuaba así, no dudaría en obrar en consecuencia. Cerro estaba

592 oficio del director general de prensa al delegado provincial de su departamento en Valladolid. 21/8/1946. Ibid. 
Los años de "La Editorial Católica": redactores líricos, fervor católico, y consignas.

especialmente disgustado por el hecho de que "(...) hasta ahora han sido precisamente ciertos amigos, de quienes yo podía esperar cualquier cosa menos hostilidad, los que me han proporcionado algunos de los más graves disgustos que he tenido desde que estoy en este cargo."593 Era una exposición difícilmente mejorable de la mentalidad de partido único, o tradicionalista si se prefiere, que tenían los llamados católicos oficiales, es decir, aquellos que intervenían en la política en tanto que católicos. Mentalidad que compartían con ellos muchos correligionarios suyos ajenos a la política, gracias a la anuencia que los obispos prestaban a este modo de hacer, y a la acción de la prensa católica, que -como en el caso de Valladolid- estaba en su mayor parte en manos de estos hombres. El modo de argumentar confirma que esa mentalidad, arrancando de una comprensión deficiente de los planteamientos políticos del liberalismo, arraigó en ellos con motivo de la experiencia de la República y la guerra, y cristalizó en una postura que -como puede verse en el siguiente párrafo de la misma carta- les incapacitaba para comprender el pluralismo:

"Y como, desde el punto de vista exclusivamente católico,
hemos predicado siempre que había que acatar los poderes
constituidos, que había que buscar en cada momento el bien
posible, que había que prestar una asistencia leal, no sólo a
regímenes que nos resultaban gratos, sino a los que lo eran
menos o no lo eran en absoluto, que es políticamente, no ya
torpe sino suicida, empeñarse en entrar en una vía muerta y
quedarse al margen de actividades a las que con nuestra

${ }^{593}$ La carta se conserva en A.P.M.F.A.. La reproducimos íntegra en el apéndice 14 . 
Los años de "La Editorial Católica": redactores líricos, fervor católico, y consignas.

colaboración podemos imprimir un sentido católico y, en fin, que la "politique du pire" es siempre catastrófica, yo te confieso sinceramente que no comprendo cómo muchos amigos nuestros a quienes les parecía obligado, muy de acuerdo con las normas de León XIII y Papas sucesivos, hasta Pío XII inclusive, colaborar, no ya con la Monarquía liberal o con Maura o con Primo de Rivera, sino con la República de Lerroux y aun con la de Azaña y Largo Caballero, sientan ahora unos escrúpulos tan profundos en colaborar con Franco."

Nada decía Cerro a Martín Abril de la opinión que merecía al jefe provincial del Movimiento su desempeño de las tareas de dirección, ni tampoco de sus afirmaciones con respecto a la orientación política del periódico. Como luego veremos, Martín Abril tuvo conocimiento de todo ello; es de suponer que a través del rumor, medio de comunicación siempre activo, pero más todavía en una sociedad como ésta. En ella _como se desprende de lo que vamos relatando- el sigiloso mensajero corría por sacristías, oficinas de organismos oficiales, palacios arzobispales, gobiernos civiles, domicilios de intrigantes, y demás centros de decisión de la época.

Mientras tanto, en Madrid, el subsecretario se documentaba para contestar al oficio de Romojaro, que en parte había interpretado -por la alusión a los cupos de papel, y también por los calificativos adjudicados a algunos católicos oficiales de Valladolid- como una acusación de parcialidad formulada desde el bando falangista contra los católicos que ahora hacían y deshacían en la prensa. El organismo competente aclaró que la asignación de papel se había hecho de acuerdo con las tiradas declaradas a las Cajas Asistenciales de Prensa y 
Los años de "La Editorial Católica": redactores líricos, fervor católico, y consignas.

las previsiones de producción, y que a Libertad le había correspondido el que la Administración de la Prensa del Movimiento había decidido, ya que los periódicos de la cadena se consideraban un todo en esos repartos ${ }^{594}$. Con estos datos, el subsecretario respondió el 21 de agosto al gobernador de Valladolid, pidiéndole de paso que evitara incluir insultos en sus comunicaciones. Romojaro se apresuró a responder al subsecretario, desmintiendo cualquier intención acusatoria en su primer escrito, pero insistiendo de nuevo sobre la cuestión política de fondo, que -en su opinión- estaba detrás del comportamiento de Diario Regional :

"Ilmo. Sr.:

"Contesto a su oficio de 21 del corriente, no 2007, y tengo el honor de participarle que en mi comunicación de 22 de julio último no se involucran varios asuntos completamente distintos. Realmente no contiene más que un asunto, que se pone en conocimiento de V.I. $y$ es que "El Diario Regional" (sic) no se comporta con nuestro Régimen con la lealtad que de un periódico que depende de Prensa Católica se podría esperar; y que, como Prensa Católica así como también el director del periódico merecen todos mis respetos, y así lo hago constar en mi oficio, y no quiero achacarles culpas que sinceramente creo que no tienen, $y$ por otra parte, tengo sobrados motivos para saber a ciencia cierta que los

${ }^{594} \mathrm{La}$ distribución en 1946 fue propuesta por el Consejo Asesor Sindical aprobada en la Asamblea Plenaria de Empresas Periodísticas. Para los periódicos de Valladolid era la siguiente:

Ejemplares $\quad \mathrm{Kg}$ de papel asignados $\quad \mathrm{Kg}$ de papel adjudicados en de tirada en la Asamblea de Empresas la práctica en el mes de Periodísticas julio de 1946.

El Norte de Castilla $15.000 \ldots \ldots \ldots 10.330 \ldots \ldots \ldots \ldots . \ldots 90$

Diario Regional.....5.500 ......4.110 ......... 3.694

Libertad.......... $3.500 \ldots \ldots . \ldots 2.639 \ldots \ldots . \ldots 2 . \ldots 35$

"Informe sobre los cupos de papel prensa nacional adjudicados a los periódicos de Valladolid". Madrid, 31/7/1946. A.G.A., Sección cultura, caja 66.627 . 


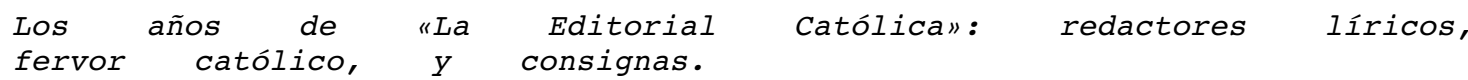

individuos llamados Escudero y Huidobro a quienes en mi escrito me refería, dirigen de hecho el periódico, $y$ demostración plena de que son enemigos de nuestro Caudillo y del Régimen que él encarna, pues ya se advertía en mi anterior comunicación que son firmantes del último manifiesto a D. Juan de Borbón y en el cual, y en su segundo párrafo, se difama al Régimen, creo muy fundadamente que ellos son los culpables del proceder de "El Diario Regional" y se lo comunicaba a V.I. para que tuviese un antecedente del hecho principal que motivaba mi comunicación. Hoy puedo añadirle que también el Presidente del consejo del periódico que nos ocupa es firmante del mismo manifiesto y el cuarto, de los cinco que firmaron de esta provincia, ha pertenecido también al Consejo.

"Realmente he podido callarme el calificativo de malvado con que designaba a esos individuos, pero crea V.I. que lo son en tal medida que debían llevarlo escrito en la frente como aviso para las personas decentes; $y$ que han estado reptando, porque cada uno se mueve como lo que es, de unos partidos políticos a otros, tenga V.I. la seguridad, como de que no hace muchos meses fueron expulsados de F.E.T. Y de las JONS. Además, este justo título que V.I. califica de insulto, no es insulto, pues para ser tal, tiene que ser directo a la persona que se hace objeto de él, cosa que a mí no me está permitido en Valladolid, por ahora, $y$ yo en mi comunicación, al referirme a ellos, me he limitado a darles un calificativo para que V.I. comprendiese mejor de quienes se trataba.

"Puede tener V.I. también la seguridad de que "El Diario Regional" hace una oposición más o menos encubierta, a nuestro Régimen; qué duda cabe, pues toda resistencia a cumplir los disposiciones de los Organismos investidos legalmente para darlas obstruye la buena marcha del Estado, y V.I. puede reclamar de los archivos de la Dirección General de Prensa todas las quejas y denuncias que su Delegación Provincial les ha enviado y también revisar, si le parece, la colección del periódico. (... ) " 595

Conocemos parte de las quejas y denuncias a que se refería, y hemos revisado la colección del periódico, y, en nuestra opinión, sólo con un concepto de oposición muy peculiar puede uno convencerse de que Diario Regional la hiciera, y, además, de forma sistemática. Más bien nos parece que el ambiente de falta de libertad viciaba las

595oficio del gobernador civil de Valladolid al subsecretario de Educación Nacional, de 30/8/1946. A.G.A., Sección Cultura, caja 66.627. El presidente del Consejo era Germán Adánez. En cuanto al documento dirigido a don Juan con motivo de su llegada tierra peninsular, en concreto a Lisboa, conocido como "el saluda", cfr. TUSELL, Javier, La oposición democrática al franquismo 1939-1962, Planeta, Barcelona, 1977, págs. 114-115. 
Los años de "La Editorial Católica": redactores líricos, fervor católico, y consignas.

relaciones, hasta el punto de hacer adecuada para describir la vida político-informativa de aquellos años la conocida frase cervantina: "en una cárcel, donde toda incomodidad tiene su asiento y donde todo triste ruido hace su habitación".

Esos tristes ruidos habían llegado ya a Martín Abril, que contestaba a la carta de Tomás Cerro agradeciéndole la suya, asegurándole su incondicional adhesión al régimen, y negando la intromisión insidiosa de Mariano Escudero u otros consejeros en la redacción del rotativo. Además, insistía, de Escudero no se podían esperar turbias maniobras de oposición:

"(...) En estos días, nuestro consejero delegado, Mariano Escudero, estaba de retiro en la Trapa. Y siempre se respeta con la más exquisita pulcritud, por parte de los consejeros, la independencia y la responsabilidad de la dirección. Es decir, que cada uno de nosotros estamos en el puesto que nos corresponde. Si hemos hecho algunas campañas de carácter local - regional, ha sido al amparo de las normas oficiales de Prensa, y siempre con la nobleza y el desinterés que en ellas se pone de manifiesto. Escudero, en este sentido, ha colaborado con la Redacción. Pero nada más. Tú ya debes conocer el señorío espiritual de Mariano Escudero y si algún día hablas con él, te convencerás de que han existido interpretaciones erróneas por parte de algunas personas. Se ha visto lo que no podía verse, $y$ se han construído hipótesis sobre plataformas de supuestos de aire. (...) "Diario Regional" seguirá en su línea de conducta de siempre. Lee con detenimiento nuestros números, $y$ te percatarás de que no puede haber en ellos motivo de censura, sino al contrario. Por eso creo que al anunciarnos posibles sanciones, obras un poco sugestionado $-\mathrm{y}$ lo comprendo- por un ambiente creado en torno a lo que no ha sido nada, no ha podido ser nada." 596

${ }^{596}$ La carta está fechada el 1/9/1946. Se conserva en A.P.M.F.A.. La reproducimos íntegra en el apéndice 15 . 
Los años de "La Editorial Católica": redactores líricos, fervor católico, y consignas.

La coletilla sobre el retiro del primer párrafo -y alguna frase más de la misiva- es otro de los rasgos típicos de estos católicos oficiales: no se sabe si sirve como argumento porque se pensaba que los que no estuvieran con Franco eran incapaces de hacer ejercicios espirituales, o porque todo el que los hacía se convertía en franquista. Fuera una cosa o la otra, lo que sí quería decir es que no se concebía pluralismo político alguno entre los católicos; y también que el título mismo de católico confería una especial capacidad para acertar en las decisiones políticas y servía para purificar cualquier error que se cometiera -recuérdese, por ejemplo, la intervención del obispo ante la destitución de Martín Abril-. De esta forma convertían el nombre "católico" en una tentadora etiqueta para los amigos del fácil medro político, y en patente de corso capaz de justificar comportamientos que, en buena ley, quizá tuvieran muy poco - nada de cristiano. Seguramente éste era un efecto no buscado, pero no parece que en la práctica reportara muchos bienes a la Iglesia, antes al contrario: por ese camino se iba derecho a convertirla en la práctica en un partido político; aunque estos católicos no gustaran de llamar partidos a sus grupos políticos.

Después de todo esto, todavía estaba pendiente de solución el recurso de Martín Abril contra la sanción que se le había impuesto a principios de verano. La historia de su solución apunta a otro importante problema que se 
Los años de "La Editorial Católica": redactores líricos, fervor católico, y consignas.

planteaba en el régimen: los solapamientos de jurisdicciones cuando de castigar a la prensa se trataba. El ministerio de la Gobernación informó del caso a la Subsecretaría de Educación Nacional, y ésta contestó que por la orden de 23 de marzo iba permitiendo a los periódicos una mayor libertad de movimientos, y que le parecía conveniente que "la política de Prensa se desarrolle con arreglo a un sólo criterion, que sería el del Ministerio de Educación Nacional. Era una respuesta razonable: ya que se comportaban como los dueños de toda la prensa nacional, bueno era que se cuidaran de su propiedad. Gobernación decidió no admitir el recurso y así se lo comunicó al director del periódico, "entendiendo que su resolución corresponde al Ministerio de Educación Nacional»597. Con esto se planteaba el problema de que este ministerio tenía que juzgar la pertinencia de la actuación de un gobernador civil. Ciertamente el nuevo Estado no tenía un ordenamiento jurídico muy coherente. Tendremos ocasión de ver cómo, casi veinte años más tarde, otro director del periódico tuvo que pasar por un problema parecido, esta vez con la autoridad militar como protagonista.

Pero a pesar de sus defectos el sistema siguió en marcha. La Delegación Provincial de Prensa pedía a los

597oficio del gobernador civil de Valladolid transcribiendo otro del ministro de la Gobernación de 16/11/1946, al director de Diario Regional. 18/11/1946. A.P.M.F.A. 
Los años de "La Editorial Católica": redactores líricos, fervor católico, y consignas.

directores de periódicos una fotografía "por expreso deseo del Sr. Director General de poseer retrato de todos los directores de diarios españoles»598, u ordenaba que se publicara un comentario -ahora suena a ironía- "sobre el tema de la rapidez y garantía en la justicia penal»599. Por su parte, el gobernador civil trataba a los periódicos como si fueran su oficina de prensa, dándole instrucciones minuciosas sobre cómo, cuándo y dónde debía publicar informaciones sobre su persona y actividades 600 .

Todo esto, y mucho más que ya nos es conocido, hace que debamos calificar al menos de delirante, el titular de Diario Regional que recogía una frase del ministro de Información y Turismo Gabriel Arias Salgado:

" Nunca el periodismo español alcanzó el rango literario y ético de ahora»601

5980ficio de la Delegación Provincial de Prensa al director de Diario Regional, 9/10/1946. A.P.M.F.A..

${ }^{599}$ Oficio de la Delegación Provincial de Prensa al director de Diario Regional, 15/4/1952.A.P.M.F.A..

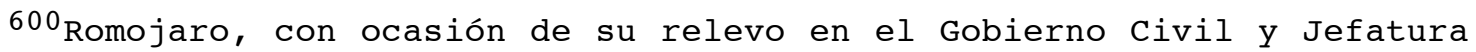
Provincial del Movimiento, envió una nota al periódico en la que indicaba que la información sobre los actos debía ir en primera página. Del acto de toma de posesión del entrante en la Jefatura Provincial del Movimiento debían publicarse solamente las frases que dictaba en la mencionada nota, no lo que allí se dijera. Los discursos en el Gobierno Civil los podían transcribir tranquilamente. En la información general se debía hacer constar que el entrante "oró ante la imagen de nuestra Señora de las Angustias, de la que es muy devoto", y que por la tarde rindió visita al Arzobispo, Capitán General y General Jefe de la Región Aérea. Nota del gobernador civil, sin membrete, 1/8/1947. A.P.M.F.A..

${ }^{601} \mathrm{DR}$, 17/12/1952, pág. 1. Los titulares completos decían: "España convalece, después de cien años de experiencias extrañas (Sr. Arias Salgado). La información debe servir al bien común, que no sólo es material, sino también espiritual. La prensa es órgano de orientación 
Los años de "La Editorial Católica": redactores líricos, fervor católico, y consignas.

El camino de vuelta al siglo $\mathrm{XX}$

Las concepciones teóricas sobre la función de la prensa de los hombres de la A.C.N. de P., siguieron sin embargo ancladas en la afirmación de la necesidad del control estatal de los medios. Fernando Martín-Sánchez lo expresaba así:

"Creo que se está incurriendo en graves errores antiestatistas. El Estado es el representante del bien común (...). El Estado es nuestro: es la sociedad organizada, es el bien común en que vivimos. (...)

"El Estado, precisamente, tendrá que garantizarle a la Prensa una información objetiva, y digo que será el Estado, porque es un problema de importancia política nacional."602

Se solicitaba una mayor libertad -hasta Herrera Oria, ahora obispo, mantuvo una pública polémica con Arias Salgado sobre la cuestión603-, pero una libertad siempre vigilada604. Pedían un modelo especial de sociedad anónima para la empresa periodística, o más en general, "para la empresa mercantil con finalidad o trascendencia

y termómetro de la temperatura moral del país. Nunca el periodismo español alcanzó el rango literario y ético de ahora".

602MARTÍN-SÁNCHEZ JULIÁ, Fernando, La Prensa en el Estado moderno, Euramérica, Madrid, s/f, págs. 12-13. Aunque la fecha de edición no consta, sabemos que este texto está basado en la conferencia que pronunció en el $\mathrm{V}$ curso de periodismo de la Universidad Internacional Menéndez Pelayo, en el verano de 1951. El resto de la obra son los textos de otras conferencias, pronunciadas en el Círculo de Prensa Balmes de Madrid y en el X curso de periodismo de la U.I.M.P. en 1956.

603 "Cuatro documentos sobre la prensa», DR, 12/3/1955, págs. 2 y 3. Recogen la correspondencia cruzada entre Arias Salgado y Herrera Oria. El exdirector de El Debate pedía una nueva ley de Prensa y que cesara el régimen de consignas; la modificación de la censura -no su supresión- y un tribunal especial para delitos de prensa.

604 "La supresión de la censura no debería hacerse sin previa acción política y legislativa que asegurara las suficientes garantías", MARTÍN-SÁNCHEZ JULIÁ, op. cit., pág. 63. 
Los años de "La Editorial Católica": redactores líricos, fervor católico, y consignas.

ideológica»605, y sostenían que los católicos debían contribuir a crear una prensa que fuera institución estatal606. Todo esto se basaba en un presupuesto que estaba en abierta contradicción con lo expuesto por Pío XII en su discurso de 1950, cuando afirmó que "[la prensa] deberá guardarse de hacer opinión: tendrá que hacer algo mejor: servirla»607. Un año después de que el Papa pronunciara esas palabras, Fernando Martín-Sánchez, afirmaba:

"Incomparablemente más importante es la misión [de la
Prensa] de dirigir la opinión, que la de informarla y
servirla" 608

A pesar de todo, seguían considerándose y actuando como representantes oficiosos del catolicismo. Aunque ciertamente no eran los únicos que pensaban así. Gabriel Arias Salgado, el primer ministro de Información y Turismo, se creía también llamado a una sagrada misión,

605Cfr. ibid., pág. 63. "Durante varios años, y concretamente en estos últimos tiempos, en que se estaba preparando el proyecto de ley de Sociedades Anónimas, he tratado de convencer, y en parte he convencido, a muchas personas de que el problema de la propiedad de las impresas periodísticas es distinto (...) la Prensa es un arma de peligrosísimo manejo con una ley de Sociedades anónimas como la que acaba de promulgarse", ibid., págs. 17-18.

606 "Pero nosotros, los católicos (...) debemos, por tanto, todos con buena voluntad contribuir al proceso de creación de la nueva institución pública "Prensa" en el Estado moderno.", ibid., págs. 6061 .

607 "Mensaje de Su Santidad al Congreso de la Prensa, en Roma", DR, 23/2/1950, pág. 5 .

608 op. cit., págs. 56-57. 
Los años de "La Editorial Católica": redactores líricos, fervor católico, $y$ consignas.

como lo pone de manifiesto un sucedido que relata López

Rodó en sus memorias:

"El radicalismo con que Arias Salgado dirigía la política de prensa lo comprobé personalmente cuando, en la primavera de 1957, me llamó a su despacho del Ministerio de Información (...). Se debatía en las Cortes el proyecto de Ley de Régimen Jurídico de la Administración del Estado, del que era yo autor principal y me correspondió su defensa en la Comisión parlamentaria correspondiente (...) .

"José Luis Villar Palasí, Subsecretario de Arias Salgado, siguiendo las instrucciones de éste, trataba de excluir del recurso contencioso-administrativo las resoluciones del Ministerio de Información $y$ Turismo en materia de prensa, radio y televisión. Yo, por el contrario, sostenía que si dichas resoluciones ministeriales quebrantaban la legalidad debían ser anuladas por los Tribunales de lo Contencioso y dar lugar a responsabilidad de la Administración.

"Abierto ya el debate parlamentario, acudí a la citación del Ministro. Empleó tonos patéticos y, poniéndose brazos en cruz, me apostrofó con estas palabras: "iNunca hubiera imaginado que tú, precisamente tú, trataras de maniatarme para impedir que siga defendiendo a Nuestro Señor Jesucristo!" En aquella ocasión me pareció un iluminado."609

Unos y otros siguieron trabajando en la fabricación de una prensa-servicio del Estado. Pero sus esfuerzos se iban a encontrar con un serio problema. La aplicación de esas medidas, dignas de un cristiano monarca de la Edad Moderna, era capaz de producir graves incomodidades a los profesionales del periodismo español, pero no los trasladaba a pasados siglos. Los avances tecnológicos hacían cada vez más abundante la información disponible, y el mundo -en virtud de unos medios de comunicación cada vez más perfectos- caminaba hacia ese estado que se ha denominado de "aldea global". En casi todos los hogares españoles había aparatos de radio por esas fechas. Las

${ }^{609}$ LÓPEZ RODó, Laureano, Memorias, volumen I, Plaza \& Janés/Cambio 16 , Madrid, 1990, págs. 340-341. 
Los años de "La Editorial Católica": redactores líricos, fervor católico, y consignas.

primeras experiencias con la televisión en España, habían comenzado en 1952 , y -lo que es más importante todavía- el modelo de vida que se ofrecía a los españoles no era el de un súbdito de los Reyes Católicos, sino el del ciudadano americano. Cine, moda, música, organización empresarial, formas de decir, supermercados..., todo eso se importaba del gigante de la Edad Contemporánea que ejercía su imperio en el más estricto sentido del término- de modo implacable. Cierto que a los españoles se les ofrecían dosis ingentes de doctrina tradicionalista a través de los domesticados medios nacionales; pero si la doctrina no se vive, se pierde, incluso como tal doctrina. El modo de vivir de los españoles no era muy distinto del de sus coetáneos extranjeros de occidente, y en lo que lo era, se iría transformando cada vez más, para amoldarse al american way of life 610 . Diario Regional recogía con asombro la fotografía de un supermercado de los EE.UU. sorprendido de que cada uno se sirviera y luego pagara al salir; anunciaba el comienzo de las industrias del automóvil en Valladolid; y constataba que la ciudad crecía cada vez más, en detrimento del entorno rural. Algo estaba cambiando en la España eterna.

A esos cambios debían corresponder, de modo natural, cambios en los medios de prensa, que en España el control

${ }^{610}$ Sobre la penetración americana en los medios de comunicación europeos después de la segunda Guerra Mundial, puede verse PIZARROSO, Alejandro, Historia de la Propaganda. Notas para un estudio de la propaganda política y de "guerra", Eudema, Madrid, 1990, pág. 433. 
Los años de "La Editorial Católica": redactores líricos, fervor católico, y consignas.

estatal trataba de impedir. Pero pese a todo, en función de lo que demandaba la nueva sociedad que estaba naciendo, éstos se orientaban cada vez más hacia las tareas informativas, y cada vez menos hacia la doctrina-opinión. Por supuesto que el nuevo mundo conocía formas de manipular la opinión, y mucho más sibilinas y efectivas que las mil llaves del Ministerio de Información y Turismo. Citaremos dos ejemplos solamente, suficientemente significativos. Víctor Gollancz (1893-1967), el fundador del Club del Libro de Izquierdas inglés, que difundió por millones obras favorables a su ideología -comunista-, podía regocijarse de haber hecho "que el público creyera [el Club] "una empresa comercial independiente" y no "la propaganda de una organización política dada"»611, que es lo que realmente era. El escritor inglés Cyril Connolly (1903-74), publicó en un editorial de la revista Horizon en junio de 1946-, los que a su juicio eran "principales indicadores de una sociedad civilizada". La lectura del resumen de ese editorial cuarenta y cinco años más tarde, y su comparación con la cita de Tomás cerro con que comenzábamos el capítulo, dice claramente quiénes fueron los vencedores en la batalla por conquistar la nueva sociedad de la segunda mitad del siglo $\mathrm{xx}$ :

"1) Abolición de la pena de muerte; 2) reforma penal, prisiones modelo y rehabilitación de prisioneros; 3 ) eliminación de los barrios bajos y de las "ciudades nuevas"; $4)$ luz y calefacción subsidiadas y "provistas gratis como el

611 Johnson, Paul, Intelectuales, Javier Vergara editor, Buenos Aires, Madrid, México, Santiago de Chile, 1990, pág. 288. 
Los años de "La Editorial Católica": redactores líricos, fervor católico, y consignas.

aire"; 5) medicina gratis, subsidios para alimentos y ropa; 6) abolición de la censura, de modo que cualquiera pueda escribir, decir y representar lo que quiera, abolición de las restricciones a los viajes y del control de cambios, final de la intervención de teléfonos o de la formación de expedientes sobre personas conocidas por sus opiniones heterodoxas; 7) reforma de las leyes contra los homosexuales y el aborto, y de las leyes de divorcio; 8) limitaciones a la propiedad de inmuebles, derechos para los niños; 9) conservación de bellezas arquitectónicas y naturales y subsidios para las artes; 10) leyes contra la discriminación racial y religiosa." 612

Se pretendió en estos años construir un paraíso católico tradicionalista en nuestro país, y se fracasó rotundamente. No obstante, como ya hemos dicho otras veces, no cambian las sociedades de hoy a mañana. La obra de estos años iba a dejar una importante huella en España; el viejo país mediterráneo que después de fracasar en su viaje al pasado, comenzaba a recorrer el camino de retorno al siglo $\mathrm{xx}$.

Este proceso encontró a Diario Regional -de nuevo- en trance de muerte. La empresa, después de rechazar la propuesta de compra que le hizo El Norte de Castilla 613, presentó expediente de crisis y decidió cerrar el periódico por causa de las "cuantiosas pérdidas sufridas en el aspecto económico". El 31 de diciembre de 1954 sería el último día en que saldría el rotativo614. La Junta

612 Ibid., pág. 325.

${ }^{613}$ Cfr. SÁnCHEZ SÁNCHEZ, José Francisco, op. Cit., págs. 103 y 106.

${ }^{614}$ Con fecha 21 de diciembre de 1954 "Diario Regional S.A." presenta, en la Delegación Provincial de Sindicatos, un Expediente de Crisis por el que se solicita autorización para despedir a sesenta trabajadores, - lo que es lo mismo, para liquidar la empresa. Así lo comunica un oficio de la Vicesecretaría Provincial de Ordenación Social al Jefe 
Los años de "La Editorial Católica": redactores líricos, fervor católico, y consignas.

Sindical Provincial se opuso a la medida, solicitando que "La Editorial Católica» prestase el apoyo económico necesario para evitar que sesenta trabajadores perdieran su empleo615. A última hora se acordó prorrogar la vida del periódico tres meses, transcurridos los cuales -gracias a la intervención del arzobispo, José García Goldáraz616_, se consiguió que el diario católico -de la mano de otra empresa- siguiera publicándose.

del Sindicato Provincial de Prensa, Papel y Artes Gráficas. A.H.P.U.V., Sección A.I.S.S., leg. 4.698 .

615Acta de la Junta Sindical Provincial celebrada el 28 de diciembre de 1954. Ibid.

${ }^{616}$ Cfr. "Cincuenta y ocho años de historia», DR, 20/3/1966, pág. 4. 



\section{Periodismo es información, y «católico» sustantivo.}

«Diario Regional, haciendo un esfuerzo de documentación e información, brinda a sus lectores un reportaje inédito sobre lo que va a ser la primera expedición a la Luna. Este pretende ser una muestra del periodismo nuevo, que continuará cultivando este diario, al servicio del lector, sin escatimar esfuerzos en bien de la verdad y la vivacidad informativa.»

Diario Regional, 3 de noviembre de 1957.

«Ya va siendo hora de que los católicos defendamos las respuestas que damos

a las preguntas de nuestro tiempo, por su grado de eficacia, por su viabilidad social, ¡porque sean las mejores soluciones humanas y no por su condición de católicas!

En el mundo, en la vida civil, hay que moverse con criterios de validez secular y no por etiquetas religiosas.»

Luis Gordon Beguer en Diario Regional, 27 de abril de 1966. 
MODERNIZACIÓN EMPRESARIAL, RUMORES, Y EL OPUS DEI

La gestión realizada por el arzobispo que citamos al final del capítulo precedente, supuso el comienzo de una nueva etapa en la vida de Diario Regional : a finales de marzo de 1955 "La Editorial Católica" abandonaba el periódico para dejarlo en manos de tres empresarios, miembros del Opus Dei. El relevo era fruto de la búsqueda de personas que ofrecieran confianza al arzobispo $y$ quisieran hacerse cargo de la gestión del rotativo. García Goldáraz se dirigió a un sacerdote del opus Dei que por entonces residía en Valladolid -Emilio Navarro-, rogándole que hiciera alguna gestión en este sentido ante miembros de la Obra que se dedicaran profesionalmente al sector editorial. Navarro se puso en contacto con el consejero delegado de S.A.R.P.E. -Sociedad Anónima de Revistas, Periódicos y Ediciones-, Andrés Rueda, y éste entró en conversaciones con Francisco de Luis, hasta llegar a un acuerdo sobre la compra de las acciones del periódico que pertenecían a "La Editorial Católica»617.

617 Testimonio personal de Andrés Rueda Salaberry. Nuestro intento de consultar el archivo personal del arzobispo resultó infructuoso. El encargado de ordenar sus papeles -Notario de la Diócesis- nos indicó que no había nada que se refiriera a Diario Regional entre los documentos que él había revisado. 
Mientras tanto, la idea de lo que ocurría con el diario -al menos en los ambientes periodísticos- era la siguiente: el 17 de marzo de 1955 el delegado provincial de Sindicatos, siguiendo las órdenes del delegado provincial de Trabajo, comunicó a la Junta del Sindicato del Papel, Prensa y Artes Gráficas la reactivación del Expediente de Crisis de Diario Regional S.A., rogándole que se pronunciara de nuevo sobre el caso618. En el acta de la reunión de la Junta se señala lo siguiente:

"Habiendo dado el Secretario lectura al informe sindical evacuado en su día, se tomó el acuerdo de ratificarlo, sin perjuicio de que se realicen las gestiones oportunas a fin de que, en el caso de que se reconociese oficialmente la crisis alegada por la Empresa y se autorizase el despido de los sesenta trabajadores afectados, se pudiese garantizar la colocación de los mismos, caso de que se confirmasen ciertos rumores existentes que indican la posibilidad de que se haga cargo otra entidad de las instalaciones de Diario Regional."619

De nuevo el rumor volvía a ser protagonista de nuestra historia. Poco después otro informe del jefe del Sindicato del Papel -basándose también en el "se dice"escribe que "la entidad Opus Dei, adquirió el periódico, continuando su publicación." 620

618 Oficio del Delegado Provincial de Sindicatos al Jefe Provincial del Sindicato de Papel, Prensa y Artes Gráficas, y contestación de éste al primero. A.H.P.U.V., Sección. A.I.S.S., leg. 4.698.

${ }^{619}$ Libro de Actas de la Junta Sindical del Sindicato del Papel, Prensa y Artes Gráficas, págs. 15-16. A.H.P.U.V., Sección. A.I.S.S., leg. 6.774 .

${ }^{620}$ Informe del Jefe del Sindicato del Papel Prensa y Artes Gráficas de Valladolid de 23 de junio de 1955. A.H.P.U.V., Sección. A.I.S.S., leg. 4.697 .

José Francisco SÁnchez da la versión del Consejo de Administración de El Norte de Castilla, S.A.: "1955 es otro año cargado de acontecimientos en la vida de Miguel Delibes y en la del 
El hecho fue que tres nuevos empresarios -Andrés Rueda, Fernando Valenciano y Vicente Picó- llegaron de Madrid, dispuestos a sacar de su agonía a un diario casi cincuentón. Según relata Picó621 -que será el nuevo consejero delegado de la empresa, y el único que permanecerá en Valladolid-, aunque jóvenes, dos de ellos tenían experiencia profesional, si bien sólo uno en empresas periodísticas: Rueda, que gestionaba además un negocio familiar de pieles y curtidos. Valenciano era ingeniero y trabajaba en la construcción. El contacto profesional entre estos dos se había dado a raíz de la intervención del último en la construcción de instalaciones de la empresa familiar de Rueda en Madrid622. Éste había decidido acudir a aquél aprovechando que Valenciano viajaba ahora con frecuencia a Valladolid, donde dirigía la construcción de la Escuela Apostólica de los Padres Dominicos. Por fin, Vicente Picó -abogado- se había unido al equipo por invitación de Rueda, para

periódico que, de hecho dirige. La empresa se encuentra en un momento de expansión. Y, además de proseguir las gestiones para la compra del Diario Regional, se interesa por otros dos periódicos (...). El balance económico de este año -en contra de lo que había sucedido el anteriorresultaría francamente optimista. Sólo un suceso viene a nublar, en un primer momento, tan halagüeñas perspectivas: la venta de Diario Regional en la última semana de marzo a una nueva empresa, "Diario Regional, S.A." -aunque posteriormente pasaría a engrosar la cadena S.A.R.P.E. (Sociedad Anónima de Revistas y Periódicos)-.»op. Cit. págs. 106-107.

${ }^{621}$ Entrevista con Vicente Picó, Madrid, 11/5/1991.

622J.A.R.S.A.: José Antonio Rueda S.A.. 
atender los aspectos técnico-jurídicos ${ }^{623}$. En definitiva, si bien los nuevos empresarios habían sido llamados precisamente por la confianza que el arzobispo tenía en los miembros del Opus Dei, esta institución, como tal, no había intervenido en la conformación de la nueva empresa; modo de actuar que iría, como veremos a continuación, contra principios básicos del Opus Dei624.

Con esto llegamos a un punto clave en el que conviene que nos detengamos, ya que la actuación en la vida pública o profesional de los miembros de la Obra ha dado lugar -al menos en nuestro país- a no pocas polémicas. Para comprender la actividad los tres nuevos empresarios, vamos a considerar previamente algunos datos de hecho $y$ de derecho referidos al Opus Dei en general, que sirven de marco y ayudan a explicar los diferentes puntos de vista que se adoptaban ante su llegada a "Diario Regional, S.A." •

\footnotetext{
${ }^{623}$ Testimonio personal de Andrés Rueda y entrevista con Vicente Picó.

${ }^{624}$ Solicitamos a la Oficina de Información del Opus Dei en España que nos indicara si se conservaban datos referidos a este asunto en los archivos de la Prelatura. El director de la oficina-Antonio Hernández Deus- nos contestó con carta fechada el 22/11/1991, indicando que no se conserva ningún documento, porque el opus Dei no intervino en los acontecimientos. A la amabilidad de Antonio Hernández debemos los datos facilitados por Andrés Rueda, con quien se puso en contacto para trasladarle algunas de las preguntas que formulábamos a la citada oficina.
} 
Por entonces el número de miembros del Opus Dei, si bien crecía con una rapidez notable, no era muy alto625, y además, muchos de sus miembros españoles marchaban al extranjero para conseguir la expansión del Instituto por otros países ${ }^{626}$. Se trata por tanto de un conjunto de personas más bien reducido, $y$ por eso no es extraño encontrar a los mismos protagonistas en actividades muy distintas, que dan lugar a equipos como el formado por Rueda para Diario Regional. Además, es precisamente en los años cincuenta cuando la actividad de sus miembros en España comienza a tener una relevancia social, en virtud de la atención que se presta a las actividades apostólicas de las que la Obra se ocupa corporativamente, o a la actuación de miembros de la institución que ocupan cargos

625 "Respecto al número de miembros, que en 1946 alcanzaba la cifra de 268 (239 de la Sección de varones y 29 de la sección de mujeres), se ha pasado en los primeros meses de 1950 a 2.954 (2.404 de la Sección de varones y 550 de la sección de mujeres). Los sacerdotes, que en 1946, cuando el Fundador llegó a Roma, eran 4, en 1950 son 23; otros 46 miembros de la Obra estaban preparándose para recibir las Sagradas órdenes; de entre ellos 11 ultimaban sus estudios en diversas facultades eclesiásticas de Roma." FUENMAYOR, Amadeo de, GÓMEZ-IGLESIAS, Valentín, ILLANES, José Luis, El itinerario jurídico del Opus Dei, historia $y$ defensa de un carisma, Eunsa, Pamplona, $1990^{4}$, págs. 195-196.

626Por estos años el Opus Dei comenzó a desarrollar su labor en los siguientes países: Portugal, Francia, Gran Bretaña, Italia, Irlanda y Francia, 1946; México y Estados Unidos, 1949; Chile y Argentina, 1950; Venezuela y Colombia, 1951; Alemania, 1952; Perú y Guatemala, 1953; Ecuador, 1954; Suiza y Uruguay, 1956; Austria, Brasil y Canadá, 1957; Japón, Kenia y El Salvador, 1958; Costa Rica, 1959; Holanda, 1960; Paraguay, 1962; Australia, 1963; Filipinas, 1964; Bélgica y Nigeria, 1965 .

"La expansión geográfica estuvo acompañada -y hecha posible- por la incorporación al Opus Dei de nuevos miembros, no sólo en España, sino en las diversas naciones a las que había ido extendiéndose su apostolado. Los 2.954 miembros -de los cuales 23 sacerdotes- en el momento de la petición de aprobación de 1950, han pasado a ser, a principios de la década de 1960, 30.353, de los cuales 307 son sacerdotes." Ibid., págs. 196 y 301. 
públicos ${ }^{627}$. No obstante, para el Opus Dei, lo fundamental resulta ser la actividad apostólica que desarrollan sus miembros personalmente, y no las labores que promueven de modo corporativo628. Esta forma de actuar responde, según su fundador, a la esencia misma del espíritu de la institución, netamente laical. Tanto el concepto como los modos prácticos que conlleva esa mentalidad constituían una novedad, que generó no pocas incomprensiones y un complejo problema de Derecho Canónico, que no ha sido resuelto por la Iglesia hasta 1982. Y, al menos en parte, de esa novedad derivaba también uno de los problemas más frecuentes con que iban a encontrarse los miembros del Opus Dei, especialmente en España: la acusación de secretismo que se imputaba a sus actividades. Una de las raíces del problema se encuentra en la diversa

${ }^{627}$ En nuestro periódico, por ejemplo, la primera noticia aparecida sobre el Opus Dei se refiere a la visita efectuada por el ministro de Asuntos Exteriores a una de sus labores apostólicas: el Instituto Tajamar, un centro educativo del madrileño barrio de vallecas: "Martín Artajo (...) También visitó el Instituto del Opus Dei" Diario Regional, 27/12/1949, pág. 5 .

628 "El Fundador (...) describía al Opus Dei como “Una gran catequesis": su labor consiste primordialmente, en una actividad formativa, en dar a sus miembros, y a cuantos se acerquen a la obra, una formación que les permita vivir sus tareas $y$ ocupaciones de forma hondamente cristiana. Así lo afirmó desde el principio (...). También las Constituciones de 1950 reflejan esta realidad: "Como norma general, el Opus Dei no tiene un modo específico de acción colectiva externa. Ante todo, debe cuidar de la formación espiritual y apostólica de los socios. Estos realizan el apostolado mediante el ejercicio de sus tareas y oficios públicos o mediante asociaciones legítimamente constituidas, según lo aconsejen las circunstancias de tiempo y lugar, siempre con total respeto de las legítimas leyes de la sociedad civil" $(\mathrm{n}$ ㅇ 7 )

"En suma, el acento se pone en la labor individual que cada uno de los miembros puede y debe realizar, con libertad y responsabilidad personales, en el ejercicio de su trabajo profesional: tal es el fruto fundamental del Opus Dei." FUENMAYOR et al, op. cit., págs. 276-277. 
interpretación que de su actividad hacen los protagonistas y otras personas ajenas a la institución. Para los miembros de la Obra, la actuación de ésta como un grupo es excepcional, mientras que muchos de los observadores ajenos a ella entienden cualquier actividad de sus miembros como una actuación de la institución. Esta interpretación -aunque equivocada desde el punto de vista de los protagonistas-, resulta comprensible si se tiene presente que se aplican al Opus Dei las mismas categorías que a las órdenes religiosas $-y$ a asociaciones de seglares creadas por ellas-, que eran el instrumento apostólico de la Iglesia por antonomasia. Hasta el momento, los laicos habían sido siempre un elemento auxiliar en las tareas evangelizadoras, cuya misión consistía en secundar las iniciativas de los clérigos, ayudándoles a llegar donde su estado no se lo permitía. Ese modelo es precisamente el rechazado por los miembros del Opus Dei: para ellos su actuación -que en nada difiere de la de cualquier otro ciudadano, católico o no- puede tener en sí misma un valor sobrenatural, que no deriva de una conexión especial con las estructuras eclesiásticas: es la de un fiel corriente, y nada más. Al mismo tiempo, hay otro aspecto de su modo de hacer que afecta particularmente a la prensa, por referirse a la publicidad de sus actividades:

"Resulta significativo que, en el primero de los capítulos de las Constituciones, e inmediatamente después del número 5 , texto encaminado a marcar, ya desde el principio, que los miembros del Opus Dei no son religiosos, Mons. Escrivá haya incluido otro destinado a hablar de lo que, desde los comienzos, calificó como humildad colectiva: "El Opus Dei - 
declara este número- profesa la humildad colectiva, y en consecuencia no editará periódicos ni publicaciones de ningún género con el nombre de la obra, a no ser para uso de los mismos socios; sus miembros no usarán distintivos, y hablarán prudentemente de la Obra con quienes no pertenezcan a ella, pues su actuación debe ser sencilla y no llamativa; y el Opus Dei no participa, de ordinario, en actos sociales ni se hace representar en ellos." "629

Por otro lado, y en lo que se refiere específicamente a la prensa, las ideas del fundador significaban una renovación de lo que se conoce en ambientes católicos como apostolado de la opinión pública. Así lo describe Pedro Cantero Cuadrado, un sacerdote español vinculado a la A.C.N. de P. desde 1931 hasta que fue nombrado obispo en 1951, y que mantuvo un trato asiduo con Escrivá de Balaguer:

"(...) Ya en los años de mis primeras relaciones con la A.C.N. de P. Y, más tarde, cuando trabajé en el diario "Ya", había hablado con Josemaría [Escrivá] muchas veces de la necesidad de informar los medios de comunicación social con el espíritu cristiano. Me fui dando cuenta así, poco a poco, del planteamiento original que hacía (...) •

"Josemaría no era partidario de gastar medios materiales hombres y dinero- para crear órganos de prensa, radio, etc., con carácter más o menos confesional. Veía claramente que su labor -y la de la obra en cuanto tal- no debía ser la de crear empresas o mover directamente órganos de opinión, sino la de realizar un intenso trabajo apostólico entre personas de todo nivel, también entre estos profesionales. Así, insensiblemente, se encontraría la Iglesia con hombres y mujeres que le eran fieles $y$ se dedicaban a difundir su doctrina sin comprometer a la Iglesia, poniendo en juego únicamente su libertad y responsabilidad de cristianos honrados." 630

${ }^{629}$ Ibid. pág. 269.

${ }^{630}$ CANTERO CUADRADO, Pedro, Josemaría Escrivá de Balaguer: un hombre de Dios. Testimonios sobre el Fundador del Opus Dei. 2, Palabra, Madrid, $1992^{3}$, págs. 57-58. 
Esos eran los presupuestos en que los nuevos empresarios basaban su actuación. Por eso, si su interés por los medios de prensa tenía un cariz apostólico, tenían también muy claro que lo que adquirían era una empresa. La titularidad de "Diario Regional, S.A." los convertía en empresarios de prensa -lo mismo que si no fueran católicos-, no en apóstoles. No dudaban que el Opus Dei no se responsabilizaba de su gestión, y mucho menos que se entrometiera en ella; es más, se sentían molestos cuando alguien no lo entendía así, algo que resultaba frecuente en la España de aquellos años ${ }^{631}$.

Pero si se observa con detenimiento lo que ocurría, resulta patente la dificultad que tendría para entender la cuestión cualquier persona que no conociera a fondo el espíritu y los modos de actuar de la Obra. Era un hecho que los periódicos católicos venían siendo gestionados por laicos desde tiempo atrás, por motivos que ya hemos expuesto. Esos laicos entendían su tarea como netamente católica, y lo mismo entendía la jerarquía: era la famosa prensa católica oficiosa de la que hablábamos al principio del capítulo precedente. Pues bien, si Rueda y sus colegas se habían hecho cargo del periódico, era porque el arzobispo confiaba en ellos en cuanto católicos, por más que ellos no tuvieran intención de dar a su trabajo -ni

${ }^{631}$ Cfr. entrevista con Vicente Picó; y también FONTÁN, Antonio, Los católicos en la Universidad española, Rialp, Madrid, 1961, págs. 5566. LE TOURNEAU, Dominique, El Opus Dei, Oikos Tau, Barcelona, 1986, págs. 47-50. 
siquiera extraoficialmente- un carácter confesional. Correspondiendo a la confianza del arzobispo, seguían en la línea de fidelidad a la doctrina católica que estaba establecida en los estatutos de la empresa, y el modo de hacerlo era poniendo al frente del periódico hombres de confianza, que resultaban ser también miembros del Opus Dei. Es decir, como cabía esperar, heredaban el modelo de actuación que era característico de la prensa católica; un modelo que no reflejaba nada bien su idea de fondo de deslindar actividad profesional y condición de católicos o de miembros del opus Dei. Como consecuencia de todo ello, el periódico podía ser visto con toda naturalidad por los vallisoletanos como un órgano del Opus Dei; más todavía cuando se daba otra circunstancia, anecdótica si se quiere, pero claramente condicionante de la opinión pública: sabemos que en el segundo piso del edificio de Diario Regional se habían instalado en 1952 los locales de la Acción Católica. Los nuevos empresarios pidieron que lo desalojaran y fijaron en él su residencia, con lo que se convirtió en la sede material de uno de los centros de la Obra en Valladolid. Para el vallisoletano medio estaba claro lo que sucedía; por eso, cuando se le decía que el periódico no era del Opus Dei, no es extraño que se sintiera un tanto perplejo: por un lado todos los indicios le decían lo contrario, y por otro parecía que la Obra pretendía ocultar su relación con el periódico. La consecuencia del malentendido -para quien no se tomara la 
molestia de aclararlo- era fácil de extraer: querían mantener en secreto esa relación. Un curioso secreto, conocido por toda la ciudad.

Otra cuestión que nos interesa más todavía es la siguiente: admitido que los miembros del Opus Dei que trabajaban en el periódico lo hacían con absoluta libertad y responsabilidad personales; ¿qué actitud tenía el opus Dei como institución ante el diario?, ¿los directores de la Obra se preocupaban del diario en sí, considerándose moralmente responsables de su orientación? En suma ¿consideraban al periódico una tarea apostólica, o no? En los Estatutos del entonces Instituto secular se contemplaba la posibilidad de que éste se responsabilizara de la formación impartida en lugares como residencias de estudiantes o centros educativos. Ese tipo de iniciativas creció en número y diversidad precisamente en estos años ${ }^{632}$. Parece que con el periódico se adoptó inicialmente

632 "Pero, aunque, como declara el decreto Primum Inter, "los socios del Opus Dei actúan y operan más bien individualmente" (\$ 21 ), no se excluye que -solos o con otras personas- promuevan actividades de carácter y finalidad apostólicos, de las cuales el Opus Dei, como corporación, pueda asumir la garantía moral de su recta orientación doctrinal o apostólica. Esta posibilidad estaba ya prevista (...) en documentos y textos anteriores, habiendo sido incluso llevada a la práctica: Academia DYA, en 1933; residencias de estudiantes constituidas en Madrid y en otras ciudades, a partir de 1939... Esas realizaciones habían sido, hasta 1950, pocas y, en todo caso, no muy variadas: residencias de estudiantes y casas de retiro y convivencias, casi exclusivamente. En 1950, con el desarrollo de la labor, se entrevén ya $-y$ no como posibilidad teórica sino inmediata y concretaotras manifestaciones: centros de enseñanza, dispensarios y otras obras benéficas, centros para la capacitación de obreros y campesinos, etc.; muchas de las cuales irán tomando cuerpo en la década que entonces se iniciaba o en la sucesiva. En más de un momento, Mons. Escrivá puso de manifiesto -lo había hecho ya en años anteriores, y lo seguirá haciendo en el futuro- la conveniencia de que existan algunas 
una actitud de este tipo, para cambiar a principios de los años sesenta, por indicación expresa del fundador ${ }^{633}$. Todo apunta a que en los comienzos de su actividad, si bien estaban claros los presupuestos para la actuación de los miembros de la actual Prelatura, no lo estaban tanto los modos prácticos, en lo que se refiere a relaciones entre la Obra y actividades apostólicas promovidas por sus miembros con garantía corporativa634. No es extraño que fuera así, no sólo por la novedad del fenómeno, sino porque, en ese tipo de labores, eran herederos en muchos casos de otros modos de hacer que no podían cambiar de un plumazo: hubiera parecido a muchos católicos $-\mathrm{y}$ entre ellos, a no pocos obispos- falta de compromiso o una traición. Además, en la articulación jurídica de la obra el fundador seguía la norma de que el derecho fuera después de la vida, una lógica medida de prudencia para quien debía defender un carisma que carecía -incluso en la

de esas actividades, ya que constituyen un punto de referencia importante para el desarrollo de la labor. Pero, al mismo tiempo, insistió constantemente en que esas obras serían siempre pocas, ya que lo propio del Opus Dei no es la promoción de labores determinadas sino la formación de personas." FUENMAYOR et al, op. cit., págs. 277-78.

633Entrevista con Antonio Hernández Deus, director de la oficina de información de la Prelatura Opus Dei en España. Madrid, 26/9/1991.

634Así, por ejemplo, en Diario Regional se publicó lo siguiente: "En la actualidad, dicho Instituto secular se halla extendido por una treintena de países. En América, lo mismo que en otros continentes, los socios de las dos Secciones, masculina y femenina, del Instituto, desarrollan una amplia serie de actividades apostólicas, entre las que destacan Universidades, numerosas residencias de estudiantes, escuelas-talleres para obreros, escuelas del hogar, Prensa, librerías y casas editoriales, explotaciones agrarias e industriales, empresas económicas y otras.". "Distinción al Presidente General del Opus Dei", 3/4/1956, pág. 1. Es obvio que no se distinguen con claridad en la información qué son propiamente actividades apostólicas del Opus Dei, y qué actividades profesionales de sus socios. 
legislación eclesiástica- de cauces adecuados para reflejarlo fielmente. Esto hacía normal que hubiera tanteos y rectificaciones hasta que se acertaba con fórmulas que se consideraban acordes con el espíritu de la institución 635 .

Diario Regional sería un ejemplo de esto: inicialmente, se entendió que una labor de prensa podía ser considerada una labor apostólica, en la que la Obra garantizaría su catolicismo. No lo haría por medio de directrices especiales, sino de forma indirecta: a través de la formación que daba a los miembros del Instituto que trabajaban en el periódico. El diario en conjunto recibía esa garantía del hecho de que en los puestos clave se colocaban personas que eran miembros del opus Dei o de su confianza. En pocos años se advirtió la inadecuación de este modo de hacer con el espíritu de la Obra, y se rectificó: parece que se apercibieron de que el modelo de prensa católica resultaba incompatible con los presupuestos por los que el Instituto se regía. Veremos cómo, en la práctica, esta rectificación estaba implícita en la actuación de los miembros del Opus Dei en el periódico desde el principio.

Aclaradas esas cuestiones previas podemos ya adentrarnos en la descripción de la actividad desplegada

${ }^{635}$ Cfr. FUenMAyOR et al, op. cit., págs. 94-98, y passim. 
por los nuevos empresarios, con el fin de reanimar el periódico. Vicente Picó apunta dos datos que le llamaron la atención a su llegada a Valladolid: el gerente saliente les preguntó si tenían intención de que Diario Regional saliera al día siguiente, $y$ encontraron en la mesa del director los útiles del personal de limpieza: no hace falta decir más para hacerse una idea del estado de la empresa. No había publicidad gestionada para los próximos días, los trabajadores y los redactores estaban desanimados hido presupuestadas las indemnizaciones para efectuar los despidos-, y la organización era un dorado recuerdo de mejores tiempos. Hacía falta entusiasmo para salir de una situación semejante, y eso, sobre todo, fue lo que trajo el nuevo equipo.

Al frente de la redacción se puso al hijo de uno de los primeros colaboradores de Justo Garrán: Jesús María Zuloaga, que hasta ese momento dirigía La Actualidad Española, y que sería reconocido por el Ministerio como director seis meses más tarde636. Zuloaga trajo con él a tres jóvenes colaboradores: Manuel Fernández Areal,

${ }^{636}$ Cfr. "Periódico Católico Agrario de Valladolid", por Leandro Pérez, en Estafeta Literaria, no 272-273, correspondiente al 17-31 de agosto, pág. 28. La Delegación del Ministerio de Información y Turismo comunicó oficialmente al periódico la aprobación por el Ministro del nombramiento como Director en octubre de 1955. "Como saben nuestros lectores (...) está al frente de Diario Regional desde el mes de mayo pasado", DR 23/10/1955, pág. 1 . 
Esteban Farré Gual, y José Antonio Vidal-Quadras ${ }^{637}$. Ellos serían los encargados de imponer otro ritmo entre los redactores, mientras que Picó se ocupaba de reconstruir la empresa. Buscó para eso la ayuda de personajes vallisoletanos $y$ de otros miembros del Opus Dei, procurando que estuvieran representados todos los sectores de la ciudad en el nuevo proyecto; y consiguió en parte que así fuera.

En diciembre de 1956 tuvo lugar una ampliación de capital de dos millones de pesetas, que situaba el total en tres millones. Hay que decir, de todos modos, que los accionistas serían realmente los que ahora se incorporaran: cuando el Ministerio pidió la lista completa para la inscripción de "Diario Regional, S.A." en el Registro de Empresas Periodísticas en 1959, la confección de esa relación dio no pocos quebraderos de cabeza al gerente, ya que nadie sabía dar razón de quiénes eran ${ }^{638}$. Era lógico, dado el estado de desorganización de la empresa, y -sobre todo- si se considera que se trataba de accionistas de una sociedad que nunca repartía dividendos.

${ }^{637}$ Cfr. Ibid.; manuscrito autobiográfico de Manuel Fernández Areal, págs. 18-19; y entrevistas mantenidas con el autor el 2/8/1987 y $10 / 8 / 1988$.

${ }^{638}$ La ley hacía entonces obligatorio que las acciones de las empresas periodísticas fueran nominativas. El periódico se vio obligado a publicar un aviso para completar la relación de accionistas. Cfr. DR, 6/1/1959, pág. 3. Cfr. también entrevista con Manuel Fernández Areal, 2/8/1987. Puede verse la solicitud de inscripción y las reclamaciones de la Dirección General de Prensa en A.G.A., Sección Cultura, caja 82.671 . 
La relación de suscriptores de las nuevas acciones da una idea de cuáles habían sido los logros de Picó. A grandes rasgos la situación era la siguiente:

a) El paquete de acciones de la serie $\mathrm{C}$ por valor de 500.000 ptas. que antes pertenecía a "La Editorial Católica", había sido comprado a partes iguales por Andrés Rueda, Fernando Valenciano y Vicente Picó. De las nuevas acciones de la serie D Picó suscribía 140.000 ptas, con lo que pasaba a ser el mayor accionista de la empresa con 300.000 ptas.. Valenciano invirtió 100.000 ptas. más, que le hacían el segundo accionista de "Diario Regional, S.A." •

b) Un 46\% de las nuevas acciones había sido suscrito por 42 accionistas vallisoletanos. Los tres más importantes eran Juan María Roger -un empresario catalán que tenía en Valladolid una planta de producción textil-, que adquirió acciones por un valor nominal de 250.000 ptas.-convirtiéndose así en el tercer accionista de la empresa-; Santiago López -el principal promotor de la fabricación de automóviles en la ciudad-, que invirtió 100.000; y el arzobispo que aportó la misma cantidad que López •

c) De los otros inversores vallisoletanos ninguno llegaba a las 100.000 ptas. Entre ellos había, tal como deseaba Picó, una representación de casi todo. Hay que destacar a Víctor Jolín, un conocido médico de la ciudad, que aportaba 50.000 ptas. y sería el presidente del 
Consejo de Administración; a Manuel Jalón, un empresario de la publicidad, que invertía 30.000; y a Arturo León padre e hijo, que desembolsaban 31.500 -el hijo, miembro del Opus Dei, sería muchos años secretario del Consejo-. El numeroso grupo de los restantes eran todos pequeños accionistas: medianos y pequeños empresarios, profesores universitarios, y profesionales, entre los que no faltaban hombres de la A.C.N. de P. Como Mariano Escudero o Felipe Pastor, que ya nos son conocidos.

d) El resto de los nuevos accionistas estaban domiciliados en Madrid y eran en su mayor parte miembros del Opus Dei. Sólo hay que exceptuar a Francisco de Luis y Guillermo Gil de Reboleño, que seguían vinculados a la empresa con cantidades simbólicas. Entre los miembros de la Obra a los que Picó recurría había también de todo, desde arquitectos a profesores universitarios, pasando por empresarios, jueces y hombres vinculados al mundo del cine o del periodismo -Fernando Arcos, Jorge Collar-, sin que faltaran algunos cuyos apellidos podían ser de utilidad para la obtención de créditos -Carbonell, Lahuerta, Planell, Ortiz-Echagüe-, ni otros que procedían de Valladolid -Rafael Echevarría, y Ramón Llamas, hijo de una de las fundadoras de la Liga Anticomunista de los años de la República-. En total, este grupo suscribía el 54\% del capital emitido, no sabemos si porque no se había conseguido más de los vallisoletanos, o porque interesaba 
que la mitad del capital estuviera en manos de personas de confianza.

A fin de cuentas, $y$ en lo que a nosotros más nos interesa, no parece que en este momento se hubiera superado la idea de prensa católica como obra benéfica. Si comparamos esta relación de inversores con la que teníamos para los años treinta, todo lo que podemos decir es que en lugar de una suscripción benéfica entre los católicos activos de Valladolid, ahora tenemos lo mismo ampliado a miembros de Opus Dei que no son vallisoletanos. La modernización empresarial no vendría por este lado, sino por la vía de hecho del comportamiento de los gestores de la sociedad; ya que, en efecto, Picó y sus colegas iban a trabajar en el levantamiento de la empresa sin apelar para nada a su condición de católica.

Esta situación significaba un equilibrio precario que años más tarde acabaría por romperse. La confesionalidad era para estos hombres un lastre que abandonarán primero en la cabecera del diario -con el consiguiente escándalo para algunos-639, y en la propia estructura de la empresa más adelante. A nuestro parecer, en esta cuestión está en buena medida la clave del fracaso de la empresa, que se vio inevitablemente envuelta en el hundimiento del modelo

${ }^{639} \mathrm{El} 1 / 4 / 1956$ desapareció de la cabecera el lema "periódico católico". El hecho produjo extrañeza y algunas quejas entre lectores y suscriptores, según relatan Zuloaga, Picó y Fernández Areal. 
de prensa católica: de los dos elementos en pugna -su intención de trabajar con una nueva mentalidad por un lado, y el peso de la tradición por otro-, pesó más aquel al que la opinión pública hizo más caso, es decir, el segundo.

Pero los signos más agudos de esa crisis no se dieron hasta finales de los años sesenta. En los que ahora nos ocupan -1955-67- la historia fue otra: la reanimación exitosa de un diario moribundo. No vamos a entrar en la descripción pormenorizada de la actividad empresarial de estos años, por otro lado muy intensa. En los primeros meses el Consejo de Administración se reunía semanalmente, ocupándose de promover la creación de una red de corresponsales en los pueblos, de publicar un folleto informativo sobre el periódico para atraer publicidad, de realizar promociones a base de concursos y mejoras informativas, de reorganizar la plantilla, etc.. Los logros iniciales, fruto de la intensa dedicación a la empresa, y del entusiasmo de los redactores del que luego nos ocuparemos, permitían obtener créditos e introducir mejoras que culminaron en el cambio de domicilio en junio de 1959. Para entonces se había superado ya la situación crítica y la empresa estaba en franco crecimiento640.

640 Testimonios de Andrés Rueda, y Jesús María Zuloaga y entrevista con Vicente Picó. 
Todo ese trabajo se había realizado en estrecho contacto con La Actualidad Española, publicación de la que procedían algunos de los nuevos redactores $y$ diversos apoyos empresariales, sobre todo en materia de publicidad ${ }^{41}$. Este ejemplo no pasó inadvertido para otras publicaciones de provincias similares a Diario Regional, que entendieron que podían obtener auxilio "del Opus" para reflotar sus exhaustas economías. Ni que decir tiene que semejante interpretación de los hechos no era nada grata a quienes estaban consiguiendo con su esfuerzo personal lo que otros interpretaban como fáciles logros de un poderoso Opus Dei, cada vez más mitificado por dimes y diretes. Pero de hecho, animados en efecto por la experiencia, los hombres de La Actualidad Española impulsaron la ampliación de la cadena de publicaciones en la que Diario Regional iba a estar incluido: la Sociedad Anónima de Revistas y Periódicos, SARPE.

Esta decisión coincidía con el momento en que el opus Dei adoptaba una actitud más clara con respecto a estas iniciativas, eludiendo ya cualquier compromiso de garantizar moralmente la orientación de medios de prensa. Esto no significó la retirada masiva de sus miembros de los respectivos consejos de administración, ya que no estaban en ellos en calidad de miembros de la Obra, sino de accionistas; y precisamente por eso, aunque la actitud

\footnotetext{
${ }^{641}$ Entrevista con Vicente Picó.
} 
de los directores de la Obra cambiara, la realidad práctica permaneció de momento inalterada. Sólo con el tiempo se vería el efecto que implicaba esa decisión.

Por lo que hace a "Diario Regional, S.A.", la conexión con S.A.R.P.E. se plasmaba en la presencia de directivos de la cadena en los consejos de administración: Enrique Casellas -consejero delegado de S.A.R.P.E.-, José Luis Olaizola, Emilio Fernández de Caso y Ricardo Puig642. Junto a ellos seguían estando en el consejo vallisoletanos como Víctor Jolín, Francisco Pérez de los Cobos, Francisco Mateo -que lo había presidido en 1936-, Arturo León, etc. A finales de 1964 se decidió ampliar el capital social en cuatro millones de pesetas, decisión que se ejecutó en abril del año siguiente 643 , para apoyar el plan de mejoras

${ }^{642} \mathrm{Cfr}$. las anotaciones del Registro de Empresas Periodísticas en A.G.A., sección Cultura, caja 82.671. El control de la Dirección General de Prensa llevaba a que ante los cambios en los consejos se solicitara al delegado provincial informes personales sobre los nuevos consejeros. Antolín de Santiago remitía por lo general los informes que le facilitaba la policía, en los que suele constar que todos estos hombres eran de intachable conducta moral y religiosa y que o bien constaba su adhesión a los principios del Movimiento, o no se les conocían actividades políticas.

643 Cfr. "Segunda copia de la escritura de aumento de capital y modificación de Estatutos otorgada por: don José-Ramón Abril Martín, en representación de la Sociedad Anónima Diario Regional" Notaría de D. Miguel Hoyos de Castro. Valladolid. № 2743 de 8 de julio de 1967 . A.P.G.A.M.. Cfr. también Registro de Empresas Periodísticas, con número 196, tomo 3, Sección Personas Jurídicas, Folio 156, inscripción 1a. Oficio de la Dirección General de Prensa, Servicio Régimen de Empresas y Medios Informativos, Sección Empresas, al Gerente de Diario Regional S.A., de 18 de septiembre de 1967, hoja 2. A.H.P.U.V., Sección cultura, caja 28. No se encuentra la relación nominal de suscriptores que debería ir unida al expediente.Cfr. también el informe del gerente del periódico al director general de Prensa de 4 de mayo de 1965. A.H.P.U.V., Sección Cultura, caja 28. Pueden verse en el apéndice 3 otros aspectos concretos de la ampliación. 
previsto por la empresa, según se declaraba en la escritura de ampliación de capital:

"(...) de las dos etapas que el Consejo se propuso llevar a cabo, está cumplida una de ellas cual es la de haber reducido la plantilla del personal de la Empresa, que se llevó a feliz término a principio del presente año. Ahora es aconsejable, acometer la segunda etapa, mejorar de forma decisiva todos los elementos que componen los talleres de Diario Regional, con arreglo a un plan cuidadosamente estudiado y que se da a conocer a la Junta»644.

En cuanto a los suscriptores de las acciones, S.A.R.P.E. desembolsó un capital de 1.850 .000 ptas.645, con lo que la cadena se convertía en accionista mayoritario, al poseer al menos un $27 \%$ del capital 646 .

Lo más destacable de todo esto es el cambio de mentalidad que se ha operado. En ocasiones precedentes, este tipo de acontecimientos iban acompañados de las habituales declaraciones de intenciones, sobre la necesidad de defensa de los intereses católicos, el sacrificio y entusiasmo de los consejeros y accionistas, etc.. Ahora nada se decía en ese sentido, entendiendo que

644Cfr. "Segunda copia de la escritura..." citada. En cuanto a la reducción de plantilla, se despidió a 14 trabajadores después de llegar a un acuerdo con ellos. Cfr. oficio del delegado provincial a director general de Prensa, de 21/4/1964, A.G.A., sección Cultura, caja 82.671 .

645 "Copia del acta de protocolización de documento, a instancia de D. Arturo León Alvarez, en representación de "Diario Regional, S.A.", Notaría de D. Miguel Hoyos de Castro, Ilustre Colegio Notarial de Valladolid, 1 de julio de 1970 , no 1970. A.P.G.A.M..

646 Aunque no tenemos constancia de otro tipo de transacciones, es probable que S.A.R.P.E. hubiera adquirido más acciones de las series A, B, C Y D, además de la pequeña cantidad que consta en 1959. Al menos eso parece indicar la venta a P.E.S.A. que se efectuará en 1970 y de la que nos ocuparemos en su momento. 
las mejoras debían apreciarse en el producto que se ponía a la venta. Así, por la vía de hecho, la confesionalidad del medio había desaparecido, en la misma medida en que se había acentuado la profesionalidad. El resultado final era una empresa modesta, pero sólida; algo que hasta entonces nunca había tenido Diario Regional, y que permitía por fin que el esfuerzo de las redacciones por mejorar el periódico diera frutos visibles.

\section{UN NUEVO PERIODISMO}

\section{El dilatador de pupilas}

El hecho que acabamos de describir es uno de los factores que más pesan en la definición del periódico, ya que desde ahora -normalizada la empresa-va a ser el carácter de las redacciones lo que dibuje los perfiles del rotativo. Dicho de otro modo: la información que se da y cómo se da son los elementos básicos del nuevo Diario Regional.

En este sentido, la breve etapa que Jesús María Zuloaga pasó al frente del periódico -de abril de 1955 a enero de 1957- resultó fundamental. Podría resumirse su labor como la formación de un equipo capaz de descubrir los contenidos informativos de la vida vallisoletana. El periodismo que hasta entonces se venía haciendo era normalmente pasivo: las noticias llegaban a la redacción o 
se buscaban en los lugares de rutina -Comisaría, Ayuntamiento, Diputación, etc.-. El nuevo director veía las cosas de otra forma. Las oficinas de la redacción eran el lugar de elaboración de las noticias, pero éstas estaban en la calle, y había que saber descubrirlas. Para eso era premisa ineludible salir a buscarlas ${ }^{647}$ El reporterismo, animado por la capacidad de descubrir en lo cotidiano asuntos que podían convertirse en noticia, debía ser el eje del trabajo. $Y$, en efecto, reportajes $y$ entrevistas serán la novedad de mayor relieve en las páginas de Diario Regional. Cualquier asunto, si se enfocaba del modo adecuado, podía ser desde entonces un acontecimiento: la vida de los barrios, la de los pueblos, los niños que hacían la colecta del Domund, la llegada de los universitarios para hacer el servicio militar en Montelarreina, o la marcha de las industrias de Valladolid648. Las campañas de opinión que antes eran

${ }^{647}$ Entrevistas con Manuel Fernández Areal y Fernando de la Torre.

${ }^{648} \mathrm{Cfr}$. por ejemplo "Una realidad provincial. Todos los pueblos tendrán agua. El plan de la Diputación alcanza a 148 localidades", DR, 1/10/1955, pág. 1; "Nuestros enviados especiales visitan las tierras anegadas de nuestra provincia. En la ruta de las inundaciones", 20/12/1955, págs. 1, 9 y 10; "Por favor, unas perrillas para el Domund", 23/10/1955, págs. 1 y 4; "Valladolid ha adquirido rango de primera categoría en la industria nacional", 1/10/1955, pág. 5: en los días siguientes publicarán entrevistas con los principales industriales, y un serial titulado "Fomento industrial de valladolid". En junio de 1955 se organiza un concurso para los alumnos de la I.P.S. (servicio militar para universitarios) que va acompañado de informaciones sobre la vida campamentaria, y en ese verano se dedican páginas especiales a las fiestas de cada pueblo. 
características del periódico, desaparecieron -rara vez se hacían editoriales- para dejar paso al reportaje ${ }^{649}$.

La personalidad de Zuloaga -vital, de un entusiasmo contagioso650- ayudaba a que ese ambiente fuera difundiéndose entre los redactores. Ciertamente, se apoyó sobre todo en los más jóvenes, que no hacía falta reorientar, y eran los que más tiempo dedicaban al periódico651, pero consiguió también que los más veteranos

${ }^{649}$ Esto no significaba la ausencia de reclamaciones de mejora, sino que esas reclamaciones llegaban siempre a través de encuestas o reportajes elaborados por el periódico. En 1955 hemos encontrado como materias más frecuentes de reclamación la vivienda, el mal estado de las carreteras, la falta de teléfonos, y la de maquinaria agrícola.

${ }^{650} \mathrm{Su}$ iniciación en el periodismo -como él mismo narra- tuvo lugar muy pronto: "Entre los dieciséis y los diecisiete años era yo escribano de varones enamorados que no sabían cómo llegar a la adorable criatura que les quitaba el sueño.

"(...) Yo nací en el 20, hijo de un periodista apasionado y gran viajero que, sin embargo, me cerró la puerta de La Gaceta del Norte de Bilbao. Usé -metafóricamente- la ventana (...). En 1949 me caso y (...) viajamos a Madrid para demostrar redundantemente lo ya demostrado. iEran los famosos "cursillos" para poder lograr el para mi inútil carné de prensa! Mi viaje de nupcias duró, pues, cuatro meses. En esta única ocasión lo diré "todo". Salí con el no 1.

"En 1952 aparece La Actualidad Española. Por primera vez en mi vida era Director. Y se trabajó allí tanto que publicamos 60 números sin pasar por la censura. Así lo expresó el Director General entonces reinante. Era testigo Antonio Fontán, pensamiento y empresa de "LAE". Dijo Aparicio: "El Sr. Zuloaga, con esa cara de vasco impávido que ostenta, está realizando difíciles equilibrios con la censura"." Testimonio personal de Jesús María Zuloaga, fechado en Madrid el $28 / 10 / 1991$

${ }^{651}$ Testimonio personal de Zuloaga. Algunos eran redactores que se habían incorporado a Diario Regional con Santaella, -por lo general como colaboradores, ya que no tenían carnet de periodistas-: Rafael Andreu, Félix González Ferrández -que firma alguna de sus secciones "Feliciano"-, Cirilo Muñoz López Palomo -"Carlos Zeda"-, José Luis Pérez Herrero; otros se habían incorporado con Zuloaga: Manuel Fernández Areal, José Antonio Vidal-Quadras, Esteban Farré Gual, Francisco Artacho, y Luis González Armero -“Ito"- que procedía de Libertad.

Zuloaga evoca del siguiente modo aquella adaptación: "(...) Recorrimos uno por uno los pueblos de la provincia (los domingos). Un mes sin cambiar la cara del ancestral rotativo. 
colaboraran en el mismo sentido, a base de colocar a cada uno el lugar en que mejor podía rendir: Leandro Pérez hizo reportajes sobre la historia de las calles de Valladolid, o entrevistó a actores; Miguel Montalvo apoyó la participación del periódico en la organización de la Vuelta Ciclista a España; Luis González Armero alentó la iniciativa de crear Trofeo Nacional San Pedro Regalado para toreros, etc.652. Al mismo tiempo, ese estilo más activo en el trabajo, consiguió que la nueva mentalidad llegara a los vallisoletanos, especialmente a los que no estaban habituados a dirigirse a un periódico. Primero fueron los redactores de Diario Regional los que acudieron

"(...) José Antonio Vidal-Quadras, Manuel Fernández Areal, y Esteban Farré Gual, fueron los "refuerzos" que llegaron conmigo. Hicieron todo bien, junto con la desconcertada redacción que, muy pronto, entró en harina. Tuve con ellos trato igual."

${ }^{652}$ La distribución teórica del trabajo en la redacción la tenemos en la contestación que se da al cuestionario para la elaboración del Anuario de la Prensa: director Jesús María Zuloaga. Redactor jefe, Enrique Santos Herrera; confeccionador José Luis Pérez Herrero; secretario de redacción Manuel Fernández Areal; Arte, Leandro Pérez; cine; Félix González Ferrández; Deportes, Rafael Andreu de la Cruz y Miguel Montalvo; dibujante Luis González Armero; economía y finanzas Leandro Pérez; Editoriales el director y Manuel Fernández Areal; fotógrafo Ignacio Teresa Sanz; infantiles, Luis Olmo, colaborador; extranjero Enrique Santos; Local Francisco de Raymundo y Cirilo Muñoz López-Palomo; nacional, José Luis Pérez Herrero; libros, Leandro Pérez; Literaria, Francisco Javier Martín Abril; pasatiempos, Luis Olmo; religión Francisco Faus; Reportajes, todos los redactores; sociedad, idem.; sucesos, Cirilo Muñoz López Palomo; teatro, Leandro Pérez; toros Luis González Armero. Corresponsales en España: agencias nacionales; extranjero agencias Efe, Fiel y Logos. Colaboradores: Manuel Fernández Areal, José Antonio Vidal-Quadras, Félix González Ferrández, Luis González Armero, José Manuel Gil de Antuñano y Esteban Farré Gual. Anuario de la Prensa Española, Año IV, volumen I, Diarios, pág. 54 .

Sobre las iniciativas en torno a la Vuelta Ciclista y el Trofeo Nacional San Pedro Regalado, Cfr. "Vuelta Ciclista a España 1956. Organizada por Diario Regional con Prensa Reunida", DR, 1/1/1956, pág. 1; y "Diario Regional en alianza con la Federación Nacional de Peñas Taurinas. Toda la afición nacional estará representada en el Trofeo Nacional, iniciativa de nuestro periódico", DR, 16/10/1955, pág. 1. 
a tal o cual pueblo para conocer la impresión que había causado el pedrisco, o a un barrio para hacer un reportaje sobre la vida en él. Con el tiempo, desde los pueblos o los barrios llamaban ya a la redacción para comunicar lo que les parecía que podía ser noticia653.

Realmente, no había otra forma de comportarse si se quería competir con El Norte de Castilla. El poderoso decano vallisoletano jugaba con ventaja: era por antonomasia "el periódico", hasta el punto de que en Valladolid lo normal era que el público pidiera "un Norte" cuando compraba un diario, lo mismo si quería comprar el Marca, Diario Regional, o cualquier otro. Todo lo más, cuando el nuestro cambió su formato a tabloide en 1956, se le distinguía pidiendo "un Norte de los pequeños»654. Esa arraigada popularidad de la competencia exigía un esfuerzo de imaginación y de calidad a cualquiera que quisiera abrirse camino en el mercado vallisoletano. Zuloaga lo comprendió, e hizo del periodismo de calle su arma de combate. El Norte, como relata Sánchez Sánchez, advirtió el cambio con cierta alarma, y reaccionó compitiendo en el mismo terreno: de ahora en adelante ya no se esperarían las noticias en las redacciones, era necesario salir a buscarlas si se quería evitar el "pisotón" informativo del contrario. El siguiente párrafo de una carta del consejero

\footnotetext{
653Entrevistas con Jesús María Zuloaga, José Luis Cebrián, Manuel Fernández Areal, Andrés Romero Rubio, y Fernando de la Torre.

${ }^{654}$ Entrevista con Fernando de la Torre.
} 
delegado de El Norte -Fernando Altés Villanueva- a otro consejero -Jaime Alba-, fechada poco después de llegar Zuloaga a la dirección, resume bien la situación:

"La contrapartida del optimismo y la buena marcha de las cuentas me la está dando este mes el colega (...) con sus aciertos $y$ esfuerzos que contrastan con las omisiones, cansancio y fracaso de nuestra redacción.

"El director del colega acredita que es todo un periodista, no regatea medios y nos ha "pisado" varias informaciones de interés, motivo de otros tantos apercibimientos a D. Gabriel [el director de $E l$ Norte] y de expresar a Miguel [Delibes, que llevaba en la práctica la dirección] mi inquietud y descontento."655

La estructura informativa del periódico varió en el sentido que señalan las pautas que hemos descrito: aumentaron la información sobre los pueblos y los barrios conseguida en trabajos "de campo", el número de entrevistas, los reportajes -con importante carga gráficatanto de agencia como de redacción propia, los números extraordinarios, etc. Comenzó la publicación de un suplemento dominical, se sucedieron los concursos, y se introdujeron mejoras en las secciones tradicionales: en información local -sin duda la mejor atendida-, mercados agrícolas, información provincial y regional, finanzas, internacional, crónicas nacionales elaboradas por corresponsales, e información de agencia. Los deportes crecieron en importancia de forma notable, hasta el punto

${ }^{655}$ SÁnCHEZ SÁnCHEZ, José Francisco, op. cit., págs. 107-108. La fecha de la carta -19 de julio de 1955-, que no aparece en la publicación, la conocemos por la consulta del manuscrito mecanografiado de la tesis doctoral del autor, a quien hemos de agradecer su amabilidad por facilitarnos el mismo, así como algunas otras informaciones que son fruto de su investigación. 
de ser causa de ediciones extraordinarias, o del envío de reporteros al extranjero; $y$ se crearon secciones especialmente dedicadas a la mujer. Por otro lado, la sección religiosa adquirió un tono diferente y el periódico dejó de tener por característica la dedicación de espacios generosos a cuestiones estrictamente religiosas. Finalmente, el cumplimiento de las consignas se encargó casi en exclusiva al redactor jefe -Enrique Santos- que se cuidaba de ella en la sección "Mirador Nacional»656.

La maquetación experimentó cambios paralelos a los que hemos ido describiendo para los contenidos. Además de hacerse más ordenada, evitando los ángulos en los textos, y de incorporar mayor información gráfica, se hizo también más variada, en función de la importancia que se quería dar a las noticias. En abril de 1956 el formato cambió de sábana a tabloide, más manejable, y -sobre todo- útil para la confección de páginas monográficas; y el número de páginas, que había aumentado de seis/ocho a ocho/diez, pasó a ser de dieciséis/veinte.

Como resultado de todo esto, a la altura de la Semana Santa de 1956, Zuloaga podía decir que se había dado cima a una primera etapa de renovación del periódico, y en

${ }^{656}$ Puede verse una relación detallada de las secciones en el apéndice 2 . 
efecto así era657. Aunque con medios precarios, Diario Regional era ahora sobre todo un órgano informativo, en el que se hacía gala de una notable curiosidad periodística, bien distinto del mismo periódico en los cuarenta o los primeros cincuenta, y ya no moribundo.

\section{Innovaciones, deprisa.}

La labor de Zuloaga no pasó inadvertida, y pronto recibió la oferta de dirigir un diario madrileño: $E I$ Alcázar. Al frente de Diario Regional quedaría -desde el 4 de enero de 1957- un joven de veintitrés años, José Luis Cebrián Boné. Licenciado en Derecho, había cursado los estudios de Periodismo al tiempo que preparaba su doctorado en Derecho Internacional y trabajaba como redactor en La Actualidad Española, dirigida entonces por Antonio Fontán. Por estos años su característica más destacada eran sus grandes deseos de aprender. En el semanario citado había comenzado por trabajar en el archivo y servicio de documentación, le interesaban las cuestiones que se referían a maquinaria y a los medios de telecomunicaciones -dudaba si se dedicaría al periodismo escrito o a la televisión658-, había estudiado con cierto

${ }^{657}$ Este extraordinario se editó con portada y contraportada impresas en ofsset. Fue el mayor éxito editorial de la etapa de zuloaga al frente del periódico: se vendieron 7.000 ejemplares. Cfr. testimonio de Jesús María Zuloaga.

${ }^{658} \mathrm{Su}$ memoria de licenciatura en Periodismo fue un estudio sobre televisión. 
detalle algunos modelos de prensa extranjera, y -por sus estudios de Derecho- seguía de cerca todo lo que se refería a política internacional, especialmente la guerra fría y el desarme. La estancia en el rotativo vallisoletano fue en realidad el comienzo de su carrera periodística. Vino a Valladolid invitado por el consejero delegado del periódico, en principio para hacer prácticas que le ayudaran a conocer la prensa diaria: solicitó ocuparse de la información internacional y de funciones que le permitieran hacerse una idea cabal de la estructura organizativa del periódico, y sus características técnicas. La empresa lo colocó como adjunto al director, algo así como un subdirector sin nombramiento oficial ${ }^{659}$. Tras unos meses de trabajo, cuando Zuloaga recibió la proposición de volver a Madrid, se le ofreció quedarse al frente del periódico provisionalmente, hasta que llegara el nuevo director ${ }^{660}$. Cebrián aceptó. El empleado más joven de la empresa -después de un ordenanza- se ponía así al frente de Diario Regional. Poco más tarde -con fecha 5 de febrero661_ llegó el nombramiento oficial como subdirector en funciones de director, y la empresa le hizo saber que no tenía intención de relevarlo. El nombramiento oficial

${ }^{659}$ Entrevista con José Luis Cebrián. Se ocupaba entonces de las tareas de cierre y dedicaba mucho tiempo a los talleres. Hacía también la sección de internacional "Ventana al mundo".

${ }^{660}$ La noticia del paso de Zuloaga a El Alcázar se dio en DR 16/1/1957. ${ }^{661}$ oficio del director general de Prensa a José Luis Cebrián Boné, A.P.M.F.A.. Cfr. también, DR, 17/2/1957, pág. 16 últ.. 
de director llegó con fecha 2 de noviembre662. Años más tarde, otro periodista veía así su carrera:

"José Luis Cebrián Boné, nacido en 1933, abogado y periodista, "cerebralmente monárquico"; con devoción personal hacia Antonio Fontán -"mi único y personal maestro en periodismo"- había seguido una carrera meteórica en el Diario Regional de Valladolid (director a los 23 años, en escasos meses triplicó la tirada), La Actualidad Española y, sobre todo, en El Alcázar, que cogió con una circulación de 18.000 ejemplares y que en el lapso de cuatro años la incrementó en más de cien mil ejemplares" 663

"José Luis Cebrián, con Juan Luis Cebrián (Informaciones, El País), Jesús de la Serna (Pueblo, Informaciones), Romero (Pueblo) y Ansón ( $A B C$, "Efe") ha sido uno de los cinco grandes del periodismo español en los años sesenta y setenta." 664

Cebrián señala como característico del periódico en estos años un dinamismo innovador, que a la vuelta de los años le parece desproporcionado665. El análisis de la colección, y el testimonio de otros protagonistas 666 confirma lo adecuado de la proposición: el estilo implantado por Zuloaga va a ser corregido y aumentado en estos años -1957-58-, hasta el punto de que no es posible hablar de una estructura informativa fija en el

6620ficio del director general de Prensa a José Luis Cebrián Boné. Se aprueba también el nombramiento de Enrique Santos Herrera como sustituto en caso de ausencia o destitución. A.P.M.F.A..

663ALFÉREZ, Antonio, Cuarto poder en España. La prensa desde la Ley Fraga 1966, Plaza \& Janés, Barcelona, 19872, pág. 36. Los textos entrecomillados proceden de entrevistas con Cebrián publicadas en Pueblo e Informaciones en 1975 y 1967 respectivamente.

664 Ibid., pág. 128 .

${ }^{665}$ Entrevista con José Luis Cebrián Boné.

${ }^{666}$ Entrevistas con Andrés Romero Rubio y Fernando de la Torre de la Orden. 
periódico667. Hay un ritmo casi alocado en la introducción de variaciones, que tiene como causa un afán continuo de mejora basado en la atención prestada a la actualidad -"el periódico vivía pegado a la ciudad»668-, y como medio que lo hacía posible, un personal contagiado de ese espíritu innovador y entregado a su trabajo, tanto en los talleres como en la administración y la redacción ${ }^{669}$. La desproporción está en la relación entre medios y fines: un periódico de provincias, segundón, de escasa tirada, técnica y económicamente bastante limitado, se inspira en el estilo del Daily Express en su esquema general, imita a Pueblo en su página de opinión, tiene continuamente enviados especiales cubriendo informaciones en la región, pero también en Valencia, en Jaén, o en el Tour de Francia; publica las primeras páginas monográficas que un diario español dedica a la televisión, o hace un reportaje sobre los viajes interplanetarios, cuando éstos no han hecho sino comenzar su fase experimental670.

${ }^{667}$ Puede verse en el apéndice 2 el esquema básico de la estructura informativa.

${ }^{668}$ Entrevista con José Luis Cebrián Boné.

${ }^{669}$ Entrevistas con José Luis Cebrián Boné, Andrés Romero Rubio y Fernando de la Torre de la Orden.

670Entrevista con José Luis Cebrián Boné. Cfr. también, la página monográfica dedicada a la televisión en DR, 20/1/1957; "La televisión española progresa... (muy lentamente)", 3/4/1957, pág. 1; "Por primera vez en España un reportaje interplanetario. El primer viaje a la luna", DR, 3/11/1957, pág. 1; "Historia de la luna roja", reportaje sobre el primer satélite artificial puesto en órbita por la U.R.S.S., publicado a lo largo del mes de octubre de 1957, firmado por José Luis Cebrián y Ricardo Estarriol; "¿Petróleo en Jaén?", DR 31/3/1957, pág. 1 -los días siguientes se publican crónicas de los enviados especiales-. Otras mejoras en esta línea fueron el "Servicio 
El esfuerzo del conjunto dio resultado y la conexión con la ciudad -especialmente con los barrios, a los que se dedicó una atención preferente671-aumentó, confirmando así una tendencia que será muy propia del periodismo de Cebrián:

"Otra premisa de Cebrián era su obsesión por hacer un periódico con las tres "D": documentado, dinámico y divertido. $Y$ por encima de todo, conseguir un producto eminentemente popular." 672

cartográfico de Diario Regional", la introducción de gráficos en la información deportiva para ilustrar jugadas de fútbol o similares, la publicación de un modelo diario en la sección de modas, etc.

${ }^{671}$ Se publicaron seriales sobre todos los barrios de la ciudad, que en ese momento había comenzado ya un proceso de expansión industrial. Cfr. por ejemplo los dedicados a los barrios de Las Delicias 23/2/1957 y ss.-, de Santa Clara o Barrio España -10/3/1957 y ss.-, de San Juan -17/3/1957 y ss.-, Barrio Girón -16/6/1957 y ss.-, de la Overuela -23/7/1957 y ss.-, de Los Pajarillos -2/5/1957-, etc.

672ALFÉREZ, Antonio, op. cit., pág. 128. 


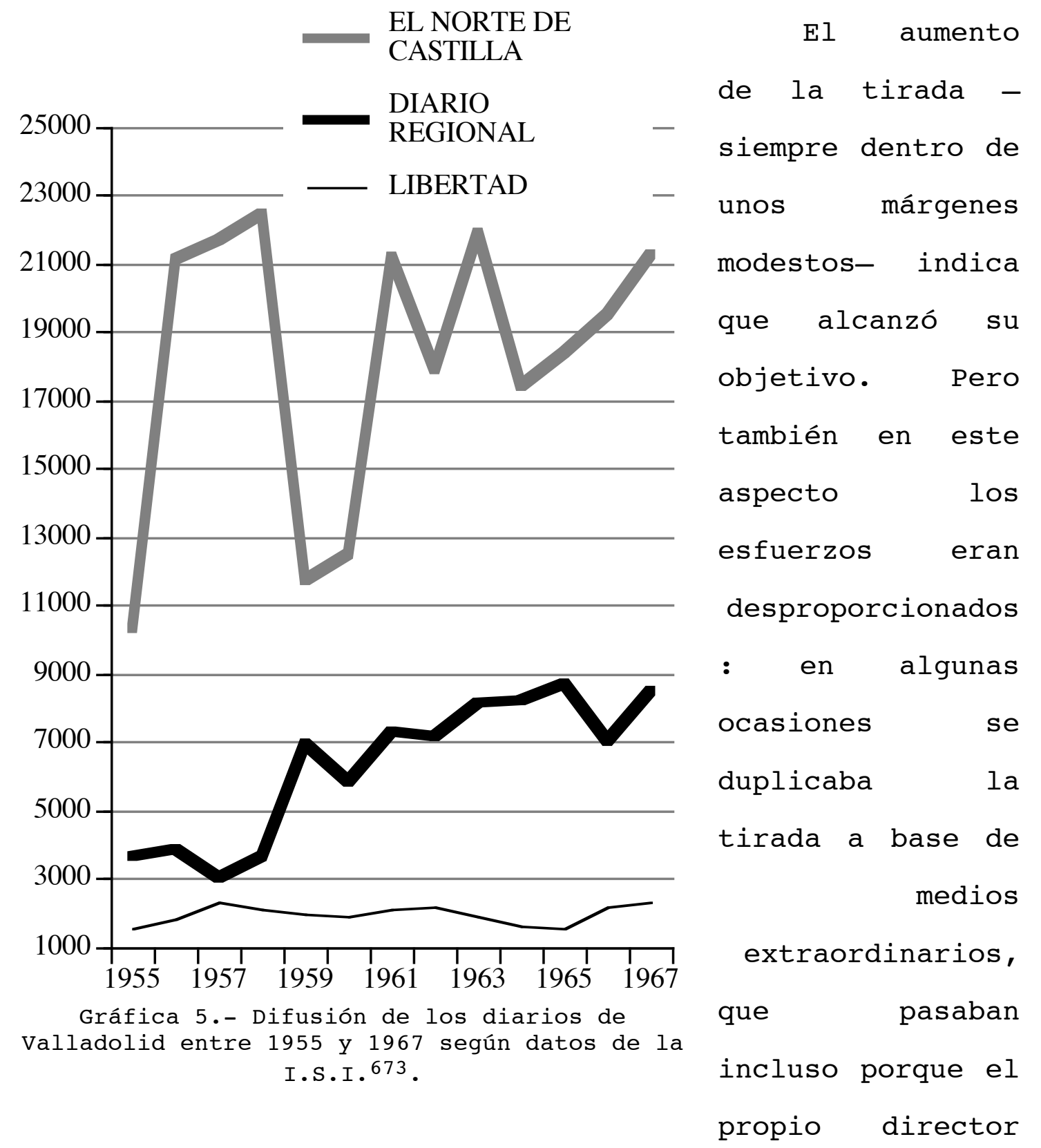

se desplazara al lugar de venta personalmente674. Los reportajes más populares, los que se ocupaban de sucesos o

673Fuente: NIETO TAMARGo, Alfonso, op. cit., cuadro 14 . Cebrián nos indicó que la tirada habitual no llegaba a los 2.000 ejemplares cuando él llegó al periódico. Ventas de 3.000 o 4.000 ejemplares se consideraban éxitos notables. Parece que los datos que utiliza Nieto están muy deformados, pero pueden servir de forma meramente indicativa de una tendencia.

${ }^{674}$ Fue por ejemplo el caso de un incendio en Toro, una localidad zamorana situada a poco más de sesenta kilómetros de valladolid. Cebrián se desplazó él mismo para hacer el reportaje -dos redactores 
tenían un matiz espectacular, cuando se daban como primicia aseguraban tiradas extraordinarias, pero sólo dependían de la actividad de la redacción en tanto que se sabía detectarlos y acudir al lugar del suceso merced al equipo de enviados especiales que se había formado: era el caso de los reportajes sobre el petróleo que hemos mencionado, del que se hizo con motivo de la rotura de una presa en el norte de Zamora675, de la muerte de unos montañeros al norte de Palencia676, o de las inundaciones y la subsiguiente reconstrucción en Valencia677.

Pero el esfuerzo ordinario cuajaba en triunfos menos espectaculares, aunque tuvieran más trabajo detrás. Los informes sobre Tierra de Campos, sobre los barrios, sobre la industria y el urbanismo en Valladolid, o sobre los viajes espaciales, eran posibles gracias a esfuerzos de documentación prolongados en el tiempo, que, sin embargo,

estaban fuera como enviados especiales, y otro estaba enfermo-, y se encargó también de distribuir la edición ordinaria $-y$ la extraordinaria que se hizo en vista del éxito- vendiendo los ejemplares del periódico él mismo con la ayuda del secretario del Consejo de Administración. Entrevistas con José Luis Cebrián Boné y Arturo León Álvarez. Cfr. también DR, 14/4/1957 "Incendio en Toro", pág. 1, íntegra.

675 «Ribadelago arrasado por las aguas», DR, 10/1/1959, pág. 1 .

676 "Tres montañeros han sucumbido en el Curavacas. Nuestros enviados especiales, los únicos periodistas que han llegado a la montaña", DR, 28/4/1957, pág. 1 .

${ }^{677}$ Con motivo de las inundaciones se desplazaron a Valencia un redactor y un fotógrafo cuyos reportajes elaborados sobre el terreno fueron un éxito de ventas. Entrevistas con José Luis Cebrián Boné y Andrés Romero Rubio. 
tenían un éxito menor678. En los pueblos a los que se dedicaba un reportaje se compraban normalmente uno o dos ejemplares del periódico, que luego leían todos los habitantes, sin que eso supusiera un aumento de tirada. Cebrián buscaba entonces el apoyo de los concursos ${ }^{679}$, o pulsar las teclas más sensibles de la ciudad. Esa fue la raíz de otro estilo de campañas de promoción, que se apoyaban en un recurso muy caro a Cebrián: el aprovechamiento de la sensibilidad pública ante los diversos acontecimientos o conmemoraciones. Surgieron así iniciativas como la publicación de un "Álbum de recuerdos vallisoletanos" coleccionable 680 , con profusión de fotografías; la edición de un suplemento infantil681; el recuerdo de Onésimo Redondo y la historia de los 18 de julio682; el análisis detallado de un nuevo Gobierno683; la

${ }^{678}$ Entrevista con Andrés Romero Rubio. En estos años se crearon en el periódico los ficheros de los pueblos de la provincia y de los barrios.

${ }^{679}$ Uno de ellos, organizado en julio de 1957 junto con una agencia de viajes, hizo aumentar la tirada en un 10\% según Cebrián. Utilizaron ya entonces el método de publicidad escalonada que luego ha sido tan frecuente.

${ }^{680} \mathrm{La}$ publicación comenzó en noviembre de 1957 , con motivo del cincuentenario del periódico. Se apoyó sobre todo en el trabajo de una colaboradora de Diario Regional que se encargaba de la sección dedicada a la mujer, Mercedes de la Viña Zuloaga, que recogió material gráfico y relatos de las familias vallisoletanas.

${ }^{681}$ Comenzó a publicarse -en color- junto con el suplemento de los domingos en mayo de 1958 .

${ }^{682}$ Cebrián consideraba $-y$ es un análisis bastante certero- que dos rasgos característicos de Valladolid eran el "falangismo desilusionado", y la pervivencia de un espíritu liberal, característico de las élites tradicionalmente próximas a $E l$ Norte de Castilla. Preparó un número extraordinario para el 18 de julio de 1958, que anunció desde tres semanas antes, en el que reconstruía toda 
entrevista exclusiva con el alcalde 0 el gobernador civil684; la minuciosa cobertura informativa de la Vuelta Ciclista a España685; la promoción y recogida de ayudas para Valencia después de las inundaciones, o para la colegiata destruida por un incendio en Toro, 0 de aguinaldos para los combatientes de Ifni686. Tales campañas fueron otros tantos ejemplos de movilizaciones de todo el

la historia de la fecha. En ese momento estaba ya expedientado por supuesto menosprecio de las instituciones y personalidades del régimen, como veremos más adelante.

${ }^{683}$ Fue el caso del número de 26/2/1957, del que vendieron incluso los números rotos, según recuerda Cebrián.

${ }^{684}$ Con motivo del nombramiento de Antonio Ruiz Ocaña como gobernador civil de la provincia, mientras que los otros periódicos daban escuetamente la noticia, Diario Regional publicaba una entrevista en exclusiva realizada por José Manuel Carril, que era con Romero el entrevistador más activo del diario. Cfr. "Antonio Ruiz Ocaña Gobernador de Valladolid. Su primer saludo a la provincia a través de "Diario Regional". Las primeras declaraciones", DR, 25/6/1957, pág. 1. Algo similar ocurrió con el nombramiento de José Luis Gutiérrez Semprún como alcalde de la ciudad: dedicaron a la noticia un editorial, publicaban una biografía y una entrevista. En resumen, decuplicaban la información que ofrecía El Norte de Castilla. Cfr. "Nuevo alcalde: D. José Luis Gutiérrez Semprún. Tomará posesión el próximo miércoles", "Biografía: un personaje de España. Nuevo Alcalde de Valladolid. José Luis Gutiérrez Semprún»; "Entrevista: Hoy... El Alcalde de Valladolid", DR, 24/3/1957, págs. 1 y 3.

${ }^{685}$ Según Cebrián se trataba de unos acontecimientos más populares, que conseguía duplicar la tirada. El periódico publicaba con ese motivo mapas, y adelantaba noticias en la pizarra que se colocaba en la fachada de sus locales.

${ }^{686} \mathrm{El}$ 6/11/1957 comenzó la cuestación pro damnificados por las inundaciones, con el lema "La sonrisa de la Virgen". El éxito fue notable y motivó el envío de los reporteros una vez más a Valencia, para elaborar otro reportaje extraordinario sobre la reconstrucción de la ciudad. Se publicó el 9/11/1957 consiguiendo de nuevo un éxito de ventas. Para las informaciones sobre Ifni y los aguinaldos del combatiente, cfr. por ejemplo "La situación de las zonas próximas a Sidi Ifni", DR, 28/11/1957, pág. 1; "Franco felicita a las tropas de Sidi Ifni por su heroico comportamiento", "La situación de Sidi Ifni. sospechosa actitud de Muley Hasan", DR, 29.XI.1957, pág. 1. La iniciativa llevó a una tensión con el alcalde, que opinaba que el periódico se extralimitaba en su afán de movilizar a los ciudadanos. Al final la campaña fue adelante $y$ se enviaron dos camiones con donativos. 
personal del diario en busca de novedades que atrajeran público, que consiguieran que el periódico latiera con el mismo pulso de la ciudad, como gustaba decir al director.

Esta forma de hacer el periódico trajo consigo básicamente- tres consecuencias: lo hizo acreedor de un estudio desde el punto de vista de las Ciencias de la Información, sobre todo como ejemplo de creatividad periodística; modificó de facto el modelo de prensa conocido hasta entonces en la ciudad, y por ende el de prensa católica del que era representante el periódico; y se salió del modelo de prensa definido por las leyes españolas del momento, ya que no se hace un periodismo al servicio del Estado, sino en función de lo que se estima demandan los lectores. La primera de ellas queda fuera de los objetivos del presente estudio, la segunda vemos preferible estudiarla en conjunto -más adelante- para el periodo que abarca este capítulo, la tercera dio frutos inmediatos de los que nos ocuparemos a continuación.

\section{El nuevo periodismo no gusta a las autoridades}

Hay un par de recuerdos del doctor Romero Rubio que resultan útiles para comprender la situación en que se colocaba la redacción del periódico frente a las autoridades. El hoy profesor de Teoría de la Información nos describió más o menos así el comienzo de un día de trabajo en sus tiempos de joven redactor: sentado frente a 
una mesa en la que se apilaban un buen número de sobres oficiales de color azul -procedentes de Sindicatos, de la Delegación de Información, del Gobierno Civil, o de cualquier otro organismo oficial-, pensaba -pongamos por caso- qué podía hacerse para elaborar el próximo reportaje, cuál sería la entrevista más interesante o cómo podría conseguir la fotografía de un satélite a buen precio. Tarde o temprano acababa reparando en los sobres y se ocupaba en dar salida a aquellas notas de inserción oficial u oficiosamente obligatoria, sin prestar demasiada atención a esa tarea rutinaria. Casi al final de la jornada de trabajo -o cuando por el teletipo llegaban noticias que lo merecieran- se montaba una "pizarra" a base de recortes de textos, fotografías y titulares manuscritos, con objeto de colocarla en la fachada. Pero antes había que cumplimentar el trámite de la censura previa. Él mismo, u otro redactor, ayudados por algún ordenanza, cogían la "pizarra" y la llevaban a la Delegación de Información para su revisión. A Romero se le quedaron especialmente grabadas en la memoria las noches de niebla en que realizaba esta operación a las dos o a las tres de la mañana, y no tanto por el hecho del trajín con la pizarra a cuestas, sino por la densidad de las nieblas vallisoletanas: la censura era lo normal, más normal que aquellas heladoras nieblas ${ }^{687}$.

${ }^{687}$ Entrevista con Andrés Romero Rubio. 
Esas dos anécdotas reflejan bien el ambiente de acostumbramiento ante la injerencia estatal en el trabajo, y la habilidad para burlar esa intromisión de forma que el periódico resultara perjudicado lo menos posible. Ahora bien, las cosas se complicaban cuando -a pesar de la atención que se prestaba a las notas oficiales- alguna autoridad se sentía herida. No importaba sobre qué se escribiera, uno u otro podía considerar que se le hacía una crítica indirecta cuando se sugería la corrección de esta deficiencia, o se hacía notar el abandono en que se encontraba aquel asunto, o -simplemente- no se le mencionaba como era de su gusto en la reseña de algún acto público. La consecuencia de esos roces llegaba en forma de multas que, de ordinario, se acababan pagando en los cupos de papel688.

Con estos presupuestos no puede extrañar que el estilo de Cebrián resultara molesto: la eficacia informativa era una flagrante contradicción con el modelo de "país en el que nunca pasa nada malo" difundido por la censura689. Ni el director ni sus redactores tenían una intención política animosa frente al régimen, pero tampoco

${ }^{688}$ Idem, y entrevista y Relato autobiográfico de Manuel Fernández Areal.

${ }^{689}$ Cfr. SINOVA, Justino, op. cit., págs. 242 y ss. y passim. Puede verse también nuestro análisis de las consignas conservadas en el A.P.M.F.A., "El régimen de consignas de prensa durante el franquismo: análisis de una fuente", en Actas del Congreso de Jóvenes Historiadores y Geógrafos, Madrid, EUDEMA, 1989, tomo II, págs. 739747 . 
se entusiasmaban con su exaltación. Para un hombre como Cebrián, que tenía seis años al acabar la guerra, el régimen de Franco, era un dato, y no el más importante. De ahí que su actividad profesional pueda calificarse como de una ingenua independencia en lo que a política se refiere. Si se fijaba en Onésimo Redondo, era porque pensaba que su figura vendía en Valladolid, la misma causa que le llevaba a publicar un extenso reportaje sobre Animal farm, en absoluto halagador para una dictadura690. Pero el régimen tenía medios eficaces para hacer notar al joven director que ese cargo no era apto para ingenuos. Un artículo de Diario Regional titulado "Franco insinúa que él puede dar más libertades a los españoles»691, traducción de otro del New York Times, fue el primer motivo que el delegado de Información, Antolín Santiago, tuvo para hacer notar a Cebrián su disgusto. Poco más tarde, el reportaje sobre petróleo en Jaén fue también causa de amonestación al periódico, por exceso de sensacionalismo. La iniciativa de recoger donativos para los combatientes de Ifni provocó tensiones con el alcalde; y con el gobernador hubo también problemas, en noviembre de 1957, por un artículo titulado "Los huevos a 29 pesetas la docena»692, que no le pareció nada oportuno: Cebrián fue amenazado con el destierro. El 24 de enero de 1958, aparecía en primera página un

\footnotetext{
${ }^{690} \mathrm{Cfr}$. "Rebelión en la granja», DR, 23/2/1957, pág. 3.

${ }^{691} \mathrm{DR}, 23 / 3 / 1957$, pág. 1.

692DR，26/11/1957，pág. 15 .
} 
artículo titulado "Cae otro dictador. Golpe de Estado en Venezuela», que informaba sobre la deposición de Pérez Giménez, y que contribuyó a aumentar la tensión política693.

Con esos precedentes, un suceso que quizá no hubiera pasado de la anécdota en otras circunstancias, vino a empeorar la situación. El director General de Prensa, Alejandro Muñoz Alonso, visitó Valladolid el 23 de marzo. José Manuel Carril, uno de los redactores especializados en entrevistas, formado en la casa, acudió al hotel para pedirle unas declaraciones. Entre otras preguntas, le formuló una sobre cómo veía la futura ley de prensa, a la que Muñoz Alonso contestó con una grosería. Carril, perplejo, interrumpió la conversación y se volvió al periódico. El director decidió corresponder al político con una fría acogida en la visita que les dispensaría esa noche. En opinión de Cebrián eso supuso "la declaración de guerra»694.

No sabemos si efectivamente fue así, pero dos meses más tarde el delegado provincial le abría un expediente que iba a ser definitivo. La causa inmediata era "(...) la forma en la que fue presentado en [Diario Regional] y en

\footnotetext{
${ }^{693}$ Entrevista con José Luis Cebrián Boné e informe del delegado provincial de Prensa al juez instructor de la causa 26/58, A.G.A., Sección Cultura, caja 66.624 .

${ }^{694}$ Entrevistas con José Luis Cebrián Boné y Manuel Fernández Areal.
} 
su número correspondiente al día 18 de mayo el discurso pronunciado por S.E. el Jefe del Estado en la sesión de las Cortes Españolas del día precedente en la que asimismo fue promulgada la Ley Fundamental del Reino."695 El expediente fue leído a Cebrián por Antolín de Santiago el 31 de mayo696. El encausado presentó pliego de descargo, en el que alegaba razones técnicas y de valoración informativa que justificaban su actuación. El razonamiento era característico de Cebrián:

"PRIMERO.- La dedicación de gran parte de la primera plana del número correspondiente al día 18 del pasado mes de mayo de 1958, a los sucesos de política internacional que se desarrollaron en Francia, Argel y Orán, tiene la siguiente explicación:

"a) Era información de primera mano proporcionada por el corresponsal de DIARIO REGIONAL en París, don Rafael Andreu de la Cruz.

"b) Dicho corresponsal, por haber trabajado durante varios en Valladolid es muy conocido entre el público vallisoletano.

"c) Dicho corresponsal es el único que con carácter fijo mantiene nuestro periódico en el extranjero. Por una vez que ocurrían sucesos de extraordinaria actualidad en Francia y podíamos recibir noticias directas, quisimos resaltarlo en nuestra primera página."

Seguían a continuación las justificaciones técnicas de los pequeños tipos con que se anunciaba el discurso de Franco, de las fotografías de De Gaulle, etc., y la negación de

${ }^{695}$ Propuesta del juez instructor del expediente al ministro de Información y Turismo, de fecha 30 de julio de 1958, resultando primero, A.G.A., Sección cultura, caja 66.627.

696Entrevista con José Luis Cebrián Boné. Cuando el expedientado le hizo ver al delegado que con semejantes argumentos, tal como era la Ley de Prensa, podían destituirlo en cualquier momento, santiago Juárez le contestó que vería lo que podía hacer, aunque -añadió- su comportamiento le parecía bastante grave. La fecha exacta de la lectura del pliego de cargos la conocemos a través del de descargo que citamos más abajo. 
cualquier intención política en la colocación del discurso del Caudillo en las páginas interiores ${ }^{697}$. Las alegaciones sirvieron de poco. Antes de informar al expedientado de la existencia de la causa, el juez había pedido antecedentes al delegado provincial. La contestación de Antolín de Santiago fue una relación de nueve casos en los que se consideraba que el comportamiento de Cebrián era manifiestamente contrario a las órdenes que se le daban desde la Delegación, o desconsiderado en el tratamiento de informaciones acerca de las autoridades públicas, hasta el punto de que se había retirado al director del periódico la censura delegada desde el mes de abril698.

${ }^{697} \mathrm{Pliego}$ de descargos de José Luis Cebrián Boné, dirigido al juez instructor designado para la tramitación del expediente 26/58, fechado el 3 de junio de 1958. A.G.A., loc. Cit.. El subrayado es nuestro.

${ }^{698} \mathrm{En}$ resumen, el informe del delegado señalaba las siguientes "anormalidades e irregularidades", "tomando como punto de partida los últimos meses del pasado añon: 29/11/1957, comenta aumentos de precios cuando el gobernador civil lo ha prohibido; 15/2/1958, mutila y fracciona la información sobre el Consejo de Ministros; 5/3/1958, da poca importancia a los actos conmemorativos de la fusión de FE y JONS; 17/3/1958, no ofrece información alguna sobre la recepción de Franco a los directores de periódicos y emisoras del Movimiento; 28/3/1958, otra vez da noticias sobre la elevación de precios; en varias ocasiones ha publicado notas sobre misas por los mártires de la Comunión Tradicionalista, lo que se le había prohibido expresamente; 19/3/1958, no publica un discurso del ministro Secretario General del Movimiento; 10/4/1958, en un artículo de Enrique Santos se afirma que el Estado incumple sus obligaciones:

"El Estado, centinela y garantía [del buen funcionamiento de la sociedad] incumple sus compromisos, sus obligaciones, sus deberes. Puede parecer anacrónico, incomprensible. Pero es cierto. (...) el Estado en el año 1956 encargó con prisa, con suma diligencia, un trabajo que todavía no ha pagado (...). [Se trata de] un problema (...) que se origina por la falta de cumplimiento de sus deberes por parte del Estado, de la Administración que tan rigurosamente exige a los demás ciudadanos el exacto cumplimiento de sus deberes."

Con motivo de este último hecho, el delegado provincial informó a la Dirección General, y retiró a Diario Regional la censura 
El instructor desestimó las alegaciones de Cebrián, y -a lo largo de ocho considerandos- desgranó los argumentos que demostraban la "manifiesta resistencia pasiva y desvío de las normas y principios que regulan la actividad periodística" en la actuación del expedientado, para concluir:

"(...) el Instructor entiende que la sanción no puede ser simplemente corregida por una multa (sic), por importante que ella fuere, sino que ha de trascender en la escala jerárquica punitiva, enmarcándola en el apartado b) de los cuatro que según su gravedad señala el citado artículo 20 de la Ley de Prensa, que prevee (sic) la destitución del Director responsable de los actos que dan origen a este expediente, por lo que procede elevar las actuaciones practicadas con la presente propuesta de resolución a la consideración superior, del Excmo. Sr. Ministro.

delegada: en adelante todo lo que publicara el periódico había de pasar consulta previa. La Dirección General dio el visto bueno a la medida el 16/4/1958, resolución que le fue comunicada al periódico días más tarde con el siguiente oficio, conservado en A.P.M.F.A.:

«MINISTERIO DE INFORMACION Y TURISMO. DELEGACION PROVINCIAL DE VALLADOLID. Dirección General de Prensa. Sección A.G. Núm. 106.

"Con esta fecha recibo del Iltmo. Sr. Director General de Prensa, un oficio del 16 actual, número 219, que textualmente dice: “En virtud de las facultades que me están conferidas he tenido a bien resolver que el periódico DIARIO REGIONAL de esa capital, quede sometido ante esa Delegación Provincial de Información y Turismo a la obligada consulta previa de cuantos originales, fotografías, etc. hayan de publicarse en dicho diario. Lo que comunico a V.I. para su conocimiento y cumplimiento a partir de la fecha de recepción de este oficio, debiendo dar traslado de esta decisión al Director del referido periódico. Dios guarde a V.I. muchos años. El Director General de Prensa. Firmado: Adolfo Muñoz Alonso.- Iltmo. Sr. Delegado Provincial de Información y Turismo.-Valladolid." Lo que en cumplimiento de cuanto se me ordena procedo a trasladarle a los efectos que en el mismo se indican, y para su debido conocimiento y cumplimiento

"Por Dios, por España y su Revolución Nacional-Sindicalista.

"Valladolid, 23 de abril de 1958.

"EL DELEGADO PROVINCIAL. Fdo: A. de Santiago y Juárez"

Finalmente, el 4/5/1958, el periódico no publicó información sobre una reunión de la Comisión Delegada de Asuntos Económicos que había presidido Franco. Informe del delegado provincial del Ministerio de Información y Turismo al juez instructor del expediente no 26/58, de fecha 31 de mayo de 1958. ibid. Recogemos íntegro este informe en el apéndice 16 . 
"Por todo lo expuesto el Instructor que suscribe tiene el honor de elevar a la superior consideración y más elevado criterio de V.E. la siguiente

\section{PROPUESTA}

"Imponer a D. JOSE LUIS CEBRIAN BONE en su calidad de Director de DIARIO REGIONAL la sanción de DESTITUCION DE SU CARGO. " 699

Dos meses más tarde, el Director General elevaba un oficio al ministro, que era copia exacta de la propuesta del instructor $-\mathrm{ni}$ siquiera se corrigió la ortografía-, salvo en su último párrafo, digno de figurar en los anales de la historia del periodismo español:

\footnotetext{
"Esta Dirección General de Prensa, de conformidad con la propuesta de la Delegación Provincial de este Ministerio en Valladolid, es del parecer que procede imponer como sanción a Don José Luis Cebrián Boné, en su calidad de director del "DIARIO REGIONAL" la destitución de su cargo por su manifiesta incapacidad para el ejercicio del mismo." 700
}

La parsimonia en la tramitación del expediente puede explicarse con algunos datos que aporta Cebrián. La empresa le había hecho saber que el Ministerio estaba presionando para que lo sustituyeran, medida que los empresarios no estaban dispuestos a tomar. En septiembre, Franco visitó Tordesillas con motivo de la fiesta del Toro de Vega. El director de Diario Regional tuvo entonces ocasión de saludar al Director General, que le insinuó -en palabras de Cebrián- que estaba condenado a muerte como

${ }^{699}$ Propuesta del juez instructor al ministro citada.

700 Oficio del director general de Prensa al ministro de Información y Turismo, de fecha 30 de septiembre de 1958. Ibidem. Transcribimos íntegro el documento en el apéndice 17. 
director. Todavía pasarían casi dos meses antes de que Antolín de Santiago comunicara la resolución definitiva, y es sorprendente el modo en que lo hizo: llamó a su despacho a Andrés Romero y le dio el recado, en términos nada corteses ${ }^{701}$.

Cebrián marchó a Madrid, donde se incorporó de nuevo a La Actualidad Española como subdirector. Nadie -salvo los más allegados- supo el motivo del traslado. En Diario Regional se publicó una nota en la que se comunicaba que había sido nombrado subdirector del semanario702.

Es significativa la comparación de los hechos descritos con los que relatamos para el caso Martín Abril. En esta ocasión nadie acudió al arzobispo: ese era un recurso impensable desde el punto de vista de la mentalidad laical propia de los miembros del Opus Dei. Por contraste, si la mentalidad de algunos católicos españoles había cambiado, la de las autoridades del régimen en poco - nada cabe distinguirla de la que tenían catorce años atrás, mentalidad que, además de demostrar una vez más una interpretación muy sui generis de la justicia -quizá se deba identificar con la arbitrariedad-, demostraba un grado de miopía cultural y política poco común que, ya entonces, pero sobre todo más adelante, daría sus frutos.

${ }^{701}$ Entrevista con Andrés Romero Rubio.

${ }^{702}$ Cfr. DR 30/11/1958, pág. 3 . 
Quizá el que más nos importe aquí sea el siguiente: hacían imposible cualquier tipo de innovación o de modernización periodística, aunque fuera hecha por personas que no fueran radicalmente intransigentes con el régimen. Probablemente no podía ser de otra forma: semejante efecto es típico de las dictaduras, que consiguen así hacer imposible que las releven personas afines a su ideario. Un rígido sistema de control como el franquista, por lo mismo que conseguía ahogar la libre iniciativa de los ciudadanos en su pantano normativo, sembraba de sal el campo en que hubieran podido nacer muchos proyectos de futuro. Y -lo que nos parece más grave- al autonominarse católico, empujaba a buscar las soluciones alternativas lejos de los principios cristianos, o al margen de ellos.

\section{Las opiniones de Fernández Areal.}

La marcha de Cebrián a Madrid dejó al frente del periódico teóricamente al redactor jefe, Enrique santos Herrera, que trabajaba al mismo tiempo como funcionario civil del Ministerio del Aire. En la práctica, el nuevo director era Manuel Fernández Areal, si bien el nombramiento oficial no llegó hasta agosto de 1959703.

703 «D. Manuel Fernández Areal, confirmado como director de "Diario Regional"", DR, 3/9/1959, pág. 3. Cfr. también la carta del delegado provincial del Ministerio de Información y Turismo a Manuel Fernández Areal, de 8/9/1959. A.P.M.F.A.. El texto de la carta, además de ilustrar sobre el modo de hacer del delegado, resulta curioso a la luz de acontecimientos posteriores:

"Querido amigo: "Correspondo a tu escrito de fecha 2 de los corrientes. Días pasados te envié el nombramiento al periódico, con el que 
Areal tenía una formación similar a la de Cebrián: era licenciado en Derecho, y se había iniciado en el periodismo con Jesús María Zuloagoa, en la que podemos llamar -con frase de Germán Losada704_ "la escuela de La Actualidad Española ". Su estancia al frente del periódico, que se prolongó hasta 1965, lo convierte en el director más longevo después de Martín Abril. Podemos caracterizar su estilo con dos notas: el mantenimiento $-\mathrm{y}$ remanso- de la vitalidad informativa impulsada por los directores anteriores, y la creciente importancia concedida a la opinión en el diario. Fueron años de consolidación del esfuerzo de reanimación del periódico ${ }^{705}$,

te adjuntaba una carta de felicitación, la cual confirmo, confiando no me darás mucha "guerra" en esta etapa de Director de verdad."

Como veremos más adelante, el final de la dirección de Fernández Areal está marcado por el Consejo de Guerra al que fue sometido por las autoridades militares.

${ }^{704}$ Entrevista con Germán Losada. Este periodista caracteriza como representantes de esa “escuela" a Zuloaga, Cebrián, Areal y Tallón.

${ }^{705}$ por lo que se refiere a la difusión, además de los datos basados en las aportaciones a la Institución San Isidoro que sirven para elaborar la gráfica 5, contamos con un informe del administrador del diario del Movimiento de la ciudad-Libertad-. Según él, el mercado de lectores vallisoletanos a la altura de 1963, se repartía así entre los tres diarios :

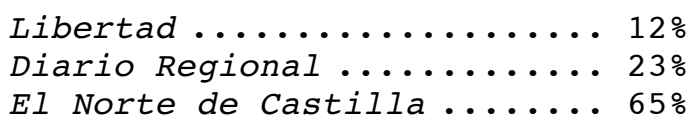

En opinión del profesor Ricardo M. Martín de la Guardia -que está ultimando su tesis doctoral sobre el diario Libertad, y a cuya generosidad debemos la localización de estos datos-, es probable que la estimación sobre la difusión de Libertad esté exagerada. Cfr. Carta-Informe del Administrador de "Libertad" al Administrador General de Prensa y Radio del Movimiento. Valladolid, 5/12/1963. A.G.A., Sección Medios de Comunicación Social del Estado, varios. Fondo de 
en los que Areal contó con el respaldo de una empresa si no fuerte, sí estabilizada, y de un equipo de redactores que mantenía las señas de identidad que hemos descrito poco más arriba. Hubo pocas incorporaciones de nuevos redactores: José Luis Pérez Herrero, venido del Diario de León; Fernando de la Torre, que de ordenanza pasó a tipógrafo atendedor al tiempo que iba aprendiendo de la mano de Areal las técnicas básicas del periodismo; así como José Antonio Antón y José de la Fuente, que trabajaban como auxiliares de la redacción. Junto a ellos había otros jóvenes vallisoletanos que frecuentaban la redacción por afición al periodismo y hacían esporádicamente algún trabajo para el Diario : María Aurora Viloria, Justino Sinova, Carlos Soria, etc ${ }^{706}$. Por otra parte, Andrés Romero Rubio y Luis González Armero dejaron el periódico. El alma de la redacción era por tanto Areal, que era prácticamente el único que se dedicaba a tiempo completo al diario707.

Asuntos Económico-Administrativos. Caja no 20, Carpeta Reunión Administradores.

706Cfr. SINOVA, Justino, op. cit., pág. 12, y entrevistas con María Aurora Viloria y Germán Losada.

${ }^{707} \mathrm{En}$ el apéndice 5 recogemos la composición oficial de las redacciones en 1960 y 1961. En cuanto a las respuestas a los cuestionarios para las estadísticas oficiales de la prensa, tenemos lo siguiente:

En 1961: Redactor jefe Enrique Santos Herrera. Arte, Luis González Armero; cine Félix González Ferrández; deportes Miguel Montalvo Jambrina y José de la Fuente colaborador; dibujante Luis González Armero; fotógrafo Filadelfo González; hogar y modas, Mercedes de la Viña y Rita Recio, colaboradoras; local y libros, Leandro Pérez; reportajes Andrés Romero Rubio; religión, Cristino Solance; teatro, Leandro Pérez, toros, Luis González Armero; tribunales Miguel Montalvo Jambrina. Corresponsales en el extranjero Rafael Andreu de la Cruz. Gerente, José María Corominas Utgés. Anuario de la Prensa Española. 
La estructura informativa, además de las secciones habituales ${ }^{708}$, se caracterizaba por la atención concedida a los reportajes -de agencia o de redacción-, y por las secciones semanales que poco a poco se fueron introduciendo. Entre las más cuidadas estaba la que atendía a los temas agrícolas -"Diario Regional en el Campon-, que se complementaba con otra de carácter cultural descriptivo, "Castilla a través de Diario Regional". Las dos eran fruto del interés de Areal por las cosas y gentes de Castilla, que ya había manifestado en su anterior estancia en el periódico, y que había terminado cuajando en dos frutos bien distintos: por un lado un libro del propio Areal publicado en 1957 , y por otro una sección similar de El Norte de Castilla elaborada por

Año V, vol. I., Diarios y semanarios, Ministerio de Información y Turismo, Dirección General de Prensa, Madrid, 1961-62, pág. 44.

En 1965: director Manuel Fernández Areal; redactor jefe Tomás Santos Corchero, es también confeccionador. Archivo y documentación, José Antonio Antón; arte: Tomás Santos corchero; cine, Félix González Ferrández; deportes, Miguel Montalvo Jambrina; humor P. García; editorial Manuel Fernández Areal; hogar, Mercedes de la Viña; extranjero, José Luis Pérez Herrero; local, libros y teatro, Leandro Pérez; modas, Mercedes de la Viña; toros, José Luis Pérez Herrero, redactor gráfico Filadelfo González. Anuario de la Prensa Española, vol. I, Dirección General de Prensa, Madrid, 1965, pág. 58.

En cuanto a los pluriempleos, Enrique Santos trabajaba como funcionario en el Ministerio del Aire, José Luis Pérez Herrero como funcionario de Tráfico, José de la Fuente tenía una agencia de publicidad, Leandro Pérez era profesor de la Escuela Normal, Luis González Armero, era corresponsal en Valladolid de Cifra, Félix González Ferrández de Logos, y varios de los redactores trabajaban también en la radio. Para los pluriempleos periodísticos puede verse la relación de corresponsales de la provincia en el informe del delegado provincial de Prensa a la Dirección General de fecha 5/9/1963, A.G.A., Sección Cultura, caja 14.492. En el mismo expediente se señala que "Los tres diarios locales tienen una serie, muy numerosa, de corresponsales, en su mayoría informativos y administrativos al mismo tiempo, en muchos pueblos de la provincia."

${ }^{708}$ Puede verse en el apéndice 2 una relación completa de las secciones. 
Miguel Delibes, que aprovechó la idea de Areal al tiempo que la mejoraba con el estilo característico del escritor vallisoletano. En cuanto a las ideas del director sobre esta cuestión, ya en 1957 había expuesto un punto de vista que explica bien éstas y otras iniciativas suyas: en su opinión, lo peor de los castellanos era "su falta de espíritu emprendedor. Todos dejan que la vida transcurra por su cauce normal, saturados de la historia de sus antepasados, y sin preocuparse por crear opinión propia." 709

Las demás secciones semanales se ocupaban de cine y teatro, de temas para la mujer, y de otras cuestiones que pretendían atraer lectores específicos: "Finanzas"; "Página militar"; "Página de tráfico"; "Arte, ciencias y letras"; "Ventana al turismo"; "Valladolid juvenil" y "Pantalla cultural". Las dos últimas enlazan con esa preocupación -característica de Areal- por crear opinión. De hecho, "Pantalla cultural", con sus comentarios bibliográficos y su subsección "Paso a la juventud", se erigió en la página de opinión de Diario Regional. Lo mismo que ocurría con otras secciones semanales, contaba con la colaboración más o menos estable de diversas personas, que en este caso solían estar relacionadas con el mundo universitario vallisoletano. El apartado juvenil

${ }^{709}$ Cfr. la reseña del libro de Areal-Pueblos, hombres y cosas de Castilla - en DR, 17/2/1957, pág. 15. La sección de Delibes en El Norte se denominó "Ancha es Castilla". Puede verse el origen de la misma en SÁNCHEZ SÁNCHEZ, José Francisco, op. cit., pág. 110. 
fue cobrando fuerza hasta independizarse, en un proceso que corría paralelo a la atención que la opinión pública prestaba a una juventud cada vez más agitada, como fue la de los sesenta.

Pero la sección semanal que resulta más representativa de esa preocupación del director por movilizar la opinión fue otra, que duró apenas un año: "Diario Regional propone un tema: opine usted". Se organizó en noviembre de 1960 con la colaboración de Radio Valladolid, con el fin de "promover la opinión pública". Se apoyaba en una emisión radiofónica en la noche de los lunes denominada "Tertulia de los lunes", en la que varios invitados participaban en un debate sobre la cuestión propuesta. El periódico publicaba después una síntesis de la tertulia, y cartas con opiniones de los lectores. Los temas que se abordaron fueron de lo más variado: desde las relaciones laborales y la cogestión empresarial, a la escultura de Berruguete, pasando por los parques de la ciudad, o la conveniencia de diferenciar los bachilleratos de letras y ciencias.

Con todo, la sección opinante más característica del periódico no fue ésta, sino otra -diaria- firmada por el director con sus iniciales, que apareció también en 1961. $\mathrm{Su}$ título resulta revelador respecto a la mentalidad de Areal: "Sin esconder la mano". Por su enfoque y contenidos puede calificarse también como representante de esa 
ingenua independencia que caracterizaba a los profesionales de esta generación, que no habían conocido la guerra civil. En último término, "Sin esconder la mano" venía a llenar el hueco que dejaba la falta de editoriales -que pese a ser más frecuentes que con Cebrián, se publicaban raras veces-, con un matiz significativo: Areal no quería que se confundiera su opinión con la del periódico, y por eso prefería firmar personalmente los fondos que redactaba710. Esta forma de actuar no era privativa de Diario Regional : lo mismo cabe decir para El Norte de Castilla, y -en menor medida- para Libertad 711. De alguna forma la vida profesional estaba empujando para que -de hecho- renaciera una opinión que la legislación vigente trataba de ahogar. Parece claro que el proceso de paulatina apertura del régimen tuvo por causa este tipo de comportamientos más que una decidida acción institucional que la promoviera. Por el contrario -pese a lo que digan algunos de sus protagonistas- la acción de los políticos españoles en estos años tendió más a frenar ese proceso de acercamiento a posturas democráticas que a acelerarlo ${ }^{712}$.

\footnotetext{
${ }^{710}$ Entrevistas con Manuel Fernández Areal.

711 Además de poder verse en las colecciones de los diarios, puede confirmarse esta tendencia en los "Partes mensuales de Prensa" que la Delegación Provincial remitía a Madrid. En la etapa de Arias Salgado esos partes consistían en un resumen -tres o cuatro páginas- de los aspectos más destacados de las publicaciones locales. Se conservan los correspondientes a Valladolid en 1959 y 1960 en A.G.A., Sección Cultura, cajas 6.042 y 6.043 .

712Cfr. por ejemplo López RODó, Laureano, Memorias, pág. 310 y FRAGA IRIBARNE, Manuel, Memoria breve de una vida pública., Planeta, Barcelona, 1980, epílogo.
} 
Los sueltos de Areal abordaban los asuntos más dispares, siempre en un tono de cierta provocación, de opinión encendida y categórica, que respondía a su manera de ser por un lado, y por otro a una manera de entender la prensa que había expuesto ya en 1959:

"Del periódico casi enteramente literario, aunque noticioso en origen, hemos pasado a la pura noticia rodeada en ocasiones de literatura, acompañada de colaboraciones no estrictamente periodísticas. Y la cuestión que ahora se debate -y en la que caben, naturalmente, términos medios- es la siguiente: ¿debe el periódico informar $\circ$ ha de tender $a$ educar?"

Ciertamente, continuaba, la misma disposición de la información es ya orientadora -no hay información pura-, pero estimaba oportuno que

"Junto a la entrevista, la crónica, la noticia que difunde verdad y la lleva a los más apartados rincones, está -debe estar- el artículo doctrinal, el editorial orientador, el "pondus" del periódico, que lo caracteriza, lo distingue y lo individualiza. (...)

"Informar y educar, orientar, son los fines y causas justificativas de la existencia de órganos de difusión que llamamos periódicos y que hoy, en nuestros días, adquieren caracteres de urgente necesidad, misiones de honda responsabilidad para el periodista consciente." 713

Es notable el cambio que se ha operado con respecto a Cebrián, y en cierta forma, la vuelta a planteamientos que identifican prensa y educación, tan comunes entre los católicos, que están en la raíz de la definición de prensa católica como prensa de opinión y no de masas. De todos modos, aun situándose en esta línea, hay un matiz en los planteamientos de Areal, que inicialmente es sólo un germen, pero que con los años llegará a ser una de sus

713 "Informar y orientar», editorial, 26/9/1959, pág. 1 . 
mayores preocupaciones: la defensa de la libertad de opinión.

Esa defensa sigue inicialmente un doble camino: por una lado la denuncia de las presiones ejercidas por las autoridades públicas sobre los periodistas:

"Porque querer amordazar la opinión pública, tratar de que los demás no opinen -cuando las materias son realmente opinables, cuando no están comprendidas dentro de aquellas que son de $f e$ o han sido declaradas por el Magisterio de la Iglesia, en cuyo caso no cabe duda y estamos seguros de su certeza- es una forma de totalitarismo ideológico que puede llegar incluso a terrenos tan de suyo indiferentes o intelectualmente insignificantes como pueda ser el deportivo, por ejemplo." 714

${ }^{714}$ Fernández Areal, "Sobre la opinión ajena», DR, 17/7/1960, pág. 11. Es posible que Fernández Areal tuviera en la cabeza alguna de las consignas que se recibían en las redacciones, y que el archivaba, que rayaban en ocasiones lo cómico, como la siguiente, remitida directamente por el director general de Prensa, con fecha 6/7/1956, que se conserva en el A.P.M.F.A.:

"Mi querido amigo:

"Hoy empieza en el vecino país la Vuelta Ciclista a Francia y en este deporte como en todos los demás, es preciso que cuide de manera especial el que todas las informaciones que se publiquen así como las crónicas, entrevistas, y cualesquiera trabajos sobre su desarrollo, prescinda de cuanto en las mismas se pueda verter que contribuya a fomentar los partidismos, las banderías y en general, cuanto pueda contribuir a sembrar divisiones en la afición española o hacer derivar los motivos exclusivamente deportivos por derroteros que están manifiestamente en pugna con lo que debe ser la información de cualquier competición de esta naturaleza.

"Estoy seguro de su sincera colaboración, para procurar conseguir que todo lo que se publique en su periódico sobre esta Vuelta Ciclista a Francia, ha de contribuir eficazmente a evitar divisiones dentro del Deporte Nacional del Ciclismo.Le agradece su colaboración y le saluda afectuosamente, "Fdo.: Juan Aparicio" 
Un año más tarde volvía sobre lo mismo con tonos más fuertes:

"Por eso el derecho a intervenir y a participar en determinadas funciones se concreta, en el caso genérico de los más, de los pasivos, en un derecho a estar informados y a opinar. [cita a continuación el discurso de Pío XII a los periodistas católicos en 1950 que nos es conocido] (...)

"Si hemos traído aquí estas dos citas de un mismo Pontifice, que tuvo que soportar y sufrir los ataques de un dirigismo totalitario -entiéndase régimen fascista italianoencaminado muchas veces a desvirtuar las propias palabras del Papa y cambiar su significado, es porque nos parece necesario en este momento el argumento de autoridad. Quizá así algunos que profesan nuestra misma fe comprendan que esa fe exige sacrificio, a veces en forma de doblegarse ante la opinión ajena, cuando es acertada.

"Insistimos en que las tareas comunitarias, y quizá estemos hablando en abstracto, exigen cooperación. A algunas personas parece que no les gusta el tema de la cooperación, quizá por ser "enemigos de la verdadera y libre opinión de los ciudadanos" (Pío XII en el mismo discurso citado). Y baste.»715

715Fernández Areal, «Derecho a opinar», DR, 2/12/1961, pág. 1 .

Por esas fechas se habían recibido en el periódico entre otras, las siguientes consignas, que se conservan en A.P.M.F.A.:

"Queda totalmente prohibida la publicación de noticias, comentarios, reportajes o alusiones de cualquier índole sobre la posible concesión de un título de Princesa a Doña Fabiola de Mora, hasta nueva orden.

"Valladolid, 8 de octubre de 1960"

"Esta Delegación Provincial ha podido comprobar que, a pesar de su trascendencia, ese periódico no ha publicado aun ningún comentario al mensaje habitual que, con motivo del fin de año, dirigió a los españoles S. E. el Jefe del Estado.

"Mucho le agradeceré pues, que, a la mayor brevedad, proceda a glosarle (sic) en sus puntos más principales, a base de la publicación mínima de dos comentarios. "Dios guarde a V.S. muchos años.

"Valladolid, 10 de enero de $1.961 "$

"Queda terminantemente prohibida la publicación de toda noticia, alusión, información, comentario, etc. acerca de las manifestaciones de S.E. el Jefe del Estado en su reciente discurso sobre la necesidad de modificar los acuerdos de las bases Hispanonorteamericanas, sin que previamente haya sido consultada a esta Delegación Provincial. " 13 de octubre de 1961 " 
La incisividad -0 agresividad si se prefiereperiodística, que para Cebrián significaba sobre todo investigación, reporterismo y veracidad, para Areal, significaba algo más: el deber del periodista de crear opinión.

"Y, sí, los que nos dedicamos a escribir, los que tenemos en las manos un periódico no podemos quedarnos atrás, no podemos consentir que las mejoras anheladas [habla en concreto de las del campo castellano], el curso de una reforma de cualquier tipo beneficiosa para la sociedad se retrase por encontrarnos ausentes de la polémica o al margen de la batalla. No podemos permanecer tranquilos, ocupándonos del turismo en Palma de Mallorca o exclusivamente de los problemas deportivos. guste o no guste, tenemos que decir la verdad y preparar un clima adecuado (...) sembrando ideas, tratando de influir decisivamente sobre quienes, porque tienen capacidad de pensar, pueden ser determinados a una acción más justa si nosotros sabemos orientar a la opinión hacia más justas realizaciones. " 716

Era un anticipo de la idea de prensa como "parlamento de papel» que se acuñará más adelante, en vísperas de la transición; y era también una forma de pensar que colocaba a Areal en una postura incómoda frente al Ministerio de Información. Las consiguientes sanciones, como luego veremos con detenimiento, no tardaron en llegar. En nuestra opinión, fueron precisamente esas sanciones las que hicieron que esta línea de pensamiento pasara en Areal de ser un germen, a ser el elemento vertebrador de su pensamiento ${ }^{717}$.

\footnotetext{
716 Fernández Areal, "Noble tarea», DR, 21/2/1962, pág. 1

${ }^{717}$ Cfr. por ejemplo sus obras El control de la prensa en España, Guadiana de ediciones, Madrid, 1973; y La libertad de prensa en España (1938-1971), Editorial Cuadernos para el Diálogo, Madrid, 1971, passim.
} 
En cuanto a la otra línea de argumentación, se centraba en la defensa del derecho de los católicos a una información veraz sobre la Iglesia y en general sobre la vida de otros católicos, que se entendía impedida por el monopolio informativo ejercido por las grandes agencias informativas:

"Hora es ya de arrancar el monopolio informativo de quienes lo utilizan para, con un sentido sectario, manejar la opinión pública de los pueblos a su antojo. Conviene decir a los hombres la verdad sobre todo aquello de que se les informa. Las noticias no pueden ser un instrumento político, un medio de deformar las mentalidades de los hombres, una ocasión de coartar voluntades -porque indirectamente a esto se llega-, sino que ha de ser instrumento de formación, útil para llevar a los hombres la verdad, para decir a todos lo que todos y cada uno quieren saber, sin escamoteos, ni mentiras, que así se llaman." 718

"La Iglesia está siendo perseguida hoy, directa e indirectamente, en muchos países. Se la combate abiertamente cárcel, ejecuciones, torturas, expulsiones del país-, o solapadamente, con campañas destinadas a ridiculizarla, a menospreciarla, a hacerla antipática.Quienes en un caso u otro actúan, suelen hacerlo invocando la libertad y la ausencia de "fanatismo", siendo -como son- fanáticos persecutores de la fe, que es lo más elevado, lo más preciado que el hombre posee y lo que puede dar la razón de su existencia y, por ende, su felicidad. (...)

"Una buena forma de ayudar a la Iglesia perseguida es comprometiéndose a difundir la verdad, a ayudar a quienes no tienen la luz de la fe, a dar doctrina sana en todo momento, creando climas católicos en los que la paz sea fruto necesario, sembrando semilla de libertad auténtica porque nadie más libre que el católico, caminante seguro sobre la firme base de la fe y libre luego para actuar -con la profundidad que su fe le atribuye- en cualquier terreno: Política, Ciencia, Economía, Artes, Letras, Negocios...» 719

\footnotetext{
718Fernández Areal, "Informar con la verdad", DR, 15/3/1959, pág. 5.

719 "Oración por la Iglesia perseguida", editorial en el "Día de la Iglesia perseguida", DR, 5/4/1949, pág. 1.Cfr. también "Informar con verdad", editorial, 16/1/960, pág. 1, "Una de las importantes misiones de la Prensa -cada vez más- es informar con verdad, dar a conocer los hechos, no deformar la realidad. y es preciso que la opinión pública se entere, para que pueda ser rectamente informada y actuar como tal, de los múltiples ataques que la Iglesia padece en muchas ocasiones. Así se sabrá en dónde milita cada uno, qué busca, y cuáles son sus fines."
} 
En el fondo se trataba de la difícil cuestión de distinguir entre servicio a la opinión y propaganda720, y de la defensa de la libertad del periodista frente a la empresa, y en concreto frente a las grandes empresas. Areal lo resumía así cuando comentaba la expulsión de una redactora del New York Herald Tribune por falta de acuerdo ideológico con la empresa:

"¿Quiere usted comentar la actuación política de alguien que no le cae simpático a un periódico de esos que se dicen apolíticos, liberales, amplios? No podrá.

"¿Le gustaría a usted que no se silenciasen ciertas noticias que, por ejemplo, destacan la labor positiva de la Iglesia? Esos periódicos tan amplios, tan amigos de la libertad -propia, claro- le negarán todo derecho a exigir esa información." 721

Las citas de Areal que hemos reproducido bastan para hacerse cargo de su inclinación a abordar grandes temas en pocas líneas. Hemos resaltado los que se refieren a la definición de la prensa, dejando de lado una dura campaña contra el decreto de Fraga que concedía el título de periodista a los que -sin tener el título académico correspondiente- acreditaran ciertos méritos de hecho ${ }^{722}$.

\footnotetext{
${ }^{720}$ En una colaboración publicada en DR, después de hablar del mimo con que atendían los gobiernos a la opinión pública, se analizaba su moralidad, para concluir: "La inmoralidad se da cuando la información, la propaganda, se ha hecho unilateralmente, imposibilitando la acción de los demás, y de un modo tan penetrante, persuasivo, asediante, que por fuerza la actitud del público tenga que ser pasiva, llena de un espíritu de aceptación incondicional. Se llega incluso a dañar la personalidad, a destruir los derechos naturales del hombre." "Opinión pública", por W.R., DR, 3/3/1959, pág. 4 .

${ }^{721}$ Fernández Areal, "iViva la libertad!", DR, 9/9/1964, pág. 1.

722 En el "Parte mensual de prensa" correspondiente al mes de julio de 1963, fechado el 5/8/1963, Antolín de Santiago escribía: "Ha realizado una campaña a fondo, de tono duro y de censura para el Consejo
} 
Pero junto a éstas cuestiones hubo muchas otras: la Iglesia perseguida, el derecho a enseñar y la libertad de enseñanza, la paz, la formación positiva, el diálogo, las necesidades materiales de Castilla, la participación de los ciudadanos en la política, las relaciones laborales, las desviaciones doctrinales entre los católicos, etc. ${ }^{723}$. De algunas de ellas nos ocuparemos más adelante, en el resto -que son la mayor parte- no podemos entrar por quedar fuera de nuestro objetivo y porque harían en exceso prolijo nuestro análisis. Pero sí queremos anotar que esta vitalidad opinante del periodista gallego empapó el resto de las secciones: las encuestas sobre urbanismo, sobre la industria, el cooperativismo, o los reportajes 0 colaboraciones sobre cuestiones sociales, sobre el Concilio, o sobre la Universidad -por citar algunos temas-

Nacional de Prensa y para la misma Dirección General, rechazando de plano la disposición de 3 de julio del corriente año sobre concesión a título excepcional del carnet profesional de periodista. Sobre ello ha publicado hasta cuatro artículos en primera plana, sección fija "Sin esconder la mano"." Areal comenzó por negarse a publicar la nota oficial que se le remitía desde la Delegación, y dando a conocer su negativa en un suelto en primera página con un tono desafiante "Nuestra profesión", DR, 26/7/1963, pág. 1-, y continuó luego con los artículos que menciona el delegado. No obstante, Fernando de la Torre, el antiguo ordenanza que ejercía de hecho funciones de periodista en Diario Regional se acogió al Decreto con el beneplácito de Areal, y cuando le fue negado el carnet, el mismo Areal redactó el recurso que sirvió para que finalmente se lo concedieran. Entrevista con Fernando de la Torre.

El parte mensual citado puede verse en A.G.A., Sección Cultura, caja 14.492 .

${ }^{723} \mathrm{Cfr}$. por ejemplo "Necesidad de una formación positiva", 10/5/1959, pág. 1; "El derecho a enseñar", 20/2/1959, pág. 4; "El diálogo", 8/11/1959, pág. 1; "Participación política", 24/7/1960, pág. 11, el artículo se enfocaba como un comentario de política internacional con motivo de la campaña electoral de Kennedy; "Campo", 1/11/1961, pág. 1; "Relaciones laborales", 11/11/1961, pág. 1; "Seamos sinceros", 25/1/1962, pág. 1; "Cooperativismo", 1/2/1962, pág. 1; "Para la familia", 20/3/1962, pág. 1; "Ciertas uniones", 9/5/1962, pág. 1; "Doctrina entera", 8/6/1962, pág. 1 . 
, eran siempre una llamada al lector -a veces de forma directa y apremiante- para despertar su opinión ${ }^{724}$. No hay duda de que en la actitud de Areal -y en la de tantos otros profesionales anónimos que mantuvieron posturas parecidas- hay que buscar una de las causas del despertar de la opinión pública que se produjo en estos años, a pesar de la acción gubernamental.

\section{Del "control rutinario" al Consejo de Guerra}

$\mathrm{Si}$ los modos de hacer de los periodistas que no habían hecho la guerra estaban cambiando, no se puede decir lo mismo de la ley que regulaba sus actividades. Su letra seguía vigente, con objeto de que tampoco su espíritu desapareciera: las autoridades buscaban así positivamente la perpetuación en el ámbito de la opinión pública del espíritu beligerante de la guerra civil725.

${ }^{724}$ Pueden verse por ejemplo el censo de industrias vallisoletanas y las entrevistas con industriales de valladolid publicados el 9/11/1959, págs. 9-11, y 13-14; en febrero de 1960 se realiza una campaña sobre la canalización y limpieza de los ríos; "La verdad sobre la triste situación de nuestros campos", 22/11/1960, págs. 14 y 15, reportaje por Andrés Romero Rubio y Pedro López Rodero; el 27/5/1962 se publican los resultados de tres encuestas en el suplemento dominical. Los temas eran: racionalizar el campo, la cooperativa azucarera, y la conveniencia de hacer regional la Feria de Muestras.En enero de 1963 se dedican varios artículos a una polémica con la cámara de comercio sobre la carestía de los productos. En febrero del mismo año se realiza una encuesta con el título "Valores humanos en el medio rural" que se ocupa de los problemas económicos, los cargos directivos de las entidades oficiales agrarias, la iniciativa privada, y la información y documentación de los agricultores entre otros temas.

725 "(...) pese a las matizaciones aducidas por algunos miembros del sector católico oficial, parece claro que los principios básicos de la ley de 1938 -y sobre todo la concepción de la prensa en el nuevo Estado- permanecieron prácticamente inalterados en las décadas de los cuarenta y cincuenta, dando lugar a una de los fenómenos de continuidad más característicos del franquismo: el acuerdo 
Pero tal estado de cosas no podía mantenerse sin que dejara de generar un conflicto permanente entre los órganos de control oficial y los medios. No obstante, la práctica habitual de las Delegaciones del Ministerio en cada provincia variaba buscando un entendimiento cordial - al menos la apariencia del mismo- siempre que fuera posible; entendimiento que también era deseado por los periodistas, ya que constituía la única forma de seguir adelante con sus tareas. En los meses en que se consumó la destitución de Cebrián, el parte mensual de prensa afirmaba -con frase que ya era rutinaria en esos documentos- que "siguen siendo cordiales y normales las relaciones de este centro delegado con la Prensa local»726. Hasta cierto punto decían la verdad. Lo "normal» era que si un director resultaba incómodo, fuera destituido.

Los años de la dirección de Fernández Areal nos dan a conocer las inercias y los cambios que en este terreno se fueron produciendo. Lo primero que cabe destacar es que la ausencia de editoriales, que en años anteriores era causa de amonestaciones, ahora era consentida. Ciertamente, la

generalizado sobre la necesidad del control de los medios de comunicación". MARTIN DE LA GUARDIA, Ricardo M., "Católicos y falangistas ante la renovación del concepto de prensa. 1938-1962", comunicación presentada al Colloque International Eglise, État et Societé en Espagne, France et Italie (époque contemporaine), en febrero de 1992.Cfr. también M. FERNÁNDEZ AREAL, El control de la prensa..., pág. 232; J. TERRÓN MONTERO, La prensa de España..., pág. 101; J. TUSELL, Franco y los católicos..., pág. 344 .

${ }^{726}$ Partes mensuales de prensa correspondientes a los meses de octubre y diciembre de 1958, de fecha 5/11/1958 y 10/1/1959, respectivamente. A.G.A., Sección Cultura, caja 6.041 . 
tendencia a omitir el artículo editorial -consecuencia lógica de un estado de opinión amordazada como el que se vivía- no era privativa de Diario Regional, sino que había sido incorporada por El Norte, el otro diario no estatal de la ciudad, que "no cultiva ahora el editorial"727. La consecuencia es que los editoriales publicados eran ahora los obligados, con lo que los perfiles de los diarios, si atendiéramos a esta sección, resultarían cuando menos pintorescos. El viejo periódico liberal publicaba en el mes de abril de 1959 tres editoriales: uno dedicado a la conmemoración de la fusión de Falange Española y las J.O.N.S. el cuatro de marzo, otro sobre el nuevo seminario diocesano, y otro sobre el día del seminario; y en el mes de junio del mismo año, El Norte publicaba dos, dedicados al Día de la Prensa e Información de la Iglesia728.

No obstante, ese viraje del decano vallisoletano hacia temas eclesiales no era sólo producto de campañas teledirigidas, era también consecuencia de una doble causa: por un lado, la discusión sobre cuestiones religiosas se estaba poniendo de moda a principios de los sesenta, en vísperas del Concilio Vaticano II; y por otro, en España, dada la confesionalidad del régimen y la

${ }^{727}$ Parte mensual de prensa correspondiente al mes de febrero de 1959, 3/3/1959. A.G.A., Ibid., caja 6.042. De Diario Regional tenemos datos similares para esas fechas. Por ejemplo en el mes de diciembre de 1958 publican tres editoriales en todo en mes. Cfr. el parte correspondiente a dicho mes que citamos más arriba.

${ }^{728}$ Partes mensuales de prensa correspondientes a los meses de marzo y junio de 1959, de fecha 10/4/1959 y 3/7/1959. Ibid., caja 6.042. 
frecuente confusión de ámbitos de influencia en lo político y en lo religioso, las opiniones vertidas sobre cuestiones religiosas tenían frecuentemente sabor político. De esta forma se llegó a una situación que puede parecer paradójica, en la que era El Norte el que más se ocupaba de las cuestiones religiosas, mientras que Diario Regional prefería, por el momento, atender a otras, y afrontar las cuestiones religiosas de otra manera, evitando su politización.

Como es sabido, el ambiente de polémica en torno a esas cuestiones fue subiendo de tono en los años del Concilio, dando lugar a lo que podríamos llamar una escalada en la crítica eclesiológica, que termina por hacer habitual la sección de religión en todos los periódicos. Tenemos noticias de cómo se vivió esto en Valladolid a través de los partes mensuales de prensa, que cambiaron el esquema de su contenido -buscando un mejor control de las publicaciones- con la llegada de Fraga al ministerio729; y también, a través de unos nuevos partes

${ }^{729} \mathrm{El}$ nuevo índice del parte, que lo hacía más minucioso, fue desde 1963 el siguiente:

1.- Impresión del Delegado sobre las relaciones de esta publicación con la Delegación Provincial.

2.- Normas e instrucciones cursadas a la publicación por orden de la Dirección General de Prensa.

3.- Normas e instrucciones cursadas a la publicación por sugerencia de otras autoridades u organismos.

4.- Observaciones sobre el cumplimiento de estas normas.

5.- Campañas observadas en la publicación.

6.- Relación nominal de redactores y colaboradores que han tomado parte en estas campañas.

7.- Textos y fotografías sometidos a la consulta previa de la Delegación Provincial. 
Periodismo es información, y "católico" sustantivo

denominados "Informes reservados" que las Delegaciones debían enviar al Ministro con la misma periodicidad que los anteriores. Hicieron su aparición en 1964, probablemente con el fin de mantener a Madrid lo más informado posible con respecto al ambiente de la opinión pública, cuando estaba en ciernes la publicación de la nueva Ley de Prensa que el mismo Fraga auspiciaba730. A la vista de los datos que en ellas se señalan hay que concluir que, en efecto, las polémicas suscitadas en este apartado tuvieron como protagonista a El Norte de Castilla 731 . previa.

8.- Textos y fotografías retenidas o modificadas por la consulta previa.

9.- Observaciones sobre el cumplimiento del trámite de consulta 10.- Copias de las galeradas o pruebas a que se refiere el apartado 8 .

11.- Movimiento de personal de plantilla de la publicación y sus corresponsales nacionales o extranjeros.

12.- Observaciones especiales sobre la publicación en general.

13.- Novedades técnicas de la publicación (Maquinaria, utillaje, papel, sistemas de impresión, publicidad, etc.)

14.- Novedades referentes a la finalización y explotación (empresa, publicidad, distribución, precio de venta, etc.)

A.G.A., Sección Cultura, caja 14.491.

${ }^{730}$ Dichos informes fueron solicitados en una circular ministerial de $25 / 5 / 1964$ y su contenido se fue precisando en escritos posteriores. Tenían básicamente el siguiente esquema: Asuntos políticos: Internacionales, nacionales y locales. Asuntos económicos. Asuntos eclesiásticos. Educación Nacional. Turismo. Educación Popular. Cinematografía y Teatro. Radio y Televisión. Cfr., entre otras, A.G.A., Sección Cultura, cajas 23.061 y 35.174 .

${ }^{731}$ Suelen partir de artículos de José Jiménez Lozano y José Luis Martín Descalzo, referidos precisamente a asuntos eclesiásticos: "Puede señalarse el artículo que firmado por José Jiménez Lozano se publicó en "El Norte de Castilla", sección "Última columna", en el que, como es costumbre en el citado escritor, se arremete contra la Iglesia española por su subordinación al Estado. El artículo se titulaba "La Iglesia no es una Corte" y ha sido ampliamente comentado en los sectores cultivados de la ciudad." Informe reservado no 1 correspondiente al mes de mayo de 1964, fechado el 10 de junio de 1964, pág. 9. A.G.A., Sección Cultura, caja 35.176. Cfr. también el informe correspondiente al mes de agosto de 1964, de fecha 10/9/1964, pág. 5 (Ibid. caja 37.175); y el de septiembre del mismo año, de fecha 
En este campo Diario Regional no planteó problemas, pero no puede decirse lo mismo de otros. De entrada, siguieron menudeando las omisiones por lo que se refiere a la atención que se estimaba debida a las autoridades políticas 732 . La columna de Areal "Sin esconder la mano" era objeto de comentarios en casi todos los partes que la Delegación enviaba a Madrid, y no faltaban críticas más o menos abiertas a la actuación de las autoridades. Por ejemplo, con ocasión de la conmemoración de los «XXV años de paz", el periódico afirmaba que lo importante ahora era saber dónde se iba733, o se manifestaba extrañeza ante la supresión de determinados párrafos en los textos oficiales

20/10/1964, pág. 3 (Ibid. caja 35.174), en el que Santiago y Juárez escribía: "En su columna "Ciudad de Dios" de "El Norte de Castilla" su colaborador José Jiménez Lozano publicó un artículo sobre la libertad religiosa, aludiendo directamente a la Iglesia española, que ha sido muy comentado."

732 "No publicó los discursos del ministro de Trabajo y del ministro de Educación antes citados, y sí un brevísimo extracto del pronunciado por el ministro de Comercio en Zaragoza.

"(...) No publicó la nota de la Dirección General de Prensa sobre la censura en las informaciones y comentarios sobre la política internacional.

"Para dar la noticia de la estancia del ministro de la Gobernación en Valladolid publicaba como información gráfica la fotografía del coche del ministro ante el hotel."

Parte mensual de prensa correspondiente al mes de octubre de 1960, fechado el 6/11/1960. A.G.A., Sección Cultura, caja 6.043.

"No publicó el discurso pronunciado por S.E. el Jefe del Estado en Santiago de Compostela el domingo día 15, ni dio información alguna del acto que presidió el Caudillo con motivo de la entrega de títulos de la concentración parcelaria»

Idem. correspondiente al mes de septiembre de 1963, fechado el 3/10/1963. Ibid. caja 14.491.

733 "Diario Regional” dio en primera página la fotografía del Caudillo y un editorial, en el que se viene a decir que para colmar la paz cuyos veinticinco años ahora se conmemoran la opinión necesitaría saber a donde vamos, interrogante con el que se cierra el comentario". Informe reservado correspondiente al mes de julio de 1964, pág. 2 . A.G.A., Sección Cultura, caja 35.176 . 
de los discursos de los ministros, que sin embargo eran retransmitidos íntegros por radio o televisión ${ }^{734}$.

Al fin -lo mismo que ya le ocurriera a su predecesor, las diversas amonestaciones y sanciones recibidas culminaron en 1964 con la retirada de la censura delegada, con lo que Diario Regional volvió a estar sometido a la censura previa. En esta ocasión la gota que vino a colmar el vaso fue un artículo sobre la situación del campo castellano, que se enmarcaba en la línea de denuncias sobre la situación de la agricultura de la región que el periódico venía haciendo. El tono de esas reclamaciones era el que hemos visto como característico de Areal. En 1963 el periódico había realizado, entre otros, un reportaje en forma de encuesta con el tema general de "valores humanos en el medio rural". Se atendía, entre otras cuestiones, a los problemas económicos, cargos directivos, iniciativa privada e información y documentación de los agricultores. Entre los resultados más sobresalientes del estudio, el periódico había destacado la escasa rentabilidad del campo, y que las expectativas de mejora de los agricultores se cifraban sobre todo en la esperanza de una decidida acción gubernamental que los apoyara735. El director del periódico

\footnotetext{
${ }^{734}$ Parte mensual de prensa correspondiente al mes de junio de 1963 , de fecha 5/7/1963. Ibid. caja 14.491.

${ }^{735}$ Los trabajos se publicaban con el título "Valores humanos en el medio rural". Cfr. DR, 7/2/1963, págs. 8-9: "La actual escasa rentabilidad del campo es un determinante para que el hombre crea más
} 
dedicó a renglón seguido dos artículos a glosar las que él entendía consecuencias más destacadas de la encuesta: la necesidad de una reforma agraria, y de la mejora de las condiciones de vida de los agricultores castellanos, especialmente de los jornaleros, que según él sobrevivían en condiciones infrahumanas ${ }^{736}$.

Este tipo de advertencias se toleraron, pero cuando se publicó a toda plana un artículo del corresponsal de Villalón de Campos -Emigdio Fraile- que enlazaba esa clase de argumentos con la gestión del Servicio Nacional del Trigo y el Banco de Crédito Local, la capacidad de aguante de los vigilantes de la prensa tocó su techo737. Pero quizá lo más importante sea notar que el enojo no procedió en absoluto de observar falsedad en lo que se decía, sino del hecho simple y llano de que se diera publicidad a una opinión desfavorable respecto a la gestión de los asuntos públicos, aunque se sabía que -de hecho- ésta era vox populi, según lo hacía notar el delegado a Madrid:

"Mientras el ritmo industrial de la ciudad sigue subiendo,
con los anuncios de próximas nuevas instalaciones de
factorías, al calor del Polo de Desarrollo -aunque no con el

en la eficacia del dinero que en cualquier otro medio."; 8/2/1963, pág. 8, "El agricultor siempre cree que es el gobierno el que remediará sus males y le permitirá seguir viviendo"; 9/2/1963, pág. 8 "para dentro de diez años la estructura de nuestro secano será totalmente distinta". Este tipo de artículos eran frecuentes: en 1962 se habían realizado otras encuestas sobre "Racionalizar el campo", "La cooperativa azucarera", y "iFeria Regional de Muestras?". Cfr. DR, suplemento, 27/5/1962.

736 "Sin esconder la mano», DR, 10/2/1963, pág. 1, y 12/2/1963, pág. 1 .

${ }^{737}$ Cfr. Parte mensual de prensa correspondiente al mes de septiembre de 1964, fechado el 5/10/1964. A.G.A., Sección Cultura, caja 17.935. 
volumen y la importancia de otras ciudades favorecidas también por el Plan de Desarrollo Económico- la situación en el campo no ha experimentado mejoría alguna después de la campaña agrícola, ya que en general las cosechas han sido malas (...). Ello hace que cunda el descontento entre los labradores, castigados ya por cinco años de cosechas deficitarias, sin que el pequeño aumento en el precio del cereal rey haya supuesto alivio alguno. Los problemas continúan siendo los mismos: las deudas y los créditos, los altos precios a que tienen que pagar la maquinaria agrícola y los descuentos en el Servicio Nacional del Trigo, además de la falta de mano de obra en el campo, por el éxodo de la juventud sobre todo. En las reuniones de las hermandades, de la Cámara Oficial Sindical Agraria y de los campesinos en general, sale a relucir siempre este estado de cosas, que ha tenido también reflejo en la Prensa, en un fuerte artículo del corresponsal de "Diario Regional" en Villalón de Campos, lo que determinó la implantación de la previa consulta ante esta Delegación de cuantos originales se refieran directamente a problemas agrarios." 738

A pesar de esta medida los artículos en torno a los problemas del campo siguieron elaborándose -y publicándose sin pasar la censura previa739-, mientras se insistía en que la reiteración de las denuncias no iba contra nadie en concreto, como se decía en el editorial de presentación de un número especial -publicado en octubre de 1964- que salió a la calle con el título "Nuestro Campo se muere":

"No es la primera vez que hablamos de nuestro Campo. Ni probablemente, podrá ser la última, pues no habrá más remedio que seguir diciendo la verdad, a ver si se nos oye.(...)

"DIARIO REGIONAL se ha arriesgado en más de una ocasión a decir la verdad. Y no por vano placer de "meterse" con éste o con el otro, o con un organismo determinado o... no, DIARIO REGIONAL siempre ha tratado de servir a quienes más necesitan de ayuda, y desde hace ya demasiados años, quienes más necesitan de ayuda en España son los hombres del Campo."740

\footnotetext{
${ }^{738}$ Informe reservado correspondiente al mismo mes, de fecha 20/10/1964, pág. 2. Ibid. caja 35.174 .

${ }^{739} \mathrm{Cfr}$. nota 126 .

$740 \mathrm{DR}, 25 / 10 / 1964$, pág. 3.
} 
La reacción de la Delegación ante ese comportamiento iba desde informar a Madrid, a la retención del artículo correspondiente ${ }^{74}$, pasando por la apertura de expediente al director, como fue el caso del número al que corresponden las líneas que acabamos de reproducir ${ }^{742}$. Ahora bien, por coincidencias cronológicas, cuando Madrid resolvió sancionar a Areal por el número dedicado al campo moribundo y algún otro artículo, su situación frente a las autoridades había cambiado sustancialmente, merced a la intervención inesperada de la jerarquía militar en la vigilancia de la prensa; intervención que iba a hacer llegar el nombre de Diario Regional y de su director más allá de nuestras fronteras ${ }^{743}$.

No era la primera vez que Fernández Areal escribía en su columna sobre cuestiones militares, es más, ni siquiera era la primera vez que ponía por escrito su idea de que un

741 Cfr. Parte mensual de prensa correspondiente al mes de octubre de 1964, de fecha 5/11/1964. A.G.A., Sección Cultura, caja 17.947.

742 En el oficio en que se comunica la apertura del expediente, de fecha 5/11/1964, se hacía notar que no habían cumplido con el requisito de previa censura en el caso del reportaje titulado "Nuestro Campo se muere", $y$ de otro que llevaba por título "El campo está triste", firmado por Cesáreo Hernández Gutiérrez, y publicado del 4/11/1964, "contraviniendo instrucciones que con referencia al tema del agro, le fueron comunicadas por la superioridad." A.P.M.F.A.. Cfr. también el parte mensual de prensa correspondiente al mes de noviembre, fechado el 5/12/1964. A.G.A., Sección Cultura, caja 17.953.

$743 \mathrm{En}$ el A.P.M.F.A. se conservan recortes de informaciones sobre su caso de las siguientes publicaciones periódicas, entre otras: Le Monde, Le Figaro, Republique du Centre, L'Independent, Nouvelle Republique, France Soir, Liberté de L'Est, La Croix, de Francia; The Times de Londres; Die Welt, Neu zurger Zeitum, de Alemania; Novedades y Excelsior de México. El artículo aparecido en este último, titulado "España: La de San Quintín", lo firmaba Salvador de Madariaga. 
Periodismo es información, y "católico" sustantivo

servicio militar más corto sería también un mejor servicio744. Por añadidura, las relaciones de Diario Regional con el Ejército parecían estar en un momento espléndido: se había concedido ese año al periódico el "Premio Ejército" por su "Página Militar", y los capitanes que colaboraban en la redacción de la misma habían sido condecorados $^{745}$. También era cierto que no había faltado algún roce con las autoridades castrenses por un motivo u otro...746 Pero, desde luego, nada hacía sospechar que aquel

${ }^{744} \mathrm{Cfr}$. sus artículos «Nosotros, los oficiales de complemento", DR, 11/12/1958, pág. 4; y "Un servicio largo", DR, 24/11/1962, pág. 1, en el que comentaba -adhiriéndose a la tesis del colega- un artículo en la revista $S P$ que sugería reducir la "mili» a seis meses.

${ }^{745} \mathrm{Cfr}$. "Nuestro director recibe el premio Ejército otorgado a DIARIO REGIONAL", DR, 1/7/1964, pág. 1. Los militares que colaboraban en el periódico eran Ramón Touceda y Leopoldo de la Reina. La iniciativa para solicitar la concesión de las condecoraciones a los colaboradores partió de ellos mismos, que le pidieron a Areal que iniciara las gestiones, que este realizó inmediatamente. Les fue concedida la medalla militar con distintivo blanco en el mes de agosto de 1964 . Relato autobiográfico de Manuel Fernández Areal, pág. 85.

746Antolín de Santiago le había hecho notar que su artículo sobre los oficiales de complemento no había sentado bien en la Hermandad de Alféreces Provisionales; en 1959 hubo un pequeño choque con autoridades del Ejército del Aire con motivo de una carta al director publicada por el periódico; y últimamente Areal se había negado a que los militares censuraran previamente lo que se iba a publicar en la "Página Militar". Por fin, el Capitán General se había sentido molesto porque la iniciativa para la concesión de la medalla a los colaboradores militares hubiera partido del director del periódico. Cfr. para todo ello nuestro artículo, escrito en colaboración con el profesor Ricardo M. MARTÍN DE LA GUARDIA, "La represión de la opinión en la prensa periódica y el procesamiento a periodistas: el caso de Fernández Areal", en La Oposición al Régimen de Franco. Estado de la cuestión y metodología. Madrid, UNED, 1990, tomo I, vol. 2, págs. 417427, en el que analizamos pormenorizadamente -si bien en una primera aproximación- los sucesos que nos ocupan, que también ha sido relatados sumariamente por Henry F. SCHULTE en su obra The Spanish Press. 1470-1966. Print, Power, and Politics, University of Illinois Press Urbana, Chicago, London, 1968, págs. 54-56; y Antonio COLL GILABERT, De profesión periodista, Noguer, Barcelona, 1981, págs. 181183. Un relato del ambiente que con relación a la censura se vivía en el periódico por aquellos años, puede verse en SINOVA, J., La censura..., págs. 11-12. El autor realizaba entonces trabajos esporádicos para el periódico. 
día fuese a desatarse semejante tormenta. Y sin embargo ahí estaba el oficio del Juez Instructor citándole por "presunto delito de injurias al Ejército y Fuerzas Armadas". La causa no era otra que el "Sin esconder la mano" de ese día -6 de noviembre de 1964-, titulado "Un proyecto realista". En él, tomando ocasión de una iniciativa francesa, Areal sugería reducir a tres meses el servicio militar ${ }^{747}$.

Esa misma tarde ingresó en prisiones militares, dónde permanecería un día incomunicado. Mientras tanto se sucedían los contactos entre autoridades militares y del Ministerio de Información para dar una salida no demasiado escandalosa, pero ejemplar, al "caso Areal". La historia de esos contactos constituye un buen ejemplo de cómo se ejercía el poder político en aquellos años, con el interés añadido de que se trata de un acto de represión dirigido por militares contra periodistas, en los años de “liberalización" de la prensa. Puede, pues, considerarse un pulso entre uno de los soportes clásicos del régimen y una de las bazas legitimadoras que éste mismo quería hacer suyas en los años sesenta: la apertura y el apoyo en la sociedad civil.

Fraga recuerda el episodio como un desagradable incidente, que vino a ensombrecer la recepción a A. O.

${ }^{747}$ Lo recogemos íntegro en el apéndice 18. 
Sulzberger -"el amo del New York Times", como lo llama el ex-ministro- en plena campaña de transformación de la imagen del régimen de prensa:

"Sábado, 7: Recepción en honor de Sulzberger. Un incidente serio: la jurisdicción militar de valladolid detiene y procesa al director de Diario Regional; tema que nos dará bastante trabajo. No pudimos evitar el procesamiento, pero sí logramos que fuera, primero puesto en libertad y luego indultado..."748

Probablemente hubo un pacto entre Ministerios en el que se llegó en efecto a un arreglo de ese estilo. Así lo relata el general Armada:

"Una escena curiosa, que presencié, se desarrolló entre el ministro del Ejército y el entonces ministro de Información, don Manuel Fraga Iribarne. Se trataba de un artículo de un periodista de Valladolid -me parece que escribía en El Norte de Castilla 749- y que el capitán general consideró ofensivo para los militares, indicando que había malestar en las unidades. Don Pablo Martín Alonso ${ }^{750}$ llamó a don Manuel Fraga y éste acudió al Ministerio con rapidez. El general, de forma sencilla pero rotunda, le expresó al ministro el disgusto que le producía esta noticia. "a los militares -agregó- hay que dejarlos tranquilos; cuando se excitan, es difícil controlarlos. Aunque la disciplina se impone con las medidas que sean necesarias, es mucho mejor evitar problemas. Mandar con prestigio es fácil; hacerse obedecer con coacción es sencillo; pero a la larga puede no ser el mejor sistema. La autoridad tiene que existir sin tener que hacer alardes. Ahora bien, no hay nada que más estimen los subordinados que un superior que los respalde. Por eso quiero que usted, como ministro de Información, tome las medidas que sean necesarias para sancionar la falta y para que no vuelva a producirse. Por mi parte, yo, como ministro del Ejército, daré seguridades al capitán general de Valladolid de que me sumo a la indignación de los jefes, oficiales y suboficiales de la región, que se castigará al culpable y que si se volviese a producir el menor indicio de falta a la institución militar, yo sería el primero en actuar para dejar a salvo el honor de las Armas.

748FRAGA IRIBARNE, Manuel, Memoria..., Planeta, Barcelona, 1980, pág. 124 .

${ }^{749}$ Se equivoca Armada. De todos modos, el error es disculpable por lo que ya sabemos.

${ }^{750}$ En ese momento el ministro era Camilo Menéndez Tolosa. 
"Don Manuel Fraga, con su clara inteligencia, con su sentido de la autoridad y como hombre de Estado, comprendió perfectamente el mensaje (...), que expresaba lo que el Ejército aprecia más que es sentirse respaldado por sus jefes, los cuales tienen que mantenerlos en su sitio, pero nunca ceder a presiones de los medios de información. Por ese camino del enfrentamiento, de la calumnia, de la crítica irresponsable, se llega a situaciones en que siempre pierde el que tiene menos fuerza (...)." 751

La extensa cita resulta sin duda interesante. Ahora bien, si el Estado franquista consideraba a los periodistas una milicia a su servicio, Fraga bien podía haberse aplicado las frases de su colega militar para defender a uno de sus directores. Nada de eso ocurrió: esta vez -desmintiendo a Cervantes- la lanza embotó la pluma.

Armada acierta de lleno cuando dice que "siempre pierde el que tiene menos fuerza»: mientras los ministros conversaban, y -después- como consecuencia de esa conversación, sucedieron otras cosas que Fraga no menciona en su diario, y que no dejan de ser significativas. El encarcelamiento de Areal se había producido sin notificación escrita alguna, lo mismo que su puesta en libertad; el director general de Prensa en persona Jiménez Quílez- se había preocupado de urgir a la Delegación vallisoletana para que se asegurara de que en Diario Regional se publicaba lo antes posible una rectificación -de la que ni el periódico ni Areal salían

751 ARMADA COMÍN, Alfonso, Al servicio de la Corona, Planeta, Barcelona, 1982 , pág. 74 . 
nada airosos-752, y Areal era suspendido de sus funciones de director de la publicación sin que se hubiera tramitado el expediente sancionador correspondiente, que realmente sólo se había incoado753. El mismo Jiménez Quílez presionaba sobre la empresa para que despidiera a Areal ${ }^{754}$. Por fin, el periódico -esta vez todo él, y no sólo los escritos sobre agricultura- pasaba a estar en régimen de censura previa. Resulta clara la inexistencia de garantías jurídicas sólidas, aún dentro de las ya estrechas leyes del régimen. Areal afirma, ante estas circunstancias, que cualquier ciudadano estaba potencialmente amenazado de comparecer ante un Consejo de Guerra, y hay que concluir que todo parece demostrar que así era755.

752El artículo, titulado "Una respuesta", y firmado con tres asteriscos -que la gente interpretó como firma de un coronel- apareció en Diario Regional el 8/11/1964. Lo recogemos íntegro en el apéndice 19 .

${ }^{753} \mathrm{En}$ la notificación que recibió Areal se le comunicaba la apertura de expediente por el artículo "Un proyecto realista", en el que "se vierten expresiones ofensivas al Ejército español". "Pliego de cargos" del Juez Instructor de la Delegación Provincial del Ministerio de Información y Turismo, fechado el 7/11/1964, recibido por Areal el 10/11/1964. A.P.M.F.A.. El mismo día Areal recibía un oficio de la delegación que le comunicaba que "Con fecha de hoy se recibe, en esta Delegación Provincial, escrito del Ilmo Sr. Director General de Prensa, de fecha 7 del actual, en el que se dispone la suspensión de sus funciones de Director de "Diario Regional", en tanto se sustancie el Expediente abierto a Vd. en esta delegación por la publicación del artículo "Un proyecto realista" (...)". A.P.M.F.A.. La orden de destitución había sido dada el mismo día 7 según consta en oficio del director general de Prensa al delegado en Valladolid, de fecha 7/11/1964. A.H.P.U.V., Sección Cultura, caja 28.

${ }^{754}$ Relato autobiográfico de Fernández Areal, pág. 142 .

755Entrevista con Manuel Fernández Areal y relato autobiográfico, pág. 150. También en este aspecto se revivían viejos problemas preliberales, como puede verse en el cuidadoso resumen de los problemas jurídicos y de hecho generados en torno al control de la prensa en nuestro país en el siglo XIX que realiza ALMUIÑA FERNÁNDEZ, La prensa vallisoletana..., tomo I, págs. 163-376. Un claro precedente 
A fin de cuentas lo ocurrido era consecuencia de que el teniente general Valero Valderrábano Samitier «se había calzado las espuelas", y no había fuerza legal capaz de parar la "militarada": así definió la acción el que era subsecretario de Información, Pío Cabanillas, algún tiempo más tarde756.Todo lo más se buscaba suavizar el efecto de la cólera del militar, para evitar que fuera a más el eco que la noticia estaba teniendo fuera del país. En el interior no había problemas: la censura se encargó de que en ningún periódico español se publicara absolutamente nada sobre el caso. En Valladolid el rumor se encargaba de transmitir las novedades, ayudado por una medida que prudentemente había adoptado Areal: ante el temor de que la prisión militar supusiera incomunicación y se alargara, después de comparecer ante el juez y antes de presentarse en el cuartel que éste le indicó, redactó algunas cartas

del solapamiento de la jurisdicción militar con la civil y penal que afectaba a la prensa fue la Ley de Jurisdicciones, de 23 de marzo de 1906, vigente hasta la Segunda República. En virtud de ella, se sometían a los tribunales militares los delitos contra la patria y el ejército cometidos a través de los papeles periódicos. Cfr. CENDÁN PAZOS, F., op. cit., págs. 153-154, y LEZCANO, Ricardo, La Ley de Jurisdicciones 1905-06. (Una batalla perdida por la libertad de expresión), Akal, Madrid, 1978.

${ }^{756}$ Relato autobiográfico de Fernández Areal, pág. 185. De la misma opinión era el gobernador civil de la provincia -Antonio Ruiz Ocaña-, que atendió cordialmente a Areal e intentó evitar que se llegara al Consejo de Guerra. Ruiz ocaña pensaba que como máxima autoridad provincial y ex-combatiente de la División Azul tenía todas las credenciales para llegar ante Valero con cierto ascendiente. Llamó a Fernández Areal poco después de que fuera puesto en libertad, y le explicó que aquello había que arreglarlo "por el bien de España, porque la polvareda desatada en el extranjero no favorecía a la nación" (ibid.). Propuso a Areal entrevistarse con Valero, y éste aceptó con la condición de que el gobernador estuviese presente durante la entrevista. Ruiz llamó al capitán general, que con maneras fuertes le hizo saber que si venía con el autor del artículo no lo recibiría. 
dirigidas a amigos, periodistas y funcionarios del Ministerio de Información para darles cuenta de lo que estaba acaeciendo757. Las opiniones callejeras acabaron por plasmarse en dos hojas volanderas que aparecieron en buzones y parabrisas de los coches, una a favor y otra en contra del procesado758. Otros optaron por escribir al depuesto director para manifestarle su apoyo759; y finalmente- entre los colegas hubo de todo. Algunos, como Virgilio Peña, director de una de las emisoras de radio de la ciudad y fiscal Jurídico Militar, debían actuar por oficio contra el colega; los colaboradores de la "Página Militar" desaparecieron como por ensalmo; los más callaron por miedo, alegando como disculpa que había sido un desliz de Areal que no tendría graves consecuencias -Diario

${ }^{757}$ Relato autobiográfico de Fernández Areal, pág. 93.

${ }^{758}$ Se conservan en A.P.M.F.A., sin que nos sea posible determinar quiénes fueron sus redactores. La información enviada -con mucho retraso por cierto- por la delegación provincial a Madrid describía así la situación: "Por unos días constituyó el tema de todas las conversaciones, pues el hecho se difundió rápidamente, lo sucedido al director del periódico local "Diario Regional", D. Manuel Fernández Areal, detenido durante veinticuatro horas y procesado por la jurisdicción militar, como consecuencia de la publicación de un artículo titulado "Un proyecto realista" y firmado con sus iniciales, el cual fue estimado injurioso para el Ejército. El artículo defendía la opinión de que debía ser reducido el tiempo de servicio en filas y en él se deslizaban algunas frases escritas ligeramente y molestas para las Fuerzas Armadas. Sometido a expediente por la Dirección General de Prensa, el señor Fernández Areal ha sido sustituido entre tanto en la dirección del diario por el redactor-jefe D. Tomás Santos Corchero. El incidente no ha tenido mayor repercusión en el público que los comentarios consiguientes, divididos en sus apreciaciones, $y$ la circulación de una hoja clandestina, sobre la libertad de Prensa, que ha sido recibida por correo por distintas personas $y$ entidades o depositadas en buzones o coches aparcados, etc. sin que haya podido saberse su procedencia." El subrayado es del receptor del informe. Informe reservado correspondiente al mes de noviembre de 1964, de fecha 24/12/1964. A.G.A., Sección Cultura, caja 35174.

${ }^{759}$ Las cartas se conservan en A.P.M.F.A.. 
Regional al fin $y$ al cabo "era de derechas"-760, y otros tuvieron la valentía de manifestar su disgusto y protesta $y$ pedir acciones coordinadas que contrarrestaran "la militarada» ${ }^{761}$.

Pero ninguno de los intentos de detener el proceso surtió efecto. Areal se aprestó a preparar su defensa, contratando para ello un abogado prestigioso, e intentando esta vez personalmente que el ministro de Información le apoyara: la gestión resultó otra vez infructuosa762. Al

${ }^{760}$ Entrevista con César Alonso de los Ríos. Madrid 22/10/1988. Este periodista -entonces redactor de $E l$ Norte- destacaba que esta actitud de consentimiento de las arbitrariedades alegando una u otra razón para justificarse era una de las causas que hacía posible tal estado de cosas.

${ }^{761}$ Las reclamaciones tuvieron lugar con motivo de la visita de Fraga a Valladolid algunas semanas más tarde. Miguel Delibes, director de El Norte de Castilla, Jesús Vasallo, director de Libertad, Mạ Teresa Íñigo y Virgilio Peña, directores de las emisoras de radio de la ciudad, pidieron audiencia la ministro para manifestarle su indignación, y para reclamar una intervención decidida del Ministerio de Información en favor de Areal.

${ }^{762}$ El abogado defensor fue Ferrer Sama, Catedrático de Derecho Penal. En cuanto a la entrevista con Fraga, Areal la relata así:

"Consigo, al fin, ser recibido por Fraga. Me recibe serio, violento, con su tradicional traje azul con rayas blancas y su mirada perdida en el infinito. No me mira a la cara. Me dice que se me recibe, porque yo he insistido en que se me recibiera, pero que mi conducta es intolerable.

"Le respondo, muy claramente, muy despacio, que la situación es análoga a la en que podría encontrarse él mismo (ha aludido a mi condición de oficial de complemento y él también lo es y acaba de hacer un acto externo de gran adhesión al Ejército, al jurar bandera por segunda vez, como acto patriótico, con sus compañeros de servicio militar en la Milicia Universitaria).

"Fraga se exaspera -se exasperó numerosas veces a lo largo de la corta entrevista- y me dice que un capitán general en su territorio es como un obispo en su diócesis y que puede hacer en él lo que le dé la gana y que es muy cómodo venir a pedir que le saquen a uno las castañas del fuego, después de haber metido la pata.

"Le digo, en el mismo tono, despacio, con calma, que yo no he venido a pedir que me saquen las castañas del fuego, entre 
final, la celebración del Consejo tuvo lugar el 11 de febrero de 1965. Asistieron numerosos corresponsales españoles y extranjeros ${ }^{763}$, y de nuevo la noticia volvió a tener eco internacional, para desgracia de los pregoneros de la apertura del sistema. Areal fue condenado -en su condición de alférez de complemento- a seis meses y un día de prisión militar, por delito de injurias al Ejército,

otras razones porque no creo que haya metido la pata. La pata la ha metido el capitán general, ya que yo soy un periodista español que puede opinar sobre la conveniencia o no del tiempo que se ha de dedicar a hacer el servicio militar y que lo mismo que yo digo, lo han dicho también muchos militares y por escrito, y yo he aportado ejemplos en mis escritos al Juzgado Militar.

"Fraga se impacienta. vuelve a decirme que, pues he metido la pata, la responsabilidad es mía.

"-Por supuesto, siempre lo ha sido -le contesto-, nunca he hurtado las espaldas, nunca me he ocultado, siempre he dado la cara. Pero ustedes me han mandado tres expedientes a la vez, lo cual ha servido de argumento al capitán general para demostrar ante todo el mundo que soy un insensato y que el Ministerio de Información lo reconoce así. Además, ustedes me han dejado en la calle, suspendiéndome en funciones de director -sanción que no aparece en la ley de Prensa, por cierto- y ahora todavía me amenaza usted.

"-Veo que usted no agradece lo que se está haciendo por usted, termina Fraga y, sin más, abre la puerta de su despacho, llama a González Seara, su secretario particular; y me echa a cajas destempladas.

"-Buenas noches, dice.

"-Buenas noches, digo.

"Y me voy."

Relato autobiográfico, págs. 195-196.

${ }^{763}$ Areal cita entre otros a los siguientes: "Se han desplazado desde Madrid, el director de la U.P.I. (Carlos Mendo), Moya (redactor jefe de la Associated Press, porque su jefe estaba en Lisboa), Buckley, director de Reuter; Novais, corresponsal de Le Monde; Görtz, de Die Welt,y otros que no recuerdo como se llaman. También Cebrián [José Luis]; Luis Ignacio Seco, director de La Actualidad Española; Mauro Muñiz, redactor jefe de esta revista; Antonio Herrero Losada, director de Europa Press; Morán, de la misma Agencia; Zuloaga, etc. Están también algunos colegas locales, como Miguel Delibes, director de $E l$ Norte de Castilla; el gerente del periódico, Altés; Félix Antonio González, subdirector; Tomás Santos, redactor jefe de Diario Regional, redactores de los tres periódicos y de las dos emisoras. Hay también ya bastante gente. casi todos amigos míos $y$ muchos desconocidos." Relato autobiográfico, pág. 221. 
pero el Tribunal añadía a la sentencia una propuesta de indulto ${ }^{764}$.

El conocimiento de la sentencia reavivó el descontento entre los periodistas, que confiaban en que el director de Diario Regional fuera absuelto. Los españoles presentes -los corresponsales extranjeros no lo hicieron por temor a posibles represalias- dirigieron mensajes de protesta al presidente de la Federación Nacional de Asociaciones de la Prensa -Pedro Gómez Aparicio-, y a autoridades del Ministerio, recriminándoles la pasividad con que se habían conducido ante el desarrollo de los acontecimientos. Gómez Aparicio contestó a los redactores de la nota negando que su actitud hubiera sido pasiva y

764 "FALLAMOS que debemos condenar y condenamos al procesado Alférez de Complemento de Infantería en situación de disponible DON MANUEL FERNANDEZ AREAL como autor de un delito de injurias al ejército a la pena de SEIS MESES Y UN DIA DE PRISION COn las accesorias de suspensión de empleo y suspensión de todo cargo público, profesión, oficio, y derecho de sufragio durante el tempo que dure la condena, así como al comiso de los ocho ejemplares del DIARIO REGIONAL que han quedado en poder de la Empresa y del original (...).

"OTROSI DECIMOS: Que el Tribunal estima que atendidas las circunstancias personales del culpable, en particular el largo tiempo que lleva alejado del servicio activo, el desconocimiento de problemas técnicos complejos que no es de extrañar en quien no es oficial profesional, las premiosas (sic) condiciones de trabajo en que se elabora un periódico e inducen al empleo irreflexivo en muchas ocasiones de estos medios efímeros de difusión, su anterior labor periodística de realce de las virtudes militares premiada con uno de los máximos galardones, el que la motivación peca más de ligereza que de mala fe, concurriendo posiblemente una concepción equivocada de la misión del Ejército y en general de las fuerzas armadas, parece que la aplicación rigurosa de la ley conduce en el presente caso a una pena notablemente excesiva, cuya única corrección se encuentra en la vía de gracia, por lo que acaso fuera pertinente, y así se manifiesta respetuosamente en este lugar, que la Autoridad Judicial Militar en uso de las facultades que le concede el artículo 183 del vigente Código de justicia Militar interesara del Gobierno la condonación total o parcial de la pena impuesta."

Sentencia del Consejo de Guerra, A.P.M.F.A.. 
haciendo notar una vez más, en la misma línea que el Ministerio, que el responsable de todo lo ocurrido no era otro que el propio Areal765.

Un mes después de dictada la sentencia el Ministerio repuso a Areal como director de Diario Regional, y una semana más tarde llegó el indulto ${ }^{766}$. Se ponía fin así a un capítulo pintoresco de la historia del periódico, de tintes anacrónicos ${ }^{767}$, que, como dijimos, resulta aleccionador por lo que hace a qué cambiaba y qué seguía igual en la España de Franco. Si se compara el caso de Areal con la destitución fallida de Martín Abril y la efectiva de Cebrián, parece claro que se debe concluir que los comportamientos radicales en el control de los medios ya no eran posibles sin que generaran un revuelo indeseable en la opinión pública, especialmente en la internacional. Esto, que era consecuencia lógica de la progresiva integración mundial que se iba logrando merced

${ }^{765} \mathrm{La}$ carta se conserva en A.P.M.F.A.. Se conservan también las contestaciones a esa carta de varios de los firmantes, entre otros José Luis Cebrián Boné y Miguel Delibes.

766oficio del delgado provincial del Ministerio de Información transcribiendo un telegrama del director general de Prensa, de fecha 8/3/1965. A.P.M.F.A.. El indulto le fue comunicado el 16 de marzo de 1965, si bien los problemas con la jurisdicción militar no terminaron ahí: el capitán general estimaba que el indulto no afectaba a las penas accesorias, que sí debía cumplir Areal, asunto que traerá consecuencias menores más adelante.

${ }^{767}$ Un comentarista extranjero calificaba el caso de "el más estúpido" producido últimamente en España, y concluía su información y comentario diciendo: "Si los jueces militares hubieran sido agentes provocadores al servicio del antifranquismo, no lo hubieran hecho mejor". Louis CHEVROT, en Europe Magazine, no 1029, 24 de febrero-2 de marzo de 1965. El recorte se conserva en A.P.M.F.A.. 
a las mejoras técnicas, no podía dejar de afectar a España, y menos cuando se estaba siguiendo una política de progresiva trasparencia y de salida del aislamiento. Otra conclusión, no menos importante que la anterior, es la constatación de que la fuerza de la sociedad civil iba creciendo en detrimento de la eficacia de los modos autoritarios de las jerarquías políticas -no se puede decir lo mismo de las militares, al menos de todas ellas-, que de esta forma se iban haciendo cada vez más residuales. La transición del autoritarismo a la democracia, por la vía de hecho, y en el terreno social antes que en el político, se estaba generando ya. No podía ser de otra forma en un país que estaba en pleno desarrollo económico, y esto siguiendo no los principios ideológicos inspiradores del régimen, sino la más pura ortodoxia liberal al uso768.

Ahora bien, cosa distinta es cómo vieran cada uno de los actores el desarrollo de los acontecimientos. Para la mayor parte de los protagonistas de esa transición de hecho, detrás de estas cuestiones no se escondía una voluntad de reforma política bien determinada, al contrario, parece evidente, que, como se ha puesto de relieve por autores de muy diversa orientación, la tónica

${ }^{768}$ Cfr. MOYA, Carlos, Señas de Leviatán. Estado nacional y sociedad industrial: España 1936-1980, Alianza Editorial, Madrid, 1984, págs. 123-134. Del mismo autor, El poder económico en España (1939-1970). Un análisis sociológico, Tucar, Madrid, 1975, págs. 119-142. FUSI AIZPURÚA, Juan Pablo, Franco..., págs. 144-149. Payne El régimen..., págs. 484 y $\mathrm{ss}$. 
general era de apatía política769; pero no, como se puede ver en los hechos que hemos relatado, de apatía profesional. Y en ese sentido es en el que nos parece primordial resaltar el avance de la sociedad civil y de su autonomía como factor fundamental de los cambios que se estaban produciendo.

Por lo que se refiere a los personajes contrarios al cambio, los "franquistas de oficio" si se nos permite la expresión, quizá valga la pena destacar la reacción del único personaje que había tenido parte en las destituciones de los tres directores del periódico: el delegado provincial del Ministerio de Información, Antolín de Santiago. El funcionario demostraba una notable capacidad para navegar en todas las aguas. Al mes siguiente de producirse la detención de Areal, su informe sobre las relaciones entre la Delegación Provincial y Diario Regional era el siguiente:

"Normales, después de ser puestas a prueba por la
publicación del artículo que motivó la dentención y
procesamiento por la jurisdicción militar de su director don
Manuel Fernández Areal, separado de sus funciones en tanto se
le incoa el oportuno expediente." 770

${ }^{769}$ Cfr. FUSI AIZPURÚA, Juan Pablo, Franco..., págs. 172-176. LóPEz PINA, Antonio y ARANGUREN, Eduardo L., La cultura política de la España de Franco, Taurus, Madrid, 1986, especialmente el capítulo 4ㅇ, págs. 6375 .

770 parte mensual de prensa correspondiente al mes de noviembre de 1964, fechado el 5/121964. A.G.A., Sección Cultura, caja 17.953. 
Si páginas atrás hemos destacado la importancia de la pasividad general para que fueran posibles comportamientos políticos que violaban derechos fundamentales, ahora hay que hacer notar el papel que desempeñan estos cuadros políticos intermedios en el mantenimiento de una situación política que tiende a la petrificación. No es pequeña la importancia de estos hombres, que ayudan a hacer realidad el "nunca pasa nada» que tan útil era para conferir estabilidad al régimen. Probablemente Santiago Juárez decía a Madrid lo que Madrid quería oír, y quizás es también ese el motivo de su prolongada permanencia en el cargo, ya que en buena medida conseguía con su comportamiento hacer "normales" todos los acontecimientos, fueran éstos los que fueren. En ese sentido el régimen tenía en él un excelente servidor.

Ahora bien, el que ahora otros protagonistas o espectadores de esos mismos hechos se negaran a considerarlos como normales, era un índice claro de desgaste y descomposición del sistema vigente. El comportamiento de algunos profesionales de la prensa que describimos más arriba parece confirmar nuestra afirmación, y, más todavía, el de Areal a su vuelta al periódico. Poco después de reintegrarse a la dirección aparecía un artículo suyo en defensa de la libertad de expresión, convenientemente camuflado de comentario 
internacional771; en junio la censura previa tenía que suprimir algunas frases de otro artículo suyo sobre el sentido de la justicia772; y las campañas de denuncias o los artículos conflictivos no disminuyeron en el periódico, que siguió manteniendo su línea beligerante. En definitiva, Areal no sólo no se arredró, sino que consolidó con motivo de estos incidentes su postura de defensa de la libertad de expresión, como quedará claro en los libros que publicará años más tarde, y que en parte son fruto de sus experiencias vallisoletanas.

No obstante, al menos en una sociología de provincias, todavía tenía fuerza proscriptiva el choque con las autoridades del régimen. Areal se sentía cada vez más incómodo en una ciudad en la que algunos evitaban su trato con más o menos disimulo, la convivencia con las autoridades militares se hacía poco menos que imposible, y todos lo miraban a través del prisma de su procesamiento. Al menos subjetivamente así lo percibió él, y ese fue el motivo que le llevó a dejar la ciudad del Pisuerga y a buscar en Madrid otros horizontes profesionales ${ }^{773}$.

\footnotetext{
771 «Sin esconder la mano. El Sha dice la verdad», DR, 13/4/1965, pág. 1 .

772 "Le fueron suprimidos en el artículo "Sentido de la justicia" de la sección "sin esconder la mano", firmado por M.F.A. unos párrafos por improcedentes (día 26)." "Igualmente, en una entrevista con el representante italiano en la Asamblea Nacional Belenista, se suprimieron unas líneas en que se afirmaba la falta de ayudas oficiales al belenismo en España." 5/7/ A.G.A., Sección Cultura, caja. 19.837.

${ }^{773}$ Relato autobiográfico, págs. 316 y 325.
} 


\section{Un trabajador de la prensa}

El domingo 31 de octubre de 1965, Diario Regional daba la noticia del cambio de director ${ }^{774}$. Manuel Fernández Areal pasaba el relevo a José Tallón García, un andaluz de 37 años que había trabajado como gerente de "Diario Regional, S.A." años atrás775. Su historial profesional había comenzado lejos del periodismo: en 1953 era factor de ferrocarriles. Una vida de intenso trabajo, al que supo unir una mejora continua de su cultura profesional, le había llevado a realizar los estudios de Magisterio, Derecho, Económicas, y Periodismo, al tiempo que trabajaba ya en empresas de prensa. Después de regentar la administración de "Gráficas Andrés Martín, S.A.", en Valladolid, desde 1957 a 1960, se encargó de la gerencia de Diario Regional entre 1960 y 1962. Se trasladó luego a Madrid donde ocupó el cargo de subdirector de Publicidad de S.A.R.P.E.. Más tarde dirigió el departamento de distribución y promoción de la misma cadena, hasta que en 1965 pasó a trabajar como redactor de los servicios informativos de TVE. Ese mismo año regresó a Valladolid para dirigir Diario Regional. Su posterior evolución profesional es también significativa: en 1967

\footnotetext{
774 «Nuevo director de DIARIO REGIONAL», DR, 31/10/1965, pág. 1.

${ }^{775}$ El alta de Tallón como gerente tiene fecha oficial de 28/11/1960, y su baja y el alta de su sucesor -José Ramón Abril Martín - de 7/4/1962, según consta en las comunicaciones al Registro de Empresas Periodísticas efectuadas por la empresa. A.G.A., Sección Cultura, caja 82.671 .
} 
dejó la dirección del periódico para ocuparse de la de una Escuela de Turismo y la del Instituto Castellano de Nuevas Profesiones (I.N.C.A.), iniciativas docentes con sede en Valladolid, y posteriormente marchó a trabajar en la Universidad de Navarra. Allí comenzó su carrera universitaria, al lado de Nieto Tamargo. Se doctoró en Derecho, y se trasladó más adelante a Madrid, donde ganó en 1982 la cátedra de Empresa Informativa en la Universidad Complutense. Al mismo tiempo se especializó en cuestiones relativas al marketing y la publicidad, fue gerente de "Ediciones Universidad de Navarra" (1968-73), y director de la "Editorial de la Universidad Complutense de Madrid" (1984-86). Lo expresivo de su trayectoria vital hace superfluo cualquier comentario: Tallón se puede definir como un trabajador paciente y tenaz del periodismo, y así lo percibían ya los que colaboraron con él en los dos años que estuvo al frente del Diario Regional 776 .

Por lo que se refiere a las novedades que trajo al periódico, y atendiendo en primer lugar a las formales, Tallón prestó atención al diseño, acentuando la carga

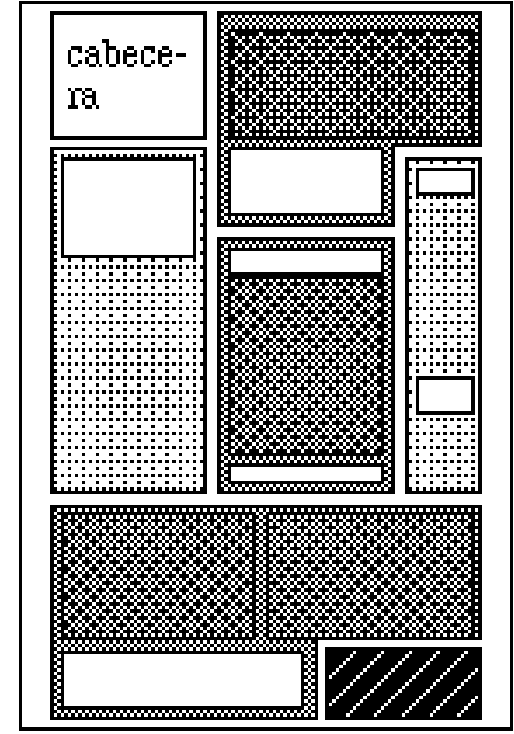

Publicidad Fotograrias $\square$ Titulares, cabecerss y pies de foto

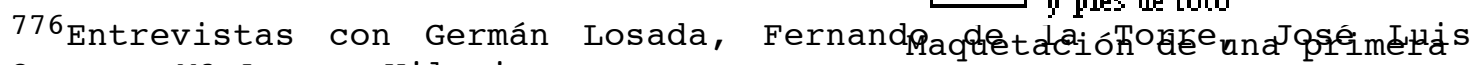
Orosa y Ma Aurora Viloria. página de Diario Regional en 1966. 
gráfica de las informaciones -especialmente en la primera página-; concediendo mayor importancia a las horizontales en la maquetación -lo que hizo más fácilmente legibles las páginas del Diario-; y enriqueciendo las secciones diarias con otras semanales especialmente cuidadas, entre las que destacan los suplementos o secciones dominicales ${ }^{777}$. La cabecera cambió también de diseño en 1966: se redujo su tamaño, cambiaron los tipos, y pasó a publicarse en blanco sobre fondo rojo. Aparecieron nuevas manchetas para las secciones recién creadas o tradicionales, y se elaboraron páginas casi exclusivamente gráficas los domingos, que se publicaban con el significativo título de "Chismorama". En resumen, el diseño se agilizó, en consonancia con los nuevos vientos que soplaban ya en los medios escritos.

Por otro lado, el periódico consiguió en estos años una mayor homogeneidad en la calidad de sus secciones: una lógica consecuencia de la maduración de los redactores que se habían ido formando con Areal, y de la incorporación a la plantilla de otros nuevos -a los que Tallón prestaba una atención preferente-, que tenían un horizonte profesional centrado ya de forma casi exclusiva en el

${ }^{777}$ Al "Extra de Diario Regional» que se publicaba se añadieron a fines de 1966 dos nuevos suplementos tras la preceptiva autorización del Ministerio de Información: "Chío" y "Agenda Femenina". Cfr. A.G.A., Sección Cultura, caja 24.003.

Puede verse una descripción detallada de la estructura informativa del periódico en estos años en el apéndice 2 . 
periodismo778. Puede decirse que los años sesenta fueron también los años de la definitiva profesionalización de la prensa de provincias en nuestro país: el pluriempleo en trabajos distintos del periodismo irá siendo cada vez más raro, y su formación se irá haciendo cada vez más específica, al menos en la vertiente que podríamos llamar técnica. Como consecuencia, se observa una consolidación de las mejoras que en la elaboración de entrevistas y reportajes se venía apuntando desde años antes, y un mayor equilibrio en la calidad de las informaciones. Esto es también resultado de la acentuación del carácter informativo de los contenidos publicados, denominador común de los años que analizamos en el presente capítulo. Inevitablemente, esa tendencia informativa hace también que buena parte del periódico sea fruto de informaciones de agencia, cuyo número -y calidad- también se incrementó.

Continuaba siendo cuidada la información sobre los pueblos de la provincia, y la regional se concentraba casi

\footnotetext{
${ }^{778}$ Entre otros hay que citar a Mạ Aurora Viloria, José Luis Orosa, José Antonio Antón, Juan Holgado y Germán Losada. Entrevista con José Tallón. Sólo uno de ellos -José Antonio Antón- figuraba en la plantilla oficial del periódico, como auxiliar de redacción. El resto realizaban algo parecido a las actuales prácticas, de forma extraoficial, y se irán incorporando a la redacción cuando obtengan los títulos correspondientes. La plantilla oficial era la siguiente: José Tallón García, director; Tomás Santos Corchero, redactor jefe; Leandro Pérez Gómez, redactor; Miguel Montalvo Jambrina, redactor; Francisco Javier Martín Abril, redactor; José Luis Pérez Herrero, redactor; Félix González Ferrández, redactor; Fernando de la Torre de la Orden, redactor; José de la Fuente Mendive, redactor; José Antonio Antón Reglero, auxiliar de redacción. "Relación nominal de todos los que tienen un puesto fijo o trabajo eventual en las redacciones de los periódicos diarios y Hoja del Lunes de esta provincian, A.G.A., Sección Cultura, caja 23.061.
} 
siempre en un día a la semana. Se amplió y mejoró la nacional, y la internacional; se editaron con frecuencia, aprovechando motivos muy diversos, números especiales; aparecieron 0 se consolidaron secciones dedicadas a los jóvenes, el mundo universitario, los niños, la mujer, etc.; y aumentó el número de colaboradores, hasta llegar a publicarse secciones que estaban íntegramente redactadas por éstos bajo la dirección de algún coordinador que era también colaborador del periódico779.

A todo esto -que tenía frecuentemente por objeto ganar nuevos lectores- deben sumarse iniciativas de tipo empresarial en el mismo sentido: anuncios por palabras gratuitos para los suscriptores, concursos, promociones especiales en la publicidad, etc.. No podía ser de otra forma en quien había sido gerente antes que director. Los logros, no obstante, fueron siempre concretos y modestos. El periódico permanecía, en medio de dificultades, en la misma tónica económica de años anteriores, es decir, sobrevivía780.

Por contraste con Areal, Tallón no demostraba gran interés por definir sus opiniones. Fueron raros los artículos firmados por él mismo, y sólo se cultivaron los

\footnotetext{
779 Este era el caso de la sección "Estar al día" que abordaba temas de interés religioso, de la "Academia de Papel", cuya publicación coordinada por el profesor Alfonso Candau, catedrático de Historia de la Filosofía, la "Tertulia Literaria", "Club Juvenil", etc.

${ }^{780}$ Entrevista con José Tallón.
} 
editoriales de forma más frecuente a partir de septiembre de 1966. Con motivo de ese cambio se publicaron algunos fondos en los que Tallón puso de manifiesto cuál era su punto de vista sobre la opinión en el periódico. En uno de ellos, que tenía tintes de declaración programática, escribía:

\begin{abstract}
"Nos gusta -somos partidarios- la libertad responsable; nos enamora la verdad dicha con caridad. Las opiniones interesadas, las mentiras ocultas no nos van: sin claridad y sin verdad la libertad es metáfora en manos de unos cuantos. "Procuraremos decir lo que pensamos, poner en letras de molde nuestra opinión. Sin dogmatismos ni magisterios aparentes. Se nos podrá criticar porque no "poseemos" el don de la infalibilidad. Pero no podrán buscar, quienes así lo pretendan, intenciones ocultas o intereses recónditos. Cuando tengamos que decir algo, lo diremos, sin tapujos y con respeto para las personas y las instituciones. Sin dejar de hablar por miedo al qué dirán, o al diálogo.

"No queremos formar grupo o partido alguno. Y como esto es negativo, lo expresaremos en forma positiva: todo lo noble y humano tiene cabida entre nosotros. Las aspiraciones dignas por mejorar el nivel de vida, el deseo humano de una patria mejor, la defensa plausible de una mayor libertad, la verdad donde quiera que se halle..., todo cabe mientras sea claro y limpio." 781
\end{abstract}

En resumen, si bien veía conveniente que se virtieran en las páginas de Diario Regional opiniones de muy distinto signo, y apostaba claramente por la transparencia informativa, entendía que debía evitarse que el periódico mismo opinara. Un programa ideal, y difícil de mantener, que si bien se cumplió en su primera parte -se demostró incisividad en la información, y la sección de opinión llegó a ocupar dos páginas-, al intentar cumplirse en la segunda, contribuyó a desdibujar el perfil ideológico del rotativo. Y esto, en los años de liberalización de la 
prensa, merced a la promulgación de la ley de 1966, significaba correr el peligro de hacer un periodismo invertebrado.

Tratar de opinar "sin formar grupo o partido alguno" es -en la práctica- tarea poco menos que imposible. Se apuntaba aquí un problema de nada fácil solución que se iba a plantear cada vez con más intensidad a los periódicos españoles en esos años de transición: partiendo de un ambiente de general despolitización, se entraba en otro en el que ésta se iba intensificando, especialmente en algunos sectores de la sociedad -en primer lugar los más cultivados-, entre los que cabe contar a buena parte de los lectores habituales de periódicos. Todo esto acontecía, además, en un país en el que no existían grupos políticos bien definidos, $y$ en el que la libertad de prensa -si bien era todavía precaria- era ya mayor que las libertades políticas propiamente dichas. No resulta, pues, extraño que se tendiera a sobrecargar la función política de la prensa: se trataba de llenar a través de los medios el vacío institucional para el debate de las cuestiones públicas. Pero esa solución de compromiso -o de urgencia, si se prefiere- significaba también correr un claro riesgo de inflación política en las páginas de diarios y revistas, que se veían empujadas a realizar una tarea que normalmente -al menos en las sociedades de tradición democrática- no les corresponde. 
La dificultad para adoptar una orientación definida en este terreno $y$ en aquellos momentos, resulta clara. Probablemente, la intención de Tallón era evitar esa definición mientras fuera posible, seguramente porque ni él mismo ni la empresa tenían nada claro cuál debiera ser ésta, y -por otro lado- tampoco tenía intención de imponer ninguna al resto de su equipo. Eso era lo que escribía unos meses más tarde:

\begin{abstract}
"Diario Regional sólo conoce una verdad política: la libre y responsable opinión de cada uno, con respeto para todas las opiniones, sin dogmatismos impropios de quien vive comunitariamente. Personalmente, quienes hacemos el periódico tenemos convicciones políticas; colectivamente ninguna, porque así lo hemos querido y así lo queremos. Estamos con todos los hombres dignos y nobles, con todos los hombres." ${ }^{782}$
\end{abstract}

Ahora bien, esa postura no parece posible mantenerla desde un periódico sin atentar directamente contra su influencia en la opinión. Por definición, un diario está con sus lectores -o viceversa-, por más que procure ser lo suficientemente amplio -o ambiguo- para ampliar cuanto pueda el número de éstos. La solución que buscaba Tallón chocaba con las aristas del anguloso problema de la prensa de masas y la prensa de opinión, sin que consiguiera resolver el dilema. En todo caso, se intentaba soslayarlo a base de reproducir frecuentemente fondos publicados en otros medios, y aumentando el número de colaboradores ${ }^{783}$.

\footnotetext{
782 "Libres y responsables», editorial, 11/12/1966, pág. 13.

${ }^{783}$ Entre otros se pueden citar Pueblo, Al día, Informaciones, Telva, Cuadernos para el diálogo, Ya, Madrid, El pensamiento Navarro, Diario de Barcelona, La Actualidad Española, El Alcázar, El Heraldo de México, etc.
} 
Da la impresión de que Tallón trasladaba aquí algunos modos de hacer que son característicos del Opus Dei. En efecto, no es difícil encontrar textos en los que se dicen cosas parecidas a las que Tallón consignaba en los editoriales que acabamos de citar, pero para referirse a la libertad y el pluralismo de los miembros de la Obra en cuestiones opinables ${ }^{784}$. Esta hipótesis parece confirmarse a la luz de lo que se escribía en otro editorial publicado con motivo del fin de año:

"No pensamos hacer balance. Pero el motivo más poderoso para no hacerlo hay que buscarlo en la propia línea directriz del periódico. Cuando se busca la verdad sin paliativos, cuando el trabajo va dirigido a fomentar todo lo que merezca el calificativo de humano, nunca se mira atrás, la mirada se dirige recta y limpia hacia el año que abre sus puertas. Un año más, un tiempo inmejorable para meterse de rondón en la vida de todos y entre todos construir un mañana más claro, más humano, más nuestro.

"Y por ser nuestro, más cristiano. Un mañana en donde la justicia asiente sus reales, en donde la libertad impere por doquier. Justicia, verdad, libertad, son condiciones imprescindibles para la vida comunitaria, para la comprensión, para esa vida vivida por todos y cada uno, para el ser humano singular y para la humanidad por entero. Sí, un año más para poner todos todo el esfuerzo, todo el afán, toda la ilusión.

784 "Una de las características del espíritu del Opus Dei, a menudo puesto de relieve por sus portavoces y con mayor insistencia aún por el Fundador, es el amor a la libertad. Un amor íntimamente conectado con la mentalidad secular propia del opus Dei, la cual hace que, en todas las cuestiones profesionales, sociales, políticas, etc., cada miembro actúe libremente en el mundo, con arreglo a lo que le dicte su conciencia, rectamente formada, y asumiendo plenamente las consecuencias de sus actos y de sus decisiones. Eso les lleva no sólo a respetar, sino también a amar, de manera positiva y práctica, el auténtico pluralismo, la variedad de todo lo que es humano; así hacen realidad lo que la Declaración de la Sagrada Congregación para los Obispos de 23 de agosto de 1982 decía con motivo de la erección del Opus Dei como Prelatura personal: "Por lo que se refiere a sus opciones en materia profesional, social, política, etc., los fieles laicos que pertenecen a la prelatura -dentro de los límites de la disciplina de la Iglesia- gozan de la misma libertad que los demás católicos, conciudadanos suyos; por tanto, la Prelatura no hace suyas las actividades profesionales, sociales, políticas, económicas, etc., de ninguno de sus miembros"." LE TOURNEAU, Dominique, El Opus Dei, Oikos Tau, Barcelona, 1986, págs. 43-44. 
Sin egoismo, sin inhibiciones, con la conciencia limpia porque no hay nada escondido que ocultar." 785

Ciertamente, es de notar el acento puesto sobre la necesidad de la libertad para hacer un mundo "más humano y más cristiano", algo que no había sido frecuente en los medios católicos españoles. Pero esta traslación de los criterios sobre el ejercicio del pluralismo entre los católicos a un medio de prensa, si ya no confesional, sí de inspiración cristiana, parece cuando menos forzada, y desde luego, poco apta para un periódico. Un diario -se quiera o no, y normalmente se quiere- con su modo de enfocar las informaciones $y$ de comentarlas, si no crea opinión, al menos ayuda a a crearla o a reafirmar la que ya tienen sus lectores ${ }^{786}$. Tratar de evitar ese efecto no deja de ser un empeño paradójico.

Hasta aquí lo que se refiere a los propósitos. En la práctica, los editoriales publicados comentaban aspectos muy variados, y con frecuencia en tono de denuncia o reivindicativo, sin abandonar la línea de moderación que se había anunciado como norma. En el primer mes de esta

785 «Un año más» editorial, 31/12/1966, pág. 13.

786 "Lo que importa señalar, en la situación en que estamos, es que la prensa, lejos de no ser nada más que un soporte para opiniones, que existirían fuera de ella, contribuye a cristalizarlas, por lo menos tanto como las expresa. No solamente porque aporta un cierto esclarecimiento a los hechos sobre los cuales la opinión se funda o cree fundarse. Sino también porque las reacciones individuales, que son frecuentemente indecisas $y$ aleatorias, tienen tendencia a modelarse sobre las de los grupos de los que la prensa es, desde ahora, si no el único, por lo menos el principal vehículo." VoyenNe, B, La prensa..., pág. 28 . 
nueva etapa, por ejemplo, se abordaron en esta sección entre otras- cuestiones como la necesidad de aumentar la cuantía del salario mínimo787; lo improcedente de una iniciativa que se presentaba como renovadora de la Iglesia y se colocaba enfrente de la jerarquía788; la necesidad de modificar la legislación sobre la asociación obrera hasta alcanzar la libertad sindical789; O la conveniencia de conceder autonomía a las universidades ${ }^{790}$. En síntesis: moderación, reclamaciones puntuales, defensa de las libertades y de la ortodoxia católica, y ausencia de campañas que pudieran definir un programa político o esbozo del mismo. Ese podría ser el retrato robot de la opinión oficial de Diario Regional con José Tallón.

Para completar esta primera aproximación viene bien referirse a la actitud adoptada por Diario Regional ante la promulgación de la nueva ley de prensa. En este sentido Tallón continuaba claramente la línea marcada por sus inmediatos predecesores en la dirección: la libertad de prensa se consideraba un bien que había que defender decididamente, también desde las páginas del periódico, para poder cumplir con dignidad las tareas informativas, ya que el pluralismo, como se desprende de los textos que

\footnotetext{
787 "Salario mínimo», 14/9/1966, pág. 13.

788 "Conspiradores en "acción"», 25/9/1966, pág. 13.

789 "Libertad de elección", 28/9/1966, pág. 13.

790 "Universidad», 12/10/1966, pág. 13.
} 
hemos reproducido, se entendía como un presupuesto inexcusable para el adecuado desarrollo de la sociedad. La mayor parte de los artículos referidos a esta cuestión -lo mismo que ocurre con muchas otras- están redactados por colaboradores o tomados de otras publicaciones, con lo que vale resumirlos diciendo que se aplaudió el fin de la ley de 1938, y se miró con prevención y desconfianza al famoso artículo 20791. De entre los editoriales del propio periódico, puede destacarse uno en que se iba algo más allá, advirtiendo del peligro de hecho que suponían ciertas actitudes de dominio social incondicionado:

\begin{abstract}
"Desaparecida la censura previa, hace falta que desaparezca ahora otro tipo de "consulta previa" al que no se presta demasiada atención. Son los que se creen, por ocupar un prominente puesto de la sociedad, dueños y señores de haciendas propias y ajenas. Son los que aconsejan casi sin concederle importancia, no hablar de determinado asunto, cuando intuyen que hurgar en dicho asunto puede dejar al descubierto su "desinteresada" intervención. Son esos buenos señores, muchas veces escondidos cerebros de segunda fila, con cuya "benévola autorización" hay que contar para poder informar al público de lo que ellos están fraguando. "Urge, pues, que de ahora en adelante la prensa se vea libre de trabas, ya no de tipo administrativo para las que existe un cauce legal, sino de esas otras que provienen de ciertos personajes que se sienten el ombligo del mundo.
\end{abstract}

${ }^{791}$ Cfr. por ejemplo "La ley de prensa" tomado de La Actualidad Española: DR, 15/4/1966, pág. 3. Conviene recordar no obstante, que desde el Ministerio se prohibió a los periódicos el comentario de la ley durante algún tiempo. En A.P.M.F.A. se conserva la transcripción de una consigna recibida por teléfono en el periódico, que dice:

"Consigna. D.G.P.

"Comentarios sobre el proyecto de ley de Prensa que constituyan crítica negativa, deben ser consultados con la Delegación antes de ser publicados. "Martes 19 octubre 1965. 11.30 de la noche."

Esto es en parte la causa de la ausencia de comentarios, y del recurso a comentarios ajenos ya publicados, $y$ por consiguiente autorizados. En ese mismo caso se encontraba El Norte de Castilla según relata SÁNCHEZ SÁNCHEZ. Op. cit., pág. 239. 
"De esta forma, esta prensa nuestra que cada día se afirma más vigorosa, tendrá amplio y despejado el campo en el que cumplir su importante y noble misión informativa." 792

Efectivamente, no se eludieron las referencias a temas conflictivos cuando se consideró necesario. A pesar de las consignas recibidas sobre el tratamiento que debía dispensarse a las informaciones sobre incidentes en la Universidad793, el periódico se ocupó de estas cuestiones con frecuencia -en un tono que no era usual en otros diarios ${ }^{794}-$, y en general, como es común a casi toda la prensa española de esos años, se hizo eco de conflictos de diversa índole que acababan con la imagen del "país en que nunca pasa nada». Ahora bien, en opinión del delegado

792 «La libertad de una nueva ley», editorial, 23/3/1966, pág. 3.

793Entre otras consta el envío de las siguientes consignas sobre este asunto: "Sobre informaciones relativas a incidentes estudiantiles, en este $O$ en otros Distritos, 2 de marzo."parte mensual de prensa correspondiente al mes de marzo de 1965, de fecha 5/4/1965, A.G.A., Sección Cultura, caja 19.543. "Sobre comentarios a los problemas universitarios 8-10-1965.", parte mensual de prensa correspondiente al mes de octubre de 1965, fechado el 8/11/1965, ibid., caja 21.197. "Que no se autorice [publicar] más que lo que facilite la propia Universidad sobre elecciones de estudiantes 11-11-1965", parte mensual de prensa correspondiente al mes de noviembre de 1965, fechado el 4/12/1965, ibid., caja 21.211 .

${ }^{794} \mathrm{En}$ un informe oficial se señalaba: "Ha venido publicando las informaciones sobre los incidentes estudiantiles y la cuestión universitaria en primera plana, titulando a dos, tres y hasta cuatro columnas, aunque ajustándose a las instrucciones transmitidas por el boletín Informativo de Prensa." parte mensual de prensa correspondiente al mes de marzo de 1965, de fecha 5/4/1965, A.G.A., Sección Cultura, caja 19.543.

Cfr. por ejemplo "Disturbios estudiantiles en la Universidad de Madrid", titular que se publicó en grandes tipos a tres columnas, en DR, 16/12/1965, pág. 5. El análisis comparado con otros medios se refiere sobre todo al diario del Movimiento Libertad, estudiado para esta misma etapa por el profesor Ricardo M. Martín de la Guardia, a quien debemos en gran parte estas estimaciones comparativas. Puede verse también "Manifestación de sacerdotes catalanes disuelta por la policía", DR, 12/5/1966, pág. 11, y algunos editoriales publicados en enero de 1966 en los que se pedía que se prestara atención a las opiniones de los jóvenes. 
provincial del Ministerio de Información, Diario Regional se destacaba por la atención prestada a los conflictos laborales, hecho que Antolín de Santiago ponía en relación con que el periódico estuviera abonado a los servicios de la agencia "Europa Press"795.

De otra parte, continuando una línea ya tradicional siguió interesándose por los problemas de la agricultura castellana, y publicando opiniones de diferentes instancias sobre las posibles soluciones que cabía adoptar, etc. ${ }^{796}$ Para abordar esos problemas se acudió con frecuencia a la encuesta, entendida no en en un sentido técnico-estadístico, sino simplemente como recogida y publicación de opiniones de distintas personas interesadas en el asunto del que se tratara. De algunas sabemos que tuvieron un eco notable, como fue el caso de la que se ocupaba del problema de la emigración; y de todas podemos decir que traslucían una creciente movilización de la

795 "Abonado este periódico a la agencia Europa Press, viene publicando informaciones $y$ noticias que no suelen aparecer en los servicios repartidos por otras agencias informativas, $y$ especialmente sobre problemas, conflictos y reclamaciones laborales.". Informe semanal de prensa de fecha 19/10/1966, A.G.A., Sección Cultura, caja 23.624.

${ }^{796}$ Cfr. por ejemplo las numerosas informaciones sobre el "Plan de tierra de campos" y la decepción ante cancelación de la visita de varios ministros a la zona que había sido anunciada, en octubre de 1965. El Norte de Castilla y Diario Regional publicaron varios suplementos extraordinarios dedicados a la cuestión y se hicieron eco de la decepción general. Informe reservado correspondiente al mes de octubre de 1965, fechado en noviembre de 1965, A.G.A. Sección Cultura, caja 35.178. Puede verse también la encuesta publicada entre el 26 de junio y el 2 de julio de 1966, con el título "¿Hasta cuando? El hombre huye del campo", y el informe correspondiente, en el Informe semanal de prensa fechado el 7/7/1966, en A.G.A., Sección Cultura, caja 23.061 . 
opinión pública, y una conciencia crecientemente crítica ante la actividad pública797.

Como consecuencia de la promulgación de la nueva ley, no hubo conflictos con las autoridades del Ministerio de Información, aunque sí un pequeño incidente con el poder judicial: el fiscal ordenó el secuestro del periódico con ocasión de la publicación de una información de agencia, en la que consideró que se contenían injurias a la autoridad, en este caso judicial798. En esa ausencia de

797 "Crónica regional. Resultado de una encuesta" "En cinco años han emigrado más de nueve mil personas de 80 municipios de la provincia. El hombre del campo pide: -industrias transformadoras de los productos agrícolas

"-Reforma de las estructuras agrarias

"-Mejora de los núcleos rurales

"-Ayuda para fomentar la ganadería

"-Precios más remuneradores." DR, 3/8/1966, pág. 4. La encuesta se publicó entre el 31 de julio y el 6 de agosto de 1966. En el Informe semanal de prensa enviado por la Delegación provincial a Madrid, de fecha 10/8/1966, se decía: "Esta encuesta ha sido muy leída y favorablemente comentada, siendo manifiestamente interesante y positiva". A.G.A., Sección Cultura, caja 23.061.

Pueden verse también: la dedicada a la gestión de los alcaldes de Valladolid, a los que se les preguntaba lo siguiente : "1.- Años de gestión 2.- ¿Con qué problemas se encontró al entrar en la alcaldía? 3.- ¿Resolvió todos? 4.- Si no fue así, ¿con qué obstáculos se encontró? 5.- ¿Cuál considera la realización más importante de su gestión? 6.- ¿Qué realizaciones le hubiera gustado acometer y no pudo?". DR, 20/3/1966, págs. 10-14. La dedicada a recoger opiniones sobre la prensa, titulada "Cuarto poder", publicada los días 6 y 7/5/1966, en las págs. 15 y 11, respectivamente. La realizada entre diversas autoridades provinciales sobre la Ley Orgánica del Estado, que también fue reseñada en el Informe semanal de prensa correspondiente, de fecha 7/12/1966. A.G.A., Sección Cultura, caja 24.003 .

${ }^{798} \mathrm{El}$ periódico fue secuestrado el 23 de octubre por la citada noticia, por orden del juez de instrucción no 1 de Valladolid. El proceso finalizó con la absolución de José Tallón. Cfr. parte diario del delegado provincial del Ministerio de Información al fiscal jefe, de fecha 12/12/1966, y comunicación del delegado provincial al director general de Prensa, de fecha 12/11/1966, A.G.A., Sección Cultura, caja 23.624; y DR 11/11/1966, pág. 9. Cfr. también A.H.P.U.V., Sección Cultura, caja 27. 
problemas influyeron no poco el carácter y la habilidad del propio Tallón, conciliador y afable, al tiempo que precavido; $y$ sus convicciones, que le impulsaban a subrayar todo lo que uniera, por encima de competencias profesionales o de cuestiones políticas. Causó sorpresa, por ejemplo, cuando publicó en primera página, con fotografía incluida, una felicitación a Miguel Delibes uno de los más cualificados directivos de "la competencia"- con motivo de habérsele concedido un premio literario799. De hecho, entre sus recuerdos se cuenta el cuidadoso examen de lo que se preparaba para publicar, para evitar problemas, ya que a pesar de la nueva ley continuaron llegando consignas al periódico, si bien ahora eran menos frecuentes, y -desde 1965- se daban por teléfono las más de las veces ${ }^{800}$.

En los sistemas de control se aprecian cambios con motivo de la entrada en vigor del nuevo marco legal. Continuaron los "Informes reservados", si bien ahora se hicieron menos regulares -el comportamiento de las distintas Delegaciones Provinciales no es homogéneo- y se complementaron con otros denominados "Informes de opinión pública». Éstos no tenían ya una periodicidad exacta: las Delegaciones enviaban uno -monográfico- cada vez que tenían lugar acontecimientos que en su opinión merecieran

${ }^{799}$ Entrevistas con Germán Losada y José Tallón.

${ }^{800}$ En A.P.M.F.A. se conservan transcripciones de un buen número de esas consignas telefónicas. 
ser conocidos en Madrid" ${ }^{801}$ Los detallados "Partes mensuales de prensal desaparecieron, $y$ en su lugar se redactaban ahora "Informes semanales", con un esquema menos rígido, en los que se resumían los contenidos más destacados de cada una de las publicaciones de la provincia802. Por último, aparecieron los "Informes diarios" de prensa, que la Delegación provincial hacía llegar al fiscal junto con un ejemplar de cada diario o revista en el momento de su publicación. Solían ser breves -no pasaban normalmente de un folio-, y eran un vaciado de la publicación en cuestión que atendía más que nada a la línea editorial y los comentarios ${ }^{803}$. La desaparición de la "consulta previa" y la "consulta delegada" no se hizo bruscamente: hubo un periodo de transición en que se sugería a los medios la práctica de la "consulta

${ }^{801}$ Cfr. por ejemplo el dedicado a la dimisión del alcalde de Valladolid, de fecha 16/6/1965, A.G.A., Sección Cultura, caja 35.178; el que se ocupó de informar sobre constitución del nuevo Ayuntamiento y asamblea plenaria de la cámara oficial sindical agraria, de fecha 11/2/1967; el que se ocupaba de la polémica suscitada en la ciudad en torno a las ayudas económicas a la Universidad de Navarra, de fecha 17/4/1967; el que comentaba las reacciones ante el aumento del precio del pan, de fecha 19/4/1967; el que daba cuenta de los preparativos de un homenaje a Miguel Hernández, de fecha 24/6/1967; el que relataba los principales contenidos, incidencias $y$ reacciones ante una conferencia de Ruiz Giménez en la "Sala de Cultura" de El Norte de Castilla, de fecha 3/6/1967; todos ellos en ibid, caja 39.345.

${ }^{802}$ Para el periodo de la dirección de Tallón y el final de la de Areal, pueden verse en ibid., las cajas no 23.061, 23.624, 24.003, y 25.246 .

${ }^{803}$ Para los correspondientes a esta etapa pueden verse las cajas de la Sección de Cultura de A.G.A. no 23.061, 24.003, y 25.246. El orden del archivo de la Delegación provincial de Valladolid es cronológico -o mejor, por número de registro- y no temático, como es el caso de otras Delegaciones, lo que hace que este tipo de partes se encuentre diseminado entre toda la documentación de la Delegación, de la que se enviaba copia periódicamente a Madrid. Se conservan también copias de estos partes en la Sección del mismo nombre de A.H.P.U.V.. 
voluntaria", procedimiento al que un año después de promulgada la ley sólo se había acogido uno de los diarios vallisoletanos $-E I$ Norte de Castilla- y en tan solo una ocasión804. Realmente, la fuerza de la costumbre, aquilatada por años de censura, había conseguido que los directores tuvieran bastante claro qué era lo que podía y lo que no podía decirse, $y$ en el ambiente estaba -y también en el artículo 2o- que la nueva ley no significaba que se pudiera hablar de todo de cualquier forma. El autocontrol era una lección bien aprendida después de años de estrecha vigilancia $y$ de ir $y$ venir de oficios admonitorios, consignas y expedientes.

Por último, $y$ en cuanto a relaciones con el Ministerio se refiere, hay que decir que Tallón rompió con la tradición en un sentido: a diferencia de los dos directores que le precedieron salió del periódico por voluntad propia. Antolín de Santiago pudo permitirse incluso porponerlo -junto a otros tres periodistas vallisoletanos- para ser condecorado con motivo del "Día de la Victoria" en 1968. El delegado cantaba las excelencias de cada uno de los que proponía en el informe que envió al director general de Prensa, y hacía un breve resumen de su historial profesional, resumen que nos pone frente a otro aspecto interesante de la historia de Diario Regional y del periodismo vallisoletano.

804 Oficio del delegado provincial al director general de Prensa, de fecha 21/4/1967, en A.G.A., Sección Cultura, caja 25.676. 
El primero de los propuestos era Félix Antonio González González. Había comenzado como colaborador de Diario Regional, del que fue después redactor jefe desde 1945 hasta que marchó a $E I$ Norte en 1953. En este periódico había desempeñado los cargos de subdirector y director, y ahora continuaba en él como redactor. El siguiente era Ángel de Pablos Chapado. Redactor jefe de Diario Regional de 1939 a 1944, año en que pasó a desempeñar el mismo cargo en El Norte de Castilla, y que ocuparía también en La Hoja del Lunes. En 1968 había sido nombrado director -en funciones primero y efectivo después- de El Norte. Paralelamente, era funcionario del Ministerio de Información y Turismo -o de los organismos equivalentes- desde 1939, y en 1968 era Inspector de Prensa de la Delegación de Valladolid. Finalmente, el otro candidato a la condecoración era Luis González Armero, que había comenzado su carrera en Libertad desde su fundación, en 1931, hasta llegar a ser secretario redactor en ese diario. En 1954 dejó el periódico del Movimiento, y en 1957 comenzó a ser redactor jefe de Diario Regional, del que luego fue colaborador al tiempo trabajaba como redactor de La Hoja del Lunes, semanario del que en 1968 era redactor jefe ${ }^{805}$.

805De Tallón decía Santiago: "A lo largo de su actuación como periodista, y en especial durante el periodo que ocupó la dirección de "Diario Regional", ha demostrado su competencia, actividad e iniciativa, operándose un notable cambio en este diario, mejorando sus secciones, creando otras nuevas y dándole una orientación más actual y dinámica. 
No hay que aclarar el esquema ordinario de la "carrera de periodista" en Valladolid: los datos hablan por sí solos. Si se tiene en cuenta además que los redactores de Libertad eran funcionarios que permanecían de ordinario dentro del escalafón de la Prensa del Movimiento -González Armero es una excepción por motivos personales-, se puede concluir que Diario Regional servía de escuela o banco de pruebas a buena parte de los que luego harían el periódico de la ciudad, es decir, El Norte. Había suficientes motivos de prestigio, y algunos económicos para que así fuera ${ }^{806}$.

En este aspecto poco o nada había variado en la vida periodística de la ciudad. La evolución de los dos diarios de empresa de la ciudad, en su mutua competencia, había seguido una marcha paralela y ascendente que los situaba

"Ha estado siempre en inmejorables relaciones con los servicios de prensa de esta Delegación, mostrando en todo momento su mejor deseo de colaboración."

Oficio del delegado provincia del Ministerio de Información al director general de Prensa, de fecha 26 de febrero de 1968. A.G.A., Sección Cultura, caja 29.521 .

${ }^{806}$ Los sueldos en los diferentes medios en 1967 eran los siguientes:

Remuneración mensual en pesetas

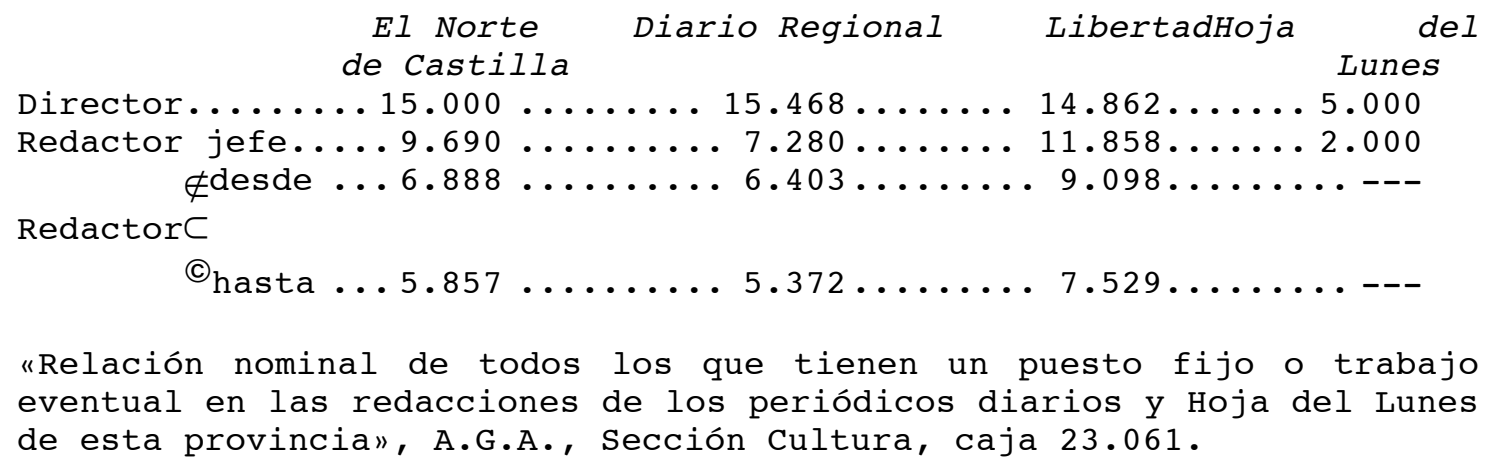


en 1967 a una considerable distancia de lo que habían sido una docena de años antes. Seguían siendo “David y Goliat"807, y de momento la pugna continuaba sin que se pudiera augurar una victoria del pequeño y combativo Diario Regional. Basta hacer memoria de las innovaciones que hemos descrito en este epígrafe, para hacerse idea de la importante transformación que había experimentado la prensa de provincias en general, y la vallisoletana en particular. Fueron años intensos en los que el periodismo de la ciudad del Pisuerga tuvo como protagonistas a unos hombres que pesarían luego en al vida nacional, como se verá en sus trayectorias, y en las de sus discípulos andando los años: Antolín de Santiago -por empezar con el factor común de nuestro relato- como director general de Teatro y Cinematografía primero, y como director de la cadena del Prensa del Movimiento después; Miguel Delibes más como novelista que como periodista; Cebrián en El Alcázar, y luego en $A B C$; Areal en Mundo, y, sobre todo, en el análisis de la historia del periodismo; y Tallón en el de la empresa y la publicidad...

Pero, aunque los protagonistas más destacados tuvieran un cierto carácter excepcional, eso no explica el conjunto de los cambios. Como señalaba a la altura de 1961 el maestro de los que fueron directores de Diario Regional en estos años, Antonio Fontán,

${ }^{807}$ La comparación es de José Luis Cebrián. 
"En el último medio siglo la Prensa ha experimentado una evolución tan extensa como profunda. En parte ha sido producida, por así decir, desde el seno de la Prensa misma: al compás del desarrollo de sus propias posibilidades. Pero en parte muy principal le ha sido impuesta desde fuera, por el progreso de la técnica, por exigencias económicas, por las transformaciones sociales $y$, en fin, por el diverso planteamiento, en nuestros días de la política.

"(...) [y al lado de esos cambios en el entorno] un verdadero ejército anónimo de profesionales de la información, cuyo trabajo oscuro y cuya vida han trazado el perfil de esa evolución histórica hasta llegar a la situación presente."808

Esa fuerte transformación se había experimentado en los periódicos españoles, de un modo particularmente intenso en los años que nos ocupan. Había fracasado el intento de llevar a España -sobre todo en lo ideológicoal pasado. La realidad material y cultural del entorno, y el consiguiente crecimiento de la sociedad civil -ese "ejército anónimo de profesionales»-, se imponían de forma incontrovertible. Ante esto, las autoridades del régimen no hacían otra cosa que adaptar paulatinamente el marco jurídico a las realidades de hecho, que proclamaban a gritos lo inadecuado del sistema hasta entonces vigente para la prensa.

De otra parte, la generalización de los receptores de radio y -sobre todo- la progresiva difusión de la televisión, orientaban por un lado al poder público y a su afán de control en un sentido distinto del que había seguido hasta el momento, y, por otro, repercutían no poco

808FONTÁN, Antonio, Situación y perspectivas de la prensa actual, Editorial Ateneo de Madrid, Madrid, 1962, pág. 7. La breve publicación reproduce una conferencia del autor pronuciada en la Asociación de la Prensa de San Sebastián el 4 de mayo de 1961. 
en la estrategia de las empresas de prensa ${ }^{809}$. Entre los muchos y rápidos cambios experimentados por las sociedades industriales en estos años, uno de los fundamentales era precisamente el que se operaba en el terreno de las comunicaciones, y -como todo cambio- éste también suponía un conflicto entre lo nuevo y lo viejo; la desaparición de dificultades añejas, y la aparición de nuevos problemas, que siempre van de la mano de cualquier logro humano y de sus consiguientes ventajas.

Por lo tanto, el futuro, como el mismo Fontán decía más adelante, era preciso planteárselo en términos bien diferentes a los que se habían utilizado en la larga postguerra de España, tanto en lo ideológico, como en lo práctico

"(...) El problema de la libertad de prensa se plantea hoy,
por todo ello, con perspectivas insospechadas para
generaciones anteriores. No sólo la amenazan el Estado o la
autoridad, sino las leyes económicas del oligopolio, la
presión de la publicidad comercial y la propia orientación
ideológica o política -cuando existe- de la empresas
editoriales."

${ }^{809}$ A la altura de 1966 una encuesta sobre la audiencia de Prensa, Radio y Televisión en España, arrojaba los siguientes resultados:

\footnotetext{
Nunca Alguna vez Frecuentemente

Lectores de periódicos........45\% ...... $32 \% \ldots \ldots \ldots \ldots . \ldots . \ldots 23 \%$

Oyentes de radio............ $8 \% \ldots \ldots \ldots 40 \% \ldots \ldots \ldots \ldots . \ldots . \ldots 4 \%$

Telespectadores............. $22 \% \ldots \ldots . \ldots 53 \% \ldots . \ldots . \ldots 25 \%$

Audiencia de la Prensa española, edita: Grupo Nacional de Diarios, Dirección técnica del estudio, "ECO", Editorial Vizcaína, Bilbao, 1966 .

En los resultados del estudio se señalaba también que entre los lectores de periódicos predominaban los varones, y la mayor parte de la audiencia se concentraba en las grandes poblaciones.
} 
"(...) Una consecuencia de la incapacidad de un periódico para extenderse indefinidamente fue el nacimiento de las cadenas periodísticas. Otra segunda, la aparición de varias ediciones locales de un mismo diario.

"(...) El interés local es, efectivamente, el más concreto y el más próximo para la mayoría de los lectores de un periódico. La atención que éstos prestan a las noticias nacionales o internacionales, muy cercanas e importantes a la hora de los grandes acontecimientos, tiene siempre un carácter reflejo, intelectual y abstracto. Por eso el porvenir es de la prensa regional que alcance a servir una comunidad natural con capacidad de mercado suficiente para absorber una circulación industrial." 810

\section{Estos factores, precisamente, serían los que}

marcarían las directrices de la política empresarial de "Diario Regional, S.A." en los años siguientes. Pero esa etapa ya no la viviría Tallón811. En la cabecera de Diario Regional del jueves 14 de septiembre de 1967 no aparecía ya su nombre. En su lugar figuraba el del nuevo director -

810 Ibid., págs. 15,19 y 20 .

${ }^{811}$ Entre los motivos para dejar la dirección que José Tallón nos expuso en la entrevista que mantuvimos con él, estaban -además de su deseo de dedicarse a al enseñanza- la venta del periódico por S.A.R.P.E. a P.E.S.A. (Prensa y Ediciones Sociedad Anónima), venta que tendrá lugar casi dos años más tarde de que él dejara la dirección. Por otra parte, según Germán Losada -entonces redactor del periódico-, la marcha de Tallón tendría que ver con la desestimación por parte de la empresa de un proyecto suyo que trataba de unir la publicación de Nuevo Diario en Madrid y Diario Regional. Se trataba de hacer un Diario Regional que en realidad serían una portada y unas páginas de local y regional añadidas al diario que se tiraría en la capital. En la cabecera sólo hacía falta cambiar una palabra en cada caso. Sin embargo José Tallón afirmó no recordar nada de esto. Es posible que por razones personales no quisiera entrar en ello y que el relato de Losada sea bastante exacto. En apoyo de esta tesis iría la afirmación de Tallón de que a su marcha del periódico éste a penas se sostenía económicamente. Teniendo en cuenta todas las medidas comerciales y empresariales adoptadas durante su estancia en el rotativo, no sería de extrañar que Tallón hubiera hecho saber que consideraba necesario adoptar decisiones empresariales de mayor calado si se quería hacer viable económicamente a Diario Regional, y quizá fueron ésas precisamente las que la empresa no quiso tomar. Desgraciadamente nos ha sido imposible constatar documentalmente ninguno de los extremos apuntados, que quedan así en la memoria de los protagonistas y en el reino de las suposiciones.

Sobre su marcha del periódico, sus ideas sobre la prensa y su dedicación a la docencia, puede verse la entrevista que se publicó en DR, el 19/5/1968, pág. 14: "José Tallón. Director de INCA". 
"adjunto interino" según el lenguaje oficial- Tomás Santos Corchero. En la segunda página del mismo número se daba la noticia de su baja a petición propia, y de su incorporación a la dirección de la Escuela de Turismo y del Instituto Castellano de Nuevas Profesiones. El tiempo de los directores de "la escuela de La Actualidad Española" había terminado y -esta vez sin advertencias previas- comenzaba una nueva etapa en la vida del diario.

\section{La SUSTANTIVACión del CATOLICismo}

Si la prensa en general se había transformado de manera ostensible en estos años, lo mismo -si no más- hay que decir de la prensa católica. En el caso concreto de Diario Regional, los cambios que tuvieron lugar en él desde que lo dejara "La Editorial Católica" y empezara a ser dirigido por miembros del Opus Dei, eran en buena medida fruto de un concepto distinto de lo que debía ser la prensa católica. Confluían, por tanto, al menos tres corrientes de transformación que separamos artificiosamente para su estudio, pero que no debemos olvidar que iban unidas en la actividad de los protagonistas de los hechos: de un lado la transformaciones que afectaban a todo tipo de prensa, de otro las que se referían específicamente a la católica o hecha por católicos, y por fin, entre éstos, las que se derivaban de la novedad que suponían los planteamientos del Opus Dei en este terreno. Ya hemos apuntado el núcleo 
de la primera de ellas, y cómo se manifestó prácticamente en el quehacer de directores y redactores de Diario Regional en estos años. Nos corresponde ahora detenernos a considerar las otras dos.

Nos son ya conocidos algunos de los esfuerzos que, a mediados de los años cincuenta, los organismos eclesiásticos correspondientes realizaban en España para definir la prensa católica812; esfuerzos que concluían con un tipo de definición que en poco o en nada se distinguía de la que se daba cincuenta años antes:

${ }^{812}$ Cfr. las notas 13 y 14 del capítulo anterior. En otro folleto publicado por esas mismas fechas, se volvía de nuevo sobre el asunto, y esta vez se establecían cuatro tipos de prensa católica, siguiendo la clasificación elaborada por Mons. Zacarías de Vizcarra, Obispo de Ereso y Presidente de la Junta Nacional de Prensa Católica:

"1 a Prensa de inspiración católica, no controlada por la Jerarquía Eclesiástica.- Es la prensa dirigida por católicos, pero sin la garantía de la censura diocesana. A esta clase de Prensa, precisamente por la ausencia de dicha garantía, no se la denomina técnicamente Prensa Católica, porque no tiene quién avale oficialmente su constante fidelidad a las normas católicas.

"2a Prensa de inspiración católica controlada por la Jerarquía Eclesiástica.- Es la Prensa que tiene la garantía de la censura diocesana. Esta segunda clase tiene derecho a llamarse, en sentido estricto, Prensa Católica.

"3a a Prensa de dirección eclesiástica claustral.- Es la que depende de alguna orden o Instituto Religioso. Esta clase de Prensa debe contar con la censura y licencia interna de su Orden o Instituto, y además debe someterse a la censura y licencia diocesana, porque son los obispos los que ejercen en cada diócesis, por institución divina, la potestad de magisterio.

"4ạ Prensa de dirección eclesiástica diocesana.- Es la que depende directamente de los Prelados Diocesanos bajo todos sus aspectos. Comprende las publicaciones oficiales de los Obispados, como los Boletines oficiales de los mismos, y las que están al servicio incondicional de los prelados Diocesanos, como las de Acción Católica Oficial. Esta Prensa es la que suele llamarse por antonomasia Prensa de la Iglesia."

Prensa Católica, folleto editado por la Junta Nacional de Prensa Católica, Madrid s/f, págs. 4-5. 
"El periódico y la revista católica han de emplearse en la defensa del dogma, de la moral y de los principios de la Iglesia. Han de ser un instrumento siempre al servicio del Prelado diocesano en beneficio de los intereses religiosos." 813

Pero si esto era lo que oficialmente teníamos en España, los católicos del resto de Europa debatían ya en otros términos la cuestión. Un buen ejemplo de esto es la conferencia pronunciada en Viena en octubre de 1957, por el Secretario General de la Unión Internacional de Prensa Católica, el P. Emile Gabel, a los participantes en el Vo Congreso Mundial de Prensa Católica. La conferencia llevaba un título esclarecedor -La prensa católica, ¿para qué?-, el mismo con el que aparecería publicada cinco años más tarde en España814. Gabel partía de un presupuesto básico: prensa es aquella publicación que se ocupa de las novedades, de las noticias de actualidad; $y$ merece el adjetivo católica aquella "que es reconocida como tal por la autoridad eclesiástica»815, sin que ese reconocimiento tenga porque concretarse jurídicamente de un modo

813Prensa Católica, pág. 5. Pueden verse también las informaciones y pastorales publicadas en Diario Regional con motivo del "Día de la Prensa Católica" -desde 1957 "Día de la Prensa e Información de la Iglesia"- en estos años: "Hoy, Día de la Prensa Católica", DR, 29/6/1956, pág. 16, últ.; "Día de la Prensa e Información de la Iglesia", 29/6/1957, pág. 3; "Arzobispado. Circular sobre el "Día de la Prensa e Información de la Iglesia"", 12/6/1958, pág. 3; "La prensa es el medio que más influye en el ambiente moral de cada país". Una pastoral del Primado sobre el "Día de la Prensa e Información de la Iglesia"", 28/6/1958, pág. 1. "Circular sobre el "Día de la Prensa e Información de la Iglesia"", por el arzobispo de Valladolid, 17/6/1959, pág. 3 .

${ }^{814}$ La prensa católica, ¿para qué?, Propaganda Popular Católica, Madrid, 1962 .

${ }^{815}$ Esta fue la definición elaborada en Milán, en una reunión de directores de periódicos católicos en marzo de 1956. La prensa..., pág. 12 . 
determinado. Como criterios para considerar católico un periódico bastarían los siguientes:

"1. El estado de hecho adquirido ante la opinión pública tras una larga tradición o eminentes servicios prestados a la causa católica.

"2. La afirmación jurídica o moral de conformarse en sus actividades periodísticas a la enseñanza y a la disciplina de la Iglesia.

"3. Ser empresa de propiedad de la curia episcopal, una congregación religiosa, un movimiento de acción católica, etc. " 816

Gabel continuaba analizando un interrogante que surge inmediatamente de la consideración de sus presupuestos: ¿puede la Iglesia, comprometida en la difusión de un mensaje trascendente, eterno $-y$ por tanto inmutable-, comprometerse con la prensa, llamada por definición a ocuparse de lo efímero? La respuesta afirmaba que puede y debe hacerlo, pero -y ésta era la novedad más importante de su discurso- sin violentar nunca la naturaleza del instrumento que se estaba utilizando:

"Si, pues, añadís el adjetivo católico al sustantivo Prensa, si incluso subrayáis el adjetivo con varios trazos rojos, la prensa, tal como la hemos definido, no deberá por ello conservar menos su fin: informar sobre el acontecimiento que sobreviene día a día. Es la ley interna de la Prensa y, al mismo tiempo, la condición de su éxito. Acontecimiento que la prensa debe relatar, explicar situar y comentar. Cuando ella toma sobre sí una demora es para mejor penetrar todavía y destacar con ella esa actualidad..." 817

El ponente estimaba que la falta de respeto hacia esa misión informativa era la responsable de la escasa

\footnotetext{
816Estos criterios habían sido los acordados en la reunión de directores citada. Ibid. págs. 12-13.

817 Ibid., pág. 17 .
} 
influencia que la mayor parte de la prensa católica ejercía en la opinión pública818. Ese era uno de los principales errores que debían corregirse. Ahora bien, si la finalidad de la prensa católica no era primordialmente apologética, sino informativa, lo mismo que ocurría con el resto de la prensa, ¿qué definía entonces a la católica por contraposición al resto? El autor señalaba la respuesta que le había dado un profesor universitario: la prensa católica debe transmitir "el pensamiento de la Iglesia sobre la actualidad»819. Se trataría por tanto de "ligar la doctrina con el acontecimiento diario":

" Es por los hechos y con ocasión de los hechos, en toda actualidad profana y religiosa, en todo lo que sucede cada día: una guerra, una huelga, un arranque de apostolado misionero, una reunión de primeros ministros, una reforma de estructuras, un congreso político, una competición deportiva, un tren de refugiados, un descubrimiento científico, una explosión de la bomba atómica, una amenaza -venga del Este o del Oeste-, como el periodista hará llegar el mensaje evangélico". Todo lo que relata debe, pues, estar mirado con visión de fe." 820

${ }^{818}$ Se refería en concreto a la prensa que tenía primordialmente una finalidad apologética. "Un católico que leyere únicamente esta Prensa no estaría bien informado sobre los problemas del día que se le plantean a su país, a su comunidad y, por tanto, a su conciencia. Por alto que se apunte, esta Prensa permanece casi enteramente aparte de la corriente general de las discusiones públicas, que tienen por blanco los acontecimientos ordinarios, los cuales, sin embargo, afectan tan profundamente la vida de los fieles, ciudadanos de una comunidad más ancha. Se comprueba un poco por todas partes, y es de lamentar, que nuestra Prensa tiene poca influencia sobre la opinión pública." Ibid., pág. 23.

819 Ibid., pág. 26.

820 Ibid., pág. 27. Lo entrecomillado está extraído de la ponencia presentada por el mismo autor al IVo Congreso Mundial de Prensa Católica celebrado en París. 
Ahora bien, como el propio Gabel señalaba más adelante, ese enjuiciamiento de la actualidad desde la fe entraña una posibilidad de divergencias, "porque no hay en verdad pensamiento de la Iglesia uniforme y oficial sobre cada acontecimiento."821 Lo que pedía el profesor universitario era imposible darlo. El juicio sobre cada acontecimiento que estuviera implícito o explícito en el trabajo de los periodistas católicos era siempre responsabilidad personal de cada uno de ellos, y el pluralismo de los católicos en el enfoque de las distintas cuestiones era por tanto deseable y normal. No se debe pedir ni esperar de la prensa católica un juicio certero y uniforme sobre la actualidad:

"No podemos ciertamente imponer nuestra Prensa a los católicos como un medio de salvación (...) .

"Si estimamos que la Prensa es una simple prolongación del púlpito, sucede entonces que un exceso de celo y una mal comprendida inquietud por la ortodoxia hacen gravitar sobre ella una carga de enseñanzas abstractas $y$ de comentarios dogmáticos insoportables e inadaptables a la psicología del lector de periódicos." 822

"(...)La acción del periodista católico (...) expresa, en nombre de todos, las reacciones de la conciencia cristiana y se hace intérprete de una opinión libre y madura. Sugiere la reflexión sin constreñir el juicio (...)." 823

La distancia entre los planteamientos de Gabel y los que por las mismas fechas eran comunes en las instancias

\footnotetext{
${ }^{821}$ Ibid., pág. 36.

822 Ibid. págs . 41-42.

${ }^{823}$ Palabras del mensaje dirigido por el Cardenal Dell'Acqua en nombre del Papa al Vo Congreso de Viena, citadas en ibid., pág. 43.
} 
oficiales de la Iglesia española resulta patente. Ahora bien, no ocurría lo mismo con los periodistas que hacían Diario Regional. Basta recordar los planteamientos profesionales de Zuloaga para advertir que esa primacía de la actualidad, de la información, eran una realidad práctica entre periodistas católicos, antes incluso de que la reflexión teórica sobre la cuestión se hubiera articulado con coherencia. Es más, la reflexión teórica iba haciéndose posible en la medida en que esa mentalidad -más profesional que confesional- iba difundiéndose entre estos periodistas. Las siguientes reflexiones de José Luis Cebrián -al hilo de una noticia de espectáculos- pueden ser un buen ejemplo: la película de Brigitte Bardot "...Et Dieu créa la femme " llenaba los cines, y -según ParisMatch- era divertida aunque quizá un poco picante. Ecclesia la condenaba sin ambages. Cebrián apostillaba:

"Al lector de Paris-Match le faltaba el juicio valorativo sobre la moralidad de película. Al de Ecclesia, quizá le falten algunos datos más sobre su contenido. Si Ecclesia hubiera tenido los medios suficientes, su información pudo ser completa.

"(...) Resulta difícil hacer un periodismo en el que vibre el sentido cristiano de la vida. Es imprescindible hacer prensa buena técnicamente, vivaz, atrayente y ágil. y a la vez, con mucho criterio, valorar las noticias, aclararlas y enjuiciarlas. No es táctica cerrar la puerta a todas las noticias "molestas". Hay que saber recogerlas con dignidad, señalando lo nocivo e interpretando a la vez lo que de positivo puedan tener» 824

Resulta claro que Cebrián había incorporado ya, en el quehacer diario, las tesis de Gabel que hemos reproducido

824 "Las dos caras de una noticia», DR, 8/1/1958, pág. 4 . 
más arriba. Esto resulta tanto más llamativo cuanto que el ambiente reinante en España no era propicio a la adopción de este tipo de posturas. Ya lo vimos por lo que hace a las argumentaciones en torno a la cuestión de la prensa católica, pero es que no sólo en ese terreno era frecuente la toma de posturas que se autodefinían como "las auténticamente católicas". Otro periodista, colaborador de Diario Regional, describía así ese ambiente, en 1958:

"Tratar de encontrar fundamentos que superen el orden de lo natural para apoyar puntos de vista y situaciones de hecho que no tienen de por sí esta dimensión trascendental es una manifiesta inclinación que se da -antes de hoy y ahora- en muchos de nosotros. Quizá alguien califique este fenómeno de "defecto nacional". Y sería una sugestiva tarea buscar una explicación -seguramente de orden religioso- para esta característica de nuestro pueblo. El español siente necesidad de un firme apoyo -y mejor si no es simplemente humano- en que basar su actuación. Necesita sentirse respaldado por unos argumentos que le ofrezcan una garantía indudable.

"Muy probablemente, a un observador exterior y ajeno, nuestras contiendas han de producirle la desconcertante impresión de que Dios está más cercano de los españoles que de cualquier otro pueblo. Porque bien está que sea así cuando la cuestión en litigio es verdaderamente trascendente. Pero otras veces, y no pocas por desgracia, echamos mano de las cosas de Dios -de la caja de los truenos, de los argumentos irrebatibles so peligro de caer en la herejía- para defender posiciones que están fuera del orden de las cuestiones definidas. Esto, por una parte, demuestra que existe en el país una viva conciencia colectiva de lo sobrenatural; y nunca podremos agradecer bastante esta realidad de la que se encuentran privados otros países cristianos. Pero si se sacan las cosas de quicio se ahoga toda posibilidad de diálogo incluso para aquello en que éste resulta no solamente lícito, sino aconsejable. Gente que obra así está obsesionada por la idea de que todos los endecasílabos se acentúan en la sexta sílaba, cuando resultan tan perfectos y biensonantes con el acento en la cuarta y octava entre otras posibilidades." 825

En Diario Regional, por el contrario, encontramos en estos años un distanciamiento voluntariamente buscado de

825 "Servir a la Iglesia o servirse de ella. Comentarios a la carta del Cardenal Ottaviani", por José Luis M. Albertos, DR, 8/2/1957, pág. 7 . 
esas maneras de hacer. Se suprimió de la cabecera el lema "Diario católico"826, y cuando se hablaba de periodismo, se evitaba adosarle el adjetivo católico. El periodismo era en sí mismo una profesión -apasionante- que no necesitaba ningún apellido para dignificarla.

De esta cuestión se ocupó Andrés Romero en varios artículos publicados en 1957, que no tuvieron continuidad por causas que desconocemos -bien pudiera ser que no gustaran en el Ministerio-, y que trataban de definir 10 esencial de la profesión. Una de las razones para abordar el asunto era la puesta en marcha de un "Club Juvenil de Prensa de Diario Regional", que era algo así como una oficiosa "Escuela de Periodismo" que estaba naciendo en torno al periódico. En realidad, esta iniciativa no pasó de la organización de unos cursos para bachilleres interesados en ingresar en la Escuela Oficial de Periodismo, y pronto fue asimilada dentro de las actividades del Frente de Juventudes ${ }^{827}$.

En el primer -y único- artículo de lo que se anunció como una serie de de reportajes sobre el periodismo,

${ }^{826}$ Sobre las razones para la supresión del subtítulo Jesús María Zuloaga, en su respuesta a nuestro cuestionario, nos decía: "Lo de la supresión del subtítulo fue porque sobre anacrónico podía ser excluyente y hasta discriminatorio. Eran aquellos años de evidente "catolicidad oficial". Yo siempre fui de los otros".

${ }^{827}$ Cfr. "Club Juvenil de Prensa de Diario Regional. Se trata de ilusionar en nuestro estilo y en nuestra técnica profesional, a los jóvenes interesados en la vocación periodística", DR, 7/2/1957, pág. 8; Y "Valladolid: escuela de periodismo", por Andrés Romero Rubio, DR, 7/5/1958, pág. 3 . 
Romero afirmaba que lo ideológico debe estar por encima de lo económico en la empresa periodística: hace falta primero ser intelectual para ser periodista. Sólo así resulta posible penetrar en la actualidad y saber destacar lo noticiable. Para demostrarlo, ahí estaban los ejemplos de Ortega, Unamuno y D'Ors. Por otro lado -continuabahace falta trabajar en equipo: si Balmes fracasó en el periodismo fue porque era un solitario. Por fin -en su opinión- había que fijarse, como ejemplos de publicaciones con capacidad de penetración intelectual de la actualidad, en La Revista de Occidente, La Codorniz y El Debate; y como ejemplo de empresas que contaban con equipos bien articulados de periodistas, en Time y Life ${ }^{828}$. Más adelante, al hablar del "Club Juvenil de Prensa", el mismo redactor daba los siguientes consejos para hacer buen periodismo:

"1.- El periodismo es el arte de contar la vida como es. Diciendo siempre la verdad. Teniendo siempre también una divina proporción de las cosas, sin que un humano volumen sensacionalista salpique de barro el camino de la información a seguir.

"2.- Espíritu de observación siempre despierto. Sentido de la actualidad. Estilo de escritura cuidado y ágil.

"3.- Espíritu de responsabilidad en constante estado de alerta: no sacrificar la seriedad $y$ el sentido común al sensacionalismo, ni la verdad a las imaginarias "exigencias" del público lector.

"4.- El periodista debe ser técnico en una o varias especialidades (editoriales, crónicas, política internacional, cine, etc. etc.), pero debe entrar en la redacción de un periódico dispuesto a saber hacer de todo, porque ese todo, y no una o varias especialidades, es el periodismo.

828 "La prensa en el mundo. El periodista es el intelectual moderno que vive de cara al futuro presintiendo $y$ adivinando la actualidad noticiable. Un hombre que está en el saber intelectual y opera con el saber científico" por Andrés Romero Rubio, DR, 10/2/1957, pág. 2 . 
"5.- La misión del periodismo es: informar, formar y entretener. haciendo esto posible siempre por caminos de criterio, de sugestividad e interés.

"6.- La claridad, la brevedad y la síntesis es la trilogía del periodismo moderno.

"7.- En periodismo se escribe, se lucha y se piensa siempre en defender los intereses de la opinión pública. Opinión que está integrada por el militar $y$ el artesano, pasando por el religioso, el artista o el campesino. Por esto el periodismo, el hacer buen periodismo, consiste en saber tener una informativa, formativa y entretenida conversación con la sociedad toda, sin dar nunca ocasión a que ella nos llegue alguna vez a llamar pesados." 829

Bastaría la lectura de estos párrafos para acreditar el viraje en los planteamientos profesionales que venimos describiendo.

Sólo hubo un par de ocasiones en que se hizo mención de la catolicidad del medio, las dos durante la dirección de Fernández Areal. La primera tuvo lugar con ocasión de la celebración del "Día de la Prensa e Información de la Iglesia" -trasladado al 17 de enero- en 1960. Diario Regional publicó un editorial en el que se insistía en la misión formativa de la prensa -una cuestión muy querida a Areal, que luego detallaremos-, y en la responsabilidad de los padres a la hora de llevar a casa publicaciones. El editorial llevaba como título un viejo lema que hacía años que no aparecía en el diario: "En el hogar católico, el periódico católico»830. La segunda tuvo una razón de ser más polémica: Diario Regional entró en conflicto con las salas de espectáculos con motivo -según los empresarios de

829 "Jugar a hacer periodismo", por Andrés Romero Rubio, DR, 30/5/1958, pág. 3 .

${ }^{830} \mathrm{DR}, 17 / 1 / 1960$, pág. 1 . 
los cines- de las tarifas que el periódico quería aplicar a las carteleras publicadas, y -según Areal- a esto había que añadir motivos morales. El director escribió en esa ocasión frases que encajaban perfectamente en el viejo esquema de prensa católica:

"[Las empresas quieren reducir las tarifas de publicidad y] nosotros no obedecemos órdenes de ninguna empresa de espectáculos, ni estamos para servir sus particulares intereses, como siempre hemos demostrado.

"[La otra causa del conflicto es que Diario Regional ] no publica nunca anuncios de películas, revistas, obras de teatro calificadas con el número cuatro desde el punto de vista moral. Ello ha levantado ronchas, nos consta, pero ésta es nuestra norma de conducta y por este camino estamos dispuestos a continuar. Sabemos que nuestra línea es la que hay que seguir.

"(...) porque somos responsables de la salud espiritual de muchos lectores que nos siguen $y$ no hemos venido a ganar dinero, sino a cumplir una misión, por lo menos social y aún la calificaríamos con términos mucho más altos; al negarnos a aceptar la más mínima presión económica, hemos visto cómo se nos retiraba la publicidad de toda una cadena de salas."831

Poco más adelante, Areal volvía sobre la cuestión, agradeciendo los apoyos, y -citando en letras capitales palabras del Cardenal Dell'Acqua- llamando a los católicos a apoyar al periódico:

$"(\ldots)$ [agradecemos] la actitud de esos lectores, suscriptores, consejeros, amigos, fundadores incluso del periódico que nos han llamado por teléfono para decirnos: "sigan, sigan adelante; si esto se hubiera hecho hace tiempo, quizá no habríamos llegado a situaciones que a todos nos resultan desagradables. No cedan, sigan. Cuenten con nosotros." (...)

" “(...) EL PROBLEMA DEL PERIÓDICO CATÓLICO NO PUEDE SER RESUELTO MÁS QUE POR LA COLABORACIÓN DE TODAS LAS VOLUNTADES Y LA CONVERGENCIA DE TODOS LOS ESFUERZOS." "832

831 «A nuestros lectores», por Manuel Fernández Areal, DR, 28/6/1960, pág. 1 .

832 "Agradecimiento a nuestros lectores", por Manuel Fernández Areal, DR, 29/6/1960, pág. 1. Las palabras de Dell'Acqua habían servido ese 
El carácter excepcional de estas argumentaciones, viene a reforzar, por contraste, el manifiesto cambio de orientación que se había operado. La raíz de esa nueva mentalidad hay que buscarla en planteamientos que son propios del Opus Dei. Ya vimos, al referirnos a la transformación de la empresa, que el fundador de la Obra tenía en este terreno ideas originales, que contrastaban con las que normalmente circulaban en los ambientes eclesiásticos en aquellos años. Las mismas palabras de Cantero Cuadrado que citamos anteriormente sirven para explicar en buena medida este fenómeno de acentuación de la profesionalidad entre los católicos periodistas. Ciertamente, éste es uno de los puntos nucleares en el espíritu del Opus Dei, uno de los que ha motivado que se califique a Josemaría Escrivá como precursor del

año como eslogan preparatorio para el "Día de la Prensa e Información de la Iglesia".

La polémica continuó y se complicó debido a que las empresas de las salas de cine recurrieron ante los sindicatos, y el periódico del Movimiento, Libertad, atacó duramente a Diario Regional por su afán de monopolizar la condición de diario católico. Cfr. "No es cuestión puramente económica", por Manuel Fernández Areal, DR, 20/6/1969, pág. 1; "Puntos de partida para un entendimiento", por Manuel Fernández Areal, DR, 1/7/1960, pág. 1.; "Carta abierta al público de Valladolid", por "Las empresas de espectáculos de Valladolid", ibid. (Como entradilla, antes del título, se señala: "A través de la Delegación Provincial de Información y Turismo nos ha llegado el siguiente escrito de las empresas de espectáculos, que insertamos sin añadir, ni quitar, ni hacer alteraciones. Tampoco necesitamos aclarar ningún punto, porque todo cuanto teníamos que decir, lo hemos dicho ya bien claro."); y el Parte mensual de prensa correspondiente al mes de junio de 1960, de fecha 7/7/1960, en el que el delegado provincial del Ministerio relata su versión de los acontecimientos, en A.G.A., Sección Cultura, caja 6.043 . 
Concilio833, y quizá el que más relevancia tiene a la hora de analizar la presencia de miembros de esta institución de la Iglesia en el periódico vallisoletano, y lo que influía en su trabajo la condición de miembros de la Obra.

En efecto, el acento puesto sobre la mentalidad laical por el espíritu del Opus Dei, lleva de la mano al reconocimiento de la autonomía de las cuestiones temporales y a la libertad y consiguiente responsabilidad en el ejercicio de las tareas profesionales, evitando en absoluto adjetivarlas como católicas. Así lo expresaba Escrivá en una homilía pronunciada en 1967:

\begin{abstract}
"Pero a ese cristiano [que busca la santidad en su trabajo ordinario] jamás se le ocurre creer o decir que él baja del templo al mundo para representar a la Iglesia, y que sus soluciones son las soluciones católicas a aquellos problemas. iEsto no puede ser, hijos míos! Esto sería clericalismo, catolicismo oficial o como queráis llamarlo. En cualquier caso, es hacer violencia a la naturaleza de las cosas. Tenéis que difundir por todas partes una verdadera mentalidad laical, que ha de llevar a tres conclusiones:

"a ser lo suficientemente honrados, para pechar con la propia responsabilidad personal;

"a ser lo suficientemente cristianos, para respetar a los hermanos en la fe, que proponen -en materias opinablessoluciones diversas a la que cada uno de nosotros sostiene;

"Y a ser lo suficientemente católicos, para no servirse de nuestra Madre la Iglesia, mezclándola en banderías humanas."834
\end{abstract}

833Cfr. por ejemplo, ESZER, Ambrogio, O.P., Relator General de la Congregación para las Causas de los Santos, "Actualidad eclesial del mensaje de Josemaría Escrivá», en El Norte de Castilla, 9/1/1992, pág. 28; y el "Decreto pontificio sobre el ejercicio heroico de las virtudes del siervo de Dios Josemaría Escrivá de Balaguer", de 9/4/1990, en Josemaría Escrivá de Balaguer. Itinerario de la causa de canonización, Palabra, Madrid, 1991, págs. 51-53.

834 Conversaciones con Monseñor Escrivá de Balaguer, Rialp, Madrid, 198917, no 117, págs. 239-240. El texto pertenece a la homilía "Amar al mundo apasionadamente", pronunciada en el campus de la Universidad de Navarra el 8/10/1967. 
De ahí arrancaba, precisamente, una de las novedades centrales de entre las que transformaron el periodismo de Diario Regional en estos años. Se trataba en definitiva, y de una forma general, de modificar el enfoque con que tradicionalmente se afrontaba la cuestión de la relación entre la Iglesia y las realidades temporales, relación que el Concilio Vaticano II haría pivotar en torno al papel que corresponde a los laicos en la vida de la Iglesia835. Ésta, desde un punto de vista laical, no necesita acercarse a las realidades temporales, porque son sus propios miembros -plenamente inmersos en ellas- los que las crean, modifican o destruyen. A la crucial pregunta formulada por Gabel sobre si la Iglesia podía y debía comprometerse con la actualidad, siendo su mensaje atemporal, era factible responderse fácil y coherentemente desde la teología del laicado. Cuestión distinta es si los laicos estaban o no preparados para realizar ese tipo de tareas del modo que se describe ${ }^{836}$.

${ }^{835}$ Cfr. Constitución Apostólica Lumen gentium, no 36, y Apostolicam actuositatem, no 7, en Concilio Vaticano II. Constituciones. Decretos. Declaraciones, B.A.C., Madrid, 1965, págs. 71-74 y 512-514, respectivamente.

${ }^{836}$ No obstante, ese tipo de respuesta ha sido interpretada por algunos como una especie de camuflaje de intereses ocultos, bien de la Iglesia en general o del Opus Dei en particular. De alguna forma, se interpreta -ya sea por la novedad del fenómeno o porque no se quiere ver otra cosa- que el laico carece de autonomía, y que si interviene en cuestiones temporales lo hace como representante "secreto" de la jerarquía católica. Ése era justamente el planteamiento latente en una pregunta formulada por un redactor de Le Figaro al fundador del Opus Dei: 
Esto suponía abandonar el esquema tradicional de prensa católica para hablar de católicos que hacen prensa, o de católicos periodistas. De esta forma no se corre ya el peligro -tan real, como hemos tenido ocasión de comprobar- de que el empeño por subrayar el adjetivo, terminara por desvirtuar gravemente -0 incluso por destruir- al sustantivo. Al contrario, ahora la sustantividad de la prensa quedaba puesta de relieve, si bien con esto la Iglesia se ve comprometida en una tarea seguramente más difícil: dotar a los laicos de una formación tal, que les capacite para actuar con criterio cristiano en esa actividad concreta. Pero esa dificultad lleva aneja otras ventajas: de rechazo, la Iglesia se ve libre de compromisos con lo temporal que no podían por menos que enturbiar -cuando no adulterar- su mensaje espiritual; y de alguna forma se favorece que el apellido

"El hecho de que algunos miembros de la Obra estén presentes en la vida pública del país, ¿no ha politizado, en algún modo, el Opus Dei en España? ¿No comprometen así a la Obra y a la Iglesia misma?

"Ni en España ni en ningún otro sitio. Insisto en que cada uno de los socios del opus Dei trabaja con plena libertad y con responsabilidad personal, sin comprometer ni a la Iglesia, ni a la Obra porque $\mathrm{ni}$ en la Iglesia ni en la Obra se apoyan para realizar sus personales actividades. Gentes formadas en una concepción militar del apostolado y de la vida espiritual, tenderán a ver el trabajo libre y personal de los cristianos como una actuación colectiva. Pero le digo, como no me he cansado de repetir desde 1928 [fecha de la fundación del Opus Dei], que la diversidad de opiniones y de actuaciones en lo temporal y en lo teológico opinable, no es para la Obra ningún problema : la diversidad que existe y existirá siempre entre los miembros del Opus Dei es, por el contrario, una manifestación de buen espíritu, de vida limpia, de respeto a la opción legítima de cada uno."

Conversaciones..., no 38, pág. 93. El autor de la entrevista -publicada en Le Figaro el 16/5/1966- es Jacques GUILLÉMÉ-BRÛLON. 
católico no resulte etiqueta apetecible para nadie, ya que nadie puede pensar que la Iglesia como tal va a solidarizarse con las soluciones que -a título individualcada uno escoja como más adecuadas en el terreno de 10 temporal. En otras palabras, se conseguiría conjurar el peligro del clericalismo o de la mentalidad de partido único entre los católicos. Ese es el espíritu que anima las palabras que recogíamos como segunda entradilla de este capítulo:

\footnotetext{
"Ya va siendo hora de que los católicos defendamos las respuestas que damos a las preguntas de nuestro tiempo,por su grado de eficacia, por su viabilidad social, iporque sean las mejores soluciones humanas y no por su condición de católicas! En el mundo, en la vida civil, hay que moverse con criterios de validez secular y no por etiquetas religiosas." 837
}

Se había recorrido un largo camino desde los tiempos de combate de la IIa República, un camino que permitía ahora hacer comprensibles, aceptables y deseables para los católicos las sociedades pluralistas, sin ceder para nada en la integridad del propio catolicismo.

Todo esto, que -por lo que se refiere al ámbito que más nos interesa- se venía apuntando en las reflexiones de algunos católicos dedicados al periodismo, y en la vida y espiritualidad de algunos católicos, fue recogido en los documentos del Concilio Vaticano II, y más en concreto en el Decreto sobre los Medios de Comunicación Social -Inter

837 "Menos etiquetas religiosas", por Luis Gordon Beguer, DR, $27 / 4 / 1966$. 
mirifica- que desde su promulgación sirvió de punto de referencia constante a la hora de teorizar sobre la materia.

En Diario Regional se publicaron dos comentarios firmados por Ángel Benito, que incidían sobre la transformación del concepto de prensa católica a la luz del Decreto conciliar. El autor concluía que a partir de ese documento no tenía ya sentido utilizar como adjetivo de la prensa su catolicismo:

\begin{abstract}
"(...) en la segunda sesión del Concilio Ecuménico Vaticano II se ha ultimado $y$ promulgado el "Decreto sobre los instrumentos de comunicación social" (...) define con claridad cómo debe ser la prensa que el apostolado actual de la Iglesia necesita y hacia dónde debe dirigirse la preparación de los hombres -los laicos más que los sacerdotes- que, bien capacitados técnicamente $y$ con una profunda formación doctrinal han de desarrollar un apostolado personal $y$ responsabilizado a través de los distintos mass-media. (...)

"(...) perfila un concepto de lo que antes se solía llamar prensa católica, mucho más amplio, positivo y actual. Se dice en el párrafo 14: "Para difundir el espíritu cristiano entre los lectores, promuévanse los periódicos que merezcan el nombre de católicos, es decir, aquellos que -ya estén directamente $o$ indirectamente bajo la autoridad eclesiástica, ya sean promovidos y dependan de católicos- se editan abiertamente para difundir opiniones que entren en el derecho natural y concuerden con la doctrina católica y que miren con atención, divulguen y comenten rectamente las noticias que tocan a la vida de la Iglesia."

"Es decir, una prensa $-\mathrm{y}$ también cine, radio y TVinformada desde dentro por la doctrina de la Iglesia; dirigida en sus fines a contribuir con la Iglesia misma al perfeccionamiento último de todos los hombres (...); católica por esta radical condición de los hombres que la sirven, no por la fácil y exclusivista calificación de "católica" a la prensa, la radio, etc., convirtiendo en adjetivo lo que debe ser $y$ es por su misma esencia absolutamente sustantivo: la profesión sin condiciones de la fe católica que no puede ser detentada en exclusiva por nadie." 838
\end{abstract}

\footnotetext{
838 "Católicos periodistas", por Ángel Benito, DR, 16/1/1964, pág. 3. Esta transformación en el enfoque parece estar muy extendida, pero todavía no generalizada después del Concilio: "Confesamos sinceramente nuestro criterio: es en el campo inmenso de la prensa neutra y de los medios de comunicación masivos, que por naturaleza
} 
Periodismo es información, y "católico" sustantivo

La tendencia que se había venido apuntando en años anteriores quedaba así ratificada. Las consecuencias que cabía extraer eran claras: en primer lugar la cristianización desde dentro de las tareas periodísticas correspondía -por su misma naturaleza- a los laicos, que para realizarla debían contar con una adecuada preparación por la que la Iglesia debía velar oportunamente839; y en segundo término, se hacía notar la responsabilidad que se debía atribuir también a los lectores:

"(...) se hace especial hincapié en la libertad de los receptores de la información, como el aspecto más delicado de la actual coyuntura política de la sociedad de masas. (...) el Concilio insiste de un modo positivo en la necesidad de elevar los niveles culturales para un correcto funcionamiento de la opinión pública; para que la acción de los distintos instrumentos técnicos de la comunicación social (...) no recorte en ningún caso la libertad de los ciudadanos. (...) "Defender y tutelar la verdadera y justa libertad de información que hoy es imprescindible en nuestra sociedad, especialmente en lo que se refiere a la prensa; fomentar la religión, la cultura y las

siempre serán neutros y pluralistas, hacia donde debemos hoy mirar los católicos en esta hora de Dios del Post-Concilio. Asegurar la presencia de nuestros cristianos, sobre todo seglares, como tales con conciencia de su misión, con vocación apostólica, en un ambiente pluralista, es sin duda una de las tareas más fructíferas que ahora podamos emprender." CUNILL, Ramón, Prensa, opinión pública y renovación conciliar, Lección inaugural leída el día 17 de octubre de 1966, en el acto de apertura de curso 1966-67, Escuela de Periodismo de la Iglesia, Madrid, 1967, pág. 16.

839 "Porque los trabajos de la prensa son eminentemente seculares, el Decreto conciliar, sin despreciar la importante colaboración de los sacerdotes $y$ religiosos, dice, textualmente: "Deben formarse especialmente seglares en la técnica, en la cultura, en la vida moral, multiplicando las escuelas, facultades o institutos de periodismo, cine, radio y TV... haciendo que en ellos se alcance una completa formación profesional, vivificada por el espíritu cristiano, especialmente en lo que hace relación a la doctrina social de la Iglesia." Ibid. Puede verse también el trabajo publicado por Manuel FERNÁNDEZ AREAL comentando el mismo Decreto en el folleto Frutos del Concilio. Decreto sobre los medios de comunicación social, S.A.R.P.E., Madrid, 1965, especialmente las páginas 6-11, y 15-20. 
bellas artes; $y$ defender a los receptores para que puedan disfrutar libremente de sus legítimos derechos." 840

Esta segunda cuestión era, a nuestro parecer, tan importante o quizá más que la primera. En efecto, por vez primera se incidía en un punto que evitaba la tradicional mitificación del poder de los medios de comunicación que había sido lugar común en los escritos de propaganda católica durante años. Muchas de las reflexiones sobre la importancia de la prensa habían nacido del intento de explicar un proceso de progresiva secularización y de retroceso de las creencias en el mundo contemporáneo. La responsabilidad de semejante estado de cosas se atribuía al predominio de las publicaciones acatólicas sobre las que lo eran. Este razonamiento venía a afirmar implícitamente que los sujetos receptores de información eran, por así decirlo, "perfectamente manipulables". De que predominara un tipo de manipulación u otra dependía que se generara un tipo de sociedad u otra.

Ciertamente este tipo de análisis no era privativo de los pensadores católicos. La concepción de los medios de información como medios de propaganda -sin duda con un fundamento real en muchos casos- había sido la más extendida durante mucho tiempo, hasta que la reflexión sobre esos medios -con base en la experiencia- había

840 "La Iglesia y la información", por Ángel Benito, DR, 23/2/1964, pág. 3 . 
venido a llamar la atención sobre el fenómeno contrario841, tal como hacía Fontán en 1964:

"No es menos frecuente, sobre todo cuando se contempla el problema desde dentro del oficio, advertir que los directores, inspiradores y realizadores de estos medios de comunicación y de difusión, se debaten constantemente en una realidad proteica e insoslayable, tan concreta como fantástica y a primera vista inaprehensible. Los gustos y las aficiones del público, las exigencias técnicas, comerciales, políticas y económicas de los propios instrumentos que manejan; las derivadas de hábitos sociales arraigados en el ambiente colectivo o de las tradiciones de los propios órganos que gobiernan o inspiran, les asedian de tal modo, que uno acaba por preguntarse si la verdad no estará más bien en el extremo contrario. Es decir, que en vez de ser la prensa, la radio, la televisión, etc., quienes conforman la mentalidad contemporánea es ésta quien se manifiesta a través de estas técnicas de una manera prácticamente necesaria y unívoca."842

Este reconocimiento de dobles implicaciones entre prensa y sociedad era consecuencia del avance de la prensa

${ }^{841} \mathrm{Cfr}$. DADER, José Luis "La evolución de las investigaciones sobre la influencia de los medios $y$ su primera etapa: Teorías del impacto directo", en el libro que el autor escribe en colaboración con Alejandro MUÑOz ALONSO, Cándido MONZÓN, y Juan Ignacio ROSPIR, Opinión pública y comunicación política, EUDEMA, Madrid, 1990, págs. 226-230. Dader establece el siguiente esquema de evolución histórica de las investigaciones sobre los efectos de los medios:

1. Periodo de creencia en la influencia poderosa y directa de los mass media. (De 1920 a 1940 aproximadamente).

2. Periodo de creencia en la influencia muy limitada o restringida de los mass media. (De 1940 hasta mediados de los años sesenta)

3. Periodo de transición y creencia moderada en la capacidad de influencia efectiva de los medios. (Desde mediados de los años sesenta hasta mediados o finales de los setenta).

4. Periodo de nueva interpretación sobre la poderosa capacidad de influencia de los medios. (Desde mediados de los años setenta hasta la actualidad).

Puede verse también la referencia de Alejandro PIzARROSO a la diferencia entre comunicación y persuasión y las graves dificultades de definición que esa distinción entraña. Historia de la propaganda..., págs. 26-28.

842 FONTÁN, Antonio, "Las técnicas de difusión y sus condicionamientos sociales", Ponencia de la XXII Semana Social de España, Barcelona, junio de 1964. Citado por Ángel BENITO en "La libertad de información", en Nuestro Tiempo, no 135, septiembre de 1965, págs. 233-256. 
informativa en detrimento de la de opinión, y de la mayor profundidad de los estudios en torno a estos problemas, que -como suele ocurrir con cualquier estudio sobre cuestiones sociales- acababan por poner de relieve la complejidad del fenómeno estudiado, complejidad, por otra parte, característica de los sistemas sociales que se han dado en llamar avanzados843. Que el discurso de los católicos hubiera llegado a este mismo punto lo que pone de relieve es que sus reflexiones sobre los medios de comunicación se realizaban desde una perspectiva que podemos calificar de profesional, por contraposición con la que hemos encontrado otras veces, más propia de quien trata de desentrañar el secreto de una poderosa arma enemiga.

Si la prensa se entendía tiempo atrás como un sucedáneo vergonzante de la educación, e incluso de la predicación, ahora se insistía en que no era ése su papel, en que la información -aunque siempre subjetiva- era, también siempre, el fin posible y deseable de la actividad periodística rectamente entendida. Así lo expresaba Fernández Areal en un comentario al mismo Decreto conciliar:

"Olvidar que los medios de comunicación social tienen como fin primario informar (...), necesariamente conduce a desvirtuar esos medios, a convertirlos en algo que no son ellos mismos y,

${ }^{843} \mathrm{Cfr}$. BELL, Daniel, El advenimiento de la sociedad postindustrial. Un intento de prognosis social, Alianza Editorial, Madrid, 1976, págs. 28-53. 
Periodismo es información, y "católico" sustantivo

en consecuencia lógica, a perder el público para quien se creía escribir o divulgar." 844

Cabe preguntarse entonces dónde quedaba la misión de formar que tradicionalmente se atribuía a la prensa, y en la que Areal, por cierto, tanto hincapié había hecho. La respuesta puede buscarse en otro artículo suyo:

"Si es importante el segundo de los fines atribuidos a la prensa escrita -formar- es preciso comprender que, en este sentido amplio que al periódico le corresponde $y$ no en el concreto y delimitado de educar al modo que pueda hacerlo la escuela, la misma aportación de hechos es, en sí misma, formadora, por cuanto aumenta la capacidad de formulación de una opinión, porque enriquece el caudal de conocimientos del lector que, al ser informado -con verdad- estará en disposición de juzgar, de decidir directa o indirectamente muchas cuestiones que le afectan como miembro de una sociedad." 845

844Manuel FERNÁNDEZ AREAL, art. cit., pág. 9.

Tesis parecidas había puesto de relieve el Cardenal Koenig en una conferencia pronunciada en la reunión de periodistas, organizada en Asís, por "Pro Civitate Christiana", los días 6 y 7 de noviembre de 1965 sobre el tema: "Libertad e información". El texto de la conferencia fue publicado por la "Kathpress" de Viena en su boletín de 10 de noviembre de 1965, y Diario Regional publicó un extracto del mismo, al que pertenece el siguiente párrafo:

"A menudo se ha presentado a la prensa, principalmente a la prensa católica, como la cátedra moderna a partir de la cual se puede alcanzar a hombres que la palabra del sacerdote en la cátedra jamás alcanzará. Esta comparación es al mismo tiempo exacta e inexacta, porque el sacerdote en la cátedra no puede, en la Iglesia, entablar un diálogo; el periodista tiene que esperar siempre la contracción [sic por reacción o respuesta]. El sacerdote puede partir de la idea de que sus oyentes en la iglesia comparten por principio su opinión; el periodista tiene que hablar de modo que le comprendan, incluso aquellos que no opinan como él. El sacerdote proclama su verdad a tiempo y a destiempo.; para el periodista no puede serle indiferente si lo que dice es oportuno o inoportuno, porque tiene que esforzarse en hablar de modo que sus palabras sean aceptadas. Y sin embargo ambos, el sacerdote $y$ el periodista tienen esto en común, tienen que poner toda su energía en servir a la verdad y, quizá, al término de una vida llena de esfuerzos tendrán que reconocer que sin duda no han conseguido gran cosa para acercar entre sí a los hombres de Dios. Por este motivo ambos se hallan expuestos a la gran tentación de la resignación."

"El Concilio y la opinión pública", por el Cardenal Koenig, DR, 19/12/1965, pág. 2 del suplemento.

845Manuel FERNÁNDEZ AREAL, "La información libre, presupuesto de la opinión públical, en Nuestro Tiempo, no 129, marzo de 1965, pág. 346. 
Pero en ese proceso formativo desempeñaba un importante papel el receptor, que no era un mero sujeto pasivo del proceso. Y de ahí que unos y otros insistieran ahora en lo definitivo de la actitud que adoptara ante los contenidos que los medios le ofrecieran, ya que la información -y la opinión- debía definirse como un proceso complejo en el que tanto promotores como receptores eran responsables del producto final846. La tarea de la Iglesia, en este caso, debía orientarse en el sentido de facilitar a los fieles criterios claros que ayudaran a que éste fuera lo menos manipulable posible, o ttal como decía Benito- a garantizar su libertad ${ }^{847}$.

En vista de todo esto es necesario concluir que no algo, sino mucho, había cambiado en la actitud de los católicos frente a la prensa, y que ese cambio había sido recogido por extenso en los documentos del último Concilio. Parecía haber tocado a su fin el periodo

El artículo giraba en torno a algunas de las ponencias y comunicaciones presentadas a la IIa semana Internacional de Prensa, celebrada ese mismo año en Barcelona bajo los auspicios del Instituto de Ciencias Sociales.

846 "Para que haya verdadera información es necesaria una doble libertad: la libertad de los promotores de la opinión y la libertad de los receptores." José Luis M. ALBERTOS, "Objetividad e interpretación de las noticias", en Nuestro Tiempo, no 100 , octubre de 1962 .

${ }^{847}$ Además de los textos ya citados, puede verse un desarrollo más pormenorizado de las mismas ideas en "La prensa y su libertad", por Ángel BENITO, en Nuestro Tiempo, no 120, junio de 1964, págs. 814-816; $y$ en el artículo del mismo autor titulado "Prensa, religión y política", en ibid., no 167, mayo de 1968, págs. 563-575, en el que concluía: "Sólo andando el tiempo y ya en nuestra época, con la presente Ley de Prensa e Imprenta y la posterior Ley de Libertad Religiosa, parece que empieza a aclararse el verdadero sentido y papel de la prensa hecha por católicos: profesional y pluralista, libre y responsable (...)." (pág. 568). 
histórico que había hecho lamentarse a Tocqueville, cuando describía magistralmente una desconcertante realidad:

"Todavía se encuentran entre nosotros cristianos llenos de celo, cuya alma religiosa anhela nutrirse de las verdades de la otra vida. Ellos serán, sin duda, quienes luchen en favor de la libertad humana, fuente de toda grandeza moral. Al cristianismo, que ha hecho a todos los hombres iguales ante Dios, no le repugnará ver a todos los ciudadanos iguales ante la ley. Mas por un cúmulo de extraños acontecimientos, la religión se encuentra momentáneamente comprometida con los poderes que derroca la democracia, llegando a ocurrir a menudo que rechaza la igualdad que ama, y maldice a la libertad como si se tratara de un adversario, siendo así que si la llevara de la mano podría santificar sus esfuerzos.

"(...) iLos hombres religiosos combaten a la libertad, y los amigos de la libertad a las religiones; espíritus nobles y guerreros elogian la esclavitud, y almas bajas y serviles preconizan la independencia; ciudadanos honrados e instruidos son enemigos de todo progreso, al tiempo que hombres sin patriotismo ni moral se convierten en apóstoles de la civilización y de la cultura!

"¿Es que todos los siglos se han parecido al nuestro?"848

Ahora bien, justamente en el momento en que se generalizaba el descubrimiento de la libertad como presupuesto necesario para la actuación de los católicos, algunos de éstos -especialmente en España- creían descubrir en el marxismo el único camino hacia la felicidad humana. Es posible que esto no fuera sino una consecuencia de la peculiar situación política española, que llevó a algunos a entender que no podrían ser defensores de la dignidad del hombre si no se oponían a la dictadura franquista, y a identificar esa oposición con la adhesión a movimientos de izquierda, más o menos revolucionaria. Pero básicamente, ese movimiento era

848 TOCQUEVILLE, Alexis de, La democracia en América, tomo I, Alianza Editorial, Madrid, 1989, págs. 17 y 18. 
"No fue la falta de dureza de la política [a finales de los sesenta] lo que produjo la rebeldía de la juventud, sino los grandes cambios culturales y sociales de la década anterior. La secularización, que se había acentuado tan repentinamente tuvo su contrapartida ideológica, ya que a pesar de que los mismos ideólogos del régimen estuvieron de acuerdo con Daniel Bell en denunciar el "crepúsculo de las ideologías" e instaron a los españoles a concentrarse en el desarrollo económico, los estudiantes y la élite intelectual más joven -cuyo contacto con la Europa occidental era en esos momentos mucho más estrecho que diez años antes- descubrieron una nueva ideología materialista en las ideas neomarxistas importadas en bloque de Francia e Italia. El nuevo "marxismo cañi" no era más que un refrito de ideas extranjeras sin apenas elaboración u originalidad, pero sirvió de marco intelectual favorable a las nuevas élites que crecían en una sociedad que se había vuelto de repente materialista y semiopulenta, pero que seguía sometida a la represión política. España, que no tuvo nunca una intelectualidad marxista importante durante la generación revolucionaria de los años treinta, empezó a adquirir una de segunda mano al final de los sesenta." 849

Los efectos de esas transformaciones se hicieron sentir con fuerza en la Iglesia española, que estaba además afectada por la crisis cultural y religiosa que se originó en torno al Concilio Vaticano II, especialmente aguda entre el clero850. De ahí arrancaba en parte una

849PAYNE, Stanley G., El régimen..., págs. 539-540. Como una confirmación de las tesis de Payne, puede verse el testimonio personal de Francisco FERNÁNDEZ BUEY, en "Estudiantes y profesores universitarios contra Franco. De los sindicatos democráticos estudiantiles al movimiento de profesores no numerarios (1966-1975)", en La Universidad española bajo el régimen de Franco (1939-1975), Juan José CARRERAS ARES, Miguel Ángel RUIZ CARNICER (editores), Institución Fernando el Católico, Zaragoza, 1991, págs. 476-477.

850 "La primera víctima de esta transformación [del desarrollo económico] no fue el régimen, sino su principal apoyo cultural, la religión tradicional. Una España altamente urbana, sofisticada, materialista, nominalmente educada y hedonista, cada vez más inclinada hacia el tipo de vida secular y consumista de Europa occidental, dejó simplemente de ser católica en la manera tradicional. Aunque la mayoría de los españoles no rechazaron su identidad religiosa, ya no se identificaban con los valores $y$ prácticas tradicionales de la 
corriente que tendía a criticar la postura institucional de la Iglesia, y a sugerirle que transformara su actividad y enseñanzas en un programa de promoción humana, a ser posible dentro de la ortodoxia de la izquierda marxista, que era -según este sector- el camino de la salvación o poco menos. De todo este fenómeno parece interesante resaltar más que su contenido -por interesante que seaotra cuestión: de nuevo se establecía que la opción política de unos cuantos católicos debía ser vinculante para la Iglesia en su conjunto. Es decir, el viejo esquema clerical, que podía parecer debilitado a la luz de los comportamientos que más arriba describimos, demostraba estar bien vivo.

Pero, además, este tipo de planteamiento tenía unas serias implicaciones doctrinales: si lo aceptaba, la Iglesia debía rectificar sus repetidas condenas de las

religión per se." PAYNE, El régimen..., pág. 511. La crisis de transformación tenía también manifestaciones importantes entre el clero: "Sin embargo, el decenio de 1950, que presenció el cenit del neocatolicismo, reveló también los primeros indicios de un nuevo descenso de la devoción religiosa. Algunos indicadores de actividad religiosa habían comenzado a decrecer a fines de los cuarenta. En número de seminaristas permaneció alrededor de los 8.000 de 1951 a 1965, pero el total anual de nuevas ordenaciones empezó a descender lentamente a partir de 1956, aunque el número de sacerdotes alcanzó su máximo, para la España contemporánea, en 1963, con 34.374 (contando el clero regular en funciones de sacerdotes). En las tres principales ciudades "rojas" -Madrid, Barcelona y Valencia-, donde era mayor la necesidad de la labor misionera urbana, el número de sacerdotes aumentó en más del 10\% en los años cincuenta, pero en 1960 no había alcanzado todavía el nivel de 1931. Si bien muchos no veían claramente esto, a la sazón, la sociedad urbana, industrial y consumista de los cincuenta estaba inaugurando una nueva fase de secularización. Esta "sociedad del desarrollo" no alimentaba tantas vocaciones religiosas como la de los cuarenta. La respuesta a las misiones populares declinaba asimismo, y se emprendían menos misiones nuevas, ni siquiera de un modo más modesto y con menos intrusión pública." PAYNE, Stanley G. , El catolicismo..., págs. 237-238. 
doctrinas marxistas para aplaudirlas en esta nueva etapa de su historia. La confusión que genera este planteamiento resulta clara: si se parte del a priori de que el magisterio de la Iglesia debe ser reformado -para hacerlo coincidir con las posturas de estos grupos-, cualquier alusión a él puede ser fácilmente interpretada como maniobras de los "inmovilistas" en su oposición a los "progresistas".

Todo esto hacía que en la cuestión de los medios de prensa católicos se planteara un nuevo problema: el de la falta de unidad. Así lo expresaba Ramón Cunill en su lección de apertura de curso de la Escuela de Periodismo de la Iglesia en 1966:

"Quizá lo que más debe preocupar al informador [católico] en estas horas es el valor social y cristiano de la unidad, la unidad real y la aparente, porque no sólo tenemos el deber de estar unidos, sino de parecerlo.

"(...) La opinión pública en la Iglesia es, según decía Pablo VI "Diálogo entre los miembros de una comunidad en la cual la caridad es el principio constitutivo", por ello tal diálogo jamás debe eludir la práctica de la virtud de la obediencia en un lugar donde el ejercicio de la función propia de la autoridad por un lado $y$ el de la sumisión por otro, vienen reclamados tanto por el orden de una bien compuesta sociedad como por la constitución jerárquica de la Iglesia (...).

"En todos los periodos históricos de renovación se llega fácilmente a lo que el $\mathrm{P}$. de Lubac, en su libro Paradoxes, llama la "pasión reformista", que -son palabras textuales"está en la Iglesia generalmente en proporción inversa a la vida sobrenatural, y por esta razón nunca proceden de aquella pasión las auténticas bienhechoras reformas." 851

Diario Regional se ocupó más de una vez de estas cuestiones, y siempre en la misma línea: no cabía hablar

${ }^{851}$ CUNILL, Ramón, op. cit., págs. 15, 26-27 y 28 . 
más que de una Iglesia, y el respeto al magisterio era el presupuesto básico para la existencia de una opinión pública dentro de ella. Lo contrario no significaría más que sustituir la doctrina católica por las que cada uno quisiera imponer:

"Amor, comprensión, respeto para la opinión ajena, incluso para el error -tratando de hacerle ver al equivocado su postura falsa-, sí, pero sin ceder en la doctrina, porque es de justicia transmitirla intacta, de forma que los demás tengan acceso favorable a su fin." 852

"Pero últimamente le están saliendo muchos espontáneos doctores a la Iglesia, muchos jovencitos dogmatizadores desde su pretendida ortodoxia cristiano-social, definidores por sí y ante sí sin más garantía de acierto que su audacia, ni más profundidad en su conocimiento que cuatro lecturas mal digeridas $-y$ no precisamente de textos evangélicos, sino de ensayos de heterodoxos y textos de quasi-marxistas, progresistas y muchos análogos etcéteras-, sin más experiencia que su insensatez, ni más autoridad para interpretar y definir que su deseo de sembrar la confusión y hacernos tontos a quienes, gracias a Dios, tenemos buena nariz para oler lo que huele mal. (...)

"A estos "intérpretes" de la doctrina de la Iglesia, que se arrogan el derecho de acertar siempre, les parece que comunismo y cristianismo tienen mucho en común y por eso les revienta que se descubra el juego de quienes quieren aprovecharse de la doctrina sana para sembrar la cizaña."853

852 "Sin esconder la mano. La verdad es la verdad", por Manuel Fernández Areal, DR, 29/4/1962, pág. 1. Cfr. también "Sin esconder la mano. Aviso para navegantes", DR, 4/4/1962, que comenta una pastoral de los obispos de Centroamérica y Panamá sobre la penetración del comunismo en ambientes cristianos; "Sin esconder la mano. Sinceridad", DR, 8/4/1962, que impugna a los que defienden el divorcio y similares y no quieren dejar de llamarse católicos; "Sin esconder la mano. Ciertas uniones", DR, 9/5/1962, pág. 1: "A un católico le está prohibido colaborar, secundar los programas de actuación comunista, porque el comunismo es una doctrina errónea, negativa, de odio."; "Sin esconder la mano. Aclarandon, DR, 24/5/1962, pág. 1: justicia social no es lo mismo que clasismo a favor de los trabajadores, o promoción de la lucha de clases.

853 "Sin esconder la mano. Juegos de palabras", por Manuel Fernández Areal, DR, 12/6/1962, pág. 1. Cfr. también "Sin esconder la mano. Confusionismo", DR, 20/10/1962, pág. 1: sobre los que critican a la Iglesia de forma desmedida y pretenden que los alaben por servirla; "Sin esconder la mano. Sin confundirse", DR, 20/6/1962, pág. 1: el comunismo -decía el autor del fondo- es algo más que un partido 
Para algunos, sobre todo para los autodenominados "progresistas", esto significaba la identificación del periódico con la línea "tradicional" o "retrógrada", como también se decía. De ahí a la identificación del medio como característico de un Opus Dei inmovilista, no hay prácticamente distancia alguna. La presencia de miembros de la Obra en algunos ministerios venía además como anillo al dedo para quienes quisieran identificar franquismo y catolicismo "tradicional", frente al "renovador" y antifranquista. Por otro lado, una reciente campaña de la prensa del Movimiento reforzaba esa implicación del Instituto en las actividades de sus socios ${ }^{854}$. Las continuas aclaraciones de distintos miembros del Opus Dei, afirmando que si estaban en un cargo u otro no era sino a título personal, que libremente actuaban y personalmente respondían de sus actos, y que por tanto no era justo involucrar a la Obra en sus asuntos, quedaban para quien quisiera oirlas ${ }^{855}$

político, es una filosofía incompatible con el cristianismo "y trata de convertirse en una mística con falsos planteamientos".

854Cfr. PAYNE, El régimen..., págs. 544-545. La campaña motivó una carta del fundador al Ministro Solís en que defendía la libertad de los miembros de la obra para actuar en política como quisieran, sin implicar por ello en modo alguno a la institución. Ha sido publicada en ROMERO, Emilio, Papeles reservados, (Vol. II), Plaza \& Janés, Barcelona, 1986, págs. 159-162. Cfr. también GómEz PÉREZ, Rafael, El franquismo..., págs. 254-256.

${ }^{855}$ Cfr. entre otros los siguientes artículos sobre la cuestión publicados en DR: "Cuestiones de actualidad. El Opus Dei y la política» por Julián HERRANZ, 21, 23, 24 y 25/4/1957, pág. 3; "El Opus Dei", serie de artículos del mismo autor, tomado de La Vanguardia de Barcelona, 29/6/1962, pág. 3, id pág. 9-10: "Los miembros del Instituto no llevan hábito porque no son religiosos"; 1/7/1962, "No hay fines políticos, sólo espirituales. El Opus Dei no responde de las 
Era una notable paradoja. Los que se habían caracterizado por su talante renovador en el ejercicio de la profesión, rompiendo con viejos esquemas $y$ adelantándose a las declaraciones de la jerarquía en la avaloración de la libertad, eran tildados ahora de retrógrados, y tenían que defender su independencia en cuestiones profesionales, que era puesta continuamente en entredicho. Se trataba de una batalla que no iba a terminar pronto. De hecho, la mayor parte de los que vivieron esa época recuerdan Diario Regional como "un periódico del opus", salvo los que pertenecen a esa organización. A éstos les resultan molestos los modos de decir que puedan significar que la Obra intervenía en el gobierno de la publicación. Por otro lado, cuando se pregunta a los que no pertenecen a la actual Prelatura si la Obra ejercía algún tipo de influencias o presiones en su trabajo, o en la orientación del periódico, la respuesta es siempre negativa856.

actividades, privadas o públicas de sus socios"; 3/7/1962, "Libertad profesional y política de todos y cada uno de los miembros"; 4/7/1962 "Hombres y mujeres de todos los sectores de la sociedad y de todas las profesiones. (...) El porqué de ciertas falsedades y calumnias. Es un fenómeno que por su novedad resulta difícil de comprender, y más por aquellos que no son católicos o son francamente anticatólicos."; "El Opus Dei está al margen de la política" Carta de A. ULLASTRES al New York Times, DR, 4/2/1964, pág. 20, últ.; "El Opus Dei es una realidad espiritual universal. No puede ser contemplada desde un punto de vista político" 7/2/1964, pág. 1; "El Opus Dei es una realidad exclusivamente espiritual", tomado de La Actualidad Española, contesta al difundido editorial de Pueblo, 31/3/1964; "El Opus Dei y la política" por Antonio HERRERO LOSADA, 21/10/1965, pág. 3 .

${ }^{856} \mathrm{Es}$ el caso por ejemplo de Fernando de la Torre, Mạ Aurora Viloria, o Germán Losada. 
Dejando a un lado intenciones menos rectas, cabe explicar esto en función diferentes factores. Algunos se han ido apuntando ya. Resta otro que nos parece de interés para nuestra historia, y que podríamos denominar la inercia de las mentalidades. Como apuntamos al hablar de la empresa, los miembros del Opus Dei que protagonizaron estos hechos, se veían comprometidos por una mentalidad que no era la suya: la que interpretaba cualquier actividad de un católico como actividad oficial de la Iglesia o de alguna de sus instituciones. El modelo tradicional de prensa católica era probablemente uno de los más confusos en este sentido, y la sucesión de miembros de la obra en la dirección del periódico y su presencia numerosa en los consejos de administración, no contribuían en absoluto a clarificar las cosas. Al contrario, aunque no gustara que así fuera, ayudaban a hacer pensar que todo seguía como antes, sólo que con el Opus Dei como protagonista.

Probablemente el modelo de prensa católica anterior, del que eran herederos, no les ayudó nada en su tarea de cambiar el periódico. Pero es que un cambio de ese calado requiere tiempo. Es ley histórica: no se cambian en pocos años las mentalidades colectivas. 


\section{Debilitamiento, enajenación, y muerte de un diario.}

«El Ilmo. Sr. Director General de Prensa conoce los pormenores de la situación crítica por que atravesamos, que de no superarse ha de determinar el cierre y suspensión del periódico.»

Carta del gerente de «Diario Regional, S.A.» al delegado provincial del Ministerio de Información, de 30 de julio de 1970.

«Mañana inaugura
nuestro periódico,
que es también
el suyo,
una nueva andadura
en el mundo
de la prensa
de Valladolid»

«A sus manos ha llegado un nuevo

DIARIO REGIONAL en el que notará cambios de forma y contenido.»

Diario Regional, 15.III.1975

\author{
Diario Regional. \\ Independiente \\ castellano, \\ 9.X.1977.
}

\author{
«Gracias «Un grupo, pues, \\ muy sinceras de profesionales \\ a la acogida que \\ ayer dispensaron \\ nuestros lectores \\ a la nueva etapa de \\ EL DIARIO» \\ del mundo \\ de la información \\ se ha hecho cargo \\ de DIARIO \\ REGIONAL.» \\ El diario. Regional, \\ libre e \\ independiente, \\ 16.XI.1978.
Diario Regional, 24.X.1979


Siglas PARA UnA CRISIS: DE "S.A.R.P.E." A "P.E.S.A.", Y DE "P.E.S.A." A "CINISA"

Pesaba una maldición económica sobre el viejo modelo de prensa católica. Aunque algunos teóricos lo habían advertido, casi nadie quería saber que la modernización económica del país haría sonar también la hora de la verdad para esos medios, mitad informativos mitad benéficos. Pero los veredictos condenatorios de las leyes del mercado son implacables, moralmente ciegos, y no reparan en idearios ${ }^{857}$.

La historia de "Diario Regional, S.A." a finales de los sesenta y en los primeros años setenta cabe resumirla como la constatación una inviabilidad empresarial, que tuvo por protagonistas a tres empresas distintas: un baile de siglas para llegar a una sola conclusión. No obstante, es preciso señalar que hay una doble causa para los cambios de titularidad en los propietarios de las acciones

857 "Las ideas y las informaciones tendrán perdurabilidad en la medida en que la empresa esté fundamentada sobre sólidas bases económicas." "En no pocas ocasiones se ha afirmado que la empresa periodística, por su naturaleza específica y propia, es siempre una empresa económicamente deficitaria. Y esta afirmación suele venir avalada por razonamientos de índole intelectual o de carácter espiritual. Sin embargo, después de analizar algunos supuestos en los que se invocan esos nobles principios, se puede observar que los razonamientos y la remisión a fines superiores a los meramente mercantiles sólo pretenden, en definitiva, justificar planteamientos iniciales utópicos, realizaciones empresariales que desconocen los más elementales criterios económicos 0 , lo que no es infrecuente, la aplicación de principios y estructuras puramente comerciales bancarias, etc.- al ámbito de la prensa." NIETO TAMARGo, Alfonso, La empresa..., págs. 10 y 16 . 
de "Diario Regional, S.A.": por un lado la difícil situación económica de la sociedad, y por otro, la progresiva diversificación empresarial de sus propietarios.

Señalamos en el capítulo anterior que la concentración de miembros del Opus Dei en una determinada empresa de prensa era, desde comienzos de los sesenta, un efecto no deseado de lo que había sido en un principio S.A.R.P.E.. Con el paso de los años, la independencia con que actuaban los propietarios de la empresa -fueran o no del Opus Dei- iba a poner de manifiesto lo que significaba el abandono de hecho del modelo de prensa católica tradicional. Es propio de la vida de las empresas su transformación en función de las distintas coyunturas económicas y de la estrategia seguida por sus directivos. Eso acaba por generar rupturas en el seno de unas, creación de otras, fusiones, y desapariciones. A finales de los sesenta lo que había sido un grupo de empresarios más o menos homogéneo -S.A.R.P.E.- comenzó a desmembrarse. Nació en primer lugar Prensa y Ediciones Sociedad Anónima, P.E.S.A. -inicialmente P.U.S.A.-, en torno a El Alcázar, con la intención de hacer del periódico un medio aperturista y monárquico. Antonio Alférez señala entre sus principales promotores -casi todos ellos jóvenes- a Pablo Bofill, José Juan Cebrián, Carlos Soria, Esteban Morán 
Merino, y Florentino Pérez Embid858. Junto a El Alcázar, la empresa lanzó Nuevo Diario en 1967, otro periódico con el mismo talante, que se trataba de orientar especialmente hacia el mundo universitario. Cuando Fraga cerró El Alcázar de P.E.S.A., el grueso de los redactores de éste pasó a Nuevo Diario que se convirtió así en el buque insignia de la cadena ${ }^{859}$.

La historia de este periódico estuvo sembrada de dificultades, y precisamente cuando arreciaban éstas, fue el momento en que Diario Regional vio unidos sus destinos a los del colega madrileño. La conexión entre los dos databa de los tiempos de Tallón, pero no se consolidó en lo empresarial hasta marzo de 1970, fecha en que P.E.S.A. pasó a ser propietaria de las acciones de "Diario Regional, S.A." que hasta entonces habían sido de S.A.R.P.E.860. Casi inmediatamente -en junio de 1970- se

${ }^{858}$ ALFÉREZ, Antonio, Cuarto poder..., pág. 127.

${ }^{859}$ Fraga retiró a P.E.S.A. el permiso para usufructuar la cabecera de El Alcázar el 28 de septiembre de 1978, un día después de que José Luis Cebrián se hubiera reincorporado a la dirección del rotativo tras una corta estancia al frente de Nuevo Diario. El Tribunal Supremo dictó sentencia un año después contra la medida del Gobierno, pero P.E.S.A. nunca volvió a publicar El Alcázar. El periódico vespertino, que había alcanzado una tirada de 150.000 ejemplares con Cebrián y Apostua, recuperó la laureada en su cabecera, y perdió en un año 140.000 lectores. Cfr. ALFÉREZ, op. cit., págs. 130-133. Cfr. también las informaciones publicadas por DR, que dedicó frecuentemente espacio a informar sobre P.E.S.A. y el conflicto de El Alcázar, tomado de Nuevo Diario, DR, 3/10/1968, pág. 13.

${ }^{860}$ Con fecha $31 / 3 / 1970$, se transmitieron 7.335 acciones, de 500 ptas. cada una, y 735 acciones de 100 ptas. cada una (total, 3.741.000 ptas), de titulares de la Sociedad Anónima de Revistas, Periódicos y Ediciones (S.A.R.P.E.), a la empresa Prensa y Ediciones Sociedad Anónima (P.E.S.A.). Hojas 1 y 2 del oficio de la Dirección General de Prensa, Sección Empresas al consejero delegado de "Diario Regional, 
declaró una crisis que estuvo a punto de acabar con Diario Regional.

El informe del Consejo de Administración con motivo de esa situación pintaba con tintes sombríos la historia económica de la empresa:

"Durante los 62 años de vida del periódico, su explotación ha sido prácticamente deficitaria, -con la excepción de tres años de pequeños beneficios- $y$ su mantenimiento ha sido posible gracias al apoyo de personas interesadas en su supervivencia.

"En los últimos cinco años, se incrementa notablemente el déficit de la explotación, lo que lleva consigo el llegar a una situación insostenible, ya que el afianzamiento financiero prestado a Diario Regional por Consejeros, colaboradores y simpatizantes del mismo ha desbordado sus posibilidades personales.

"Confirmando esta realidad, se declara que los créditos avalados personalmente llegan a la cifra de 6.658.000,00 pesetas.

"Por una serie de hechos y circunstancias (...) se ha hecho imposible que P.E.S.A. preste la ayuda y colaboración que se deriva de su condición de accionista mayoritario." 861

Es un buen resumen del efecto que la liberalización del mercado editorial, y el crecimiento económico general, estaban produciendo sobre una empresa que necesitaba de comportamientos benéficos, de desinteresados donativos, para mantenerse862. Germán Losada recuerda que por aquellos

S.A." de 22 de febrero de 1972 comunicando la inscripción 2 a en el folio 247, tomo 27 del Registro de Empresas Periodísticas. A.H.P.U.V., Sección Cultura, caja 28.

861 "Informe explicativo que presenta el Consejo de Administración de Diario Regional, S.A.", de 6 de junio de 1970. A.H.P.U.V., Sección Cultura, caja 28 .

${ }^{862}$ La Orden Ministerial (Ministerio de Información y Turismo) de 13 de diciembre de 1967 estableció que se debían mantener durante un año, a contar desde el 18 de noviembre de 1967, las tarifas publicitarias de la prensa, radio, televisión, cine y demás medios publicitarios. En mayo de 1970 se liberalizaron totalmente las tarifas de publicidad. Sobre este punto puede verse el Boletín de las Cortes Españolas, 
años no era raro que se acudiera a Arturo León -el secretario del consejo de administración- para conseguir pagar las nóminas, ya que no había liquidez en las arcas de la empresa. León buscaba los apoyos económicos necesarios y se salía del apuro por el momento863.

Esa situación de debilidad económica crónica había tratado de paliarse con la entrada de P.E.S.A. como accionista mayoritario, pero la nueva empresa no había conseguido el milagro. El periódico estaba al borde de la tumba en el verano de 1970 .

"Las previsiones con base en la colaboración de Prensa y Ediciones, S.A. (P.E.S.A.) han fracasado. (...) la vida del periódico se extingue por horas, por días, por muy pocos días. " 864

No era la primera vez que ocurría algo así, y el remedio se buscaba ahora en la ayuda del Estado. Al fin y al cabo, a eso estaban acostumbrados los periódicos -y otras empresas- después de años de proteccionismo económico.

Con fecha 30 de julio había papel para sacar el periódico cinco días más, y no había dinero para adquirir nuevas remesas. El informe remitido por el gerente -José

27/2/1971, pág. 27.747. Cfr. NIETO TAMARGo, op. cit., pág. 155, nota 58 .

${ }^{863}$ Entrevista con Germán Losada.

${ }^{864}$ Carta del gerente de "Diario Regional, S.A.", José Ramón Abril Martín, al delegado provincial del Ministerio de Información y Turismo, Carlos Sánchez Álvarez, de fecha 26/6/1970. A.H.P.U.V., Sección Cultura, caja 28. 
Ramón Abril Martín- al delegado provincial del Ministerio -Carlos Sánchez Álvarez- volvía a poner sobre el tapete la "única solución" que se veía como salida ante la inminencia del cierre: la ayuda estatal. Se solicitaba un adelanto en el pago de la publicidad institucional, como forma de sobrellevar este verano de infarto. En la base del problema estaba el cambio que se había operado en la modalidad de subvención del Estado a la prensa: en mayo de 1970, al tiempo que se liberalizaban las tarifas de publicidad, del canon de papel se había pasado al pago por publicidad institucional publicada en cada medio. Eso suponía que desde entonces los más débiles cobraban menos. Se había acabado la beneficencia estatal con los medios, y las normas del mercado estaban empezando a golpear duramente a los modestos 865 .

${ }^{865}$ Cfr. DR, 9/5/1970, "Posición ante el plan sobre la prensa", editorial, pág. 13; y carta del gerente del periódico al delegado provincial de fecha 30/7/1970, en A.H.P.U.V., Ibid.. El delegado provincial hacía un resumen de las causas de la crisis, apuntando lo siguiente:

"La crisis avícola desencadenada en la primavera por la quiebra de "Mirapinos, S.A."; algunos de los miembros del Consejo de Administración son igualmente empresarios avicultores y se vieron alcanzados por la citada crisis, debiendo desentenderse de la atención económica que dedicaban a "Diario Regional".

"Las bajas tiradas características de los meses de junio, julio y agosto, con la consiguiente reducción de los ingresos por publicidad.

"Deudas: la presión bancaria sobre la normalización de un pasivo vencido de 12.479 .743 pesetas."

"Informe sobre "Diario Regional"", del delegado provincial al director general de Prensa, de fecha 26 de octubre de 1970. A.H.P.U.V., Sección Cultura, caja 28. 
El delegado provincial informó de la crisis al director general de Prensa866, y la ayuda oficial -550.000 ptas. con cargo al sistema de publicidad de interés general- llegó a finales de agosto. Resultó vital, pero no fue la única recibida, ni la más cuantiosa: P.E.S.A. corrió con la parte más importante de las mismas, mediante un préstamo de 2.500 .000 ptas. concedido en el mes de julio. Esa inyección de numerario permitió que el periódico llegara hasta el mes de septiembre, en el que se celebran las fiestas de la ciudad y la "Feria de Muestras"; un buen momento para la publicidad, que aportó un nuevo respiro al agónico rotativo867.

Pero esa momentánea salvación no significaba ni mucho menos el fin de los problemas: aunque se habían normalizado los intereses vencidos que estaban impagados en verano, las deudas seguían sin amortizarse; la papelera que abastecía al periódico se negaba a suministrar más papel si no se le pagaba el que ya se le debía; el personal no había cobrado la paga de beneficios correspondiente al ejercicio de 1969, y eso cuando debía librarse ya la de 1970. Esto último significaba una

${ }^{866}$ Copia del télex en A.G.A., Sección Cultura, caja 39.129. En este documento se detallan la cuantía de los intereses impagados y el último plazo dado por las Cajas de Ahorro de Salamanca y Provincial de Valladolid para efectuar ese pago: el 31 de julio de 1970. En A.H.P.U.V., Sección Cultura, caja 28, pueden verse las copias de las cartas de las entidades crediticias que apremian al pago de esos intereses, de fechas 10 y 23 de julio de 1970 .

${ }^{867}$ Cfr. el citado "Informe sobre "Diario Regional"", de fecha 26 de octubre de 1970 . 
amenaza continua de huelga, que podía conseguir lo que no conseguían los acreedores: que el periódico no saliera. Y si no salía unos días, la falta de publicidad impediría pagar nada en absoluto de lo que se debía. En resumen, una precaria situación que podía provocar una sucesión de desastres en cascada, que en otoño seguían amenazando con acabar con el diario. Ahora todo el afán era llegar a Navidad, la siguiente etapa dorada de la publicidad.

Ante semejante estado de cosas, la gerencia no podía esperar más que soluciones ajenas a la empresa, concretamente del accionista mayoritario, P.E.S.A., que a su vez se enfrentaba con serios problemas en Nuevo Diario. Así lo comunicaba el delegado provincial al director general de Prensa en un informe sobre Diario Regional :

"Parece ser que durante la semana pasada, el gerente de P.E.S.A., D. José Luis Marín, aseguró al de "Diario Regional" que la marcha de las negociaciones permitía presumir que a fines del presente mes se consumase la transmisión de aquel periódico a otra empresa; entonces, PESA podría dedicar toda su atención a "Diario Regional", que quedaría como cabeza de serie de su cadena.

"En el caso de que aquella transmisión se efectuase, cabrían varias posibilidades en torno a la actitud que PESA (accionista mayoritario) adoptase respecto a "Diario Regional":

"1․- Venta de las acciones que posee de "Diario Regional" y que la califican como socio mayoritario.

"20.- Dedicar atención preferente a "Diario Regional", reforzándolo económicamente, reestructurándolo y promocionándolo dentro de la región castellana, a fin de que cumpla el objetivo que encierra el título de la publicación. "3․- La gerencia de "Diario Regional" teme que el proyecto de P.E.S.A. sea la transferencia de la rotativa a León (para el "Diario de León"), y que la impresión de la publicación se traslade a Madrid, si bien manteniendo un ligero servicio de redacción y administración en Valladolid, de manera que el diario no perdería una cierta significación 
Debilitamiento, enajenación, y muerte de un diario

localista. Naturalmente, esta solución plantearía grandes problemas de tipo laboral y administrativo."868

Los titubeos de P.E.S.A., motivados en parte por las presiones que el Gobierno ejercía sobre la empresa, terminaron por hacer que ésta vendiera Nuevo Diario, pero también que abandonara Diario Regional. En el fondo se trataba de una crisis de orientación tanto ideológica como económica, que provocaba una nueva escisión en lo que había sido la empresa869. Juan Pablo de Villanueva, director de Nuevo Diario hasta su cambio de orientación, emprendió una serie de iniciativas que trataban de dar salida a los periodistas que tampoco habían querido seguir en el diario madrileño tras la venta870. A ese grupo estaban vinculados los que se hicieron cargo de Diario Regional en mayo de 1971: la "Corporación de Inversiones Industriales, S.A.", CINISA ${ }^{871}$. La nueva empresa era

${ }^{868}$ Ibid.

869 "En 1969, cuando el "Gobierno monocolor" de tecnócratas -muchos de ellos miembros del Opus Dei-, hubo presiones sobre "P.E.S.A." para que silenciara su actitud crítica y la empresa editora acabó vendiendo Nuevo Diario a "Prensa Económica S.A.", que contaba con el respaldo financiero de la familia Oriol. Juan Pablo de Villanueva no aceptó dirigir un diario con las alas recortadas y fue nombrado director Salvador López de la Torre (...)." ALFÉREZ, A., op. Cit., págs. 88-89

870 "Juan Pablo de Villanueva (...) puso en marcha una serie de proyectos autogestionarios, en compañía de otros "damnificados" de Nuevo Diario: Juan Kindelán, Sucre Alcalá, Ramón Pi, Nicolás de Laurentis, Luis Infante y José María García Hoz. Crearon Informe Diario (una especie de boletín de recortes y resúmenes de prensa); Flash (Agencia de relaciones públicas); "Novo Press", que se convertiría en "Multipress", agencia de colaboraciones; y entrarían a formar parte del equipo direccional de El sol de Málaga." Ibid., pág. 155.

${ }^{871} \mathrm{La}$ operación consistió en la transmisión de 7.335 acciones (de 500 pts. cada una) y 735 (de 100 pts. cada una), de "Diario Regional S.A.", por parte de sus titulares la Compañía Mercantil P.E.S.A. a la Sociedad de Corporación de Inversiones Industriales, S.A. (CINISA). En 
propietaria también de la mayoría de las acciones de las editoras de El Diario de Ávila y del Diario de León 872, lo que parecía indicar que se concebía como el instrumento para crear una prensa regional en Castilla.

Al menos, esos parecían ser sus designios, a tenor de lo que se trató en la junta general de accionistas inmediatamente posterior a la compra. El delegado provincial se lo resumía así al entonces director general de Prensa, Alejandro Fernández Sordo:

"Otros asuntos tratados en la misma sesión han sido los siguientes: 1) presentación de un proyecto de revitalización del diario, dándole un auténtico matiz y difusión regional, en Avila y León se mantendría un servicio local mediante los oportunos encartes de las páginas de este tipo. El centro de la redacción del diario permanecería en Valladolid. A estos efectos se han contratado ya los servicios de distribución con la empresa "Distribuidora Vallisoletana". Dentro de esta línea estaría el intensificar la diversificación del contenido de Diario Regional respecto de otras publicaciones existentes en esta misma zona, tratando con ello de ampliar el ámbito de su audiencia, para captar un tipo de lector que quizás no encuentre en el mercado periodístico actual un producto adecuado a sus apetencias (sector juvenil fundamentalmente).

"2) El principal obstáculo que se opone a la inmediata puesta en marcha de este plan es el endeudamiento de Diario Regional, S.A. que en estos momentos asciende a veintidós

el momento de la compra de las acciones de "Diario Regional, S.A.", los accionistas de CINISA, y la distribución entre los mismos del capital social de la empresa eran:
Da . María Gambarte Senosiain....5.050.000
D. Javier Rico Gambarte..........50.000
D. Álvaro de Toro Moreno..........50.000
D. José Ródenas Moreno.........2.500.000

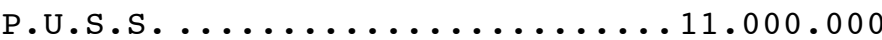
D. José Ferrer Bomsons .........12.750.000
D. Guillermo Bañares Martí.......500.000

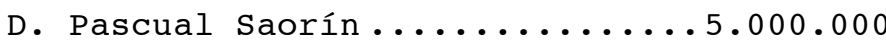
Caja lab. pop. de Mondragón.....3.000.000

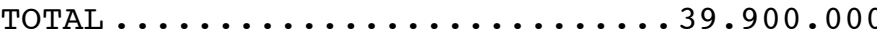

Cfr. A.H.P.U.V., Sección Cultura, caja 28.

${ }^{872}$ CINISA era propietaria del 51,333\% del capital social de "La Editorial Católica Abulense, S.A.", editora de El Diario de Ávila, y del 58\% del capital de "Diario de León, S.A.". Cfr. NIETO TAMARGO, op. cit., págs. 75 y 76 . 
millones de pesetas. Por ello, es más que probable que por parte de los nuevos directivos, trate de gestionarse cerca de esa Dirección General la concesión de un préstamo que le permita cubrir parte de sus compromisos más apremiantes (...).

"La crisis de publicidad que viene afectando a los diarios de esta capital, gravita por supuesto también sobre Diario Regional mermando las posibilidades de realización del plan de relanzamiento antes citado. Sin embargo, últimamente hay signos de una débil revitalización, que se espera continúe a ritmo creciente. Por otra parte, la empresa ha entrado en contacto con empresas publicitarias de dimensión nacional habiéndose asegurado su participación en las campañas previstas por las mismas a partir del próximo otoño. Por ello, en la dirección de Diario Regional, S.A. son optimistas en el sentido de estimar que a partir del próximo mes de septiembre comience a equilibrarse progresivamente el binomio costeingresos. Dicho binomio ha arrojado en el pasado mes de abril, a título de ejemplo, un déficit de trescientas mil pesetas" 873

El encargado de poner por obra todos esos proyectos era el nuevo presidente del consejo de administración, Emilio Fernández de Caso874, del que Fernández Sordo se apresuró a pedir informes a su delegado vallisoletano, lo mismo que del resto de los nuevos miembros del consejo. El delegado se los remitió después de enviarle una carta explicativa que dice algo sobre las trastiendas del aparato estatal875. Como ya adelantamos, los nuevos

873 Informe por teletipo del delegado provincial del M.I.T. al Director General del Prensa de 2 de junio de 1971, en A.H.P.U.V., Sección Cultura, caja 28.

${ }^{874}$ Entrevistas con Luis Conde Pardo y Arturo León Álvarez. Cfr. también, el informe por teletipo del delegado provincial del M.I.T. al director general de Prensa de 2 de junio de 1971, en A.H.P.U.V., Sección Cultura, caja 28, en el que se lee: "El Consejo de Administración de Diario Regional, S.A., queda reducido a cinco miembros, mínimo autorizado por la ley. No hay vicepresidente, por lo que los poderes quedan restringidos al presidente $y$ al consejerogerente. Al parecer, el presidente mantendrá un intenso contacto personal con el resto de los directivos, desplazándose a esta capital una vez por semana."

Puede verse la composición del consejo de administración en el apéndice 3 .

${ }^{875} \mathrm{En}$ carta de 11 de junio de 1971 el delegado vallisoletano le dirá: "Por supuesto, no he pretendido limitarme a los meros datos personales de los nuevos miembros del Consejo de Administración de "Diario 
consejeros procedían de P.E.S.A., residían en Madrid, y compartían sus tareas con Arturo León y José Ramón Abril Martín, que era también gerente de Diario Regional. Fernández de Caso, en concreto, era Catedrático excedente de Escuelas de Comercio y director general de "Movierecord, S.A."; era vocal del consejo de administración de "Diario Regional, S.A." desde 1966, había desempeñado el cargo de administrador del Diario de León, y puestos administrativos en S.A.R.P.E. y P.E.S.A..

La tarea del nuevo consejo no fue fácil. La redacción, como luego veremos, no estaba en uno de sus mejores momentos, y hacía falta tomar medidas serias si se quería revitalizar la empresa. En este sentido, el hombre clave resultó ser Luis Conde Pardo, el administrador del diario, que desde principios de 1972 se ocuparía -primero extraoficial y luego oficialmente- de la gerencia. Su labor de búsqueda de publicidad a base de promociones y de patear calles y establecimientos comerciales, ayudó a mejorar la situación económica, dentro siempre de la languidez característica de esta empresa, a la que no nos

Regional, S.A.", sino a los que era dable poseer en aquellos momentos en que con toda urgencia quise darte a conocer estas novedades. Dado que los nuevos miembros residen en Madrid, he interesado datos de la Jefatura Superior de Policía, que espero me remitan pronto. Por otra parte, es cierto que mantenemos buenas relaciones con el Gerente y Director de "Diario Regional", y a través de ellos en una primera toma de contacto conseguí los datos que te transmití, no habiendo creído aconsejable por el momento profundizar excesivamente en la cuestión, lo que haré a medida que se vayan presentando oportunidades sobre el caso". Una anotación a lápiz señala que "Se informó en carta posterior". A.H.P.U.V., Sección Cultura, caja 27. La reclamación de Fernández Sordo, fechada el 11 de junio de 1971 puede verse en la misma caja, y los informes sobre los consejeros -que recogemos a pie de página en el apéndice 3- en la caja 28. 
atrevemos a llamar negocio: mientras que las pérdidas acumuladas a 31 de diciembre de 1971 ascendían a 8.252.306,48 ptas.; del 1 al 30 de abril de 1972, las pérdidas habían sido de $42.154,72$ ptas. Dicho de otra forma, en un año, habían conseguido reducir las pérdidas en un 95\%. No se hacían ricos, pero algo parecía mejorar aquel eterno enfermo ${ }^{876}$.

En junio de 1972, la junta general de accionistas aprobó las medidas que proponía el consejo para normalizar la situación: se incorporó el saldo de la Cuenta de Regularización a las Cuentas de Capital y de la Reserva Legal previstas en la Ley de Sociedades Anónimas, y se sustrajo al capital social el monto total de pérdidas resultante -con lo que éste quedó reducido a 28.000 ptas.y el valor de las acciones decreció proporcionalmente. En el mismo momento, se aprobó una ampliación de capital por un total de 7 millones de pesetas: 17.500 nuevas acciones, serie $F$, de 400 pts. nominales cada una, que fueron adquiridas en su totalidad por CINISA $^{877}$.

876 "Escritura de incorporación del saldo de la Cuenta de Regularización de Balance al capital y reducción de capital social.otorgada por don Arturo León Alvarez ("Diario Regional, S.A.")", Notaría de D. Francisco Pastor Moreno, Valladolid, 20 de marzo de 1973, no 385. Archivo Privado Gráficas Andrés Martín, A.P.G.A.M.. Debemos la consulta de estos documentos a la amabilidad de D. José María Noriega. Para la comparación con las pérdidas del año anterior, cfr. el dato apuntado en el informe por teletipo del delegado provincial del M.I.T. al Director General del prensa de 2 de junio de 1971, anteriormente citado.

877 "Escritura de aumento de capital otorgada por D. Arturo León Alvarez ("Diario Regional, S.A.")", Notaría de D. Francisco Pastor Moreno, Valladolid, 20 de marzo de 1973, no 386. A.P.G.A.M.. 
Los ajustes empresariales se habían llevado por delante al director de Diario Regional, Tomás Santos Corchero, provocando algunas situaciones de tensión que más adelante detallaremos; habían hecho dimitir al antiguo gerente José Ramón Abril Martín, que no se entendía bien con Fernández de Caso878; estaban a punto de llevarse la maquinaria a Ávila; y hasta iban a terminar con criterios de larga tradición en el rotativo:

"En cuanto a la línea de actuación a seguir, se acordó una mayor apertura en todos los aspectos, incluso en el religioso y político, por estimar que esta nueva postura, está más en consonancia con los tiempos actuales e incluso resulta más rentable. En este sentido se ha acordado incluso rectificar la política seguida hasta el momento respecto a la publicidad, admitiendo anuncios en la cartelera de espectáculos, sin tener en cuenta la calificación religiosa de los mismo e incluso los de las salas especiales de Arte y Ensayo, que hasta el momento eran rechazados." 879

El mercado se había impuesto, definitivamente. Cosa distinta era que Diario Regional consiguiera imponerse en

Cfr. también el oficio de la Dirección General de Prensa, Sección empresas, a D. Luis Conde Pardo en representación de Diario Regional S.A., de fecha 9 de enero de 1974. Inscripción con el número 196, Tomo 27, Sección de Personas Jurídicas, al Folio 248 Inscripción 9a. A.H.P.U.V., Sección Cultura, caja 27; y Boletín Oficial del Estado, no 168, de 14/7/1972, pág. 12.746.

${ }^{878}$ Cfr. "Informe sobre "Diario Regional, S.A." , de fecha 18/11/1971, del delegado provincial al director general de Prensa. A.H.P.U.V., Sección Cultura, caja 27. El cese se produjo con fecha 24/1/1972, y se nombró para sustituirlo a Carlos Rodríguez Lafora, vocal del consejo de administración, nombramiento puramente teórico. En la práctica la gerencia estuvo desde entonces en manos de Luis Conde Pardo, al que más adelante se le atribuirían formalmente las funciones de gerencia. Cfr. inscripción en el Registro de Empresas Periodísticas, folio 248, Inscripción 5ạ, Tomo 27, comunicada en oficio de la Dirección General de Prensa, Sección Empresas al presidente del consejo de administración. A.H.P.U.V., ibid. Confirmamos y matizamos estos datos en la entrevista con Luis Conde Pardo.

879 "Informe sobre la junta general de "Diario Regional, S.A." , de fecha 15/6/1972, enviado al director general de Prensa por su delegado en Valladolid. A.H.P.U.V., Sección Cultura, caja 27. 
el mercado. Ese era el desafío que tenían por delante los nuevos gestores. Para enfrentarlo Luis Conde siguió con sus numerosas gestiones; se contrató un nuevo director, Esteban Greciet; y se llegó a inspeccionar el local que albergaría en Ávila la impresión de los tres diarios de la cadena. Se trataba de reestructurar completamente la empresa, centralizando allí o en Valladolid las redacciones, con delegaciones en las otras dos provincias donde se publicaban los periódicos ${ }^{880}$.

Pero si la gestión de Luis Conde permitió que la empresa no fuera un desbarajuste, la idea de Ávila se abandonó, y ni la dirección de Greciet, ni la política empresarial de esos años supusieron un éxito en las tiradas ${ }^{881}$. En 1974 se contrató a un nuevo director, Ignacio Bel, y Fernández de Caso dejó la presidencia del consejo de administración. Todo parece indicar que no había alcanzado las metas que se habían fijado. Detrás de estos sucesos estaba una vieja afirmación, repetida una y otra vez por quiénes se habían encargado de la gestión del diario: "esto no es viable" 882 .

A pesar de todo, se siguió adelante. En junio de 1974 se incorporaron tres nuevos consejeros, uno de los cuales

\footnotetext{
${ }^{880}$ Entrevista con Luis Conde Pardo.

${ }^{881}$ Cfr. más adelante notas 57 y 74 .

882Entrevista con Arturo León Álvarez.
} 
-el consejero delegado, Juan Pablo de Villanueva- tenía vitola de experto en empresas periodísticas y merecida fama de buen gestor, a la vez que de buen periodista ${ }^{883}$.

Los efectos de las iniciativas del nuevo equipo se mostraron a los vallisoletanos el 16 de marzo de 1975. Diario Regional salió ese día a la calle con una nueva fachada, merced a la completa transformación de la maquinaria del rotativo. El director, en el acto de presentación de los nuevos talleres, enumeraba orgulloso las mejoras introducidas, que iban desde el taller fotográfico a la composición, y culminaban con la nueva rotativa, que imprimía en ofsset con una calidad hasta entonces desconocida en la prensa vallisoletana ${ }^{884}$. Tecnológicamente Diario Regional era ahora el número uno de los diarios vallisoletanos, eso estaba fuera de toda duda.

${ }^{883} \mathrm{Cfr}$. en el apéndice 3 la relación completa de miembros del consejo.

${ }^{884}$ Se había procedido a la renovación completa de los talleres, y el periódico pasa a imprimirse en ofsset. El laboratorio cuenta con una cámara Kimsch autovertical, una cámara de vacío Vapuntfilt y una procesadora de Kodak para papel PMT. En la sección de composición se instalaron tres ordenadores electrónicos de la casa Compugraphic, dos de los cuales se alimentaban con cinta kilométrica perforada en teclados Datek 3000. Las platinas fueron sustituidas por mesas transvista de montaje, y para la consolación se instaló una prensa Combilux con luz de yodo. La rotativa es una Goss Community, que contaba con cinco cuerpos de impresión y un plegador modelo suburban de la misma casa. Podía imprimir periódicos de 40 páginas en blanco y negro o de 24 en color, a una velocidad de 20.000 ejemplares por hora. "Palabras del director de DIARIO REGIONAL, don Ignacio Bel", DR, 16/3/1975, pág. 17 
Poco más tarde, en junio, tuvo lugar otra ampliación de capital, esta vez de 56.224 .000 ptas. -56.224 acciones, serie G, de 1000 ptas. de valor nominal cada una- que respondía a la renovación de los equipos ${ }^{885}$. Quedaba así completado el saneamiento de la empresa, y se estaba en buenas condiciones de saber si aquello era o no viable, de una vez por todas. Parece que CINISA se puso un plazo para comprobarlo, y a la altura de 1977 la decisión estaba tomada: Diario Regional estaba en venta. A la vista de los datos sobre tiradas e ingresos por publicidad que tenemos, nada parece indicar que las cosas hubieran ido mucho peor en esos dos años de lo que habían ido antes, más bien da la impresión de que los empresarios estimaron que el esfuerzo por sacar adelante el periódico no valía la pena.

885 "Segunda copia de la escritura de aumento de capital social y modificación de los Estatutos de la Sociedad Mercantil Anónima "Diario Regional, Sociedad Anónima", otorgada por Don Arturo León Alvarez, como Presidente del Consejo de Administración", Ramón v. Modesto Chaumel, Notario, Valladolid, 26 de mayo de 1976 , no 618 . A.P.G.A.M.. Entrevista con Ramiro Nieto Bermejo. 
Tiradas mensuales

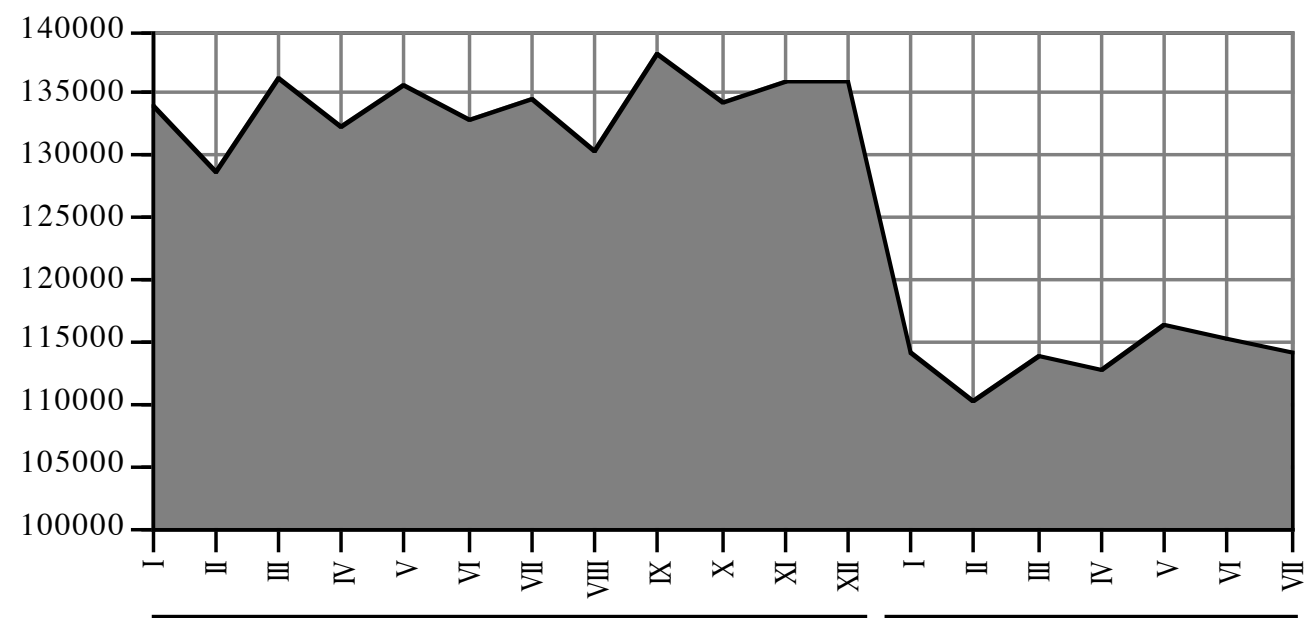

1976

1977

Gráfica 6: Tirada mensual de Diario Regional de enero de 1976 a julio de 1977. Fuente: "Partes de tirada mensuales" en A.P.G.A.M. y elaboración propia.

A la vista de los datos que se han conservado, parece que a principios de 1977 ya estaba tomada la decisión de cejar en el empeño por sacar adelante el periódico ${ }^{886}$.

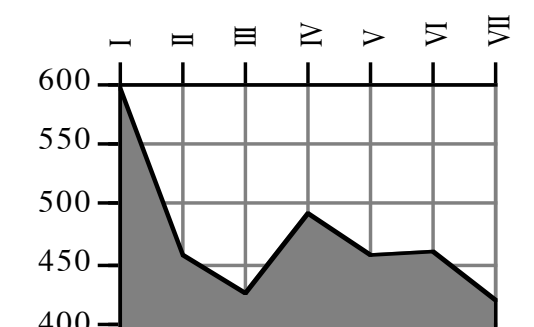
$400-$ $350-$ $300-$ $250-$

Gráfica 7.- Media diaria Ciertamente, eran significativas las de ventas de Diario cifras de ventas en la capital que en el primer semestre de 1977. Fuente: "Venta se manejaban: estaban -como media- local", ibid., y elaboración en torno a los 450 ejemplares

diarios. A eso había que sumar unos 1.000 suscriptores, y las ventas de la provincia -unos 500 ejemplares-, con 10

${ }^{886}$ Tomás de la Cruz, entonces vicepresidente de CINISA nos ha confirmado que así era: se había decidido reducir costes y comenzar las negociaciones para la venta. 
que cabe concluir que escasamente se superaba una difusión d e 2.000 ejemplares diarios de media887.

Se llegaba así al final de una etapa crucial en la vida del periódico; aquella en la que se había querido hacer un diario, si no confesional, sí de inspiración cristiana, sin escamotear las leyes del mercado con pretextos ideológicos. El resultado estaba a la vista: en opinión de los propietarios, no merecía la pena seguir adelante con aquella empresa. Los diversos intentos de transformar el periódico para hacerlo rentable o -al menos- no deficitario, no habían dado resultado sino en momentos muy concretos y breves. La razón última de esto debe buscarse en las características de la sociedad vallisoletana, y del mercado de prensa de la ciudad, para los que el producto ofrecido no tenía interés suficiente 888 . Y esto por varias razones, que podríamos esquematizar así:

1a) en general, a los españoles les interesan poco los diarios. Nuestros índices de lectura es sabido que son

887 "Partes de tirada mensuales" correspondientes a 1976 y 1977, y "Venta local" enero-julio de 1978, que incluyen datos comparativos con los mismos meses de 1977. A.P.G.A.M..

${ }^{888}$ En palabras de Horacio SÁENZ GUERRERO "Todo periódico es grande por unas razones que se conocen en teoría, aunque muchas veces se opere por instinto. Ha de merecer la confianza de la sociedad en que está inmerso. Un periódico que no sintonice con la sociedad a la que pertenece, que no sepa interpretarla, que no refleje sus problemas, sus preocupaciones y no la oriente en los casos de necesidad, nunca será un gran periódico y hasta probablemente dejará de ser un periódico.". Citado por ALFÉREZ, op. cit., pág. 72. 
bajos comparados con los que tenemos para otros países europeos: a finales de los setenta, mientras que un $61 \%$ de los franceses y un 83\% de los alemanes leían la prensa a diario, en España sólo un 22\% de los ciudadanos leía el periódico todos los días. Por lo que se refiere a la difusión, la prensa diaria española en la década de los setenta tendió a la baja, y los grandes diarios de información general vieron caer su difusión en un $8,12 \%$ entre 1976 y 1979. A la altura de 1982, la prensa española estaba a la cola de la europea -junto con Portugal y Grecia- con menos de 90 ejemplares de diarios por 1.000 habitantes ${ }^{889}$.

2a) En Valladolid en concreto, la prensa diaria es fundamentalmente $E l$ Norte de Castilla. Los otros periódicos pueden tener un grupo fiel de lectores suscriptores en su mayor parte-, que difícilmente aumenta, a pesar de que con motivo de algunas promociones concretas, o determinados días, por razones varias, puedan aumentar -duplicando o triplicándola incluso- su tirada. Esto resulta ser una constante de la ciudad, que pone de

${ }^{889}$ IGLESIAS, Francisco, "La crisis de la prensa diaria en España", en Nuestro Tiempo, no 308, febrero de 1980, págs. 4-21. El autor basa su estudio sobre la caída de difusión en la comparación de la de los diarios $A B C, E l$ Alcázar, Informaciones, Pueblo, Ya, Diario 16, El Imparcial, y El País. La difusión conjunta de éstos pasó de 718.772 ejemplares diarios de media desde julio de 1976 a junio de 1977, a 660.433 entre julio de 1978 y junio de 1979. En la prensa de Barcelona la caída de la difusión en el mismo periodo fue de un 9,5\%; en la deportiva, de un 19,16\%; y en la de provincias se observa también una disminución de la difusión como tónica general, aunque hay también excepciones. Sobre esta misma cuestión puede verse también "Los "nuevos periódicos"", VV. AA., en la revista citada, no 342, diciembre de 1982, págs. 4-36. 
manifiesto el apego a las tradiciones que existe entre los lectores de periódicos vallisoletanos. Esto puede interpretarse como índice de lo estáticas que resultaban ser las clases medias y altas de la ciudad, en la que impera un sistema cerrado de élites -muy típico de provincias- que probablemente sea especialmente marcado en ésta ${ }^{890}$.

3ạ) Si la prensa vallisoletana por excelencia está bien definida, el otro factor de distorsión del mercado regional de prensa es la proximidad de Madrid, que -a la altura de los años setenta- permitía la llegada a Valladolid de los diarios impresos en la capital del país a primeras horas de la mañana.

4a ) La crisis económica de los años setenta repercutió con notable intensidad en las empresas de prensa: cambió la actitud de Estado frente a ellas; las dificultades generales del mercado hicieron caer la publicidad; el poder adquisitivo de los potenciales compradores disminuyó, y el precio del papel prensa se incrementó ${ }^{891}$. Esto implicaba la necesidad de introducir reformas tecnológicas y empresariales que rentabilizaran

${ }^{890}$ Esta caracterización de la sociedad vallisoletana ha sido puesta de manifiesto para el siglo XIX por el profesor ALMUIÑA FERNÁNDEZ, en La prensa vallisoletana..., tomo I, pág. 112-121, y tomo II, págs. 595 y ss. y 729-731.

${ }^{891}$ Cfr. SÁNCHEz TABERnERo, Alfonso, El Correo..., págs. 452-454, e IGLESIAS, Francisco, art. cit., especialmente págs. 15-18. 
las empresas. La estrechez económica coincidió, además, con el momento en que se hacían también necesarias reorientaciones ideológicas. La consecuencia fue el incremento del número de nacimientos y defunciones de periódicos, hasta alcanzar la cifra de 1.112 nuevos títulos entre 1975 y 1978. Mientras tanto, la media nacional de ejemplares devueltos aumentaba hasta situarse en un 20\% de los enviados a los puestos de venta, y el de desapariciones -aunque no conozcamos la cifra exacta- era mayor todavía que el de nacimientos ${ }^{892}$.

5a) Finalmente, conviene insistir en que el modo de gestionar Diario Regional había dejado de tener similitudes con las obras de beneficencia, $y$ no se diferenciaba en nada del habitual en cualquier otra empresa de prensa. Los empresarios, por tanto, no se sentían motivados por "la defensa de los intereses católicos", sino por la eficacia de su gestión. Corroborado el desinterés del público vallisoletano por un medio que habían intentado reiteradamente que resultara atractivo, decidieron abandonarlo.

De todo lo dicho, nos interesa resaltar especialmente lo que hemos apuntado como quinta razón de la puesta en venta del diario. A nuestro modo de ver, esta conclusión

${ }^{892} \mathrm{Cfr}$. VV. AA. "Los "nuevos periódicos"", loc. cit.; y el capítulo "El cementerio de Gutenberg" en ALFÉREz, Antonio, op. cit., págs. 81122 . 
estaba implícita en la decisión inicial de profesionalizar la gestión de la empresa y la elaboración del periódico. En una sociedad como la vallisoletana, donde las tradiciones tienen tanto peso y las innovaciones se abren camino con dificultad, los potenciales lectores miraban al periódico como un segundón, situado políticamente a la derecha de El Norte, y de escasa calidad. Esto unas veces era cierto, y otras no, pero -pese a los cambios que se habían producido en el periódico- la opinión pública sobre él nunca cambió de forma sustancial. En consecuencia perdió la batalla del mercado; y como ésa era la única que quería librar, ya que la ideológica había sido prudentemente apartada, la lógica económica sugería vender, y así se hizo.

Aunque el comprador tardó en aparecer, al fin, se consiguió encontrar alguien interesado en mantener un periódico de segunda fila en Valladolid. Pero antes de ocuparnos de los nuevos -y singulares- empresarios, conviene que nos detengamos en el análisis del periodismo que se hizo en estos años en Diario Regional.

\section{Periodismo débil y vista a la izQuierda.}

José Tallón fue sucedido en la dirección del periódico por Tomás Santos Corchero, el redactor jefe de 29 años que era hijo del que ocupara el mismo cargo en los años cincuenta, Enrique Santos. El nuevo director era 
colaborador del periódico desde 1958, había terminado los estudios en la Escuela Oficial de Periodismo en 1962, y se había formado en Diario Regional, junto a Fernández Areal y Tallón 893 . La redacción no experimentó cambios oficialmente, si bien seguían prestando servicios en ella el grupo de periodistas jóvenes que habían entrado con Tallón, a los que se unieron por estas fechas José Antonio Crespo Frantaco, que trabajó en local e información agrícola, y -menos integrado en la redacción- Rafael Rodríguez zapatero, que elaboraba colaboraciones sobre política internacional ${ }^{894}$.

La estructura informativa del periódico se mantuvo casi la misma que con Tallón, aunque cambiaron los nombres de algunas secciones, y aparecieron otras especialmente dedicadas al mundo juvenil895. Los análisis de mayor calado se dejaban en manos de colaboradores de agencia -Pedro Calvo Hernando en política nacional y Luis Ignacio Parada en economía-, y seguían cuidándose las secciones de local en las que la advertencia de lo que no iba bien en Valladolid seguía siendo frecuente. Pero lo más

${ }^{893} \mathrm{Cfr}$. "Censo electoral sindical. Declaración laboral de la empresa", de 29/1/1966, en A.H.P.U.V., Sección A.I.S.S., leg. 6.622; "Plantilla de la redacción de Diario Regional", de fecha 21/4/1969, en el mismo archivo, Sección Cultura, caja 28; e "Informe sobre la publicación "Hoja del Lunes"" de fecha 11/4/1973, enviado por el delegado provincial al director general de Prensa, en el mismo archivo, Sección Cultura, caja 28 .

${ }^{894}$ Puede verse en el apéndice 5 la plantilla oficial completa del periódico en estos años.

${ }^{895} \mathrm{La}$ relación completa de secciones puede verse en el apéndice 2 . 
característico del estilo de Santos Corchero aparecía en los editoriales, que cobraron un tono de denuncia un tanto estridente que los aproximaba al sensacionalismo. Además, por comparación con las etapas anteriores, se advertía una caída en la calidad y el peso de las argumentaciones. Ese tono fue pronto observable también en la titulación y la elección de las noticias de primera página, en la que la bicromía se empleaba con más frecuencia, y de forma poco ordenada 896 .

La pérdida de pulso en las informaciones del periódico, y el desorden en la confección del mismo, aumentó por temporadas -quizá coincidiendo con momentos en los que el director debía ausentarse con motivo del cumplimiento del servicio militar-, pero cada vez estaba más claro, también para los propios redactores, que la calidad era un valor en baja en Diario Regional 897. Los años de innovaciones ágiles habían pasado a la historia. Todo lo más, ahora se volvía sobre viejas ideas de

${ }^{896}$ Como ejemplos de editoriales de ese estilo pueden verse -todos ellos en la página 13- "Información sobre la cuota sindical", DR, 13/12/1967; el del 14/1/1968, que defiende la participación de los obreros en los beneficios de las empresas; el del 16/11/1968, "Juicio a una cátedra", que sostiene que el cuerpo de catedráticos nunca aceptará las reformas que son necesarias en la Universidad; el de 19/11/1968, pidiendo mayores contrapartidas por la instalación de bases militares norteamericanas en España; o "iNo a Torrejón!", publicado el 20/3/1970. En cuanto a los titulares, puede citarse, por ejemplo, la primera página del 30/3/1969, dedicada al festival de Eurovisión. En grandes tipos blancos sobre fondo rojo, se leía: "iEspaña es diferente! Empate a cuatro en el eurofestival. El festival de la confraternización europea".

${ }^{897}$ Entrevistas con Germán Losada, Fernando de la Torre y Mạ Aurora Viloria Nieto. 
directores anteriores, como la información sobre los barrios o la atención a las cuestiones de interés humano, que inevitablemente nacían un poco viejas, y apenas tenían continuidad898.

Por lo que hace a la orientación política, el periódico apostaba claramente por la apertura del régimen y la democratización de la vida política: se pedía vitalidad a los gobiernos para acelerar el cambio político, $y$ un nuevo estilo que olvidara pasados enfrentamientos. Era la antítesis del Diario Regional de los años de la guerra civil. Si entonces se clamaba por la depuración, ahora se hacían editoriales pidiendo que el Estado atendiera a los mutilados del Ejército republicano, - que se reincorporara al servicio activo a los funcionarios depurados por motivos políticos ${ }^{899}$. El primero de abril de 1969 se afirmaba en el editorial que la fiesta del día, treinta años después del fin de la contienda, debía ser entendida como

\footnotetext{
"la expresión de una voluntad colectiva de diálogo, respeto y tolerancia. Porque es testimonio de un pueblo que ha recobrado el pulso de su existencia, que sabe que es imposible volver hacia atrás, que considera definitivamente superadas las querellas y enfrentamientos del pasado, que se esfuerza en potenciar los valores de la paz y darles plena dimensión en un
}

${ }^{898} \mathrm{Es}$ el caso por ejemplo de la sección "Tema vivo..." aparecida en enero de 1969, y que se publicó irregularmente algunas semanas, u otra titulada "MA", siglas de "Todos merecen atención", que se dedicó a reportajes sobre los barrios de la ciudad, en las mismas fechas que la anterior.

899 "Mutilados del ejército republicano", editorial, DR, 18/1/1968, pág. 13. "Funcionarios depurados", editorial, 7/6/1969, pág. 13. 
Debilitamiento, enajenación, y muerte de un diario

futuro construido con el trabajo, la ilusión y la esperanza de todos los españoles." 900

Con respecto al futuro político del país, otro editorial fustigaba la actitud de los que se negaban a dejar paso a nuevas maneras de hacer -los "integristas ideológicos"-, ahogando así las esperanzas de la mayoría de los españoles:

"El proceso de liberalización política, acerca de cuyo alcance real no vamos a insistir ahora, no acaba de convencer a determinados sectores del integrismo ideológico de nuestro país. (...)

"No creemos que éste sea el medio más adecuado de encarar la nueva etapa política que se avecina. Las bases sobre el asociacionismo no necesitan que se puntualice que "pudieran entenderse como el germen inicial del pluripartidismo". Las cosas están ya suficientemente claras. De lo que se trata es de liberalizar más aún el proyecto y no de torpedearlo desde el integrismo ideológico. Las apelaciones al pueblo se deben traducir en una convocatoria abierta a todos, con poder de sufragio $y$ de participación, $y$ no en un mecanismo de contención." 901

La actitud del Ministerio de Información ante este tipo de declaraciones era tolerante. Les preocupaban más otro tipo de denuncias puntuales, y no las grandes declaraciones de principios, que eran moneda de uso común en casi todos los medios 902 , aunque todavía quedaran

900 "Treinta años después», editorial, DR, 2/4/1969, pág. 13 .

901 "Cuando el recelo ahoga la esperanza", editorial, DR, 11/6/1969, pág. 13. Pueden verse también "Democracia y participación popular", editorial, 12/11/1969, pág. 13; "Problemas políticos para 1970", editorial, 8/1/1970, pág. 13; "Lecciones de una huelga", editorial, 10/1/1970, pág. 13; "Peligrosidad social", editorial, 25/1/1970, pág. 13; "Las libertades políticas", editorial, 30/4/1970, pág. 13, "Amnistía política", editorial, 25/5/1970, pág. 13; "Asociaciones políticas cuanto antes", editorial, 26/8/1970, pág. 13 .

${ }^{902}$ Los comentarios sobre Diario Regional en los informes semanales de prensa que el delegado provincial hacía llegar a Madrid suelen calificar de ponderados los contenidos del periódico, y a lo más se 
algunos sectores partidarios de "la imposición del bien" por vía gubernativa. Como término de comparación vale la pena citar una carta de la Hermandad Nacional Universitaria a los obispos españoles, que el vicepresidente del Gobierno, Carrero Blanco, hizo llegar a Manuel Fraga. El escrito comenzaba así:

"Excmo. y Revdmo. Señor:

"Dictado el Estado de Excepción en una grave coyuntura nacional creemos preciso, que se consiga de esta situación el máximo resultado en orden a la recuperación nacional, extirpando de raíz los focos de corrupción religiosa y moral, causa primera de la actual crisis por la que atraviesa la sociedad española."

A continuación se pedía a los prelados que se pronunciaran pronto y oficialmente sobre los problemas a que hacían mención, que instasen al gobierno para que los solucionara, y que se articulara un plan de formación moral por parte de la jerarquía católica. Entre otras propuestas concretas figuraba la siguiente, referida a la prensa:

«d) Recabar de los Organismos oficiales que los medios de cultura y comunicación de masas, de ellos dependientes, cumplan con el fin de formación y recto esparcimiento para el que fueron creados." 903

La actitud de Diario Regional en este sentido era bien distinta. Las cuestiones políticas -insistían- caían

detienen en las informaciones que se dan sobre incidentes universitarios en la ciudad. Pueden verse en A.G.A., Sección Cultura, caja 35.068 .

903Carta del Presidente de la Junta de Gobierno de la Hermandad Nacional Universitaria, Juan M. Pérez Alhama, de fecha 26/2/1969. En A.G.A., Sección Cultura, caja 35.292. 
en el ámbito de lo opinable, y ahí nadie tenía por qué imponer una u otra opción a los católicos:

"La España de hoy, surgida de la guerra civil, ha dejado atrás el dramatismo del enfrentamiento. El diálogo tiende a sustituir a la intolerancia. Por eso, a nivel de los nuevos tiempos, el planteamiento bipolar, que es uno de los motores de la historia, tiene hoy una forma actualizada de expresión. Más que hablar de una España que quiere quemar iglesias y de otra que quiere evitarlo, actitud completamente inactual, puede hablarse de una España, de unos españoles, cerrados ante el progreso, recelosos ante el futuro, y de otra España, de otros españoles, dinámicos, aperturistas, ilusionados y comprometidos con la evolución política hacia fórmulas de mayor libertad y justicia.

"El doctor Cantero se ha limitado a repetir lo que es columna medular en el pensamiento pontificio sobre la libertad política. La Iglesia ha dicho en multitud de ocasiones lo que ahora el ilustre prelado ha repetido en una atmósfera de inserena excitación. "Nadie tiene derecho a monopolizar la verdad política, nadie posee la verdad en materias opinables." Muchos españoles suscribimos enteramente su compromiso y su esperanza. Quienes se oponen a ellas, en cambio, pretenden seguir anclados en un tiempo que el ritmo de la historia desbordó. " 904

Además, por lo que se refiere a las relaciones entre

la Iglesia y el Estado -que estuvieron de actualidad con motivo de la negociación de un nuevo Concordato con Roma-, el presupuesto era la libertad e independencia de la Iglesia ante el Estado, sin que la confesionalidad estatal se considerara un objetivo deseable $e^{905}$.

904 «El monopolio de la verdad», editorial, DR, 12/4/1970, pág. 13.

${ }^{905}$ Cfr. "Libertad de la Iglesia y autonomía del orden temporal. Bases para el futuro concordato" por José Miguel Pero-Sanz, DR, 5/12/1968, pág. 13; "Adiós sin lágrimas a los Estados confesionales", por Armando Vázquez, DR, 31/10/1969, pág. 13; y "Bases para un nuevo concordato", editorial, DR, 2/10/1970, pág. 13, en el que se afirmaba:

"La Iglesia debe mirar en todo momento por que el contenido del tratado no signifique un compromiso con realidades políticas, o sociales, opinables cuando menos; ni una especie de sanción, aunque fuera implícita, de las mismas.

"El Estado, a su vez, tampoco tiene la misión de formular profesiones dogmáticas de fe (antiguo concepto de "confesionalidad"). Los documentos pactados con la Iglesia, únicamente son la consideración jurídica hacia una realidad sociológicamente constatable 
Pero esta apuesta por un futuro democrático, si bien continuaba la línea del diario en años anteriores, y estaba en consonancia con el periodismo que se hacía en Nuevo Diario -el hermano mayor de la cadena-, no bastaba para hacer el periódico atractivo. Santos Corchero no consiguió alcanzar esa meta, al menos en opinión del presidente del consejo, Fernández de Caso. Éste, con motivo de las reformas emprendidas por CINISA, decidió relevar al director, parece que sin llegar a un acuerdo con él. Fernández de Caso tenía un carácter fuerte, y el final de Santos como director tuvo un sabor amargo. Fue despedido el 21 de diciembre de 1971, medida que le cogió por sorpresa, ya que -según explicó al delegado provincial del Ministerio de Información-, antes sólo se le había hecho alguna advertencia, poco explícita, de que la empresa no estaba muy conforme con su forma de llevar el periódico.

La noticia, por las fechas en que se produjo, provocó malestar en los medios periodísticos de la ciudad. Fernández de Caso, Santos Corchero y su abogado, se reunieron el día 29 para tratar de llegar a un acuerdo, sin conseguirlo. Santos reclamó ante la Dirección General de Prensa por su despido, reclamación que éste organismo desestimó. Al mismo tiempo buscó una salida en el

(el sentir y creer de los ciudadanos): por ello un Concordato sólo es firmable insertándose en el reconocimiento de la igualdad de los ciudadanos, nunca discriminables en la vida social por motivos religiosos." 
Ayuntamiento, donde efectivamente se haría cargo de la oficina de prensa, en El Norte -que rechazó su propuesta-, y en la Hoja del Lunes, el semanario de la Asociación de la Prensa que había acogido a otros dos redactores de Diario Regional que habían salido del periódico ese mismo año, también con motivo de la reestructuración empresarial 906 .

En efecto, el despido de Santos Corchero no fue la única consecuencia que los ajustes económicos habían provocado en la redacción, que quedó reducida a la mínima expresión. Se llegó al punto de que el consejo directivo de la Federación Nacional de Asociaciones de la Prensa denunció ante la Dirección General de Prensa que Diario Regional no tenía la plantilla mínima de 5 profesionales periodistas, tal como se estipulaba en el artículo 20 del Estatuto de la Profesión Periodística. La empresa solucionó el problema dando de alta como redactora a Ma Aurora Viloria en noviembre de 1971907 . No sabemos si tuvo que ver con los cambios empresariales, pero lo cierto es que incluso Francisco Javier Martín Abril, el veterano y simbólico redactor del periódico -solamente publicaba su artículo diario, pero era un emblema de los viejos

\footnotetext{
906 "Informe sobre la situación en Diario Regional, S.A." del delegado provincial al director general de Prensa, de fecha 30/12/1971. Esos redactores eran Francisco de Anta Franco y a José Luis Pérez Herrero.

907oficio de la Dirección General de Prensa a la Delegación de Valladolid, y a "Diario Regional, S.A.", de fecha 14/10/1972. A.H.P.U.V., Sección Cultura, caja 27.
} 
tiempos, y una institución en la ciudad-, había abandonado la redacción en septiembre de 1970 para pasar a engrosar las filas de la de El Norte de Castilla, con el cargo de redactor jefe de sección. Era todo un síntoma de cómo habían cambiado los planteamientos del periodismo vallisoletano908

Tras la marcha de Santos, al frente de Diario Regional quedó como director interino el redactor jefe Fernando de la Torre, que durante su interinidad hubo de soportar algo que no se veía en el periódico desde los tiempos agitados de la Segunda República: el apedreamiento de las oficinas. Ciertamente, no fue tan intenso como los de los años treinta, pero además sospechaban que más que proceder de estudiantes enfurecidos -eran los agitadores por antonomasia del momento, y el periódico prestaba mucha atención a las cuestiones universitarias, llamando casi siempre a la moderación- podía venir de la extrema derecha:

"Pero, realmente, ¿quiénes son?..., ¿Estudiantes?... Empezamos a pensar seriamente que no. Empezamos a temernos -como ayer apuntábamos- que hay quienes están empeñados en trascender el problema de lo universitario, $y$ aprovechan el río revuelto... Esta vez, es doloroso, quizá no sea todo imputable a la agitación extremista de siempre." 909

908 "Parte de bajas", de fecha 8/2/1971, anejo a la "Declaración laboral de empresa". A.H.P.U.V., Sección A.I.S.S., legajo, 6.628. "Confirmación anual específica de plantilla de El Norte de Castilla", de fecha 1/1/75, en el mismo archivo, Sección Cultura, caja 37.

909 "Contra nosotros y huele a viejo», editorial, 20/1/1972, pág. 1. 
Fuera como fuese, esta vez Diario Regional no fue el único blanco de las iras de los violentos: un mes más tarde era El Norte de Castilla el que sufría una pedrea de sus locales 910 . Eran años convulsos, y los “parlamentos de papel" -como se dejaban llamar con gusto los periódicosdebieron soportar esas "formas de expresión" heterodoxas.

El nuevo director -Esteban Greciet Aller- llegó en mayo de 1972. Tenía 42 años, era titulado por la Escuela Oficial de Periodismo de Madrid, y hasta ese momento había sido director de La Voz de Avilés-en el que había conseguido duplicar la tirada-, además de fundador y presidente de la Asociación de la prensa de esa villa. Era también profesor mercantil, y había trabajado como comentarista de Radio Nacional, y como subdirector de La Voz de Asturias. Conocía a Fernández de Caso desde que fuera colaborador del Diario de León, y el empresario había acudido ahora a él para que apoyara su intento de reanimación del diario vallisoletano911.

Greciet no introdujo grandes novedades en la estructura informativa del periódico: se abandonaron viejas secciones que se venían arrastrando desde tiempos de Tallón, y aparecieron unos breves comentarios de la

\footnotetext{
910 «En las mismas de siempre», editorial, 22/2/1972, pág. 1.

911 "Don Esteban Greciet Aller, director de "Diario Regional" , DR, 3/5/1972, pág. 1. Puede verse una copia de su contrato como director en A.H.P.U.V., Sección Cultura, caja 27. Entrevista con Esteban Greciet.
} 
actualidad - "El día", "Clave de sol", "Desde aquí»-, que eran firmados en ocasiones por el propio director ${ }^{912}$. Se habían incorporado a la redacción -como colaboradores con título de periodista- Santiago José Sáiz y Mạ Carmen Noriega; $y$ junto a ellos, sin título de periodista, un personaje singular, José Antonio R. González _"Rafael del Naranco"- que vino con Greciet. Este último hacía un reporterismo sui generis, que daba un tono peculiar al periódico: un día entraba en la jaula de los leones del circo de turno junto con el domador, y relataba la experiencia; otro se disfrazaba de mendigo y pedía limosna en las calles céntricas, y de ahí salía un reportaje -que iba a primera página- sobre cuánto gana un pordiosero; otro vendía duros a cuatro pesetas en la Plaza Mayor, con poco éxito, por cierto... Greciet estimaba la originalidad de del Naranco, pero probablemente ese estilo no benefició mucho la imagen ni la calidad de Diario Regional 913. Por último, el periódico consiguió un nuevo apoyo con la

912 Puede verse la relación completa de secciones en el apéndice 2.

913 Pueden verse en el anexo 5 las plantillas de estos años. Entrevista con Esteban Greciet. Por lo que se refiere a las tiradas en estos años, a través de una fuente indirecta tenemos lo siguiente para 1972:

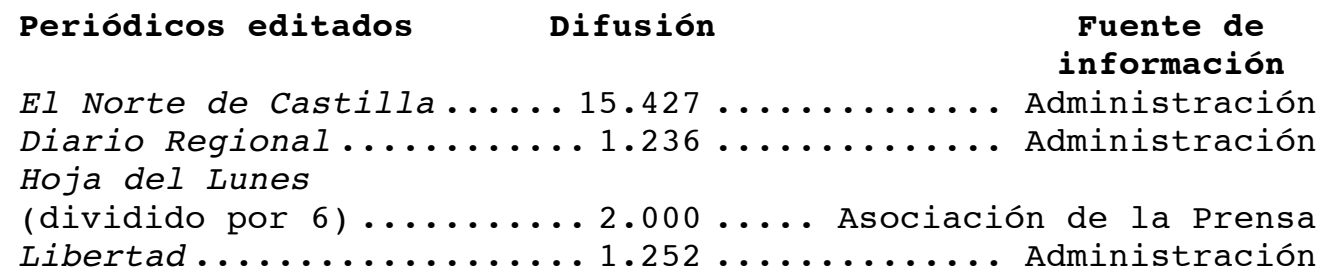

Fuente: A.G.A., Sección Medios de Comunicación Social del Estado. Análisis de Gestión. Caja no 179. Carpeta Datos Prensa. 
entrada de Ramón García en la redacción, tras jubilarse Miguel Montalvo. García fue nombrado redactor jefe en 1973, y sería un elemento fundamental para mantener la calidad de las informaciones locales, que corrían el peligro de perder su tradicional incisividad914.

Fernández de Caso había prometido a Greciet la transformación tecnológica del diario, y apoyo para su renovación completa, pero esos nuevos medios no llegaron. El nuevo director tuvo que enfrentarse con una carencia de medios que rayaba en la miseria, mientras que la aprobación de los proyectos de mejoras que presentó al consejo de administración se dilataba mes tras mes. Era casi el negativo de su situación anterior, cuando había dirigido el único diario de Avilés en el momento en que éste se remozaba por completo. Semejante situación empujaba más que nada al desánimo, sin que se vieran posibilidades de competir con cierta seriedad en el mercado vallisoletano. El periódico salía flojo, y sólo quedaba espacio para algunos comentarios editoriales más o menos incisivos, que no conseguían hacer sombra a las

914 Como era habitual, cuando un redactor conseguía suficiente pericia y conocimiento de la ciudad, buscaba un nuevo puesto -mejor remunerado y como redactor en plantilla, ya que en Diario Regional la situación económica no era nada esperanzadora- en El Norte, o fuera de Valladolid. José Antonio Antón, que había entrado en el decano vallisoletano en 1970, sería redactor jefe del mismo desde enero de 1974; y Germán Losada había pasado a ser redactor de El Norte en diciembre de 1973. Por estos años trabajaron también en Diario Regional Fernando Francés Valiño, que luego pasaría a El Norte, y Fernando Barrasa. Cfr. "Confirmación anual específica de plantilla de El Norte de Castilla", de fecha 1/1/75, en A.H.P.U.V., Sección Cultura, caja 37. Entrevistas con Germán Losada, Santiago José Sáiz y Fernando Barrasa. 
plumas de prestigio que colaboraban con El Norte 915. Esto, unido a una desordenada maquetación, y una impresión defectuosa, confería un aspecto átono y bastante pobre a las páginas del periódico de esos años.

La línea política del diario siguió siendo la misma, partidaria de la apertura y moderada, como se ponía de relieve en el mensaje a Franco que publicaban con motivo del "Día del Caudillo" en 1973:

"Al hacer llegar con esta ocasión nuestro respeto al Jefe del Estado, permítasenos la esperanza, muy fundamentada en sus propias palabras, de que el proceso político, acentuado y vitalizado en estos últimos años, continuará por las vías de apertura que todos esperamos."916

La defensa de la democratización del sistema, que se abordó en algunos editoriales, fustigando a los sectores inmovilistas, llegó a provocar un pequeño incidente con el diario del Movimiento de la ciudad -Libertad-, cuando desde Diario Regional se hicieron algunas alusiones a la Falange, indicando que debía transformarse para llegar a convivir con otras fuerzas políticas917. Diario Regional contestó así a las acusaciones de mimetismo político que se le hacían desde Libertad:

915Entrevista con Esteban Greciet.

916 «37 años de afán renovador», editorial, DR, 2/10/1973, pág. 16, últ..

${ }^{917}$ Los editoriales considerados ofensivos por Libertad eran "Esta España pendular", editorial, DR, 24/12/1972, pág. 2; y "La Falange ayer y hoy", editorial, 28/12/1972, pág. 2 . 
"Lo que nos asombra no es la falta de realismo de quienes parecen anclados en año 36 , como el que se nos atribuya curiosos propósitos inconfesables. Nosotros -digámoslo muy alto- no estamos en contra de la Falange, sino en favor de la puesta al día, del remozamiento de unos postulados que es obvio no pueden tener vigencia en toda su integridad. Nadie con sentido común puede pretender ahora hacer viable el totalitarismo a ultranza, el sindicato vertical y la voluntad de imperio. Y todo esto, es sabido, está en los 26 puntos de la Falange. José Antonio hoy -lo ha dicho Pilar Primo de Rivera- no lo suscribiría.

"El problema (...) está en la búsqueda airada de enemigos, en la interpretación aventurada e intransigente de las opiniones ajenas, en los atentados absurdos -como el que acaba de ser objeto una librería local-, en la exégesis parcial de las leyes fundamentales.

"(...) DIARIO REGIONAL no cambia de línea, como sibilinamente aventura "Libertad". Nuestros afanes son limpios y conocidos.

"No hace falta seguir. En el fondo, entendemos, se trata de un malentendido. Seguramente que ellos y nosotros no deseamos otra cosa que una España en paz, una España justa y puesta al día, en la que las tensiones y los conflictos no pasen de aquí: es decir, de las palabras."918

No tenemos noticias de que la autoridad gubernativa interviniera en este caso. Aunque la libertad de prensa distaba de ser una realidad de hecho en estos años, los procedimientos se habían suavizado mucho, los expedientes eran menos frecuentes, y la intervención de los funcionarios de Información y Turismo no era tan continua como años atrás. La ley $9 / 68$ de Secretos Oficiales -contra la que Santos Corchero había escrito algunos editoriales en su día919- era ahora el aparato legal que permitía administrar a voluntad los ámbitos de aplicación del artículo 20 de la ley Fraga. La lista de materias declaradas reservadas o secretas a principios de los

\footnotetext{
918 «Nuestros conocidos afanes», editorial, 30/12/1972, pág. 2.

${ }^{919} \mathrm{Cfr}$. los informes semanales de prensa de fecha $20 / 1 / 1968$, correspondiente a los días 14-20/1/1968, y de 9/3/1968, correspondiente a los días 3-9/3/1968, en A.G.A., Sección Cultura, caja 35.068 .
} 
setenta era ciertamente extensa, pero no parece que el periódico cometiera errores en el tratamiento de esas cuestiones sobre las que se advertía de antemano920. El espíritu censor del Estado estaba en franco retroceso, como había hecho notar el propio ministro de información Sánchez Bella921, pero eso no impedía que las autoridades provinciales o municipales siguieran inspeccionando celosa, y aun recelosamente, las publicaciones de sus demarcaciones. Constan por ejemplo las protestas del

920 Entre otras, según las relaciones que se conservan entre la documentación de la delegación del Ministerio de Información y Turismo de Valladolid -A.H.P.U.V., Sección Cultura, caja 25-, estaban las siguientes:

-Deliberaciones del Consejo del Reino. 28/12/1973.

-Posibles viajes del Jefe del Estado o del Príncipe.

-Actuación de las autoridades en la persecución de hechos delictivos. Especialmente evitar los bulos en casos como el asesinato del Almirante Carrero. 21/12/1973.

-Informe de la Comisión mixta Gobierno-Consejo Nacional sobre participación política de los españoles. 4/12/1973.

-Informe sobre la reforma fiscal. 27/11/1973

-Informaciones sobre la República de Guinea en relación con España. $13 / 8 / 1973$.

-Deliberaciones y acuerdos de las tres Universidades de Barcelona en relación con la aplicación del decreto 2056/1972 de 26 de julio a las citadas Universidades. 21/2/1973.

-Toda información, comentario o noticia sobre los informes y documentación en general, relativos a las actuaciones llevadas a cabo por el Secretario General de la Dirección General de Universidades e Investigación, D. Fernando Laquens Marquesans, en virtud de la orden ministerial del 24 de abril de 1972, por la que se le nombraba Juez Instructor de los hechos acaecidos por aquel tiempo en la Universidad de Zaragoza.

-Comentarios sobre Guinea. 11/8/1972.

-Comentarios sobre el Sahara. 20/7/1972.

-Procesamiento de tres sacerdotes por el Tribunal de orden Público. $9 / 6 / 1972$.

-Documentos referentes al Gobierno de la Nación que sean estudiados en el Consejo Nacional. 20/5/1972.

-Informe sobre la reforma fiscal. 27/4/1973

-Información sobre las gestiones del rector de la Universidad de Barcelona en orden a la normalización de la actividad académica. $25 / 3 / 1972$.

921 "Importante discurso de Sánchez Bella sobre el mundo del espectáculo: "la censura es innecesaria"", DR, 6/9/1972, págs. 1 y 9. 
alcalde de Valladolid por un reportaje publicado en Diario Regional, y las del gobernador civil de la provincia, que amenazó con sancionar al periódico por haber anunciado un festival folk que él no había autorizado. En los dos casos la irritación de los jerarcas no fue muy lejos y no hubo sanciones922. El delegado de Información y Turismo, por su parte, solía limitarse a comunicar a Madrid el descontento que habían generado tales o cuales informaciones en unos $u$ otros; $y$ lo que antes fuera motivo de sanciones ahora apenas si daba lugar a una pequeña nota al final del informe de prensa que se enviaba a diario a Madrid:

"(...) ha sorprendido y ha sido objeto de desfavorables
comentarios, especialmente en círculos militares, la
titulación que hace "Diario Regional" en su no de hoy en 1 a
página: "XXV aniversario del fin de la guerra civil", a la por
otra parte brevísima reseña de los actos que tuvieron lugar
ayer en esta ciudad con motivo del aniversario de la
victoria." 923

${ }^{922 \mathrm{El}}$ reportaje se titulaba "Otro pueblo que desaparece: Villavellid", y fue publicado en DR el 2/3/1973, pág. 9. Las amenazas del gobernador y su posterior decisión de no proceder contra el periódico constan en el informe por teletipo a Madrid del delegado provincial -Carmelo Romero Andrés desde enero de 1972- a la Dirección General. En estos años, además de las hojas de lectura de cada diario o revista que se remitían al fiscal con la prensa, los delegados enviaban un breve informe a Madrid pro teletipo, en el que extractaban los contenidos más destacados de las publicaciones de la ciudad. Los documentos citados se encuentran en A.H.P.U.V., Sección Cultura, caja 25. Esteban Greciet nos ha confirmado que durante su permanencia en la dirección no hubo sanciones.

923 Teletipo del delegado provincial del Ministerio de Información y Turismo en Valladolid a la Dirección General de Coordinación Informativa, de fecha 2/4/1974, en A.H.P.U.V., Sección Cultura, caja 27 . 
Debilitamiento, enajenación, y muerte de un diario

"nota.- es de destacar el hecho de que ni "El Norte de Castilla" ni "Diario Regional" hacen mención alguna del cumpleaños del Jefe del Estado." 924

Pero si las autoridades toleraban el aperturismo del periódico, algunos lectores se mostraban más intransigentes en este punto. Los comentarios publicados con motivo del asesinato de Carrero Blanco, llamando a la serenidad, a la moderación, y a evitar extremismos de izquierda o de derecha, fueron causa de que se recibiera en la redacción un anónimo en los siguientes términos:

"[Su postura] como director del diario es una repugnante traición, que el firmante $y$ otros sufridos seguidores de su regocijante y caduca publicación no toleramos, por lo cual suspendemos su adquisición e iniciamos campaña para reconquistar, si aún es posible, el respetable y limpio historial de tan querido diario, deteriorado hoy por la simple iteración de ridículas piruetas direccionales.

"Se envían copias de estas líneas al Consejo de Administración y a CINISA.

"Y sepa, señor "aperturista", que el marxismo está condenado por la Iglesia." 925

En otro orden de cosas, el periódico se ocupaba de vez en cuando de la confusa situación por que atravesaban algunos sectores católicos del país. Normalmente, los artículos se referían a cuestiones doctrinales que eran puestas en duda o simplemente rechazadas por algunos sectores del clero o elementos próximos al mismo. Eso se atendía de ordinario -ya desde tiempos de Santos Corcheroen la sección "Estar al día", que elaboraba un grupo de

924 Teletipo del delegado provincial del Ministerio de Información y Turismo en Valladolid al jefe de gabinete de estudios de la Dirección General de Prensa, de fecha 2/4/1974, ibid..

925Archivo Privado de Esteban Greciet Aller (A.P.E.G.A.). 
sacerdotes de la ciudad, $y$ en la que se evitaban las polémicas: simplemente se exponía la doctrina sobre puntos concretos del dogma o la moral católicos. Pero las situaciones de desconcierto dieron lugar también a editoriales que reflejaban bien los momentos que se atravesaban. Uno de ellos estaba dedicado a defender a los obispos de los ataques que se les dirigían por parte de algunos católicos:

"No se dan cuenta los cristianos que atacan hoy, de tantas maneras, al Episcopado español en colectivo el mal que hacen a la Iglesia. No se trata de defender o atacar las posturas de prelados concretos con nombres y apellidos, sino de ofender a la Iglesia española y a la Iglesia universal de un modo que induce a pensar si de lo que se trata es de clarificar o bien -lo que parece más probable- de desunir a partir de ciertos supuestos específicamente subjetivos. (...)

"Decimos todo esto por la campaña de descrédito y de solfa que algunos sectores parecen estar llevando a cabo, incluso desde dentro del clero algunas veces. Triste actitud ésta, cuyas consecuencias no pueden ser en ningún momento halagüeñas, puesto que no está basada en la caridad cristiana. Las gentes no están sobradas de auténtica formación religiosa y confunden el mundo de lo sobrenatural, que el sacerdote representa, con el sacerdote mismo. Lo que se pone en peligro, pues, el la misma fe de nuestro pueblo." 926

Ciertamente, no eran años fáciles, como se podía ver en otro editorial, dedicado a comentar unas palabras del arzobispo -Félix Romero Menjíbar, que había sucedido a García Goldáraz en en julio de 1970- sobre la situación de la diócesis, en las que el prelado se lamentaba de la falta de unidad y de sentido sobrenatural que demostraban algunos comportamientos ${ }^{927}$.

\footnotetext{
926 «Cuando peligra la fe», editorial, 10/1/1973, pág. 2 .

927 "No ha tenido reparo en señalar una suerte de defectos en torno a una cierta alegría pastoral, la anarquía práctica, falta de una
} 
Greciet era un católico convencido, miembro de la Acción Católica, y próximo a posturas políticas demócratacristianas. Cuando se incorporó al periódico, la empresa le había hecho presente que era preciso para aceptar el cargo la aceptación del asesoramiento de un sacerdote en las cuestiones doctrinales que se publicaran, ya que ésa era la fórmula que se había adoptado para garantizar la ortodoxia del diario en materia de doctrina católica. El compromiso se plasmaba en una carta que el director dirigía al presidente del consejo de administración, solicitando ese asesoramiento928. Greciet contó para tal fin, primero con José Antonio Burriel, sacerdote del Opus Dei, y luego con Santiago Francia, canónigo palentino, y miembro de la Sociedad Sacerdotal de la Santa Cruz, inseparablemente unida a la Obra. Las relaciones con el primero fueron fluidas $y$ no se

auténtica pastoral de conjunto, la actitud antieclesial de ciertos grupos que se dicen católicos, individualismo, extremismo, etc.

"No hay duda de que se han hecho muchas y muy buenas cosas en la Iglesia diocesana en estos años (...). Pero vivimos unos tiempos en los que el amor propio (...) lleva a todos y cada uno de los cristianos a sentirse depositarios de la verdad, disgregando la unidad en fracciones llenas de criterios subjetivos, afectivos $y$, lo que es más lamentable, atentatorios contra la verdadera fuerza cohesiva de la Iglesia, como es la comprensión y la caridad. Falta humildad y falta confianza en aquello mismo en que se dice creer.

"No estamos acostumbrados, ciertamente, a que se exponga con esta rotundidad y rigor la situación de la comunidad cristiana. El arzobispo no ha caído en la fácil tentación del triunfalismo descarnado, sino que ha puesto el dedo en la llaga.(...)" "Un diagnóstico certero y oportuno" editorial, 26/5/1973, pág. 16 .

${ }^{928} \mathrm{El}$ texto de la carta modelo que se le facilitó desde la empresa -se conserva en A.P.E.G.A.- era el siguiente:

"Teniendo en cuenta la importancia de lo religioso en el tratamiento de la actualidad periodística, así como la necesidad de ofrecer al lector una visión ortodoxa, quisiera que me autorizara para contar con el sacerdote ...................... asesor en dichos temas." 
presentaron problemas, pero, con Francia, Greciet se entendía peor, lo que provocó de vez en cuando situaciones molestas, cuando no coincidieron los criterios de uno y otro. El director había sido uno de los partidarios de eliminar las restricciones en los anuncios de cartelera de cine por razones morales, $y$ entendía que en materia religiosa, el periódico debía seguir una línea menos "conservadora", como se decía entonces"929.

Con todo, en lo que más preocupaba a la empresa, los esfuerzos de Greciet $y$ de su equipo no consiguieron que Diario Regional mejorara su trayectoria930. La dimisión de

${ }^{929}$ Las diferencias de criterio en torno a estos asuntos no tenían una importancia trascendental, pero son reveladoras sobre los momentos que se vivían. Una anécdota en relación con la proyección de la película "Jesucristo Superstar" puede resultar ilustrativa. La proyección de la cinta fue motivo de división entre la opinión católica de la ciudad, y mientras unos aplaudían, otros organizaron actos de desagravio público a la puerta del cine en que se proyectaba. Arturo León, secretario del consejo, hizo saber a Greciet que estimaba oportuno no publicar comentario alguno sobre la cuestión. El director se mostró en desacuerdo con esa postura, ya que, a su entender, se trataba de cierta relevancia periodística. León le pidió entonces que -al menosla crítica de la película no fuera netamente elogiosa. Greciet prefirió dejar hacer a María Aurora Viloria, que entonces se encargaba de las críticas de cine, sin advertirle nada sobre el particular. Entrevista con Esteban Greciet.

${ }^{930}$ Un informe elaborado por los servicios de la cadena de prensa del Movimiento ofrecía los siguientes datos para la prensa vallisoletana en 1973:

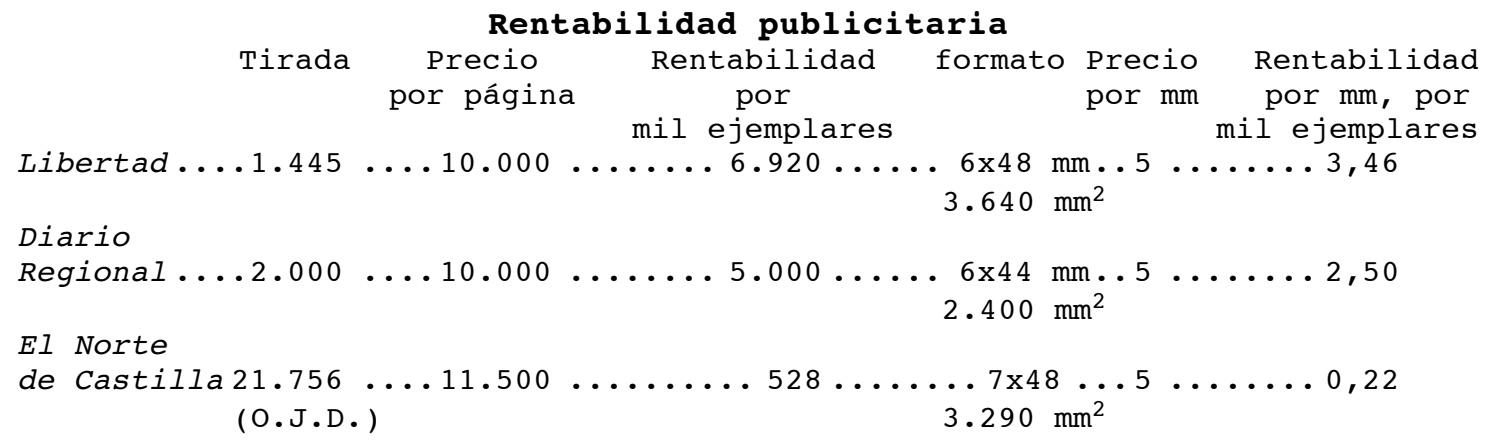


Fernández de Caso como presidente del consejo de administración, y la entrada de Juan Pablo de Villanueva y otros en ese órgano, acarrearon nuevos cambios en la redacción, empezando por el relevo en la dirección.

Juan Pablo de Villanueva comenzó a frecuentar la redacción en diciembre de 1973, y da la impresión de que no estaba en su ánimo continuar con Greciet como director del periódico. Al menos, eso nos parece deducir de las quejas por falta de confianza que Greciet le presentó en mayo de 1974. Por aquellas fechas la situación se presentaba insostenible desde todos los puntos de vista y aparecía clara la necesidad de emprender reformas decididas si se quería seguir adelante con la publicación. El director envió a Juan Pablo de Villanueva un informe que era al mismo tiempo, una señal de alarma, un memorial de agravios $y$ un ultimatum ${ }^{931}$. Greciet comenzaba desmintiendo los rumores -publicados por Pueblo- que hablaban de su pronta incorporación a la dirección de otro periódico, para pasar enseguida a hacer notar que "Es

Informe sobre la elevación de tarifas publicitarias. División comercial. 1973. pág. 19. A.G.A., Sección Medios de Comunicación Social del Estado. Análisis de Gestión. Caja no 148. Carpeta Informes y Datos publicitarios varios.

Luis Conde Pardo sostiene que el periódico conseguía mantenerse a base de números extraordinarios, que gracias a las promociones publicitarias que suponían, permitían sufragar las pérdidas ordinarias.

931 "Informe del director de "Diario Regional" de Valladolid", de fecha $7 / 5 / 1974$ y carta adjunta, dirigidos a Juan Pablo de Villanueva. A.P.E.G.A.. 
fundamental una decisión urgente sobre el inmediato futuro del periódico y, en caso de supervivencia, poner en marcha un plan concreto de mejora y promoción."932

Una vez más, el periódico estaba al borde de la desaparición. Greciet pintaba con tonos sombríos el estado de la empresa y arremetía con dureza contra el comportamiento del administrador general -Luis Conde-, del que se sentía distanciado por una disparidad de criterios que el periodista consideraba insalvable. En resumen, Greciet pedía un inmediato y decidido golpe de timón en el gobierno de la empresa, además de toda la confianza del consejo para guiar la publicación, o -lo que era lo mismoel relevo del administrador general933.

932 Ibid., pág. 1.

933Entre otras cosas, Greciet mostraba su disconformidad con el salario que se le abonaba, con la política de personal, con la de contratación de colaboraciones y con el salario de algunos colaboradores que realmente trabajaban como redactores -Rafael Rodríguez Zapatero, José Antonio R. González y Juan Carlos Real-. A continuación trataba pormenorizadamente del origen de algunas deudas impagadas -sumaban 27.000 ptas.- que le parecían una demostración del mal estado de cosas. Realmente, la alusión a esas deudas no era más que el modo de comenzar la descripción del problema más agudo que se ventilaba, es decir, si la empresa iba a apoyar sus propios criterios - los del administrador. Esa era la cuestión que se afrontaba en el apartado central del informe, que era también el más duro. Bajo el epígrafe "relaciones con el administrador", Greciet exponía su opinión sobre la conducta de éste, para concluían así:

"En definitiva, que el administrador y el firmante hablan idiomas radicalmente distintos $y$ no será fácil que se entiendan en lo sucesivo a pesar de toda la buena voluntad y la paciencia de quien ni mucho menos ha dado el primer paso para este lamentable estado de cosas."

Finalmente, Greciet exponía su convencimiento de que el periódico podía sacarse adelante, y terminaba con unas frases que hablan por sí solas de cuál fuera su estado de ánimo:

"Un director necesita un mínimo de medios, unas directrices genéricas, un voto de confianza y un plazo para pedirle responsabilidades (al principio, hace año y medio, ya 
La respuesta del consejo de administración no tardó en llegar. El 20 de mayo el director recibió una comunicación del presidente del consejo en que se le comunicaba que la empresa había decidido prescindir de sus servicios. Todo parece indicar que su ultimatum no había hecho sino precipitar la idea de Villanueva de realizar un cambio en la dirección ${ }^{934}$.

Éste llamó para que se hiciera cargo del periódico a Ignacio Bel Mallén. Con 27 años, Bel era licenciado en Derecho y Ciencias de la Información, y había estado al cargo de las oficinas de prensa de las Universidades de Santiago de Compostela y de Educación a Distancia. Más inclinado a la docencia que al periodismo, había dejado su puesto en la U.N.E.D. con el cambio de rector en 1974, y estaba trabajando para las agencias "Multipress" y "Flash"

se habían enviado dos planes de mejora y un programa de promoción).

"En otro caso, es preciso resolver cuanto antes para bien - para mal, con objeto de que cuantos dependemos de esta empresa podamos tomar a tiempo medidas de futuro y poner coto a la frustración profesional que esta situación supone." Ibidem.

${ }^{934}$ Carta de Emilio Fernández de Caso, presidente de "Diario Regional, S.A.", a Esteban Greciet, de fecha 16 de mayo de 1974. A.P.E.G.A..

Por estas fechas, Greciet -según relata él mismo- fue llamado a Madrid, donde Villanueva y Fernández de Caso le comunicaron que el consejo había aprobado por unanimidad el cambio de director. Se le agradecieron sus servicios, sin darle más explicaciones sobre su relevo. Al venir a Diario Regional Greciet había rechazado otras propuestas de dirigir diarios, algunos de ellos pertenecientes a la cadena del Movimiento. Cuando se le comunicó el cese, hizo presente a Fernández de Caso que se quedaba sin trabajo y que agradecería que le buscara algún puesto en otro periódico. Fernández de Caso aseguró que buscaría algo, pero la promesa se quedó en eso. Greciet marchó entonces a El Correo de Zamora, en el que ocupó el cargo de redactor jefe, hasta que volvió a Valladolid, para realizar las mismas funciones en Libertad. 
que había creado Villanueva. Cuando éste le propuso marchar a Valladolid, Bel aceptó con la ilusión de afrontar su primera experiencia en prensa diaria.

Cuando llegó a Valladolid, en julio de 1974935, apenas si sabía nada de la ciudad, y menos de Diario Regional. Según le parece recordar, el periódico tenía entonces una difusión que no superaba los 1.000 ejemplares diarios, y estaba en una situación penosa. Aunque a la altura de 1991 nos dijera que "lo mejor hubiera sido cerrarlo", en 1974 CINISA tenía todavía esperanzas de hacer un periódico regional, y él asumió con ilusión la tarea936.

Bel insiste en sus recuerdos en algo que conocemos bien: encontró una ciudad en la que El Norte de Castilla lo podía todo, pero sin hacer un periodismo deslumbrante. La primera impresión es que se leía poco. Además la prensa de Madrid vendía desde la primera hora, y era difícil hacerle sombra. Pero -como siempre había ocurrido- al recién llegado le pareció que allí había sitio para otro periódico bien hecho. Su primera tarea fue ilusionar a una redacción que encontró competente pero desanimada: Ramón García, José de la Fuente, Mạ Aurora Viloria, Fernando de la Torre, Jesús Orobón,... eran gentes con cariño al periódico, que dedicaban cuanto tiempo

\footnotetext{
${ }^{935} \mathrm{Cfr}$. "Ignacio Bel, nuevo director", DR, 24/7/1974, pág. 1. Puede verse también su contrato en A.H.P.U.V., Sección Cultura, caja 27. ${ }^{936}$ Entrevista con Ignacio Bel.
} 
hiciera falta a sacarlo adelante, pero que no veían horizonte de esperanza.

Bel entendía también que era necesario cambiar la línea del periódico, darle una nueva imagen entre los lectores. El Diario Regional que encontró le parecía que era percibido como un periódico conservador a ultranza, sin audiencia, que significaba poco o nada en la ciudad, y que se identificaba con los sectores socialmente reaccionarios. El nuevo director -que era miembro del Opus Dei- pensaba que la clave era romper con aquel estereotipo: hacer un diario abierto, netamente pluralista y liberal en lo político, y que no pudiera identificarse con "la derecha pura y dura". Era un planteamiento muy típico de un hombre de su edad en los momentos finales del franquismo, y demostraba también que Bel desconocía la historia del periódico, al confundir lo que se pensaba del diario con lo que éste había sido o intentado ser.

Su táctica, no obstante, sí fue una novedad. Consciente de que semejante cambio exigía un notable esfuerzo, procuró animar a su redacción, y entró en contacto con redactores de $E I$ Norte de Castilla ofreciéndoles un puesto en el "nuevo periódico" que quería hacer. Las conversaciones se llevaron a cabo con la mediación de Luis Conde, José de la Fuente y Jesús Orobón -que por su condición de veteranos tenían cierto ascendiente ante redactores de El Norte que procedían de 
Diario Regional-, y no fueron fáciles. Desde el decano vallisoletano se miraba al segundón "con un absoluto desprecion937, y pronto se vio que, por más que se ofrecieran a hombres como Losada puestos como la subdirección o la jefatura de redacción, éstos no estaban dispuestos a aceptar el cambio. Diario Regional, era "el de enfrente" ideológicamente. El Norte era para los vallisoletanos la izquierda, el progresismo; y los periodistas de la ciudad no estaban dispuestos a arriesgar su carrera en un intento de modificar las etiquetas que tan bien funcionaban, que eran también garantía de estabilidad profesional y económica, tanto en el presente como en el futuro.

Derrotado en el primer asalto, Bel cambió de táctica e intensificó su política de contratación de jóvenes profesionales -la mayoría con los estudios a medias- para la redacción de Diario Regional. Ellos no estaban marcados por el pasado del periódico, y quizá así consiguiera lo que se había propuesto. Para garantizar el éxito, se cuidó de dejarles las manos libres para escribir lo que quisieran. $Y$ en efecto, fue una etapa la de Bel caracterizada por la ausencia absoluta de directrices o control del director en el trabajo de sus redactores, según afirman varios de los que trabajaron allíi38. Se

\footnotetext{
937Entrevistas con Germán Losada e Ignacio Bel.

${ }^{938}$ Entrevistas con Francisco Barrasa y José Luis Guerrero.
} 
turnaban en la redacción de la sección "La calle", que venía a ser el comentario general sobre el estado de Valladolid que se hacía cada día. Bel llegó a contratar los servicios de un stalinista, Anastasio Pulido, miembro del Partido Comunista de España marxista-leninista -el P.C.E. m-l, escindido del F.R.A.P.-, que tenía en su trabajo una garantía de no ingresar en prisión, y en el director del periódico un protector que intercedió por él en varias ocasiones. Como Pulido -lo mismo que los demás redactores- gozaba de plena libertad en su trabajo, consiguió que las páginas de Diario Regional sirvieran de apoyo para el arranque de los movimientos vecinales vallisoletanos, de cuyas reuniones él mismo -junto con su amigo Félix Jiménez- daba cumplida cuenta en generosas superficies de papel939.

El cambio del periódico fue advertido por el delegado provincial, que destacaba en sus informes el tratamiento que el diario daba a las cuestiones laborales y de orden público -que fueron causa de la apertura de tres expedientes en 1974, todos ellos sin consecuencias940_; y de este modo hacía notar que

\footnotetext{
${ }^{939}$ Idem.

940A.H.P.U.V., Sección Cultura, caja 25.
} 
"Es de señalar el sensacionalismo que Diario Regional viene dado por colaboradores del periódico que no ostentan el título de periodistas. (sic )"941

Pero el delegado no era el único sorprendido. Los lectores estaban confundidos, y las bajas de suscriptores eran un indicio de ello. Al fin y al cabo, "el que quería izquierdismo ya tenía $E l$ Norte", esquema que era más válido todavía para el público, que para los funcionarios del Ministerio. Probablemente a muchos de los habituales de Diario Regional les sorprendió el tratamiento que el periódico daba a los problemas universitarios, más atenta a las opiniones de estudiantes y "penenes" que a la del rector; que se clamara por la amnistía política, se calificara de "chasco" el gobierno Suárez de 1977 -por lo que suponía de continuidad con el régimen-, y se dedicara todo un reportaje en el dominical al P.S.O.E. de Felipe González; que se afirmara que la derecha estaba perdida por haber admitido a Arias en sus filas -eso era "alinearse con el franquismo»-; o que se estimara oportuno legalizar al Partido Comunista942. Más de uno tendría la

941 Teletipo del delegado provincial de Prensa, al director general de Régimen Jurídico de Prensa, de fecha 3/10/1974. Relata dos amonestaciones de la delegación a DR, por su tratamiento de temas de orden público -actuación de la fuerza pública-, y concluye con la frase que reproducimos. A.H.P.U.V., Sección Cultura, caja 27.

942 «El rector agredido por los estudiantes", DR, 30/1/1975, pág. 1; "Mesa redonda con seis representantes estudiantiles", DR, 31/1/1975, págs. 12-13; DR, 8/2/1975, pág. 13; "Cuatro facultades cerradas", titulares a toda plana en primera página, y en pág. 2, "Drástica medida", editorial, DR, 9/2/1975. "El ritmo de la apertura", por Juan Pablo de Villanueva, DR, 26/8/1975, pág. 3; "iVaya chasco!", editorial, DR, 9/7/1976, pág. 3; el reportaje sobre el P.S.O.E. en el Magazine de 28/3/1976. Sobre la legalización del P.C.E., en un primer momento se publicaron colaboraciones que mostraban recelos por no considerarlo un partido democrático, pero pronto la línea del 
impresión de que su periódico se había pasado al enemigo, y que ahora era un suplemento de El Norte para filoradicales ${ }^{943}$.

Pero Bel siguió adelante con su plan. La renovación de la maquinaria mejoró el aspecto del periódico -que desde que llegara el nuevo director tenía una primera página más ordenada- y lo hizo materialmente más legible. Junto con las nuevas máquinas llegaban nuevos redactores, todos con edades por debajo de los 23 años: José María Esteban -que sucedería a Ramón García en la jefatura de redacción-, Miguel Ángel Cifuentes, Jesús Díez Lobo, Francisco Rodríguez, Francisco Barrasa, Luis Ayllón, etc.. Se formó así una redacción ilusionada, que no miraba las horas de trabajo y era laboralmente cómoda: no es momento el primer empleo para pensar en reivindicaciones salariales. Todos estaban convencidos de que el periódico estaba mejor hecho que El Norte, y es posible que así fuera, pero eso no era bastante. En estos años hubo también bajas: Ramón García se fue para hacerse cargo de la oficina de prensa de FASA-Renault, Miguel Ángel Pérez

periódico fue favorable a la legalización. Cfr. por ejemplo "Juguemos todos, dice don Santiago", editorial, DR, 30/3/1977, pág. 3. Sobre la entrada de Arias Navarro en Alianza Popular, cfr. "Arias y Alianza Popular", por "Critilo", DR, 24/4/1977, pág. 2 .

943 Un pequeño incidente en concreto puede resultar ilustrativo: en las Navidades de 1976, concretamente el día 24 de diciembre, un artículo titulado "Carabanchel: feliz Navidad" protestaba contra la detención de Carrillo y por la existencia de presos políticos. El día 26 se publicaba una carta firmada por "L.", que bajo el título "España y la Navidad de todos" advertía que el periódico debía explicar por qué el artículo se dedicaba a Carrillo y no había ninguna mención de Oriol y Urquijo, entonces secuestrado, hechos que han podido "dar lugar a cierta inquietud y controversia entre nuestros lectores." 
Cifuentes a Europa Press, Fernando de la Torre a El Norte de Castilla..., y todos por razones bien sencillas y comprensibles: otras empresas pagaban mejor.

Un razonamiento paralelo iba a hacer que la aventura de Bel tocara a su fin. Los empresarios de CINISA pensaron que otros negocios eran más rentables, y decidieron también abandonar Diario Regional 944. Para Luis Conde -el gerente- semejante decisión era un error manifiesto. Se había conseguido sanear el periódico, cancelar las deudas, y mejorarlo técnicamente: no era momento de vender. En su opinión la cadena hubiera debido sostener al negocio deficitario con el apoyo de los que iban bien, en espera de tiempos mejores, que de seguro llegarían. Como tantos otros, Conde pensaba que en Valladolid debía haber más de un diario; pero daba la impresión de que quienes podían pagarlo -y hacerlo, que los periodistas en esto no eran excepción- no parecían dispuestos a invertir en ello ${ }^{945}$.

${ }^{944}$ Parece que lo que se abandonó fue la idea de promover un periódico regional castellano. La decisión fue tomada en buena medida por iniciativa del nuevo vicepresidente de la empresa, Tomás de la Cruz, y era firme a comienzos de 1977. Una de las razones que empujaron a de la cruz a tomar esa decisión con respecto a Diario Regional fue el escaso apoyo empresarial que encontraban en Valladolid para sacar adelante el periódico. Razonamientos parecidos se hicieron para Ávila y León, y así, en 1977 El Diario de Ávila se vendió al grupo de Adolfo Suárez y Agustín Rodríguez Sahagún. En León, también en ese año, se comenzó a repartir participaciones del capital de Diario de León entre empresarios leoneses, que sacarían adelante el periódico, con notable éxito. Más tarde CINISA desaparecería, y sus integrantes seguirían caminos divergentes, dentro de las empresas de prensa y publicidad. Entrevistas con Tomás de la Cruz y Ramiro Nieto Bermejo.

${ }^{945}$ Entrevista con Luis Conde Pardo. 
Así terminaba una etapa de la vida del periódico que había comenzado con las gestiones del arzobispo García Goldáraz en 1954. Si los empresarios eran católicos, eran más bien católicos empresarios, y cuando no les gustaba el negocio, variaban el rumbo de la empresa. La primacía de la profesionalidad sobre los planteamientos confesionales, o -dicho de otra forma- los modos seculares de trabajo, tenían estas consecuencias. No consideraban la decisión un fallo de su celo como católicos, sino un acuerdo racional del consejo de administración, en vista de la marcha de la empresa. Y lo mismo cabe decir -mutatis mutandis- de Bel. Por otra parte, el pluralismo y la independencia de los miembros del Opus Dei que habían intervenido en la gestión de la empresa y en la dirección del periódico -que como sabemos no eran todos los empresarios, ni todos los directores de estos años- eran presupuestos que permitían predecir los avatares por los que se había pasado. El periódico había cambiado de orientación más de una vez, y la empresa lo mismo. Por otra parte, la retirada de CINISA no significaba la salida de todos los miembros de la Obra de la empresa. Arturo León siguió en el consejo de administración, y Luis Conde en la gerencia, hasta que decidieron abandonar también ellos la nave ${ }^{946}$.

946 Hay autores partidarios de otro tipo de interpretaciones, que a nuestro juicio deforman la realidad de los hechos. Así, Jesús TIMOTEO ÁLVAREZ, en su artículo "La información en la era de Franco: Hipótesis interpretativa", Historia de los medios de comunicación en España. Periodismo, imagen y publicidad (1900-1990), Ariel, Barcelona, 1989, págs. 221-230. Timoteo Álvarez afirma que uno de los componentes del 
"Sistema informativo franquista", fue la prensa del Opus Dei. Para justificar su aserto señala que esa prensa se distingue del resto de los grupos en que no forma cadena con sus medios, sino que la vinculación entre ellos se limita a "las relaciones personales entre sus respectivos directivos o a la presencia de miembros de la obra en sus consejos". Y continúa: "Esa situación va a permitir el desarrollo de grupos tan aparentemente dispares y contradictorios como el de Calvo Serer en Madrid o el de Sebastián Auger en Barcelona (así como una presencia en múltiples frentes nuevos: Movirecord, la editorial Sarpe, etc.)."

En nuestra opinión esta explicación responde al a priori de que los miembros del Opus Dei siempre actúan coordinados -secretamentesea cual sea la actividad que desarrollen. Los datos históricos parecen indicar otra cosa. La génesis y el desarrollo de S.A.R.P.E., por ejemplo, y la división de la empresa, pueden verse como producto de una trayectoria empresarial normal y corriente, o como resultado de un afán conspiratorio que lleva a los del Opus Dei a camuflarse sin cesar. El riesgo de esta segunda interpretación es que puede llevar a conclusiones como las de Timoteo Álvarez, que nos parecen alejadas de la realidad.

No sabemos si Auger era o no del Opus Dei, pero, aunque lo fuera, afirmar que las diferencias entre él y Calvo serer son aparentes exigiría una explicación justificada que el autor no aporta. De otra parte, en la diversificación de frentes a que alude, se refiere a distintas empresas en las que en efecto hay miembros de la Obra; pero justamente el orden en que las cita es el contrario al cronológico, que se supone que sería el que justificaría la afirmación que acaba de hacer. En la descripción de la evolución de las empresas propietarias de Diario Regional que hemos hecho se refleja bien esa diversificación, pero si siguiéramos la interpretación de Timoteo difícilmente podríamos explicar la historia de cada una de ellas si no aceptamos el prejuicio conspiratorio. Parece más fácil, más riguroso, y más respetuoso con la dignidad de los protagonistas, aceptar que actuaban libre $y$ responsablemente, $y$ ese es el criterio que hemos seguido.

Por otra parte quizá su modo de emplear los datos -la clasificación empresarial que ofrece (cfr. en la pág. 229) no era así durante el franquismo, sino en 1980- unida al tipo de interpretación descrito, contribuyan a que su análisis resulte equivocado. Probablemente la historia de "Diario Regional, S.A." que nos resta por analizar sirva para aclarar algo la confusión cronológica en que incurre Timoteo Álvarez. En efecto, como ejemplo de cadenas empresariales durante el franquismo, el autor señala -entre otras- el grupo de Auger y CINISA, y menciona a Diario Regional entre los medios de la cadena de Auger. Como veremos, eso no es cierto hasta 1979, cuando Franco había ya fallecido, y esto mismo desvirtúa también los datos que aporta para CINISA.

Una interpretación muy parecida a la de este autor, cronológicamente anterior, $y$ de menor rigor histórico, es la que ofrece J. TERRÓN MONTERO en su obra La prensa en España durante el régimen de Franco. Un intento de análisis político, Centro de Investigaciones Sociológicas, Madrid, 1981, págs. 184-185. El autor, que no utiliza fuentes directas, construye toda su explicación a partir de las afirmaciones de "J. Ynfante" en su obra La prodigiosa aventura del "Opus Dei", Ruedo Ibérico, París, 1970, en la que es imposible encontrar apoyos documentales. Cita también Los católicos en la España franquista de Guy HERMET, 2 vol., Siglo XXI, Madrid, 1985 (1 â edición en francés, 1980), que a su vez toma todos sus datos de "Ynfante". 
$\begin{array}{lllllllll}\text { LA TURBULENTA } & \mathrm{Y} & \text { CORTA } & \text { VIDA } & \mathrm{D} & \mathrm{E} & \mathrm{L} & \text { INDEPENDIENTE }\end{array}$ CASTELLANO

Podría suponerse que un periódico con sesenta y nueve años de tradición, maquinaria nueva, y sin deudas pendientes, es fácil de vender. Pues bien, no fue así. Por la sencilla razón de que Diario Regional seguía siendo tal como lo advirtiera en su día Justo Garrán- una herencia peligrosa. En eso no había cambiado nada. La empresa vendedora no ocultaba que el diario generaba normalmente pérdidas, y que quien se hiciera con él debería afrontarlas si no cambiaban mucho las cosas. Pero, pese a todo, el comprador terminó por aparecer, o -al menos- eso pareció.

Un grupo de empresarios vallisoletanos se mostraba preocupado por el tipo de información laboral que ofrecía El Norte de Castilla. En su opinión no había en la ciudad ningún órgano que informara desde el punto de vista empresarial, y les parecía que ese periódico debía existir. De todos modos, si la preocupación existía, no había una voluntad firme de embarcarse en una aventura de prensa. Un joven empresario, Manuel Casado, yerno de Antolín de Santiago, hizo suyo el propósito de aglutinar fuerzas para comprar Diario Regional. Casado era un hombre

Con otra orientación tenemos la obra de Antonio ALFÉREz que venimos citando, en la que se señala de vez en cuando que tal o cual periodista o empresario pertenece al opus Dei, pero sin establecer implicaciones entre la Obra como tal y las actuaciones profesionales de esas personas. 
simpático, amigo de aventuras empresariales, y -según algunos- un tanto alegre en los negocios. Su idea era hacerse con el periódico para contar con un elemento que apoyara la imagen de sus empresas, entonces en expansión ${ }^{947}$. Casado entendía -lo mismo que el resto de los interesados- que hacía falta una figura de peso, con prestigio profesional y ascendiente moral en la ciudad, que sirviera de banderín de enganche para recaudar el capital necesario para la adquisición de la empresa -algo más de cuarenta millones-. La elección recayó sobre un antiguo redactor de Diario Regional, que si seguía vinculado al mundo de la prensa -era vicepresidente de la Asociación de la Prensa- se dedicaba fundamentalmente a la atención de su despacho de abogados, uno de los más prestigiosos de la ciudad. De esta forma, Jerónimo Gallego comenzó a presidir las reuniones que se celebraban en el hotel Felipe IV, en algún despacho de abogados, o en la sede de una empresa metalúrgica - Metales Extruidos»-, con

${ }^{947}$ La idea de Casado era ampliar y diversificar sus negocios, y contar entre ellos con una empresa de prensa con la finalidad que señalamos en el texto. Tenía además otros proyectos que no iban a ser aceptados por sus compañeros de compra. Según él, no importaba mucho que las pérdidas del diario ascendieran a unos veinte millones anuales, ya que esperaba que se alcanzara la cifra de veinte socios compradores -entre ellos tres bancos-, con lo cual el periódico, para cada uno de ellos, no supondría más que la aportación de un millón anual en concepto de gastos de imagen. Por otra parte, para rentabilizar la empresa Casado era partidario de aglutinar en torno a "Diario Regional, S.A." otras empresas afines, concretamente una de artes gráficas y otra de publicidad. Lo cierto es que Casado cerraría su agencia de publicidad y trasladaría al personal a "Diario Regional, S.A.". Según él, estaba al alcance de la mano la creación de la mayor imprenta de Valladolid, y la consolidación de un grupo empresarial que conseguiría arrostrar sin graves inconvenientes las pérdidas que generara el periódico. Todo ese proyecto se basaba, entre otras cosas, en el apoyo decidido que el resto de los compradores le prestaran, sobre todo en el terreno financiero. Entrevista con Manuel Casado. 
el fin de llegar a un acuerdo entre los potenciales compradores.

Gallego era amigo personal de Federico Silva Muñoz, y candidato al Senado por Alianza Popular en las elecciones de 1977. Quizá por esto, algunos lo vieron como "el hombre de A.P." para hacerse con Diario Regional 948. Sin embargo él no lo entendía así, y si había entrado a formar parte del grupo de personas que pensaban en comprar el periódico, era porque personalmente estaba convencido de que debía haber otro diario en Valladolid, y de que merecía la pena luchar por sacarlo adelante. De hecho, tiempo atrás, Gallego se había unido a otro grupo de vallisoletanos -similar al que ahora se estaba formandopara la publicación de la revista Támara. Aquel intento murió pronto: llegó a editarse un número cero, pero nada más. Tenía otros antecedentes en la gestión de empresas de prensa que sí tenían que ver con su amigo silva: por iniciativa de éste había desempeñado el cargo de director general de Informaciones en 1966, hasta que Emilio Romero entró en la dirección del periódico ${ }^{949}$.

Ahora estaba decidido a apoyar la iniciativa de aquellos empresarios, que convocaban a otros colegas para tratar de la conveniencia de que "gentes de orden" -es

\footnotetext{
948Entrevista con Fernando de la Torre. ${ }^{949}$ Entrevista con Jerónimo Gallego.
} 
llamativa la coincidencia con la terminología de la Segunda República, pero esa fue la que se empleó- se hicieran cargo de la edición del diario en venta. A las reuniones asistían distintos industriales de la ciudad, propietarios de empresas de mayor o menor envergadura, que iban desde el comercio tradicional al metal, pasando por los transportes, las gasolineras o la construcción: Francisco López, Juan Posadas, los hermanos García Abril, los hermanos Soler, los Muñoz de las jugueterías, Jesús Mateos, Antonio Fernández, y un nutrido grupo de constructores recientemente enriquecidos con sus negocios. Sobre todo entre los de la construcción, había un cierto temor a que la transición política perjudicara gravemente sus negocios, y ese era un acicate no pequeño para prestar su apoyo a la iniciativa que los reunía.

Pero ni los temores ni los entusiasmos eran bastantes para que se llegara a concretar algo definitivamente. Y en esto, llegó el rumor: el P.S.O.E. estaba interesado en la compra del periódico y CINISA estaba dispuesto a vendérselo si se seguía demorando la decisión definitiva950. Eran los últimos días de junio de 1977 y la noticia hizo que se convocara una reunión con el objeto de concretar algo en firme, ya que se temía -con razón, como

950 Aunque, en efecto, CINISA había entablado negociaciones con otros empresarios para vender el periódico, no se trataba de empresarios vallisoletanos. A Tomás de la cruz no le consta que ninguno de ellos estuviera vinculado al P.S.O.E., aunque tampoco puede afirmar con seguridad lo contrario. Entrevista con Tomás de la Cruz. 
luego se vio- que si se entraba en el mes de julio, ni siquiera la amenaza socialista sería bastante para hacer que "las gentes de orden" abandonaran sus vacaciones y se ocuparan de este asunto. Pese a todo, la última reunión volvió a ser confusa, salvo en un aspecto: todos estaban de acuerdo en depositar su confianza en Jerónimo Gallego. Lo que él hiciera -decían- sería suscrito y apoyado por todos.

El representante de la empresa vendedora -Tomás de la Cruz, vicepresidente de CINISA- hizo saber poco más tarde a Gallego que si no se cerraba el trato pronto, la venta se consumaría, pero ellos no serían los compradores ${ }^{951}$. Se entró así en la etapa final, en la que se redactó ya un compromiso de compra. En él se fijaba el precio y se acordaba la forma de pago, estableciéndose que las letras irían avaladas por dos empresarios de la ciudad, cuya solvencia determinarían los directores de las sucursales del los bancos de Vizcaya y Castilla en Valladolid. Días más tarde -a finales de julio-, de la cruz volvió a apremiar a Gallego, insistiendo en que si la compra no se formalizaba de inmediato todo lo hecho hasta ahora quedaría en nada.

${ }^{951}$ Parece ser que Gallego había estado interesado en retrasar la compra hasta después de las elecciones, para evitar presiones de tipo político en los primeros momentos al nuevo equipo que se hiciera cargo del periódico. Entrevistas con Jerónimo Gallego y Tomás de la Cruz. 
Tal y como se temía, no había prácticamente nadie de "las gentes de orden" en la ciudad por esas fechas, de modo que Gallego -empujado por la confianza que se había depositado en él-, y con él Manuel Casado, decidieron cerrar el trato. Acudieron al notario, y cuando se llegó a la cláusula de los industriales avalistas, de la cruz afirmó que le bastaba con el aval de Jerónimo Gallego. Éste aceptó la propuesta confiando en respaldo que se le había ofrecido, y se firmo la escritura de compra, con Jerónimo Gallego y Manuel Casado como compradores nominales. La primera letra -por valor de unos diez millones- vencía en mayo de 1978, y tanto Gallego como Casado suponían que para entonces todo estaría en orden en el aspecto financiero.

De vuelta de las vacaciones comenzaron a comprobar que los prometidos apoyos no eran todo lo numerosos que se había asegurado. Unos porque ya estaba hecha la compra, otros porque no atravesaban buen momento en sus empresas, otros por lo que fuere, se fueron desentendiendo en cadena de aquel embarazoso asunto. No obstante, algunos sí que acudieron y se pusieron a trabajar junto a Casado y Gallego, éste último bastante preocupado por el rumbo que tomaban los acontecimientos ${ }^{952}$.

952Según Manuel Casado la colaboración recibida fue la aportación de un millón de pesetas por parte de unos veinte teóricos socios. Él sostenía que con eso sólo habría suficiente para sufragar las pérdidas del primer año del periódico, y que los gastos de compra, por tanto, quedaban sin atender. 
Como en los primeros tiempos de "Diario Regional, S.A.", allá por los años veinte y treinta, se constituyó un consejo de redacción que se encargaría de asesorar al director de la publicación en la orientación del periódico. En él estaba Alfonso Candau, el Catedrático de Historia de la Filosofía y Rector de la Universidad, que venía colaborando con el periódico desde tiempos de Tallón; y junto a él, algunos de los empresarios que no se habían echado atrás: Francisco López, Juan Posadas, Antonio Fernández y Jesús Mateos eran algunos de ellos, según recuerdan Gallego y Casado. El abogado ex-periodista no formó parte del consejo, procuró no aparecer mucho por la redacción para evitar que se le acusara de intrusismo, $y$ que se identificara al medio con el partido en que militaba. Al fin y al cabo él había sido redactor años atrás y conocía bien el ambiente que se respira en una redacción.

Como director se contrató a Pedro Muñoz García, que había sido recomendado a Casado por un amigo suyo segoviano. Muñoz había trabajado como corresponsal de Madrid en Bonn, y era hasta su venida a Valladolid el director de Diario de Castilla en Segovia, con el que había conseguido algunos éxitos puntuales. Llegó decidido a hacer un diario distinto -se cambiaron incluso los tipos y, por supuesto, la cabecera-, parecido a El País -la maquetación de la primera página era una copia descarada de la del diario madrileño-, políticamente independiente, 
y castellanista. Eso decía el lema inserto en la cabecera el 9 de octubre del 78; cuando se presentó el transformado Diario Regional ante los vallisoletanos: "Independiente castellano". El editorial de ese día, "Un nuevo periódico", era -otra vez- una declaración de principios de renovación:

"A sus manos ha llegado un nuevo DIARIO REGIONAL en el que notará cambios de forma y contenido. Cualquier innovación que nuestros lectores descubran viene dada por la nueva responsabilidad que, cara a la defensa de los intereses generales de Castilla, hemos aceptado sin reserva.

"El día 7 de marzo de 1908, cuando DIARIO REGIONAL vio la luz, se escribían, en la columna editorial, estas palabras: “El periódico que, con las presentes líneas inaugura su publicidad, no viene a levantar pendón de una nueva agrupación política ni a servir a cualquiera de las otras existentes..." Desde entonces han pasado sesenta y nueve años y varias épocas en la historia del periódico. En medio de todos los cambios, grandes o pequeños, una cosa nos queda de entonces: el deseo de no "levantar pendones de agrupaciones políticas". Es decir, estamos firmemente resueltos a observar con el máximo rigor la independencia de nuestro DIARIO. Ya sabemos que es difícil, pero no nos quedaremos en el intento. En el futuro, eludiremos todo compromiso material o afectivo, político o social que no esté íntimamente vinculado con el firme propósito de ser útiles a nuestros lectores de manera incondicional, objetiva y honesta. (...) $) 953$

953DR, 9/19/1977, pág. 1 .

En la segunda página, dentro del un recuadro que contenía los datos empresariales del periódico, se apostillaba:

"DIARIO REGIONAL entiende que la participación de los lectores, cualquiera que sea su ideología, es una de las mejores aportaciones para la salvaguardia de su independencia.

"Apoye nuestra independencia informativa con sus colaboraciones objetivas.

"DIARIO REGIONAL no es órgano de ningún partido político. Aspira a ser portavoz de los intereses generales de Castilla. Nuestro único compromiso con los lectores no viene dictado por ningún partido en particular, sino los problemas generales de nuestra región.

"DIARIO REGIONAL ha aceptado el nuevo desafío que para los medios de comunicación social entraña la actual situación de cambio y se ha propuesto como objetivo prestar su mayor colaboración en favor del más provechoso desarrollo político, social y económico de nuestra región." 
Muñoz conservó prácticamente la misma redacción de Bel -salvo Anastasio Pulido, que al parecer ingresó en prisión con la marcha de su protector ${ }^{954}-$, con Luis Ayllón como redactor jefe, y la incorporación de José Luis Guerrero y algunos otros redactores o colaboradores en los meses siguientes. Las dificultades económicas llevaron a que se recurriera incluso a Miguel Montalvo -un hombre que había entrado en el diario en 1932-, que volvió, ya jubilado, a trabajar en deportes955. De nuevo la ilusión y el entusiasmo fueron los principales capitales del periódico para dar la batalla, y pronto se volvería también a comprobar que aquello no bastaba.

Las dificultades económicas se hicieron patentes en cuanto se aproximó el vencimiento de la primera letra, en mayo de 1978. No había dinero para pagar, y se supo que estaba en marcha un procedimiento ejecutivo de embargo contra los firmantes de las letras. De hecho, los problemas habían sido éstos desde el primer momento: había cundido el desánimo -o la inhibición- entre los empresarios, y Manuel Casado -por dejación de los demás-

954 Entrevista con Francisco Barrasa.

${ }^{955}$ La redacción quedaba estructurada así: Luis Ayllón, redactor jefe; Jesús Díez Lobo, información autonómica y municipal; Francisco Rodríguez, información autonómica; Francisco Barrasa, laboral; Mạ Aurora Viloria, local; Marta Arrarte, campo; Santiago Gallego, jefe de deportes; Juan Carlos Real, deportes; José Luis Guerrero, teletipos, internacional y cierre; Julio Rubio, Universidad; Miguel Montalvo, deportes; Rafael Rodríguez Zapatero, política nacional; César Tejedor, auxiliar de deportes; y desde 1978 Julio Martínez.

Entrevista con José Luis Guerrero. 
había ocupado la delegación del consejo de administración, haciéndose cargo prácticamente en solitario de la gestión de la empresa. Luis Conde Pardo, en cuanto oyó hablar a Casado -en septiembre de 1977- de hipotecar el periódico, se hizo cargo de cuál podía ser la marcha de la empresa, y dejó la gerencia, que fue ocupada de nuevo por José Ramón Abril Martín 956.

La situación era, por tanto, grave. Gallego y Casado -cada uno a su modo-, se prepararon para enfrentar lo peor, que efectivamente llegó. Comenzó el embargo de sus bienes: era el principio del duro quebranto económico que les esperaba. Pedro Muñoz había pensado que se podría llegar a animar a otros empresarios para que sostuvieran el diario, y quizá por eso su versión insiste en que fue a principios de 1978 cuando los empresarios vallisoletanos decidieron con su actitud -con su "falta de coraje empresarial", en palabras suyas- que no hubiera otro periódico en la ciudad ${ }^{957}$.

956 "Copia del poder y revocación de otro, otorgado por: Don Jerónimo Gallego Pérez, en nombre y representación de la Sociedad Anónima Diario Regional", Notaría de D. Miguel Hoyos de Castro, Valladolid, 29 de agosto de 1977, no 3.158. A.P.G.A.M.. Puede verse la composición del consejo de administración en el apéndice 3. "Copia de la escritura de revocación de poder, otorgada por: don Jerónimo Gallego Pérez, en representación de la Sociedad "Diario Regional Sociedad Anónima", de fecha 3 de septiembre de 1977. Notaría de D. Miguel Hoyos de Castro, no 3.245. Ibid.. Entrevistas con Luis Conde Pardo, Jerónimo Gallego, Manuel Casado, Pedro Muñoz, José Luis Guerrero y Francisco Barrasa.

957Entrevistas con Jerónimo Gallego, Manuel Casado y Pedro Muñoz García. 
Ciertamente, las cosas no habían ido mal para el Independiente Castellano en los primeros momentos de esta nueva etapa. Aunque no fuera para echar las campanas al vuelo, las ventas locales habían aumentado una media de 200 ejemplares diarios con respecto al año anterior, y se habían conseguido pequeños éxitos puntuales que causaron alarma en El Norte de Castilla 958. Sin embargo, con el paso de los meses se comprobó una vez más que rara vez se iba más allá de una difusión de 2.000 ejemplares, y que la venta local tendía a la baja.

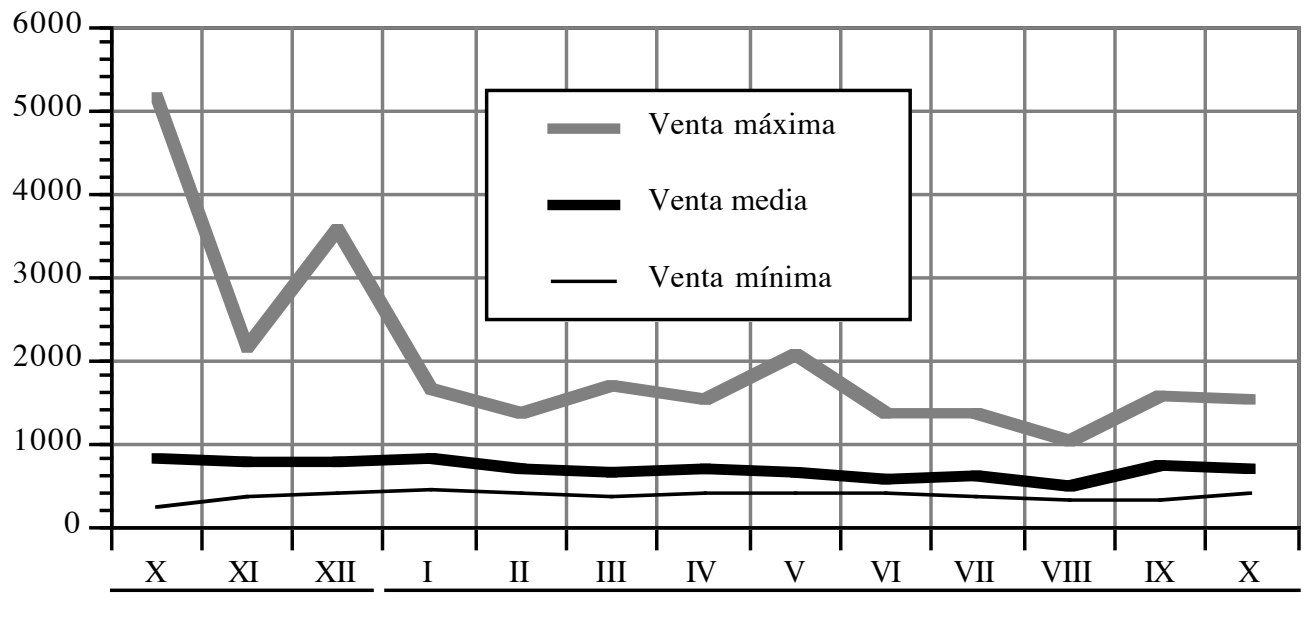

1977

1978

Gráfica 8: Venta máxima, mínima y media en Valladolid, en los meses de dirección de Pedro Muñoz.

Fuente: "Venta local" de los meses correspondientes en A.P.G.A.M., y elaboración propia.

Muñoz -que seguía la actividad de sus redactores más de cerca que Bel-, buscaba dar una proyección regional a

\footnotetext{
958Manuel Casado disiente de esta versión de los hechos y asegura que lo que realmente había puesto nervioso a El Norte de Castilla era la nueva empresa que se había formado. Según el entonces propietario del diario, ellos nada sabían de las dificultades internas de la empresa, pero sí creían que había tres bancos decididos a apoyar la nueva andadura de Diario Regional, lo que no dejaba de constituir un serio refuerzo de la competencia.
} 
las informaciones del diario, aumentando las páginas de información sobre las provincias de la naciente Comunidad Autónoma, y procuraba dar fe de la independencia del periódico prestando atención a todas las corrientes políticas, incluidas las más marginales: desde la Liga Comunista Revolucionaria a la Confederación Nacional del Trabajo, pasando por la Falange Auténtica de Pedro Conde. Como resultas de esto, los números del periódico se convirtieron no pocas veces en una galería de contrastes ${ }^{959}$.

En cuanto al castellanismo del periódico, lo mismo que ocurriera en la Segunda República, la vista de los meseteños se volvió a Cataluña. Pedro Muñoz se desplazó a Barcelona para entrevistar a Tarradellas, y menudearon los artículos que llamaban a hacer algo por que Castilla no perdiera el tren autonomista: "Castilla nacionalidad" se titulaba un editorial que impugnaba las declaraciones efectuadas por Enrique Múgica en el Club siglo XXI, distinguiendo entre regiones y nacionalidades ${ }^{960}$. De ahí que sorprenda el editorial que semanas más tarde se

959Para Jerónimo Gallego este tipo de reportajes e informaciones eran también una maniobra de distracción para evitar que el periódico pudiera identificarse con Alianza Popular. Cfr. por ejemplo el reportaje dedicado a la C.N.T. en el suplemento dominical de 5/2/1978. Entrevistas con Pedro García y Jerónimo Gallego.

${ }^{960} \mathrm{La}$ entrevista se publicó en DR, 2/2/1978, pág. 13. "Castilla nacionalidad", DR, 10/1/1978, pág. 1. Al parecer Muñoz redactó este editorial después de hablar con Gabriel Cisneros sobre el tratamiento que se pensaba dar a estos problemas en la Constitución. Entrevista con Pedro Muñoz. 
dedicaba a comentar la celebración del Aberri Eguna en abril de 1978. Llevaba por título "Ultraje a la Patria", y decía:

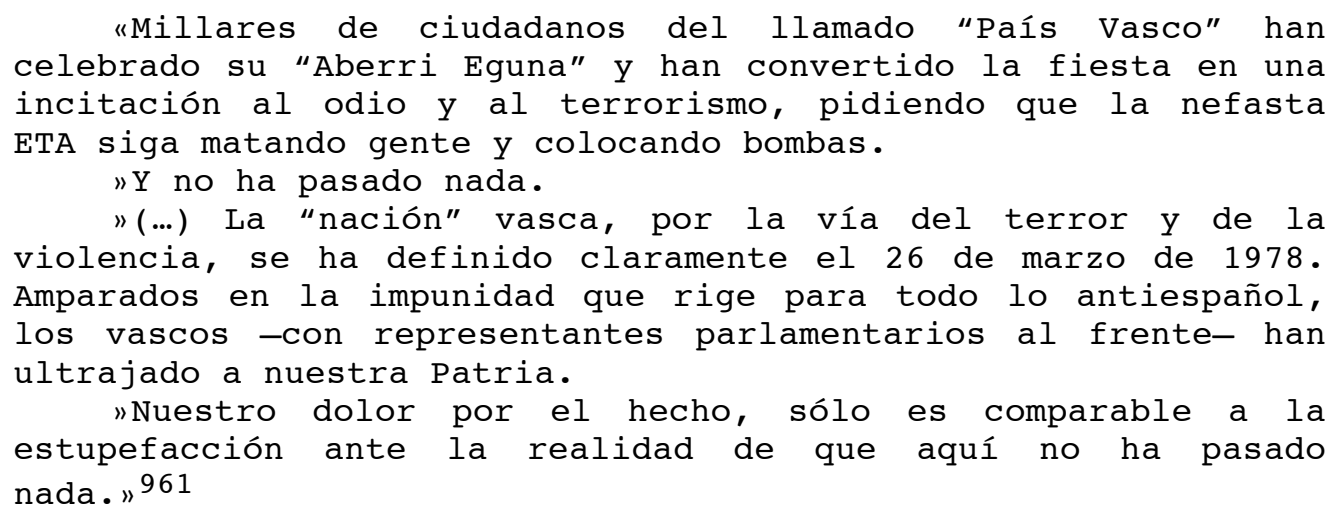
celebrado su "Aberri Eguna" y han convertido la fiesta en una incitación al odio y al terrorismo, pidiendo que la nefasta ETA siga matando gente y colocando bombas.

Es posible que este editorial se debiera a la intervención de algún consejero -parece ser que algunos eran especialmente sensibles ante los atentados terroristas y el problema vasco-, pero no dejaba de ser desconcertante. Un mes más tarde se anunciaba con grandes tipos la concesión de la preautonomía a Castilla y León, y en el editorial se hablaba del comienzo de una nueva etapa en la historia de Castilla962. A los dos días las informaciones sobre la fiesta autonómica de Villalar volvían a ser motivo para hablar de ultrajes a la Patria en un editorial titulado "Las manchas de Villalar»963. Da la impresión de que la convivencia entre redactores y

\footnotetext{
${ }^{961} \mathrm{DR}, 29 / 3 / 1978$, pág. 3.

${ }^{962} \mathrm{DR}, 23 / 4 / 1978$, pág. 1 .

963 «Villalar-78 deslucido por los incidentes», DR, 25/4/1978, pág. 1.
} 
empresarios no estaba resultando fácil en algunos aspectos .

Pero la gota que colmó el vaso no llegó por motivos políticos. Dos redactores -José Luis Guerrero y Jesús Rubio-, una vez transcurridos unos meses de su entrada en la empresa habían solicitado la afiliación a la seguridad Social. Ante el silencio que obtuvieron por respuesta, decidieron presentar esa reclamación ante la autoridad laboral. Un mal día, 23 de octubre, de vuelta de Burgos donde se habían desplazado para elaborar un reportaje con motivo del procesamiento de terroristas etarras- se encontraron con Manuel Casado en la redacción. El consejero, con malas maneras, les comunicó que estaban despedidos 964 .

Inmediatamente Francisco Barrasa pidió la liquidación y comunicó que se marchaba por solidaridad con sus colegas. Hubo más protestas entre el personal de redacción, y la respuesta no se hizo esperar: a las veinticuatro horas habían llegado cartas de despido al director, $y$ a un buen grupo de redactores incluido el redactor jefe. Era el final del Independiente Castellano.

964Entrevista con José Luis Guerrero. Cfr. el oficio dirigido por Guerrero a la Magistratura de Trabajo № 1 de Valladolid, de fecha 3/2/1979, y la sentencia de la Magistratura de Trabajo mencionada no 4281-82/78. Ambos documentos se conservan en el Archivo Privado de José Luis Guerrero Elvira. 
La versión que Manuel Casado da de los hechos difiere radicalmente de ésta. Según él, la decisión de despedir a algunos periodistas estaba relacionada con un complot en el que estaban implicados Pedro Muñoz y otros, en connivencia con $E l$ Norte de Castilla, conspiración que intentaba acabar con el nuevo Diario Regional 965.

Los redactores despedidos pleitearon ante la autoridad judicial laboral, y el director ante la civil. Mientras, los que se habían quedado en el periódico pagaban un alto precio por el mantenimiento del empleo, al aparecer como insolidarios con sus compañeros ${ }^{966}$. Todo el capital humano del periódico, con su carga de entusiasmo y de proyectos, se había tirado por la borda; tal como estaban las cosas en la empresa eso significaba volver a empezar, y eso fue justamente lo que ocurrió.

965Éste sostiene, como ya indicamos, que El Norte más que impresionado por la buena marcha de Diario Regional, estaba un tanto alarmado por la presencia de tres bancos en la nueva empresa. Como forma de contraatacar, los de El Norte habrían iniciado una labor de zapa entre los periodistas de Diario Regional que culminó -siempre según Casadocon la adhesión de Muñoz García a su plan para debilitar el renaciente periódico. Entrevista con Manuel Casado.

966 Puede verse en el apéndice 5 la relación de los redactores en 1979 que coincide prácticamente con los que no fueron despedidos.

Los trabajadores siguieron destinos dispares. Guerrero, por ejemplo, demandó a la empresa ante la Magistratura de Trabajo no 1 de Valladolid, y ésta dictó sentencia condenatoria para la empresa, que optó por readmitir a Guerrero. El impago de haberes continuó, y el redactor readmitido volvió a denunciar a la empresa. La Magistratura de Trabajo ordenó la resolución del contrato que pedía el trabajador, y, más adelante, el embargo de bienes de "Diario Regional, S.A." para satisfacer los haberes de los redactores demandantes, que sumaban 503.331 ptas.. Cfr. oficio de José Luis Guerrero a la Magistratura de Trabajo de fecha 3/2/1979, sentencia de la Magistratura de Trabajo no 1 de 19/2/1979 (no 398/79), oficio del mismo redactor de 5/3/1979 y edicto de embargo de la Magistratura, de fecha 22/3/1979, todos ellos en el Archivo Privado de José Luis Guerrero Elvira. 


\section{CON EL IMPARCIAL Y CONTRA TODOS.}

El 26 de octubre de 1978 se hacía público en la cabecera del periódico el cambio de director: María Aurora Viloria era la nueva directora en funciones. Era la primera vez que una mujer dirigía un periódico en Valladolid, y no iba a ser para ella una experiencia muy agradable. La redacción había quedado diezmada por los despidos, y en los ambientes periodísticos de la ciudad se manifestaba sin recato la animadversión hacia el periódico. El Norte de Castilla, que acogió a Pedro Muñoz García como gerente, podía respirar tranquilo por lo que a competencia se refiere.

Por otra parte, la situación interna de la empresa parecía ir cada vez peor. Manuel Casado hacía y deshacía a su gusto en el maltrecho diario, mientras la solución al impago de las letras seguía siendo de momento el embargo de los firmantes y nada más. En vista de que ni del periodismo ni de los empresarios vallisoletanos cabía esperar ningún auxilio, Casado lo buscó fuera. Diario Regional unió así sus destinos a los de El Imparcial tres semanas después de que se consumaran los despidos. Realmente, el grupo del rotativo madrileño, aunque firmó las letras para comprar las acciones ${ }^{967}$, tampoco aportó dinero de inmediato en cantidades estimables; sobre todo

\footnotetext{
${ }^{967} \mathrm{Cfr}$. en el apéndice 3 las operaciones de compra efectuadas.
} 
trajo consigo un cambio de orientación en el diario, merced al cual, se comenzó a hacer un periodismo sensacionalista de ultraderecha.

Desde Madrid venían a la capital de Pisuerga tres o cuatro días por semana redactores del rotativo madrileño Julio Merino y Valentín González, entre otros968- con el fin de orientar al colega vallisoletano. Otra vez volvió a cambiar la apariencia externa del periódico, que por primera vez en su historia dejó de llamarse Diario Regional para pasar a ser El diario, con el subtítulo regional, libre e independiente. La sobrecarga de adjetivos en la cabecera era preludio de otras sobrecargas que estaban por llegar.

Los titulares de la primera página el 15 de noviembre -el primer día de El diario- marcaban la pauta que se iba a seguir:

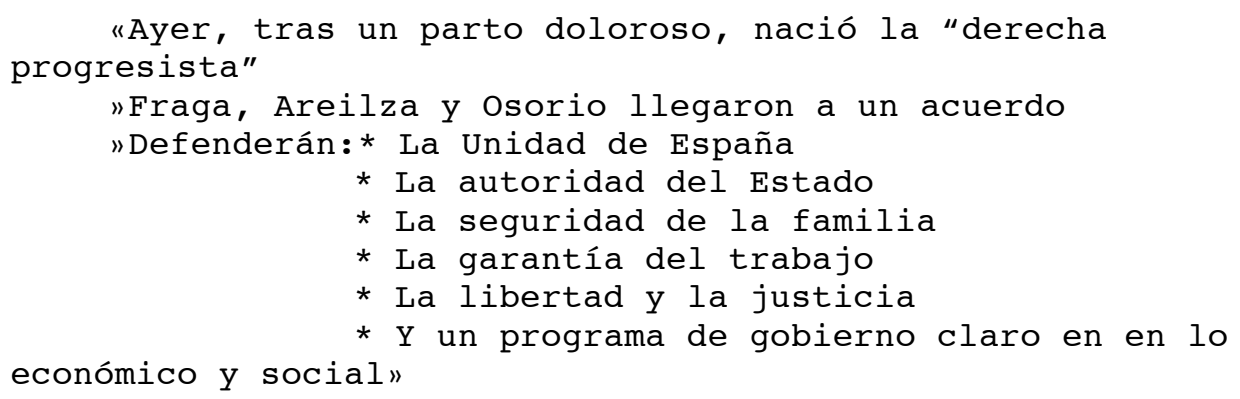

${ }^{968}$ Son algunos de los que recuerdan José Luis Guerrero, Francisco Barrasa, y Manuel Casado. Este último apunta que aunque no le gustaba la nueva orientación, era la única salida para mantener viva la empresa. 
No había más texto sobre esto en la primera página. Al día siguiente, un editorial agradecía la acogida dispensada por los lectores al periódico, al tiempo que demandaba apoyo popular en la batalla que habían emprendido:

"Gracias muy sinceras a la acogida que ayer dispensaron nuestros lectores a la nueva etapa de EL DIARIO, un periódico regional, libre e independiente, que ha iniciado su nueva andadura con el beneplácito de esos lectores que cada día apoyan nuestro esfuerzo y nos ayudan en la tarea que nos hemos impuesto de servir fielmente la noticia de cada día, el comentario apasionado en defensa de los valores de nuestra región, de España.

"Somos conscientes de que Castilla y León necesitan la ayuda que en el pasado se les negó y en el presente se les discute. Somos conscientes de que sólo el esfuerzo de todos puede conseguir aunar las voluntades en beneficio de nuestra región. Por nuestra parte, no escatimaremos lo que sea necesario para que la voz de nuestros lectores, a través de nuestras páginas, se alce contra la injusticia, contra la falacia, contra la mentira, contra las maniobras de todo tipo, $y$ llegue a las alturas $y$ a las cabañas. $Y$, por parte de nuestros lectores sólo deseamos que día a día comprendan nuestra labor y nos ayuden a llevarla a cabo con la mayor honestidad." 969

Tres días más tarde, los titulares de primera página volvían a tener unas proporciones gigantescas, $y$ un contenido todavía más estridente que los de días anteriores. Al lado de una fotografía de Franco se leía:

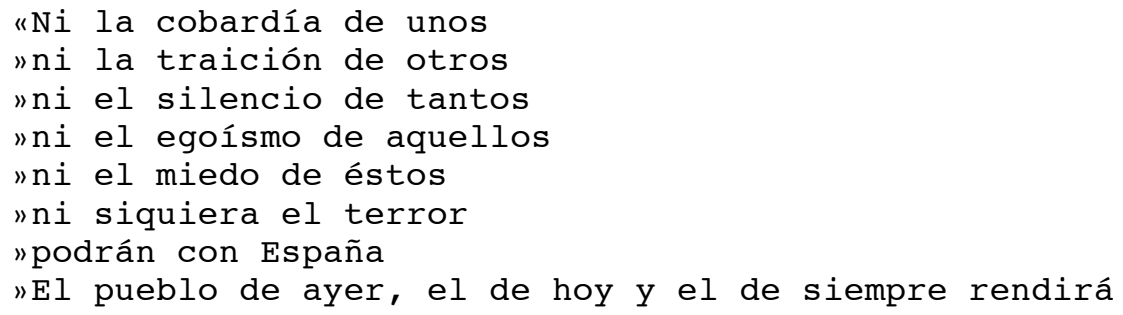

969 "Gracias a nuestros lectores", editorial, El diario, 16/11/1978, pág. 13 . 
homenaje, esta mañana, a la memoria de Franco y a una etapa de paz» 970

El editorial que seguía a semejante presentación era una lección de nostalgia en tonos incendiarios, característica de la extrema derecha de esos años ${ }^{971}$. Los días siguientes se hizo una propaganda semivelada de votar "No" en el referendum constitucional, mientras que otros días se hacían exhibiciones de radicalismo regionalista o reportajes sobre partidos de extrema izquierda, con el mismo tono sensacionalista ${ }^{972}$.

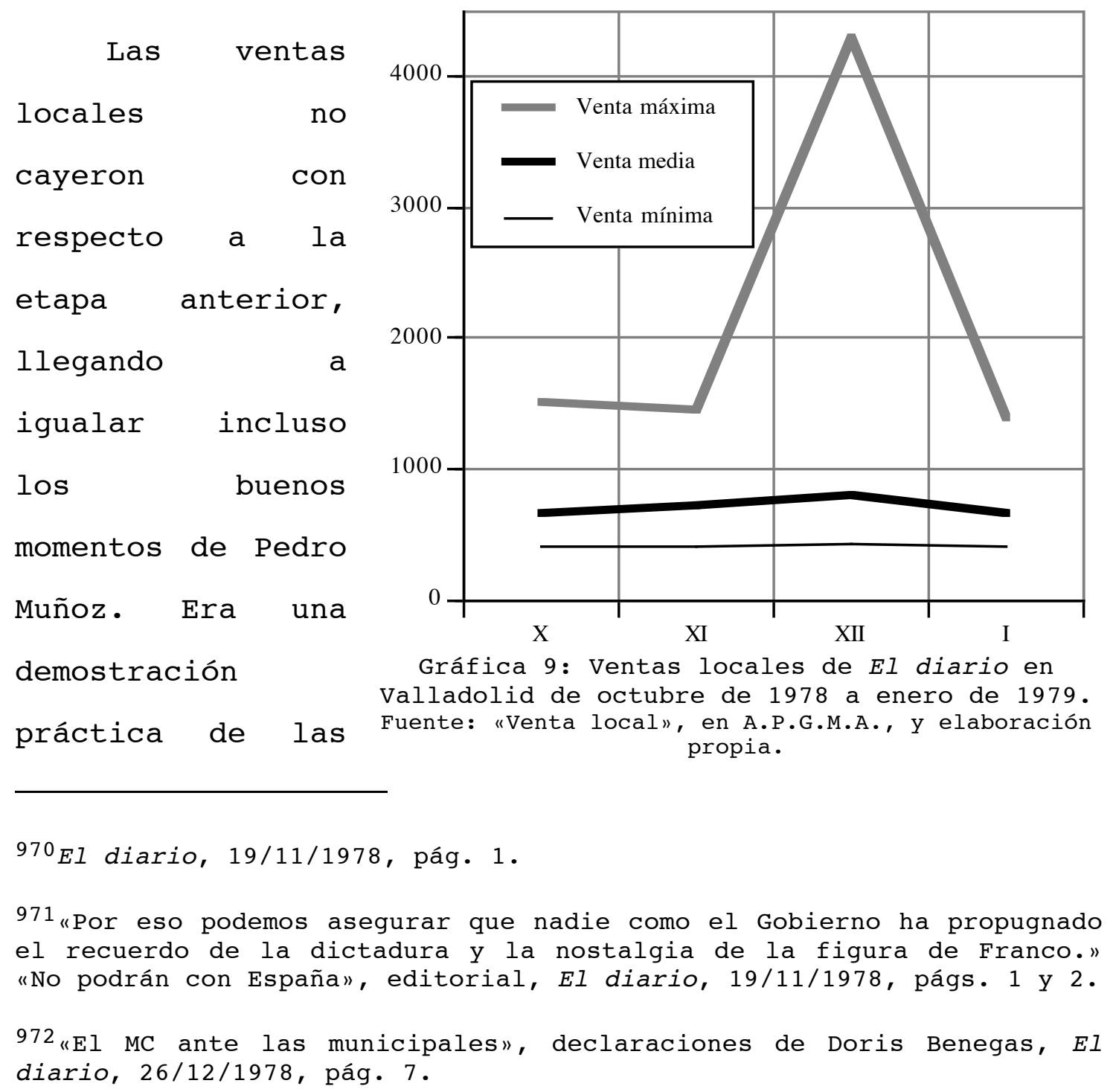


peculiaridades del mercado de prensa, y también de la escasa significación que tienen esos datos en los primeros momentos de un periódico.

En cuanto a los contenidos, se continuó en la línea descrita, entre insultos ${ }^{973}$ y análisis políticos que recordaban los que hacía el periódico en la Segunda República. Sólo que ahora con Adolfo Suárez en el papel de Azaña. El último día de 1978 un editorial anunciaba:

\begin{abstract}
"La coordinadora de Derecha Democrática Española ha visto ya la trascendencia de la convocatoria de elecciones y ha hecho un llamamiento a todas las fuerzas políticas, sin distinción de partidos o sectores, que se consideren comprendidas dentro del amplio marco de la derecha, para que dejando a un lado matices diferenciales, participen en un esfuerzo común de la mayor urgencia, para arbitrar una fórmula eficaz que permita constituir una alternativa electoral unitaria.» 974
\end{abstract}

Poco más tarde se llamaba a la convergencia a las fuerzas de derecha, para formar una "social-cristiana progresista y democrática", como única solución frente al marxismo que se venía encima975.

973Este era el titular de primera página del 14/1/1979: "Señor Martín Villa: es usted el hazmerreir de Europa".

974 "Hay poco tiempo", editorial, El diario, 31/12/1978, pág. 2. Cfr. también el del 3/1/1979, "La derecha no está".

975 «Sólo puede vencer en las próximas elecciones una derecha socialcristiana progresista y democrática. Una vez más, en la historia de estas últimas décadas, las derechas y las izquierdas van a disputarse el voto de los millones de españoles. Porque como siempre, la derecha más o menos conservadora o liberal, burguesa o trabajadora, tradicionalista o progresista, inmovilista o reformista y capitalista o social, se mantiene desunida por cientos de direcciones internas", titulares en primera página. "Una derecha social-cristiana progresista y democrática", editorial, págs. 1 y 2. El diario, 9/1/1979. 
Por azares del destino, el número del 17 de enero resultó un retrato bastante completo del periódico. La primera página estaba encabezada por gruesos tipos que anunciaban:

"La España no marxista ha perdido la última oportunidad"

Debajo entre dos fotografías enfrentadas de Manuel Fraga y Blas Piñar, se leía:

\footnotetext{
"Una vez más se presenta a las elecciones enfrentada y dividida. Los españoles, desengañados, o se abstendrán o darán su voto a UCD, lo que significa otra vez la colaboración con la izquierda marxista"
}

En el tercio inferior dos pequeños recuadros encerraban una explicación y el comienzo de un agresivo comentario firmado por Manuel Casado, que llevaba el expresivo título de "Por qué no cerramos". La explicación señalaba: Regional"

"Por un fallo mecánico. El martes no salió Diario El comentario de Casado daba cuenta de las razones profundas de esa falta a la cita con los lectores -la primera desde la huelga general de 1936-:

\footnotetext{
"(...) en esta última etapa, cuando hemos querido agilizar la información $y$ dar una nueva imagen se ha establecido un tremendo complot dentro y fuera de la empresa. Un boicot que no tiene más objetivo que llevarnos al final incluso adelantándolo."
}

Por eso no se había podido tirar el periódico en otras máquinas, por eso las emisoras de la ciudad se habían negado a dar la noticia de la avería mecánica, por eso los 
bancos se negaban a adelantar las nóminas de los empleados del periódico, porque se había fraguado una conspiración en la que "están involucrados casi todos". Pero nada detendría la marcha del regional, libre e independiente diario:

"(...) A pesar de las zancadillas, de los complots, de las zapas, de la falta de ayuda, de los comprados de dentro y de fuera vamos a seguir. Aquí vamos a estar contra viento y marea y pase lo que pase. Ni cerramos ni cedemos. Nuestra meta es defender la verdad, servir a nuestros ideales con honestidad y trabajar. Trabajar aunque no nos acepten, trabajar aunque no encajemos, trabajar sin acobardarnos y seguir viviendo gracias, precisamente, a ese trabajo y a esta verdad que vamos a proclamar a los cuatro vientos en beneficio de valladolid. Pese a quien pese y caiga quien caiga." 976

Ciertamente El diario de ese día había conseguido hacer una síntesis de sí mismo difícilmente superable. Pero, por si faltaba algo, al día siguiente, un editorial continuaba la línea del artículo de Casado, arremetiendo contra los periodistas que habían sido despedidos del periódico:

\footnotetext{
"Petulancia, vanidad, a veces ignorancia, les hacen creerse figuras insustituibles en esta especie de anarquismo sin ideales que han creado. Y les (sic) hay que boicotean, a lo mejor sin objetivo, las bases de aquello que debieran defender. Y quien cambia de opinión alternativamente sin saber de qué lado inclinarse.

"Pero como hay buenos y malos [periodistas], votamos y aplaudimos a los idealistas, que todavía quedan. (...) Y rechazamos y denunciamos a los otros, a ésos que todos conocemos, a los mediocres, envidiosos, ignorantes 0 trepadores. A los que tanto daño hacen a esta profesión a la que dicen servir." 977
}

\footnotetext{
976 "Por qué no cerramos", El diario, 17/1/1979, págs. 1 y 3 .

977 "Aquí estamos», editorial, El diario, 18/1/1979, págs. 1 y 2 .
} 
Si hay editoriales que parecen una declaración de guerra, éste lo era.

Pero la disposición de librar una loca batalla en mil frentes no era del gusto de todos. En sesión celebrada el 24 de febrero, el consejo de administración aceptó la dimisión del presidente, Arturo León, del secretario, Jerónimo Gallego, y de los consejeros Agustín Díez Hierro y Nicolás de Laurentis Vilches. El nuevo consejo estaría presidido por Manuel Casado, tendría por secretario a Rafael Rodríguez Zapatero -marido de Mạ Aurora Viloria, militante del partido Carlista, $y$ ahora redactor de periódico-, y por consejeros a María Aurora Viloria, Ramón Abril Martín, y Miguel Ángel Casado Gómez, hermano del presidente. El poder para actuar en nombre de la sociedad se otorgaba ahora a favor de Manuel Casado. En definitiva, Casado sólo978. Éste, además, se había enfrentado definitivamente con algunos bancos a raíz del comentario que hemos citado, en el que virtió diversas acusaciones contra ciertas entidades crediticias, que estaban -en su opinión- en el centro del complot que denunciaba979.

978 "Copia de la escritura de nombramiento de Consejo de Administración y poder, por: Diario Regional, S.A.", Ramiro Barbero Arranz, Notario de Valladolid, 14 de marzo de 1979 , no 580. A.P.G.A.M..

${ }^{979}$ En la entrevista con Manuel Casado éste creía recordar que la causa real de que el periódico no saliera fue una huelga en el periódico. Casado recuerda que debía pagarse la extraordinaria de Navidad, y desde Madrid se ordenó la transferencia, pero un banco se negó a hacerla efectiva. El retraso en el trámite provocó el impago y la huelga. 
No parece exagerado afirmar que el periódico marchaba a la deriva, sin una idea clara de lo que se quería que fuera, y -lo que era más grave- de cómo llegar a serlo. Con motivo del aniversario de la publicación se publicó un editorial que miraba al pasado en busca de la identidad perdida, y reafirmaba la voluntad de permanencia "pese a quien pese". De paso, se echaba mano de la defensa del cristianismo y de las ideas de Justo Garrán como justificación de la propia existencia. Éste fue el resultado de ese ejercicio de retórica:

"El periódico ha cambiado frecuentemente de empresa, ha cambiado aún con más frecuencia de mancheta, pero siempre, y esto es lo importante, ha seguido manteniendo unos valores a los que jamás ha renunciado. Y esta defensa le ha acarreado muchos males, le ha traído muchos enemigos y hasta nombres más o menos despectivos. Sin embargo, y aunque esto sea un error, quiere seguir defendiendo los principios del cristianismo, porque eso quiso su fundador, $y$ quiere seguir defendiendo además la libertad de todos, reconocida ahora en esta democracia.

"Hace poco más de un mes, DIARIO REGIONAL dijo que aquí estaba $y$ pensaba seguir. sus deseos se han cumplido $y$ el periódico, no sin algunos problemas, ha llegado a ver un nuevo aniversario. Y verá otros muchos, porque quienes lo hacen, lo viven $y$ lo sienten, así lo quieren. Por más trabas, por más zancadillas, por más dificultades que se pongan en el camino. Seguir sin renunciar a nada de lo que ha sido su ideario y que no es otro que la defensa de los valores de la libertad, de la concordia, del entendimiento de todos."980

Semejante modo de proceder no podía prolongarse por mucho tiempo. Los fallos judiciales sobre los despidos habían sido contrarios a la dirección de la empresa y había que indemnizar a los redactores, o readmitirlos abonándoles los salarios debidos. No se hizo y la Magistratura de Trabajo ordenó en el mes de marzo el 
embargo de los bienes de la empresa981. Las deudas siguieron creciendo al mismo tiempo que el sensacionalismo, y a finales de mayo la capacidad de aguante de los trabajadores -sólo se les había pagado la mitad del sueldo en abril, y se les adeudaba la paga de beneficios- llegó a su límite. Fueron a la huelga todos los de talleres junto con parte de los de administración, y el periódico no salió los días 30 y 31 de mayo. En el editorial publicado el 1 de junio, después de pedir disculpas a lectores y suscriptores, clamaban contra la inexistencia de una legislación adecuada que regulara la huelga, y contra los defectos del país en general982. Pero -dejando a un lado las peroratas- cada vez estaba más claro que o se conseguía dinero o habría que cerrar. La caída de El Imparcial acabó con las esperanzas de que esa empresa proporcionara auxilio alguno, y aunque "Diario Regional, S.A." no estaba en quiebra formalmente, la ausencia de una gestión adecuada dejaba poco lugar a dudas sobre lo que sería el futuro si no se cambiaba de rumbo ${ }^{983}$. En efecto, a los pocos días, el 7 de junio El diario no estaba en los kioscos.

\footnotetext{
${ }^{981}$ Cfr. nota 110. Guerrero fue uno de los readmitidos. Volvió a la redacción para no hacer absolutamente nada -reportajes que iban a la papelera en cuanto los entregaba- en un apartado rincón de la biblioteca.

982 "El puesto de trabajo", editorial, El diario, 1/6/1979, págs. 1 y 2 .

${ }^{983}$ Puede verse el balance contable de la empresa en junio de 1979 en el apéndice 4 .
} 
Casado no se dio por vencido, y en el verano de 1979 encontró la solución, otra vez en Madrid, aunque fuera catalana de origen ${ }^{984}$.

Final, AUNQue No FELiz

El presidente del consejo entró en contacto con Sebastián Auger y se convenció de que había descubierto la solución a todos los problemas de Diario Regional; hasta el punto de que cuando Jerónimo Gallego le sugirió que era el momento de cancelar las deudas de la compra que todavía estaban pendientes, Casado se negó a exigir prontitud en los pagos al catalán. Estaba convencido de que una vez que éste se hiciera cargo de la gestión del periódico, no sólo desaparecerían los problemas, sino que las ganancias no tardarían en llegar. Por fin estaban ante un negocio rentable 985 .

Sebastián Auger era un empresario catalán con aires de grandeza, doctor en Derecho por la Universidad de Barcelona, y licenciado en Ciencias Políticas por la de Madrid. Había construido su flamante seudoemporio de prensa -el "Grupo Mundo"- con el objetivo de llegar a Madrid avalado por un prestigio suficiente para aspirar a

\footnotetext{
984Al parecer fue Máximo Garrido, de El Imparcial quien le guió hasta Sebastián Auger.

985Entrevista con Jerónimo Gallego.
} 
una cartera ministerial986. En 1979, mientras se encontraba en plena batalla para hacerse en exclusiva con Informaciones -que quería convertir en "un diario progresista de claro apoyo a los procesos autonómicos en marcha»-987, entró en conversaciones con Manuel Casado. A la altura del 10 de agosto habían llegado ya a un acuerdo por el que Auger se comprometía a hacerse cargo de Diario Regional. A primeros de septiembre se formalizó la venta de acciones a "Barcelona Press, S.A.", "Ilustración S.A." Y "Ediciones Cataluña Express, S.A.", por un valor nominal de algo más de 41 millones de pesetas ${ }^{988}$. Al mismo tiempo se concedían poderes como apoderado general del periódico a Francisco Javier de Qintana Justafré -abogado residente en Barcelona-, Antonio Herrero Sáiz y Luis Fernández Briceño -los dos residentes en Madrid-, con carácter solidario e indistinto, por lo que serían ellos los que en adelante llevaran la dirección de la compañía, relevando a Casado en esas tareas.

El periódico volvió a aparecer el 24 de octubre, de nuevo transformado en su aspecto externo y en su línea. La directora -en propiedad desde el mes de febrero- seguía siendo María Aurora Viloria. En el editorial -«Buenos

986ALFÉREZ, op. cit., págs. 85 y 110.

987 Ibid., pág. 111.

${ }^{988}$ Certificación del secretario y el presidente del consejo de Administración de "Diario Regional, S.A." de fecha 5/9/1979, y "Póliza de operaciones al contado" de fecha 13 de diciembre de 1979. A.P.G.A.M. . 
días, otra vez»- se relataba la historia de los meses de vida sumergida y el final feliz de la misma:

"Por eso, porque quería seguir adelante, la anterior empresa editora de DIARIO REGIONAL se puso en contacto con profesionales específicos de la información, que ahora cuentan con la mayoría de las acciones."

Se detallaban uno a uno los medios que formaban parte del "Grupo Mundo", como si cada uno de los títulos fuera un aval de futura grandeza, prosperidad económica y éxito periodístico.

"Un grupo, pues, de profesionales de la información se ha hecho cargo de DIARIO REGIONAL"

Esa esperanzada afirmación -que no dejaba en buen lugar a los gestores anteriores- concentraba todas las esperanzas de los trabajadores del atribulado rotativo. Pero, para su desgracia, la frustración no tardaría en llegar.

Pasaban las semanas y el apoyo económico del catalán no iba más allá de las promesas. Auger había hecho un hermoso discurso ante los trabajadores del periódico y no había vuelto a aparecer ${ }^{989}$. Casado tranquilizaba a todos asegurándoles que no había nada que temer; pero pronto llegaron noticias que indicaban lo contrario. Desde EI Norte de Castilla se avisó a Jerónimo Gallego de que Auger estaba decidido a llevarse la maquinaria de Diario

${ }^{989}$ Entrevistas con Mạ Aurora Viloria, Manuel Casado, y Jerónimo Gallego. Puede verse también "Auger gana la batalla de la prensa libre», por Sebastián Auger, DR, 20/11/1979, pág. 13. 
Regional a Informaciones. Casado y Gallego viajaron a Barcelona para entrevistarse con el empresario catalán, y allí se confirmó la noticia, en una conversación notablemente violenta. Gallego se negó a permitir el traslado, que significaba la pérdida de todos los puestos de trabajo en Valladolid. En contrapartida, Auger se desentendía de los destinos de Diario Regional aunque no lo dijese expresamente ${ }^{990}$.

No obstante, el periódico siguió saliendo, aunque fuera ya un enfermo caquéctico, cada vez con menos páginas. En febrero de 1980 la empresa editora de Informaciones iniciaba un expediente de suspensión de pagos. El globo comenzaba a desinflarse. Lo mismo que se hiciera en el vespertino madrileño, los trabajadores de Diario Regional intentaron salvar la empresa, y siguieron adelante hasta que la falta de papel y tinta hizo imposible prolongar más la agonía del setentón ${ }^{991}$. Falleció el día de su setenta y dos cumpleaños. El editorial que le sirvió de epitafio -"Despedida y aniversario»- decía así:

"Si todas las despedidas son como morir un poco y lo único que las hace llevaderas es la esperanza del reencuentro, decir adiós a un periódico es algo infinitamente amargo. Sin embargo hoy, DIARIO REGIONAL se ve obligado a hacerlo. Con este número, en el que van puestas las ilusiones de cuantos lo hacemos, rompemos por el momento el contacto con la calle. DIARIO REGIONAL no acudirá mañana a la cita con su público. No

${ }^{990}$ Casado niega que el objetivo de la visita a Barcelona fuese éste. Según él, iban allí para reclamar el pago de las letras, pero no había por parte de Auger una voluntad malintencionada con respecto a Diario Regional.

${ }^{991}$ Entrevista con Mạ Aurora Viloria y ALFÉREZ, op. cit., pág. 112. 
podemos decir por cuanto tiempo, sencillamente porque no lo sabemos, pero tenemos puestas todas nuestras esperanzas en que también para esta muerte haya una resurrección. Y esta fe en el retorno es lo que hace soportable la forzada despedida.

"Por una de esas casualidades no buscadas ni queridas, hoy DIARIO REGIONAL cumple 72 años. Un 7 de marzo de 1908 salió a la calle por primera vez. Aquel fue un buen día, sin duda, para quienes tuvieron sus ilusiones cumplidas en estas páginas que veían la luz por vez primera. Y hoy, setenta y dos años después, el mismo periódico, cargado con la experiencia de casi tres cuartos de siglo, se despide sin saber hasta cuando. Ha cambiado mucho, ha sufrido muchos avatares $y$ muchas borrascas que le han hecho embarrancar, que no zozobrar, en múltiples ocasiones, pero ha adquirido esa madurez y ese lugar entre los vallisoletanos y los castellanos, todos, que a partir de esta mañana de marzo estará vacío, aunque sea, tal vez, por poco tiempo.

"La crisis de la prensa no es un tópico ni una frase al uso. Es una realidad que está acabando inexorablemente con la vida de muchos periódicos mientras otros están amenazados de muerte. Un sistema de subvenciones que premia a los que más tienen y dejan en la estacada a los que necesitan una ayuda, hace tambalear todas las empresas privadas y amenaza de muerte a la prensa realmente independiente.

"Y esa crisis ha envuelto por segunda vez a DIARIO REGIONAL cuando aún no había conseguido recobrarse del todo de la anterior. Los trabajadores que nada saben de gestiones empresariales, de dificultades de financiación, de ausencia de créditos o de cualesquiera otras razones, han luchado hasta el último momento por sacar adelante el periódico. Todos unidos han aguantado sin cobrar desde diciembre, esperando que con su postura la solución fuese más factible. Pero no ha sido así y se ha solicitado una suspensión de relaciones laborales por cuatro meses que puede dar un respiro a trabajadores y empresa para hacer factible ese retorno que todos esperamos sea el definitivo.

"Hemos intentado en estos últimos meses hacer un periódico en el que todos sin excepción tuviesen un lugar abierto. No ha habido cortapisas de ninguna clase salvo la defensa de los principios en los que creemos. Los problemas, que nos obligaron ya hace días a reducir páginas, han impedido desarrollar la labor hasta sus últimos objetivos. Pero aún así, no se ha perdido la ilusión $\mathrm{ni}$ se ha regateado el esfuerzo. Hoy, en la angustia de saber que se ha llegado al final -aunque tal vez sólo sea por un corto tiempo- pedimos disculpas por no haber sabido hacerlo al gusto de todos.

"Las despedidas no deben prolongarse demasiado. Por eso hoy agradecemos a nuestros lectores, anunciantes, colaboradores, amigos $y$ a todos cuantos se han sentido identificados con DIARIO REGIONAL, el apoyo prestado. Y decimos sencillamente, que esperamos volver a encontrarnos pronto." 992

992DR, 7/3/1980, pág. 1 . 
Pero esta vez no hubo resurrección. Los bienes de la empresa se subastaron para pagar a los empleados $y$ acreedores. La vistosa maquinaria se fue a Santander y la biblioteca a una de las Cajas de Ahorros acreedoras. Ma Aurora Viloria, junto con otros trabajadores de administración y talleres, fue acogida en $E l$ Norte de Castilla, y el resto de los empleados tuvo que buscarse otros medios de vida.

En cuanto a los empresarios, Gallego sufragaba con su trabajo como abogado el precio de su error en el verano de 1977; Auger estaba en paradero desconocido cuando se dictaron contra él dos órdenes de busca y captura en 1982, y Casado había perdido buena parte de su patrimonio y casi toda la credibilidad empresarial en algunos ambientes de la ciudad.

Era un triste final, que dejó un sabor amargo en muchos vallisoletanos relacionados con el mundo de la prensa.

Libertad había desaparecido en 1979: nadie pujó por él en la subasta. Sólo quedaba El Norte de Castilla como diario de Valladolid, y pasaría mucho tiempo antes de que alguien se arriesgara a abrir otro rotativo en la capital 
del Pisuerga. Cuando se hiciera, la iniciativa no partiría de empresarios vallisoletanos ${ }^{993}$.

El recuerdo de Diario Regional, envuelto en un halo de nostalgia, perviviría en el recuerdo de los que habían protagonizado su historia. Para unos era increíble que hubiera desaparecido -«después de todo lo que se había trabajado en él»-; para otros era inevitable que desapareciera - "nunca fue viable»-; para otros "fue una penal; y para todos, eran otros tiempos. Así es la historia.

993En 1990 comenzó a publicarse una edición vallisoletana del diario Alerta de Santander -con el subtítulo "El periódico de Valladolid" -, y en 1991 salió a la calle El Mundo, que sustituía su subtítulo habitual -"del siglo XXI"- por "de Valladolid"en su edición de la capital del Pisuerga. 
Conclusiones 
Afrontamos este estudio conscientes de su complejidad, $y$ hemos de concluirlo reiterando esa aseveración. Así ocurre -por suerte- con todo problema humano. Quizá proceda de ahí el atractivo de las humanidades y el debate que siempre suscitan y suscitarán este tipo de estudios y reflexiones. No obstante, es forzoso que terminemos exponiendo algunas conclusiones que -a nuestro juicio- se derivan de cuanto hemos expuesto.

La Segunda República representó el fin del monólogo liberal y la oportunidad de entrar en un diálogo democrático. Por desgracia, fue una oportunidad perdida. La turbulenta vida de los españoles estaba suficientemente sembrada de odio, y el desarrollo material era lo bastante pobre, como para generar radicalismos que acabaron con un proyecto que sólo fue verdaderamente democrático en las mentes y acciones de una exigua minoría, tanto por la derecha como por la izquierda.

La situación política vallisoletana era paradigmática con respecto a lo que fue en esos años la vida en las provincias españolas de tradición agrícola. Una minoría liberal, convenientemente ilustrada, había conseguido hacerse con las riendas de la sociedad. Los más vivían en la capital de la provincia y -por su escaso dinamismo empresarial- lo esperaban casi todo de la capital de la nación. En el campo, las tradiciones eran el más fuerte 
elemento de articulación social, mientras que las condiciones materiales de vida estaban marcadas por una pobreza arrastrada desde mucho tiempo atrás. Como tal sociedad tradicional, tenía unas élites bien definidas a las que se prestaba un dócil asentimiento a través del esquema caciquil. Ése había venido a ser el modus vivendi de compromiso entre una sociedad atrasada y unas capas rectoras que se plegaban gustosas a los vientos liberales que soplaban desde el corazón del país.

Había además en la urbe grupos de trabajadores que experimentaban una creciente proletarización, al ritmo de la débil industrialización; en el campo, un también incipiente proletariado agrícola engrosaba sus filas debido a los efectos negativos que el proceso de modernización económica generaba sobre el sector primario. En la era de la electricidad, el petróleo y el acero, los negocios de los corros trigueros de Chicago se hacían sentir incluso en rincones perdidos de Castilla. El mundo estaba cambiando y -al menos en lo que se refiere a las condiciones materiales de vida- se estaba unificando.

El fin de la etapa liberal significó una oportunidad para los marginados del sistema: por un lado los tradicionalistas, por otro los partidos y movimientos de clase. Mientras tanto, buena parte de los católicos veían nacer un nuevo, poderoso, y más radical enemigo en esos grupos de izquierda, lo que les confirmaba en la idea de 
que sólo una adecuada respuesta institucional podía contener la marea revolucionaria que ya estaba a punto de irrumpir. No obstante, había otros que creían posible la convivencia democrática y la implantación pacífica de los criterios de los creyentes. Diario Regional sirvió de portavoz por unos meses a esos potenciales modernizadores. Pero pronto su voz se vio acallada por los que no veían otra solución que un partido católico fuerte que hiciera frente a unos disciplinados izquierdistas decididos a hacerse con el poder. Las viejas élites liberales locales apenas si sabían qué hacer con las ruinas de su cacicato. Desconfiaban de los recién llegados a las lides políticas, y buscaban un entendimiento con la izquierda. Al fin y al cabo, con la derecha hacía décadas que venían combatiendo y, por cierto, venciendo.

El intento católico tradicionalista consiguió un cierto éxito en la ciudad y se concibieron esperanzas de que, de nuevo, los reyes de España -pocos hubieran admitido sustituir la palabra rey por presidente-, y con ellos el país, vieran garantizado institucionalmente su catolicismo. Fueron pocos los que se percataron de las graves deficiencias materiales, culturales y espirituales que había en la vida de las clases populares españolas; y fueron todavía menos los que se movilizaron para remediarlas. Los más confiaban en la reacción institucional como solución de todos los males. Y, cuando ésta se vio imposible, ante el temor de perder 
definitivamente la batalla política, aplaudieron la solución militar.

El periódico católico vallisoletano había cumplido su papel de aglutinante de voluntades de las élites de la derecha confesional. Hizo vibrar a unos cuantos -la acción política es cosa de pocos- y ganó los combates electorales en la provincia, y, en menor medida, en la capital. Había alcanzado su meta, y pudo comprobar que su estilo daba buenos resultados en los sectores económicamente más atrasados, y hasta ahora social y políticamente menos concienciados. Cuando se produjo el Alzamiento militar aplaudió con entusiasmo, convirtiéndose en un órgano influyente cuando el país quedó dividido en dos zonas irreconciliables.

No era -ahora tampoco- un órgano informativo. No hay información en la guerra, sino propaganda. Como para eso había sido concebido, se encontró a gusto en la nueva situación, mientras avizoraba el nacimiento de una nueva España, grande y católica, fruto de una cruel purificación por el fuego del solar patrio.

Pero si a algunos el fuego pudo purificarlos, a otros los consumió. Las violencias de unos y otros dejaron su dolorosa huella en el país, y en el diario, el amargo sabor de quien ve que su enemigo de siempre -el periódico 
liberal- sobrevive pese a todo, $y$ se hace un hueco en la nueva España.

Las élites tradicionales habían conseguido salir prácticamente indemnes de la catástrofe, adaptándose mansamente a los nuevos tiempos. Por su parte, el nuevo régimen político acabó con las "frívolas" maneras del pasado e impuso su dominio vi militari, asumiendo la defensa del catolicismo como objetivo institucional. No había ya batallas políticas que librar, y el periódico perdió su razón de ser más caracterizada. Quedaban, eso sí, la literatura y la crónica piadosa, pero éstas -que podían bastar y de hecho bastaban para que se editara un buen número de revistas- no resultaban suficientes para que se editara un diario.

Los católicos vallisoletanos participaron activa o pasivamente en la nueva oleada evangelizadora de los años cuarenta, al estilo del Antiguo Régimen. En una sociedad deshecha, llevada al pasado por la miseria heredada de la contienda, aquello dio resultado, y -aunque algunos 10 hicieran por conveniencia- no pocos se adhirieron con fervor a las creencias, encontrando en ellas consuelo y aliento para seguir adelante en los duros momentos de la larga postguerra. Pero Diario Regional no podía vivir a base de espíritu misionero. No es eso el periodismo. Ignacio Valverde, el hombre de la Escuela de El Debate que dirigiera el periódico en los últimos años de la 
República, había podido hacer un periódico más moderno, informativo, combativo, y -cómo no- apologético. Esa era la tarea que habían de llevar a cabo, si querían sobrevivir.

De nuevo se recurrió a los hombres de El Debate para volver a intentarlo. Pero ¿cómo podría ser combativo ahora, en una sociedad oficialmente católica? ¿cómo informar en el país donde -gracias a la censura- nunca pasa nada? Era una tarea difícil para aquellos periodistas, que resolvieron a base de ingenio, notas de vida municipal, y comentarios ardientes sobre la vida católica.

Ahora bien, si la pugna política había sido la más íntima razón de ser del diario, la llama sagrada que mantuvo vivo al periódico tiempo atrás, allegándole los medios económicos para sobrevivir, ahora que estaba apagada, sólo siendo un buen diario, sólo así, se podría mantener.

La batalla periodística había comenzado, y se sucedieron los intentos de ganarla..., sin conseguirlo. El Norte de Castilla contaba con una buena gestión empresarial, y con el aval de la tradición, sólo levemente interrumpida por la guerra. Eso era bastante para que una sociedad como la vallisoletana le considerara "su caudillo" natural y le tributara la correspondiente 
"adhesión inquebrantable". Cierto que para los más era un caudillaje comercial más que ideológico, de anuncios por palabras, podríamos decir. Pero, siguiendo con el símil, es que esa sección es de las más populares en un diario provinciano, y lo dice casi todo sobre su grado de implantación.

Con Diario Regional estaban los que -también por tradición- habían estado siempre con él. Y, significativamente, con el nuevo periódico oficialista Libertad- no había casi nadie, al margen de quienes 10 recibían por oficio. Era, en lenguaje de mercado de prensa, el mensaje que anunciaba el fracaso de la "revolución política" falangista que se había pregonado. Ahí estaba para que lo oyera quien quisiera escucharlo.

Pero eso no arredró a las autoridades en su afán de hacer de la prensa un corifeo del Estado. Diario Regional fue sancionado, $y$ un director estuvo depuesto sobre el papel, antes de que el arzobispo vallisoletano saliera en su defensa públicamente. No fueron las críticas -que no hubo tantas- el motivo principal de la sanción: 1o que no gustaba a los atentos vigilantes de la prensa, eran los descuidos, las deficiencias formales y valorativas como se escribía en los expedientes-, las faltas de entusiasmo a la hora de cantar las excelencias del Caudillo o sus ministros, o, en fin, las poco disimuladas preferencias monárquicas de algunos de los hombres del 
diario. Asombra que pudiera pensarse en construir así -con métodos policiales, ahogando toda iniciativa, y a base de propaganda- una "gloriosa España católica", pero aquellos gobernantes estaban seguros de conseguirlo.

Los intentos de sacar a flote Diario Regional fueron en vano. "La Editorial Católica" lo abandonó a su mala suerte, y sólo el empeño del arzobispo, que todavía creía en la necesidad de un medio específicamente católico, le salvó la vida. A su alrededor siguieron, como apoyos, los pocos vallisoletanos que creían en el proyecto, y se consiguió la ayuda foránea de miembros del Opus Dei.

Corría el año 1955 cuando se reestructuró la empresa editora de nuestro periódico. Poco más tarde una reestructuración más intensa afectaría a todo el país. En el siglo de los avances vertiginosos, las libertades, las democracias, el pluralismo y la descolonización, cuando la ingente cantidad de lo nuevo apenas dejaba tiempo para pensar en lo antiguo, España renegaba de los partidos políticos, la libertad, hablaba de imperio, y miraba al pasado como única esperanza. Se trataba de una anomalía histórica en toda regla; y pronto hubo de modificarse el rumbo para evitar la ruina definitiva: "la España eterna" debió abrirse al mundo, olvidar sus postulados tradicionalistas, hacer caso a los dictámenes del Fondo Monetario Internacional, y firmar tratados con los Estados 
Unidos. Era el comienzo del fin de la utopía tradicionalista.

Con el fin de la "España eterna" sonó la hora de la modernización, y la sociedad civil comenzó a asumir el protagonismo que le corresponde en un proceso de ese estilo. Desde el punto de vista pastoral, la jerarquía católica se encontraba de nuevo con el problema de la pérdida del sentido cristiano en amplios sectores de la sociedad, y muchos comenzaron a percibir lo inútil -si no perjudicial- que resultaba el apoyo institucional para hacer frente a esos problemas. El innegable fracaso práctico de los presupuestos ideológicos del sistema político franquista, constituía una lección importante para los católicos tradicionalistas. Años de discusiones y guerras con motivo de la orientación que debía darse a la gestión de la cosa pública no habían conseguido que reconocieran lo que ahora se había demostrado: la alianza con el poder político era una solución obsoleta para los problemas religiosos de las sociedades industriales.

Un razonamiento paralelo al que había puesto fin a la idea tradicionalista desplazó también los viejos modos de hacer de la llamada prensa católica, tan ligada a las añejas contiendas políticas que ahora se desestimaban. El fin de los planteamientos confesionales en general, y en materia de prensa en particular, fue anterior -en algunos sectores del catolicismo español- a las declaraciones 
oficiales de la jerarquía en ese sentido. Así, en Diario Regional los nuevos gestores retiraron en 1956 el lema "diario católico" de la cabecera. Estaban convencidos de que el rótulo no aportaba nada bueno a su afán de cristianizar la sociedad. Más que a etiquetas había que atender a la validez humana de la propia actividad si se quería hacer la apología de la fe. Riqueza interior, una intensa espiritualidad, eran tan necesarias como siempre, que en eso no cambiaban los tiempos. Pero en la actividad profesional no había soluciones católicas, sino católicos que ofrecían soluciones. No debía pensarse que éstas tuvieran garantía divina por el hecho de que las formulara un bautizado, eso era confundir los términos del problema.

Como consecuencia, la pluralidad de opciones de los católicos frente a las cuestiones temporales era no sólo admisible sino deseable. Y en cuanto a qué debía ser un medio de prensa hecho por católicos, la respuesta no ofrecía dudas: una publicación profesionalmente bien hecha, que no lesionara las enseñanzas de la doctrina ni los preceptos de la moral católica.

Diario Regional cambió de estilo con motivo de relevos en la dirección, la redacción y la gerencia. A veces fueron causa de esas transformaciones el consejo, el mandato o el castigo por parte de unas autoridades políticas a las que no siempre gustaba lo que se publicaba en el diario. Seguían comportándose como dueñas de las 
empresas que vigilaban: dos directores del periódico fueron depuestos por el Ministerio de Información en el plazo de seis años, y las advertencias, amonestaciones, consignas y expedientes se contaron por millares.

Pero, pese a todos los cambios, la historia periodística del diario seguía siendo una misma melodía interpretada en distintos tonos: una dura competencia con El Norte de Castilla que sólo daba lugar a éxitos muy localizados. Esa pugna profesional confirió al periodismo de la ciudad una notable viveza, y propició la dignificación y mejora de los profesionales que la protagonizaron. Las mejoras técnicas se sumaron a esos esfuerzos personales para incrementar la calidad de las informaciones; y las económicas ayudaron a que la profesión dejara poco a poco de ser un segundo empleo. La suma de todos esos factores ayudó a que las tareas del periodismo comenzaran a ser en provincias una dedicación profesional digna, capaz de llenar la vida de algunos. Podría decirse que era el final de la primera etapa de la profesión periodística en Valladolid, una época en la que la historia del periodismo había sido la de personajes singulares. Comenzaba la consolidación de una profesión que todavía se está haciendo, y se ponía sobre el tapete en un ámbito concreto- lo que significaba el fortalecimiento de la sociedad civil. 
La contrapartida económica de lo descrito fue el endurecimiento de la competencia en ese terreno, siempre con El Norte como indiscutible punto de acumulación del mercado publicitario, y líder en ventas. "Diario Regional, S.A." era una empresa que a duras penas conseguía sostenerse. Abandonada a las fuerzas del mercado, privada de apoyos como la utilidad en la vida política o en la religiosa, sólo si se rentabilizaba sería viable y atractiva para alguien. No se alcanzó esa rentabilidad y una empresa tras otra, todas fueron deshaciéndose del rotativo. Cuando se llegó al punto de no contar con ningún apoyo fuera de Valladolid, la empresa se hundió. No hubo nadie en la ciudad que, teniendo los medios económicos para afrontar esa tarea, quisiera hacerse cargo de ella.

En Ávila, un colega suyo que atravesaba dificultades similares, fue vendido a un grupo de hombres encabezado por Adolfo Suárez y Agustín Rodríguez Sahagún. En León, otro diario con una historia paralela a la del nuestro fue adquirido por empresarios de la ciudad que lo sacaron adelante. En Valladolid no hubo políticos ni empresarios que se tomaran en serio la empresa. Era todo un signo del asentimiento que se prestaba en la ciudad al poderío de El Norte de Castilla.

De este modo, la desaparición del diario puso de manifiesto dos realidades diferentes: una era fruto del modo de ser de la sociedad vallisoletana, y en especial de 
sus élites políticas, económicas y culturales, que decidieron con su actitud que no debía haber un segundo periódico en la ciudad. Este comportamiento puso de manifiesto, a nuestro entender, el notable conformismo con que esas élites afrontaban su existencia, y la escasez de iniciativas renovadoras entre ellas. Eran, si se quiere, unos grupos sociales plácidamente dominantes, que no necesitaban proyectos de futuro para asegurar su preeminencia.

La otra realidad tenía raíces más hondas y una validez más extensa e intensa. Nos referimos al cambio de actitud de los católicos frente a los modos de hacer en el mundo contemporáneo que se puso de manifiesto con la desaparición del diario católico. Dicha extinción por transformación, significó el abandono del modelo tradicionalista y la asunción de los planteamientos seculares como eje de las tareas evangelizadoras. Una importante novedad cuyos frutos sólo conoceremos con el tiempo. En lo que esos fenómenos tienen de espiritual, sería pretencioso y vano cualquier intento de análisis. Las únicas conclusiones que nos es posible y lícito extraer se mueven en el orden de la vida social y política, pero nunca más allá. En ese sentido, estamos convencidos de que se puede afirmar que la historia de la prensa católica en estos años es una de las mejores guías para percibir el debilitamiento, la agonía y el fin de los planteamientos tradicionalistas entre los católicos 
españoles, lo mismo que el surgimiento entre ellos de nuevas soluciones para afrontar los problemas planteados en el mundo contemporáneo.

La Segunda República, con su final dolorosamente traumático, pudo haber servido para demostrar la inviabilidad de las maneras de hacer que se habían empleado en esos años; es decir, el intento de unificar políticamente a los católicos para la defensa de su fe. Pero no fue así, y el régimen de Franco se convirtió en el mayor experimento católico tradicionalista de la historia de Europa. La evolución del país durante el mismo demostró que el aislamiento de los católicos resultaba, además de indeseable, imposible, $y$ que en las sociedades contemporáneas la religión del príncipe -o del Estadopoco o nada significa sobre cuál sea la de su pueblo. La sociedad civil, alimentada por la acción de los ciudadanos -tanto si son católicos como si no lo son-, es una realidad que se impone a los designios institucionales. Si éstos no responden a las necesidades que esa sociedad plantea, toda su obra es precaria y su ruina segura, por católica que sea. Los nuevos modos de vida de la civilización industrial o postindustrial reclaman esfuerzos en otra dirección. Quien quiera conseguir informar la sociedad con unos determinados valores, será preciso que lo haga desde abajo, desde la raíz, de modo que ese resultado se alcance como suma de las íntimas convicciones de cada uno de los ciudadanos, $y$ no por 
dictados ajenos a esa intimidad. Si nuestro análisis es correcto, el proceso descrito resulta ser la historia de un progreso en el enraizamiento del respeto a las libertades, y -por tanto- una llamada a la responsabilidad y un motivo de esperanza. 


\section{Bibliografía}


ObRAS DE REFERENCIA:

ABELLA, Manuel, La vida cotidiana durante la guerra civil: la España nacional, Planeta, Barcelona, 1973.

ABELLA, Rafael, Por el Imperio hacia Dios.Crónica de una posguerra (1939-1955), Planeta, Barcelona, 1978.

ARMADA COMÍN, Alfonso, Al servicio de la Corona, Planeta, Barcelona, 1983.

ARTOLA, Miguel, Partidos y programas políticos, 2 vol., Alianza Editorial, Madrid, 1991.

AZAÑA, Manuel, Memorias políticas $y$ de guerra, 2 tomos, Grijalbo, Barcelona, $1981^{4}$.

BEAUVOIR, Simone de, El pensamiento político de la derecha, Barcelona, 1971.

BELTRÁN GUELL, Felipe, Preparación y desarrollo del Movimiento Nacional, Valladolid, 1938.

BELL, Daniel, El advenimiento de la sociedad postindustrial. Un intento de prognosis social, Alianza Editorial, Madrid, 1976. 
BENEYTO PEREZ, Juan, El nuevo Estado Español, Cádiz, Biblioteca Nueva, 1939.

BLINKHORN, Martin, Carlismo y contrarrevolución en España (1931-1939), Barcelona, Crítica, 1989.

CANTERO CUADRADO, Pedro, Josemaría Escrivá de Balaguer: un hombre de Dios. Testimonios sobre el Fundador del opus Dei. 2, Palabra, Madrid, tercera edición, 1992.

CARASA SOTO, Pedro "Modernización de la sociedad vallisoletana en el primer tercio del siglo Xx", en Arquitecturas en Valladolid. Tradición y modernidad. 19001950, tomo I, págs. 9-29.

CARASA SOTO, Pedro, MARCOS DEL OLMO, Concepción, MARTÍNEZ FERNÁNDEZ, Mateo, MARTÍN DE LA GUARDIA, Ricardo, PÉREZ SÁNCHEZ, Guillermo, Alfonso XIII y la Segunda República (1898-1936), Gredos, Madrid, 1991

CARRERAS ARES, Juan José, RUIZ CARNICER, Miguel Ángel (editores), La Universidad española bajo el régimen de Franco (1939-1975), Institución Fernando el Católico, Zaragoza, 1991.

CASTAÑo COLOMER, José, La JOC en España (1946-1960), Ediciones Sígueme, Salamanca, 1978. 
CIRICI, Alexandre, La estética del franquismo, Gustavo Gili, Barcelona, 1977 .

CONCILIO VATICANO II. Constituciones. Decretos. Declaraciones, B.A.C., Madrid, 1965.

CHAPAPRIETA, Joaquín, La paz fue posible, Ariel, Barcelona, 1971 .

CHUECA, Ricardo, El fascismo en los comienzos del régimen de Franco. Un estudio sobre FET-JONS, Centro de Investigaciones sociológicas, Madrid, 1983.

DAHMS, Hellmuth Günther, La guerra española de 1936, Rialp, Madrid, 1966

DíAz, Elías, Pensamiento español 1939-1973, Edicusa, Madrid, 1974 .

ESCRIVÁ DE BALAGUER, Josemaría, Conversaciones con Monseñor Escrivá de Balaguer, Rialp, Madrid, 198917.

FERNÁNDEZ, Carlos, El general Franco, Argos Vergara, Barcelona, 1983 .

FERNÁNDEZ BUEY, Francisco «Estudiantes y profesores universitarios contra Franco. De los sindicatos democráticos estudiantiles al movimiento de profesores no numerarios (1966-1975)", en CARRERAS ARES, Juan José, RUIz 
CARNICER, Miguel Ángel (editores), La Universidad española bajo el régimen de Franco (1939-1975), Institución Fernando el Católico, Zaragoza, 1991, págs. 476-477.

FRAGA IRIBARNE, Manuel, Memoria breve de una vida pública., Planeta, Barcelona, 1980.

FUENMAYOR, Amadeo de, GÓMEZ-IGLESIAS, Valentín, ILLANES, José Luis, El itinerario jurídico del Opus Dei, historia y defensa de un carisma, Eunsa, Pamplona, cuarta edición, 1990 .

FUSI AIZPURÚA, Juan Pablo, "La Edad de las Masas (1870$1914) "$, en Historia Contemporánea, Revista del Departamento de Historia Contemporánea de la Universidad del País Vasco, no 4, Bilbao, 1990, págs. 261-272.

GARCÍA DE LA RASILLA ORTEGA, Mạ del Carmen, El Ayuntamiento de Valladolid: política y gestión (18981936), Ayuntamiento de Valladolid, Valladolid, 1991.

«Repercusión del problema marroquí en la vida vallisoletana (1909-27)", Investigaciones Históricas, Secretariado de Publicaciones de la Universidad de Valladolid, no 6, 1986, págs. 187-214.

GARCíA FERNÁNDEZ, Jesús, Crecimiento $y$ estructura urbana de Valladolid, Los libros de la Frontera, Barcelona, 1974. 
GARCÍA-NIETO PARIS, J.N., El Sindicalismo Cristiano en España, Deusto, Bilbao, 1960 .

GIL PECHARROMÁN, Julio, Renovación Española. Una alternativa monárquica a la Segunda República, (2 tomos), Servicio de Publicaciones de la Universidad Complutense, Madrid, 1985 .

GIL ROBLES, J. Mạ, No fue posible la paz, Ariel, Barcelona, 1968 .

La monarquía por la que yo luché (1941-45), Taurus, Madrid, 1976 .

GIMÉNEZ ARNAU, José Antonio, Memorias de memoria, Destino, Barcelona, 1978 .

GIMÉNEZ CABALLERO, Memorias de un dictador, Planeta, Barcelona, 1979 .

GOMÁ Y TOMÁS, Isidro (Card.), Pastorales de la guerra de España, Madrid, 1955.

GONZÁLEZ RUIZ, Nicolás, y MARTÍN MARTÍNEZ, Isidoro, Seglares en la historia del catolicismo español, Madrid, 1968 .

GRANADOS, Anastasio, El Cardenal Gomá, Primado de España, Espasa-Calpe, Madrid, 1969. 
HEINE, Harmut, La oposición política al franquismo, Grijalbo, Barcelona, 1983.

HUGHES, Emmet John, L'Espagne de Franco, Editions du temps present, Paris, 1948

JEREZ MIR, Elites políticas y centros de extracción en España, 1938-1957, 2 vol., Centro de Investigaciones Sociológicas, Madrid, 1982.

JOHNSON, Paul, Tiempos Modernos, Javier Vergara Editor, Buenos Aires, 1988 .

Intelectuales, Javier Vergara editor, Buenos Aires, Madrid, México, Santiago de Chile, 1990.

LAín ENTRALGo, Pedro, Descargo de conciencia, Barral, Barcelona, 1976 .

LE TOURNEAU, Dominique, El Opus Dei, Oikos Tau, Barcelona, 1986, págs. 47-50.

LINZ, Juan J., "Una teoría del régimen autoritario. El caso de España", en Política y sociedad en la España del siglo XX, Akal, Madrid, 1978.

LINZ, J. J. Y STEPAN, A, La quiebra de las democracias, Alianza Editorial, Madrid, 1977. 
LOJENDIO, José María de, Régimen Político del Estado Español, Bosch, Barcelona, 1942.

LÓPEZ LÓPEZ, Alejandro, El boicot de las derechas a las reformas de la II República española: la minoría agraria, Ministerio de Agricultura, Pesca y Alimentación, Madrid, 1984 .

LÓPEZ PINA, Antonio y ARANGUREN, Eduardo L., La cultura política de la España de Franco, Taurus, Madrid, 1986.

LÓPEz RODó, Laureano, La larga marcha hacia la Monarquía, Taurus, Madrid, 1976 .

Memorias, 3 vol., Plaza \& Janés/Cambio 16, Madrid, 19901992 .

MAEZTU, Ramiro de, Defensa de la Hispanidad, Espasa Calpe, Madrid, 1974

MARCOS DEL OLMO, Mạ Concepción, Sociología electoral en Castilla-León durante la Segunda República, tesis doctoral inédita, Valladolid, 1990 .

Las elecciones del Frente Popular en Valladolid, Diputación Provincial de Valladoli, Valladolid, 1986.

"Los agricultores vallisoletanos y la legislación triguera de 1932", Investigaciones Históricas, Secretariado de 
Publicaciones de la Universidad de Valladolid, $\mathrm{n} \cong$ 4, 1983, págs. 431-457, 1983 .

MARSAL, J.F., et. al. , Antonio, Pensar bajo el franquismo. Intelectuales $y$ política en la generación de los años 50, Ediciones Península, Barcelona, 1979.

MARTÍN DE LA GUARDIA, Ricardo M.; PÉREZ LÓPEZ, Pablo; PÉREZ SÁNCHEZ, Guillermo A., "La sociedad castellana a comienzos del siglo $\mathrm{Xx}$ : comportamientos ante el nacimiento, matrimonio y muerte", Investigaciones Históricas, Secretariado de Publicaciones de la Universidad de Valladolid, no 9, 1989, págs. 251-286.

MAURA, Miguel, Así cayó Alfonso XIII, Ariel, Barcelona, 1966

MAZA ZORRILLA, Elena, "Asociacionismo confesional en Valladolid. La Asociación Católica de Escuelas y Círculo de Obreros, 1881-1914", Investigaciones Históricas, Secretariado de Publicaciones de la Universidad de Valladolid, no 1, 1987, págs. 169-202.

"Los seguros sociales: la pluralidad de cauces en el primer bienio republicano, 1931-33", Ibid., no 10, 1990, págs. págs. 41-70. 
MENÉNDEZ PELAYO, Marcelino, Historia de los heterodoxos españoles, 2 tomos, Biblioteca de Autores Cristianos, Madrid, $1967^{2}$.

MÍgUez GONZÁLEZ, Santiago, la preparación de la transición a la democracia en España, Universidad de Zaragoza, Zaragoza, 1990 .

MORODO, Raúl, Acción Española. Orígenes ideológicos del franquismo, Madrid, Tucar Ediciones, 1980. La transición política, Tecnos, Madrid, 1984.

MOSCOVICI, Serge, La era de las multitudes. Un tratado histórico de psicología de las masas, Fondo de Cultura Económica, México, 1985.

MOYA, Carlos, El poder económico en España (1939-1970). Un análisis sociológico, Tucar, Madrid, 1975.

MOYA, Carlos, Señas de Leviatán. Estado nacional y sociedad industrial: España 1936-1980, Alianza Editorial, Madrid, 1984 .

PALACIOS BAÑUELOS, Luis, Las elecciones en Burgos. 19311936. El Partido Nacionalista Español, Madrid, Publicaciones de la Cátedra de Hạ Contemporánea de España, Universidad Complutense, 1981. 
PALOMARES IBÁÑEZ, Jesús María, Valladolid 1900-1931, Ateneo de Valladolid, Valladolid, 1981.

El socialismo en Castilla. Partido y Sindicato en Valladolid durante el primer tercio del siglo $X X$, Universidad de Valladolid, Caja de Ahorros y M. de P. de Salamanca, Valladolid, 1988 .

"Aproximación al regionalismo castellano durante la Segunda República", Investigaciones Históricas, Secretariado de Publicaciones de la Universidad de Valladolid, no 6, 1986, págs. 169-186.

"Líderes del socialismo castellano: Remigio Cabello, fundador de la agrupación socialista de Valladolid (18691936)", Investigaciones Históricas, Secretariado de Publicaciones de la Universidad de Valladolid, no 5, 1985, págs. 267-294.

PAYNE, Stanley G., El fascismo, Madrid, Alianza Editorial, 1982 .

El régimen de Franco 1936-75, Alianza Editorial, Madrid, 1987 .

La revolución española, Argos Vergara, Barcelona, 1978. 
PEMÁN, José Mạ, Mis almuerzos con gente importante, Dopesa, Barcelona, 1970

Mis encuentros con Franco, Dopesa, Barcelona, 1976

PÉREZ ESCRIBANO, Fernando, La Cruzada del escándalo, Madrid, 1969 .

PÉREZ SÁNCHEZ, Guillermo A., "La evolución del empleo y del salario en el Ayuntamiento de Valladolid: 1875-1930. Análisis cuantitativo", Investigaciones Históricas, Secretariado de Publicaciones de la Universidad de Valladolid, $\mathrm{n}$ ㅇ 10, 1990, págs. 9-39.

"Los trabajos municipales de invierno del Ayuntamiento de Valladolid", Ibid., no 11, 1991, págs. 199-227.

"Los Talleres Principales de Reparación de la Compañía del Norte en Valladolid: un estudio de Historia Social (18611931 )", Ibid. , no12, 1992, págs. 255-283.

POULANTZAS, Nicos, Fascismo $y$ dictadura, Siglo XXI, Madrid,

Poder político y clases sociales en el Estado capitalista, Siglo XXI, Madrid, 1975. 
POWELL, Charles T., El piloto del cambio. El rey, la Monarquía y la transición a la democracia, Planeta, Barcelona, 1991

PRADO MOURA, Ángel de, El movimiento obrero en Valladolid durante la Segunda República, Junta de Castilla y León, Salamanca, 1985 .

PRESTON, Paul, Las derechas españolas en el s. XX: autoritarismo, fascismo y golpismo, Madrid, Editorial Sistema, 1986.

RAMÍREZ, Manuel, España 1939-1975. Régimen político e ideología, Madrid, Guadarrama, 1978.

REDONDO, Gonzalo, La Iglesia en el Mundo Contemporáneo. II.- de León XIII a Pío XI (1878-1939), Eunsa, Pamplona, 1979 .

REIS, Carlos, Para una semiótica de la ideología, Madrid, Taurus, 1987 .

RIDRUEJO, Dionisio, Con fuego y con raíces. Casi unas memorias, Planeta, Barcelona, 1976

ROGGER, Hans; WEBER, Eugen, The European Right. A historial Profile, Berkeley, Los Angeles, University of California Press, 1965. 
ROLDÁN, Santiago, y GARCIA DELGADO, José Luis, La formación de la sociedad capitalista en España. 1914-1920, Confederación Española de Cajas de Ahorros, Madrid, 1973.

ROMERO, Emilio, Papeles reservados, 2 vol. , Plaza \& Janés, Barcelona, 1986.

RUIZ-MANJÓN CABEZA, Octavio, El Partido Republicano Radical, Tebas, Madrid, 1976.

"Evolución política", en La Segunda República y la guerra, tomo XVII de la Historia General de España y América, Madrid, Rialp, 1986, págs. 3-80.

SERRANO, Manuela, Proceso de desarrollo urbano de Valladolid, 1900-1965, tesis doctoral inédita.

SOLÍs, Ramón, el Cádiz de las Cortes. La vida en la ciudad en los años de 1810 a 1813, Instituto de Estudios Políticos, Madrid, 1958 .

Texto del Concordato entre la Santa Sede y España el 27 de agosto de 1953 y textos anejos, Madrid, 1961.

SUÁREZ FERNÁNDEZ, Luis, Francisco Franco y su tiempo, 8 tomos, Fundación Nacional Francisco Franco, Madrid, 1984.

THOMAS, Hugh, La guerra civil española, Grijalbo, Barcelona, 1976 . 
TOCQUeVILle, Alexis de, La democracia en América, 2 tomos, Alianza Editorial, Madrid, 1989.

TUÑÓN DE LARA, Manuel, Medio siglo de cultura española (1885-1936), Madrid, Tecnos, 1971.

TUSELL, Javier y AVILÉS, Juan, La derecha española contemporánea. Sus orígenes: el maurismo, Espasa, Madrid, 1986

TUSELL, Javier; ALTED, Alicia; y MATEOS, Abdón (eds.), La Oposición al Régimen de Franco. Estado de la cuestión y metodología, 3 volúmenes, Madrid, UNED, 1990.

TUSELL, Javier, La oposición democrática al franquismo 1939-1962, Planeta, Barcelona, 1977 .

La dictadura de Franco, Alianza Editorial, Madrid, 1988.

La España de Franco. El poder, la oposición y la política exterior durante el franquismo, Historia 16, Madrid, 1989.

VIRGILI BLANQUET, María Antonia, Desarrollo urbanístico y arquitectónico de Valladolid, 1851-1936, Ayuntamiento de Valladolid, Valladolid, 1979.

VV.AA., Aproximación a la historia social de la Iglesia española contemporánea, Biblioteca "La Ciudad de Dios", Real Monasterio del Escorial, 1978. 
VV.AA., Estudios históricos sobre la Iglesia española contemporánea, Biblioteca "La Ciudad de Dios", Real Monasterio del Escorial, 1979.

\section{LA PRENSA:}

ABELLÁN, Manuel L., Censura y creación literaria en España (1939-1976), Península, Barcelona, 1980.

"Censura y práctica censoria", Sistema, $\mathrm{n} \cong 22$, enero de 1978 , págs. 29-52.

"Análisis cuantitativo de la censura bajo el franquismo (1955-76)", Sistema, no 28, enero de 1979, págs. 75-89.

ALBERT, Pierre, et TERROU, Fernand, Histoire de la presse , Presses Universitaires de France, Paris, 19704.

ALBERT, Pierre; GUASCH, Juan María, SÁNCHEz ARANDA, J. Javier, Historia de la prensa, Rialp, Madrid, 1990.

ALFÉREZ, Antonio, Cuarto poder en España. La prensa desde la ley Fraga 1966, Plaza y Janés, Barcelona, 1986².

ALMUIÑA FERNÁNDEZ, Celso, La prensa vallisoletana durante el siglo XIX (1808-1894), 2 tomos, Servicio de publicaciones de la Diputación provincial de Valladolid, Valladolid, 
"La prensa regional y provincial en la comunidad autónoma de Castilla y León", en La prensa española durante el siglo XIX. I Jornadas de especialistas en prensa regional y local, Instituto de Estudios Almerienses, Granada, 1988.

"Prensa y poder en la España Contemporánea", en Investigaciones Históricas, no 1, 1979, págs. 297-326. "Clericalismo y anticlericalismo a través de la prensa española decimonona", en La cuestión social en la Iglesia española contemporánea, Biblioteca "La Ciudad de Dios", Real Monasterio del Escorial, 1981, págs. 125-175.

"Medios de comunicación de masas y conciencia regional", en La identidad cultural castellano leonesa ante la Europa Comunitaria, Editorial Centro de Estudios Ramón Areces, Madrid, 1991, págs • $295-350$

"La prensa periódica", en Historia General de España $y$ América , tomo XVI-1, Revolución y Restauración (18681931), Rialp, Madrid, 1982, págs. 135-154.

"Proceso a la Prensa Vasca (1936-39). La Inquisición franquista y la formación de la Causa General", en Comunicación, cultura y política durante la II República y la guerra civil, Departamento de Cultura de la Diputación Foral de Bizkaia, Servicio Editorial Universidad del País 
Vasco,

Bilbao,

1990 .

Tomo

I，

págs .

$46-80$.

"La prensa escrita como documento histórico", en Haciendo historia. Homenaje al profesor Carlos Seco, Editorial de la Universidad Complutense, Madrid, 1989, págs. 616-624.

"Periódicos y periodistas", no 46 de Cuadernos Vallisoletanos, Obra Cultural de la Caja de Ahorros Popular, Valladolid, 1988 .

ALtABELlA, José, El Norte de Castilla en su marco periodístico (1854-1965), Editora Nacional, Madrid, 1966.

"Notas para la prehistoria de las agencias de prensa en España" en Estudios de Información, núms. 21-22, enerojunio

Fuentes crítico bibliográficas para la historia de la prensa provincial española, Servicio de Publicaciones de la Universidad Complutense de Madrid, Madrid, 1983.

ÁLVAREZ, Dolores, et. al. Noticia, Rumor, Bulo: ensayo sobre algunos aspectos del control de la información, Madrid, 1976. 
AMADOR CARRANDI, F., Ensayo bibliográfico de las obras y folletos publicados con motivo del Movimiento Nacional, Granada, 1940 .

ARIAS-SALGADO, Gabriel, Textos de doctrina y política de la Información, Ministerio de Información y Turismo, Madrid, 1955.

BELLENGER, C. et. al., Histoire Générale de la presse française, Presses Universitaires de France, Paris, 19691976 .

BENEYTO, Antonio, Censura y política en los escritos españoles, Euros, Barcelona, 1975.

BENEYTO, Juan, Planteamiento del régimen jurídico de Prensa y Propaganda, Reus, Madrid, 1944.

Ordenamiento jurídico de la información, IEP, Madrid, 1961 .

BENITO, Ángel, Fundamentos de Teoría general de la información, Pirámide, Madrid, 1982.

"La prensa y su libertad", en Nuestro Tiempo, no 120, junio de 1964, págs. 814-816.

"La libertad de información", en Nuestro Tiempo, no 135, septiembre de 1965 , págs. 233-256. 
BOGART, Leo, La prensa y su público, Eunsa, Pamplona, 1985.

CASTILLO CASTILLO, José, Sociedad de públicos, discurso de apertura del curso 1990-91, Ediciones Universidad Complutense, Madrid, 1990.

CASTRO FARIÑAS, José Antonio, De la libertad de Prensa, editorial Fragua, Madrid, 1971.

CENDÁN PAZOS, Fernando, Historia del derecho español de Prensa e Imprenta (1502-1966), Editora Nacional, Madrid, 1974 .

COLL GILABERT, Antonio, De profesión periodista, Noguer, Barcelona, 1981 .

CONESA, Fernando, La libertad de la empresa periodística, Eunsa, Pamplona, 1978 .

CHECA GODOY, Alfonso,Prensa y Partidos políticos durante la II República, Servicio de Publicaciones de la Universidad de Salamanca, Salamanca, 1989.

CHOMSKY, Noam, Ilusiones necesarias. Control del pensamiento en las sociedades democráticas, Ediciones Libertarias/Prodhufi, Madrid, 1992. 
DELEGACIÓN NACIONAL DE PRENSA, Anuario Estadístico de la Prensa Española, Año I. 1943-44, Delegación Nacional de Prensa, Madrid, 1944 .

DELIBES, Miguel, La censura de prensa en los años 40 (y otros ensayos), Ámbito, Valladolid, 1985.

DESANTES GUANTER, J. Mạ., El autocontrol de la actividad informativa, Cuadernos para el diálogo, Madrid, 1973.

DESVOIS, J.M., La prensa en España (1900-1931), Siglo XXI, Madrid,

«Un grupo de presión en la IIa República: la Federación de Empresas Periodísticas de las Provincias de España" en La prensa de los siglos XIX Y XX, Servicio de Publicaciones de la Universidad del País Vasco, Bilbao, 1986, págs. 367382 .

ELORRIAGA FERNÁNDEZ, G., Periodismo político en la España actual, Madrid, 1973.

ENCISO RECIO, Luis Miguel, Nipho y el periodismo español en el siglo XVIII, Universidad de Valladolid, Valladolid, 1956.

Prensa económica española en el siglo XVIII, Universidad de Valladolid, Valladolid, 1958. 
"Nipho y los comienzos de la prensa diaria en el continente europeo", en Estudios de Historia Social, no 52-53, enero-junio 1990 .

FERNÁNDEZ AREAL, Manuel, El control de la prensa en España, Guadiana de ediciones, Madrid, 1973.

"Cuarenta años de censura en la España de Franco", en Opinión, números 32 (14-20/5/1977) y 33 (21-27/5/1977), págs. 65-72 y $69-75$ respectivamente. La Ley de Prensa a debate, Plaza y Janés, Barcelona, 1971.

La libertad de prensa en España (1938-1971), Editorial Cuadernos para el Diálogo, Madrid, 1971. "La información libre, presupuesto de la opinión pública", en Nuestro Tiempo, no 129, marzo de 1965, pág. 339-356.

FONTÁN, Antonio, Situación y perspectivas de la prensa actual, Editorial Ateneo de Madrid, Madrid, 1962.

"Prensa, Radio y TV, en la sociedad de hoy", en Nuestro Tiempo, no 164, noviembre 1964 .

GARCÍA ALIX, La prensa española ante la Segunda Guerra Mundial, Madrid, 1974. 
GIL NOVALES, Alberto, Las sociedades patrióticas (18201823). Las libertades de expresión $y$ de reunión en el origen de los partidos políticos, Tecnos, Madrid, 1975.

GINER, Juan Antonio, "Journalist, Mass Media and Public Opinion in Spain, 1938-1982", en MAXWELL, Kenneth (ed.), The Press and the Rebirth of Iberian Democracy, Greenwood Press, Westport, Conneticut, 1983.

GÓMEZ APARICIO, Pedro, Historia del periodismo español, tomo IV. De la Dictadura a la Guerra Civil, Editora Nacional, Madrid, 1981.

"La libertad de prensa en la IIa República", en Gaceta de la Prensa Española, no 147, 1963.

GÓMEZ REINO, Enrique, Aproximación histórica al derecho de la imprenta y de la Prensa española (1480-1966), Instituto de Estudios Administrativos, Madrid, 1977.

GONZÁLEZ RUIZ, Nicolás (dir.), Enciclopedia del periodismo, Noguer, Barcelona, 1966.

GONZÁlez PÁRAMO, J.M., Política de Prensa. Dialéctica de la Empresa Periodística, Grijalbo, Barcelona, 1972.

GRUPO NACIONAL DE DIARIOS, Audiencia de la prensa española, Editorial Vizcaína, Bilbao, 1966. 
GUBERN, J.M., La censura. Función política y ordenamiento jurídico bajo el franquismo (1936-1975), Península, Barcelona, 1980 .

GUZMÁN, Eduardo de, Historias de la prensa, Penthalon Ediciones, Madrid, 1982.

HARRIS, R. E., The Spanish Press in an autoritarian State, Los Ángeles, 1964 .

The Spanish Press in transition. Applications of the 1966 Press Law, Los Ángeles, 1967.

HERMET, Guy, "La Presse espagnole depuis la suppresion de la censure", en Revue Française de Science Politique, 1968, págs. 44-67.

IGLESIAS, Francisco, Historia de una empresa periodística. Prensa Española. Editora de "ABC" $y$ "Blanco $y$ Negro" (1891-1978), Prensa Española, Madrid, 1980.

"La crisis de la prensa diaria en España", en Nuestro Tiempo, no 308, febrero de 1980, págs. 4-21.

INSTITUTO DE LA OPINION PUBLICA, "Estudio sobre los medios de comunicación de masas en España» (I, II y III), en Revista Española de la Opinión Pública, primer y segundo volumen, Madrid, 1964, tercer volumen, 1965. 
JUANA, Jesús de, La posición centrista durante la Segunda República (El periódico Ahora, 1930-1936), Universidade de Santiago de Compostela, Servicio de Publicaciones, 1988. Contiene una extensa bibliografía sobre prensa.

LEARCHUNDI, Alberto, La Gaceta del Norte: sus 83 años de vida, Universidad del País Vasco, Bilbao, 1985. "La Gaceta del Norte 1901-1984. Muerte ideológica de un diario" en Prensa en los siglos XIX $y$ XX, Universidad del País Vasco, Bilbao, 1986.

LEÓN CORREA, Francisco Javier, León en el último tercio del siglo XIX. Prensa y corrientes de opinión (1868-1898), Diputación Provincial de León, León, 1988.

LEZCANO, Ricardo, La Ley de Jurisdicciones 1905-06. (Una batalla perdida por la libertad de expresión), Akal, Madrid, 1978 .

LÓPEZ DE ZUAZO ALGAR, Antonio, Diccionario de Periodismo, Ediciones Pirámide, Madrid, 1977 .

Catálogo de periodistas españoles del siglo XX, Facultad de Ciencias de la Información de la Universidad Complutense, Madrid, 1981 . 
LÓPEZ PINTOR, Rafael, La opinión pública española del franquismo a la democracia, Centro de Investigaciones sociológicas, Madrid, 1980.

MARTÍN DE LA GUARDIA, Ricardo M., "La Organización Sindical Española ante la ley de febrero de 1971: Tácticas propagandísticas en la conformación de un estado de opinión", Investigaciones Históricas, Secretariado de Publicaciones de la Universidad de Valladolid, $\mathrm{n} \cong$ 11, 1989 , págs. $251-272$.

"Consideraciones sobre la empresa preriodística como factor clave para la historia de la prensa (siglos XIX y XX)", en Actas del I Congreso de jóvenes historiadores $y$ geógrafos, Tomo II, ADES, Madrid, 1990, págs. 651-662.

MARTÍN DE LA GUARDIA, Ricardo M., y PÉREZ LÓPEZ, Pablo, "La represión de la opinión en la prensa periódica y el procesamiento a periodistas: el caso de Fernández Areal", en La Oposición al Régimen de Franco. Estado de la cuestión y metodología. Madrid, UNED, 1990, tomo I, vol. 2, págs. 417-427

MARTÍN-SÁNCHEZ JULIÁ, Fernando, La Prensa en el Estado Moderno, Madrid, Euramérica, s.f.. 
MARTÍNEZ ALBERTOS, José Luis, "Objetividad e interpretación de las noticias", en Nuestro Tiempo, no 100 , octubre de 1962 .

MAURA GAMAZO, Gabriel, Lo que la censura se llevó (18381954), Fundación Antonio Maura, Madrid, 1988.

MELLONI, Alessandra, y PEÑA-MARÍN, Cristina, El discurso político en la prensa madrileña del franquismo, Bulzoni editore, Roma, 1980 .

MÍNGUEz GOYANES, José Luis, Onésimo Redondo (1905-1936). Precursor sindicalista, Madrid, Editorial San Martín, 1990 .

MINISTERIO DE EDUCACIÓN NACIONAL, SUBSECRETARÍA DE EDUCACIÓN POPULAR, Anuario de la Prensa Española, Año II. 1945-46, Ministerio de Educación Nacional, Subsecretaría de Educación Popular, Madrid, 1945.

MINISTERIO DE INFORMACIÓN Y TURISMO. DIRECCIÓN GENERAL DE PRENSA, Anuario de la Prensa Española, Año III Vol. I.- Diarios

Vol. II.- Revistas, Ministerio de Información y Turismo. Dirección General de Prensa., Madrid, 1953-1954.

$\begin{array}{rrrrr}\begin{array}{c}\text { Anuario } \\ \text { Vol. }\end{array} & \text { I.- } & \text { Diarios, } & \text { Año } & \text { IV, } \\ \text { Vol. II.- Revistas, 1957, Ministerio de Información y }\end{array}$


Turismo. Dirección General de Prensa., Madrid, 1955-57. Anuario de la Prensa Española, Año V, Vol. I.- Diarios $y$ semanarios Vol. II.- Revistas, Ministerio de Información y Turismo. Dirección General de Prensa., Madrid, 1961-1962.

Anuario de la Prensa Española, Año VI, Ministerio de Información y Turismo. Dirección General de Prensa., Madrid, 1970 .

MINISTERIO DE TRABAJO Y PREVISIÓN, SERVICIO GENERAL DE estadísticA; Estadística de la Prensa Periódica de España referida al 31de diciembre de 1927, Imprenta de los hijos de M.G. Hernández, Madrid, 1930.

MOLINERO, César, La intervención del Estado en la Prensa, Dopesa, Barcelona, 1971.

MORI, Arturo, La prensa española de nuestro tiempo, Ediciones Mensaje, México, 1943.

MUÑOZ ALONSO, Alejandro; MONZÓN, Cándido; ROSPIR, Juan Ignacio; DADER, José Luis, Opinión pública y comunicación política, Eudema, Madrid, 1990.

NIETO TAMARGO, Alfonso, El concepto de empresa periodística, Eunsa, Pamplona, 1967. 
La empresa periodística en España, EUNSA, Pamplona, 1973. La prensa gratuita, Eunsa, 1984.

PALOMARES IBÁÑEZ, Jesús Mạ, "Las estadísticas de la Prensa periódica y la Prensa de Galician, Investigaciones Históricas, Secretariado de Publicaciones de la Universidad de Valladolid, no 3, 1982, págs. 257-294.

"Prensa y política en Galicia: la prensa periódica compostelana", Ibid., no 4, 1983, págs. 391-430.

PELAz LÓPEz, José-Vidal, "Catálogo de publicaciones periódicas de la provincia de Palencia (1898-1936), Investigaciones Históricas, Secretariado de Publicaciones de la Universidad de Valladolid, no 11, 1991, págs. 229250 .

PÉREZ LÓPEZ, Pablo, «El régimen de consignas de prensa durante el franquismo: análisis de una fuente", en Actas del I Congreso de jóvenes historiadores y geógrafos, Tomo II, ADES, Madrid, 1990, págs.739-747.

PIZARRoso, Alejandro, Historia de la Propaganda. Notas para un estudio de la propaganda política y de "guerra", Eudema, Madrid, 1990

PRADOS Y LÓPEZ, Manuel, Etica y estética del periodismo, Madrid, Editora Nacional, 1943. 
REDONDO, Gonzalo, Las empresas periodísticas de José Ortega y Gasset, 2 vols., Rialp, Madrid, 1970.

REVEL, Jean François, El conocimiento inútil, Planeta, Barcelona, 1989 .

ROMERO RUBIO, Andrés, Medios de comunicación y sociedad, Ferreira, Madrid, 1971 .

SAIZ DE VALDIVIELSO, Alfonso C., Triunfo y tragedia del periodismo vasco (Prensa y política) 1900-1939, Editora Nacional, Madrid, 1977

SÁNCHEZ SÁNCHEZ, José Francisco, Miguel Delibes, periodista, Destino, Barcelona, 1989.

SÁNCHEZ TABERnERo, Afonso, El Correo Español-El Pueblo Vasco y su entorno informativo (1910-1985), Servicio de Publicaciones de la Universidad de Navarra, Pamplona, 1989. Contiene una extensa bibliografía sobre prensa.

SCHULTE, Henry F., The Spanish Press. 1470-1966. Print, Power, and Politics, University of Illinois Press Urbana, Chicago, London, 1968.

SIEBERT, Fred S., PETERSON, Theodore, SCHRAMM, Wilbur, Four Theories of the Press, Urbana \& Chicago, University of Illinois Press, 1963. 
SINOVA, Justino, La censura de prensa durante el franquismo (1936-51), Espasa Calpe, Madrid, 1989.

TALLÓN GARCía, José, Papel y empresa periodística, Eunsa, Pamplona,

Empresa y empresario de la información, Dossat, Madrid, 1981 .

"Análisis de la difusión de la prensa española durante el quinquenio 1976-1980", en Homenaje al profesor José Mạ Desantes Guanter, Fragua, Madrid, 1987.

Economía de la información, editado por el autor, Madrid, 1987 .

TERRÓN MONTERO, J., La prensa en España durante el régimen de Franco. Un intento de análisis político, Centro de Investigaciones Sociológicas, Madrid, 1981.

TIMOTEO ÁLVAREZ, Jesús, Del viejo orden informativo. Introducción a la Historia de la Comunicación, la Información y la Propaganda en Occidente, desde sus orígenes hasta 1880, Editorial Universidad Complutense, Madrid, 1985. Contiene una extensa bibliografía sobre prensa. 
TIMOTEO ÁLVAREZ, Jesús, et. al., Historia de los medios de comunicación en España. Periodismo, imagen y publicidad (1900-1990), Ariel, Barcelona, 1989.

TUÑóN DE LARA, M, , ELORZA, A., PÉREZ LEDESMA, M. (Coords.), Prensa y sociedad en España (1820-1936), Edicusa, Madrid, 1975.

TUÑÓN DE LARA, Manuel (dir); GARITAONAINDÍA, C., GRANJA, J.L. de la, PABLO, S. de (eds.), Comunicación, cultura y política durante la II República y la guerra civil. 2 tomos, Departamento de Cultura de la Diputación Foral de Bizkaia, Servicio Editorial Universidad del País Vasco, Bilbao, 1990 .

TUÑÓN DE LARA, Manuel (dir.), La prensa en los siglos XIX y XX. Metodología, ideología e información. Aspectos económicos y tecnológicos, Servicio de Publicaciones de la Universidad del País Vasco, Bilbao, 1986.

VOYENNE, Bernard, La prensa en la sociedad contemporánea, Editora Nacional, Madrid, 1968.

VV.AA., "Los "nuevos periódicos"", en Nuestro Tiempo, nㅇ 342, diciembre de 1982 , págs. 4-36.

VV.AA., Metodología de la Historia de la prensa española, Madrid, Siglo XXI, 1982 . 
LOS CATÓLICOS Y LA POLÍtica:

ÁLVAREZ BOLADO, Alfonso, El experimento del Nacional Catolicismo 1939-75, Edicusa, Madrid, 1976.

ALZAGA, Oscar, La primera Democracia Cristiana en España, Ariel, Barcelona, 1973.

ANDRÉS GALLEGO, José, La política religiosa en España: 1868-1913, Editora Nacional, Madrid, 1975.

ANGELOZZI GARIBOLDI, Giorgio, Pío XII, Hitler y Mussolini, Acervo, Barcelona, 1988.

ARBEOLA, Víctor Manuel, Socialismo $y$ anticlericalismo, Taurus, Madrid, 1973.

ARRESE, José Luis, Capitalismo, Comunismo, Cristianismo, Madrid, Ediciones Radar, 1948.

AZNAR Y EMBID, Severino, Impresiones de un demócrata cristiano, Madrid, 1931.

AZPIAZU, Joaquín (S. J.), El Estado Católico. Líneas de una idea, Rayfe, Madrid-Burgos, 1939.

BENAVIDES GÓMEZ, Domingo, Democracia y cristianismo en la España de la Restauración: 1875-1931, Editora Nacional, Madrid, 1978 . 
El fracaso social del catolicismo español, Arboleya Martínez. 1870-1951, Nova Terra, Barcelona, 1973.

CÁRCEL ORTÍ, Vicente, La persecución religiosa en España durante la segunda República (1931-1939), Rialp, Madrid, 1990

CAZORLA PÉREZ, J., "Las relaciones entre los sistemas eclesial, social y político en la España contemporánea: un esquema interpretativo", en La España de los años 70. III. El Estado y la política, Ed. Moneda y Crédito, Madrid, 1974 .

CUENCA TORIBIO, José Manuel, Relaciones Iglesia-Estado en la España Contemporánea, Alhambra, Madrid, $1989^{2}$.

Estudios sobre la Iglesia española del XIX, Rialp, Madrid, 1973.

La Iglesia española ante al revolución liberal, Rialp, Madrid,

CHAO REGO, José, La Iglesia en el franquismo, Madrid, 1976 . 
DANSETTE, A., Hitoire religieuse de la France contemporaine ("L’Église Catholique dans la mêlée politique et sociale), Flammarion, Paris, 1965.

FERNÁNDEZ AREAL, Manuel, La política católica en españa, Dopesa, Barcelona, 1970.

FERNÁNDEZ GORRINDO, Félix, "La Federación de Sindicatos Agrícolas Católicos de Valladolid", Investigaciones Históricas, Secretariado de Publicaciones de la Universidad de Valladolid, no 1, 1979, págs. 231-262.

FOGARTY, Michael P., Historia e ideología de la democracia cristiana en la Europa occidental, 1820-1950, Tecnos, Madrid, 1964 .

FONTÁN, Antonio, Los católicos en la Universidad española, Rialp, Madrid, 1961.

FRANCO, Francisco, Pensamiento católico, Madrid, 1958.

GÓMEZ PÉREZ, Rafael, El franquismo y la Iglesia, Rialp, Madrid, 1986.

GONZÁLEZ RUIZ, Nicolás, y MARTÍN MARTÍNEZ, Isidoro, Seglares en la historia del catolicismo español, Raycar, Madrid, 1968 . 
GUERRERO, E. Y ALONSO, J.M., Libertad religiosa en España, Madrid, 1962

HERMET, Guy, Los católicos en la España franquista, 2 vol., Siglo XXI, Madrid, 1985 (1a edición en francés, $1980) \cdot$

HERRERA ORIA, Ángel, Meditación sobre España. Ideario político-social de Ángel Herrera, La Editorial Católica, Madrid, 1976.

JARLOT, Georges, La Iglesia ante el progreso social y político, Ediciones Península, Barcelona, 1967.

LABOA, J. M., Iglesia y religión en las constituciones españolas, Encuentro Ediciones, Madrid, 1981.

MARQUINA BARRIO, Antonio, La diplomacia vaticana y la España de Franco (1936-45), Madrid, 1983

MARTÍN, Isidoro, El Concordato español de 1953, Madrid, 1953.

MARTÍN-SÁNCHEZ JULIÁ, Fernando, Ideas sobre los Propagandistas, La Editorial Católica, Madrid, 1953. Selección de discursos pronunciados por el Presidente de la A.C.N. de P. desde 1937 a 1952. 
MONTERO MORENO, Antonio, Historia de la persecución religiosa en España, 1936-39, La Editorial Católica, Madrid, 1961

MONTERO, José Ramón, La C.E.D.A.. El catolicismo social y político en la II República, (2 vols.), Ediciones de la Revista del Trabajo, Madrid, 1977

PAYNE, Stanley G., El catolicismo español, Planeta, Barcelona, 1984 .

PETSCHEN, Santiago, La Iglesia en la España de Franco, Ediciones Sedmay, Madrid, 1977.

RUIZ RICO, Juan José, El papel político de la Iglesia católica en la España de Franco (1936-1971), Tecnos, Madrid, 1981 .

TUSELL, Javier, Historia de la Democracia Cristiana en España, 2 vol., EDICUSA, Madrid, 1974.

Franco y los católicos, la política interior española entre 1945 y 1957, Alianza Editorial, Madrid, 1984.

VALLS MONTES, Rafael, La Derecha Regional Valenciana (1930-1936), Edicions Alfons el Magnanim, Institució Valenciana d'Estudis i Investigació, Valencia 1992, no 51. 
VAUSSARD, M., Histoire de la Démocratie Chrétienne. France-Belgique-Iltalie, Editions du Seuil, Paris, 1956.

\section{LOS CATÓLICOS Y LA PRENSA:}

BENITO, Ángel, "Prensa, religión y política», en Nuestro Tiempo, no 167, mayo de 1968, págs. 563-575.

CÁCERES SEVILLA, Adela de, El Debate como Empresa Social Católica, Tesis doctoral, Salamanca, 1987.

"Participación de los católicos de El Debate en la política", en Historia, literatura, pensamiento. Estudios en homenaje a María Dolores Gómez Molleda, Narcea de Ediciones, Salamanca, 1990, vol.I, págs. 249-266.

CAPUANO, Carlo, La stampa cattolica in Italia, Sellenio editore, Palermo, 1982 .

CUNILL, Ramón, Prensa, opinión pública y renovación conciliar, Lección inaugural leída el día 17 de octubre de 1966, en el acto de apertura de curso 1966-67, Escuela de Periodismo de la Iglesia, Madrid, 1967.

DESVOIS, Jean Michel, "Las fuerzas de resistencia en la prensa. De La Gaceta del Norte a El Debate", en España entre dos siglos (1875-1931). Continuidad y cambio, Siglo XXI, Madrid, 1991, págs. 235-247. 
FERNÁNDEZ AREAL, Manuel, Frutos del Concilio. Decreto sobre los medios de comunicación social, S.A.R.P.E., Madrid, 1965.

GABEL, Emile, La prensa católica, ¿para qué?, Propaganda Popular Católica, Madrid, 1962.

GARCÍA ESCUDERO, José María, El pensamiento de "El Debate". Un diario católico en la crisis de España (19111936), La Editorial Católica, Madrid, 1983.

«Don Ángel Herrera y El Debate en la evolución de la Iglesia y el catolicismo español", en Aproximación a la historia social de la Iglesia española contemporánea, Biblioteca "La Ciudad de Dios", Real Monasterio del Escorial,

"Ya". Medio siglo de historia (1935-1985), La Editorial Católica, Madrid, 1984 .

GUÉRIN, Paul, Presse Populaire Catholique et Presse Démocrate Chrétienne en Wallonie et à Bruxelles (18301914), Editions Nauwelaerts, Louvain, Paris, 1975.

GODFRIN, Jacqueline et Filippe, Une centrale de presse catholique: la Maison de la Bonne Presse et ses publications, Presses Universitaires de France, Paris, 1966 . 
GONZÁLEZ, Antonio, El Espíritu Religioso de la Prensa Católica, Roma, 1950. Ponencia presentada en el Congreso Internacional de la Prensa Católica.

GONZÁLEZ-RUIZ, Nicolás, "Orígenes y principales características de La Editorial Católica", en Gaceta de la Prensa Española, no 145, julio de 1963, págs. 69-74.

GUASCH BORRAT, Juan María, "El Debate» y la crisis de la Restauración (1910-1923), Eunsa, Pamplona, 1986.

HOURDIN, Georges, La prensa católica, Casal y Vall, Andorra, 1959.

JUNTA NACIONAL DE PRENSA CATÓLICA, Prensa Católica, folleto editado por la Junta, Madrid s/f.

LÓPEZ PELÁEZ, Antolín, La importancia de la Prensa, Gustavo Gili, Barcelona, 1907.

LUIS DÍAZ MONASTERIO, Félix de, Francisco de Luis. Del periodismo a la política y al mundo de la empresa, Fundación Humanismo y Democracia, Madrid, 1983.

MARTÍN-SÁNCHEZ JULIÁ, Fernando, La Prensa en el Estado moderno, Euramérica, Madrid, s/f.

Opinión pública, prensa y Estado. Nuevas formas de 
propiedad de los periódicos, Universidad Internacional Menéndez Pelayo, Santander, 1951.

MARTÍN DE LA GUARDIA, Ricardo M.; y PÉREZ LÓPEZ, Pablo, "La represión de la opinión en la prensa periódica y el procesamiento a periodistas: el caso de Fernández Areal", en La Oposición al Régimen de Franco. Estado de la cuestión y metodología. Madrid, UNED, 1990, tomo I, vol. 2, págs. 417-427.

OFICINA GENERAL DE INFORMACIÓN Y ESTADÍSTICA DE LA IGLESIA EN ESPAÑA, O.G.I.E.I., La Prensa de la Iglesia en España, Madrid, 1957 .

PÉREZ GÓMEZ, Leandro, "Periódico Católico Agrario de Valladolid", , en Estafeta Literaria, no 272-273, correspondiente al 17-31 de agosto, pág. 28 .

PÉREZ LÓPEZ, Pablo, "La Masonería en la prensa confesional en Castilla durante la Segunda República y la guerra Civil: Diario Regional de Valladolid 1931-39", en Masonería , revolución y reacción, tomo I, Instituto de Cultura Juan Gil Albert, Alicante, 1990, págs. 391-409.

PÉREZ VILARIÑO, José, Los periódicos ante las autonomías, Akal, Madrid, 1982. A pesar de lo que pueda dar a entender el título, el contenido es un análisis del tratamiento otorgado por algunos periódicos españoles a la Asamblea conjunta de obispos y sacerdotes. 
Bibliografía

TARÍN IGLESIAS, José, "Un siglo y medio de prensa católica en España», apéndice de la edición española de la obra de G. HOURDIN citada. 
Fuentes 
1. Escritas. ARChivos y hemerotecas consultados:

Archivo Central del Ministerio de Cultura. Madrid.

Archivo de Correos. Valladolid.

Archivo de "Edica». Madrid.

Archivo Diocesano de Valladolid.

Archivo General de la Administración. Alcalá de Henares.

Archivo Privado de Gráficas Andrés Martín. Valladolid.

Archivo Histórico Nacional.

Archivo Privado de Esteban Greciet Aller.

Archivo Privado de José Luis Guerrero Elvira.

Archivo Privado de Manuel Fernández Areal.

Archivo Provincial de Hacienda de Valladolid.

Archivo Provincial y Universitario de Valladolid.

Hemeroteca de El Norte de Castilla. Valladolid. 
Hemeroteca de la Biblioteca Universitaria Reina Sofía de la Universidad de Valladolid.

Hemeroteca Municipal de Madrid.

Hemeroteca Municipal de Valladolid.

Hemeroteca Nacional. Madrid.

Registro Mercantil de Valladolid.

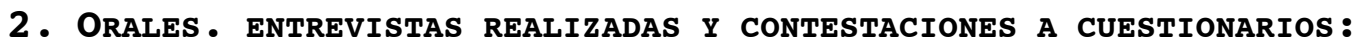

BARRASA, Francisco

BEL MALLÉN, Ignacio

CASADO GÓMEZ, Manuel

CEBRIÁN BONÉ, José Luis

CONDE PARDO, Luis

CRUZ SERNA, Tomás de la

FERNÁNDEZ AREAL, Manuel

FERNÁNDEZ POMBO, Alejandro
Redactor de DR (1975$78)$.

Director de DR (197477 ) .

Vocal (1977-79) y

Presidente (1979-80)

del consejo de

administración.

Director de DR (1957$58)$.

Administrador $y$ gerente de DR (197277 ) .

Vicepresidente de CINISA en 1977.

Redactor (1955-56) y director (1958-65) de DR.

Redactor de Ya en los años en que DR pertenecía a la cadena de "La Editorial Católica, S.A.". 
GALLEGO GÓMEZ, Jerónimo

GARCÍA DOMÍNGUEZ, Ramón

GARRÁN, María

GONZÁLEZ GONZÁLEZ, Félix Antonio

GRECIET ALLER, Esteban

GUERRERO ELVIRA, José Luis

HERNÁNDEZ DEUS, Antonio

LEÓN ÁLVAREZ, Arturo

LOSADA GONZÁLEZ, Germán

MUÑOZ GARCÍA, Pedro

NIETO BERMEJO, Ramiro

PALACIOS, Emilio

PICÓ AMADOR, Vicente
Redactor de DR (194953) y miembro del consejo de administración de DR, S.A. (1977-79).

Redactor jefe (197375) y director interino (1974) de DR.

Hija del fundador del diario, Justo Garrán.

Redactor y redactor jefe de DR (1945-53).

Director de DR (197274 ).

Redactor de DR (197880 ) .

Director de la oficina de Información de la Prelatura Opus Dei en España en 1991.

Secretario (1958-66, y 1969-74), vocal (196669), y presidente (1974-79) del consejo de administración de DR, S.A..

Redactor de DR (196673 ).

Director de DR (197778 ).

Vocal del consejo de administración de DR, S.A., y de CINISA (1974-76).

Consejero Secretario de "Edica" en 1991.

Miembro del consejo de administración de $\mathrm{DR}$, S.A. (1955-59). 
RIOJA, Mariano

ROMERO RUBIO, Andrés

RUEDA SALABERRY, Andrés

SINOVA, Justino

TALLÓN GARCÍA, José

TORRE DE LA ORDEN, Fernando de la

VILORIA NIETO, María Aurora

ZULOAGA ZULOAGA, Jesús María
Consejero delegado de "La Editorial

Católica, S.A." en 1955.

Redactor de DR (1957$63)$.

Miembro del Consejo de Administración de $\mathrm{DR}$, S.A. (1955-58).

Colaborador y redactor en prácticas de DR (1962-63).

Gerente (1960-62), y director de DR (196567 ).

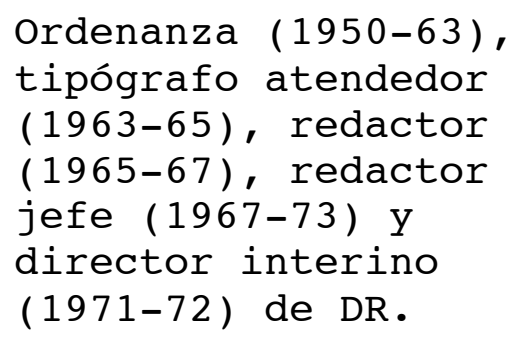

Redactora (1964-78) y directora de DR (1978$80)$.

Director de DR (195557 ). 

Apéndices 
ApÉndice 1.- Ficha descriptiva de Diario Regional.

Título, subtítulo y lemas

\begin{tabular}{|c|c|c|}
\hline Título & Subtítulo & Lemas \\
\hline \multirow{6}{*}{$\begin{array}{l}\text { Diario Regional } \\
7 / 3 / 1908-14 / 11 / 19 \\
78\end{array}$} & & $\begin{array}{l}\text { "Religión } \approx \text { Patria } \\
\approx \text { Orden } \approx \text { Trabajo" } \\
\text { 19/11/1931- } \\
2 / 1 / 1940\end{array}$ \\
\hline & & $\begin{array}{l}\text { "Segundo año } \\
\text { triunfal" } \\
21 / 7 / 1937- \\
17 / 7 / 1938\end{array}$ \\
\hline & & $\begin{array}{l}\text { "Tercer año } \\
\text { triunfal" } \\
19 / 7 / 1938-1 / 4 / 1939\end{array}$ \\
\hline & & $\begin{array}{l}\text { "Año de la } \\
\text { victoria" } \\
2 / 4 / 1939- \\
31 / 12 / 1939\end{array}$ \\
\hline & & $\begin{array}{l}\quad \text { "Periódico } \\
\text { católico" } \\
2 / 1 / 1940-1 / 4 / 1956\end{array}$ \\
\hline & & $\begin{array}{l}\text { "Independiente } \\
\text { Castellano" } \\
\text { 9/10/1977- } \\
\text { 14/11/1978 }\end{array}$ \\
\hline $\begin{array}{l}\text { El diario } \\
15 / 11 / 1978-7 / 6 / \\
1979\end{array}$ & $\begin{array}{l}\text { regional-libre-e } \\
\text { independiente } \\
\text { 15/11/1978- } \\
7 / 6 / 1979\end{array}$ & \\
\hline \multicolumn{3}{|l|}{$\begin{array}{l}\text { Diario Regional } \\
24 / 10 / 1979-7 / 3 / 19 \\
80\end{array}$} \\
\hline
\end{tabular}

\section{Datación}


Apéndices

Primer número:

7 de marzo de 1908. El primer número analizado es de uno de enero de 1931.

Ultimo número

El último número analizado, y último número del periódico es el del 7 de marzo de 1980 . 
Números extraordinarios

FECHA Págs. MOTIVO

5/6/1932 16 Con motivo de la reforma del periódico, dando cuenta de las nuevas instalaciones.

13/4/193 16 XIX aniversario de la Redención, Jueves 3 Santo.

25/5/193 16 Estaba anunciado con motivo del mitin 3 agrario que se iba a celebrar en Valladolid este día, que fue prohibido por el ministro de Gobernación. Los titulares son de protesta, se mantiene el extraordinario.

25/2/193 16 Primer aniversario de la publicación de la 4 "Página médica».

29/3/193 16 Jueves Santo.

4

20/5/193 Juventud Obrera Católica. 4

18/4/193 16 Jueves Santo. 
30/6/193 20 Acto de la J.A.P. en Medina del Campo.

5

29/9/193 12 I Feria de Muestras de Valladolid.

5

22/12/19 12 Lotería y Navidad.

35

14/6/193 24 Exposición mundial de la prensa católica. 6

18/7/193 16 Aniversario del alzamiento.

7

12/10/19 8 Día de la hispanidad.

37

$14 / 4 / 193 \quad 8$ Semana Santa

8

17/7/193 16 Aniversario del alzamiento.

8

28/3/193 2 Edición vespertina con motivo de la toma 9 de Madrid.

12/10/19 8 Día de la hispanidad. 


\section{1/3/194 8 Jueves Santo. \\ 0}

18/7/194 6 Aniversario del alzamiento.

0

1/1/1941 8 Comienzo del año.

10/4/194 6 Jueves Santo.

1

22/12/19 2 Lista de la lotería de Navidad.

41

18/4/194 16 Semana Santa.

3

22/4/194 8 Semana Santa.

3

27/6/194 10 Fiestas de Burgos.

3

19/9/194 Fiestas de San Mateo en Valladolid.

3

2/4/1944 28 Semana Santa. Se trata de un suplemento de formato reducido. Equivaldría a 14 páginas con el formato habitual. 
Apéndices

25/3/194 16 Semana Santa.

5

?/?/1946 16 Semana Santa.

4/4/1947 8 Semana Santa.

12/2/195 8 Dedicado al Año Santo.

0

12/10/19 8 Suplemento dedicado al Año Santo.

50

2/4/1950 10 Semana Santa.

18/3/195 8 Semana Santa.

1

20/9/195 8 Suplemento con motivo de las fiestas de 3 Valladolid.

31/12/19 13 Especial fin de año.

53

15/4/195 14 Semana Santa.

4

20/9/195 14 Fiestas de Valladolid.

4 
18/9/195 16 Fiestas de Valladolid.

5

28/4/195 24 Vuelta ciclista a España.

6

10/6/195 29 Feria del Campo.

6

18/4/195 36 Semana Santa.

7

14/9/195 38 Fiestas de Valladolid.

7

17/11/19 42 Cincuenta aniversario del periódico.

57

29/12/19 26 Fin de año994.

57

9/3/1958 28 Dedicado a la mujer. Colaboran 30 mujeres vallisoletanas.

25/5/195 28 Número dedicado a Castilla.

8

994 Con José Luis Cebrián cambia el concepto de los extraordinarios. Se hacen más frecuentes y dejan de ser monográficos para ser el número del día al que se le añaden unas páginas especiales monográficas. En esos casos no señalamos el número de páginas. 
22/6/195 Especial verano.

8

31/8/195 Dedicado a Medina del Campo

8

14/9/195 Fiestas de Valladolid.

8

12/10/19 28 A la memoria de Pío XII.

58

28/12/19 Fiestas de Navidad.

58

26/3/195 40 Semana Santa.

9

16/6/195 32 Dedicado al campo.

9

20/9/195 32 Fiestas de Valladolid.

9

29/11/19 32 Dedicado a la industria de Valladolid. 59

18/9/196 32 Fiestas de Valladolid. 0 
Apéndices

27/11/19 Dedicado a la industria de Valladolid.

60

30/3/196 116 Semana Santa

1

9/1963 56 Fiestas de Valladolid.

20/9/196 38 Fiestas de Valladolid.

4

6/6/1965 48 Construcción y obras hidráulicas.

12/9/196 68 Feria Regional de Muestras.

5

19/9/196 48 Fiestas de Valladolid.

5

31/10/19 44 Tierra de Campos.

65

11/9/196 104 Feria de Muestras

6

17/9/196 56 Fiestas de Valladolid

7 
Normalmente, a partir de 1967 los números extraordinarios son menos frecuentes que los suplementos de páginas especiales, sin que se distingan bien uno de otros.

\section{Suspensiones}

1a.- Del 11 de agosto de 1932 al uno de septiembre del mismo año por orden gubernativa.

2a..- Se suspende la publicación por vacaciones de los trabajadores del 14 al 22 de agosto de 1933, en virtud del convenio laboral recientemente firmado.

3a.- No se publica el 6 de octubre de 1934 como consecuencia de la huelga general revolucionaria. El día 7 tampoco se publica, pero se ponen en circulación unos folios a multicopista con el título "suplemento de Diario Regional ".

4a.- No se publica el 6 de mayo de 1936 por una huelga general declarada en Valladolid ese día. 


$$
\text { 5a.- No sale los días } 19 \text { y } 20 \text { de junio de } 1936 \text { por }
$$
una huelga general declarada en Valladolid en esos días.

$$
\text { 6a.- No se publica el } 16 \text { de enero de } 1979 \text { por una }
$$
avería mecánica, según los editores.

7ạ.- No se publica los días 30 y 31 de mayo de 1979 por una huelga de todo el personal del periódico, excepto la redacción y parte de la administración.

8a..- No se publica desde el 7 de junio al 24 de octubre de 1979 por dificultades económicas y de gestión de la empresa.

\section{Colección}

Hemeroteca de la biblioteca "Reina Sofía" de la Universidad de Valladolid: colección completa excepto el tercer trimestre de 1936, el cuarto trimestre de 1950, el 
tercer trimestre de 1952, el primer trimestre de 1955, y los días 21 a 31 de octubre de 1951.

Hemeroteca de El Norte de Castilla : Colección completa.

Hemeroteca del Ayuntamiento de Valladolid: El tercer trimestre de 1936, por el mal estado en que se encuentra precisa una autorización especial para su consulta. Colección incompleta.

Hemeroteca Municipal de Madrid: Colección incompleta.

Hemeroteca Nacional: Colección incompleta.

Sede social: administración, redacción y lugar de impresión.

Calle Duque de la Victoria, 18: del 7 de marzo de 1908 al 17 de septiembre de 1909 .

Calle Santiago, 86: del 18 de septiembre de 1909 al 1 de noviembre de 1944 .

Durante la segunda República las juntas de accionistas se celebran en la Casa Social Católica. 
Calle Santiago, 33: del 1 de noviembre de 1944 al 29 de junio de 1959 .

Calle Paraíso, 8: del 29 de junio de 1959 al 7 de marzo de 1980 .

\section{Formato y características técnicas}

Número de páginas

1931: 6 los diarios, 8 los festivos. Progresivamente va siendo habitual publicar 8 páginas también los martes para aumentar la información deportiva. En 1932 algunos domingos tendrá ya 10 .

En 1936 tiene normalmente 6 u 8 páginas los diarios, y 8 ○ 12 los domingos.

Con el racionamiento del papel, en octubre de 1937, pasa a tener 4 páginas dos días a la semana, y seis los domingos. Más adelante, el aumenta el número de días que sale con 4 páginas, y tendrá 6 solamente domingos y martes. 
En enero de 1940 es habitual que tenga 4 páginas los diarios y 6 los domingos.

En junio de 1940 el periódico tiene 2 páginas los diarios y 4 los domingos y algunos martes.

En enero de 1941 es frecuente que también los domingos tenga dos páginas.

En marzo de 1941 vuelve a tener 4 páginas los domingos $y$ martes, $y$ en septiembre de este mismo año vuelve a tener 4 páginas casi todos los días, sin que se aumente el número los domingos.

En 1942 algunos domingos tiene seis páginas, pero lo normal es que tenga 4 . 
En 1943 y 1944 oscila entre cuatro y seis páginas hasta que cambia el formato. Con el cambio de formato pasa a tener ocho páginas los diarios y 12 los martes y domingos .

Comparativamente, la superficie de papel impreso sería la siguiente:

\begin{tabular}{|c|c|c|c|c|c|}
\hline & \multicolumn{2}{|c|}{ DIARIOS } & \multirow{2}{*}{$\begin{array}{l}\text { MARTES } \\
\text { páginas }\end{array}$} & \multirow{2}{*}{$\begin{array}{l}\text { I DOMINGOS } \\
\text { superficie }\end{array}$} & \multirow[t]{2}{*}{ TOTAL } \\
\hline & páginas & superficie & & & \\
\hline formato antiguo & 4 & $9.380 \mathrm{~cm}^{2}$ & 6 & $14.070 \mathrm{~cm}^{2}$ & $75.040 \mathrm{~cm}^{2}$ \\
\hline formato nuevo & 6 & $7.869 \mathrm{~cm}^{2}$ & 12 & $15.738 \mathrm{~cm}^{2}$ & $70.821 \mathrm{~cm}^{2}$ \\
\hline incremento & +2 & $-16 \%$ & +6 & $+11,9 \%$ & $-5,2 \%$ \\
\hline
\end{tabular}

En febrero de 1945 los diarios tiene seis páginas, y los martes y domingos seis u ocho. 
En julio de 1945 vuelve al formato anterior, $y$ se publica con cuatro páginas los diarios, y seis u ocho los martes y domingos. Algunos días, la hoja impar tiene una pequeña solapa con dos columnas que se numera como "suplemento primero" y "suplemento segundo" en sus dos caras.

En enero de 1951 tiene seis páginas todos los días. Seguirá con este número fijo hasta que en agosto de 1954 comience a tener ocho páginas los domingos.

En noviembre de 1955 se generalizan las ocho páginas diarias, y algunos días diez.

Con el cambio de formato de 1956 pasa a tener ordinariamente 16 páginas los diarios y 20 domingos $y$ martes. El gasto de papel disminuye en la cantidad que se indica en la siguiente tabla: 


\begin{tabular}{|c|c|c|c|c|c|}
\hline & \multicolumn{2}{|c|}{ DIARIOS } & \multicolumn{2}{|c|}{ MARTES Y DOMINGOS } & \multirow[t]{2}{*}{ TOTAL } \\
\hline & páginas & superficie & páginas & superficie & \\
\hline formato antiguo & 8 & $20.768 \mathrm{~cm}^{2}$ & 10 & $25.960 \mathrm{~cm}^{2}$ & $155.760 \mathrm{~cm}^{2}$ \\
\hline formato nuevo & 16 & $20.160 \mathrm{~cm}^{2}$ & 20 & $25.200 \mathrm{~cm}^{2}$ & $151.200 \mathrm{~cm}^{2}$ \\
\hline incremento & +8 & $-2,9 \%$ & +10 & $-2,9 \%$ & $-2,9 \%$ \\
\hline
\end{tabular}

En enero de 1957 es habitual que el número de páginas sea cuando menos de catorce o dieciséis, y cuando más veinticuatro.

En 1961 tiene normalmente 16 páginas los diarios, 24 los martes, y 32 los domingos, contando los suplementos. El precio es entonces de dos pesetas.

En 1967 sale con 24 páginas los diarios y 30 los domingos, además de los suplementos. 
En 1969 sale con 16 más 8 de suplemento los domingos, 24 los martes, y 16 los diarios.

En 1973 sigue con 16 los diarios y 24 domingos y martes.

En 1975 tiene 24 páginas todos los días, más los suplementos los domingos - Magazine», 12 páginas- y martes -«De deportes", 16 páginas-.

En 197724 páginas los diarios, martes 32, 40 los domingos .

En octubre de 1977 sale con 28 páginas los diarios.

Dimensiones

$1931-31 / 10 / 1944: 59 \times 41 \mathrm{~cm}$.

$1 / 11 / 1944-14 / 7 / 1945: 43 \times 30,5 \mathrm{~cm}$ 
Apéndices

15/7/1945-1/4/1956: 59 x $44 \mathrm{~cm}$.

1/4/1956-7/3/1980: $42 \times 30 \mathrm{~cm}$.

Columnas

1931- 1944 : siete.

1944-1945: cinco.

1945 - abril de 1956: siete

1956-1980: seis.

\section{Impresor}

La propia empresa editora del periódico.

Sistema de impresión 
Máquinas de componer Typograph.

Se procede a la renovación de la maquinaria en diciembre de 1931 y primeros meses de 1932995. Se sabe que algunas máquinas se importan de los EE. UU.996. La mejora introducida con las nuevas máquinas empieza a ser visible en algunas páginas del número correspondiente al 5 de mayo de 1932, el 7 de mayo la renovación del periódico es completa. Es una rotoplana.

En noviembre de 1944 pasa a imprimirse en una rotativa "Koening \& Bauer".

En mayo del 66 hay un nuevo cambio de maquinaria. Desde esa fecha se imprime el periódico en una rotoplana997.

\footnotetext{
${ }^{995} \mathrm{Se}$ da cuenta de que ya se han comprado las nuevas máquinas con los donativos recibidos en $\mathrm{DR}, 3 / 1 / 1932$, pág. 1 .

${ }^{996}{ }_{D R}, 28 / 4 / 1932$, pág. 1.

997Cfr. 24/5/1966, pág. 17 .
} 
En marzo de 1975 se procede a la renovación completa de los talleres, $y$ el periódico pasa a imprimirse en ofsset. El laboratorio cuenta con una cámara Kimsch autovertical, una cámara de vacío vapuntfilt y una procesadora de Kodak para papel PMT. En la sección de composición se instalaron tres ordenadores electrónicos de la casa Compugraphic, dos de los cuales se alimentaban con cinta kilométrica perforada en teclados Datek 3000. Las platinas fueron sustituidas por mesas transvista de montaje, y para la consolación se instaló una prensa Combilux con luz de yodo. La rotativa es una Goss Community, que contaba con cinco cuerpos de impresión y un plegador modelo Suburban de la misma casa. Podía imprimir periódicos de 40 páginas en blanco y negro o de 24 en color, a una velocidad de 20.000 ejemplares por hora998.

\section{Zonas de difusión}

${ }^{998} \mathrm{Cfr}$. DR, 16/3/1975, págs. 14, 16 y 17. 
El periódico hace constar los siguiente puntos de venta en las fechas que se señalan:

Enero de 1931: León, Santander, Burgos, Zaragoza (kiosko de El Noticiero), Valencia y Madrid (kiosko de El Debate ) •

Julio de 1932: Oviedo, Palencia, Santander, Medina del Campo, La Bañeza, Bilbao, Torrelavega, San Sebastián.

Agosto de 1932: En Madrid. Kiosko de Teófilo Gómez, Alcalá, 22. Kiosko de El Liberal, Puerta del Sol. Kiosko de La Voz, Alcalá.

Agosto de 1936: Medina, Palencia, Peñafiel, Rioseco, Villalón, La Bañeza, Arévalo, León, Burgos, Aranda de Duero, Cuellar, Segovia, Salamanca, Nava del Rey, Mota del Marqués, Villafranca del Bierzo, Tudela de Duero

Puede encontrarse también en: Arrabal de Portillo, Bercero, Cubillas de Santa Marta, Laguna de Duero, Pozoantiguo, Sardón de Duero, Traspinedo, Tordesillas, Vecilla de Valderaduey, Villada (Palencia), La Seca, Aguilar de Campos, Rubí de Bracamonte, Torrecilla de la orden, Olmedo, Alaejos, Villarcayo (Burgos), Esguevillas, 
Castrojeriz, Valencia de don Juan (León), Valdestillas, Valoria la buena, Pesquera de Duero, Casasola de Arión, Campaspero, Cabezón, Matapozuelos, La Rúa (Orense), Villanubla, Magaz (Palencia), Dueñas (Palencia), Torquemada (Palencia), Villabrágima,zamora y Toro.

En septiembre de 1936 se añaden a la lista los siguientes lugares: Villarramiel (Palencia), Iscar, Boadilla del Campo, Villavicencio de los Caballeros, Fuente Olmedo, Barco de Valeorras (León), Cabezón de Valderaduey, Cogeces del Monte, San Miguel del Arroyo, Pozaldez, Barruelo (Palencia) y Revenga de Campos (Palencia)

De ordinario la difusión alcanza solamente Valladolid capital y provincia. 
ApÉndice 2.- Estructura informativa. Secciones •

En 1931, con Oscar Pérez Solís y Rafael Serrano

SECCIÓN Pág OBSERVACIONES

Editorial 1 No lo indica expresamente, a veces en su lugar publica un artículo de fondo firmado.

Firma regia 1 Hasta el 12 de abril.

El día 1 Con la proclamación de la

político

República cambiará el nombre por

«España bajo el Gobierno

republicano", "Bajo el Gobierno

republicano" o "Bajo el régimen

republicano" entre abril y junio

de 1931, para volver entonces a su título original.

En enero de 1933 se titulará

"Noticias políticas».

Noticias de 1 Desde el 16 de abril hasta el 3 de Madrid junio. 


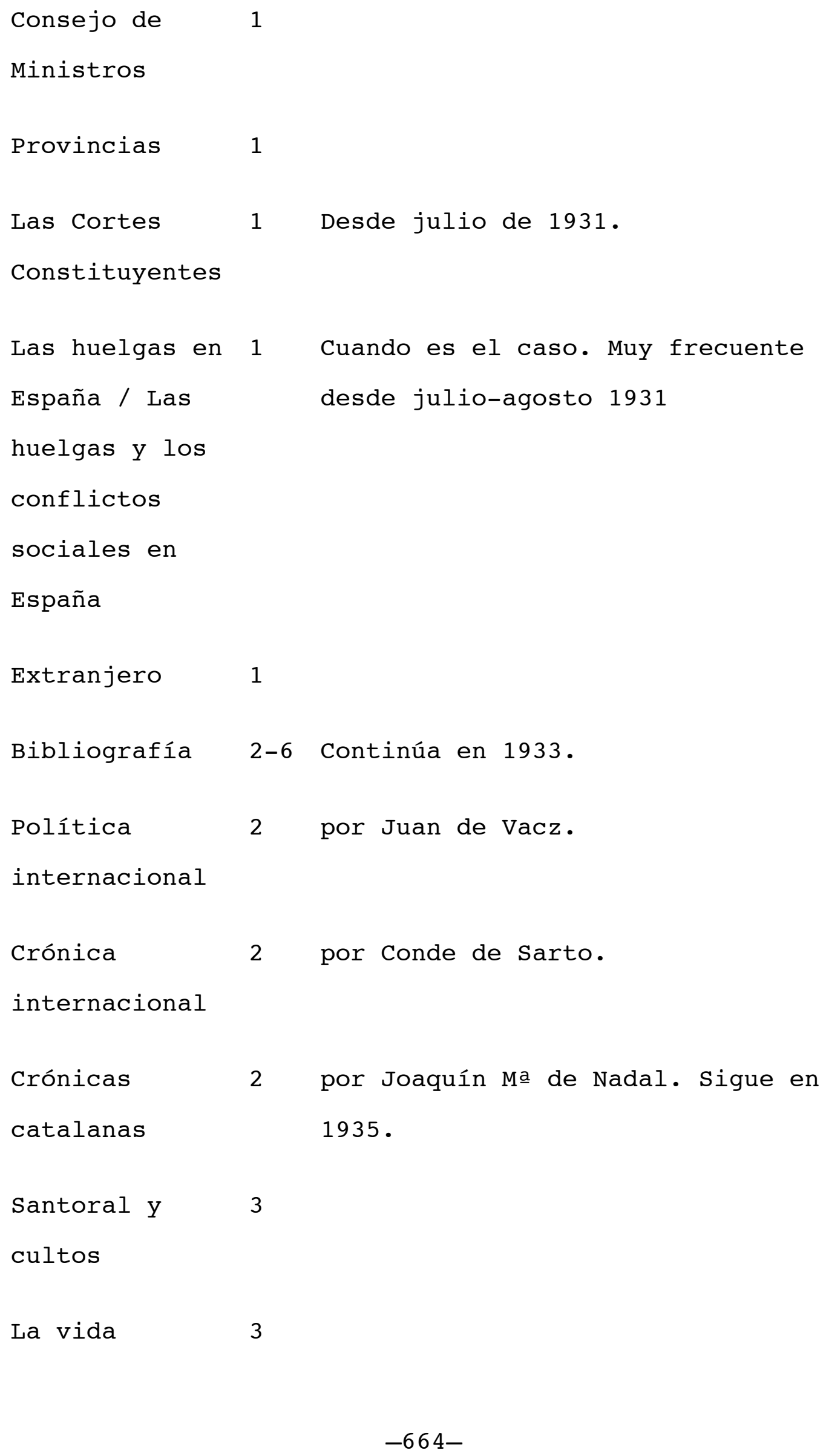


católica

Boletín $\quad 3$

demográfico

Información 3 León, Zamora, Avila, Segovia,

provincial y Santander, Burgos, Palencia,

regional

Salamanca, Ciudad Rodrigo. Varios

pueblos de la provincia de

Valladolid. No hay periodicidad en

las crónicas, que recogen sobre

todo sucesos y algunas noticias de gestión municipal.

Temas médicos 3-4 Un día a la semana. Doctor Royo Villanova.

Toros $y \quad 3$ por EME.

toreros

Deportes

2-3 Los domingos y martes puede ocupar toda una página. A partir de mediados de marzo de 1931 ocupará una página completa todos los martes y el periódico pasará a tener ese día ocho páginas.

Información 5 Incluye en los distintos días de agrícola y la semana: "Mercado de mercantil Valladolid", "Mercados 


\author{
castellanos", "Mercados \\ aragoneses" (por Z. San Germán), \\ "Mercados provinciales", "Mercados \\ nacionales". Resumen semanal del \\ mercado agrícola local. A veces \\ recoge literalmente los \\ comentarios de El Financiero de \\ Madrid: "Impresiones. Al cerrar la \\ semana". "Cotizaciones de Bolsa". \\ "Temas sociales". \\ En 1932 se titulará "Página \\ agrícola y mercantil». Frecuente \\ col. en la misma es Ramiro \\ Villarino Campero (Agencia \\ Internacional Arco) •
}




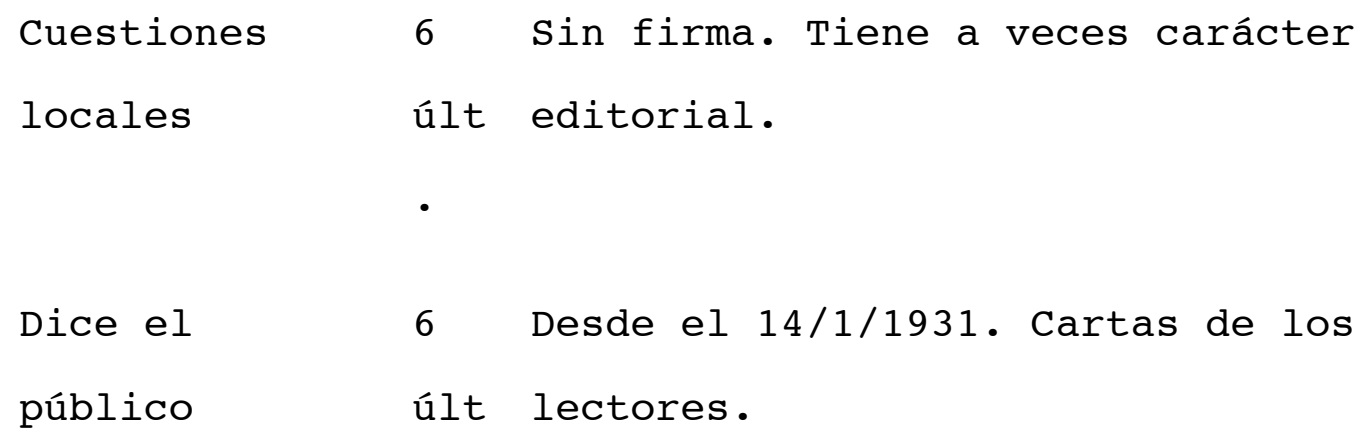




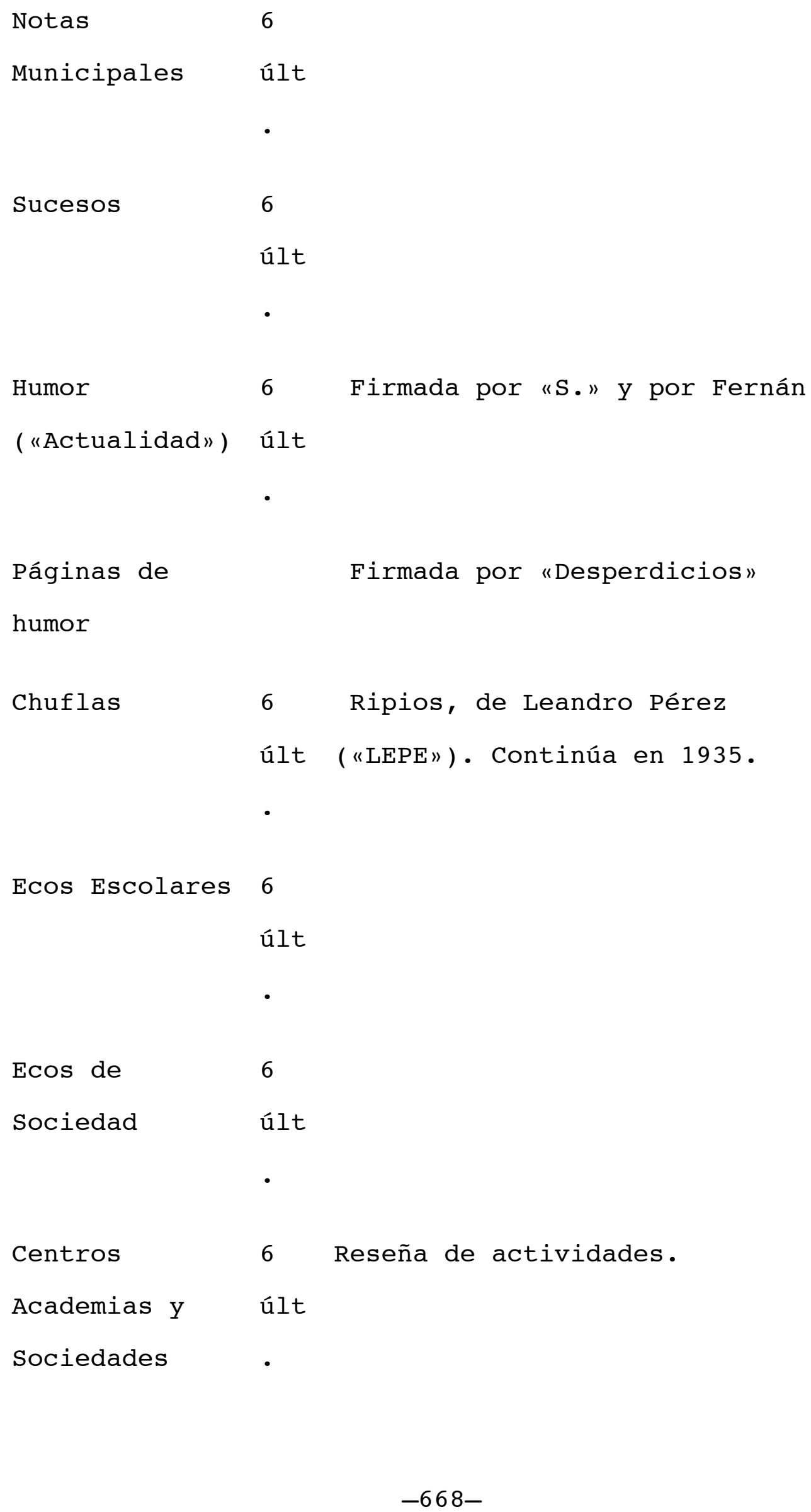


Folletón

Para el

curioso lector
Mayo de 1931: "Así es Mocou (Nueve años en el país de los soviets)", por José Douillet, cónsul de Bélgica en Rusia. Publicado con permiso de la casa editorial «Razón y Fe»

Octubre de 1931: "Los piratas del Halifax " de Julio Verne, editada por Saenz de Jubera Hnos. de Madrid.

6 Noticias o comentarios tomados de últ otros periódicos, comentados a - veces por DR.

Suscripciones

Enero de 1931: "A favor de la benéficas (colectas)
Guardia Civil y de las víctimas que murieron en el cumplimiento de su deber durante el intento revolucionario". Hay una comisión gestora ajena al periódico. Se recomienda a esa comisión que se recojan donativos no sólo en los bancos sino también en periódicos: «El público está más acostumbrado a ir a ellos". 
Enero de 1931: "Homenaje al sr.

Arzobispo: suscripción para

edificar la iglesia parroquial de

San Juan" •

Enero de 1931: "En favor de unos

artistas". Son actores de teatro

que se encuentran en una situación

difícil y que acuden a DR por

recomendación del gobernador

civil, sr. Garralda, para que el

periódico inicie una suscripción

en su favor.

mayo de 1931: "Por los obreros

parados", en colaboración con una

iniciativa del alcalde socialista,

Landrove.

Publicaciones

Comenta alguna de ellas.

y revistas 
SECCIÓN Pág

\section{OBSERVACIONES}

Brotes del día 6 Comentario editorial casi siempre últ de carácter político.

Desde Nueva 2 Crónica esporádica por Marcial York Rossell.

Reportajes de 6 Comentario sobre la política de Diario últ Valladolid, a partir de junio de Regional - 1931, firmado por "Kator y su amigo Pepe» 
Crónica

bilbaína

Página

femenina

Crónica de

viaje

Mosaico

Gaceta

deportiva

Gobierno Civil
Por G. Caballero, desde octubre de 1932 .

Aparece en junio de 1932

Por Herminio Sanz. Columna

literaria.

6 Comentario político desde finales

últ de junio de 1931, de tono irónico,

- firmado por “EFE"

Del Extranjero 1 Se destaca más la sección a partir de 1932 .

Nuevo nombre de la sección de deportes de los martes

desde julio de 1932 se incluye una "Impresión" como entradilla a la información a modo de comentario o crítica de la misma.
A ripio
6 Por "Rosello", en agosto de 1932.
tendido
últ

Los deportados

Desde que finaliza la suspensión
a Villa
en septiembre de 1932 , en
Cisneros
adelante. 


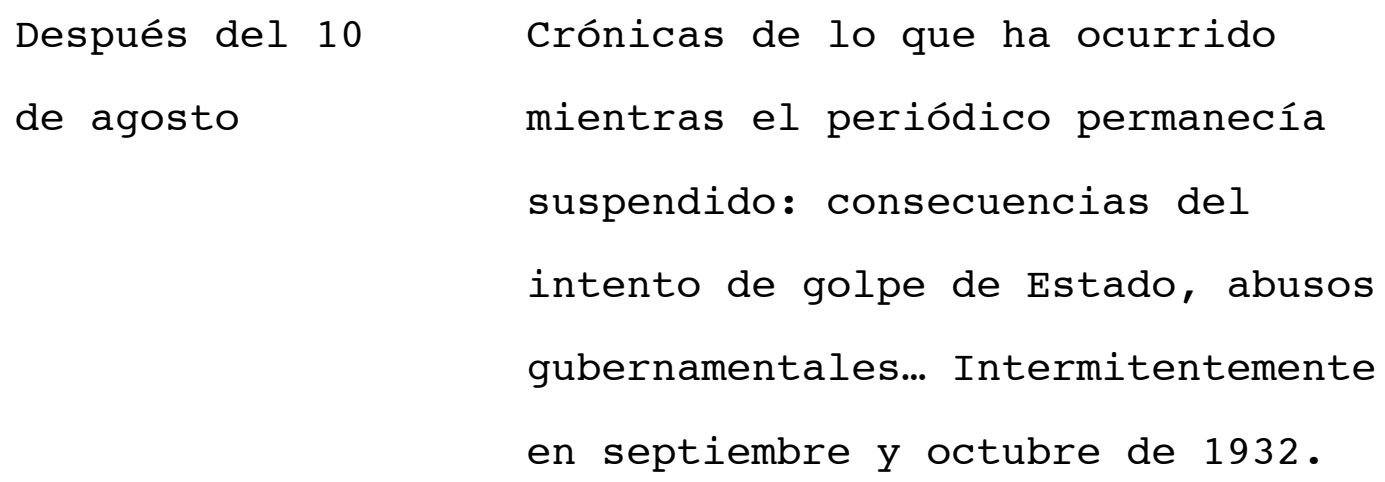

mientras el periódico permanecía

suspendido: consecuencias del intento de golpe de Estado, abusos gubernamentales... Intermitentemente en septiembre y octubre de 1932.

6 Desde septiembre de 1932:

últ desgracias ocurridas a los

- anticlericales, actos de

hostilidad a la Iglesia

fracasados.

por "ITO". su viñeta de humor es

frecuente en febrero y marzo de 1933.

Crónica de toros por "Kakiko", Francisco Gómez

Por "Parásitos", pseudónimo de José M. Martín Liébana. Informa de la programación de radio y comenta diversas cuestiones lo mismo locales que nacionales o internacionales, en tono irónico. Algunas veces se titulará también "Antena». En los momentos en que Radio Valladolid tiene una 
orientación política que desagrada a DR la sección tendrá menor relevancia y perderá regularidad. En junio de 1935 los cambios en la emisora vuelven a hacerla una sección destacada, pero tan sólo unas semanas.

Los Sports

Página
católica

Página médica
Título de la sección de deportes de los martes en septiembre y octubre de 1932

Aparece por primera vez el 22/1/1933, con el fin de "aminorar los estragos del laicismo oficial, que pretende privar al pueblo de las enseñanzas religiosas." Aparece esporádicamente, la segunda vez será el 12/2/1933.

Página semanal inaugurada el 15/3/1933, firma la presentación de la página a los médicos de Valladolid "El amigo Pepe». Se publica irregularmente al principio y luego todas las semanas. Aparecerá normalmente los sábados. A veces recibe el nombre de "Sección médica semanal". Se 
interrumpirá su publicación a finales de 1934.

La Gaceta

Boletín

Oficial de la Provincia

Ayer en las 1-? Crónica parlamentaria en 1933.

Cortes

Instantánea

política

Página Jocista León .

4-? Comienza a publicarse el
1-? Comentario político por Alvarez de

21/5/1933. A veces es "sección jocista".

Página de radio

4-? Se publica por primera vez el 5/7/1933. En diciembre de 1933 se titulará "Tribuna», y el comentario más extenso lo firmará "DONONDAS" •

Página escolar 3-? Comienza su publicación el 6/12/1933, dirigida por la Federación de Estudiantes Católicos. En la primera se 


recogen artículos de José Má Pemán
Y Enrique Herrera Oria.
En mayo de 1932 se reproduce el
folleto sobre la Reforma Agraria
publicado por el notario palentino
Antonio Alvarez Robles
Del 20 diciembre de 1933 al 5 de
enero de 1934 se publica "El
programa agrario de la CEDA.
Ponencia del señor Alvarez Robles
que sirvió de base al programa."
Miscelánea
Título de una página de los
En fobrero de 1934 se publica la
1934 .

Comidilla del 6 Comentario político irónico, día últ firmado por "Cipión". 


\begin{tabular}{|c|c|c|}
\hline $\begin{array}{l}\text { Del ambiente } \\
\text { revolucionario }\end{array}$ & 1 & $\begin{array}{l}\text { Aparece en abril de } 1934 \text {, contin } \\
\text { en mayo y junio. }\end{array}$ \\
\hline $\begin{array}{l}\text { Letras. } \\
\text { Historia. Arte }\end{array}$ & $5-?$ & $\begin{array}{l}\text { Página literaria. Aparece la } \\
\text { primera el } 29 / 4 / 1934 . \text { Se publicará } \\
\text { los domingos sin regularidad. }\end{array}$ \\
\hline $\begin{array}{l}\text { Temas de } \\
\text { actualidad }\end{array}$ & 1 & $\begin{array}{l}\text { Título del comentario político de } \\
\text { tono editorial en mayo de } 1934 \text {. }\end{array}$ \\
\hline $\begin{array}{l}\text { La cuestión } \\
\text { triguera }\end{array}$ & 1 & $\begin{array}{l}\text { Aparece en agosto de } 1934, \text { mes en } \\
\text { el que por vacaciones de los } \\
\text { obreros, se han suspendido la } \\
\text { publicación de las "Páginas" } \\
\text { jocista, femenina y médica. }\end{array}$ \\
\hline
\end{tabular}

Información $\quad 5 \quad 1934$

provincial y

regional

Información $\quad 5 \quad 1934$

agrícola y

mercantil

Pasada la

1-2 Información en torno a la

sublevación

revolución de octubre, se

publicará de noviembre de 1934 a

marzo de 1935. 
Información

militar

Suscripciones

benéficas
Es una pequeña sección que se consolida en junio de 1935.

abril de 1932: para atender los

gastos de reparación tras el

asalto violento de Diario

Regional y la Casa Social Católica

Enero de 1934: por los obreros

católicos parados.

Octubre de 1934: en favor de los

soldados vallisoletanos en el

frente (Asturias) y la compra de

camas para los heridos. 


\section{SECCIÓN}

Pág

Editorial

La vida en la capital

Temas locales
El editorial se coloca siempre en la primera columna de la primera página, y normalmente va a una sola columna. Es también frecuente que se publiquen dos editoriales, situados en la primera y última columna de la primera página.

6 Da nombre a toda la página, que se últ dedica a información local.

El [día] de 6 Un breve comentario de la vida de [mes ] en últ la ciudad en el día anterior: la Valladolid - fiesta que se celebró, actos culturales, ambiente, el tiempo, ...

Notas

agrícolas y

financieras 


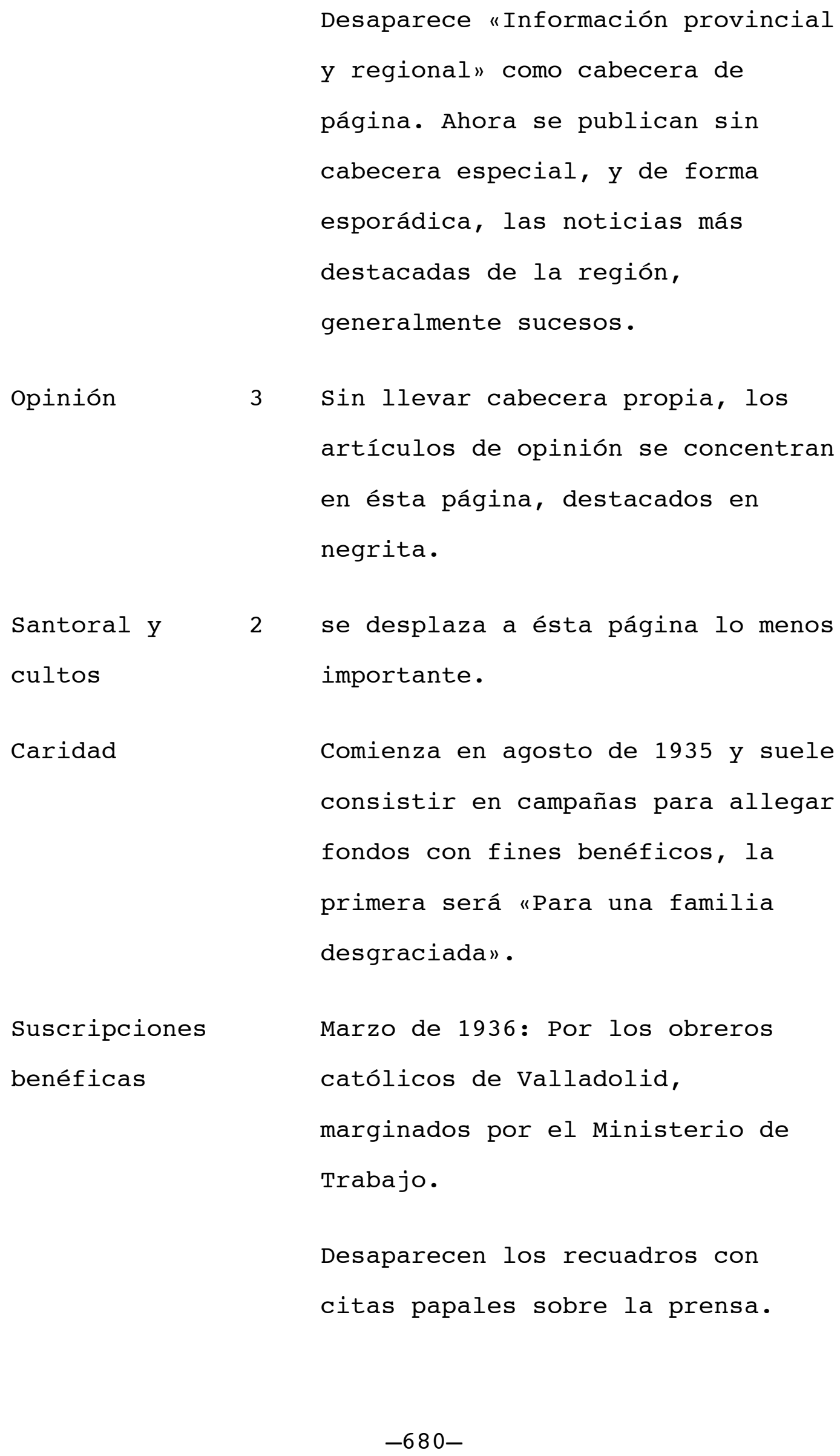


Radio Crónica

Diario

Regional en

Madrid

Para los

maestros

Diario

Regional en

París

Diario

Regional en

Lisboa

Ante la
Vuelve otra vez en octubre de 1935, pero ocurre como en ocasiones anteriores: no se consigue que mantenga la regularidad Crónicas del corresponsal Foces. Editada por la Asociación Católica del Magisterio, sale por primera vez el 6/11/1935, y aparecerá los miércoles. Firma el saludo León Montañés, que habla de "una campaña en pro de la enseñanza primaria", cfr. Firmas: Rafael López Sánchez, Eduardo Zurro Llorente, Corresponsal J. Gómez del Barco. Informa por ejemplo del conflicto italo-abisinio.

Corresponsal Fernando Costa

Tavares

3 Comienza el 18/12/1935 Juicio 
pantalla

\section{Viñeta}

revolucionaria

Los libros y

los autores

Sección médica

semanal

Editoriales de 1

Diario

Regional

Con

prismáticos moral de los espectáculos

cinematográficos que sustituye la nota que enviaba diariamente la

Junta Diocesana de la Juventud

Femenina de Acción Católica.

Aparece en enero de 1936 con

relatos de asesinatos durante la revolución de 1934 .

Sección de crítica bibliográfica, semanal, que aparece con este título desde finales de 1934. Se trata mayoritariamente de publicaciones de Acción Católica, colección "Pro Ecclesia et Patria», y ediciones FAX.

Es el nombre que se da ahora habitualmente a la página médica. Firman: M. Montero-Charlas de Puericultura-,

Aparecen bajo este encabezamiento dos o tres editoriales en primera página en torno a las elecciones de febrero de 1936. Comentarios breves de tipo político en forma de alegorías, 
firmados por "siete".

Guión de la

cultura

Folletón

Cartas a

Diario

Regional
Comentario cultural por Miguel Herrero García.

"Los Protocolos de los Siete

Sabios de Sión", en mayo de 1936.

8 Comienza a publicarse en junio de últ 1936. 


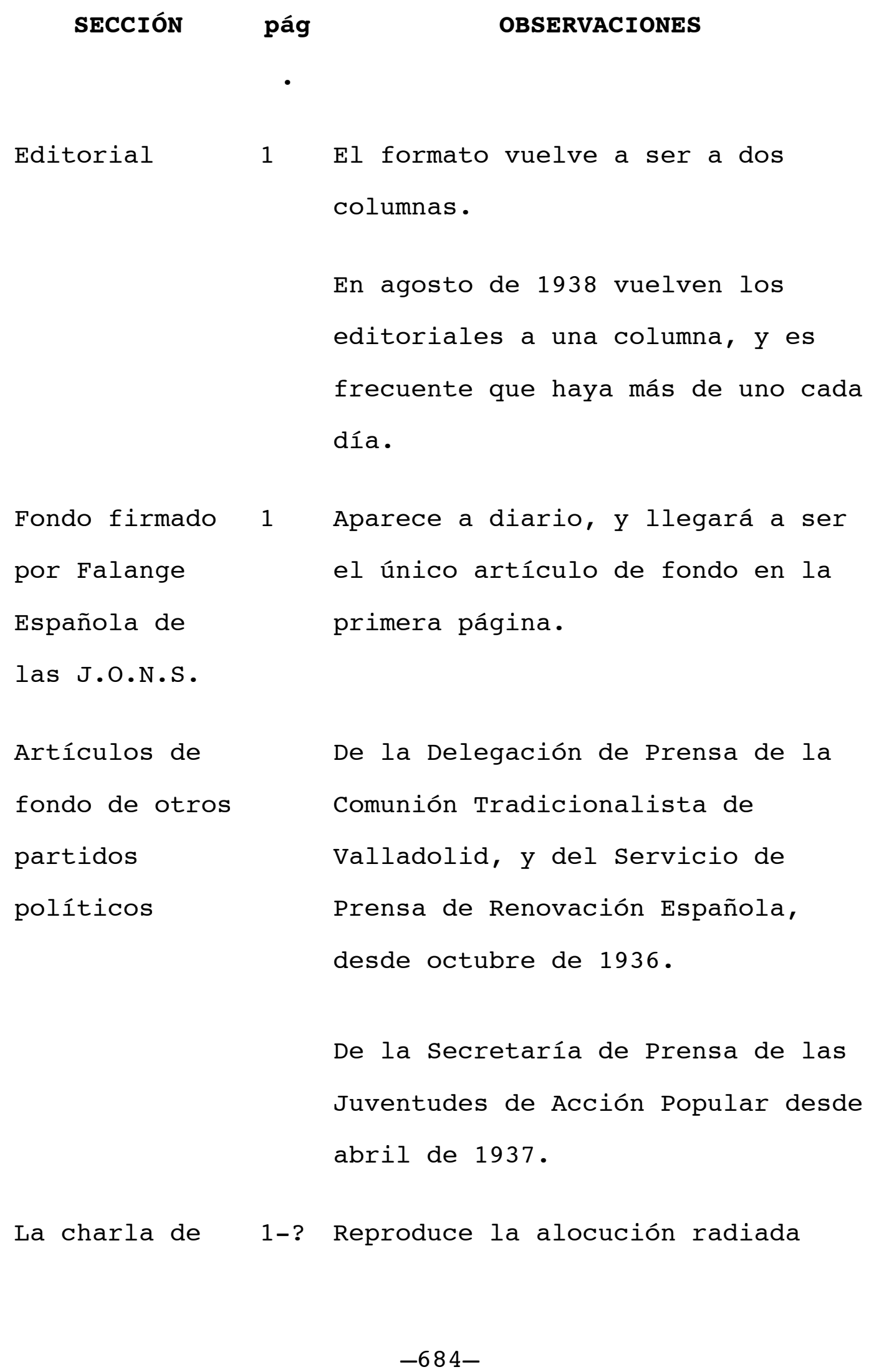




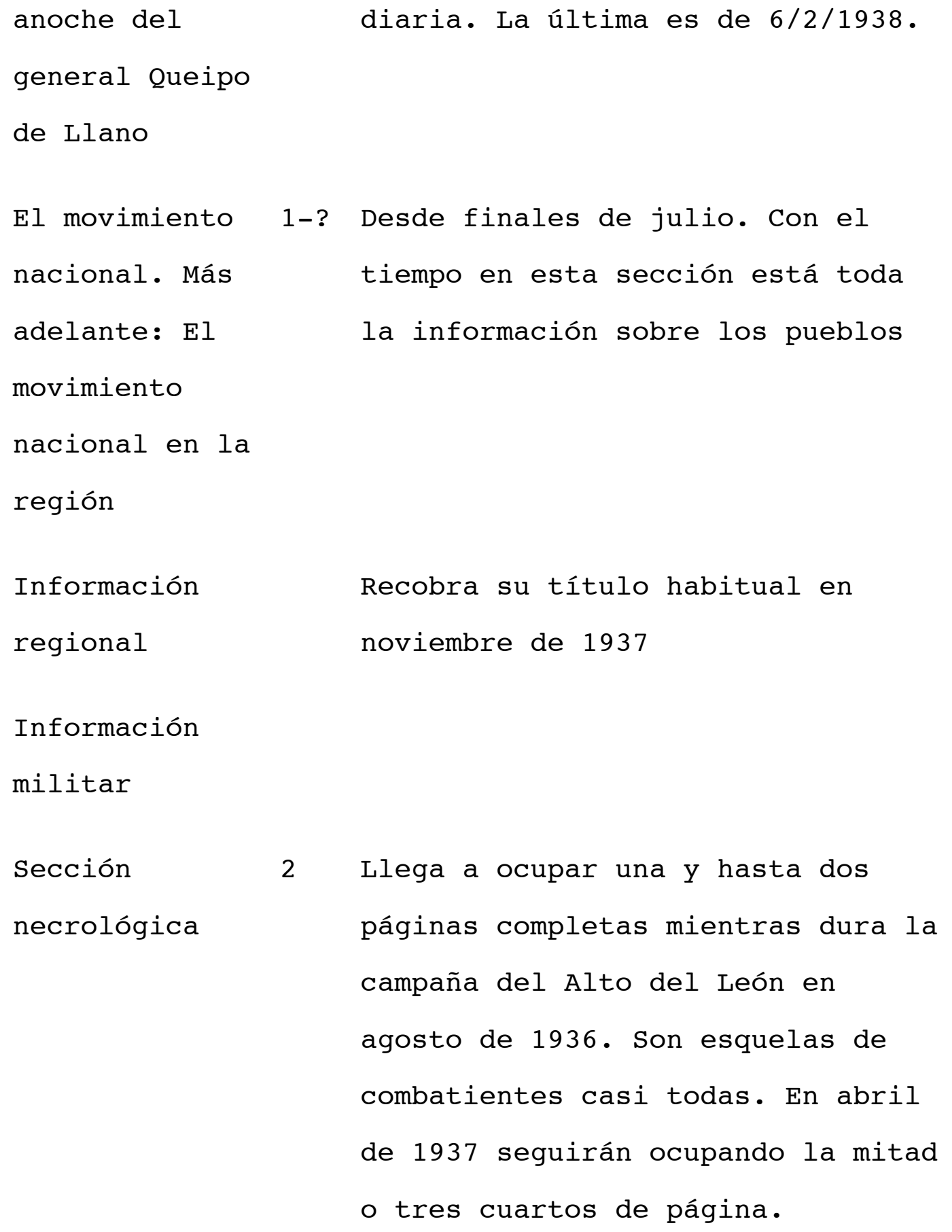




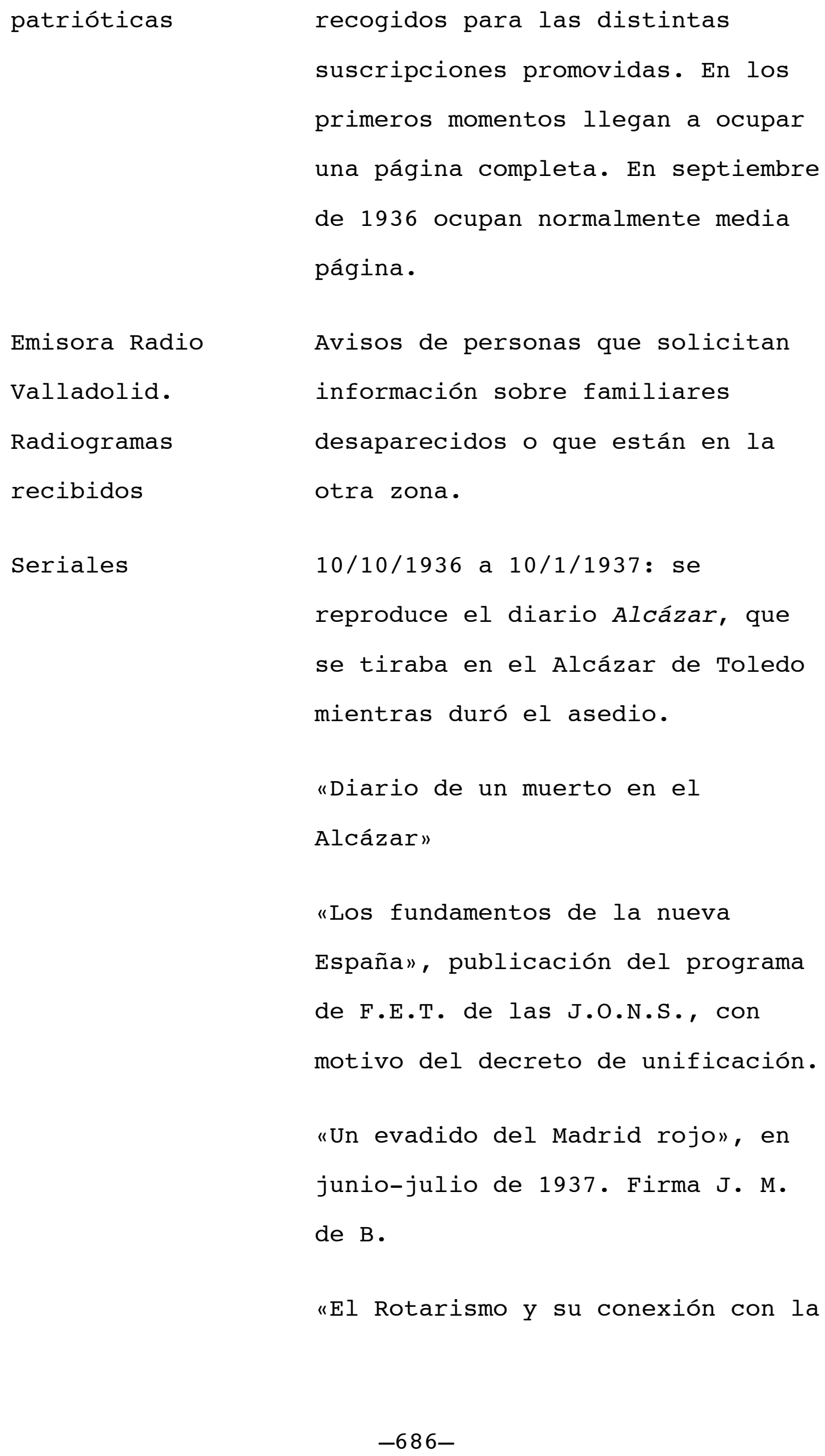


Masonería", septiembre de 1937.

"Documentos secretos", correspondencia entre Aguirre, Prieto y el general Gamir. Octubre de 1937 .

«Ejercicios Espirituales por la prensa", por el P. Remigio Vilariño, S.J. Noviembre de 1937. "Ley de responsabilidades políticas", febrero-marzo de 1939.

Página jocista

o Sección jocista

Deportes

Temas locales
3

3 de 1936

La única "página" que no interrumpe su publicación. últ Comienza a ser irregular en - febrero de 1937. En enero de 1938 ha perdido totalmente tono de denuncia que antes tenía.

Pólvora en últ Comentarios breves de tono salvas - irónico, referidos normalmente a la política en la zona del Frente Popular. La firma “El Capitán Centellas", Luis García Sicilia 


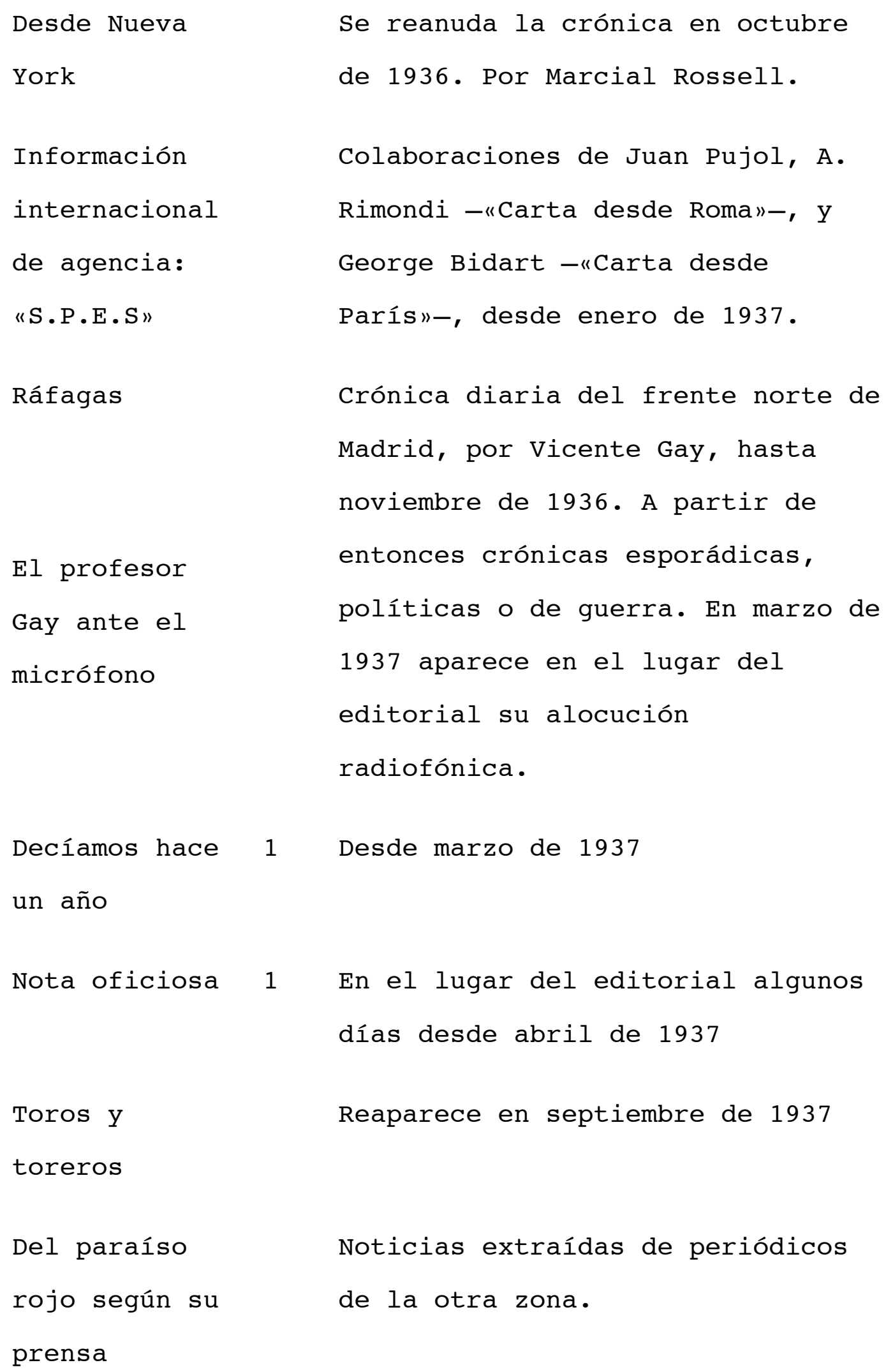


Página médica

Página

femenina

Publicaciones

y revistas

F.E.T. y de

las J.O.N.S..

Convocatorias

y órdenes

Página

religiosa

El campo, las

cosechas y los

mercados

Los libros $y$
Reaparece en enero de $1938^{999}$.

Tiene como subsecciones fijas:

Bibliografía, Noticias locales,

Noticias nacionales, Noticias

internacionales

Reaparece en enero de 1938.

Reaparece en febrero de 1938.

Desde poco después del decreto de unificación.

Sale los domingos sin cabecera propia. Se consolida en marzo de 1938: comentario del Evangelio, artículos de fondo, etc.

Reaparece esporádicamente en agosto de 1938 .

Sección de crítica bibliográfica

${ }^{999}$ Cfr. la presentación de esta segunda época, con declaración de objetivos y valoración de lo conseguido en la anterior en "De ayer... a hoy", por Doctor Laguna, DR, 15/1/1938, pág. 5 
los autores

Folletón que reaparece en octubre de 1938.

3 "Centinela contra francmassones..." del 30/10/1938 al 19/11/1938.

"La urbanización de Valladolid" por Juan Agapito y Revilla, $17 / 12 / 1938$ a $11 / 1 / 19391000$.

1000 Recoge las conferencias pronunciadas en el Ayuntamiento los días 3 y 9 de marzo de 1935 . 


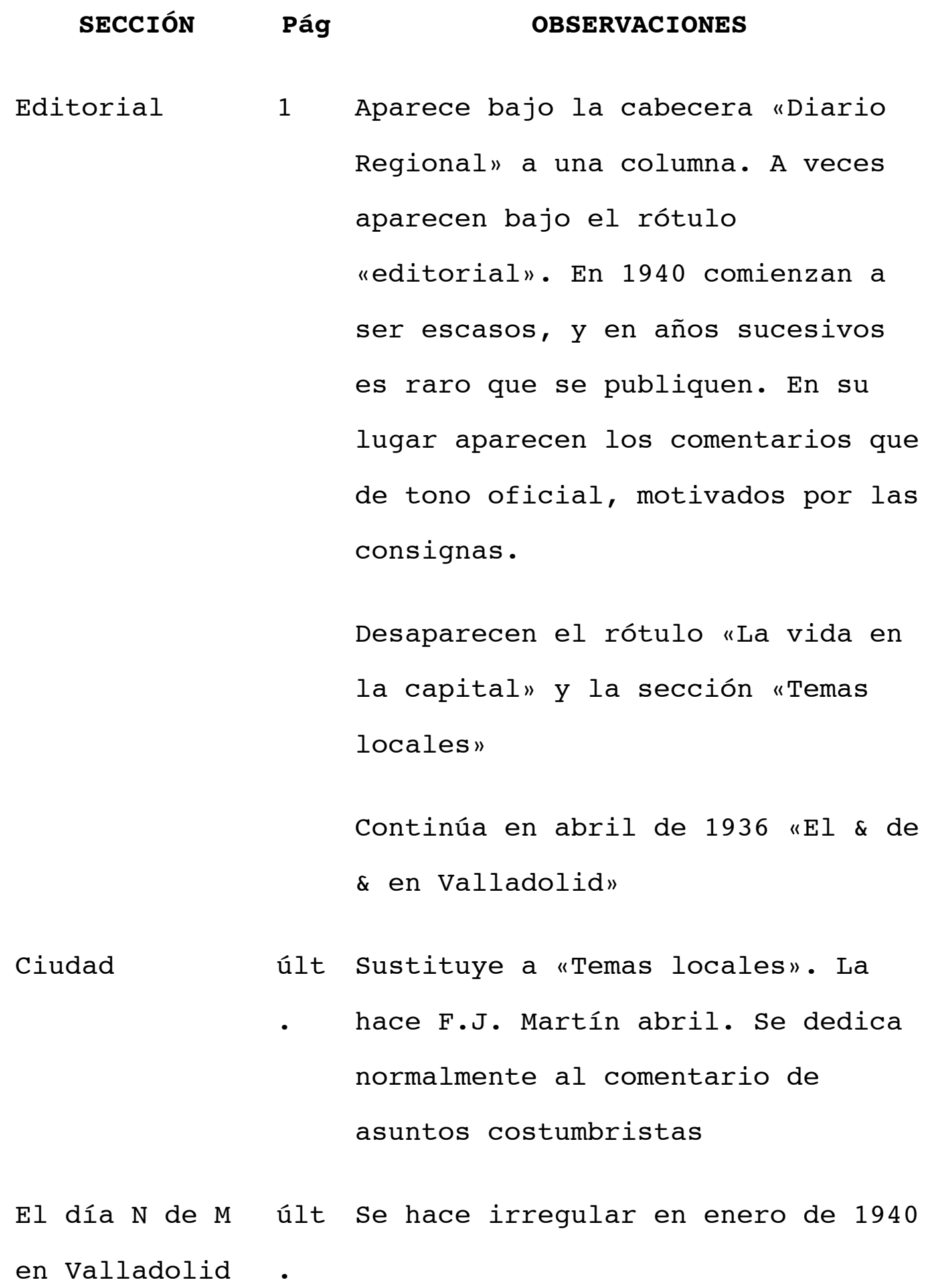




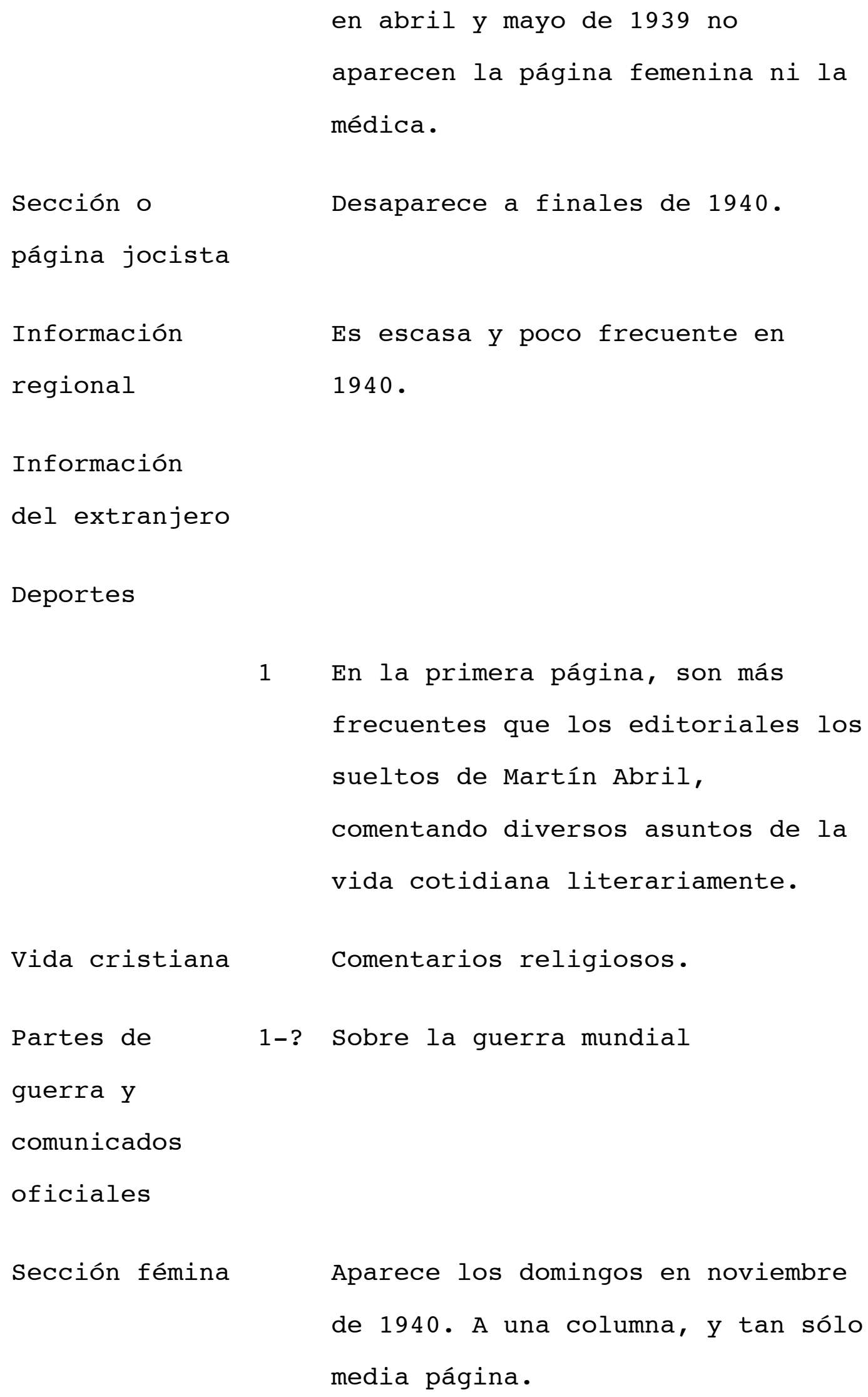

1 En la primera página, son más frecuentes que los editoriales los sueltos de Martín Abril, comentando diversos asuntos de la vida cotidiana literariamente.

Vida cristiana Comentarios religiosos.

Partes de 1-? Sobre la guerra mundial guerra y comunicados oficiales Sección fémina Aparece los domingos en noviembre de 1940. A una columna, y tan sólo media página. 


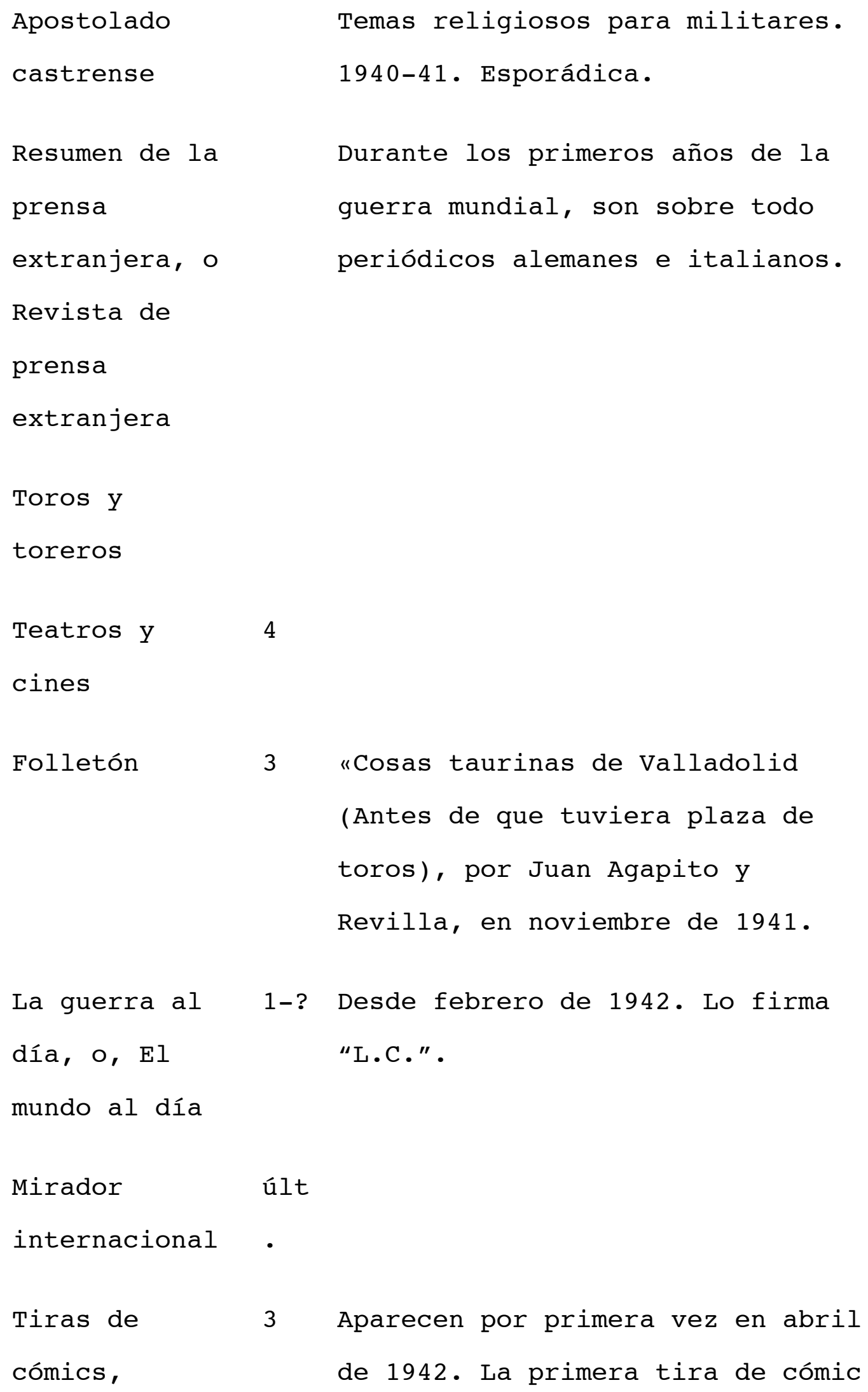


pasatiempos

Notas del

municipio,

Provincia $y$

municipio, o

Municipio

Postales de

Valladolid

Valladolid al

día

Universidad

Moda

Esquina

Intereses fue "La costilla de don Porfirio Bombilla»

últ Aparece en junio de 1942 .

Fotografías de Valladolid a tres columnas, con un pie de foto que las comenta. Por Luis Calabia.

2 Aparece en septiembre de 1942 . Contiene información sobre la Diputación, Hacienda, boletín demográfico, efemérides -desde 1908-, anuncios, etc. Aparece en noviembre de 1942 y no es regular. Aparece en diciembre de 1942. A una columna, una fotografía y un breve comentario.

últ Aparece en 1943. Comentario sobre

- temas locales. Por Angel de Pablos .

2 Aparece en 1943. 
Apéndices

$\begin{array}{ll}\text { internacionale } \quad & \text { en agosto de 1943. En } 1944 \\ \text { s } & \text { aparecerán también de Argel, } \\ & \text { Estocolmo, Vichy -desde abril de } \\ & 1944- \\ & \\ \text { Mujer } & \text { Incluye Cocina y Charlas } \\ & \text { femeninas. }\end{array}$

Croniquilla

madrileña 
A PARTIR DEL CAMBIO DE FORMATO EN NOVIEMBRE DE 1944

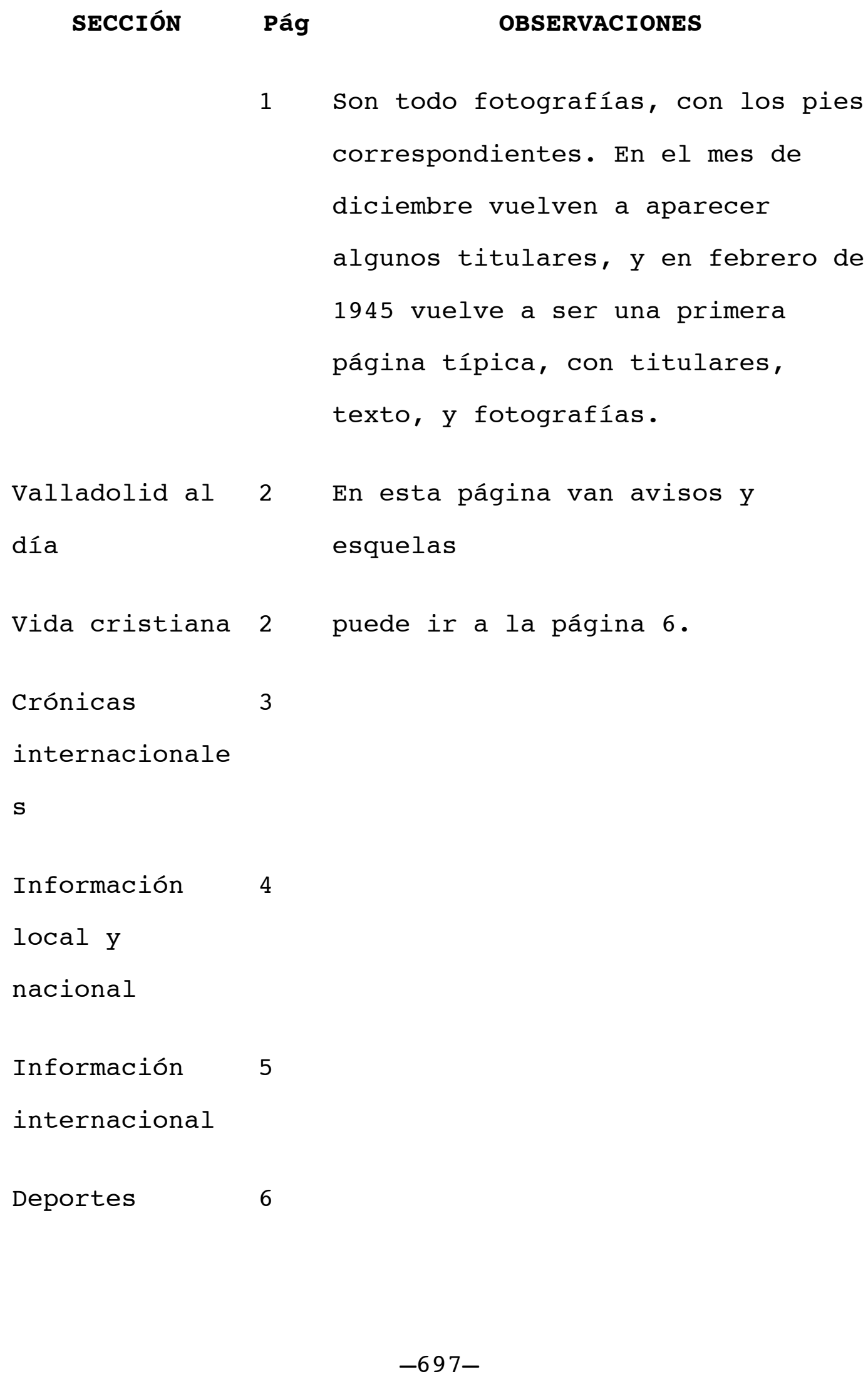




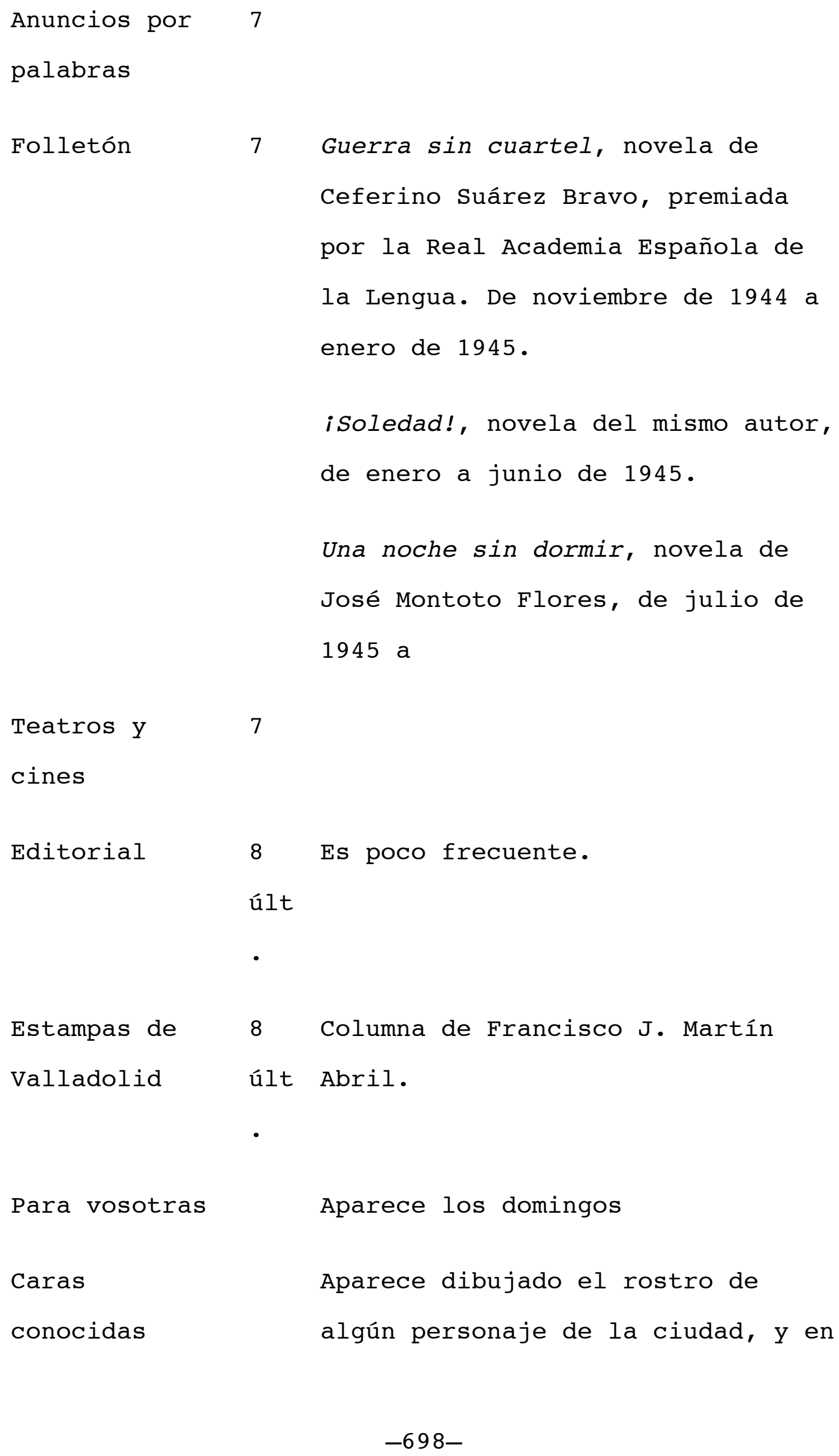


el pie se comenta elogiosamente algo sobre él.
Información

regional

Libros

Agricultura

Literatura y

arte

La calle

Espuma de la

semana

Aire de la

ciudad
Se dedica una página íntegramente

a este tema los domingos. Comienza

en 1945. Contiene un artículo

general, cuestiones técnicas,

publicaciones, noticiario

extranjero, refranero, las ferias,

y legislación.

Idem .

Comentario de temas de la ciudad, que se refiere casi siempre a posibles mejoras. 1945 .

Resumen de las informaciones más destacadas. 1946 .

2 Columna de Martín Abril en 1946. 


\begin{tabular}{|c|c|c|}
\hline SECCIÓN & Pág & OBSERVACIONES \\
\hline Editorial & 1 & Sigue siendo poco frecuente. \\
\hline $\begin{array}{l}\text { Valladolid, o } \\
\text { Ayer }\end{array}$ & 1 & $\begin{array}{l}\text { Comentario breve de las } \\
\text { actividades de la ciudad. }\end{array}$ \\
\hline $\begin{array}{l}\text { Cristal de } \\
\text { color }\end{array}$ & 1 & $\begin{array}{l}\text { Comentarios de tono irónico o } \\
\text { festivo de asuntos diversos. }\end{array}$ \\
\hline Cosas del día & últ & $\begin{array}{l}\text { Comentarios sobre cuestiones } \\
\text { anecdóticas }\end{array}$ \\
\hline $\begin{array}{l}\text { Aire de la } \\
\text { ciudad }\end{array}$ & últ & \\
\hline $\begin{array}{l}\text { Valladolid al } \\
\text { día }\end{array}$ & 2 & $\begin{array}{l}\text { Sucesos, El tiempo, Sociedad, } \\
\text { Avisos, Vida cristiana, La calle... }\end{array}$ \\
\hline $\begin{array}{l}\text { Anuncios por } \\
\text { palabras }\end{array}$ & 2 & \\
\hline $\begin{array}{l}\text { Sección } \\
\text { agrícola }\end{array}$ & 3 & $\begin{array}{l}\text { Los domingos "La página del } \\
\text { campo": Ganadería y pastos, } \\
\text { Cultivos y cosechas, Miscelánea } \\
\text { agrícola, Ferias y mercados. }\end{array}$ \\
\hline $\begin{array}{l}\text { Información } \\
\text { regional }\end{array}$ & 3 & Muy escasa y esporádica. \\
\hline
\end{tabular}


Deportes

Espuma de la últ Domingos.

semana

Para vosotras

Revista de

prensa

Entrevistas

últ Figuras de Valladolid: breve

- entrevista con fotografía. 1950.

Un momento, por favor: se dedica

preferentemente a artistas. 1950 .

¿Cómo vive usted?: gente de la

calle: un taxista, un carpintero,

un vendedor de cazuelas, etc.

Gentes de Valladolid: Idem, en 1954

Aunque usted 1 Noticias pintorescas.

no lo crea

Antología
Breves párrafos extraídos de
distintos autores, por su belleza
literaria "no presuponen el juicio 


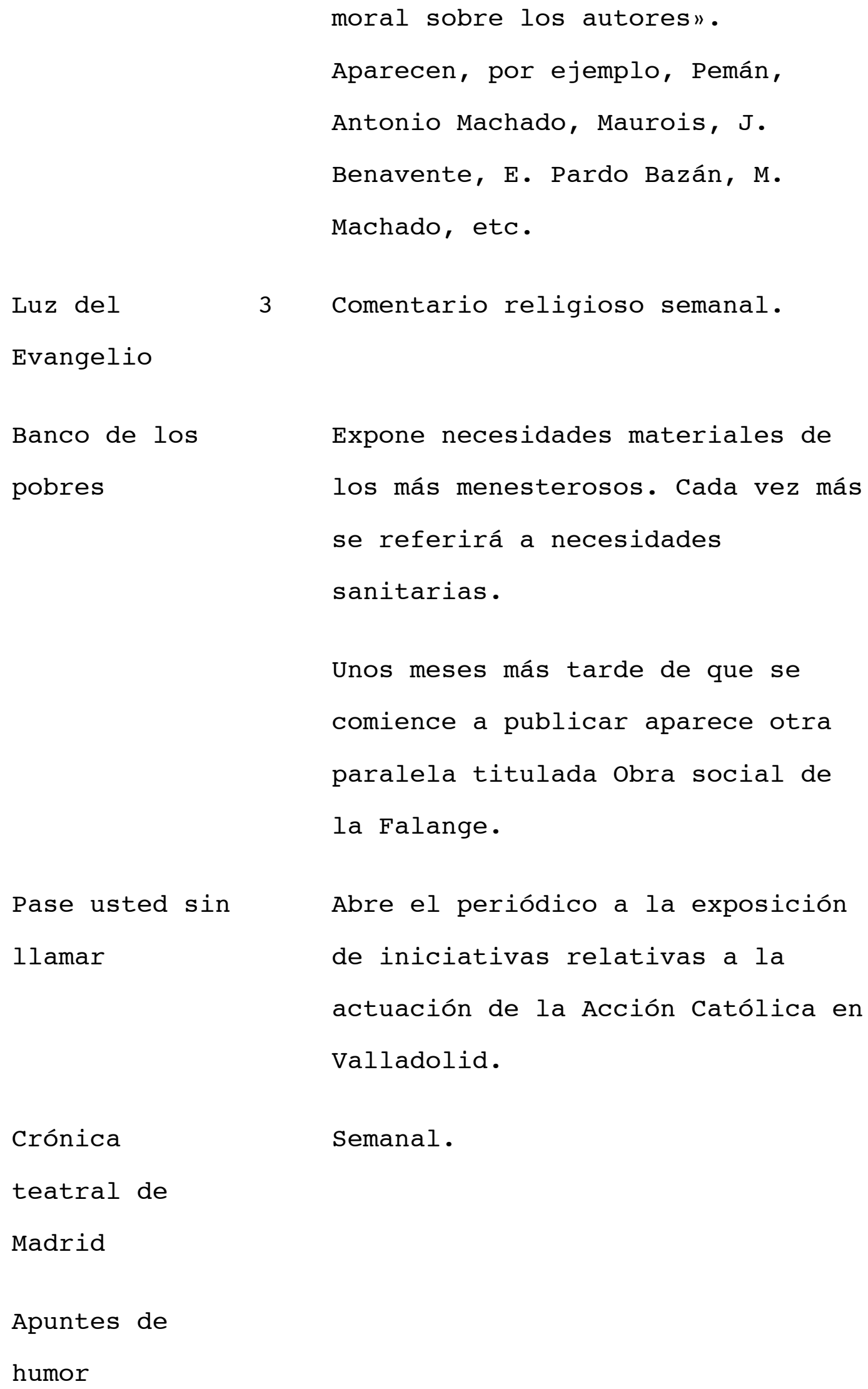


Prensa de

Madrid

Los lectores

opinan

Ventana al

mundo

Ecos urbanos

Semblanzas

Mirador
Resumen de prensa desde octubre de 1951.

3 Cartas de lectores, generalmente referidas a temas locales. Aparece solamente de marzo a julio de 1952 .

últ 1952

últ 1952.

Columna de Martín Abril en 1953.

últ 1953. 


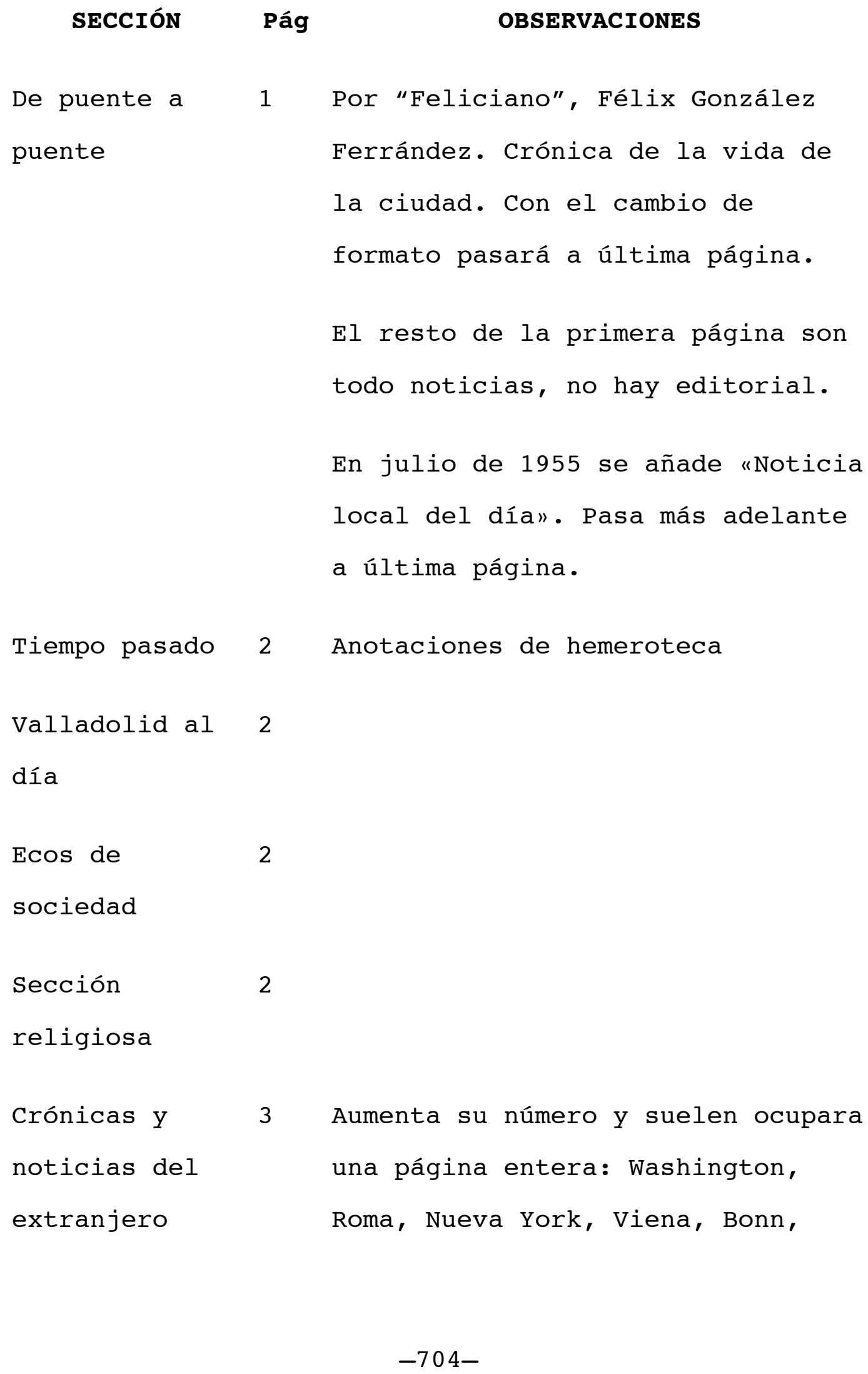


etc.

$\begin{array}{lc}\text { Carteleras } & 4 \\ \text { Programas de } & 4 \\ \text { radio } & \\ \text { Información } & 4 \\ \text { regional } & \\ \text { DR deportes } & 5 \\ \text { Reportajes, } & 6 \\ \text { crónicas, } & \text { últ } \\ \text { cartas al } & \cdot \\ \text { director } & \end{array}$

Valladolid

calle a calle

Hábleme usted

de su calle

Diario

Regional en el

campo

Modas

Crónica de
Fotografías, descripción de las calles y comentarios. Por Leandro Pérez

Entrevista por Félix González Ferrández .

Entrevistas y descripciones por Manuel Fernández Areal. Aumenta el espacio que se le dedica. Firma J.L.A.

Fernando Criado 
Madrid

Crónica de

Bilbao

Crónicas y

noticias del

extranjero por

nuestros

corresponsales

Aquí N

noticias de la

región

Divulgación

fiscal

Tierra de

todos

Información de

bolsa

Mercados

Castilla está

en el camino,

o Reportajes
Pedro Mendizábal.

Información regional puntualizada y resumida a noticias breves.

semanal

Entrevistas con personas que visitan Valladolid.

Información sobre mercados agrícolas en toda España, se incrementa en noviembre de 1955 . Descripciones sobre paisajes y gentes de Castilla, por Manuel Fernández Areal, desde el 
$17 / 11 / 1955$.

Cine "Viernes. Aquí nuestra

página

cinematográfic

a

Para ti,

lectora, esta

página

Estos son los

barrios de

Valladolid

Así es nuestra

provincia.

Datos para una

guía de

Valladolid

Folletón

Día tras día
"Hoy brilla esta estrella" por G. Ferrández, Esteban Farré, y «Punto de vista femenino. La película de la semana" por Rita Recio.

Se publica los domingos. Contiene "Tema de hoy", "Cocina", "Modas". La hacen Rita Recio y Mercedes de la Viña Zuloaga.

Reportajes dominicales. Febrero de 1956 .

Reportajes en abril de 1956.
El cañón, de C. S. Forrester, novela que se está llevando al cine en Ávila con el título "Orgullo y pasión" Columna de Francisco Javier Martín Abril. 


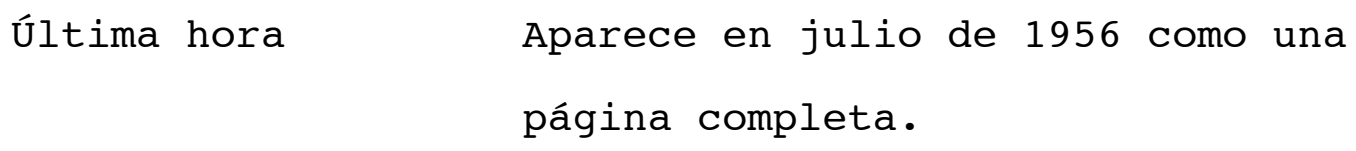

Con Jesús Mạ ZuLOAgA en 1956

\author{
SECCIÓN \\ «España» \\ «Valladolid al \\ día» \\ "Extranjero" \\ "Información y \\ comentarios. \\ Finanzas", \\ «Crónicas y \\ reportajes" \\ "Deportes"
}

Pág

OBSERVACIONES 


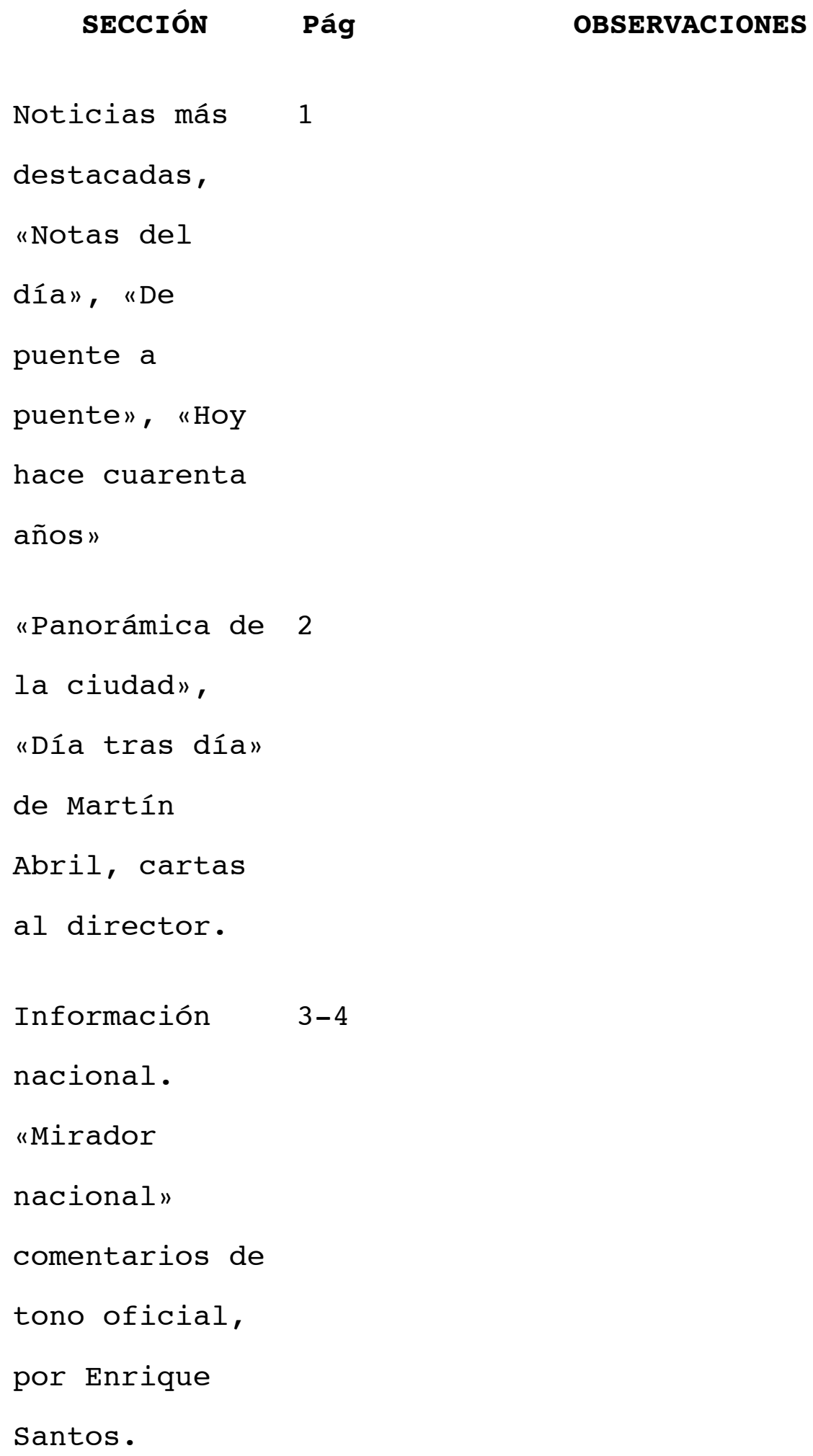




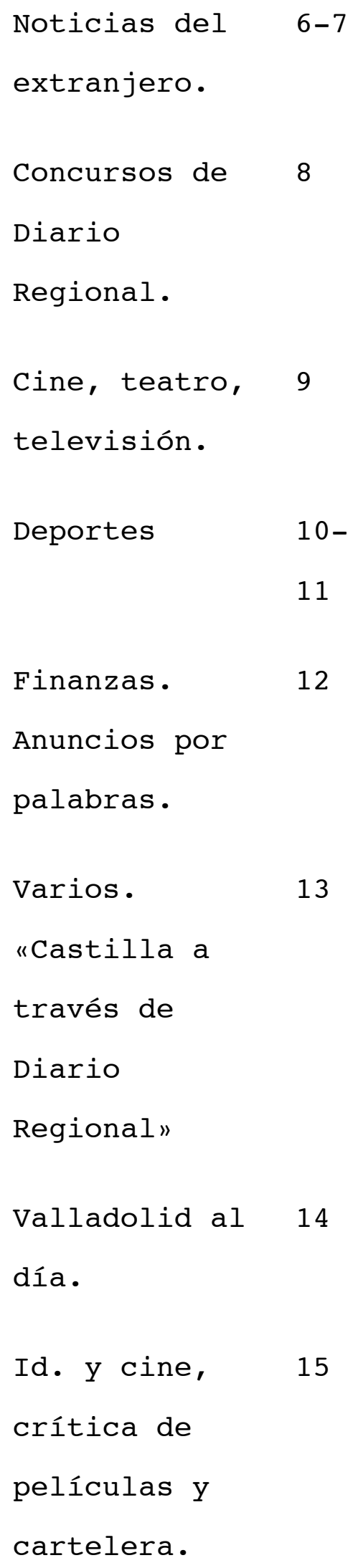


Varios,

frecuentemente

reportajes.

Para ti,

lectora, esta

página

Diario

Regional en el

campo

Aquí nuestra

página

cinematográfic

a

Pantalla

cultural
16

domingos

domingos

domingos

3 En 1959 se consolida como página de opinión en el periódico 
Con Manuel fernández Areal (1959)

$\begin{array}{cc}\text { SECCIón } & \text { Pág } \\ 1 & \text { Fotografías, amplios titulares, } \\ & \text { dos columnas de texto para otra } \\ & \text { noticia y un breve sumario. }\end{array}$

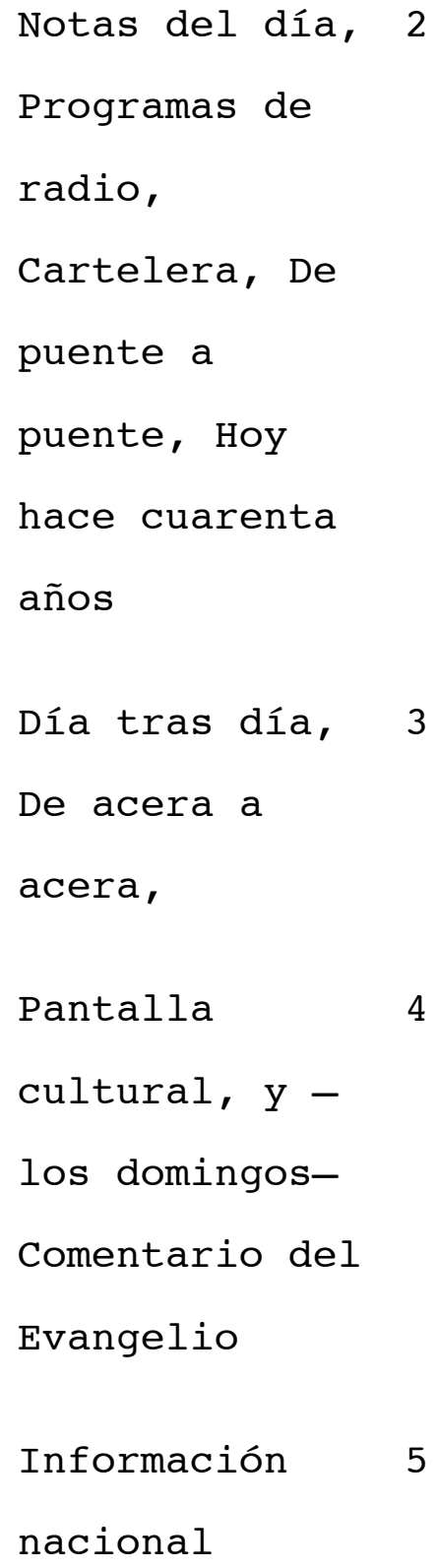




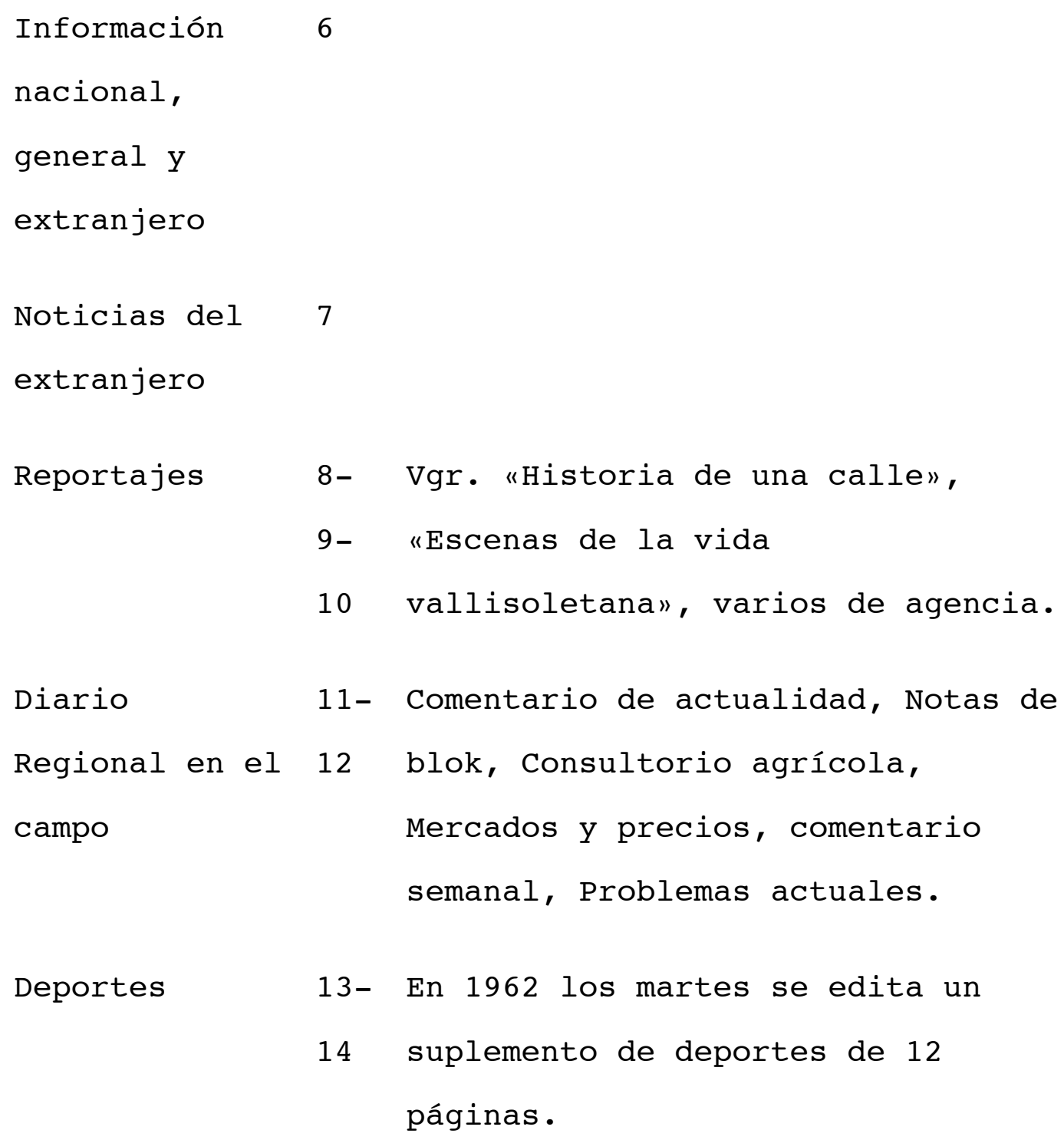

Valladolid al 18 Universidad, Ayuntamiento, 
día

Varios

Reportaje

Pantalla

cultural

Cine, teatro,

televisión

Castilla a

través de

Diario

Regional

Para ti,

lectora, esta

página

Concursos

Página militar

Tráfico 


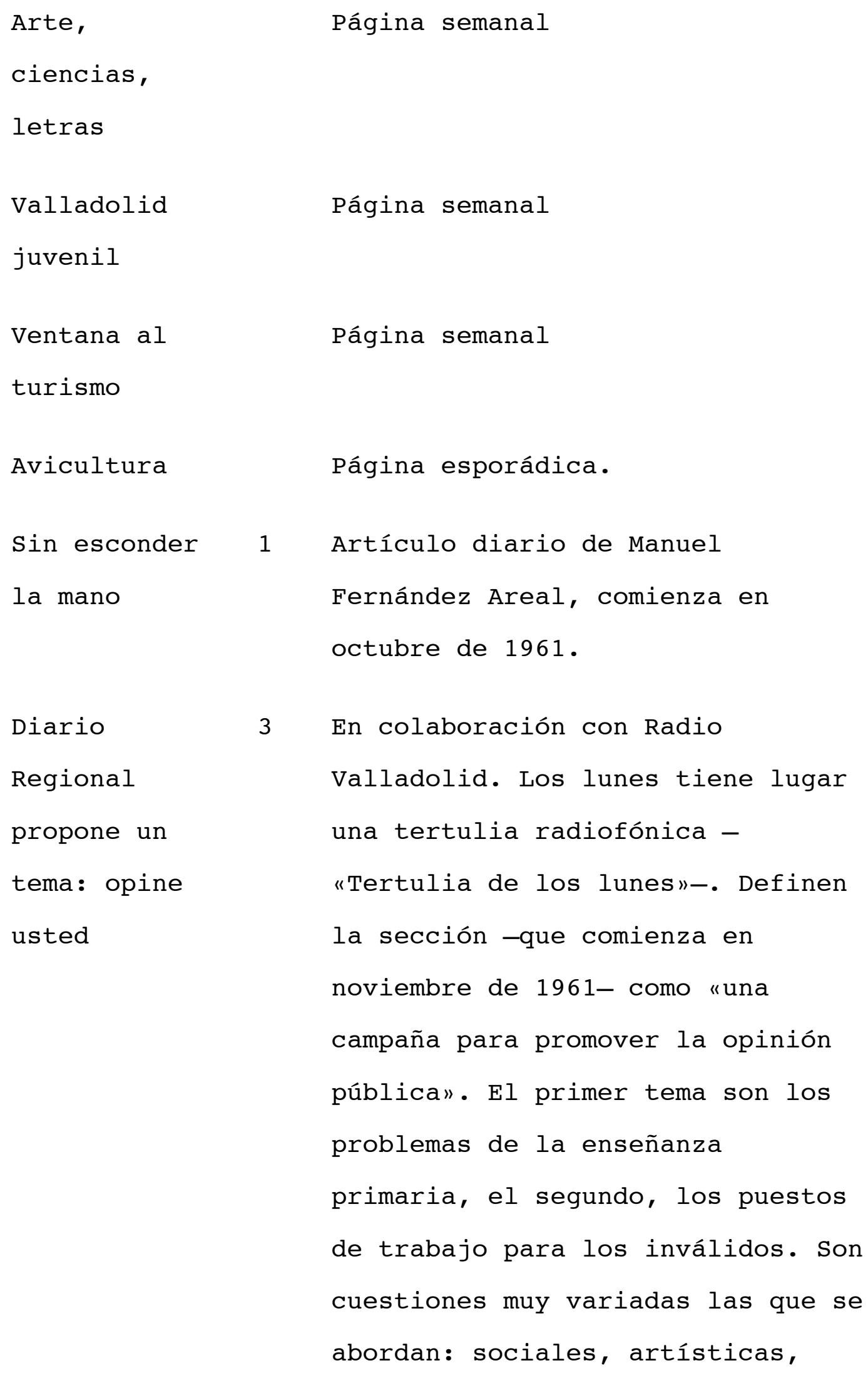


Apéndices

deportivas, locales, etc.: parques

de la ciudad, aniversario de

Berruguete, Bachillerato de

ciencias o letras, etc. Finaliza

en el verano de 1962 .

Finanzas,

Se potencia en marzo de 1963.

economía 
Con José Tallón García ( 1965 )

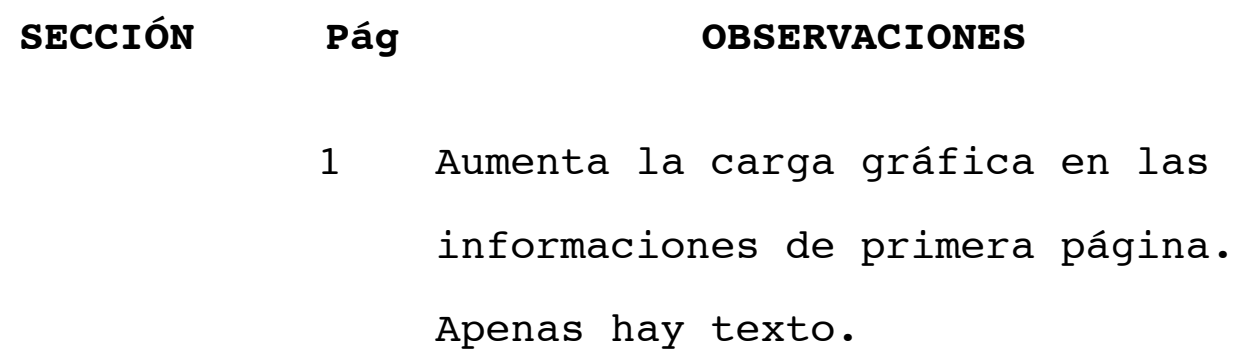

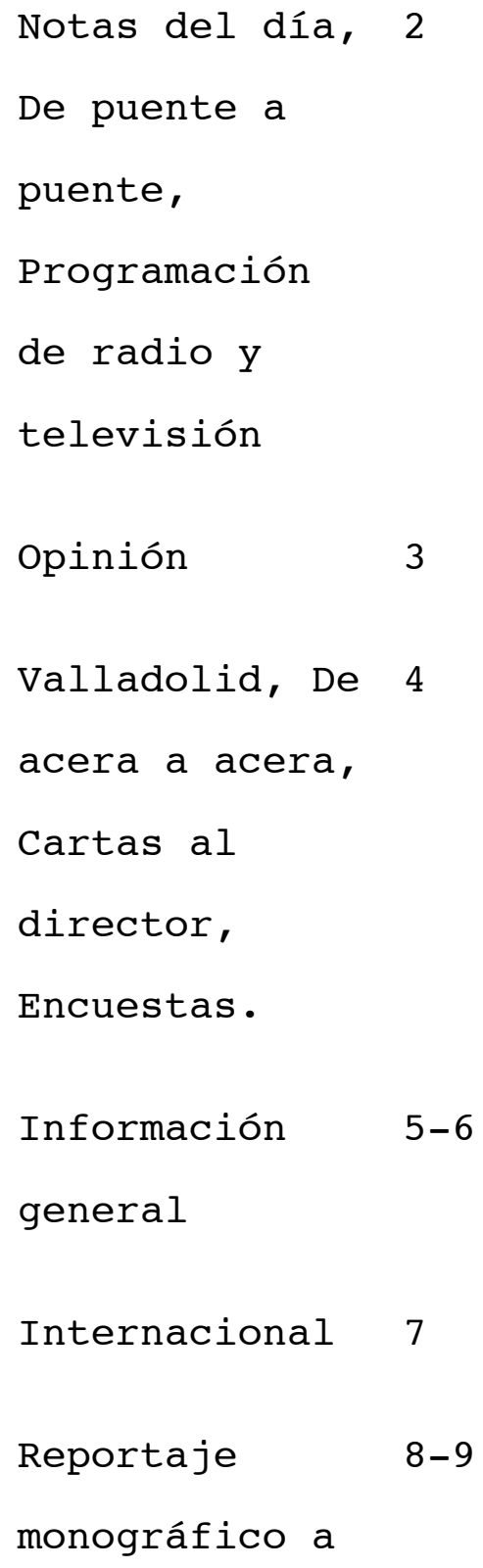


doble página

Cartelera

Agenda .

Esquelas,

ciudad.

Bolsa.

Deportes

Deportes .

Sucesos.

Anuncios

clasificados

Sección

religiosa

(cultos),

viñetas,

pasatiempos,

Hace cuarenta

años.

Última hora y 16

varios

Página

Semanal, o incluso más frecuente.

universitaria

Estar al día

Sección de comentarios religiosos, 
frecuentemente doctrinales que hacen varios sacerdotes: José Ramírez, Martín Gil, José Antonio Burriel, José María Collantes, Felipe Gago, Carlos Martín Manjarrés, Felipe Gago, José Ramírez, Epímaco Cuadrado, y otros. Comienza en enero de 1966 .

Tertulia

literaria

Libros

Cuento

Publican generalmente algunos de los que han concursado en el certamen que organiza el periódico.

Cine

Chismorama

Sale los domingos: información casi solamente gráfica.

$\mathrm{DR}$ Varias veces por semana.

agricultura,

ganadería, avicultura.

Cotilleo, A la

Comentarios

hora del café 
Club juvenil

Nuestro Hi-fi Discos y música ligera.

Mujer 66

Página femenina semanal.

Gente menuda

Página infantil semanal.

Programas de

Semanal.

TV

Crónica

Normalmente sale solamente los

regional

martes, a no ser que haya algo

destacado otros días de la semana.

Academia de

Página de opinión dirigida por

papel

Alfonso Candau, catedrático de

Universidad. suelen escribir él y

otros profesores universitarios.

Agenda

Suplemento semanal. Sale los

femenina

domingos .

Callejeando

Sección sobre cuestiones de urbanismo. Aparece en octubre de 1966.

Campo 67

Sección agrícola. Es casi diaria. 


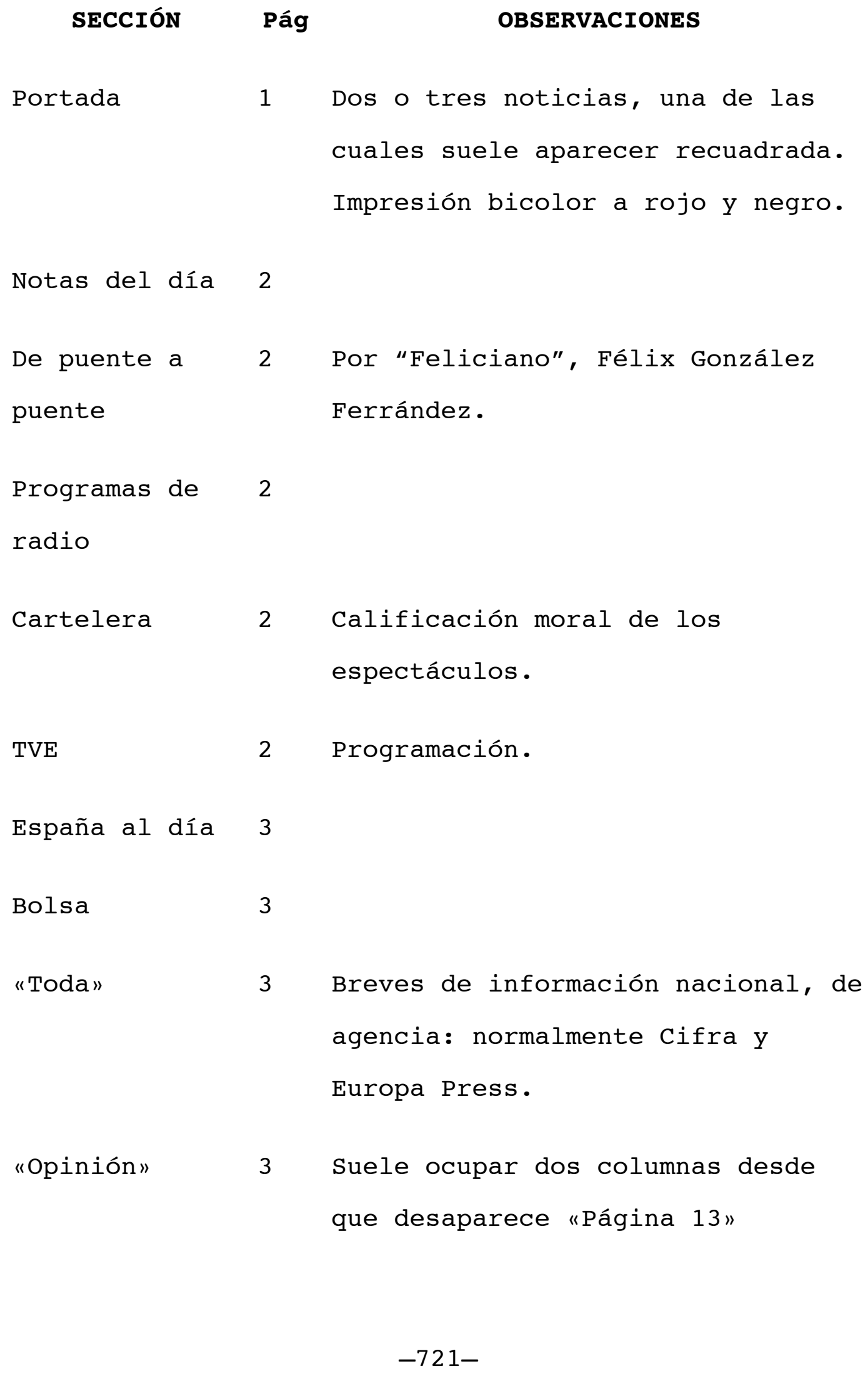




$\begin{array}{ll}\text { "Puerta de } & \text { Información desde Madrid. } \\ \text { Alcalá» } & \text { Inicialmente firma “De la Cruz, y } \\ & \text { luego lo harán otros } \\ & \text { corresponsales. }\end{array}$

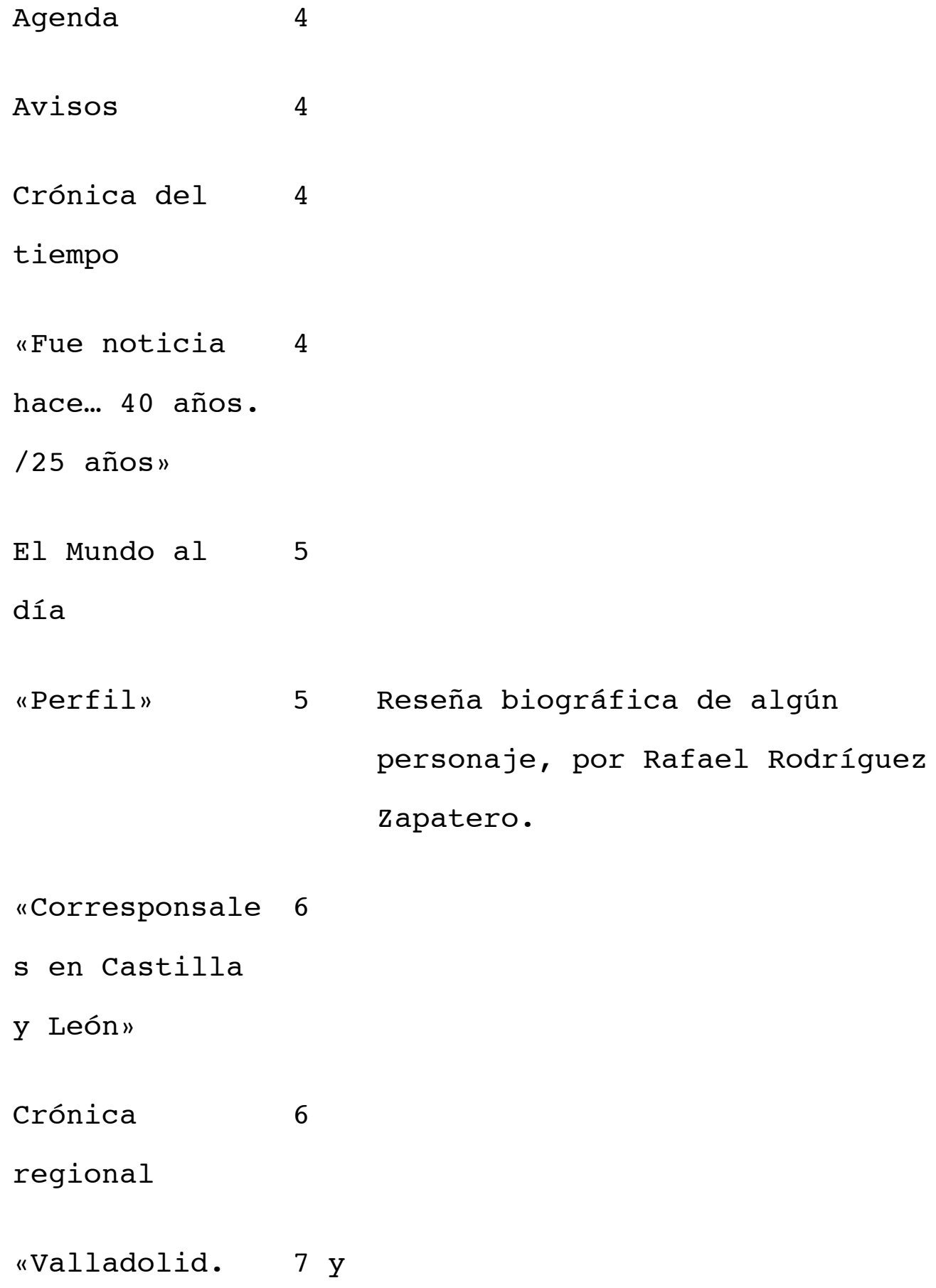


Lo que pasa» 8

"Las aceras" 9 Suelen firmar José Antonio Antón y Ma Aurora Viloria. Abundante información gráfica.

«Antena

10

deportiva»

«Todos los

deportes"

«Crítica de

12 Por "G. Ferrández".

cine"

Cartelera

12

"Página 13"

13 Esta cabecera de la sección de opinión aparecerá de forma irregular. La sección suele incluir una fotografía con un pie editorializante que firma normalmente Ma Aurora Viloria, y el artículo diario de Francisco Javier Martín Abril "Día tras día».

Anuncios por 1 palabras 4 
Apéndices

5

Sección

15

religiosa

(cultos)

Pasatiempos 15

Varios 1

6

ú

1

t

"Última hora» 1

6

ú

1

t 


\section{SECCIÓN}

"Campo 67"

"Arte"

"Gran

pantalla»

"Estar al día"

«Ventana al

mundo"

«Panorama

internacional»

\section{Pág OBSERVACIONES}

Firman Federico Sáez Vera, J. Antonio Crespo, y Frantaco

Dirigida por Mercedes de la Viña Zuloaga. Colaboran Mạ Teresa Ortega Coca, Juan José Martín González, Miguel Frechilla del Rey y Luis Carrera Molina.

Cine.

Religión. Dirige José Antonio Burriel, colaboran: Epímaco Cuadrado, Felipe Gago, Jerónimo Martín Valencia, etc..

Por José Díaz de Villegas (militar, con graduación de general, fallece en 1968).

Suele hacerlo desde 1968 Rafael Rodríguez Zapatero. 
«Cada semana

un nombre»

«Extra

Se publica los martes.

deportes"

«Motor y

Firmado por Frantaco.

tráfico»

«Palacio de

Por Jesús Lago.

justicia»

"Club juvenil"

Entre otras subsecciones incluye

"Teatro y juventud", por Leandro Pérez; "Aquí se habla de...", por

Germán Losada; "Rincón de los

lectores"; y "Hit", dedicada a los discos.

«Nosotras y

todas"

"Agenda

Suplementos dominicales.

femenina" $y$

"Chío»

"Análisis

Por Luis Ignacio Parada.

económico 
semanal»

«La semana

Por Pedro Calvo Hernando.

política de

España»

«Señor

Por Frantaco.

alcalde»

"Cuestión

Firma cualquiera de los redactores

urgente»

del diario.

"Siglo XX Y

Dos columnas dedicadas a un

cristianismo"

comentario doctrinal: reproducen

artículos de otras publicaciones,

glosan palabras del Papa o de un

obispo, etc.

"Tres en uno»

Suplemento dominical desde enero de 1970 .

«Madrid

Crónica desde Madrid, por Claudio

capital del Aguirre desde abril de 1971.

reino"

"Crónica

Por Rafael Rodríguez Zapatero,

política»

desde la misma fecha. 


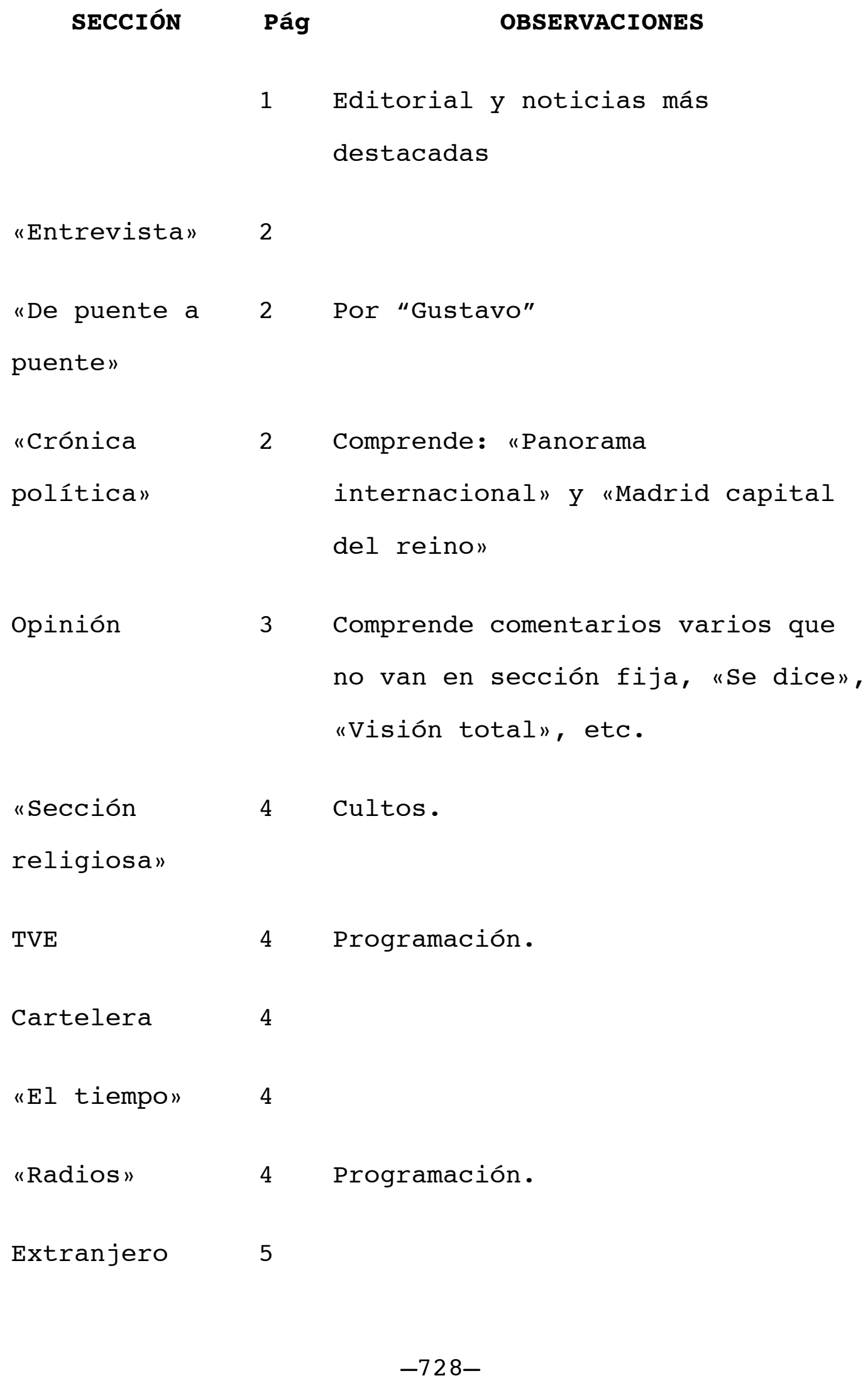


España

Opinión local
6

7 "Valladolid: lo que pasa", "El rastro" por Santiago José Sáiz, "Brumario" por Fernando Barrasa, "Cicero hit" por "Norberto Jr."

«De acera a 8

acera»

Información

9

nacional y

crítica de

televisión

Cartelera y

10

anuncios por

palabras

"Caridad",

"Agenda" ,

"Avisos"

Deportes 1

2

1

3

Varios

14 


$\begin{array}{ll}\text { Sucesos } & 15 \\ \text { Varios } & 1 \\ 6 \\ \text { ' } \\ 1 \\ \text { t } \\ \end{array}$

Con Esteban Greciet Aller (1972)

\begin{tabular}{|c|c|c|}
\hline SECCIÓN & Pág & OBSERVACIONES \\
\hline "El día" & 1 & $\begin{array}{l}\text { Resumen en } 150 \text { palabras de los } \\
\text { temas centrales de la actualidad, } \\
\text { local, nacional e internacional. }\end{array}$ \\
\hline & 2 & $\begin{array}{l}\text { Comentario editorial o firmado por } \\
\text { Esteban Greciet -en ese caso se } \\
\text { titula "Desde aquí"-. }\end{array}$ \\
\hline $\begin{array}{l}\text { "Fin de } \\
\text { semana" }\end{array}$ & & $\begin{array}{l}\text { Nuevo suplemento que ocupa las } \\
\text { páginas finales de los sábados. }\end{array}$ \\
\hline "Deportivo" & & Suplemento de los martes. \\
\hline "Coloquio" & 8 & Sección que trata de crear \\
\hline
\end{tabular}


- polémica. Ocupa las dos páginas

9 centrales del periódico.

"Paraninfo"

Temas universitarios.

1 Maquetación confusa. Suelen

publicarse tres o cuatro

fotografías y un sumario del

contenido del diario. Hay

subrayados en color, recuadros,

impresiones en negativo sobre

tramas de diferente diseño, etc.

Cartelera

2

"Valladolid» 3

"Agenda",

4

"Avisos",

"Bolsa",

"Cartelera"

(calificación

moral)

"Valladolid" 5 Incluye cartas al director.

"Valladolid» 6

TV, Radio,

6

anuncios por

palabras 


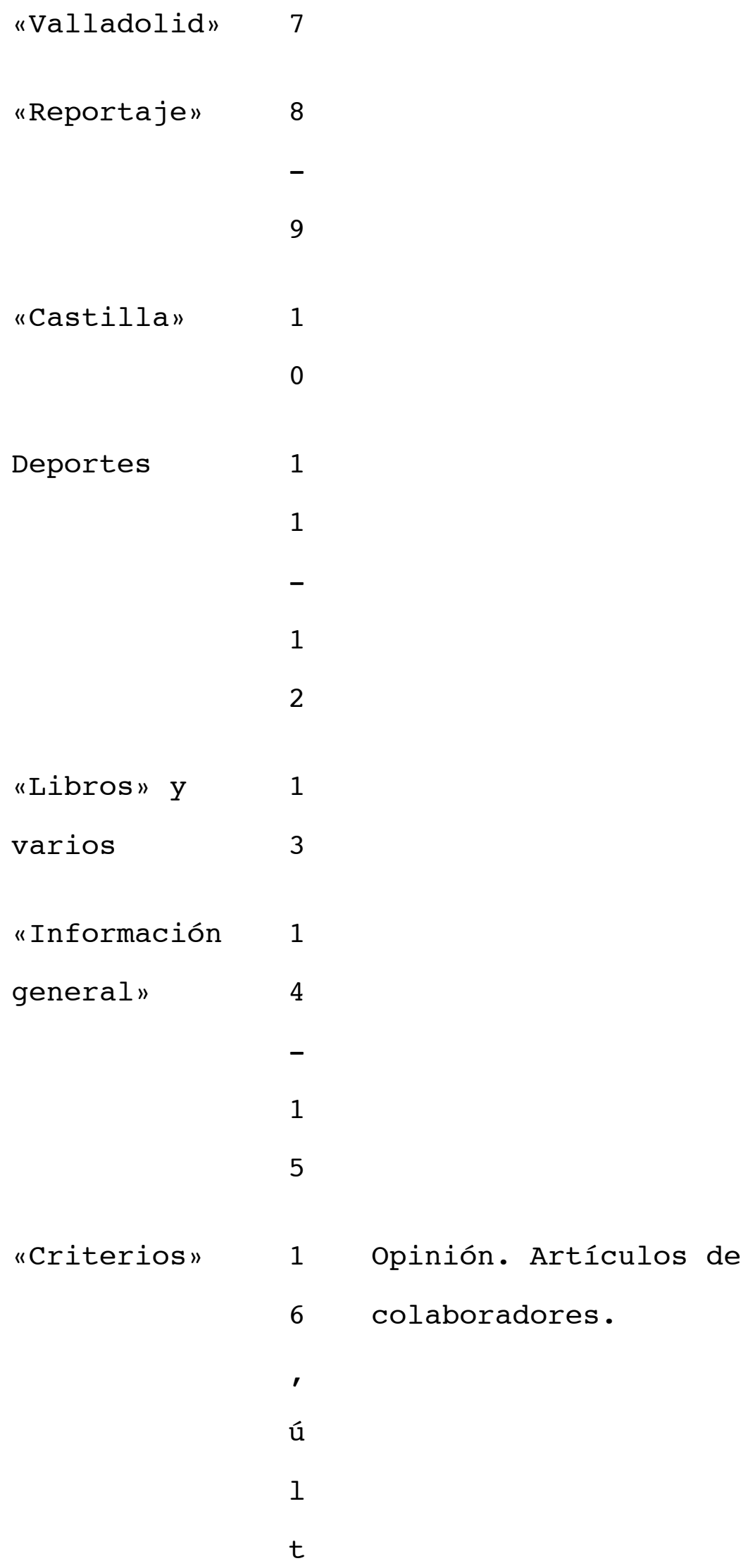




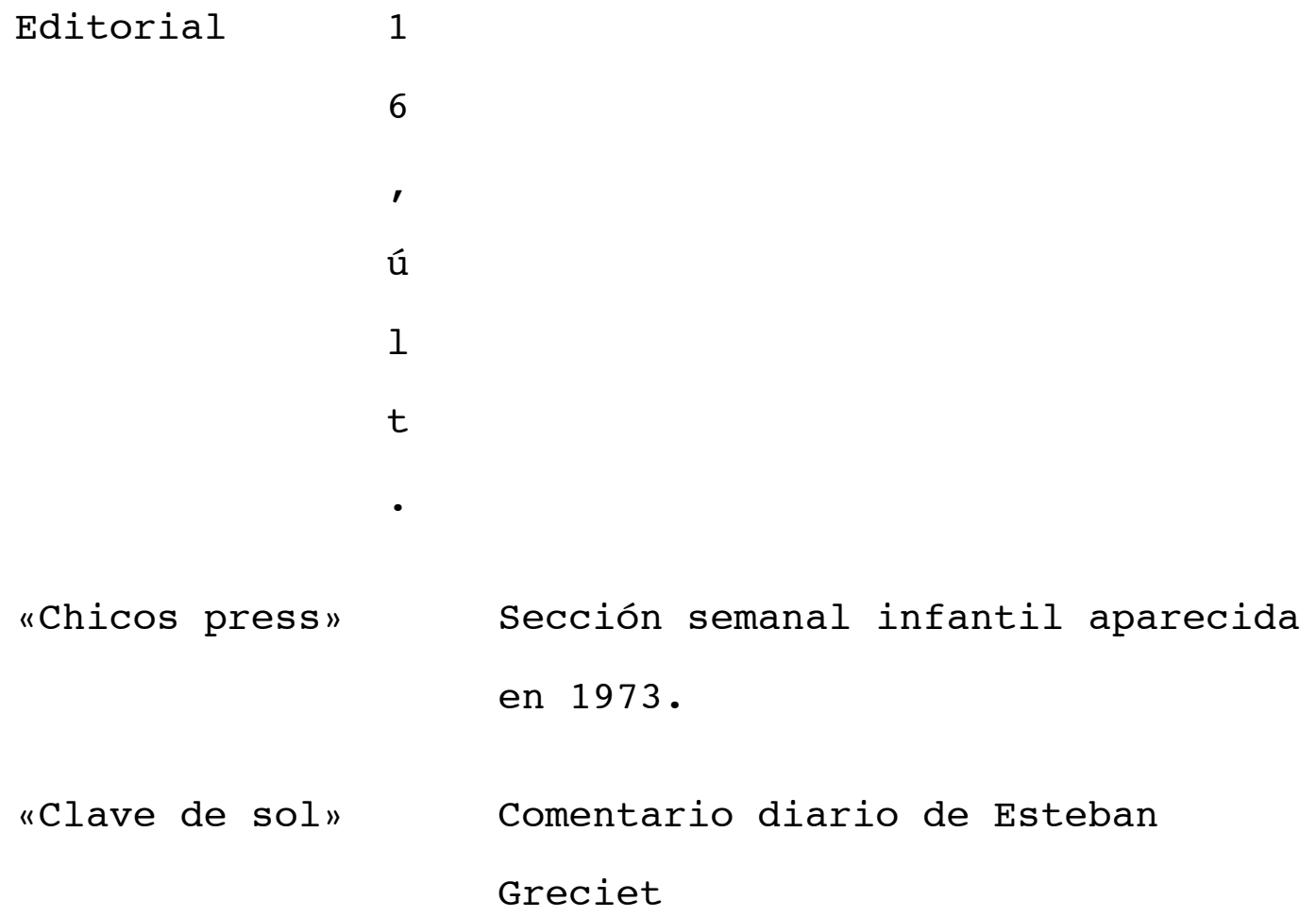




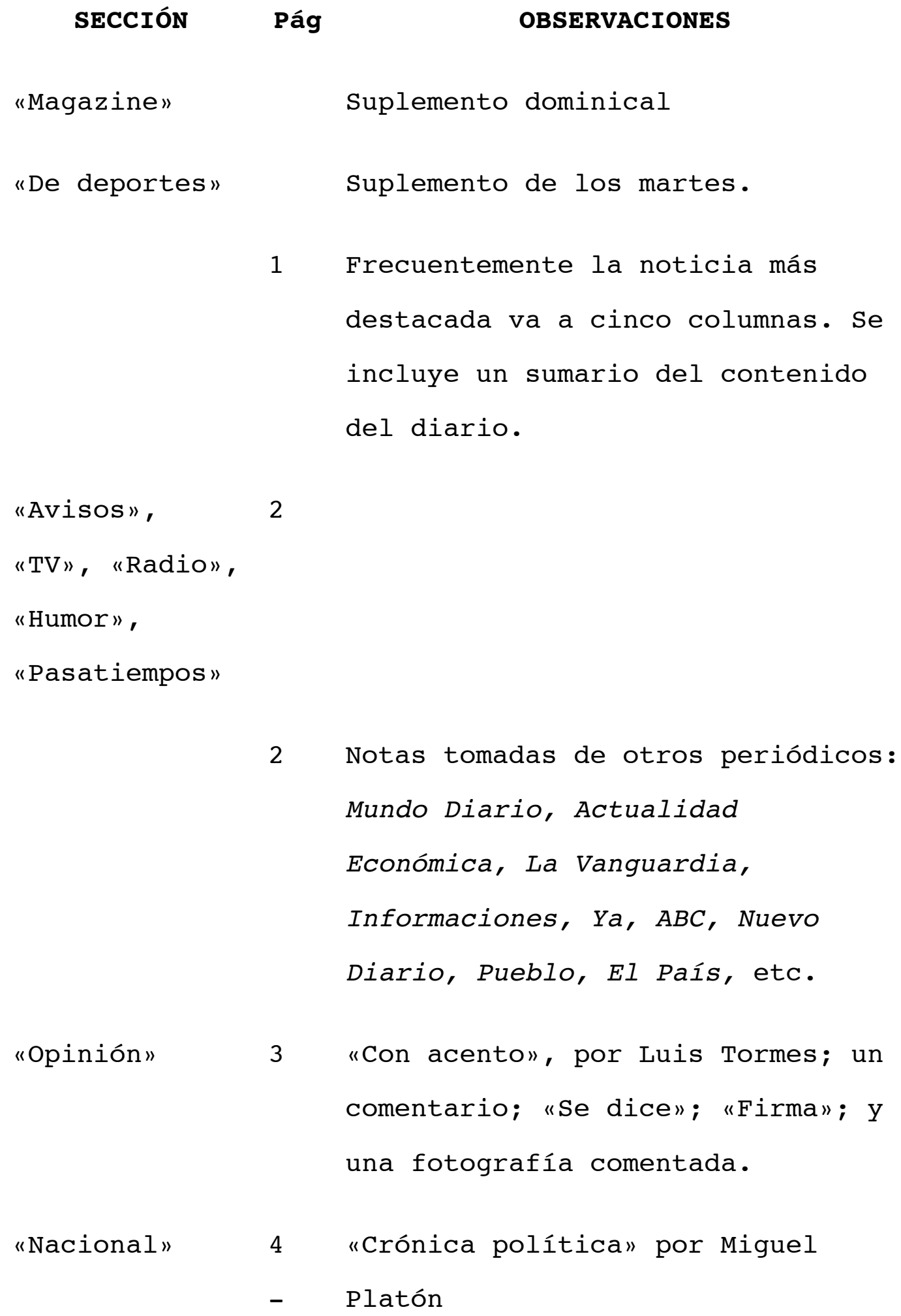

2 Notas tomadas de otros periódicos: Mundo Diario, Actualidad Económica, La Vanguardia, Informaciones, $Y a, A B C$, Nuevo Diario, Pueblo, El País, etc.

"Opinión"

3 "Con acento", por Luis Tormes; un comentario; "Se dice"; "Firma"; y una fotografía comentada.

"Nacional»

4 "Crónica política" por Miguel

- Platón 


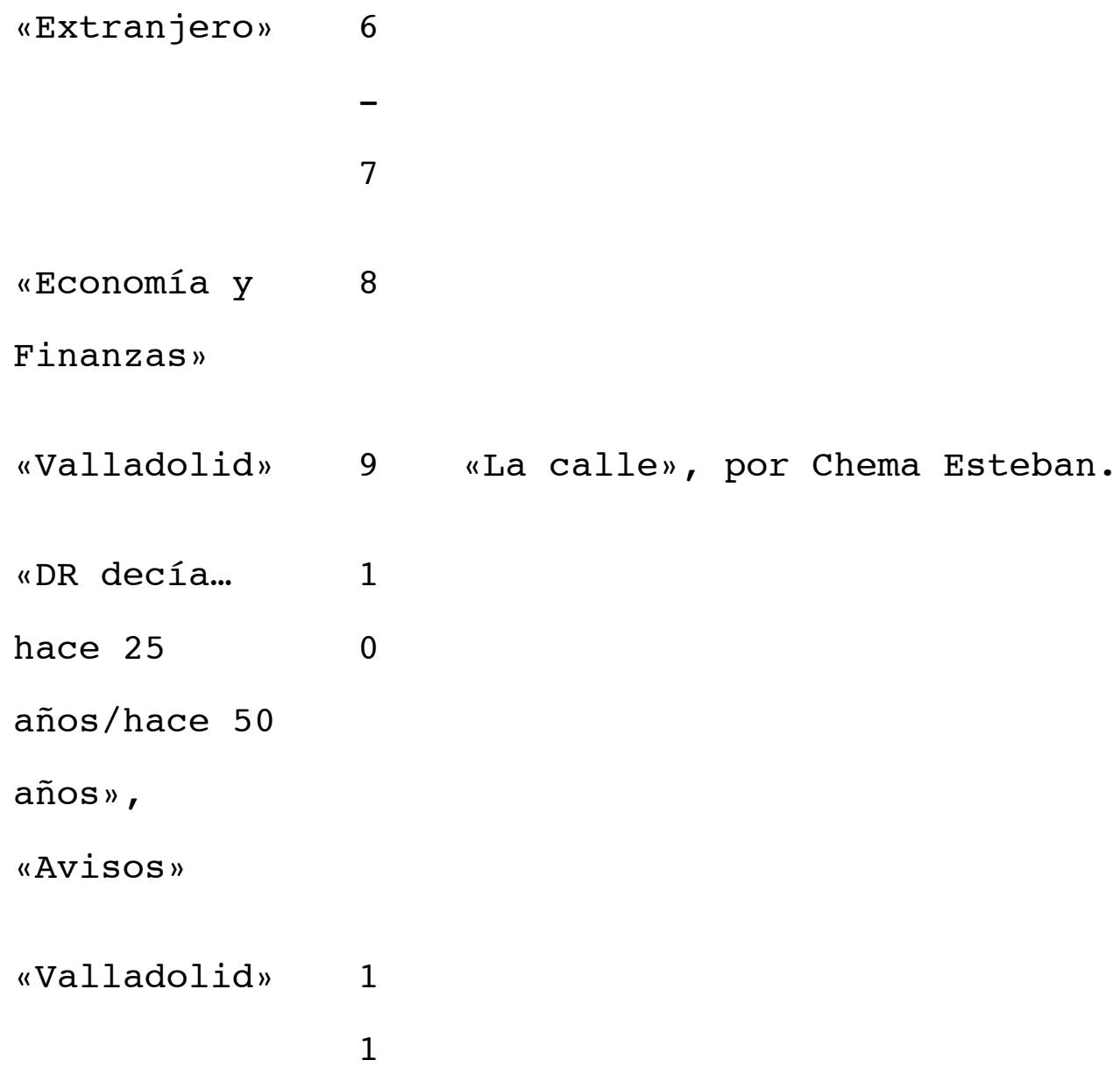


Apéndices

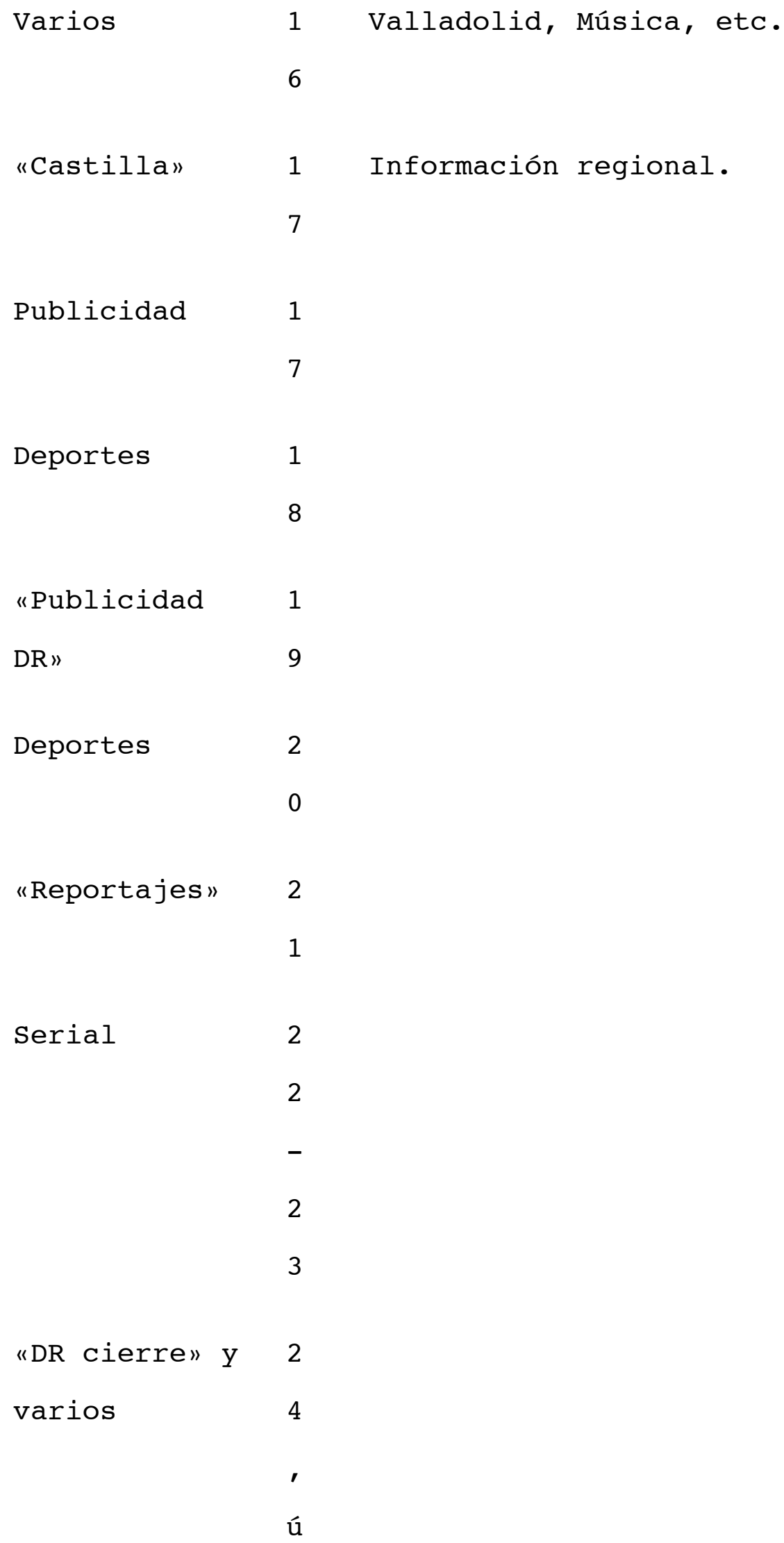


"Análisis

político

semanal"

"Artes y

Letras"

"Universidad»

"Campo»

"Juglar"
Por Ramón Pi.

Suplemento desde octubre de 1975 .

Suplemento semanal desde octubre de 1976.

Suplemento semanal.

Suplemento infantil semanal. 
Con Pedro Muñoz García ( 1977 )

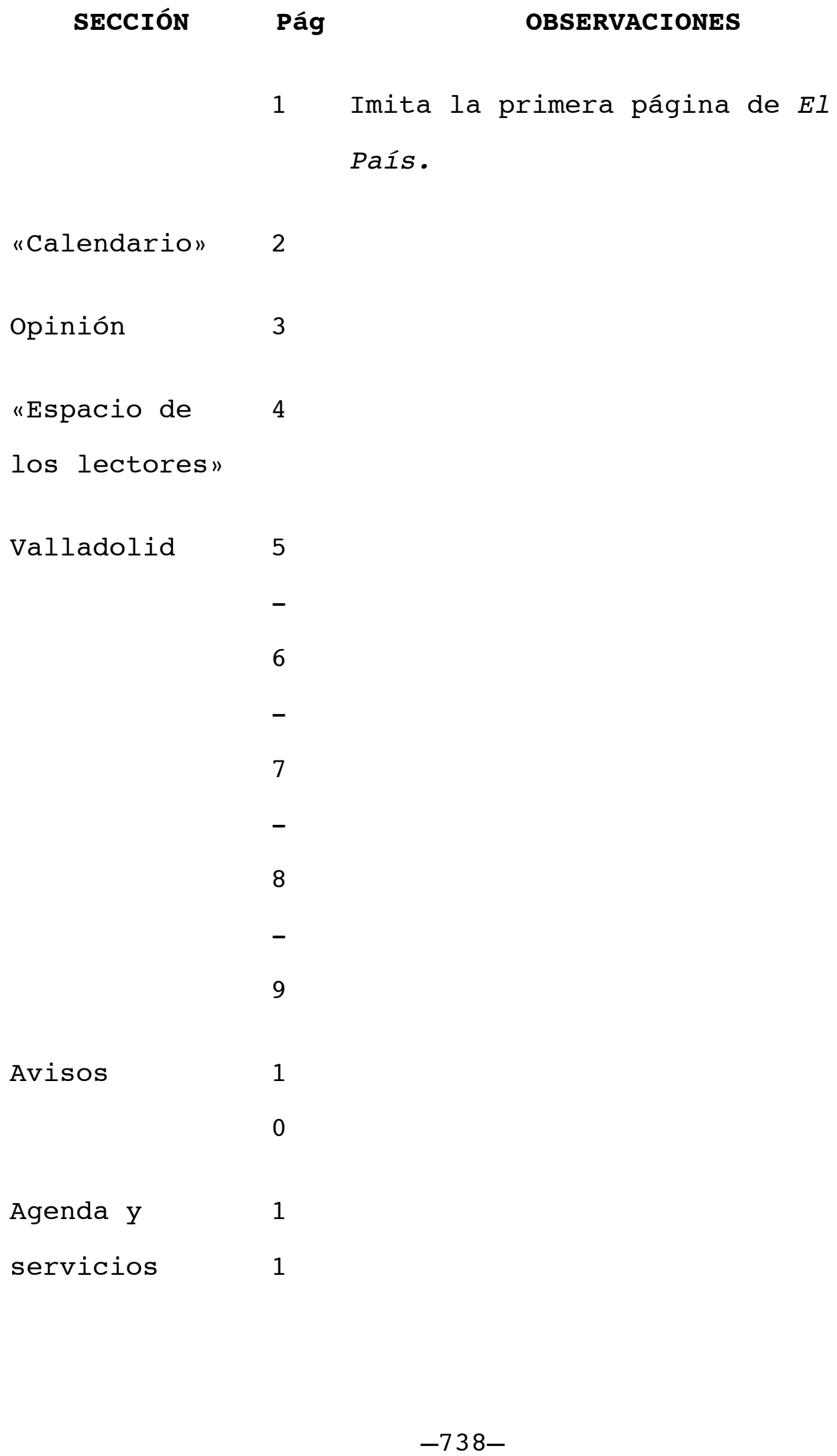

Avisos 1

0

Agenda y $\quad 1$

servicios $\quad 1$ 


$\begin{array}{ll}\text { "El campo" } & 1 \\ & 2 \\ & \\ & \\ \text { deastilla a } & 1 \\ \text { "Información } & 1 \\ \text { regional" } & 4 \\ & - \\ & 1\end{array}$

1

2

1

3

1

5

"Información 1

nacional: 6

general"

"Información 1

nacional" 7

1

8

1

9

"Información 1

nacional: 9

economía»

«Economía y 2 


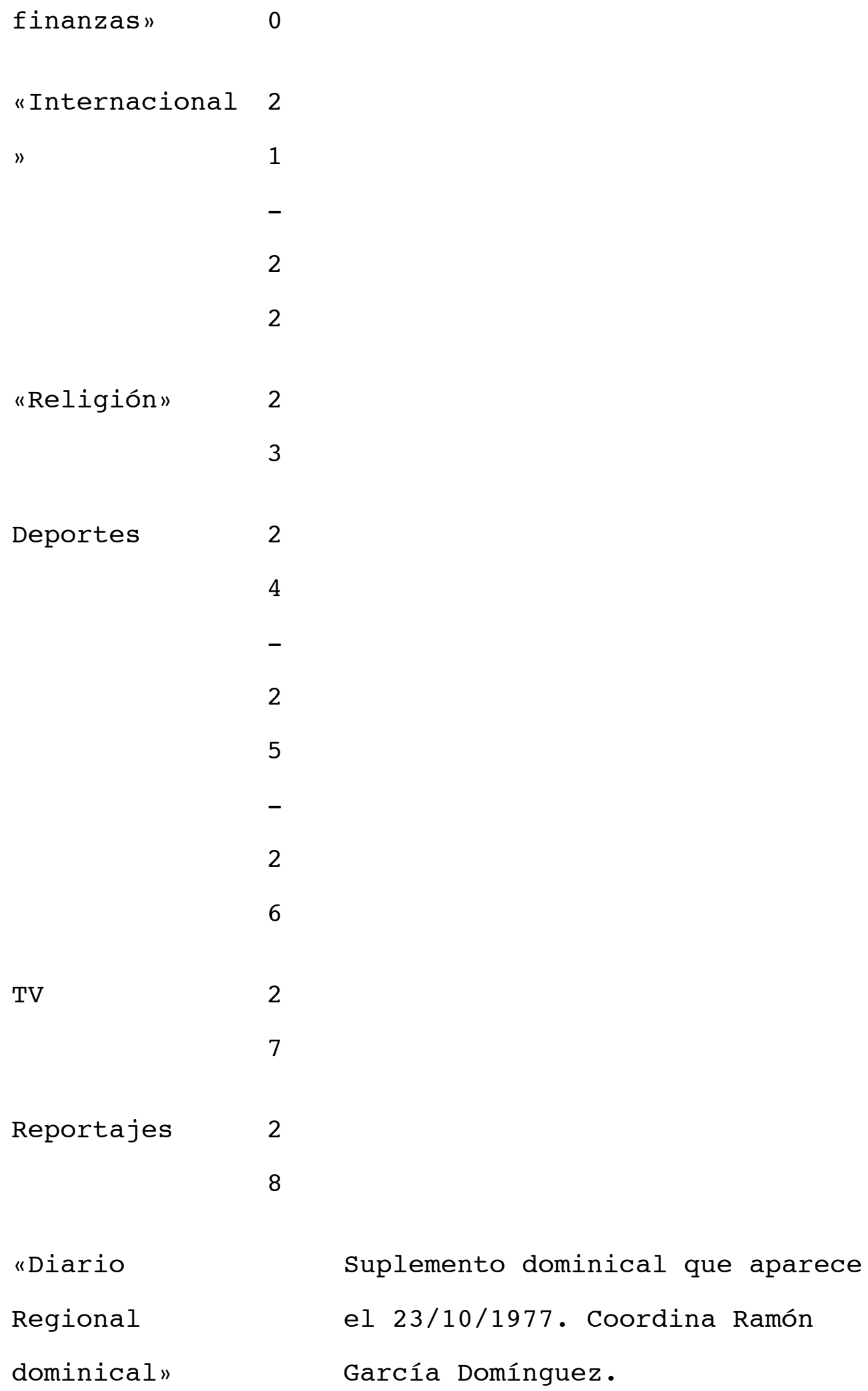




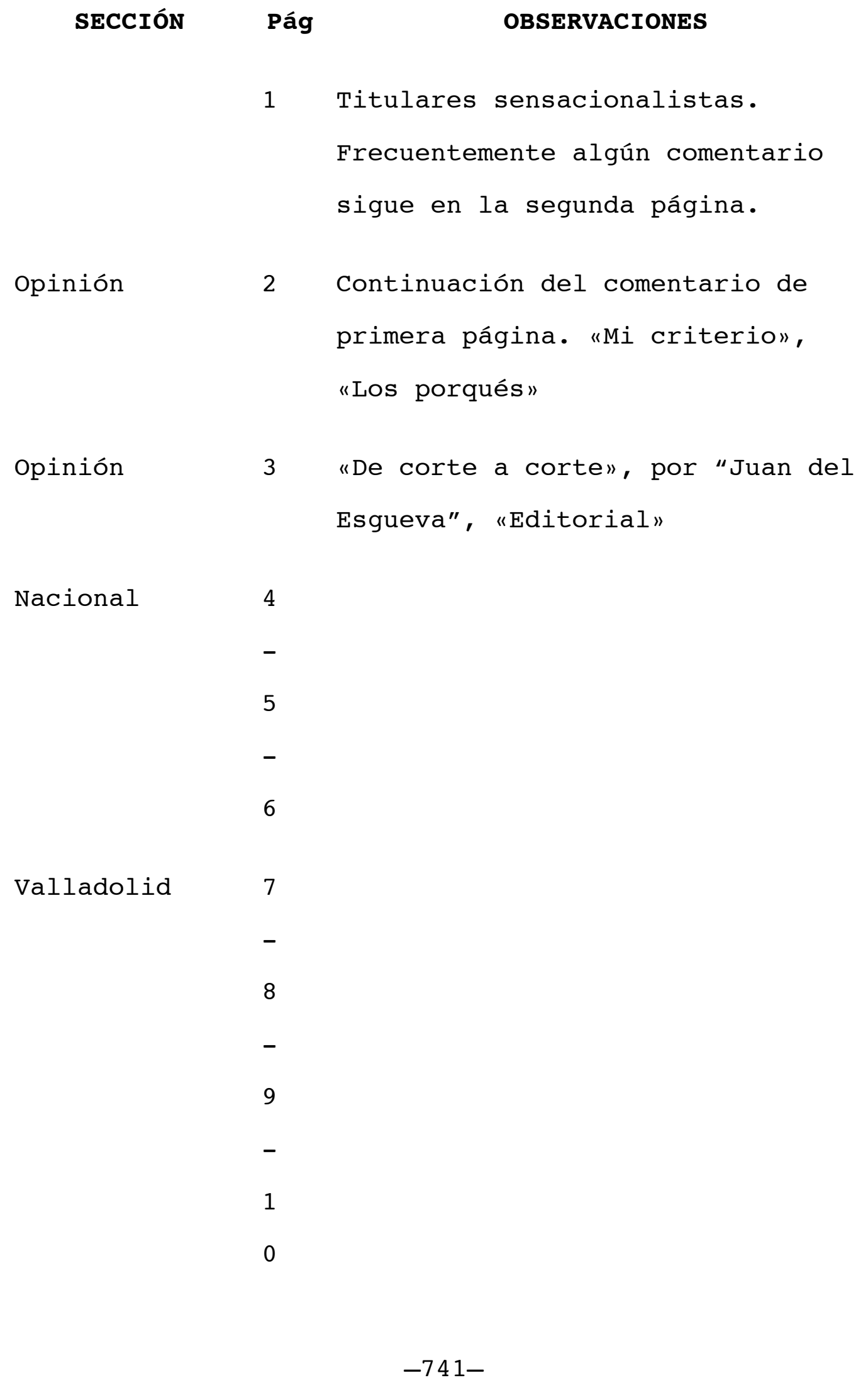




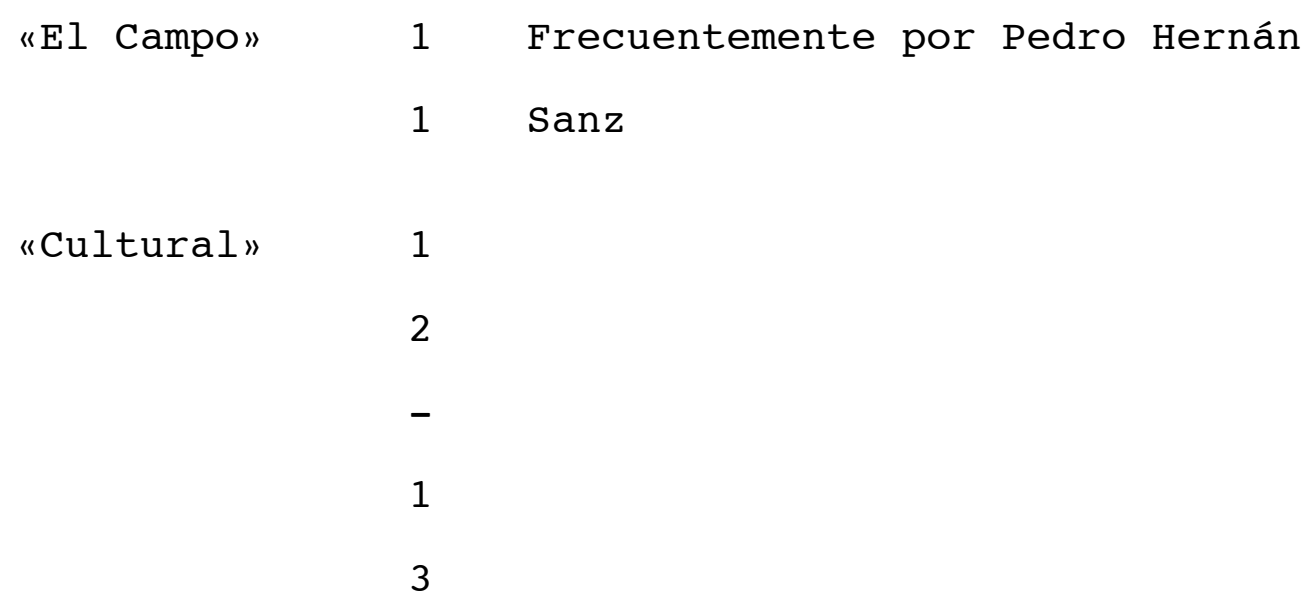


Apéndices

2

1

2
Deportes
2
2
2
3
-
2
4
-
2
5
*

Espectáculos 2

6

2

7

*

Agenda

2

8

2

9

$-743-$ 


$\begin{array}{lll} & * \\ \text { Pasatiempos, } & 3 & \\ \text { comentarios } & 0 & \\ \text { breves y humor } & * & \\ \text { Anuncios por } & 3 & \\ \text { palabras } & 1 & \\ & * & \\ \text { Reportajes } & 3 & \text { febrero de } 1980-\text { salió con } \\ & 2 & \text { solamente } 24 \text { páginas. } \\ \text { "Dominical" } & & \text { Vuelve a salir en marzo de } 1979 .\end{array}$

APÉNDICE 3.- FICHA ANALÍticA. LA EMPRESA PERIOdística "DiaRIo REgional, S.A."

Aspectos jurídicos

FUNDADORES 


$\begin{array}{ll}\text { Constantino Mateo González } & \text { propietario } \\ \text { José Jalón Semprún } & \text { abogado } \\ \text { Gregorio Merino Pinedo } & \text { propietario } \\ \text { Pascual Pinilla Jiménez } & \text { ingeniero } \\ \text { Joaquín Pérez Agote } & \text { abogado } \\ \text { Angel María Llamas Zapatero } & \text { ingeniero } \\ \text { Rafael Serrano y Serrano } & \text { notario } \\ \text { Antonio Miguel Romón } & \text { médico } \\ \text { Muntoniormo Gil de Reboleño } & \text { abogado del Cuerpo } \\ & \text { Jurídico Militar } \\ & \end{array}$

Romualdo Galindo Zorita

Estatutos Fundacionales DE «Diario Regional, S.A.» 
TITULO I.- Nombre, objeto y duración de la sociedad.

Artículo 1.- Se constituye una Sociedad Anónima que se denominará "Diario Regional" la cual se regirá por estos Estatutos, por las disposiciones de orden interior que se dicten $y$ por las leyes mercantiles.

Artículo 2.- Esta sociedad tendrá su domicilio en Valladolid.

Artículo 3.- Constituye el objeto de la Sociedad publicar por su cuenta y explotar el periódico Diario Regional y cualquiera otro que conviniera así como cualquier otro negocio o empresa relacionada con el arte de imprimir.

Artículo 4.-El criterio doctrinal de Diario Regional y de las demás publicaciones que la sociedad emprendiere, será de completa independencia, pero informada siempre en las normas y enseñanzas de la Iglesia Católica, declaradas por las Autoridades Legítimas a las que la sociedad se somete y somete también a la dependencia profesional del periódico. 
Un consejo de redacción será el encargado de mantener siempre este espíritu en las publicaciones de la Sociedad.

Artículo 5.- La duración de la Sociedad será indefinida.

TITULO II.- Capital social.

Artículo 6.- El capital será de Quinientas mil pesetas representado por dos series de acciones, una serie A de Cien pesetas cada una y otra serie B de Quinientas cada una. Habrá mil de la serie A y ochocientas de la B.

Al constituirse la Sociedad se pondrán en circulación solamente quinientas de la serie A y cuatrocientas de la B dejando el resto en cartera, y se pondrán en circulación cuando lo acuerde el Consejo de Administración.

Artículo 7.- La Sociedad podrá aumentar su capital por la emisión de más acciones o tomando cantidades a préstamo mediante la de obligaciones.- Las condiciones jurídicas y económicas de estas obligaciones, las fijará la Junta General de Accionistas a propuesta del Consejo de Administración.

Cumpliendo los mismos requisitos podrá también reducirse el capital. 
Artículo 8.- Los accionistas serán al portador e indivisibles a los efectos sociales, no reconociéndose más que un propietario por cada acción.- Estarán numeradas correlativamente dentro de cada serie y firmadas por el Presidente del Consejo de Administración y por el Gerente.

Artículo 9.- La posesión de acciones implica desde luego la conformidad del poseedor con los estatutos y reglamentos de la Sociedad y con las decisiones de la Junta General y los Consejos.

Artículo 10.- Las acciones pueden ser transmitidas libremente por actos de última voluntad.

Los socios fundadores tendrán preferencia para adquirirlas cuando se traten de enajenar por actos intervivos.

Al efecto, el que pretenda enajenarlas, dará aviso al Consejo de Administración de la cesión que intenta y del precio; el Consejo lo notificará a los socios fundadores y éstos resolverán participándole a aquél.- En esta tramitación, no se tardará más de quince días.- Pasados sin que le notifique la resolución quedará libre el propietario de enajenar a quien quisiere.

Si la resolución fuese afirmativa, los fundadores podrán adquirirlas por este orden; de mayor a menor 
aportación, y en caso de ser igual, el socio de más edad tendrá mejor derecho.

La preferencia a favor de los fundadores prevalecerá aunque el precio a que se intente la cesión sea mayor, siempre, que se abone al cedente el precio al tipo que se obtenga de tomar por base el capital que a razón de cinco por ciento resulte del último dividendo repartido, o a falta de dividendo, al tipo de emisión.

La sociedad no reconocerá la cesión de acciones por actos entre vivos que no se ajuste a los requisitos precedentes.

Artículo 11.- Los accionistas tienen derecho a los dividendos de beneficios en cada ejercicio, previa propuesta del Consejo de Administración y aprobación de la Junta General y a una parte alícuota en el haber social en el caso de disolución de la sociedad.

TITULO III.- Régimen y Administración de la Sociedad.

Artículo 12.- La sociedad se regirá.

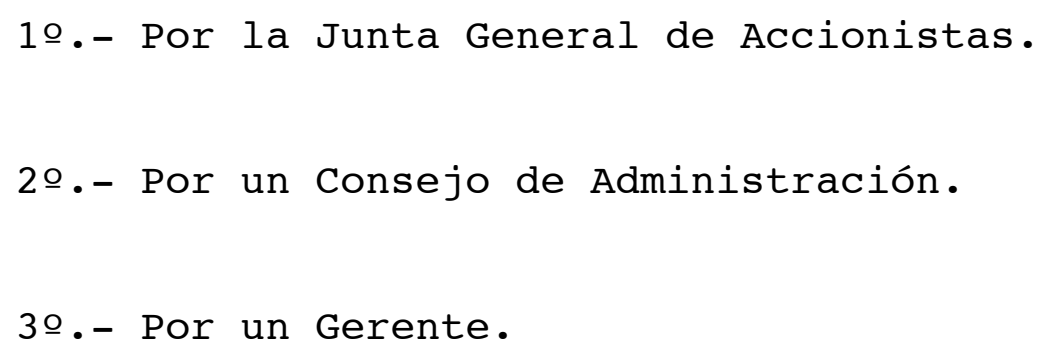




$$
\text { 4‥- Por un Consejo de Redacción. }
$$

Sección 1a..- De la Junta General.

Artículo 13.- La Junta General legalmente constituida y convocada, representa la totalidad de los accionista y sus acuerdos serán obligatorios para todos ellos.

Artículo 14.- La Junta General ordinaria, se reunirá una vez al año en la segunda quincena del mes de enero y siempre que el Consejo de Administración lo considere necesario o cuando la solicitud de dicho Consejo, accionistas que posean al menos una cuarta parte de las acciones emitidas, si se tratase de deliberar sobre asuntos económicos, y veinticinco accionistas si el objeto de la Junta estuviese relacionado con la orientación del periódico.

Artículo 15.- La reunión de la Junta General, tendrá lugar en el domicilio de la sociedad y las convocatorias deberán hacerse por medio del periódico Diario Regional con ocho días de anticipación y durante ellos si fuese ordinaria; y de días [sic ] siendo extraordinaria, indicando en este último caso el objeto.

Artículo 16.- Para tomar parte en la Junta General será preciso hacer constar debidamente haber depositado antes de reunirse cinco acciones de la serie A y una de la serie B adquiridas con tres meses de anticipación cuando 
menos.- El depósito se hará en la Caja de la Sociedad y el resguardo del mismo justificará el derecho de asistencia.

Podrá delegarse el derecho de asistencia sólo en favor de otros accionistas y por medio de cartas o poder considerados bastantes por el Consejo.

Artículo 17.- Para que pueda celebrarse la Junta General, habrán de concurrir accionistas que representen por lo menos las tres cuartas partes de las acciones en circulación.- Si no se reuniesen, se celebrará en segunda convocatoria, sea cualquiera el número de acciones representadas dentro de los quince días siguientes, pero en este caso, no podrán tratarse otros asuntos que los expresados en la primera Convocatoria.

Artículo 18.- La Junta General de accionistas será presidida por el Consejo o Quién haga sus veces, y actuará de Secretario el del Consejo.- La Mesa se formará con el Presidente, Secretario y los demás vocales del Consejo de Administración y dos escrutadores uno el mayor y otro el menor accionista presentes los cuales formarán dos listas, una de los individuos presentes o representados y otra del conjunto de votos que a cada uno corresponda, decidiéndose por la Mesa las dudas o reclamaciones que ocurriesen sobre el particular. 
Artículo 19.- Los acuerdos de la Junta General en materias administrativa o económica, se tomarán por mayoría absoluta de votos a razón de uno por quinientas pesetas nominales en acciones $y$ en materia doctrinal $y$ de orientación, por mayoría de personas a razón de un voto por cada accionista, sea cualquiera el número de acciones que posea o represente. Caso de empate, decidirá el Presidente.

En materia doctrinal o de orientación para que los acuerdos sean válidos, habrán de tomarse por los votos de las cuatro quintas partes del número de todos los accionistas que además deben representar las cuatro quintas partes del capital social en circulación.

Artículo 20.- Las votaciones serán siempre nominativas. Sólo serán secretas las que se refieran a cargos o a asuntos personales.

Artículo 21.- Corresponde a la Junta General.

1․- Nombrar los individuos del Consejo de Administración.

$$
\text { 2o.- Examinar y aprobar, si procede, las cuentas }
$$
que deberá presentar el Consejo de Administración. 


$$
\text { 3‥- Tomar en consideración y discutir en el }
$$

acto si lo estima conveniente, las proposiciones que permitan los accionistas.

4 ㅇ.-Acordar los dividendos repartibles $\circ$ que hayan de destinarse a la amortización.

5․- Acordar las adquisiciones o enajenaciones que excedan de cincuenta mil pesetas.

6‥- Resolver todas las proposiciones del Consejo sobre aumento del capital, fondo de reserva, etc.

70.- Acordar por sí, o autorizar al Consejo para que la efectúe, la emisión de acciones últ. obligaciones fijando los términos y condiciones en que deban verificarse.

8․- Nombrar la comisión inspectora de contabilidad.

9․- Y examinar y resolver sobre todos los demás puntos que especialmente se le atribuyan en estos Estatutos.

Artículo 22.-De todas las deliberaciones de la Junta se extenderá un acta que firmarán todos los individuos de la misma. 
Las certificaciones que se expedirán con el Vo Bo del Presidente.

Sección 2a..- Del Consejo de Administración.

Artículo 23.-El Consejo de Administración se compondrá de un Presidente, un Vicepresidente y cinco vocales que serán nombrados en Junta General.

El Consejo elegirá de su seno las personas que han de desempeñar los cargos de Presidente, Vicepresidente y Secretario; se renovará cada dos años, siendo designados por suerte los que hayan de cesar en la primera renovación y pudiendo ser reelegido.- La primera renovación alcanzará a cuatro miembros, la segunda a los restantes y así sucesivamente.

El Consejo puede sustituir provisionalmente hasta nueva Junta General, las vacantes que produzcan la renuncia o el impedimento permanente de alguno de sus miembros.

El primer Consejo lo formarán Don Guillermo Gil de Reboleño, como Presidente; Don Constantino Mateo González como Vicepresidente; Don Gregorio Merino Pinedo, como Secretario; y como Vocales Don Manuel Sánchez Belloso, Don Antonio Miguel y Romón, Don José Jalón Semprún, Don Pascual Pinilla Jiménez. 
Artículo 24.- Para ser miembro del Consejo de Administración, se necesitará poseer, por lo menos doce mil quinientas pesetas en acciones.- Los socios fundadores no están sometidos a esta limitación.

Artículo 25.- El Consejo de Administración se reunirá una vez al mes, cuando menos, y cuantas veces lo crea conveniente el Presidente o lo solicite de éste el Gerente.

Sus acuerdos se tomarán por mayoría de votos, decidiendo el Presidente en caso de empate y será preciso para que aquéllos sean eficaces, que estén presentes la mayoría de los miembros.

Artículo 26.- Los acuerdos del Consejo de Administración, se extenderán en el libro de actas y éstas se firmarán por todos los miembros que tienen parte en las deliberaciones.

Artículo 27.- Al Consejo de Administración corresponden las atribuciones siguientes.

1a.- Acordar la emisión y circulación de acciones y obligaciones de la sociedad dentro de las facultades que le confiere la Junta General y estos Estatutos • 
2a.- Negociar por sí o autorizar al Gerente Administrador para que lo haga en su nombre, la compra o venta de efectos pertenecientes a la sociedad, cuyo valor no exceda de cincuenta mil pesetas; o por delegación de la Junta General cuando pase de esta cantidad.

3a.- Formar los Reglamentos interiores de la sociedad e inspeccionar los actos de Administración.

4a.- Examinar y aprobar en su caso las plantillas de personal y sus sueldos y nombrar y separar los empleados a propuesta del Gerente. Cuando se trate de redactores o colaboradores retribuidos, serán además necesarios los informes del Director $y$ del Consejo de Redacción, y cuando se trate del Director del periódico, será imprescindible el informe favorable del Consejo de Redacción.

5a..- Acordar a fin de cada año el reparto que pueda hacerse a los accionistas por beneficios.

6a.- Presentar cada año a la Junta General Ordinaria la memoria del ejercicio.

7ạ.- Acordar la convocatoria de las Juntas ordinarias y extraordinarias. 
8a.- Por último, todas las funciones inherentes a la buena marcha de la sociedad y sus poderes pueden ser delegados en el Gerente o en uno de sus miembros.

Sección 3ạ.- Del Consejo de Redacción.

Artículo 28.- El Consejo de Redacción es el encargado exclusivo de dar al periódico las orientaciones convenientes, sin más límites que los del artículo cuarto. Se compondrá de cinco miembros elegidos entre accionistas a propuesta en terna del propio Consejo de Redacción.

El Director del periódico, asistirá a las sesiones del Consejo de Redacción cuando éste lo estime oportuno, con voz pero sin voto y recibirá de éste las inspiraciones e instrucciones que mejor parezcan al mismo Consejo de Redacción.- Así mismo podrá asistir a las sesiones cuando el Consejo de Redacción lo estime conveniente, el Censor del periódico que designe el Prelado, con voz y sin voto.

El primer Consejo de Redacción se compondrá de los señores siguientes: Presidente Don Rafael Serrano y Serrano y vocales Don Antonio Gimeno Bayón, Don Angel María Llamas Zapatero, Don Joaquín Pérez Agote y Don José María Rodríguez Villamil.

La primera renovación tendrá lugar a los dos años saliendo tres vocales designados por la suerte; los otros 
dos cesarán a los dos años siguientes y en lo sucesivo por este orden y plazos.

Sección 4a..- Del Gerente de la Sociedad.

Artículo 29.- El Gerente de la Sociedad será nombrado por el Consejo de Administración, pudiendo recaer el nombramiento en uno de sus miembros.

Será Administrador del periódico y además ejercerá todos los actos comerciales y adoptará las medidas que estime convenientes en todas las oficinas y dependencias de la Sociedad, siempre que no se opongan a lo dispuesto por los Estatutos, por la Junta General o por el Consejo de Administración.

Artículo 300.- Además de las atribuciones que le competen en virtud de estos Estatutos y de las que en él delegue el Consejo de Administración le corresponde de un modo concreto;

1a.- Llevar la forma de la Sociedad, comparecer en juicio y en las oficinas públicas nombre [sic ] de aquellas y representarla por sí o por tercera persona a quien haya dado poder especial al efecto, en cuantas ocasiones y lugares sea necesario o conveniente. 


$$
\text { 2a.- Formalizar y llevar a debido término la }
$$
compra venta o empréstitos que se acuerden por la Junta General o por el Consejo de Administración

3a.- Comprar los efectos y enseres necesarios para la marcha económica y ordenada del negocio, establecer la forma de Administración del periódico, entenderse con los corresponsales administrativos del mismo, y en una palabra, ejercer todos los actos que exija la buena administración.

$$
\text { 4a.- Formar el balance y cuentas generales, }
$$
presentándolos oportunamente al Consejo para que éste pueda someterlas a la aprobación de la Junta General.

5a.- Disponer y autorizar las cobranzas y pagos que hayan de hacerse por la Caja de la Sociedad.

6a..- Ser el medio de comunicación del Consejo con todo el personal de servicio de la Sociedad.

Artículo 31․- El Gerente responderá de sus actos ante el Consejo de Administración, pero estará exento de responsabilidades cuando ejecute acuerdos del mismo o de la Junta General.

TITULO IVo.- Año social, cuentas, inventarios, beneficios. 
Artículo 32.- El año social empezará el primero de enero y terminará el el treinta y uno de diciembre, formalizándose cada año, un inventario general del activo y pasivo que será presentado a la Junta General con el balance de situación y la cuenta de pérdidas y ganancias.

Todos los comprobantes de las cuentas, quedarán de manifiesto desde la fecha de la convocatoria de la Junta para que puedan ser examinados por los socios.

El primer año económico se contará desde la constitución de la sociedad hasta el fin del mil novecientos veintisiete.

Artículo 33.- Cada trimestre se hará un balance 10 más aproximado posible, del estado de la Sociedad a fin de que pueda ser examinado por el Consejo de Administración.

Artículo 34.- Se considerarán como beneficios anuales, los productos líquidos que resulten después de deducir todos los gastos y carga de la sociedad.

La distribución de estos beneficios, forma, y época de hacerlo la acordará la Junta General a propuesta del Consejo de Administración.

TITULO Vo.- Modificación de los Estatutos, disolución y liquidación de la Sociedad. 
Artículo 35.- Estos Estatutos podrán ser alterados o modificados en lo sucesivo, en la forma que la Junta General acuerde, pero si la modificación o alteración ser refiere a lo que establecen los artículos cuatro y veintiocho, será necesario para ello que se reúnan las cuatro quintas partes del capital, y las cuatro quintas partes de los accionistas que así lo deseen.

Artículo 36.- En ningún caso se podrá disolver la Sociedad se no es por falta de activo y aún entonces, es necesario el acuerdo de la Junta General en la forma prevista en artículo quinto.

Artículo 37.- Llegado el caso de disolución, la liquidación se practicará por el Consejo de Administración existente.

Artículo 38.- Durante la liquidación subsistirán las atribuciones de la Junta General la cual tendrá igualmente el derecho de aprobar las cuentas de las liquidaciones y dar finiquito de ellas a los liquidadores.

En estos términos queda constituida la sociedad Anónima "Diario Regional" que empezará a regir y operar desde el primero de enero y tendrá su domicilio legal en Valladolid por ahora de [sic ] la planta baja de la casa número ochenta y seis de la calle de Santiago. 
A los efectos consiguientes se hace constar, que la Sociedad se constituye con quinientas mil pesetas, pero sólo se ponen en circulación acciones por valor de doscientas cincuenta mil en los términos que se consignan en el número seis de los Estatutos.

(...) [Siguen unas clausulas de aceptación de los Estatutos] También consignan que los señores comparecientes y Don Romualdo Galindo Zorita son socios fundadores (...) . "1001

\section{Propiedad, capital social y accionistas.}

EN EL MOMENTO DE LA FUNDACIÓN :

El capital será de quinientas mil pesetas representado por dos series de acciones, una serie A de Cien pesetas cada una y otra serie B de Quinientas cada una. Habrá mil de la serie A y ochocientas de la B.

Al constituirse la Sociedad se pondrán en circulación solamente quinientas de la serie A y cuatrocientas de la B dejando el resto en cartera, y se pondrán en circulación

1001 «Notaría de D Ignacio Martín de los Ríos. Oficial Letrado excedente del Consejo de Estado. № 1.227 de 14 de diciembre de 1926 . 3 a copia de la escritura de constitución de la sociedad "Diario Regional, S.A." otorgada ante el Notario DON EMILIO IGLESIAS MAGADÁN", A.P.G.A.M.. 
cuando lo acuerde el Consejo de Administración1002. El mencionado acuerdo se toma el 5 de junio de 1932, fecha en que se pone en circulación todo el capital social1003.

No hay datos sobre cómo se distribuye el capital hasta 1953 (cfr. infra), y en esa fecha casi nada se dice de las acciones de las series A y B. Ahora bien, con 10 poco que se dice en esa fecha y los datos del listado de 1959 , tenemos:

1.- "La Editorial Católica, S.A." es propietaria de 730 acciones de la serie A (73.000 ptas) y 299 de la B (149.500 ptas), que compró en 1941, y venderá este paquete a los nuevos dueños de la empresa en 1955 .

2.-Hay por tanto 270 acciones de la serie A $(27.000$ ptas) y 501 de la B (250.500 ptas) que no han cambiado de dueño en 1941 con la compra de "La Editorial Católica, S.A.", y que tampoco lo hacen en 1955. Es decir, un monto de capital social permanece al margen de negociaciones

${ }^{1002} \mathrm{Cfr}$ art. 6 de los Estatutos.

1003 Por acuerdo de la Junta General de Accionistas celebrada en Valladolid el 5 de junio de 1932 se ponen en circulación, ofreciéndolas en suscripción pública, las cuatrocientas acciones de la serie $B$ de quinientas pesetas cada una, y las 500 de la serie A de 100 pesetas cada una, que están retenidas en cartera. Corresponden a las acciones no 501 a 1.000 de la serie A (cincuenta mil pesetas) y 401 a 800 de la serie B (doscientas mil pesetas).

"Escritura pública de aumento de capital y emisión de acciones de "Diario Regional S.A. que autorizó el notario que fue de Valladolid Don Luis Rodríguez de Huidobro el día 19 de febrero de 1943. Autorizada por Francisco Fernández-Prida. Abogado-Notario. Año de 1934. No 114", Certificaciones unidas, I, A.P.G.A.M.. 
posteriores. Es razonable considerar constante ese dato desde 1926 y 1932, sin que podamos discriminar qué ocurre en una y otra fecha.

3.- Se puede formular la hipótesis de que las 250.000 ptas puestas en circulación en 1932 son suscritas prácticamente todas por la misma persona, física o jurídica: concretamente, ese hipotético comprador adquiriría las 222.500 ptas que luego van a "La Editorial Católica, S.A." y que luego ésta venderá al dejar la empresa. No hay ningún dato que nos permita asegurar sin lugar a dudas si esto fue así y -menos aún- quién pudo ser ese hipotético comprador.

4.- Pero la aceptación de esta suposición resulta verosímil en el sentido de que tendríamos para 1926 una suscripción de acciones muy fraccionada, que sigue el modelo de "suscripción popular" entre los sectores más activos del catolicismo vallisoletano. El reparto de capital derivado de esa suscripción permanece inalterado en el tiempo ya que el mismo carácter -más de donativo que de inversión- que tienen los desembolsos efectuados, hace que la negociación de los títulos sea una posibilidad remota que apenas se tiene en consideración, y que en efecto casi nunca se realiza. Esto explicaría la existencia de un paquete de capital social-concretamente 277.500 ptas en acciones de las series A Y B- cuya 
propiedad no se modifica con los cambios de empresa, y de otro que se transfiere de una a otra.

5.- Por tanto podemos considerar el listado de accionistas de las series A y B que tenemos para 1959 como el mismo de 1926.

"LA Editorial Católica, S.A." ACCIONista mayoritario en 1941:

En 1941 se anuncia que "La Editorial Católica, S.A." se convierte en accionista de "Diario Regional, S.A.", la causa parece claro que es buscar mayores facilidades para el sostenimiento económico de la empresa integrándola en una cadena. No obstante la integración no será absoluta: "La Editorial Católica, S.A." no sustituye a la empresa primitiva como editora del periódico, sino que compra un $44,4 \%$ del capital1004.

No nos ha sido posible conocer con detalle la operación debido a que los archivos de "La Editorial Católica, S.A." se han destruido en su mayor parte con motivo de recientes cambios en la mencionada empresa. Tampoco hemos podido consultar actas de los Consejos de

1004 "Copia de la escritura de adaptación de los Estatutos Sociales de "Diario Regional, S.A." otorgada por don Mariano Escudero de Solís, como Consejero-Delegado de dicha Entidad. Valladolid a 23 de febrero de 1955. Ante D. Salvador Escribano y Escribano, Abogado y Notarion, A.P.G.A.M.. 
Administración de la empresa de esas fechas, aunque no sabemos con certeza si se conservan o no. El Secretario del Consejo de Administración de la empresa en mayo de 1991 y el jefe de la sección de accionistas de la misma nos hicieron saber, después de varias consultas, que no estaban en condiciones de facilitarnos el acceso a esos documentos, que ni siquiera sabían si existían, ya que en el archivo actual del Consejo se conserva sólo la documentación que se refiere a los últimos cuatro años de la empresa.

El jefe del archivo de Ya nos indicó que éste tiene únicamente fondos fotográficos $y$ no se conserva ningún otro documento. Varios empleados veteranos en la empresa, entre los que hay que destacar al periodista Alejandro Fernández Sordo, recordaban todavía papel timbrado de la empresa en el que figuraba Diario Regional como miembro de la cadena, pero nada más hemos podido averiguar.

AMPLIACión DE CAPITAL EN FEBRERO DE 1943.

Por la emisión de mil acciones de la serie C de 500 ptas. cada una, el capital social se amplía a un millón de 
pesetas ${ }^{1005}$. Todas las acciones serán adquiridas por "La Editorial Católica, S.A."•

A través del acta de la Junta General extraordinaria de accionistas de 31 de diciembre de $1953^{1006}$ conocemos que la distribución de las acciones es la siguiente:

1005 "Escritura pública de aumento de capital y emisión de acciones de "Diario Regional S.A. que autorizó el notario que fue de Valladolid Don Luis Rodríguez de Huidobro el día 19 de febrero de 1943. Autorizada por Francisco Fernández-Prida. Abogado-Notario. Año de 1943. No $114 »$. A.P.G.A.M. .

1006 "Copia de la escritura de adaptación de los Estatutos Sociales de "Diario Regional, S.A." otorgada por don Mariano Escudero de Solís, como Consejero-Delegado de dicha Entidad. Valladolid a 23 de febrero de 1955. Ante D. Salvador Escribano y Escribano, Abogado y Notario", A.P.G.A.M.. 
Apéndices

$\mathrm{n}$ ㅇ de accionistas

$\mathrm{n}$ ㅇ de acciones

2 Mariano Escudero de Solís ..... 2.030

1 acción serie A

Representando a: "La Editorial Católica, S.A."

acciones serie $A$

299 acciones serie B

1000 acciones serie $\mathrm{C}$

2 Fco. Javier Martín Abril ...... 4

2 acciones. serie B

Representado a:Germán Adánez Horcajuelo 1 acción serie A

1 acción serie $B$

1 Juan Misol ............... 1 acción serie B 
1 Francisco Mateo ...........550 acciones. serie B

2 Basilio Espeso .............. 10

5 acciones. serie $B$

Representando a: José Espeso.... 5 acciones. serie A

Por tanto de 1.000 .000 de ptas de capital "La Editorial Católica, S.A." posee en esa fecha 722.500 ptas, es decir un $72,3 \%$ del mismo; conviene notar que "La Editorial Católica, S.A." es propietaria de todas las acciones de la serie C. El otro accionista que posee una cuantía considerable es Francisco Mateo, que tiene 25.000 ptas en acciones.

Las crisis de diciembre de 1954 y marzo de 1955: "La Editorial Católica, S.A." se deshace de la empresa.

AMPLIACIÓN DE CAPITAL DE DICIEMBRE DE 1956.

Por acuerdo tomado en Junta General extraordinaria de accionistas de 11 de junio de 1956 el capital se amplía en dos millones de pesetas, quedando por tanto en tres 
millones de pesetas ${ }^{1007}$. El aumento está representado por cuatro mil acciones de 500 pesetas nominales cada una, de la serie $\mathrm{D}$, números uno al cuatro mil ambos inclusive. Las acciones números 1 al 3.000 de la serie $D$, serán intrasferibles a extranjeros. La emisión será a la par; al tiempo de realizar la suscripción se debe ingresar, por lo menos, el veinticinco por ciento de las acciones nominales suscritas, debiéndose ingresar el resto en los dos años siguientes.

Relación de accionistas en 1959.

${ }^{1007}$ Cfr. "Copia de la Escritura de ampliación de capital social de "Diario Regional, S.A." otorgada por don Juan Manuel de la Huerta López, en nombre y como representante del Consejo de Administración de dicha Sociedad. En Valladolid, a 14 de diciembre de 1956 ante D. Salvador Escribano y Escribano. Abogado y Notario. № 2179" . 
Se señalan solamente los que tienen más de quinientas pesetas en acciones, y aquellos significativos por otras razones en la vida del periódico. Los hemos ordenado por series de acciones y por cuantía de la inversión.

ALONSO DE LAS HERAS, RAFAEL

ESPESO, BASILIO

GONZÁLEZ OLIVEROS, GERMAN

MARTIN ABRIL, FRANCISCO J.

MATEO, FRANCISCO

RELIGIOSAS REPARADORAS

S.A.R.P.E.

SIERRA, BLAS

ABRIL, EUSTASIO

LLORENTE, DANIEL (Obispo de Segovia

HERRANZ,FAUSTINO

REDONDO, ANDRES
León, 6, VALL

Arco de Ladrillo, VALL

H. del Alcázar, 2, VALL

López Gómez, 20, VALL

Santiago, 28, VALL

$\mathrm{P}^{\mathrm{o}}$ de Filipinos, VALL

Gaztambide, 11, MADRID

Gamazo, 18

Santiago, $19,2^{\circ}$, VALL

SEGOVIA

S.I.M., VALL

Banco San Sebastián, VALL ?
A

100

A

100

A

100

A

100

A

100

A

100

A $\quad 100$

A $\quad 100$

A 200

A 200

A $\quad 300$ 
Apéndices

VENANCIA VELASCO, MARIA

ORTIZ-ECHAGÜE RUBIO, CESAR

ABAD, P. CAMILO

AMIGO TORRES, MANUEL

FERNANDEZ L., JUAN JULIAN

VALDIVIESO, CLEMENTE

ADANEZ, GERMAN

GARCIA, GREGORIO

BELLOSO, FRANCISCO

GARCIA SANZ, JUSTO

GARCIA, MAURO

AGUIRRE IBEITIA, LAUREANO

G. IBARRA, SOBRINOS DE

ZURITA, CLEMENTE

DE AYLLON, MARIA JOSEFA

FRANCIA, JULIO
Santiago, 76

A $\quad 1.000$

Montesquinza, 26, MADRID

A $\quad 73.400$

Tenerías, 24, VALL

A Y B 600

Leopoldo Cano, $10,3^{\circ}$, VALL

A Y B 600

MEDINA DE RIOSECO, VALL

A Y B 600

VILLABRAGIMA, VALL

A Y B 600

Santiago, 13, VALL

A Y B 700

Cánovas del C., 6, VALL

A у B $\quad 700$

$\mathrm{P}^{\mathrm{o}}$ de Zorrilla, 7, VALL

A Y B 1.100

Doncellas, 2, VALL

A y B 1.100

Doncellas, 2, VALL

A y B 1.100

Montero Calvo, 28, VALL

A Y B 1.300

Gral. Franco, 19, VALL

A Y B 1.300

María de Molina,1, VALL

A у B 1.300

Queipo de Llano, 28, VALL

A Y B 1.400

Santiago, 15

A у B 3.600 
Apéndices

PINTO, CANDIDA

LEON ALVAREZ, ARTURO

IGEA, FELIX

MISOL, JUAN

RODRIGUEZ VILLAAMIL, JOSE Mª

ARAGON, PABLO

BARREDO MAESTRO, JULIAN

BLANCO, ASUNCION

FERNANDEZ, JUAN BAUTISTA

GARCIA MARTIN, MAURO

GUTIERREZ, HERMENEGILDO

JADO, ANGEL

JALON SEMPRUN, JOSE

LOURDES, COLEGIO DE

M. ROMON, ANTONIO

NIÑO, BALTASAR
Regalado, 13, VALL

Santa María, 3, VALL

Gral. Mola, $3,3^{\circ}$, VALL

Pza. de la Universidad, 1, VALL

Gamazo, 33, VALL

Ctra. Salamanca (Hotel) VALL

Gamazo, $18,1^{\circ}$, VALL

Miguel Iscar, 8, VALL

Claudio Moyano, 8, VALL

Cantarranas, 9, VALL

Duque de la Victoria, 8, VALL

SANTANDER

Pza. de Zorrilla, 3, VALL

$\mathrm{P}^{\mathrm{o}}$ de Zorrilla, VALL

Embajadores, 2, VALL

Dos de mayo, 2, VALL
B $\quad 1.000$

A у B 4.600

A y B 11.500

B

500

B $\quad 500$

B $\quad 500$

B $\quad 1.000$

B $\quad 1.000$

B $\quad 1.000$

B $\quad 1.000$

B $\quad 1.000$

B $\quad 1.000$

B $\quad 1.000$

B $\quad 1.000$

B $\quad 1.000$

B $\quad 1.000$ 
Apéndices

ORTIZ, SIXTO

García Morato, 26

B

1.000

PIMENTEL, MULIO y Sra.

Gral. Mola, 8, VALL

B $\quad 1.000$

PINO MAZARIEGOS, FRANCISCO

Claudio Moyano, 1, $3^{\circ}$, VALL

B $\quad 1.000$

RODRIGUEZ PARDO, SANTOS

Miguel Iscar, 17

B $\quad 1.000$

SANCHEZ BELLOSO, MANUEL

Muro, 19, VALL

B $\quad 1.000$

SANZ PEREZ, FRANCISCO

Miguel Iscar, 4, VALL

B $\quad 1.000$

SILIO, LUIS

León, 4, VALL

B $\quad 1.000$

SOLANA, MARQUES DE LA

MADRID

B $\quad 1.000$

TEJERINA, POLICARPO

Gral. Franco, 18, VALL

B $\quad 1.000$

AMIGO SANJUAN, FRANCISCO

Portugalete, 7, VALL

B $\quad 1.500$

CANO, PURIFICACION

Panaderos, $8,2^{\circ}$

B $\quad 1.500$

PRIETO DE LA CAL, TOMAS

Pza. de Tenerías, 21, VALL

B $\quad 1.500$

ZAERA, FRANCISCO

Núñez de Arce, 9, VALL

B $\quad 1.500$

CAUDEVILLA, DOLORES

ECHEVARRIA, JOSE MARIA

GARCIA CHICO, ESTEBAN

Leopoldo Cano, 7, VALL

B $\quad 2.000$

Ruiz Hernández, 9, VALL

B

2.000

Duque de la Victoria, 11, VALL
B $\quad 2.000$ 
Apéndices

GARCIA, MAURO

GONZÁLEZ MARTIN, ANTONIO

MAROTO, EUSTASIA

MATEO, FRANCISCO

MONTALVO, VICENTA

PRIETO, CANDIDA

VALVERDE, CALIXTO

ALONSO DE ILERA, ADALBERTO

CAMINO DE V., DAMASO

FERNANDEZ, JULIO

FERNANDEZ DE VELASCO, MODESTA

GARRAN SAGARRA, JUSTO

GARRAN SAGARRA, Mª PILAR

ARZOBISPO, EXCMO. SR.

BLAKE, ELENA

GALINDO, ROMUALDO
Independencia, 10, VALL

B

2.000

Salvador, 10, VALL

B $\quad 2.000$

Pasión, 17, VALL

B $\quad 2.000$

Santiago, 28, VALL

B $\quad 2.000$

María de Molina, 4, VALL

B $\quad 2.000$

Salvador, 25, VALL

B $\quad 2.000$

Duque de la Victoria, 19, VALL

B $\quad 2.000$

Muro, 25, VALL

B $\quad 3.000$

Mtinez de Villegas, 2, VALL

B $\quad 3.000$

Claudio Moyano, 5

B $\quad 3.000$

Pza. de Santa Ana, 7, VALL

B $\quad 4.000$

Santiago, 15, VALL

B $\quad 4.000$

Santiago, 15, VALL

B $\quad 4.000$

San Juan de Dios, 5, VALL

B $\quad 5.000$

Gamazo, 18, 1ํ, VALL

B $\quad 5.000$

Leones de Castilla, 8, VALL

B $\quad 5.000$ 
Apéndices

GOMEZ, FRANCISCO

MERINO, GREGORIO

GIL DE REBOLEÑO, GUILLERMO

PEREZ AGOTE, JOAQUIN

DE CANALES, VDA. DE

MATEO, CONSTANTINO

GARCIA BELLOSO, MARTIN

MARTIN ABRIL, FRANCISCO J.

MIGUEL ROMON, ANTONIO

GARRAN MOZO, JOSE

GARRAN MOZO, MARIA

FERNANDEZ CANALES, TOMAS

GIMENO BAYON, ANTONIO

SERRANO, RAFAEL

CASA SOCIAL CATOLICA

S.A.R.P.E.
Santiago, 15, VALL

$\mathrm{P}^{\circ}$ de Zorrilla, 44, VALL

Juan Bravo, 10, MADRID

Claudio Moyano, 6, VALL

20 de febrero, 2, VALL

Muro, 2, VALL

Claudio Moyano, 6, VALL

López Gómez, 20, VALL

Claudio Moyano, 1, VALL

"Villa Isabel", PAMPLONA

Rivera de Garrán, VALL

Menéndez Pelayo, VALL

General Mola, $3,2^{\circ}$, VALL

Pza. el Salvador, 2, VALL

Muro, VALL

Gaztambide, 11, MADRID
B

5.000

B $\quad 5.000$

B $\quad 5.500$

B $\quad 5.500$

B $\quad 6.000$

B $\quad 6.000$

B $\quad 7.000$

B $\quad 7.000$

B $\quad 7.500$

B $\quad 8.000$

B $\quad 8.000$

B $\quad 8.500$

B $\quad 8.500$

B $\quad 8.500$

B $\quad 10.000$

B $\quad 17.000$ 
Apéndices

PLANELL FORONDA, FRANCISCO

Villanueva, 13, MADRID

B $\quad 71.000$

ECHEVARRIA ARRUABARRENA, RAFAEL

Montero Calvo, VALL

B $\quad 80.000$

PICO AMADOR, VICENTE

Españoleto, 24, MADRID

C $\quad 160.000$

RUEDA SALABERRY, ANDRES

Españoleto, 24 MADRID

C $\quad 170.000$

VALENCIANO POLACK, FERNANDO

Españoleto, 24, MADRID

C $\quad 170.000$

GIL DE REBOLEÑO, GUILLERMO

Juan Bravo, 10, MADRID

D $\quad 500$

REDONDO, ANDRES

Banco San Sebastián, VALL ?

D $\quad 500$

DIAZ DE LA SERNA, VICENTE

$\mathrm{P}^{\mathrm{o}}$ de Zorrilla, VALL

D $\quad 1.000$

ESCUDERO SOLIS, MARIANO

Gral. Franco, 10, VALL

D $\quad 1.000$

HORTELANO MARTINEZ, RAMON

Gral. Franco, 7, VALL

D $\quad 1.000$

MARTIN ABRIL, FRANCISCO J.

López Gómez, 20, VALL

D $\quad 1.000$

PEREZ MORO, FEDERICO

Santiago, 13, VALL

D $\quad 1.000$

VEGA VALENZUELA, VALENTIN

Mtinez de Villegas, 2, VALL

D $\quad 1.000$

VELASCO VILLAMAR, ELIAS

Hotel Imperial, VALL

D $\quad 1.000$

ESCRIBANO ESCRIBANO, SALVADOR

Regalado, 5, VALL

D $\quad 2.000$

JOLIN DAGUERRE, JULIO

Salvador, VALL

D $\quad 2.000$ 
Apéndices

SANTIAGO BURGOS, HERMENEGILDO

ALCALDE FERRER, DIONISIO

BLAKE Y PEREZ F., JOAQUINA

PINO MAZARIEGOS, FRANCISCO

SANTUARIO DE LA GRAN PROMESA

DIAZ CANEJA PANDO, ENRIQUE

ENCISO RECIO, LUIS MIGUEL

FERNANDEZ DIEZ, ANTONIO

GONZÁLEZ GARCIA, JOSE

LUIS DIAZ, FRANCISCO DE

MIRANDA DEL OLMO, FERNANDO

RUIZ RODRIGUEZ, JULIO

RUIZ VALDEPEÑAS, LUCRECIO

NOVAL CANDUELA, JOSE DEL

CARRION DE CASTRO, ELIODORO

CARRION DE CASTRO, MARCIAL
Santiago, 19, VALL

$\mathrm{D}$

2.000

Lencería, 1, VALL

D $\quad 2.500$

Gamazo, 18, VALL

D $\quad 2.500$

Claudio Moyano, $1,3^{\circ}$, VALL

D $\quad 2.500$

Alonso Pesquera, VALL

D $\quad 4.000$

Miguel Iscar, 3, VALL

D $\quad 5.000$

Colegio "El Salvador", VALL

D $\quad 5.000$

Sancti Spiritu, 7, VALL

D $\quad 5.000$

Miguel Iscar, 14, VALL

D $\quad 5.000$

Colonia Los Pinares, MADRID

D $\quad 5.000$

Duque de la Victoria, 15, VALL

D $\quad 5.000$

Gral. Franco, 11, VALL

D $\quad 5.000$

Gamazo, 18,2, VALL

D $\quad 5.000$

María de Molina, 11, VALL

D $\quad 6.000$

Garaje, VALL

D $\quad 8.000$

Garaje, VALL
D $\quad 8.000$ 
Apéndices

CARRION DE CASTRO, NARCISO

HERNANDEZ NIETO, CARMEN

IÑIGUEZ HERRERO, JOSE ANTONIO

MURGA GENER, JOSE LUIS

PASTOR OLMEDO, FELIPE

ESCAÑO REGERO, LUIS

LEON GALLEGO, ARTURO

MARCOS PONS, ALEJANDRO

ARCOS GARCIA, FERNANDO

LAHUERTA VARGAS, JUAN

FERNANDEZ CASTELLO, JAIME

FERNANDEZ ORTIZ, Mª ANTONIA

FERNANDEZ ORTIZ, Mª PILAR

MATEOS RUIZ, ANGEL

PAUL GONZÁLEZ, TOFILO

HERRANZ RODRIGUEZ, GONZALO
D $\quad 8.000$

Miguel Iscar, 7, VALL

D $\quad 10.000$

Españoleto, 24, MADRID

D $\quad 10.000$

Villanueva, 13, MADRID

D $\quad 10.000$

Santiago, 12, VALL

D $\quad 10.000$

Capuchinos Viejos, 12, VALL

D $\quad 12.500$

Teresa Gil, 20, VALL

D $\quad 20.000$

Montesquinza, 6, MADRID

D $\quad 20.000$

Moncloa, 3, MADRID

D $\quad 24.000$

Gurtubay, 3, MADRID

D $\quad 24.000$

Moncloa, 3, MADRID

D $\quad 25.000$

AMPUERO, SANTANDER

D $\quad 25.000$

AMPUERO, SANTANDER

D $\quad 25.000$

Gral. Franco, 12, VALL

D $\quad 25.000$

Claudio Moyano, 7, VALL

D $\quad 25.000$

Españoleto, 24, MADRID
D $\quad 30.000$ 
Apéndices

JALON MENESES, MANUEL

MARTIN NIETO, LORENZO

CARO RODRIGUEZ, ELOY

ECHEVARRIA ARRUABARRENA, RAFAEL

FERNANDEZ ALDEA, JESUS

JOLIN DAGUERRE, VICTOR

GUAITIA MARTORELL, AURELIO

LLAMAS MADURGA, RAMON

CARBONELL MASSY, FERNANDO

GABIOLA TORCO, SABINO

DIEGO LORA, CARMELO DE

COLLAR LACALLE, JORGE

ORTIZ-ECHAGÜE RUBIO, CESAR

PLANELL FORONDA, FRANCISCO

RAMOS FERNANDEZ, ANGEL

ARZOBISPO, EXCMO. SR.
Miguel Iscar, 16, VALL

D $\quad 30.000$

Españoleto, 24, MADRID

D $\quad 30.000$

Santiago, 26, VALL

D $\quad 50.000$

Montero Calvo, VALL

D $\quad 50.000$

$\mathrm{M}^{\mathrm{a}}$ de Molina, 10, VALL

D $\quad 50.000$

Pza. del Niño Jesús, s/n, VALL

D $\quad 50.000$

Montesquinza, 6, MADRID

D $\quad 55.000$

Diego de León, 14, MADRID

D $\quad 55.000$

Padilla, 1, MADRID

D $\quad 65.000$

Moncloa, 3, MADRID

D $\quad 68.000$

Diego de León, 14, MADRID

D $\quad 70.000$

Diego de León, 14, MADRID

D $\quad 80.000$

Montesquinza, 26, MADRID

D $\quad 85.000$

Villanueva, 13, MADRID

D $\quad 85.000$

Villanueva, 13, MADRID

D $\quad 95.000$

San Juan de Dios, 5, VALL
D $\quad 100.000$ 
Apéndices

LOPEZ GONZÁLEZ, SANTIAGO

VALENCIANO POLACK, FERNANDO

PICO AMADOR, VICENTE

ROGER GALLES, JUAN MARIA

\author{
COGER GALLES, JUAN MARIA
}

.
López Gómez, 4, VALL

D $\quad 100.000$

Españoleto, 24, MADRID

D $\quad 100.000$

Españoleto, 24, MADRID

D $\quad 140.000$

Aragón, 284, $8^{\circ}$, BARCELONA

D $\quad 250.000$

AMPliación DE CAPITAL DE 10 DE ABRIL DE 1965. S.A.R.P.E. ACCIONISTA MAYORITARIO.

Por acuerdo de la Junta General extraordinaria de accionistas celebrada el 30 de octubre de 19641008 se amplía el capital social en cuatro millones de pesetas: pasa de 3 a 7 millones de ptas ${ }^{1009}$. El Consejo de Administración en sesión de 21 de julio de 1965 acordó

1008Cfr. "Segunda copia de la escritura de aumento de capital y modificación de Estatutos otorgada por: don José-Ramón Abril Martín, en representación de la Sociedad Anónima Diario Regional" Notaría de D. Miguel Hoyos de Castro. Valladolid. № 2743 de 8 de julio de 1967 . A.P.G.A.M.. Cfr. también Registro de Empresas Periodísticas, con número 196, tomo 3, Sección Personas Jurídicas, Folio 156, inscripción 1a. Oficio de la Dirección General de Prensa, Servicio Régimen de Empresas y Medios Informativos, Sección Empresas, al Gerente de Diario Regional S.A., de 18 de septiembre de 1967, hoja 2. A.H.P.U.V., Sección Cultura, caja 28. No se encuentra la relación nominal de suscriptores que debería ir unida al expediente.

1009 Acordado por el Consejo de Administración en sesión de 10 de abril de 1965, en uso de la facultad concedida por la Junta General Extraordinaria de Accionistas de 30 de octubre de 1964. Informe del Gerente al Director General de Prensa de 4 de mayo de 1965. A.H.P.U.V., Sección Cultura, caja 28. 
proceder a dicho aumento de capital, "mediante la creación de ocho mil nuevas acciones serie $\mathrm{E}$, de quinientas pesetas nominales cada una, nominativas, concediéndose a los señores accionistas, un plazo de un mes para la suscripción de las citadas acciones. La proporción de dicho derecho es de cuatro acciones nuevas por cada tres antiguas, a la par»1010. Los motivos de la ampliación son:

"(...) que de las dos etapas que el Consejo se propuso llevar a cabo, está cumplida una de ellas cual es la de haber reducido la plantilla del personal de la Empresa, que se llevó a feliz término a principio del presente año. Ahora es aconsejable, acometer la segunda etapa, mejorar de forma decisiva todos los elementos que componen los talleres de Diario Regional, con arreglo a un plan cuidadosamente estudiado $y$ que se da a conocer a la Junta» •

En cuanto a los suscriptores de las acciones consta que S.A.R.P.E. ("Revistas, Periódicos y Ediciones, S.A.") suscribió y desembolsó totalmente el importe de tres mil setecientas acciones ordinarias nominativas de quinientas pesetas de valor nominal cada una de ellas, de la serie E números 1 a 3.700 , lo que supone un capital de 1.850 .000

1010 "Segunda copia de la escritura de aumento de capital y modificación de Estatutos otorgada por: don José-Ramón Abril Martín, en representación de la Sociedad Anónima Diario Regional" Notaría de D. Miguel Hoyos de Castro. Valladolid. № 2743 de 8 de julio de 1967. A.P.G.A.M. . 
ptas, a las que hay que sumar las 17.100 ptas en acciones de las series A y B que ya poseía, y con lo que tenemos un total de 1.867 .100 ptas, es decir, un 26,7\% del capital de la sociedad ${ }^{1011}$

Venta DE S.A.R.P.E. A P.E.S.A.: 31 DE MARZO DE 1970.

Transmisión de 7335 acciones, de 500 ptas. cada una, y de 735 acciones de 100 ptas. cada una (total, 3.741.000 ptas), de titulares de la Sociedad Anónima de Revistas, Periódicos y Ediciones (SARPE), a la empresa Prensa y Ediciones Sociedad Anónima (PESA) ${ }^{1012}$.

Venta DE P.E.S.A. A CINISA: 31 DE MAYO DE 19711013

1011 "Copia del acta de protocolización de documento, a instancia de D. Arturo León Alvarez, en representación de "Diario Regional, S.A.", Notaría de D. Miguel Hoyos de Castro, Ilustre Colegio Notarial de Valladolid, 1 de julio de 1970 , no 1970. A.P.G.A.M..

1012 Hojas 1-2 del oficio de la Dirección General de Prensa, Sección Empresas al Consejero-Delegado de DR S.A. de 22 de febrero de 1972 comunicando la inscripción 2 a en el folio 247 , tomo 27 del Registro de Empresas Periodísticas. A.H.P.U.V., Sección Cultura, caja 28.

1013 Oficio de la Dirección General de Prensa, Servicio Empresas, al Consejero-Delegado de Diario Regional, S.A. de 22 de febrero de 1962, págs. 1-2. 
Transmisión de 7.335 acciones (de 500 pts. cada una) y 735 (de 100 pts. cada una), de Diario Regional S.A., por parte de sus titulares la Compañía Mercantil P.E.S.A. a la Sociedad de Corporación de Inversiones Industriales, S.A. ( CINISA) •

REDUCCión y AMPLIACión DE CAPITAL DE 9 DE JUNIO DE 1972.

En la Junta General ordinaria de accionistas de la fecha que se indica se aprobaron por unanimidad, entre otros los siguientes acuerdos:

$$
\text { "(...) 60.- Incorporar de conformidad con los }
$$
dispuesto en el Decreto de 29 de diciembre de 1966, la cantidad de $1.322 .361,10$ pesetas, saldo de la Cuenta de Regularización (Ley $76 / 61$ de 23 de diciembre) a las Cuentas de Capital y de la Reserva Legal del Artículo 106 de la Ley de Sociedades Anónimas, en la forma siguiente:

$$
\text { 1․- Incorporación de } 991.771 \text { pesetas de la }
$$
Cuenta de Regularización al capital social. El capital social, incorporada esta parte de la Cuenta de Regularización, asciende a 7.991 .771 pesetas. 
2․- Teniendo en cuenta que las pérdidas acumuladas al 30 de abril de 1972 alcanzaron la cifra de 8.294.481,20 pesetas (cantidad que comprende las pérdidas al 31 de diciembre de $1971,8.252 .306,48$ pesetas más las pérdidas del periodo 1 de enero de 1972 al 30 de abril de 1972 ) en uso de la facultad concedida en el Artículo 6.3 del citado Decreto de 29 de diciembre de 1966, se efectúa la cantidad de $330.590,10$ pesetas, equivalente a la tercera parte de la que se incorpora al capital social procedente del saldo de la Cuenta de Regularización, a enjugar dichas pérdidas, por la que el total de pérdidas baja a $7.963 .891,10$ pesetas.

7ㅇ.- Reducir el capital de la Sociedad en 7.963.771 pesetas con lo que el capital de la misma queda establecido en 28.000 pesetas, reduciendo a su vez el valor de los títulos existentes, pasando a ser de 0,40 pesetas de valor cada una de las 1.000 acciones de 100 pesetas nominales, y de 2 pesetas cada una de las 13.800 acciones de 500 pesetas nominales, procediendo al correspondiente estampillado de las mismas.

8․- Modificar el capital de la Sociedad cifrado en 7.000 .000 de pesetas en 6.972 .000 pesetas menos con 10 que el capital de la misma queda establecido en 28.000 
pesetas, reduciéndose a su vez el valor de los títulos existentes $(\ldots) \cdot{ }^{1014}$

En la misma junta se acuerda aumentar el capital social en 7.000 .000 de pesetas, «mediante la creación de 17.500 nuevas acciones nominativas, de la serie $F$, de 400 pesetas nominales cada una, números 1 al 17.500, ambos inclusive". Las nuevas acciones son suscritas en su totalidad por la "Corporación de Inversiones Industriales S.A., (CINISA) $)^{1015}$.

1014 "Escritura de incorporación del saldo de la Cuenta de Regularización de Balance al capital y reducción de capital social.otorgada por don Arturo León Alvarez ("Diario Regional, S.A.")", Notaría de D. Francisco Pastor Moreno, Valladolid, 20 de marzo de 1973, no 385. A.P.G.A.M..

1015 "Escritura de aumento de capital otorgada por D. Arturo León Alvarez ("Diario Regional, S.A.")", Notaría de D. Francisco Pastor Moreno, Valladolid, 20 de marzo de 1973, no 386. A.P.G.A.M..

Cfr. también el oficio de la Dirección General de Prensa, Sección empresas, a D. Luis Conde Pardo en representación de Diario Regional S.A., de fecha 9 de enero de 1974. Inscripción con el número 196, Tomo 27, Sección de Personas Jurídicas, al Folio 248 Inscripción 9 a :

«El capital de [Diario Regional, S.A.] queda fijado, de acuerdo con las operaciones de regularización de balance y reducción de capital social que se hace constar en escritura pública de fecha 20 de marzo de 1973, en la cantidad de 28.000 pesetas, representadas por 14.800 acciones nominativas de las Series y valores nominales siguientes: Serie A: 1.000 acciones de 0,40 pesetas cada una: las Series B, C, D Y E: 13.800 acciones de 2,00 pesetas cada una.

"Según se hace constar en escritura pública de fecha 20 de marzo de 1973, se ha acordado aumentar dicho capital social en 7.000.000 de pesetas, por lo cual el capital social de "DIARIO REGIONAL, S.A." de 
AmpLiación de CAPItAL DE 19 DE JUnio de 1975.

En la Junta General de la fecha se acuerda ampliar el capital en 56.224 .000 pesetas, mediante emisión y puesta en circulación de 56.224 nuevas acciones, nominativas, serie G, de mil pesetas de valor nominal. Cumplido el plazo para ejercitar los derechos de sindicación, el 8 de mayo de 1976, han quedado totalmente suscritas todas las acciones $^{1016}$.

Venta de Cinisa a Jerónimo Gallego y Manuel Casado en julio de 1977 Y MAYO DE 1978 .

Valladolid está constituído, en la actualidad, por 7.028 .000 pesetas, representado por 32.300 acciones nominativas, con las Series y valores nominales siguientes: Serie A: 1.000 acciones de 0,40 pesetas; Series B, C, D Y E, 13.800 acciones de 2,00 pesetas, y serie F 17.500 acciones de 400 pesetas cada una. Todo ello según relación nominal de accionistas remitida por la empresa interesada, y que se incorporan al expediente que obra en el Registro de Empresas Periodísticas."

1016 "Segunda copia de la escritura de aumento de capital social y modificación de los Estatutos de la Sociedad Mercantil Anónima "Diario Regional, Sociedad Anónima", otorgada por Don Arturo León Alvarez, como Presidente del Consejo de Administración", Ramón v. Modesto Chaumel, Notario, Valladolid, 26 de mayo de 1976, no 618. A.P.G.A.M. . 
Los datos que se aportan son los que figuran en las "Pólizas de operaciones al contado" que se conservan en A.P.G.A.M.. Deben ser corregidos con los datos que tenemos a través de testimonio de los protagonistas sobre cómo se realizaron las operaciones.

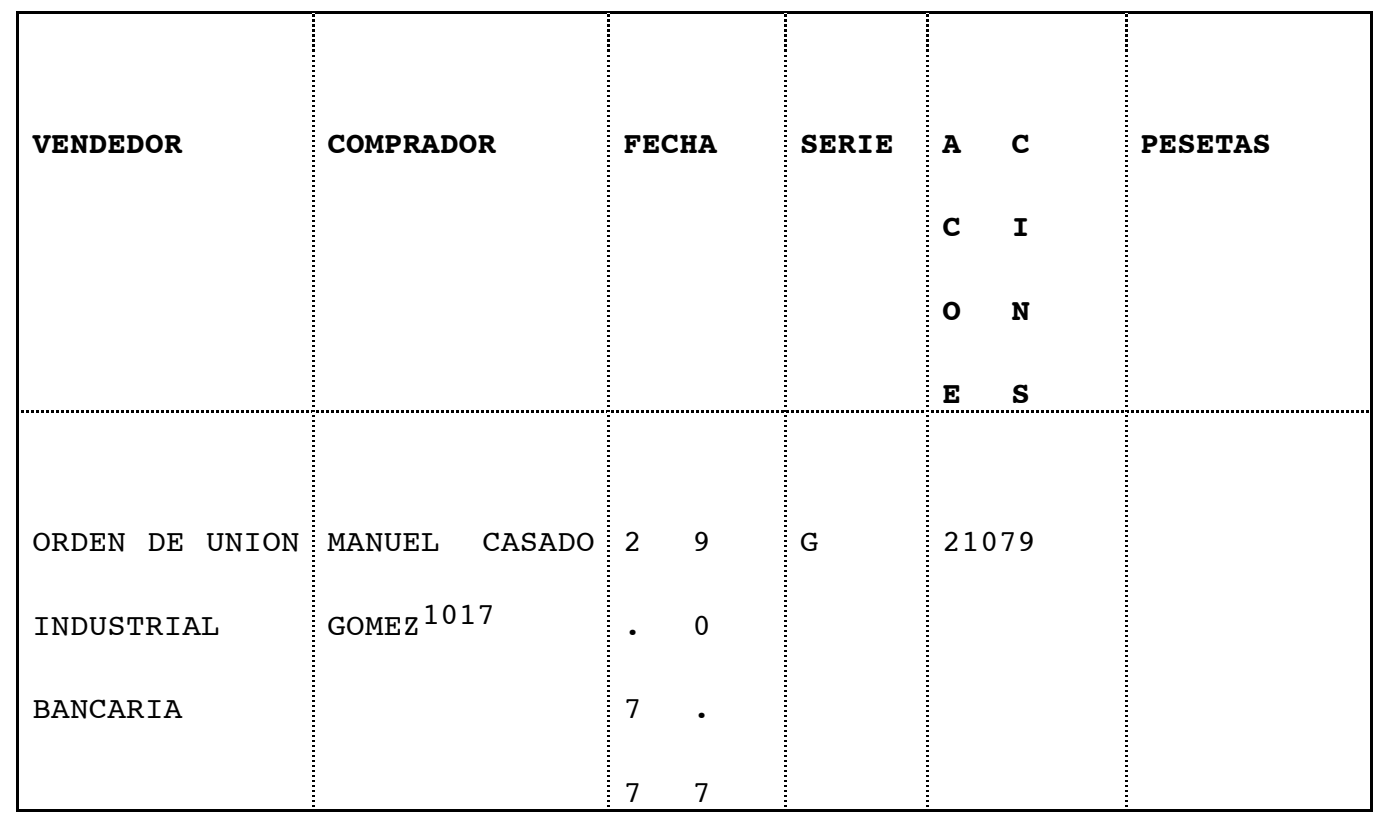

\footnotetext{
${ }^{1017} \mathrm{La}$ "póliza de operaciones al contado para valores no admitidos a cotización oficial" señala:

Pesetas nominales: $21.079 .000,00$.

cambio

$72,57 \%$

pesetas efectivas $15.297 .030,30$

derechos

$38.242,60$

impuesto T.P.

$84.150,00$

total compra

$15.419 .422,90$
} 
Apéndices

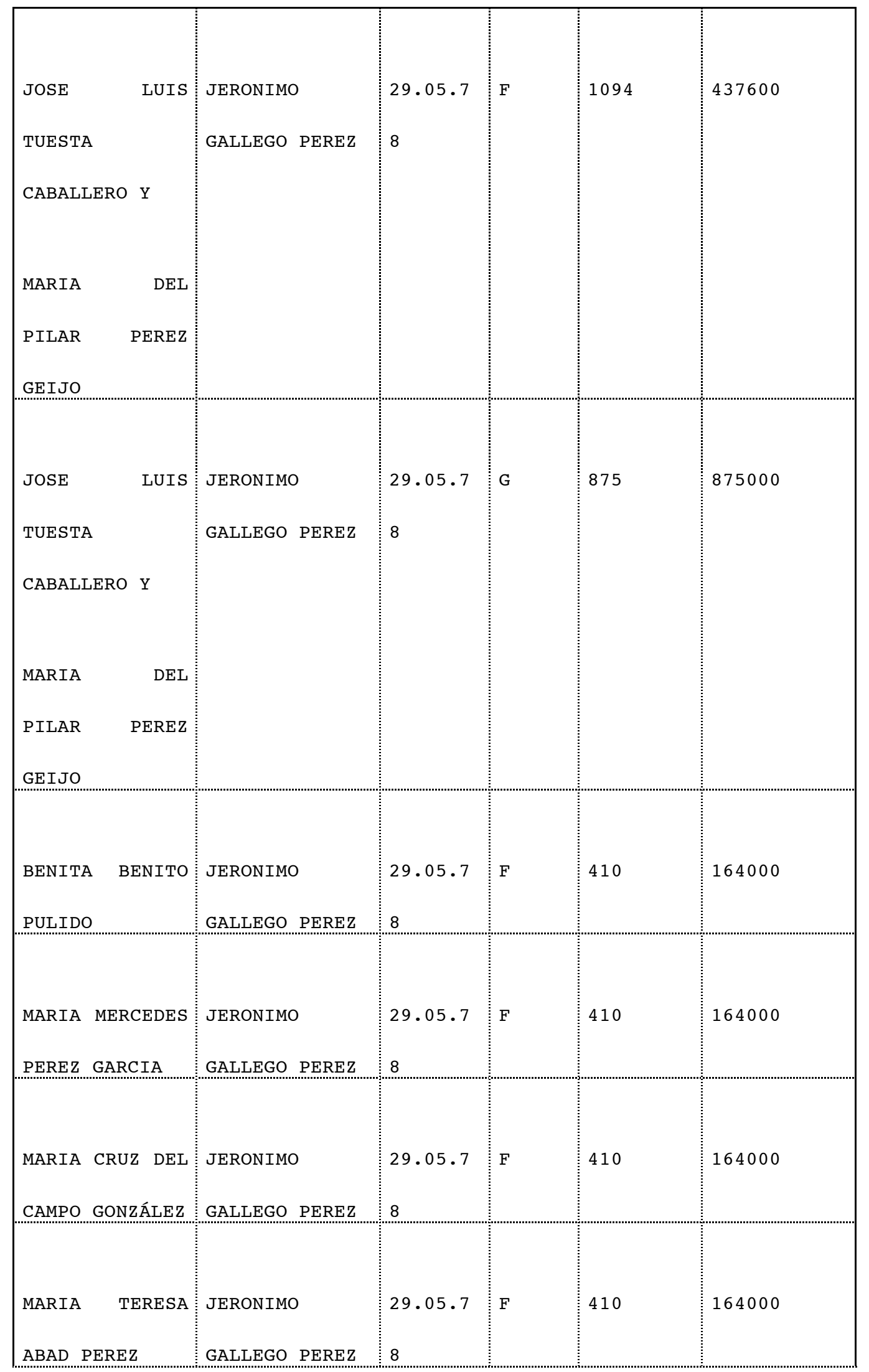


Apéndices

\begin{tabular}{|l|l|l|l|} 
& & & \\
TOTAL & & & 1968600 \\
NEGOCIADO & & & \\
\hline
\end{tabular}

VENTA DE "DIARIO REgIONAL, S.A." AL GRUPO DE EL IMPARCIAL EN NOVIEMBRE DE 1978 . 


\begin{tabular}{|c|c|c|c|c|c|}
\hline VENDEDOR & COMPRADOR & FECHA & SERIE & $\begin{array}{l}\text { A } \\
\text { C } \\
\text { O } \\
\text { E }\end{array}$ & PESETAS \\
\hline $\begin{array}{l}\text { JERONIMO } \\
\text { GALLEGO PEREZ }\end{array}$ & $\begin{array}{l}\text { MANUEL CASADO } \\
\text { GOMEZ } 1018\end{array}$ & $\begin{array}{l}11.11 .7 \\
8\end{array}$ & $\mathrm{~A}$ & 744 & 297,6 \\
\hline $\begin{array}{l}\text { JERONIMO } \\
\text { GALLEGO PEREZ }\end{array}$ & $\begin{array}{l}\text { MANUEL CASADO } \\
\text { GOMEZ }\end{array}$ & $\begin{array}{l}11.11 .7 \\
8\end{array}$ & $\mathrm{~B}$ & 361 & 722 \\
\hline
\end{tabular}

${ }^{1018}$ En la liquidación de gastos del corredor de comercio se señala: compra-venta de $14.845,60$ ptas. nom. en accs. de Diario Regional, S.A.

compra-venta de 1.968 .600 ptas. nom. en accs. de Diario Regional, S.A.

venta de 44.276.400 ptas. nom. en accs. de Diario Regional, S.A. Total a pagar: $139.184,50$ ptas

La "póliza de operaciones al contado para valores no admitidos a cotización oficial" para las acciones de las series A, B, C, D Y E, señala:

$\begin{array}{lr}\text { pesetas nominales } & 14.845,60 \\ \text { cambio } & 72,50 \% \\ \text { pesetas efectivas } & 10.773,45 \\ \text { derechos } & 6414,40 \\ \text { impuesto T.P. } & 140,00 \\ \text { total compra } & 17.327,85\end{array}$


Apéndices

\begin{tabular}{|c|c|c|c|c|c|}
\hline $\begin{array}{l}\text { JERONIMO } \\
\text { GALLEGO PEREZ }\end{array}$ & $\begin{array}{l}\text { MANUEL CASADO } \\
\text { GOMEZ }\end{array}$ & $\begin{array}{l}11.11 .7 \\
8\end{array}$ & $\mathrm{C}$ & 1000 & 2000 \\
\hline $\begin{array}{l}\text { JERONIMO } \\
\text { GALLEGO PEREZ }\end{array}$ & $\begin{array}{l}\text { MANUEL CASADO } \\
\text { GOMEZ }\end{array}$ & $\begin{array}{l}11.11 .7 \\
8\end{array}$ & $\mathrm{D}$ & 2299 & 4598 \\
\hline $\begin{array}{l}\text { JERONIMO } \\
\text { GALLEGO PEREZ }\end{array}$ & $\begin{array}{l}\text { MANUEL CASADO } \\
\text { GOMEZ }\end{array}$ & $\begin{array}{l}11.11 .7 \\
8\end{array}$ & $\mathrm{E}$ & 3614 & 7228 \\
\hline $\begin{array}{l}\text { JOSE LUIS } \\
\text { TUESTA } \\
\text { CABALLERO }\end{array}$ & $\begin{array}{l}\text { MANUEL CASADO } \\
\text { GOMEZ }\end{array}$ & $\begin{array}{l}11.11 .7 \\
8\end{array}$ & $\mathrm{~F}$ & 1094 & 437600 \\
\hline $\begin{array}{l}\text { MARIA TERESA } \\
\text { ABAD PEREZ }\end{array}$ & $\begin{array}{l}\text { MANUEL CASADO } \\
\text { GOMEZ }\end{array}$ & $\begin{array}{l}11.11 .7 \\
8\end{array}$ & F & 410 & 164000 \\
\hline $\begin{array}{l}\text { MARIA CRUZ DEL } \\
\text { CAMPO GONZÁLEZ }\end{array}$ & $\begin{array}{l}\text { MANUEL CASADO } \\
\text { GOMEZ }\end{array}$ & $\begin{array}{l}11.11 .7 \\
8\end{array}$ & $\mathrm{~F}$ & 410 & 164000 \\
\hline $\begin{array}{l}\text { MARIA TERESA } \\
\text { PEREZ GARCIA }\end{array}$ & $\begin{array}{l}\text { MANUEL CASADO } \\
\text { GOMEZ }\end{array}$ & $\begin{array}{l}11.11 .7 \\
8\end{array}$ & $\mathrm{~F}$ & 410 & 164000 \\
\hline $\begin{array}{l}\text { HEREDEROS DE } \\
\text { Da BENITA } \\
\text { BENITO PULIDO }\end{array}$ & $\begin{array}{l}\text { MANUEL CASADO } \\
\text { GOMEZ }\end{array}$ & $\begin{array}{l}11.11 .7 \\
8\end{array}$ & $F$ & 410 & 164000 \\
\hline $\begin{array}{l}\text { JOSE LUIS } \\
\text { TUESTA }\end{array}$ & $\begin{array}{l}\text { MANUEL CASADO } \\
\text { GOMEZ }\end{array}$ & $\begin{array}{l}11.11 .7 \\
8\end{array}$ & G & 875 & 875000 \\
\hline
\end{tabular}


Apéndices

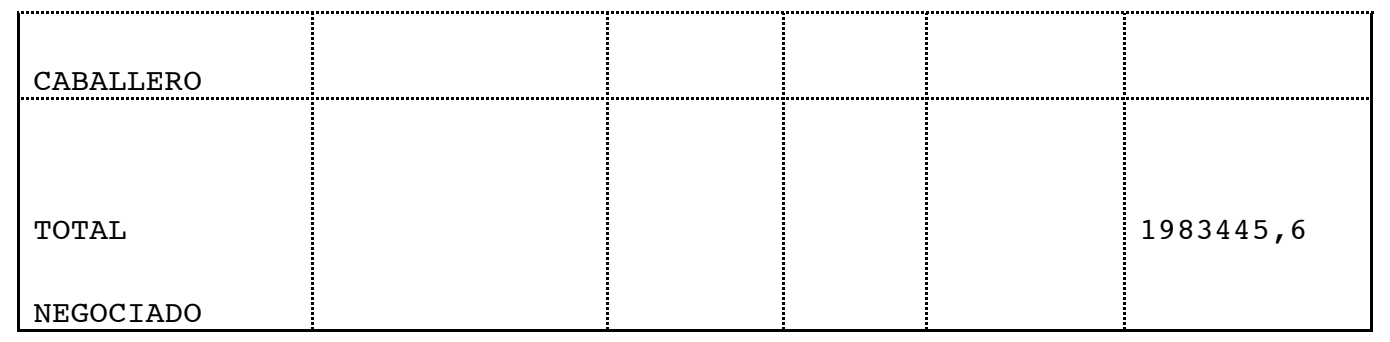

\begin{tabular}{|c|c|c|c|c|c|}
\hline $\begin{array}{l}\text { MANUEL CASADO } \\
\text { GOMEZ }\end{array}$ & $\begin{array}{l}\text { MAXIMO GARRIDO } \\
\text { CHICO }\end{array}$ & $\begin{array}{l}24.11 .7 \\
8\end{array}$ & $\mathrm{~F}$ & 2374 & 949600 \\
\hline $\begin{array}{l}\text { MANUEL CASADO } \\
\text { GOMEZ }\end{array}$ & $\begin{array}{l}\text { FERNANDO } \\
\text { LATORRE DE } \\
\text { FÉLEZ }\end{array}$ & $\begin{array}{l}24.11 .7 \\
8\end{array}$ & G & 3006 & 3006000 \\
\hline $\begin{array}{l}\text { AGUSTIN DIEZ } \\
\text { HIERRO }\end{array}$ & $\begin{array}{l}\text { MAXIMO GARRIDO } \\
\text { CHICO }\end{array}$ & $\begin{array}{l}24.11 .7 \\
8\end{array}$ & G & 9319 & 9319000 \\
\hline $\begin{array}{l}\text { AGUSTIN DIEZ } \\
\text { HIERRO }\end{array}$ & $\begin{array}{l}\text { JULIO MERINO } \\
\text { GONZÁLEZ }\end{array}$ & $\begin{array}{l}24.11 .7 \\
8\end{array}$ & $\mathrm{G}$ & 9319 & 9319000 \\
\hline $\begin{array}{l}\text { AGUSTIN DIEZ } \\
\text { HIERRO }\end{array}$ & $\begin{array}{l}\text { JORGE } \\
\text { RODRIGUEZ SAN } \\
\text { JOSE } 1019\end{array}$ & $\begin{array}{l}24.11 .7 \\
8\end{array}$ & G & 2441 & 2441000 \\
\hline JERONIMO & MAXIMO GARRIDO & 24.11 .7 & $\mathrm{E}$ & 50 & 100 \\
\hline
\end{tabular}

\footnotetext{
${ }^{1019}$ En la liquidación de gastos del corredor de comercio se señala: S.A. compra de 11.069 .100 ptas. nom. en accs. de Diario Regional,

El cambio para todos es de $94,85866 \%$
} 
Apéndices

\begin{tabular}{|c|c|c|c|c|c|}
\hline GALLEGO PEREZ & $\mathrm{CHICO} 1020$ & 8 & & & \\
\hline $\begin{array}{l}\text { JERONIMO } \\
\text { GALLEGO PEREZ }\end{array}$ & $\begin{array}{l}\text { MAXIMO GARRIDO } \\
\text { CHICO }\end{array}$ & $\begin{array}{l}24.11 .7 \\
8\end{array}$ & $\mathrm{~F}$ & 1641 & 656400 \\
\hline $\begin{array}{l}\text { JERONIMO } \\
\text { GALLEGO PEREZ }\end{array}$ & $\begin{array}{l}\text { JULIO MERINO } \\
\text { GONZÁLEZ1021 }\end{array}$ & $\begin{array}{l}24.11 .7 \\
8\end{array}$ & $\mathrm{E}$ & 50 & 100 \\
\hline $\begin{array}{l}\text { JERONIMO } \\
\text { GALLEGO PEREZ }\end{array}$ & $\begin{array}{l}\text { JULIO MERINO } \\
\text { GONZÁLEZ }\end{array}$ & $\begin{array}{l}24.11 .7 \\
8\end{array}$ & $\mathrm{~F}$ & 4375 & 1750000 \\
\hline $\begin{array}{l}\text { JERONIMO } \\
\text { GALLEGO PEREZ }\end{array}$ & $\begin{array}{l}\text { JORGE } \\
\text { RODRIGUEZ SAN } \\
\text { JOSE }\end{array}$ & $\begin{array}{l}24.11 .7 \\
8\end{array}$ & $\mathrm{E}$ & 50 & 100 \\
\hline $\begin{array}{l}\text { JERONIMO } \\
\text { GALLEGO PEREZ }\end{array}$ & $\begin{array}{l}\text { JORGE } \\
\text { RODRIGUEZ SAN } \\
\text { JOSE }\end{array}$ & $\begin{array}{l}24.11 .7 \\
8\end{array}$ & $F$ & 4375 & 1750000 \\
\hline $\begin{array}{l}\text { JERONIMO } \\
\text { GALLEGO PEREZ }\end{array}$ & $\begin{array}{l}\text { JORGE } \\
\text { RODRIGUEZ SAN } \\
\text { JOSE }\end{array}$ & $\begin{array}{l}24.11 \cdot 7 \\
8\end{array}$ & $G$ & 6878 & 6878000 \\
\hline
\end{tabular}

${ }^{1020}$ En la liquidación de gastos del corredor de comercio se señala: compra de 11.069 .100 ptas. nom. en accs. de Diario Regional, S.A.

${ }^{1021}$ En la liquidación de gastos del corredor de comercio se señala: compra de 11.069 .100 ptas. nom. en accs. de Diario Regional, S.A. 
Apéndices

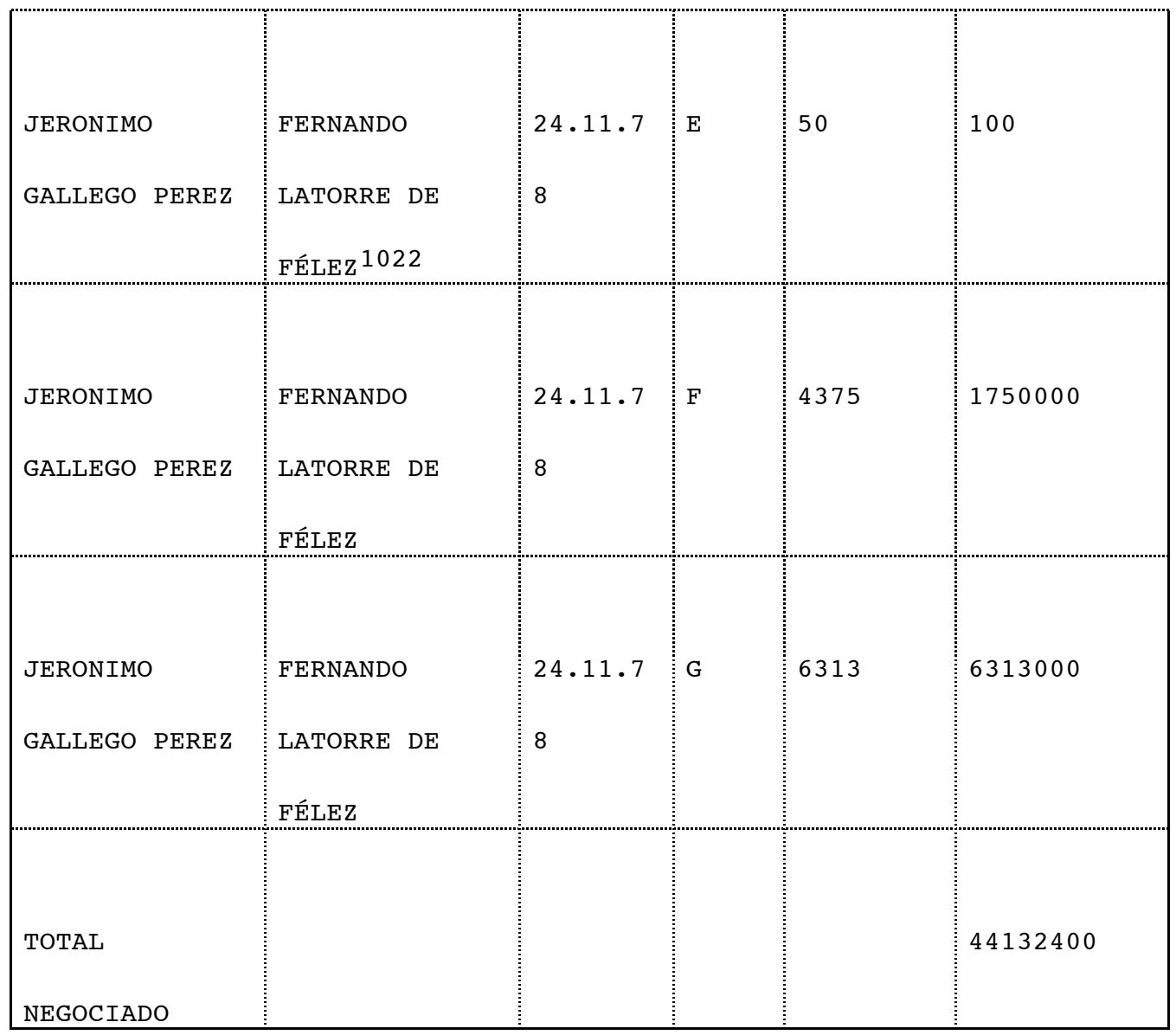

Venta de «Diario Regional, S.A." a Sebastián Auger

${ }^{1022}$ En la liquidación de gastos del corredor de comercio se señala: compra de 11.069 .100 ptas. nom. en accs. de Diario Regional, S.A. 
Cfr. lo que anotamos al comienzo del apartado anterior.

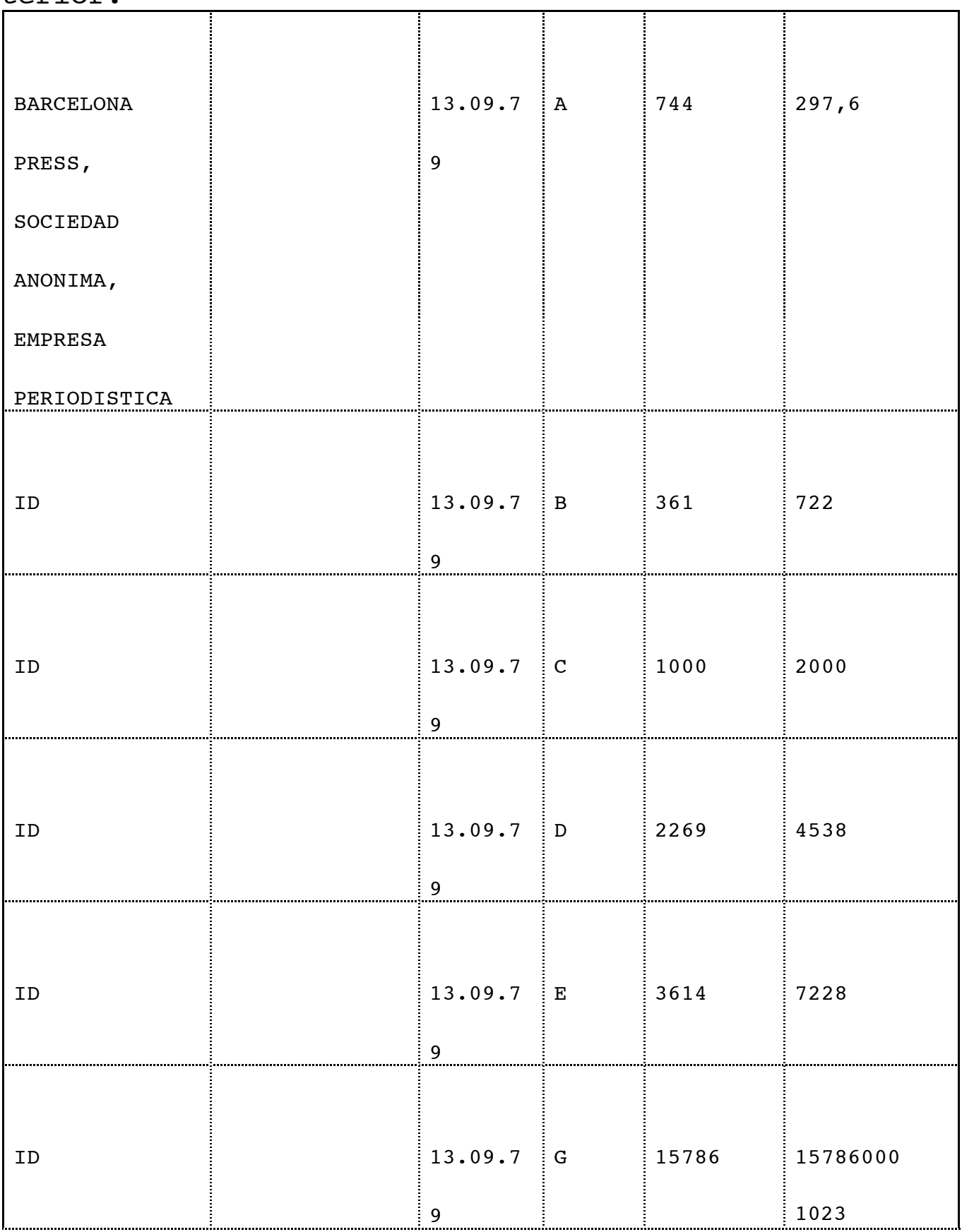

${ }^{1023} \mathrm{El}$ total desembolsado que se señala son: $15.800 .845,60$ ptas nominales, cambio 94,8586\%, $14.988 .460,00$ ptas efectivas, derechos $43.850,35$, impuesto t.p. 82.445, total compra $15.114 .755,35$. 
Apéndices

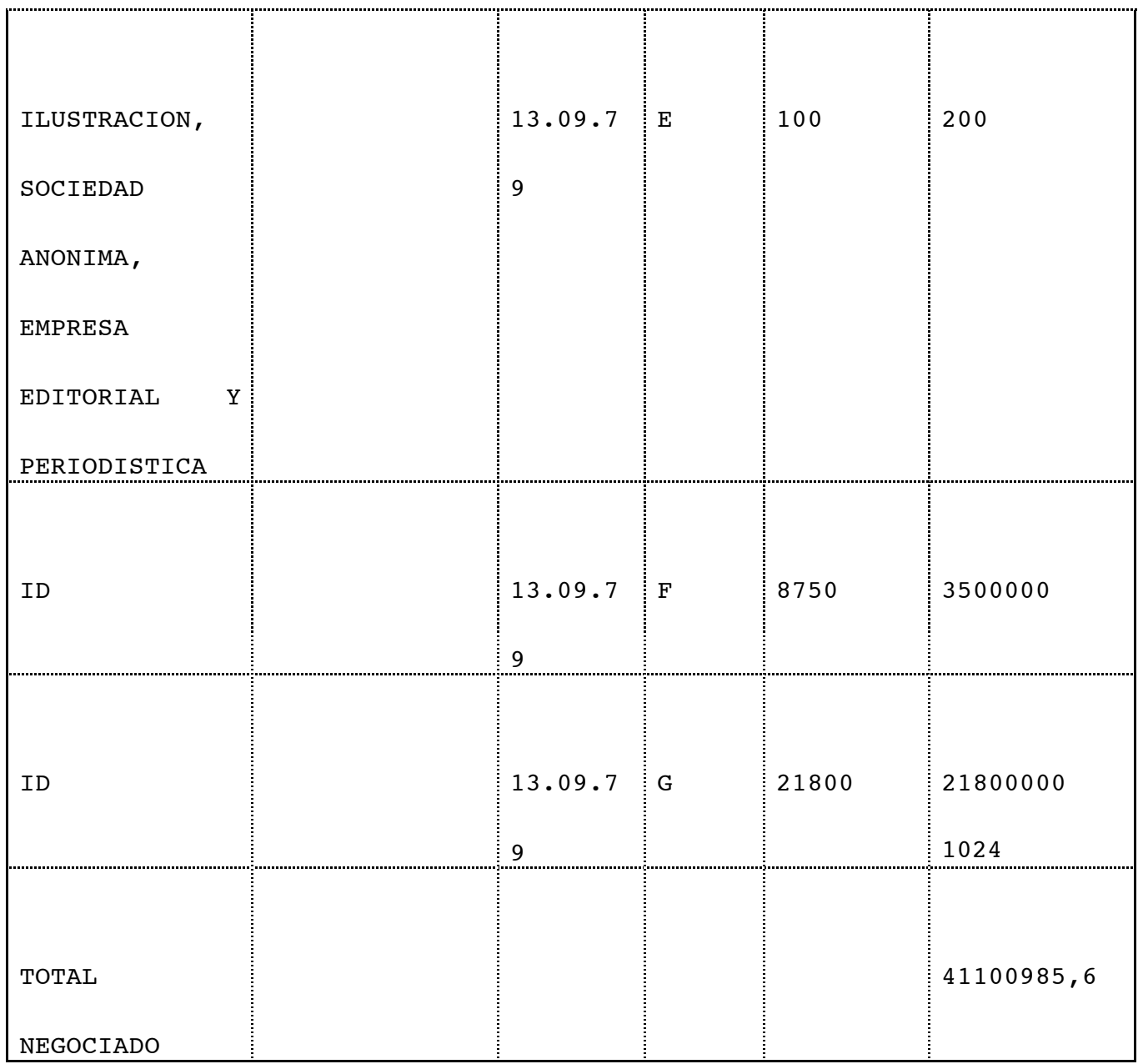

\section{Consejos de Administración}

PRIMER CONSEJO Y PRESIDENTES DEL MISMO ENTRE 1926 y 1943

${ }^{1024}$ Ptas nominales 25.300.200,00. Cambio 94,8586\%. ptas efectivas 23.999.415,00. Impuesto T.P. 132.000,00. Total compra 24.196.317,95. 


\begin{tabular}{|c|c|}
\hline Presidente & Guillermo Gil de Reboleño \\
\hline Vicepresidente & Constantino Mateo González \\
\hline Secretario & Gregorio Merino Pinedo \\
\hline Vocales & Manuel Sánchez Belloso \\
\hline & Antonio Miguel y Romón \\
\hline & José Jalón Semprún \\
\hline
\end{tabular}

En los años siguiente se suceden en la presidencia, sin que consten las fechas:

Presidencia de Joaquín Pérez Agote 29?-31?.

Presidencia de Valentín Arévalo

Presidencia de Rafael Serrano y Serrano (1931-33?) .

Presidencia de Félix Igea 33?-3?.

Presidencia de Francisco Mateo (1936) 36?-37?. 
Apéndices

Presidencia de Eustasio Abril 37?- 39?.

Presidencia de Julio Francia 39?-42?.

Presidencias de Germán AdÁnez 194242-43 y JuAn Misol 1943-451025

1025Cfr. "Escritura pública de aumento de capital y emisión de acciones de "Diario Regional S.A. que autorizó el notario que fue de Valladolid Don Luis Rodríguez de Huidobro el día 19 de febrero de 1943. Autorizada por Francisco Fernández-Prida. Abogado-Notario. Año de 1934. № 114 ", Certificaciones unidas, I, A.P.G.A.M.. 
Presidente

Vicepresidente

Secretario

Buitrago 1027

Vocales

Mariano Escudero de Solís1028

Justo García Sanz

Presidencia de Francisco de Luis 1945-55

1026 Notario (ganó la oposición en febrero de 1922). Decano del Colegio Notarial de Valladolid de 1935 a 1951.

Residió en Valladolid de 1923 a 1953.

Presidente del Real Valladolid (DR 12.V.1944, pág. 3 ).

Cfr. también DR 3.VI.1952, pág. 1, y 28.X.47, pág. 1 .

Destinado a Madrid en febrero de 1953 (Cfr. DR 20.II.1953, pág. 1, col. 7a ).

1027Abogado. Cfr DR VII. 1942 y $4 . x .47$, pág. 4 últ..

Cruz de S. Raimundo de Peñafort en mayo de 1948 .

${ }^{1028}$ Cfr. DR 18.V.1950 págs. 1 y 5, y 3.VI.1952, pág. 1. 
Presidente en funciones ${ }^{1029}$ Mariano Escudero de Solís

$(31.12 .54)$

Consejero Delegado

Vocales

(actúa
Mariano Escudero de Solís.

Germán Adánez Horcajuelo

Juan Misol Matilla

Fco. Javier Martín Abril1030 como Secretario)

PRESIDENCIA DE VÍCtoR JOLÍN DAgUeRRe 55-661031

${ }^{1029}$ Probablemente por inasistencia de Francisco de Luis.

${ }^{1030}$ En mayo de 1948 ingresa en la Real Academia de Bellas Artes de la Purísima (Valladolid). Tiene concedida la orden del Mérito Civil. Medalla de plata de la ciudad de Valladolid en noviembre de 1953 (Cfr. reportaje en DR 25.XI.1953, pág. 6 últ.). Director artístico de "Radio Valladolid" en 1955 (Cfr. DR 25.III.1955, pág. 3). Director de "Radio Valladolid" en marzo de 1957-1959. Premio Nacional de Periodismo Francisco Franco 1961 (Cfr. biografía en DR, 31.XII.1961, págs. 8 y 9 ). Comendador de la Orden del Mérito Civil (1965). Una estadística completa de su producción literaria y periodística en la entrevista publicada el 28.I.1973: 20 libros y dos más en preparación, más de 45.000 artículos.

1031 "Copia de la escritura de ampliación del capital social de “Diario Regional, S.A." otorgada por don Juan Manuel de la Huerta López, en nombre y como representante del Consejo de Administración de dicha sociedad. Valladolid, a 14 de diciembre de 1956, ante D. Salvador Escribano y Escribano, abogado y notario. № 2.179". A.P.G.A.M.. 
Presidente

Consejero Secretario
Víctor Jolín Daguerre

Andrés

Rueda

Salaberry 1032

Consejero Delegado Vicente Picó1033

CONSEJO DE ADMINISTRACIÓN EN DICIEMBRE DE 1958

Presidente

Consejero Secretario
Víctor Jolín Daguerre

Arturo León Alvarez ${ }^{1034}$

CONSEJO DE ADMINISTRACIÓN EN 1960

1032Es también consejero de "Gráficas Andrés Martín S.A.", vocal del Consejo en noviembre de 1957 (Cfr. DR 17.XI.1957, pág. 14).

1033A.H.P.U.V., Sección A.I.S.S., leg. 4698 .

${ }^{1034}$ Es también consejero de "Gráficas Andrés Martín S.A." en noviembre de 1957 (Cfr. DR 17.XI.1957, pág. 14). 


\begin{tabular}{|c|c|}
\hline Presidente & Víctor Jolín Daguerre \\
\hline Vicepresidente & Francisco Pérez de los Cobos \\
\hline Secretario & Arturo León Alvarez \\
\hline \multirow[t]{7}{*}{ Consejeros } & Francisco Mateo Martínez \\
\hline & Francisco Jiménez Huertas \\
\hline & Antonio Pardo Conde \\
\hline & Juan Urrutia \\
\hline & Antonio Gutiérrez Martín \\
\hline & Enrique Casellas Sitjá \\
\hline & Luis Martínez de Velasco \\
\hline
\end{tabular}

CONSEJO DE ADMINISTRACIÓN EN OCTUBRE DE 19641035

1035 "Segunda copia de la escritura de aumento de capital y modificación de Estatutos otorgada por: don José-Ramón Abril Martín, en representación de la Sociedad Anónima Diario Regional" Notaría de D. Miguel Hoyos de Castro. Valladolid. № 2743 de 8 de julio de 1967. A.P.G.A.M. . 
Presidente

asiste por

Vicepresidente

Consejero Delegado Enrique Casellas Sitjá

Secretario

Consejeros enfermedad)
Víctor Jolín Daguerre ( no

Francisco Pérez de los Cobos

Arturo León Alvarez

José Antonio Pardo Conde

Juan María Roger Gallés

Luis Martínez de Velasco

CONSEJO DE ADMINISTRACIÓN EN ABRIL DE $1965^{1036}$

1036 Informe del Gerente al Director General de Prensa de 4 de mayo de 1965. A.H.P.U.V., Sección Cultura, caja 28. 


\begin{tabular}{|c|c|}
\hline Presidente & Víctor Jolín Daguerre \\
\hline Vicepresidente & Francisco Pérez de los Cobos \\
\hline Secretario & Arturo León Alvarez \\
\hline Consejero Delegado & Enrique Casellas Sitjá \\
\hline \multirow[t]{3}{*}{ vocales } & Juan María Roger Gallés \\
\hline & Luis Martínez de Velasco \\
\hline & José Antonio Pardo Conde \\
\hline
\end{tabular}

CONSEJO DE ADMINISTRACIÓN EN MARZO DE $1966^{1037}$

1037 Informe del Gerente de Diario Regional S.A. al Director General de Prensa de 8 de marzo de 1966. A.H.P.U.V., Sección Cultura, caja 28. 


\begin{tabular}{|c|c|}
\hline Presidente & Víctor Jolín Daguerre \\
\hline Vicepresidente & Francisco Pérez de los Cobos \\
\hline Secretario & Arturo León Alvarez \\
\hline Consejero Delegado & Juan María Roger Gallés \\
\hline \multirow[t]{4}{*}{ vocales } & Luis Martínez de Velasco \\
\hline & José Antonio Pardo Conde \\
\hline & José Luis Olaizola Sarriá \\
\hline & Emilio Fernández de Caso \\
\hline
\end{tabular}

Ricardo Puig Pérez de Hinestrosa

CONSEJO DE ADMINISTRACIÓN EN AGOSTO DE 19661038

1038 Informe del Gerente de Diario Regional S.A. al Director General de Prensa de 24 de agosto de 1966. A.H.P.U.V., Sección Cultura, caja 28 . 


\author{
Presidente \\ Víctor Jolín
}

Vicepresidente

vocales

Hinestrosa
vacante por defunción de Daguerre

\author{
Francisco Pérez de los Cobos \\ Juan María Roger Gallés \\ Luis Martínez de Velasco \\ José Antonio Pardo Conde \\ José Luis Olaizola Sarriá \\ Emilio Fernández de Caso \\ Ricardo Puig y Pérez de
}

Felipe Pastor Olmedo

Arturo León Alvarez

José Luis Gutiérrez Semprún

José Luis del Saso Vega

Angel Mateos Ruiz

José Ramón Pérez Barrio 
Pedro Pardo Mazariegos

\author{
Antonio Gimeno Ortiz-Casado
}

Adolfo Sánchez García

Moisés Vaquero Motos

CONSEJO DE ADMINISTRACIÓN EN MARZO DE 19671039

1039 Registro de Empresas Periodísticas, con número 196, tomo 3, Sección Personas Jurídicas, Folio 156, inscripción 1ạ. Oficio de la Dirección General de Prensa, Servicio Régimen de Empresas y Medios Informativos, Sección Empresas, al Gerente de Diario Regional S.A., de 18 de septiembre de 1967, hoja 2. A.H.P.U.V., Sección Cultura, caja 28 . 


$\begin{array}{lc}\text { Presidente } & \text { vacante por defunción de } \\ \text { Víctor Jolín } & \text { Daguerre }\end{array}$

Vicepresidente Francisco Pérez de los Cobos (Valladolid)

vocales

Juan

María

Roger

Gallés

(Valladolid)

Luis Martínez de Velasco

(Valladolid)

José Antonio Pardo Conde

(Valladolid)

José Luis Olaizola Sarriá

(Madrid)

Emilio Fernández de Caso (Madrid)

Felipe Pastor Olmedo (Valladolid)

Arturo León Alvarez (Valladolid)

José Luis Gutiérrez Semprún

(Valladolid) 


$$
\text { José Luis del Saso Vega }
$$

(Valladolid)

Angel Mateos Ruiz (Valladolid)

José Ramón Pérez Barrio

(Valladolid)

Pedro

Pardo

Mazariegos

(Valladolid)

Antonio Gimeno Ortiz-Casado

(Valladolid)

Adolfo

Sánchez

García

(Valladolid)

Moisés Vaquero Motos (Valladolid)

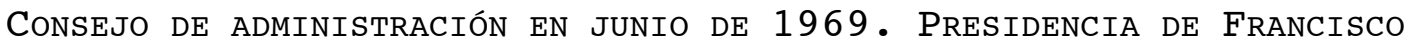
PÉRez de LOS COBOS 1040

1040Hoja 1 del oficio de la Dirección General de Prensa, Sección Empresas al Consejero-Delegado de DR S.A. de 22 de febrero de 1972 comunicando la inscripción 2 a en el folio 247, tomo 27 del Registro de Empresas Periodísticas. A.H.P.U.V., Sección Cultura, caja 28. 
Presidente

Secretario

Consejero-Delegado José Luis Martín Destrieux

vocales

20 de

\author{
Arturo León Alvarez
}

Francisco Pérez de los Cobos

José Luis Gutiérrez Semprún

José Luis del Saso Vega

Antonio Gimeno Ortiz-Casado

Adolfo Sánchez García

Moisés Vaquero Motos

Consejo DE AdMinistración EN MAYo DE 1971. PREsidencia de Emilio FERNÁNDEZ DE CASO 1041

1041oficio de la Dirección General de Prensa, Servicio Empresas, al Consejero-Delegado de DIARIO REGIONAL, S.A. de 22 de febrero de 1962, pág.. 1. A.H.P.U.V., Sección Cultura, caja 27 
Presidente

Secretario
Emilio Fernández de Caso1042

\author{
Arturo León Álvarez 1043
}

Consejero Delegado José Ramón Abril Martín1044

vocales

Diego Bando Casado1045

\begin{abstract}
1042 Catedrático excedente de Escuelas de Comercio y director general de MOVIERECORD, S.A., domiciliado en Madrid. Ha desempeñado el cargo de Administrador del Diario de León, de donde pasó a desempeñar puestos administrativos en S.A.R.P.E. y P.E.S.A.. Cfr. informe del Gerente de Diario Regional, S.A. al Delegado Provincial del Ministerio de Información y Turismo en Valladolid, e informe por teletipo del Delegado Provincial del M.I.T. al Director General del Prensa de 2 de junio de 1971, en A.H.P.U.V., Sección Cultura, caja 28.
\end{abstract}

1043 Perito Industrial y director de empresa, domiciliado en Valladolid. Cfr. informe del Gerente de Diario Regional, S.A. al Delegado Provincial del Ministerio de Información y Turismo en Valladolid, A.H.P.U.V., Sección Cultura, caja 28.

1044 Licenciado en Derecho, domiciliado en Valladolid, era gerente de Diario Regional, S.A.. Cfr. informe del Gerente de Diario Regional, S.A. al Delegado Provincial del Ministerio de Información y Turismo en Valladolid, e informe por teletipo del Delegado Provincial del M.I.T. al Director General del Prensa de 2 de junio de 1971, en A.H.P.U.V., Sección Cultura, caja 28.

1045 Licenciado en Derecho y Profesor Mercantil, domiciliado en Madrid. Procede de PESA. Su misión será, al parecer, la de enlace entre el Presidente $y$ la publicación a efectos de control administrativo interior. Cfr. informe del Gerente de Diario Regional, S.A. al Delegado Provincial del Ministerio de Información y Turismo en Valladolid, e informe por teletipo del Delegado Provincial del M.I.T. al Director General del Prensa de 2 de junio de 1971, en A.H.P.U.V., Sección Cultura, caja 28.

1046 Abogado del Estado y Delegado del Gobierno en la Confederación Hidrográfica del Duero, domiciliado en Valladolid. Cfr. informe del Gerente de Diario Regional, S.A. al Delegado Provincial del Ministerio de Información y Turismo en Valladolid, A.H.P.U.V., Sección Cultura, caja 28 . 
1047 Oficio de la Dirección General de Prensa, Servicio Empresas, al Consejero-Delegado de DIARIO REGIONAL, S.A. de 9 de enero de 1974, pág. 1. Cfr. también la inscripción $6 \underline{a}$ en el Registro de Empresas Periodísticas, folio 248, Tomo 27, en A.H.P.U.V., Sección Cultura, caja 27.

En el certificado extendido por el Secretario del Consejo de Administración se señala que en la Junta General ordinaria de accionistas celebrada en la fecha que se cita se tomaron por unanimidad entre otros los siguientes acuerdos:

"2․- Ratificar la aceptación de la renuncia del cargo de Consejero de D. RAMON ABRIL MARTIN, aceptada en su día por el Consejo de Administración así como aceptan las dimisiones presentadas en este acto por los Consejeros D. DIEGO BANDO CASADO y D. JOSE LUIS GUTIERREZ SEMPRUN .

"30.- Ratificar el nombramiento del Consejero D. CARLOS RODRÍGUEZ-LAFORA ZAVALA, español, mayor de edad, casado, Licenciado en Ciencias Económicas, con domicilio en Madrid (...) hecho provisionalmente por el Consejo. D. CARLOS RODRÍGUEZ-LAFORA ZAVALA, presente en este acto, renuncia ante la Junta a su cargo de Consejero, siendo aceptada la misma

"Nombrar nuevos Consejeros de la Sociedad a D. JULIO FERNANDEZCUETO APARICIO, español, mayor de edad, casado, Profesor Mercantil, con domicilio en Madrid (...), y a D. EUGENIO GALDÓN BARBERÁN, español, mayor de edad, casado, Ingeniero, con domicilio en Madrid (...).

"5o.- Autorizar al Consejo de Administración para que designe, si lo considera conveniente, un nuevo consejero. Si el Consejo de Administración hiciera uso de la mencionada autorización, el nuevo Consejero formará parte integrante del Consejo desde el momento de su designación, sin perjuicio de su ratificación en la Junta General de accionistas. (...)."

"Escritura de incorporación del saldo de la Cuenta de Regularización de Balance al capital y reducción de capital social.- otorgada por don Arturo León Alvarez ("Diario Regional, S.A.")", Notaría de D. Francisco Pastor Moreno, Valladolid, 20 de marzo de 1973, no 385. A.P.G.A.M.. Cfr. también inscripción $9 \underline{a}$ en el Registro de Empresas Periodísticas, en A.H.P.U.V., Sección Cultura, caja 27. 
Presidente

Secretario

vocales
Emilio Fernández de Caso

Arturo León Álvarez

Julio Fernández-Cueto Aparicio

Eugenio Galdón Barberán

CONSEJO DE ADMINISTRACIÓN EN JUNIO DE 19741048

1048En sesión celebrada el 25 de junio de 1974 la Junta General ordinaria de accionistas adoptó entre otros los siguientes acuerdos:

"1‥- Aceptar la renuncia que a sus cargos de ConsejeroPresidente y Consejero respectivamente tenían formuladas Don Emilio Fernández de Caso y Don Julio Fernández-Cueto Aparicio. (...)"

En la misma Junta fueron nombrados nuevos Consejeros con lo que el Consejo quedó como se indica en el texto.

"Primera copia de la escritura de nombramiento de Consejeros de la Sociedad Mercantil Anónima "Diario Regional, Sociedad Anónima", otorgada por Don Arturo León Alvarez, como Presidente del Consejo de Administración", Ramón V. Modesto Chaumel, Notario, Valladolid, 12 de mayo de 1976, no 562. A.P.G.A.M.. Cfr. también inscripción en el Registro de Empresas Periodísticas, Tomo 27, sección personas jurídicas, folio 249, inscripción 10ạ. A.H.P.U.V., Sección Cultura, caja 27 . 
Presidente

Consejero Delegado Juan Domínguez $z^{1049}$
Secretario

Consejeros

Consejeros
Arturo León Álvarez

Pablo de Villanueva
José Hidalgo Ortega1050

\author{
Eugenio Galdón Barberán
}

Ramiro Nieto Bermejo1051

CONSEJO DE ADMINISTRACIÓN EN JULIO DE $1977^{1052}$

\begin{abstract}
${ }^{1049}$ Soltero, periodista y vecino de Madrid.
${ }^{1050}$ Casado, abogado y vecino de Madrid.

${ }^{1051}$ Soltero, Titulado Mercantil y vecino de Madrid.

1052El 29/7/1977 el Consejo de Administración acuerda conferir poder tan amplio como sea necesario a los consejeros Jerónimo Gallego Pérez, Manuel Casado Gómez y Agustín Díez Hierro, mancomunadamente dos cualesquiera de ellos, y revocar el poder concedido a Juan Pablo de Villanueva con fecha de 12 de mayo de 1976; tales acuerdos han sido adoptados con la intervención y asesoramiento del letrado en ejercicio José Antonio Parada, del Colegio de Valladolid.

"Copia del poder y revocación de otro, otorgado por: Don Jerónimo Gallego Pérez, en nombre y representación de la Sociedad Anónima Diario Regional", Notaría de D. Miguel Hoyos de Castro, Valladolid, 29 de agosto de 1977, no 3158. A.P.G.A.M..
\end{abstract}


Constan como consejeros en esta fecha:

Presidente

Consejero Secretario

Consejeros

\author{
Arturo León Alvarez
}

Jerónimo Gallego Pérez ${ }^{1053}$

Manuel Casado Gómez

\section{Agustín Díez Hierro}

Nicolás de Laurentis Vilches

CONSEJO DE ADMINISTRACIÓN EN FEBRERO DE 19791054

1053Nacido en 1926 en Zamora, estudió Filosofía, Magisterio y Derecho, titulado en periodismo en 1949 .

Abogado. Redactor de DR en 1949-53. Vicepresidente de la Asociación de la Prensa de Valladolid en febrero de 1958 (Cfr. DR 6.II.1958, pág. 3, col. 1a y 2â) sigue en el mismo cargo en 1977, año en que se presenta a las elecciones al senado por Alianza Popular.

${ }^{1054} \mathrm{En}$ sesión celebrada por el consejo de administración el 24 de febrero de 1979, se acepta la dimisión de los consejeros Arturo León Álvarez, Jerónimo Gallego Pérez, Nicolás de Laurentis Vilches, y Agustín Díez Hierro. "Copia de la escritura de nombramiento de Consejo de Administración y poder, por: Diario Regional, S.A.", Ramiro Barbero Arranz, Notario de Valladolid, 14 de marzo de 1979, no 580 . A.P.G.A.M.. Los poderes de representación de la empresa y para actuar en nombre de ella se otorgan a favor de Manuel Casado. 


\author{
Presidente Manuel Casado Gómez \\ Consejero Secretario Rafael Rodríguez Zapatero1055 \\ Ramón Abril Martín
}

Miguel Angel Casado Gómez

María Aurora Viloria Nieto1056

Entrada de Auger en LA Gestión de Diario REgional

El 4 de septiembre de 1979 el Consejo de Administración de Diario Regional, S.A., acuerda conceder poderes como Apoderado General del Periódico a Francisco Javier de Qintana Justafré (Abogado residente en Barcelona), Antonio Herrero Sáiz (Madrid) y Luis Fernández Briceño (Economista de Madrid), con carácter solidario e indistinto, por lo que serán ellos los que lleven la

${ }^{1055}$ Colaborador de DR desde diciembre de 1967, redactor en la última etapa. Milita en el partido Carlista en 1977.

${ }^{1056}$ Licenciada en Derecho, recibe el título en enero de 1966 (Cfr. DR 26.I.1966, pág. 11).

Directora en funciones desde el 26.x.1978, sustituyendo a Muñoz García. A partir del 27.II.1979 figura ya como directora. 
dirección de la compañía. Esta decisión es "una de las primeras consecuencias operativas del documento suscrito entre D. Manuel Casado Gómez y D. Sebastián Auger Duró en Madrid el 10 de agosto de $1979{ }^{1057}$.

Con la misma fecha otro certificado del Consejero Secretario acredita la transmisión de acciones de Diario Regional, S.A. "a favor de las entidades mercantiles, todas ellas empresas periodísticas, ILUSTRACION, Sociedad Anónima, BARCELONA PRESS, Sociedad Anónima, y EDICIONES CATALUÑA EXPRESS, Sociedad Anónima (...) »1058

ApÉNDice 4.- Aspectos eConómicos

Tarifas de suscripción

${ }^{1057}$ Certificación del acuerdo tomado por el Consejo de Administración en la fecha citada de 5 de septiembre de 1979. A.P.G.A.M.. 1058 Ibid. 
Apéndices

En 1931:

Capital trimestre . 6 ptas.

semestre .. 12 ptas.

año .....24 ptas.

Fuera trimestre . 7,50 ptas.

semestre..14 ptas.

año .....26 ptas. 
Apéndices

Desde julio de 1935:

Capital mes ......2,50 ptas.

\author{
Fuera trimestre..8 ptas \\ semestre ..16 ptas. \\ por año ...30 ptas.
}


Cambio de los precios en julio de $1938^{1059}$ :

\author{
Capital mes ......2,75 ptas. \\ trimestre . 8,25 ptas. \\ semestre ..16, 50 ptas. \\ año ......33,0 ptas.
}

Fuera trimestre..9,00 ptas.

semestre ..17,50 ptas.

año $. . . .34,0$ ptas.

${ }^{1059}$ Con motivo del aumento de precio de los periódicos los domingos para la recaudación que se destina a beneficio de la prensa para el combatiente. 
Apéndices

En septiembre de 1941:

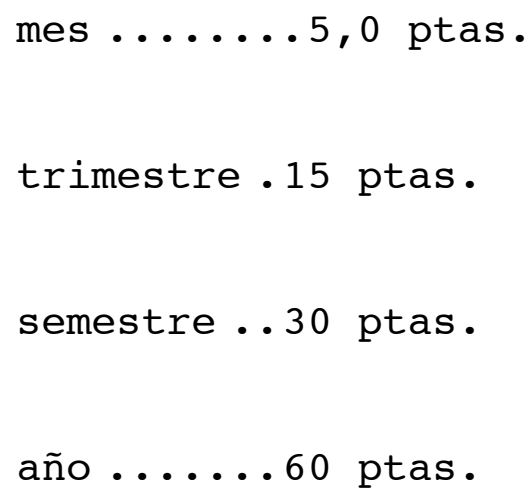

En 1944 se declara que la difusión se realiza en un 45\% mediante suscripciones ${ }^{1060}$.

En noviembre de 1950 :

mes ......15,50 ptas.

${ }^{1060}$ Cfr. Anuario de la Prensa Española. Año II. 1945-46., Ministerio de Educación Nacional, Subsecretaría de Educación Popular, Madrid, 1945, pág. 46. 
Apéndices

En noviembre de 1955:

mes ....20 ptas.

trimestre.60 ptas. 
Apéndices

En septiembre de 1967:

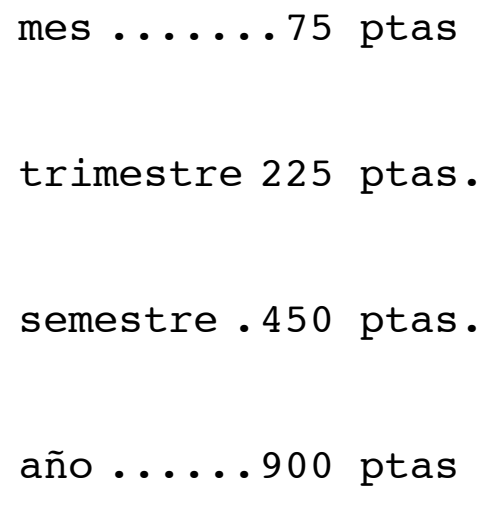

En 1978:

trimestre 930 ptas.

semestre 1860 ptas.

año ....3720 ptas. 
Fin de la contrata con "Publicitas" en junio de 1932: se comunica en un anuncio el 16 de junio de 1932.

La publicidad es gestionada de nuevo por una agencia Publicidad Anuncie- en 1941. En 1946 es publicidad "Expu» la que lo gestiona, su propietario es A. de la Fuente Ruiz •

Tarifa de anuncios breves en enero de 1939:

Hasta 7 líneas 1,10 ptas.

Cada línea más $\quad 0,15$ ptas.

Tarifa de anuncios breves en 1941:
Hasta 25 palabras 2,00 ptas.
Cada palabra más
0,20 ptas.

Tarifa de anuncios por palabras en 1943: 
Hasta 10 palabras 0,60 ptas.

Cada palabra más $\quad 0,10$ ptas.

En agosto de 1944 se pon en marcha una promoción por la que se pueden publicar anuncios simultáneamente en los siguientes periódicos: Diario Regional de Valladolid, El Ideal Gallego de La Coruña, Ya de Madrid, Ideal de Granada, La Verdad de Murcia, Hoy de Badajoz. A 2 ptas palabra. Sólo en Diario Regional, 10 céntimos palabra.

En $1944^{1061}$ :
Una página
750 ptas.
El milímetro 0,45 ptas.
Por palabra 0,10 ptas.

${ }^{1061}$ Cfr. Anuario de la Prensa Española. Año II. 1945-46., Ministerio de Educación Nacional, Subsecretaría de Educación Popular, Madrid, 1945, pág. 46 . 
Apéndices

En 1947:
Hasta 10 palabras
1,50 ptas.
Cada palabra más
0,15 ptas.

En 1948:

Hasta 10 palabras 2 ptas.

Cada palabra más 0,20 ptas.

En 1951:
hasta 10 palabras
2,50 ptas
Cada palabra más
0,25 ptas.

Tarifas de publicidad en 1953:
Una página
3.000 ptas.
Un milímetro
1,20 ptas.
Una palabra
0,25 ptas. 
Tarifa de anuncios por palabras en 1961:

Cada palabra 0,60 ptas. Mínimo, 6 ptas.

Tarifa de anuncios clasificados en 1965:

Cada palabra 1 pta.. Mínimo, 10 palabras.

Tarifa de anuncios por palabras en 1974

Cada palabra 1,50 ptas.. Mínimo 10 palabras.

Tarifa de anuncios por palabras desde octubre 1974

Cada palabra 3 ptas.. Mínimo 10 palabras.

Tarifa de anuncios por palabras en 1978:

Cada palabra 4 ptas.. Mínimo 10 palabras. 
Con recuadro

10 ptas./mm. Domingos, martes $y$

festivos, 12 ptas./mm.

Tarifas de publicidad en 1970 y 1978 .

«TARIFA DE PUBLICIDAD DE DIARIO REGIONAL.

VALLADOLID, $1^{\circ}$ DICIEMBRE 1970

MARTES Y FESTIVOS

RESTO SEMANA

SECCIÓN GENERAL PESETAS POR mm

PESETAS POR mm

Donde convenga al diario

5,50

4,50

En última página

7,50

6,25

FINANCIEROS

Convocatorias, emisiones de

acciones, obligaciones y todo

anuncio de índole bancaria o

financiera

9,00

9,00 
Apéndices

\section{OFICIALES}

Anuncios de organismos

oficiales

6,00

5,00

ENTREFILET

A insertar entre texto

9,00

7,00

ECOS DE SOCIEDAD

Notas de sociedad

4,50

3,50

MANCHETA

En primera página

8,00

8,00

ESPECTACULOS

Reclamos

5,00

4,00

Gacetillas Cine, Teatros,

Circos, Toros, deportes en

general

7,00

6,00

ESPACIOS FIJOS

Una página

$10.000,00$

$9.000,00$ 
Apéndices

Media página

$5.400,00$

$4.500,00$

Cuarto de página

$2.800,00$

$2.400,00$

ANUNCIOS POR PALABRAS

Cada palabra

1,50

Demandas de trabajo

0,40

Mínimo 10 palabras.

\section{ESQUELAS}

1 columna de ancho x $70 \mathrm{~mm}$ alto210,00

\begin{tabular}{|c|c|c|c|c|c|c|}
\hline 1 & " & " & " & x 90 & " & 360,00 \\
\hline & " & $"$ & " & x 70 & " & 630,00 \\
\hline & " & $"$ & " & x 90 & $"$ & $1.080,00$ \\
\hline & " & " & " & x 150 & " & $2.700,00$ \\
\hline & " & " & " & x 190 & " & $4.800,00$ \\
\hline
\end{tabular}

TESTIMONIOS DE GRATITUD

Publicando esquela

3,00

Sin publicar esquela

5,00 
La administración del periódico se reserva el derecho de publicar los anuncios en la fecha indicada o en otra próxima, de acuerdo con las disponibilidades de espacio, así como el de rechazar todo anuncio cuya publicación no le parezca pertinente.

Los anuncios que deban ser publicados en un lugar elegido por el anunciante y que no figuren en la tarifa, se aplicará un recargo del 50\%.

Todo anuncio abonará por inserción impuesto sobre el Tráfico de Empresas $(2,70 \%)$.

La publicidad en los números extraordinarios se tarifará como la de los días festivos.»1062

1062 Folleto informativo editado por Diario Regional, A.H.P.U.V., Sección Cultura, caja 27. 
Apéndices

Tarifas a 1 de noviembre de 1978 .

«TARIFA DE PUBLICIDAD DE DIARIO REGIONAL.

VALLADOLID, $1^{\circ}$ NOVIEMBRE 1978

MARTES Y FESTIVOS RESTO SEMANA

SECCIÓN GENERAL PESETAS POR mm

PESETAS POR mm

Donde convenga al diario

15

12

En última página

25

20

FINANCIEROS

Convocatorias, emisiones de

acciones, obligaciones y todo

anuncio de índole bancaria o

financiera

1 Página

50000

50000

OFICIALES 
Apéndices

Anuncios de organismos

oficiales

15

15

Expropiaciones

20

20

ESPECTACULOS

Reclamos

15

12

Gacetillas (por mm.)

20

20

\section{ESPACIOS FIJOS}

Una página

25000

20000

Media página

13000

11000

Cuarto de página

7000

5500

ANUNCIOS POR PALABRAS

Cada palabra

4

Demandas de trabajo

3

Mínimo 10 palabras.

ESQUELAS 
Apéndices

100 mm 1 columna

1500

$100 \mathrm{~mm} 2$ columnas

3500

$100 \mathrm{~mm} 3$ columnas

5000

$100 \mathrm{~mm} 4$ columnas

7000

$100 \mathrm{~mm} 5$ columnas

10000

TESTIMONIOS DE GRATITUD

Publicando esquela

10

Sin publicar esquela

La administración del periódico se reserva el derecho de publicar los anuncios en la fecha indicada o en otra próxima, de acuerdo con las disponibilidades de espacio, así como el de rechazar todo anuncio cuya publicación no le parezca pertinente.

Publirreportajes: 50\% de recargo

Los anuncios que deban ser publicados en un lugar elegido por el anunciante y que no figuren en la tarifa, se aplicará un recargo del $50 \%$. 
Todo anuncio abonará por inserción impuesto sobre el Tráfico de Empresas $(2,70 \%)$

\author{
La publicidad en los números extraordinarios se \\ tarifará como la de los días festivos \\ Los precios de esta tarifa se entienden por una \\ inserción.
}

TARIFAS DE PUBLICIDAD EN SUPLEMENTO DOMINICAL

BLANCO Y NEGRO

Una página 12000 ptas.

Media página 6500 ptas.

Faldones de página

(40 mm. X 3 cols.) 3000 ptas

Una columna 5000 ptas."1063

1063 Folleto informativo editado por Diario Regional, A.P.G.A.M.. Hay también una escala de primas y descuentos. 
Producción facturada (1974-79).

\begin{tabular}{|r|r|}
\hline AÑNO & $\begin{array}{r}\text { PUBLICIDAD } \\
\text { FACTURADA }\end{array}$ \\
\hline & 10755167 \\
\hline 1974 & 13372998 \\
\hline 1975 & 16373767 \\
\hline 1976 & \\
\hline 1977 & 19631958 \\
\hline & \\
\hline 1978 & 21414729 \\
\hline
\end{tabular}

Desglose de producción de publicidad en 1976 y 1978. 


\begin{tabular}{|c|c|c|c|c|}
\hline & $\begin{array}{c}\text { LIQUIDO } \\
\text { FACTURADO } \\
76 \\
\end{array}$ & $\begin{array}{c}\% \\
\text { XII } \\
76 \\
\end{array}$ & $\begin{array}{c}\text { LIQUIDO } \\
\text { FACTURADO } \\
78 \\
\end{array}$ & $\begin{array}{c}\circ \\
\text { XII. } \\
78 \\
\end{array}$ \\
\hline AGENCIAS MADRID & 336564 & 20,4 & 220240 & 11,1 \\
\hline AGENCIAS BARCELONA & 41671 & 2,5 & 182818 & 9,2 \\
\hline $\begin{array}{l}\text { ALMERIA Y SAN } \\
\text { SEBASTIAN }\end{array}$ & & & 33983 & 1,71 \\
\hline $\begin{array}{l}\text { TOTAL AGENCIAS } \\
\text { NACIONALES }\end{array}$ & 378235 & 22,9 & 437041 & 22,1 \\
\hline AGENCIAS VALLADOLID & 925023 & 56,1 & 1006308 & 50,8 \\
\hline DIRECTO & 347269 & 21 & 539472 & 27,2 \\
\hline $\begin{array}{l}\text { TOTAL PRODUCCION } \\
\text { DICIEMBRE }\end{array}$ & 1650527 & 100 & 1982821 & 100 \\
\hline $\begin{array}{l}\text { TOTAL RESUMEN DEL } \\
\text { AÑO }\end{array}$ & 12297182 & & 16378853 & \\
\hline
\end{tabular}


Apéndices

Balance de situación a 30 de junio de 19791064 .

${ }^{1064}$ Documento del mismo título en A.P.G.A.M.. 


\section{ACTIVO}

INMOVILIZADO MATERIAL ............50.179.278,06

Edificios y otras construcciones 15.662.120,29

Maquinaria, instalaciones y utillaje31.813.964,77

Elementos de transporte......488.075,00

Mobiliario y enseres .......2.215.118,00

INMOVILIZADO INMATERIAL ............ 15.580.231,19

Gastos de const. y ampliación de capital ....3.578.216,90

EXISTENCIAS 
Apéndices

Materias primas ...........659.146,76

Subvenciones (papel y 2 ptas.) 2.500.000,00

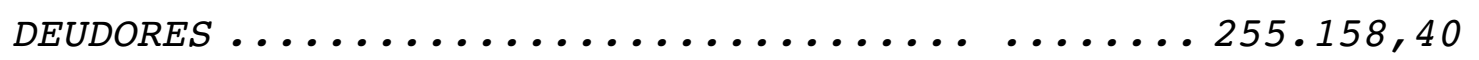

Clientes venta............255.158,40

CUENTAS FINANCIERAS ..................... $500.000,00$

Caja y Bancos c/c ........ -1.500.000,00

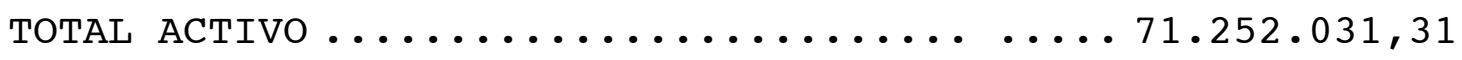


Apéndices

\section{PASIVO}

CAPITAL Y RESERVAS . $63.252 .000,00$

Capital social .........66 63.252.000,00

DEUDAS A PLAZO LARGO Y MEDIO ........... 19.500.000,00

Préstamos Caja A. Provincial . 6.000.000,00

Acreedores ............... 13.500.000,00

DEUDAS A PLAZO CORTO ...............22.000.400,00

Proveedores ............... 7.000.400,00

Remuneraciones pendientes de pago $4.500 .000,00$

Organismos de la Seguridad Social6.000.000,00 
Apéndices

Hacienda Pública........4 4.500.000,00

RESULTADOS ........................ $33.500 .368,69$

Pérdidas y ganancias ejercicios anteriores

y a 30 de junio de $1979 \ldots-33.500 .368,69$

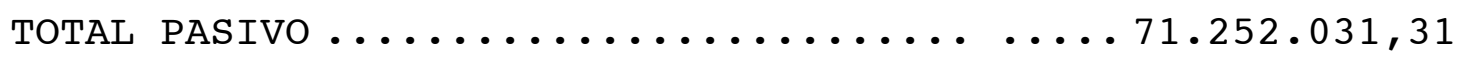

ApÉndice 5.- DiRECTORES, REDACTORES JEFE Y EQUiPOS DE REDACCión.

Directores 
Nicolás Santos de Otto, últimos años 20 .

Oscar Pérez Solís, desde mediados de 1930 a junio de 1931.

Rafael Serrano y Serrano, durante las elecciones de 1931.

Felipe Salazar Urrizola, 1931-noviembre de 1933.

Ricardo Martínez y Fernández, interino, noviembre de 1933 - agosto de 1935 .

Ignacio Valverde Mucientes, agosto de 1935- marzo de 1939

Francisco Javier Martín Abril, marzo de 1939-1952. 
Manuel Santaella, 1952-1955.

Jesús María Zuloaga y Zuloaga, junio de 1955-febrero de 1957 .

José Luis Cebrián Boné, enero de 1957-septiembre de 1959.

Manuel Fernández Areal, septiembre de 1959-octubre de 1965.

José Tallón García, octubre de 1965 a 12 de septiembre de 1967 .

Tomás Santos Corchero, 12 de septiembre de 1967 - 21 de diciembre de 1971. 
Fernando de la Torre de la Orden, interino, 21 de diciembre de 1971- 1 de mayo de 1972 .

Esteban Greciet Aller: 1 de mayo de 1972- 20 de junio de 1974 .

Ramón García Domínguez, interino desde el 20 de junio al 20 de julio de $1974^{1065}$.

Ignacio Bel Mallén: 20 de julio de 1974- 8 de agosto de 1977 .

José de la Fuente Mendive, director en funciones del 9 de agosto de 1977 al 9 de octubre del mismo año.

Pedro Muñoz García, octubre de 1977- octubre de 1978.

${ }^{1065} \mathrm{Cfr}$. inscripción en el Registro de Empresas Periodísticas, Tomo 27, sección personas jurídicas, folio 249, inscripción 10 a. A.H.P.U.V., Sección Cultura, caja 27 . 
Apéndices

María Aurora Viloria Nieto, interina desde el 26 de octubre de 1978. A partir del 27 de febrero de 1979 figura ya como directora, hasta el 7 de marzo de 1980 .

Redactores jefe 
Ricardo Martínez y Fernández ${ }^{1066}$.1912-1937

Mariano Benito Pardo (interino) .1937-1939

Angel de Pablos ...............1939-1944

Luis Calabia Ibáñez ...........1944-1945

Félix Antonio González González .1945-1953

Manuel Pérez Santaella (subdirector) 1949-1952

Enrique Santos Herrera ......... 1953-1964

Tomás Santos Corchero .........1964-1967

Fernando de la Torre de la Orden 1967-1973

Ramón García Domínguez ........ 1973-1975

${ }^{1066}$ Nacido en Santiago de Compostela el 9 de octubre de 1879, cursó estudios en la Universidad Pontificia de Comillas, y se dedicó luego al periodismo en medios católicos. Fue redactor de El Castellanode Burgos de marzo a diciembre de 1908, de Diario de Galicia, periódico católico de Santiago de Compostela, de enero hasta marzo de 1909 en que se convirtió en director del periódico, puesto que ocupó hasta abril de 1912, en que pasa a trabajar en El Noticiero, diario católico de Vigo, en el que será director interino de julio a octubre del mismo año. El 15 de noviembre se incorpora a Diario Regional como redactor jefe, cargo que ocupa hasta su muerte, ocurrida el 18 de diciembre de 1937. En ese momento era el más antiguo de la plantilla. En varias ocasiones desempeñó interinamente el cargo de director de la publicación. Poco antes de morir había sido nombrado gerente de La Industria Harinera Castellana, revista que se publicaba también en Valladolid. Cfr. su biografía en la necrológica publicada en DR, 19/12/1937, pág. 4 . 
Apéndices

José María Esteban ............1975-1978

\section{Equipos de redacción}

Plantilla en $1943^{1067}$

$\mathrm{N}^{\mathrm{o}}$ de carnet

Mariano Benito Pardo

Gerardo Serrano Fernández

Gregorio Leandro Pérez Gómez

Francisco de Raimundo Urueña

${ }^{1067}$ Delegación Nacional de Prensa, Anuario Estadístico de la Prensa Española. Año I. 1943-44., Delegación Nacional de Prensa, Madrid, 1944, págs. 30-31. Se indica que se encargan de los editoriales el director $y$ el redactor que se señala, y que el redactor jefe es también redactor deportivo y confeccionador. 
Apéndices

Plantilla en 19441068

Mariano Benito Pardo

secretario de redacción

Gregorio Leandro Pérez Gómez

Miguel Montalvo

Francisco de Raimundo Urueña

Antolín Gutiérrez cuñado

Gerardo Serrano Fernández

1068Anuario de la Prensa Española. Año II. 1945-46., Ministerio de Educación Nacional, Subsecretaría de Educación Popular, Madrid, 1945, pág. 46 . 
Apéndices

Plantilla en $1945^{1069}$

\section{REDACTORES}

Francisco Javier Martín Abril director $\quad 1.580,00$

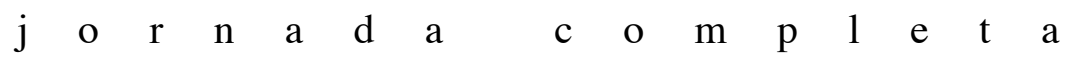

Luis Calabia Ibáñez

(hasta la fecha

Redactor Jefe,

ahora Redactor de $1^{\text {a }}$ ) $583,30 \quad$ media jornada

Félix Antonio González

Redactor Jefe

$1.100,00 \quad$ jornada

$\begin{array}{llllllll}c & o & m & p & l & \text { e } & \text { t } & \text { a }\end{array}$

Gerardo Serrano Fernández (hasta la fecha

Redactor de $2^{\text {a }}$,

ahora Redactor de $1^{\text {a }}$ ) $\quad 583,30 \quad$ media jornada

Mariano Benito Pardo

Redactor de $2^{\mathrm{a}}$

577,92

media jornada

Francisco de Raimundo

Redactor de $2^{\mathrm{a}}$

577,92

media jornada

Miguel Montalvo Jambrina

Redactor de $2^{\mathrm{a}}$

$815,00 \quad$ jornada

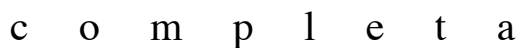

1069 "Plantilla del personal..." Sindicato Provincial del Papel, Prensa y Artes Gráficas - Valladolid. A.H.P.U.V., Sección A.I.S.S., caja 4.694. 


$\begin{array}{lrrr}\text { Antolín Gutiérrez Cuñado } & \text { Redactor de } 2^{\mathrm{a}} & 545,00 & \text { media jornada } \\ \text { Leandro Pérez } & \text { Redactor de } 2^{\mathrm{a}} & 577,92 & \text { media jornada }\end{array}$

Plantilla en 19491070

Francisco Javier Martín Abril Director

Manuel Pérez Santaella

Subdirector

Mariano Benito Pardo

Redactor

Félix Antonio González González

Redactor

Antolín Gutiérrez Cuñado

Redactor

Miguel Montalvo Jambrina

Redactor

Leandro Pérez Gómez

Redactor

José Luis Pérez Herrero

Redactor

Francisco de Raymundo Urueña

Redactor

Enrique Santos Herrera

Redactor

1070 "Nota de los productores que Diario Regional S.A. de Valladolid entrega a la Delegación de Sindicatos del Papel Prensa y Artes gráficas" de fecha 16 de septiembre de 1949. A.H.P.U.V., Sección A.I.S.S., caja 4.693 . 
Apéndices

Plantilla en $1950^{1071}$

NOMBRE CATEGORIA ALTA EN ALTA EN

PROFESIONAL LA EMPRESA L A

$\begin{array}{lllllllll}\text { C } & \text { A } & \text { T } & \text { E } & \text { G } & \text { O } & \text { R } & \text { I } & \text { A }\end{array}$

Félix Antonio González González Redactor jefe $\quad 01.02 .45 \quad 01.07 .45$

$\begin{array}{lll}\text { Enrique Santos Herrera } & \text { Redactor } 1^{\mathrm{a}} \quad 15.12 .45 & 15.12 .45\end{array}$

$\begin{array}{lll}\text { Mariano Benito Pardo } & \text { Redactor } 2^{\mathrm{a}} \quad 10.11 .10 & 10.11 .10\end{array}$

Francisco J. de Raymundo Urueña Redactor $2^{\mathrm{a}} \quad 01.10 .26 \quad 01.10 .26$

$\begin{array}{llll}\text { Miguel Montalvo Jambrina } & \text { Redactor } 2^{\mathrm{a}} \quad 01.01 .36 & 01.01 .36\end{array}$

$\begin{array}{llll}\text { Antolín Gutiérrez Cuñado } & \text { Redactor } 2^{\mathrm{a}} & 01.10 .38 & 01.10 .38\end{array}$

$\begin{array}{lll}\text { Leandro Pérez Gómez } & \text { Redactor } 2^{\mathrm{a}} \quad 01.10 .22 & 01.10 .22\end{array}$

Jerónimo Gallego Pérez $\quad$ Redactor $2^{\mathrm{a}} \quad 01.02 .50 \quad 01.02 .50$

1071 "Plantilla-escalafón del personal de esta empresa [Diario Regional S.A.].- Artículos 47 y 48 de la orden del Ministerio de Trabajo de fecha 14 de julio de 1950, B.O.E. del 2 de agosto del mismo año" Sindicato Provincial del Papel, Prensa y Artes Gráficas. Fechado el 10 de octubre de 1950. A.H.P.U.V., Sección A.I.S.S., leg. 4694. Se señalan en este censo el sueldo o jornal, quinquenios, total de ingresos, mejora salarial obtenida, fecha de nacimiento, fecha de alta en la empresa y fecha de alta en la categoría. 
Plantilla en 19531072:

$\begin{array}{lll}\text { Félix Antonio González González } & \text { Redactor jefe } & \text { Música } \\ \text { Enrique Santos Herrera } & \text { Redactor } & \text { confeccionador } \\ \text { Mariano Benito Pardo } & \text { Redactor } & \text { Toros } \\ \text { Francisco J. de Raymundo } & \text { Redactor } & \text { Información local } \\ \text { Miguel Montalvo Jambrina } & \text { Redactor } & \text { Información local } \\ \text { Leandro Pérez Gómez } & \text { Redactor } & \text { Arte, cine y teatro. } \\ \text { Jerónimo Gallego Pérez } & \text { Redactor } & \text { Tribunales } \\ \text { Rafael Andreu } & & \text { Colaborador fijo }\end{array}$

1072 Anuario de la Prensa Española. Año III, Vol. I.- Diarios Ministerio de Información y Turismo. Dirección General de Prensa., Madrid, 1953-1954, pág. 40.

1073 Aunque no se le señala oficialmente como redactor, por no tener carnet de periodista, es uno de los más activos de la plantilla. Colabora en Deportes y Mirador entre otras secciones. 
Apéndices

Plantilla en $1957^{1074}$

NOMBRE

EDAD CATEGORIA PROFES.AÑOS

DE

SERVICIO

EN LA EMPRESA

REDACCION

Enrique Santos Herrera $\quad 50 \quad$ Redactor JEFE

Francisco Javier Martín Abril49 Redactor OF. $1^{\text {a }}$

Leandro Pérez Gómez $\quad 58 \quad$ Redactor OF. $2^{\mathrm{a}}$

Miguel Montalvo Jambrina 55 Redactor OF. $2^{\mathrm{a}}$

Félix González Ferrández 32 Redactor OF. $2^{\mathrm{a}}$

Luis González Armero $\quad 50 \quad$ Redactor OF. $2^{\mathrm{a}}$

Andrés Romero Rubio

? Redactor

Ignacio Teresa Sanz

$37 \quad$ Fotógrafo

4

1074 «C.N.S. de Valladolid. Junta provincial del elecciones. convocatoria de 1957. Censo electoral sindical. Padrón de productores". A.H.P.U.V., Sección A.I.S.S., leg. 4702 . 
Apéndices

Fernando de la Torre de la Orden 21

ordenanza

7

$-856-$ 
Plantilla en $1960^{1075}$

NOMBRE

EDAD

CATEGORIA PROF. ANTIGÜEDAD

ANTIGÜEDAD

EN LA EMPRESA E N

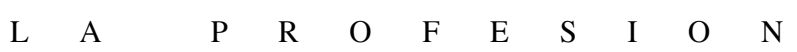

Enrique Santos Herrera

52 Redactor Jefe

12.12.45

12.12 .45

Francisco J. Martín Abril

Redactor $1^{\mathrm{a}}$

01.01 .55

01.01 .55

Leandro Pérez Gómez

61

Redactor $2^{\mathrm{a}}$

01.10 .22

01.10 .22

Miguel Montalvo Jambrina

57

Redactor $2^{\mathrm{a}}$

01.01 .36

01.01 .36

Félix González Ferrández

32

Redactor $2^{\mathrm{a}}$

01.12 .56

01.12 .56

Luis González Armero

44

Redactor $2^{\mathrm{a}}$

01.03 .57

01.03 .57

Andrés Romero Rubio

30

Redactor $2^{\mathrm{a}}$

01.05 .57

01.05 .57

Filadelfo González Rodríguez 32 32

Fotógrafo

01.03 .59

01.03 .59

1075 "Organización Sindical Provincial de Valladolid. junta provincial de elecciones. convocatoria de 1960. Censo electoral sindical. Padrón de productores". A.H.P.U.V., Sección A.I.S.S.,leg. 4709. 
Plantilla a 10 de abril de $1963^{1076}$.

NOMBRE

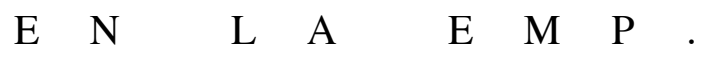

Manuel Fernández Areal director

Enrique Santos Herrera redactor jefe

Francisco J. Martín Abril redactor

Leandro Pérez Gómez redactor

Miguel Montalvo Jambrina redactor

José Luis Pérez Herrero redactor

Félix González Ferrández redactor

Luis González Armero redactor

Andrés Romero Rubio

Filadelfo González

José Antonio Antón redactor

fotógrafo

auxiliar redacción
01.12 .58

08.09.07

15.12 .45

01.05 .55

23.11.898

01.10 .22

10.11 .02

01.01 .36

24.03.25

01.01 .61

07.04 .25

01.10 .56

08.10 .06

01.03 .57

24.05 .30

01.07 .57

02.09.25

01.03.58

05.05.56

1076 "Delegación Sindical Provincial de Valladolid. Junta Provincial de Elecciones. Convocatoria de 1963. Censo Electoral Sindical", A.H.P.U.V., Sección A.I.S.S., leg. 4.714. 
Plantilla a 3 de noviembre de $1965^{1077}$.

\section{CARGOANTIGÜEDAD EN ID. EN EL}

\section{REMUNERACION}

\section{LA EMPRESA CARGO MENSUAL}

$\begin{array}{llrrr}\text { José Tallón García } & \text { director } & 15.10 .1960 & 13.10 .1965 & 15468,00 \\ \text { Tomás Santos Corchero } & \text { redactor jefe } 01.08 .1963 & 01.04 .1964 & 7280,00 \\ \text { Leandro Pérez Gómez } & \text { redactor } & 01.10 .1922 & 01.10 .1922 & 6403,75 \\ \text { Miguel Montalvo Jambrina } & \text { redactor } & 01.01 .1936 & 01.01 .1936 \\ 6403,75 & & & \end{array}$

Francisco J. Martín Abril redactor $\quad 15.03 .1939 \quad 01.05 .1955 \quad 5785,00$

José Luis Pérez Herrero redactor $\quad 15.06 .1946 \quad 01.01 .1961 \quad 5372,50$

$\begin{array}{lll}\text { Félix González Ferrández redactor } \quad 01.10 .1956 & 01.10 .1956 & 5578,75\end{array}$

Fernando de la Torre

de la Orden redactor $\quad 01.02 .1950 \quad 01.09 .1965 \quad 5991,25$

1077 Relación de 3 de noviembre de 1965. A.H.P.U.V., Sección Cultura, caja 28 . 
Apéndices

José de la Fuente Mendive

redactor

5372,50

José Antonio Antón Reglero

auxiliar

$01.08 .1956 \quad 01.10 .1959$

3570,00 
Apéndices

Plantilla a 29 de enero de $1966^{1078}$

NOMBRE

José Tallón García

José de la Fuente Mendive

Félix González Ferrández

Francisco Javier Martín Abril

Miguel Montalvo Jambrina

Leandro Pérez Gómez

José Luis Pérez Herrero

Tomás Santos Corchero

Fernando de la Torre de la Orden

José Antonio Antón Reglero
CATEG. PROF.

director

redactor

redactor

redactor

redactor

redactor

redactor

redactor

redactor

auxiliar de redacción

1078 "Censo electoral sindical. Declaración laboral de la empresa". A.H.P.U.V., Sección A.I.S.S., leg. 6.622. 
Plantilla a 8 de marzo de $1966^{1079}$.

Con posterioridad al día 4 de mayo de 1965, fecha de la última declaración han tenido lugar en Diario Regional las siguientes modificaciones:

Cesa como Director Manuel Fernández Areal, le sustituye D. José Tallón García.

Causan alta en la plantilla de redacción D. Fernando de la Torre de la Orden y D. José de la Fuente Mendive.

Plantilla a 31 de marzo de 1967

Se suman a la redacción Francisco de Anta Franco, y José Antonio Antón Reglero ${ }^{1080}$.

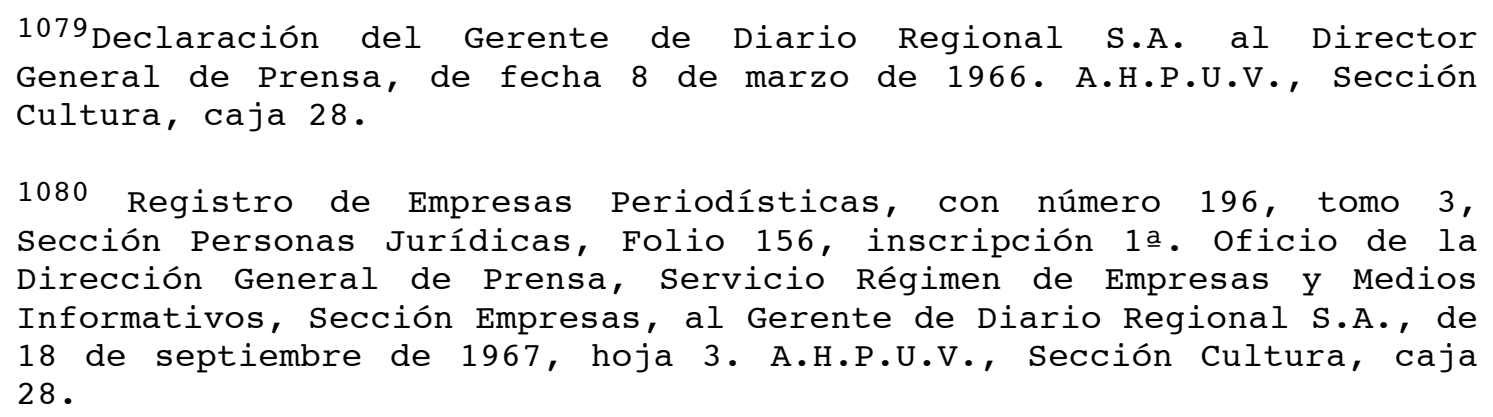


Plantilla a 21 de abril de $1969^{1081}$.

\section{CARGO}

Tomás Santos Corchero

director

Francisco J. Martín Abril

redactor

G. Leandro Pérez Gómez

redactor

Miguel Montalvo Jambrina

redactor

José Luis Pérez Herrero

redactor

Fernando de la Torre de la Orden

redactor

José de la Fuente Mendive

redactor

Francisco de Anta Franco

redactor

1081 Informe de 21 de abril de 1969. A.H.P.U.V., Sección Cultura, caja 28 . 
Plantilla el 24 de abril de $1970^{1082}$

NOMBRE

EN

Tomás Santos Corchero

Miguel Montalvo Jambrina

José Luis Pérez Herrero

José de la Fuente Mendive

Fernando de la Torre de la Orden

Francisco Javier Martín Abril

Francisco de Anta Franco
CATEGORIA

ANTIGÜEDAD

PROFESIONAL LA EMPRESA

Director

08.07 .63

redactor

01.01 .36

redactor

01.11 .61

redactor

01.10 .65

redactor

01.02 .50

redactor

01.01 .55

redactor

01.12.66

1082 "Organización Sindical Provincial de Valladolid. Junta Provincial de Elecciones Sindicales. Censo electoral sindical. Declaración laboral de la empresa", A.H.P.U.V., Sección A.I.S.S., leg. 6.628 . 
Plantilla el 6 de noviembre de 19721083:

$\begin{array}{ll}\text { Esteban Greciet Aller } & \text { director } \\ \text { Fernando de la Torre de la Orden } & \text { redactor jefe } \\ \text { Miguel Montalvo Jambrina } & \text { redactor } \\ \text { José de la Fuente Mendive } & \text { redactor } \\ \text { M Aurora Viloria Nieto } & \text { redactor } \\ \text { Santiago José Sáiz Domínguez } & \text { colaborador fijo con título de periodista } \\ & \\ M^{a} \text { del Carmen Noriega } & \text { colaborador fijo con título de periodista }\end{array}$

1083A.H.P.U.V., Sección Cultura, caja 27. 
Plantilla en diciembre de $1973^{1084}$

\begin{tabular}{lr} 
Esteban Greciet Aller & director \\
José de la Fuente Mendive & redactor \\
Fernando de la Torre de la Orden & redactor \\
María Aurora Viloria Nieto & redactor \\
Ramón García Domínguez & \\
\hline
\end{tabular}

Ramón García Domínguez

redactor

\begin{abstract}
1084 «Ministerio de Trabajo. Instituto Nacional de Previsión y Mutualidades Laborales. Relación nominal de trabajadores", A.H.P.U.V., Sección A.I.S.S., leg. 6.762.

Hay además un informe en papel timbrado del director de Diario Regional que dice:

«Datos pedidos por Juanjo:

MARIA AURORA VILORIA.- 28 años, periodista titulada y en plantilla. Licenciada en Derecho. Sabe idiomas. Desde hace muchos años trabaja en el DIARIO (no se sabe que haya trabajado en otros).

Mary CARMEN NORIEGA.- 22 años; periodista y maestra. No trabajó en otro sitio. Dentro de poco se marchará a Asturias, para trabajar en el diario REGION. No está en plantilla sino como colaboradora.

RAFAEL DEL NARANCO.- 29 años, colaborador. Piensa estudiar Periodismo. Trabajó en "La Voz de Asturias", "Región", "La Voz de Avilés", Agencia Efe, Radio Gijón, Radio Nacional de España y Radio Popular.

ESTEBAN GRECIET ALLER.- 42 años. Periodista. Licenciatura pendiente en Ciencias Políticas. Profesor Mercantil. Trabajó en Radio Nacional, "Diario de León", Agencia Europa Press, "La Voz de Asturias" (subdirector), "La Voz de Avilés" (director), y "Diario Regional" (director)". No hay fecha ni firma. Por los datos es de 1971 y podría ser un informe del Gerente o del mismo Director de Diario Regional. A.H.P.U.V., Sección Cultura, caja 27.
\end{abstract}


Apéndices

Plantilla a 1 de enero de $1974^{1085}$

CARGO FECHA DE ALTA

EN LA EMPRESA

Esteban Greciet Aller $\quad$ Director $\quad 01.05 .1972$

Ramón García Domínguez $\quad$ redactor jefe $\quad 01.08 .1973$

Fernando de la Torre de la Orden redactor $\quad 01.04 .1965$

José de la Fuente Mendive $\quad$ redactor $\quad 01.04 .1965$

$\mathrm{M}^{\mathrm{a}}$ Aurora Viloria Nieto $\quad$ redactor $\quad 01.11 .1972$

1085 "Confirmación Anual específica de plantilla" de 1 de enero de 1974. A.H.P.U.V., Sección Cultura, caja 27. 
Apéndices

Plantilla a 31 de diciembre de $1974^{1086}$

NOMBRE CATEGORIA PROFES. NACIMIENTO ALTA EN LA

EMPRESA

Ignacio Bel Mallén

director

10.04.47

20.07 .74

Ramón García Domínguez redactor-jefe

07.11 .43

01.08 .73

Benito Cacho Santiago

ayudante de redacción

22.03.31

01.11 .74

Miguel Angel Pérez Cifuentesredactor

15.05 .48

16.09.74

José María Esteban Ibáñez redactor

18.08 .50

13.09.74

José de la Fuente Mendive redactor

18.03 .33

01.10 .65

Fernando de la Torre de la Orden

redactor

22.12.35

01.02 .50

María Aurora Viloria Nieto redactor

18.05 .43

01.11 .72

1086 "Organización Sindical. Valladolid. Censo sindical al 31-XII-74. Declaración de la empresa", A.H.P.U.V., Sección A.I.S.S., leg. 6.763. 
Plantilla en 1977-781087:

NOMBRE

Pedro Muñoz García

Luis Ayllón Alonso

Francisco Rodríguez

Jesús Díez Lobo

Francisco Barrasa

$\mathrm{M}^{\mathrm{a}}$ Aurora Viloria

Marta Arrarte

Santiago Gallego

Juan Carlos Real

José Luis Guerrero

Julio Rubio

Rafael Rodríguez Zapatero

Julio Martínez
CATEGORÍA PROFESIONAL

director

redactor jefe

redactor

redactor

redactor

redactora

redactora

redactor

redactor

redactor

redactor

redactor

redactor

${ }^{1087}$ Los datos son fruto de la entrevista con José Luis Guerrero, Francisco Barrasa y Pedro Muñoz. 
Apéndices

Miguel Montalvo Jambrina

César Tejedor redactor (jubilado). Auxiliar.

auxiliar de redacción 
Plantilla en $1979^{1088}$.

NOMBRE

ALTA NACIM
CATEG PROF TOTAL A

PERCIBIR

\section{REDACCION}

$\begin{array}{llll}\text { María Aurora Viloria Nieto } 11.72 & 18.05 .43 & \text { directora }\end{array}$

$\begin{array}{llll}\text { Marta Arrarte Gómez } & 10.77 & 24.09 .52 & \text { redactora }\end{array}$

$\begin{array}{llll}\text { Jesús Romero Tardón } & 01.78 & 09.09 .53 & \text { redactor }\end{array}$

$\begin{array}{lllll}\text { Santiago Gallego G. } & 10.78 & 25.07 .29 & \text { redactor } & 29031\end{array}$

$\begin{array}{llll}\text { Rafael R. Zapatero } & 12.78 & 60.12 .34 & \text { ayudante de redacc. } 34162\end{array}$

Julio Martínez G. $\quad 10.78 \quad ? \quad$ ayudante de redacc. 34162

Fidel Torres J. $\quad 03.79 \quad 20.02 .54 \quad$ ayudante de redacc. 24998

Angel Álvaro Marcos $\quad 02.79 \quad 05.10 .51 \quad$ ayudante de redacc. 24998

Filadelfo González R. $\quad 05.79 \quad 02.09 .25 \quad$ redactor gráfico 29592

Mar del Carmen Bartolomé $05.79 \quad 26.06 .56 \quad$ ayudante de redacc. 20868

${ }^{1088}$ Relación manuscrita de la plantilla de Diario Regional, sin fecha, en A.P.G.A.M.. 
Apéndices

PERSONAL FUERA DE NOMINA (SIN SEGUROS SOCIALES)

REDACCION

Miguel Montalvo

15000

Juan Carlos Real

19000

Ignacio Amo V

5000

Fernando Martín B

8000

César Tejedor

8000

Javier Ares

10000

CORRESPONSALES LITERARIOS (REDACCION)

Palencia

10000

Venta de Baños

Salamanca

1000

Medina del Campo

1000

Medina de Rioseco

1000

Herrera de Pisuerga

1000 


\title{
Apéndice 6.- Declaración programática de Derecha Regional.
}

\begin{abstract}
"No existe una acción política concreta, coordinada y, por consiguiente, eficaz de los elementos más propiamente llamados de derecha. Por faltar esa acción, no sólo se pierden baldíamente muchas energías necesarias para el bien de la Patria, sino que se acrecienta el desequilibrio de la vida pública española, entregada casi en absoluto al empuje de las izquierdas, y, lo que aún es más grave, de las izquierdas revolucionarias, con peligro notorio para los intereses morales $y$ materiales de la sociedad española que las derechas deben proteger y fomentar.
\end{abstract}

"Este peligro crea crecientes posibilidades de triunfo para la revolución -cuyas consecuencias no serían 
meramente políticas, sino sociales también- que las izquierdas antidinásticas intentan llevar a cabo. Sería insensato que para atajar la revolución solamente se pensara en procedimiento de fuerza, aun siendo éstos inexcusables, como legítima defensa y natural réplica, en el momento de ser utilizados por los partidarios de la revolución. Esta se hace posible, en grandísima proporción, por la desidia e inhibición, con caracteres de suicidio, de las fuerzas de orden y puede ser contenida primero, y desbaratada, por fin, mediante una acción de ciudadanía, orgánica, disciplinada y entusiástica, de estas fuerzas.

"La actual dispersión de ellas debe tener rápido y radical término. Su concentración es, más que necesaria, urgentísima. Pero, si ha de tener eficacia, habrá de hacerse dentro de límites suficientemente amplios para no dejar fuera de ella sino a quienes rehuyan integrarla por discrepar de los principios fundamentales en que a nuestro juicio debe basarse y que exponemos a continuación:

"Por lo mismo que no puede haber vida social sana $y$ fuerte que prescinda $o$ se aparte de su fundamento de religiosidad, y siendo patente que nuestra civilización, en general, y la del pueblo español, muy especialmente, descansa sobre los principios esenciales de la moral católica, entendemos que ésta ha de orientar todos los 
pasos y derroteros de la acción derechista que tratamos de promover.

"Hay que defender a todo trance la conservación y el desenvolvimiento pacífico del orden social, mas no sólo en sus simples manifestaciones externas, sino tendiendo a que tenga pro base la íntima satisfacción de todos 0 , cuando menos, la mayoría de los sujetos.

"A este fin, estimamos imprescindible que orden no sea sinónimo de coacción, sino resultante de un fuerte anhelo de justicia social que, cumpliéndose por vías de pacíficos acuerdos, vaya reduciendo antagonismos de intereses, creando colaboraciones sociales cada día más amplias y suprimiendo privilegios que no tengan una lógica y humana explicación o una raíz natural indestructible.

"Por esto, en el orden de la propiedad y del trabajo, si bien rechazamos por utópicas y nocivas las doctrinas obreras revolucionarias sobre la futura organización social, sostenemos la conveniencia de realizar progresivas y en ocasiones profundas reformas legales que acerquen la utilidad del trabajo a los beneficios de la propiedad privada, la cual, estimándola nosotros necesaria y conveniente, entendemos que debe buscar con preferencia sus títulos de legitimidad en que, además del justo beneficio al individuo posesor, rinda el mayor provecho posible al conjunto de la sociedad. 
"Políticamente, aunque nos paguemos poco de teorías y doctrinarismos, pues creemos que los más importantes problemas públicos de nuestro tiempo son los económicos y sociales, admitimos el principio de que la Nación es soberana para determinar la forma y el funcionamientos de sus instituciones gubernamentales por los medios legítimos que pone a disposición de todo pueblo civilizado el ejercicio de una sana y culta democracia, igualmente apartada del despotismo y de la demagogia; pero en el presente estado político y social de nuestra Patria consideramos que es la Monarquía el régimen que mejor puede contribuir al progreso pacífico de la Nación.

"Esta línea general de nuestro pensamiento político nos conduce a estimar que toda posible reforma en la estructura del Estado español requiere una previa transformación de los procedimientos que han venido aplicándose a la gobernación pública, lo que hace precisa una radical rectificación de conductas y organizaciones políticas.

"Por ello tenemos que declara nuestra firme aspiración de hacer de la derecha una fuerza nueva y totalmente distinta de cuantas hasta aquí han existido en ese sector de la vida social española. Sin entrar a discutir los servicios que hayan podido prestar a la Patria y a la Monarquía, creemos que esas fuerzas han muerto aunque conserven apariencias de vida: que ha cesado 
su razón de existir y que el empeño de mantenerlas artificiosamente sería inútil y acaso peligroso. Mas esto no quiere decir que rechacemos a nadie, venga de donde viniere, que se solidarice con nuestros puntos de vista, ni tampoco que hayamos de rehuir ninguna alianza circunstancial con cualesquiera fuerzas monárquicas para fines concretos de elevada significación patriótica, tanto en el orden nacional como en otro más reducido.

"Lo que sí queremos consignar de una manera terminante es que en nuestra organización no han de ser admisibles otra disciplina ni otras denominaciones políticas y sociales que las suyas propias, de modo que ni por nada ni por nadie puede desfigurarse la personalidad definida e independiente de esta nueva organización, que espira a ser el vasto campo de concentración de todos los elementos de derecha hasta aquí dispersos y desorientados.

"Aunque tengamos la legítima ambición de extender por toda Castilla -campo especialmente indicado para nuestra acción- los principios que dejamos expuestos y la organización que ha de servirles, no caeremos en la petulancia de pretender, por el momento, que nuestro esfuerzo vaya más allá de lo posible. Sería absurdo que empezásemos a edificar por arriba; es lógico, y así procederemos, que nuestra labor se inicie en el ámbito local y trascienda luego a la provincia y sucesivamente a toda la región. 
"Hemos de prestar atención vivísima a los problemas generales de la región castellano-leonesa, cuya personalidad -en lo económico y cultural, sobre todo- hay que afirmar y robustecer para que tenga en el conjunto nacional la influencia que le corresponde y recoja los provechos a que tiene natural derecho, tan olvidado hace mucho tiempo. Y es claro que en este sentido consagraremos la mayor parte de nuestras preferencias al problema agrario, cuya feliz solución ha de ser la base del engrandecimiento de Castilla.

"Pero partiendo, como partimos, de la ciudad, teniendo que iniciarse en ella nuestra actuación pública, hemos de comenzarla por nuestra intervención en las cuestiones locales, aportando a ellas un programa de soluciones que satisfagan, mediante la indispensable acción municipal, las necesidades sentidas y por satisfacer de nuestro pueblo.

"Para esta primera labor, como para las sucesivas, más que número, necesitamos actividad, energía, entusiasmo y desinterés en cuantos vengan a nuestro lado. No nos interesa preferentemente la cantidad de las adhesiones posibles. Queremos, ante todo, que quienes se nos sumen sepan desde ahora cómo no son requeridos para estar pasivamente en nuestras filas, sin para trabajar con máximo ahínco en las tareas de la Derecha Regional. 
Apéndices

"La Comisión Organizadora." 
Apéndice 7 .- Manifiesto electoral de Rafael Serrano y Serrano en junio DE 1931 .

"Manifiesto electoral de D. Rafael Serrano

"Declaración política"

"Debo a mis electores esta declaración para que sepan quién soy y a quién votan.

"Doy la mayor importancia a los valores espirituales, que han hecho de la civilización cristiana, una civilización universal; por tanto, como católico, yo defenderé los derechos legítimos de la Iglesia a cuyas enseñanzas de antemano me someto y aspiraré a que las cuestiones de fuero mixto sean resueltas por la concordia de las dos Potestades.

"En la cuestión del régimen de Gobierno, profeso no sólo el acatamiento, sino el deber de actuar dentro del mismo.

"En la organización del Estado, propugno una moderada autarquía para las regiones que sepan usarla, sin daño de la unidad de la Patria. 
"Deseo un Gobierno justo que ejerza saludablemente la autoridad, con igualdad para todos; un poder ejecutivo fuerte a cubierto de los riesgos y veleidades de los órganos legislativos, ya sea implantando el sistema presidencial o ensayando aquel otro más ingenioso y nuevo que llaman dual y que funciona en la República del Uruguay, según el cual, aquellos órganos del Poder ejecutivo que representan intereses permanentes, están por encima de las oscilaciones políticas, o bien buscando algún sistema de entronque español y tradicional.

"Local sería también la contribución única, con alto límite de exención para el trabajo personal y para las pequeñas fortunas, incluso las constituidas por la tierra y con tarifa progresiva sin llegar a la confiscación en los grados superiores.

"Quiero el derecho a la libertad de enseñanza, patrimonio del padre de la familia, por ser este derecho una función social y no del Estado, sin perjuicio de que éste complete las deficiencias de la enseñanza privada.

"Deseo una legislación social que modere los excesos del capitalismo, singularmente el de las grandes empresas y acelere por cuantos medios sean justos y lícitos la evolución económica ya iniciada, para una mayor distribución de la riqueza, haciendo el bienestar económico más accesible a las ordenadas actividades del 
trabajo: doctrinas éstas, muy conformes con nuestra ideología, porque el capitalismo y sus excesos no son obra de la doctrina de Cristo que tiene un sentido más humano y de mayor justicia.

"Las reivindicaciones de los humildes están inscritas en el programa social católico con anterioridad a la sistematización científica del socialismo.

"Una agricultura próspera, sin la cual Castilla se despoblará antes de un cuarto de siglo: para ello hay que aliviar los tributos a los campesinos, estimular el retorno al campo, haciendo más suave y amable la vida del labrador; reformar el régimen de propiedad, procurando elevar a la condición de propietarios al mayor número; implantar la concentración parcelaria obligatoria indispensable en cierta medida para la explotación racional en nuestra región; impulsar la formación de un Catastro parcelario, bien hecho y que sirva de base al Registro de la Propiedad; abaratar y dar mayores facilidades a al trasmisión legal de la propiedad, etc.

"Todas o la mayor parte de estas finalidades se obtendrán en Castilla, impulsando el desarrollo de la Confederación Sindical Hidrográfica del Duero. 
"Largo sería el índice de las cuestiones que han de reflejarse en la nueva Constitución y que se discutirán en las próximas Cortes Constituyentes.

"Cualquiera que sea su tendencia, nuestra actuación procurará ser justa e imparcial, desprovista de toda pasión, sin odio para nadie ni para nada, más que para el mal, y de completo servicio y perfecta amistad para cuantos componen el cuerpo electoral, a cuya sanción noblemente me someto.

"Rafael Serrano." 
Apéndice 8.- editorial pUblicado por Diario Regional Al finalizar SU SUSPENSIÓN, EL 2 DE SEPTIEMBRE DE 1932.

"Al cesar nuestra suspensión, otra vez en nuestro puesto»

«Al reanudar hoy su publicación DIARIO REGIONAL, que, al mismo tiempo que otros muchos periódicos madrileños y provincianos -casi todos ellos católicos o de significación derechista- quedó gubernativamente suspendido desde el día 10 de Agosto, nos vemos obligados a salir a la calle poniendo sordina a cuanto en razón y justicia podríamos decir y atemperándonos a unas circunstancias en que la fuerza manda y tenemos la libertad encadenada.

"Las cosas han sido inoportunamente sacadas de su cauce legal, por el cual los católicos íbamos llevando, aunque con las trabas y dificultades sembradas a granel en el camino de nuestros derechos, la defensa de nuestra causa, que es independiente de todos los regímenes de gobierno y superior a todos ellos, $y$ ahora nos toca sufrir las consecuencias. 
"Al contemplar la situación que para los católicos ha sido creada por unos sucesos, a los cuales nuestras instituciones religiosas y sociales, así como nuestra Prensa, son completamente ajenas, hemos de limitarnos a lamentar profundamente cuanto ha sucedido, por la tremenda perturbación que ha producido en la vida española, tan necesitada de aquietamiento, de equilibrio, de normalidad y de pacificación.

"Y nos limitamos a lamentar lo sucedido, porque, como sabiamente escribió el Eclesiastés, "hay tiempo de callar y tiempo de hablar". Y ahora es para nosotros tiempo de callar, no porque no haya una verdad, una justicia y un derecho que nos asistan, sino porque quienes debieran oirnos y comprendernos no están dispuestos a lo uno ni a lo otro. Hay demasiado calor de pasión en el ambiente.

"Pero aun callando mucho, sí nos será permitido lamentar el daño material que se nos ha inferido sin que hayamos tenido la más leve participación ni la más remota concomitancia en los sucesos de los que se ha tomado pretexto para interrumpir bruscamente la comunicación con el público a un sector importante $y$, sin duda alguna, el más digno de la Prensa española, hecha alguna que otra salvedad respecto a los periódicos no suspendidos.

"En el oficio gubernativo, en el que se nos comunicó la orden de suspensión del nuestro, decíase que era debida 
a las campañas tendenciosas hechas contra el régimen. No podemos menos de rechazar tal imputación, porque leal y honradamente hemos demostrado acatamiento y sumisión al Poder hoy constituido en España, siguiendo en ello la enseñanza y el ejemplo de la Iglesia Católica. Ni una frase, ni un concepto contra la República hallará en las columnas de DIARIO REGIONAL quien, limpio de prejuicios y malas intenciones, examine sus artículos y trabajos, por mucho que en ellos escrute. Hemos sí criticado y combatido actos, disposiciones y proyectos del Gobierno, y actos y tendencias de los partidos políticos, porque en modo alguno pueden ser identificados con el régimen republicano, de suyo ilícito y honesto para la gobernación de los pueblos.

"Digamos ahora que es, por cierto, bien acerba la realidad a que hemos venido a parar; pero la tenemos bien merecida, ya que quiénes más, quiénes menos, hemos contribuido a prepararla y a traerla -nos referimos a la situación religiosa y moral del país- a fuerza de un liberalismo estúpido que acaba indefectiblemente por matar a toda institución o sociedad que le toma como principio, base y norma de gobierno.

"Nada sin embargo de cuanto nos rodea debe desalentarnos para seguir luchando en primer lugar por los derechos, libertad e intereses de la Iglesia, que es lo primordial para todo católico, $y$, en segundo, como 
ciudadanos, por los demás derechos, libertades e intereses legítimos de orden político, social y material.

"A reaparecer hoy, después de veintidós días de suspensión, ni que decir tiene que estamos firmes en nuestra posición de siempre, en nuestras convicciones, en nuestra independencia política $y$ en nuestros ideales católicos. Tenemos respeto y sumisión para el Poder público constituido, no sólo del modo pasivo, sino prestándole nuestra asistencia en todo lo que realmente sea para bien del país, para defensa del principio de autoridad y para combatir a los enemigos de los legítimos intereses espirituales y materiales de la sociedad, pero sin renunciar a enjuiciar y combatir, siempre en el terreno legal, sus decretos, sus planes, sus proyectos y sus tendencias, cuando los estimemos perniciosos o desacertados.

"Con Monarquía o con República, estamos en el mismo puesto, del que jamás hemos descendido para subirnos a la trasera de ninguna carroza triunfal, ni para colocarnos al sol que más calienta. No todos pueden decir esto. Y es que nosotros no hacemos campañas por política de partido, ni por sostener ningún caciquismo, ni por ambición, ni por ansia de medro personal, ni para engañar al pueblo. No está en eso la finalidad de DIARIO REGIONAL. 
"Los tiempos son harto difíciles; cada vez lo van siendo más; lo serán más aún seguramente. En lo humano hasta los más optimistas quizás vean poca luz por entre las espesas sombras del pavoroso nublado que recubre el horizonte de nuestro país. Mas en trance tan adverso un deber imperioso e ineludible, nos manda, en nombre de Dios y de España, dar cara a la tempestad y sacar fuerzas de flaqueza, haciendo lo que humanamente nos sea posible hacer por salvar el tesoro espiritual de nuestra fe $y$ de nuestras tradiciones católicas, que es lo que más nos importa. No se crea que, si no se pone empeño en salvar primeramente ese tesoro espiritual, van a salvarse los intereses materiales.

"Por eso queremos terminar estas líneas gritando a
todos los católicos que tengan ojos para ver y sepan darse
cuenta de lo que de ellos reclaman su propia fe y los
tiempos que corren: isursum corda! iArriba los
corazones!..."


Apéndice 9.- Manifiesto del Comité Electoral de Unión de Derechas y TEXTO DE LA CONVOCATORIA SOCIALISTA DE UNA MANIFESTACIÓN DE PROTESTA, EN MARZO DE 1933.

"A las Derechas de Valladolid»

"Las distintas entidades derechistas que recientemente han concertado un pacto de coalición es esta capital, a fin de actuar mancomunadamente en las próximas elecciones municipales, se proponen desarrollar activa campaña de propaganda. A este efecto dirigen a la opinión pública el siguiente manifiesto: 
"El comité de las fuerzas de derechas vallisoletanas, integrado por miembros pertenecientes a cada uno de los partidos o agrupaciones, reunidos en la santa hermandad de un ideal afín y ante un peligro común, alza hoy ante la opinión pública su voz que es un grito de rabia, de dolor y de vergüenza, entendiendo que permanecer callados en este momento trágico de la vida española, sería tanto como aliarse en repugnante contubernio con los enemigos de Dios, de la Patria y de la justicia social.

"Las fuerzas por este Comité representadas, ni deben, ni pueden, ni quieren adoptar la fácil postura de una cómoda inhibición, ni tampoco el gesto femenil -encubridor de repugnantes cobardías- que renunciando a toda esperanza, porque toda esperanza es final de un camino a recorrer, gimen con el tesón de plañideras asalariadas tras un ataúd que su limitación ideológica piensa, es tumba de la inmortal grandeza hispana, sin darse cuenta en su inconsciencia suicida, que lo único sobre lo cual ha caído definitivamente la losa del sepulcro, es sobre la inutilidad de su vida y sobre el egoísmo que fue norma de su actuación.

"Esta unión de las fuerzas derechistas, que no es fenómeno privativo de Valladolid, sino abrazo que funde y santifica a todos los corazones de la España digna, trae a la vida pública, junto al imperativo genérico de intervenir decisivamente en la futura lucha electoral, el 
de recoger $y$ dar cauce adecuado, a esa exigencia implacable de justicia que la Patria demanda contra los que estafando la conciencia nacional y el sentido generoso del pueblo, se alzaron sobre un pináculo de promesas incumplidas, para desde allí, convertir el jardín magnífico de la Patria en un inmenso cementerio, entre cuyas tumbas desoladas serpentean ríos de lágrimas y sangre española.

"Sólo nosotros, libres de culpa en el patente fracaso de los sucios negocios ideológicos que se llaman partidos políticos, podemos arrojar la primera piedra contra la corrupción moral que nos degrada y nos envilece. Sólo nosotros, fortalecidos con este juramento sagrado de salvar la vida y la dignidad de España, tenemos autoridad suficiente para alzarnos contra los que traidores al mandato histórico de la raza se postraron reverentes ante las tenebrosas internacionales que desde el recinto cobarde de la sombra, laboran por la ruina de España.

"Sólo nosotros, podemos lanzar a los vientos rebeldes un grito de angustia que será como una bandera teñida con la sangre de las víctimas, dorada al sol de unas llamas que borraron nuestro nombre de entre los pueblos civilizados, ennoblecida por el sacrificio, y santificada con la imagen benditísima de ese Cristo, que en un milagro de amor, permite que otra vez se alcen para El calvarios de humillación y desprecio sobre la tierra española. 
"Ha llegado la hora de que los ideales sean algo más que vanos desahogos retóricos en que la gárrula palabrería disimula la verdad del sentimiento y que sea un hecho la compenetración fraternal y cristiana.

"Es necesario, sin humillaciones ni servilismo para nadie, que resplandezca la justicia de nuestras aspiraciones sociales plasmadas en las Encíclicas de los Pontífices; llegando a una perfecta comunidad de intereses en el disfrute de los beneficios de la producción y a la modificación progresiva del régimen del salario por otro más elevado y digno; que el trabajo sea dueño conjuntamente del elemento de la producción; propugnando la mayor difusión de la pequeña industria y de la pequeña propiedad; implantación del salario familiar, la libertad de asociación y la garantía de la libre elección del trabajo, haciendo desaparecer la concentración de una excesiva riqueza en una minoría, procurando una más justa y equitativa distribución de la misma.

"Todos sabemos que por desgracia para la Patria, se pretende desde el Parlamento, las Diputaciones y Municipios, dar soluciones marxistas a todos estos problemas y por ello no basta con llamarse católico y español si luego nuestros actos o nuestras cobardes omisiones son el apoyo más firme de los enemigos de nuestro Dios y de nuestra Patria. 
"iDERECHAS ESPAÑOLAS! Frente único contra el enemigo común. Que sobre la triste realidad del momento presente, vuele como un ave de esperanza el grito de Cruzada, mientras los ojos españoles se tornan hacia la nueva aurora que sobre un horizonte tormentoso dibuja con luces de triunfo la vieja cruz militar de Santiago, que arrancada del pomo de una invicta tizona castellana se ha posado sobre nuestra bandera arrebolada por el fulgor centelleante de una leyenda que otra vez promete: iCON ESTE SIGNO VENCERAS!

"DERECHAS VALLISOLETANAS, en este momento decisivo, que cada uno cumpla con su deber.

"EL COMITE ELECTORAL DE UNION DE DERECHAS:

"Por el Comité Femenino, Acción Popular en Castilla, Centro Tradicionalista y Juntas de Ofensiva Nacional Sindicalista (J.O.N.S.): Cándida Pintó, viuda de G. Antorán; María Carrillo de Albornoz de Monedero; María de la Cuesta, viuda de Novella; Félix Igea; Francisco Pérez; Daniel Pérez; Manuel Sánchez Belloso; Norberto Sánchez Bastardo; Juan Bautista Fernández Sanjuan; Luis M. Alonso Calero; Luis Sanz; Juan Misol Matilla." 
«TRABAJADORES...»

"Ayer domingo un grupo de señoritos vagos se dedicaron a repartir unas hojas e imponiendo su lectura por la fuerza, y caso contrario echarse encima del pacífico ciudadano para atropellarle.

"Estos elementos que se aprovechan de la libertad que el régimen tiene para todos, provocan de una forma descarada tomando como base uno de los postulados que en su programa carecen. LIBERTAD.

"Ayer fueron atropellados dos trabajadores en el barrio de San Juan por esta canalla que viven con la fortuna amasada por sus ascendentes con la sangre roja de los trabajadores.

"Todos los trabajadores y toda la izquierda republicana debe de ponerse en contra de esta gente de "a Dios rogando y con la porra dando".

"Por solidaridad con nuestros compañeros Martín González y Salvador Ramos agredidos en la mañana de ayer 
por el bandolerismo fascista, debemos y no cumpliríamos con nuestro deber si a esta clase de gentuza no la aplastamos .

"No olvidemos que aspiran estas gentes a anular toda la marcha ascendente de la República y por lo tanto los beneficios que en materia social ha concedido a la clase trabajadora, $y$ antes que consentir esto, prefiramos enterrar a este naciente cocodrilo en el transcurso de la Historia.

"Hoy celebrarán un mitin en Calderón, la obligación de todos los republicanos, socialistas, etc., etc., para patentizar nuestro decidido propósito de defender la REPUBLICA contra toda la canalla, que, piensa todavía que volveremos a los pasados tiempos para someter a ESPAÑA al silencio.

"Antes que esto pueda pasar defendamos la revolución del 14 de abril y si si necesario fuera continuarla en sentido más avanzado y con todas las consecuencias.

"Hoy debe de acudir todo ciudadano consciente a una manifestación que partirá de la plaza Mayor a las siete de la tarde.

"Viva la República. Muera el Fascismo." 
APÉNDICE 10.- EDITORIAL PUBLICADO EN LOS FOLIOS MECANOGRAFIAdos DIFUNDIDOS POR EL PERIÓdICO DURANTE LA HUELGa GENERAL DE 7 DE OCTUBRE DE 1934 .

«POR ESPAÑA .- En los momentos quizás más graves por los que, desde principios del siglo anterior, ha pasado España, se encuentra DIARIO REGIONAL privado de la comunicación con el público a causa de una huelga ilegal, revolucionaria y antipatriótica, en la que unos por depravación y otros por miedo han participado causando daños considerables a los intereses de la colectividad. Nuestro personal de talleres en tales momentos nos ha privado de sus servicios; pero nosotros, ante la magnitud de las noticias que tienen que interesar enormemente a nuestros lectores, porque interesan a España entera, no queremos resignarnos a la incomunicación con ellos y nos decidimos a anticipárselas, sea como sea.

"Por esto recurrimos a esta Hoja que les ofrecemos con el propósito de levantar el espíritu patriótico cuando España ha sido felona y siniestramente atacada a mano armada por el conglomerado de sus enemigos interiores. 


\begin{abstract}
"Queremos levantar y encandecer (sic) el espíritu patriótico de todos; contribuir en cuanto podamos al aplastamiento de la traición; proclamar la soberanía española sobre todos los separatismos criminales y afirmar rotundamente nuestra actitud decidida, firme y entusiástica al lado del Gobierno para apoyarle y fortalecerle en cuanto signifique defensa y vindicación del honor, de la soberanía y de la unidad de la Nación española.
\end{abstract}

"En estos momentos queremos salir a la calle gritando: iViva España!" 
Apéndice 11.- Editorial pUblicado el PRIMER día después de la Revolución DE OCTUBRE DE 1934 .

"Vive Y vivirá España"

«Era necesario que reventara esa bolsa de pus -la anti España- que amenazaba con envenenar y pudrir la vida de nuestra Patria; era necesario para la salud del pueblo español que fuera sajado el tumor formado en sus entrañas por la miseria espiritual de unos hijos malvados; era necesario -aun siendo tan doloroso- que llegase la hora de la amputación de los miembros gangrenados del cuerpo nacional. O eso, o que España muriera.

"Pero España no podía, ni puede, ni podrá morir. Vive y vivirá España. Sube del corazón de los buenos españoles el grito de "iviva España!" y llega a los labios con el ímpetu de amor que ponemos los hombres al invocar a nuestra madre. Es grito que vuela con las alas del sentimiento, $y$ en estas horas hay que dejarle correr con toda la fuerza de las emociones sagradas; pero es necesario interpretarle no como la vehemencia de un deseo, sino como la consagración triunfante de una realidad: ivive España! 
"La creían moribunda, presa fácil para sus designios siniestros, los que, al servicio de mandatos internacionales, $o$ en la obediencia a poderes clandestinos, o con la ambición de repartirse sus vestiduras, un vez que la tuvieron crucificada en el Calvario de la desintegración nacional, acechaban el momento de apuñalarla traidoramente. Y los asesinos, los parricidas, se abalanzaron sobre ella. Pero España, vive.

"Y vivirá. Ahora más fuerte que nunca. Por las heridas que le infieren sus hijos espúreos, mana la sangre de la Patria, la sangre de sus gloriosos soldados mártires y héroes, de nombres oscuros, pero con toda la grandeza recogida cuando nacieron del vientre de España-; la sangre de las víctimas inmoladas por una barbarie afrentosa que ni siquiera tiene par con aquélla que las tribus marroquíes empleaban contra nuestros soldados porque en le Rif no eran fratricidas; la sangre, santificada por vertirse en holocausto de España, que derrama el puñal de la revolución. Pero esta sangre arrastra y barre la impureza y el veneno que se habían ido filtrando en la vida de España, que la corrompían y debilitaban, que la ponían en trance de muerte, que la hubieran matado si España no fuese inmortal.

"iLoor a los caídos por la Patria, a los que luchan por ella con las armas en la mano, a los pechos nobles y leales que se han levantado para cubrir a España! iHonor y 
gloria para los defensores de España! iExecración e ignominia para los que pretendían matarla! iQue Dios colme de felicidad eterna a los que han dado su vida por la Patria!; que la Patria cubra de laurel eterno la memoria de estos hijos beneméritos; que la Ley sea implacable, serenamente dura, pero severamente inflexible, con la canalla que ha pretendido hundir y despedazar a España; que sea raída, arrancada de cuajo, para que jamás pueda retoñar la anti-Patria del separatismo, de la masonería y de la Internacional, que han cometido el crimen de clavar sus garras sobre el peso de España para arrancarle el corazón y la vida. A pesar de la cual, España vive y vivirá. Y vedla en pie, arrogante, magnífica y victoriosa, vosotros, malvados o ilusos, que pensábais bailar el día imposible de vuestro triunfo en torno al cadáver de la Augusta Madre."

APÉNDICE 12.- Editorial PUBLICAdo EN JULIO DE 1937 DEFINIENDO LA PRENSA CATÓLICA ESPAÑola.

"Significación del periódico católico y español»

«En el año de 1932, el Gobierno republicanosocilalista que presidía Azaña, ordenó la suspensión de ciento catorce periódicos católicos, y sólo permitió la 
circulación de los periódicos que eran afectos a la política rabiosamente izquierdista que la masonería y el marxismo desarrollaban desde el poder.

"En 1936, días antes del 18 de julio, el Gobierno de alianza revolucionaria del "frente popular" tenía preparada otra suspensión de todos los periódicos católicos de España y, como en 1932, sólo hubiera dejado circular los periódicos simpatizante con el marxismo. Lo había pedido con insistencia "Heraldo de Madrid", y ya sabemos que éste y todos los demás libelos al servicio de la masonería y del marxismo no hacían más que secundar las órdenes de los políticos izquierdistas. Una petición de esta clase, previamente inspirada por ellos, significaba la justificación de sus persecuciones.

"¿Se ha pensado en la transcendencia que hubiera tenido para España la suspensión de todos los periódicos católicos, es decir, de todos los periódicos entonces llamados de derecha, que no han transigido nunca con el marxismo? Muchas, muchísimas gentes no lo han pensado ni se han dado cuenta exacta de la enorme influencia que ejercieron estos periódicos en el movimiento de legítima defensa nacional. Si el Gobierno no retrasa la medida que tenía preparada y suspende, como en 1932, todos los periódicos que no le eran afectos, hubiera ocurrido, sencillamente, una de estas dos cosas: o el movimiento de salvación nacional hubiera fracasado por falta del apoyo 
necesario para el imprescindible encauzamiento de la opinión, o los lectores, lo mismo en Valladolid que en España entera, hubieran encontrado, como único estímulo, una Prensa que condensaba su opinión en grandes titulares parecidas a ésta (sic) : “Ha estallado una sublevación militar" .

"Ese achaque de no haber sido reconocida nunca, en ciertos sectores, la enorme importancia y transcendencia de los periódicos católicos y como tales, netamente españoles, tiene como fundamento la limitada visión del materialismo, que es puramente marxista. El materialismo, en sus diversos aspectos, siguen cultivándole los marxistas y algunos aficionados; pero hay también considerables zonas de opinión que, sin ser una cosa ni otra, se han dejado contaminar por el materialismo y tienen de los periódicos un concepto de cuantiosidad. Miden la importancia de los periódicos por su peso, como si se tratase de lechazos, y piden mucho papel, muchos grabados y muchos alicientes simplemente materiales; pero un periódico no es una fonda, donde el mayor atractivo suele ser, para determinados comensales, el número de platos, sin selección de calidad.

"Más, suprímanse los valores morales y espirituales, y todo lo demás carecerá de importancia. El materialismo, por sí solo, es un peso muerto sin valor de ninguna clase. Y un hombre o un periódico que se venden por unas monedas 
Apéndices

son, además de despreciables, seguros traidores. Véase este caso aleccionador: en la zona roja ha habido periódicos liberales que se han puesto voluntariamente al servicio del bolchevismo $y$ son sus más furibundos defensores. Por el contrario, no se podrá citar un solo periódico católico, y como tal, español, que voluntariamente, haya hecho lo mismo.

"Sin las campañas de estos periódicos en los tiempos difíciles -ahora es fácil y para algunos hasta ventajoso combatir al marxismo en la zona nacionalista-, sin la defensa tenaz de los grandes ideales de Religión y Patria en la época anterior al 18 de julio de 1936, entre persecuciones y amenazas, España hubiera caído sin lucha en las garras del bolchevismo. Los periódicos católicos han sido siempre, siempre, leales a sus ideales y a sus extensas masas de lectores, que constituyen la parte más selecta del país, la única que tiene verdadera formación espiritualmente cristiana, la que ha salvado a España, porque sin el ímpetu patriótico y cristiano, que son valores estrictamente espirituales, no hubiera sido posible el empuje arrollador de las armas, que son elementos simplemente materiales.

"Todo esto no ha sido apreciado por algunos reducidos sectores de opinión. Así se ha dado el caso, de que algunos escritores y colaboradores de periódicos católicos -unos cuantos, muy pocos-, acuciados por el interés de 
unas monedas o alucinados por la mayor difusión entre los que compran periódicos como si fuesen lechazos, o para satisfacer una grotesca vanidad, han concedido sus preferencias a periódicos de abolengo liberal izquierdista. Muy lamentable... para ellos."

\section{ApÉndice 13.- Resumen de INFRACciones COMEtidas por Diario Regional,} DESDE EL 1 DE JUNIO DE 1943 HASTA OCTUBRE DE 1944.

"OFICIOS DE DEFICIENCIAS COMETIDAS POR EL “DIARIO

REGIONAL" DE VALLADOLID, DESDE EL DIA 1-6-43 HASTA LA
FECHA.

"1-6-43.- Apercibimiento por no publicar editorial.

"14-6-43.- Apercibimiento por no publicar editorial. "21-6-43.- Deficiencia técnica.

"18-6-43.- Deficiencia política Nacional. "21-6-43.- Apercibimiento por no publicar editorial. "22-6-43.- Apercibimiento por no publicar editorial. "1-7-43.- Deficiencia valorativa. 
"14-7-43.- Deficiencia valorativa.

"28-7-43.- Apercibimiento. No cumplimiento consigna.

"29-7-43.- Apercibimiento. No cumplimiento consigna.

"2-8-43.- Deficiencia técnica.

"7-8-43.- Deficiencia técnica.

"7-8-43.- Deficiencia técnica. [sic ]

"17-8-43.- Apercibimiento severo. No destaca actos presididos por el Caudillo.

"3-9-43.- Deficiencia técnica.

"10-9-43.- Apercibimiento por no publicar editorial.

"18-9-43.- Apercibimiento por no publicar editorial.

"18-9-43.- Apercibimiento por no publicar editorial. [sic ]

"7-10-43.- Deficiencia técnica.

"14-10-43.- Apercibimiento por no publicar editorial.

"25-10-43.- Deficiencia técnica.

"30-10-43.- Deficiencia técnica. 
"3-11-43.- Deficiencia valorativa.

"4-11-43.- Deficiencia valorativa.

"9-11-43.- Deficiencia técnica.

"10-11-43.- Apercibimiento por la deficiencia del no Día de los Caídos.

"13-11-43.- Deficiencia técnica.

"17-11-43.- Deficiencia técnica.

"26-11-43.- Apercibimiento. No publica editorial.

"3-12-43.- Apercibimiento. No hizo nada no día 20 sobre José Antonio.

"20-12-43.- Deficiencia valorativa.

"24-11-43.- Apercibimiento. No publica editorial.

"24-11-43.- Deficiencia política Nacional.

"7-1-44.- Deficiencia técnica.

"12-1-44.- Deficiencia técnica.

"11-1-44.- Deficiencia técnica.

"14-1-44.- Deficiencia técnica. 
"18-1-44.- Apercibimiento. No publica editorial.

"19-1-44.- Deficiencia técnica.

"28-1-44.- Deficiencia técnica.

"3-2-44.- Deficiencia valorativa.

"19-2-44.- Apercibimiento. No publica editorial.

"22-2-44.- Apercibimiento por deficiencia valorativa.

"26-2-44.- Deficiencia valorativa.

"13-3-44.- Deficiencia política Nacional.

"15-3-44.- Deficiencia valorativa.

"21-3-44.- Deficiencia información extranjera.

"24-3-44.- Deficiencia información extranjera.

"28-3-44.- Deficiencia información extranjera.

"30-3-44.- Apercibimiento. No publicó editorial.

"30-3-44.- Deficiencia técnica.

"3-4-44.- Deficiencia información extranjera. 

"3-4-44.- Apercibimiento, deficiencia información extranjera.

"3-4-44.- Apercibimiento. No da información acto de Villagarcía.

"13-4-44.- Apercibimiento. No publicó editorial.

"17-4-44.- Deficiencia técnica.

"20-4-44.- Nota desfavorable por desobediencia órdenes D.P. [Delegación Provincial]

"22-4-44.- Apercibimiento. Deficiencia valorativa.

"21-4-44.- Apercibimiento. Deficiencia valorativa.

"8-5-44.- Se propone para sanción por desobedecer órdenes.

"30-5-44.- Deficiencia. Información extranjera.

"30-5-44.- Deficiencia. Información extranjera.

"30-5-44.- Deficiencia técnica.

"2-6-44.- Deficiencia técnica y valoración.

"9-6-44.- Deficiencia técnica. 
"14-6-44.- Apercibimiento severo por no someter a censura, información actos celebrados en Medina del Campo con motivo del 2 de mayo.

"12-6-44.- Deficiencia técnica.

"13-6-44.- Deficiencia información extranjera.

"16-6-44.- Deficiencia técnica.

"24-6-44.- Deficiencia técnica.

"29-4-44.- Deficiencia política exterior.

"1-7-44.- Deficiencia política exterior.

"3-7-44.- Deficiencia y APERCIBIMIENTO. Información nacional y extranjera.

"5-7-44.- Deficiencia técnica.

"5-7-44.- Deficiencia información extranjera.

"8-7-44.- Deficiencia política Nacional.

"8-7-44.- Deficiencia información extranjera.

"13-7-44.- Deficiencia información extranjera.

"13-7-44.- Deficiencia valorativa. 
"12-8-44.- Deficiencia información nacional.

"18-7-44.- Se distingue entre los periódicos que peor hacen el extraordinario, que prácticamente no existió. [añadido a mano]

"2-9-44.- Se oficia a la superioridad por cometer varis deficiencias en los números del 23,24 y 26 de agosto.

"17-9-44.- Se propone para sanción por presentar de forma inadecuada la información referente a los nombramiento de altos cargos del Movimiento. [ añadido a mano]

"23-8-44.- Titula a una columna: "La visita que el Caudillo hizo a Santiago de Compostela", concediendo en cambio los grandes titulares a las noticias de guerra y a un artículo de Manuel Graña.

"24-8-44.- No dio información de la visita de Ministro Secretario General de Movimiento al Campamento de "Rentería".

"26-8-44.- Titula pobremente a dos columnas la visita que el Caudillo hizo en la Coruña a los campamentos de la Falange. 
"6-10-44.- Incumple la consigna que textualmente dice: “Los periódicos del viernes día 6 reproducirán el texto del discurso del Ministro de Asuntos Exteriores en la Universidad de Deusto, que publica la prensa de esta tarde.

"Además de no publicar el discurso del Ministro de Educación Nacional pronunciado en Valencia, el viaje del Ministro Secretario General del Movimiento y su estancia en Burgos y publica de manera poco adecuada, a una sola columna, las declaraciones sobre el donativo de la Falange a la Cruz Roja belga.

\section{"SANCIONES}

"17-5-44.- Con esta fecha se le sanciona con UN DIA DE HABER, como consecuencia de la falta de interés en el comentario de la labor realizada por el 1er Consejo Provincial de la Falange.

"8-6-44.- Se le sanciona con SIETE DIAS DE HABER por incumplimiento de las órdenes dadas a través 
de la D.P. de E.P. [Delegación Provincial de Educación Popular]

"14-6-44.- Con esta fecha se le anota en el expediente una NOTA DESFAVORABLE Y SEVERO APERCIBIMIENTO por no someter a la Censura la reseña y fotografías de los actos celebrados en Medina del Campo con motivo de la fiesta del 2 de mayo.

"4-9-44.- Con esta fecha se le abre expediente por las GRAVES FALTAS COMETIDAS. Y se da por terminado con fecha 18 de septiembre, con amable benevolencia." 1089

1089A.G.A., Sección Cultura, caja 66.627 . 
Apéndice 14.- Carta del director general de prensa, tomás Cerro Corrochano al director de Diario Regional Francisco Javier Martín ABRIL, DE 21 dE AgOSTO dE 1946.

«Mi querido amigo:

"He leído minuciosamente tu número del día 18 de julio $y$ los sueltos que "EL NORTE DE CASTILLA" y "LIBERTAD" han dedicado con este motivo a "DIARIO REGIONAL". He informado con todo detalle de lo ocurrido a mis superiores. El Subsecretario ha contestado en la forma que ha creído conveniente a un oficio muy áspero del Gobernador de Valladolid. $\mathrm{Y}$, por mi parte, he oficiado a nuestro Delegado en ésa para decirle que no debió autorizar los ataques que los demás periódicos os dirigieron y que la censura, que tiene en su mano prohibir cuantos textos crea no publicables, una vez publicados con su asentimiento tiene la obligación de defenderlos, puesto que la responsabilidad ha pasado a ser, por el hecho de la aprobación, no de quien los escribió sino de quien los autorizó. Le doy orden también de que te llame seriamente la atención por el número de 18 de julio en el que ciertamente hay omisiones, defectos técnicos y aun matices expresivos que, de ser intencionados, serían lamentables. 
"Quiero ahora exponerte con toda cordialidad, pero muy sinceramente, $\mathrm{mi}$ opinión en este asunto. Creo honradamente que no hay en vuestro número nada positivo que merezca sanción, pero sí que faltan cosas que yo quisiera haber visto y que no me atrevo a sospechar que se hayan omitido intencionadamente. No tengo por qué daros consejos no pedidos y créeme que no te hablaría hoy como lo hago si no fuera para advertirte con toda lealtad que sentiría en el alma tener que adoptar con "DIARIO REGIONAL" medidas graves, pero que estoy dispuesto a tomarlas si dais lugar a ello. Personalmente entiendo que quienes estamos en la misma línea en que hemos estado siempre, somos quienes pensamos que es un grave deber de conciencia para los católicos colaborar con la máxima lealtad y con el máximo espíritu de sacrificio con un régimen a quien muchos debemos la vida, a quien España no podrá agradecer bastante su liberación del caos rojo y la neutralidad en en que ha sabido conservarla durante la guerra mundial, cuyas instituciones están basadas en los más puros principios cristianos y dentro del cual podemos desarrollar una labor de apostolado que no hubiéramos podido soñar nunca. Si dentro de veinticinco años el panorama religioso y moral de nuestro país no ha cambiado radicalmente, no es al régimen político a quien debemos culpar, sino a nuestra profunda incapacidad.

"Y como, desde el punto de vista exclusivamente católico, hemos predicado siempre que había que acatar los 
poderes constituidos, que había que buscar en cada momento el bien posible, que había que prestar una asistencia leal, no sólo a regímenes que nos resultaban gratos, sino a los que lo eran menos o no lo eran en absoluto, que es políticamente, no ya torpe sino suicida, empeñarse en entrar en una vía muerta $y$ quedarse al margen de actividades a las que con nuestra colaboración podemos imprimir un sentido católico y, en fin, que la "politique du pire" es siempre catastrófica, yo te confieso sinceramente que no comprendo cómo muchos amigos nuestros a quienes les parecía obligado, muy de acuerdo con las normas de León XIII y Papas sucesivos, hasta Pío XII inclusive, colaborar, no ya con la Monarquía liberal o con Maura o con Primo de Rivera, sino con la República de Lerroux y aun con la de Azaña y Largo Caballero, sientan ahora unos escrúpulos tan profundos en colaborar con Franco.

"Te repito que no te digo todo esto con ánimo de molestar a nadie (no sé cuál es tu actitud personal en este punto y por ello no me refiero a ti concretamente) ni te hablaría en el tono que lo hago si no creyera un deber de amistad dejar muy claro que si "Diario Regional" adoptara actitudes reticentes, equívocas últ. hostiles, es decir, dejase de actuar con la más absoluta lealtad, yo me vería obligado a obrar en consecuencia. Y créeme que te lo digo profundamente contristado, porque hasta ahora han sido precisamente ciertos amigos, de quienes yo podía 
Apéndices

esperar cualquier cosa menos hostilidad, los que me han proporcionado algunos de los más graves disgustos que he tenido desde que estoy en este cargo.

"Saluda con todo afecto a todos los de esa Casa y tú recibe un abrazo muy cordial de tu ya viejo amigo y compañero,

"Tomás Cerro." 
Apéndices

Apéndice 15.- Carta de francisco Javier Martín Abril a tomás Cerro, de 1 DE SEPTIEMBRE DE 1946.

«Mi querido amigo y respetado jefe:

"Mucho he agradecido el tono cordialísimo de tu carta del 21 de agosto, que recibí hace muy pocos días. En realidad, querido Cerro, ¿cómo van a ser nuestras relaciones, sino así, empapadas de sinceridad y de compañerismo, ya viejo compañerismo en esta común tarea de salvar lo esencial por encima de toda contingencia? Somos hombres de Cristo, y ello exige mucho, porque en nosotros no puede caber la ficción, ni el egoísmo, ni nada que no esté respaldado por una decisión de conciencia.

"Acepto la reprimenda, porque para mí la autoridad es una cosa muy seria. Pero puedes estar absolutamente seguro de que al confeccionar el número del pasado 18 de julio, no hubo en nosotros ninguna torcida intención, ninguna reticencia. Tú mismo reconoces "que no hay en vuestro número nada positivo que merezca sanción." En estos días, nuestro consejero delegado, Mariano Escudero, estaba de retiro en la Trapa. Y siempre se respeta con la más exquisita pulcritud, por parte de los consejeros, la independencia y la responsabilidad de la dirección. Es decir, que cada uno de nosotros estamos en el puesto que 
nos corresponde. Si hemos hecho algunas campañas de carácter local o regional, ha sido al amparo de las normas oficiales de Prensa, y siempre con la nobleza y el desinterés que en ellas se pone de manifiesto. Escudero, en este sentido, ha colaborado con la Redacción. Pero nada más. Tú ya debes conocer el señorío espiritual de Mariano Escudero y si algún día hablas con él, te convencerás de que han existido interpretaciones erróneas por parte de algunas personas. Se ha visto lo que no podía verse, y se han construído hipótesis sobre plataformas de supuestos de aire.

"Yo sé muy bien a qué atenerme en mis determinaciones, y mi manera de pensar y de sentir con relación al régimen, está patente en multitud de artículos firmados, en libros y folletos. Ahora mismo, estoy bajo la influencia del discurso de nuestro Fernando Martín-Sánchez en la clausura de la Asamblea de secretarios de la A. C. N. de P. Pero, en fin, todo esto sería para tratado en una conversación, uno enfrente del otro, que tengo ganas de celebrar contigo. La charla terminaría, necesariamente, en un rotundo abrazo, a pesar de que en el curso de ella, quizá disintiéramos en algunos matices, nunca en lo fundamental.

" "Diario Regional" seguirá en su línea de conducta de siempre. Lee con detenimiento nuestros números, y te percatarás de que no puede haber en ellos motivo de 
censura, sino al contrario. Por eso creo que al anunciarnos posibles sanciones, obras un poco sugestionado -y lo comprendo- por un ambiente creado en torno a lo que no ha sido nada, no ha podido ser nada.

"He leído con mucha atención tu carta que, vuelvo a decirte, agradezco en el alma y estimo en lo que vale.

"Todos los de esta Casa te saludan. hazlo tú de mi parte, muy cariñosamente, a Ignacio Valverde. Y recibe un fuerte abrazo de tu buen amigo y subordinado,

"Firma: Francisco Javier

Martín Abril." 
Apéndice 16: informe del delegado provincial de Prensa al juez instructor de LA CAUSA de José Luis Cebrián Boné, de 31 de mayo de 1958

«Esta Delegación Provincial, en cumplimiento de lo interesado por V.S. en su oficio de 31 de mayo del año actual, tiene el gusto de informarle de lo siguiente:

"Del detenido estudio del archivo periodístico y de documentos de esta Delegación Provincial, y tomando como punto de partida los últimos meses del pasado año, se ha observado respecto de la estimación que el Sr. Cebrián Boné, Director de "Diario Regional" ha otorgado a diversas informaciones nacionales y locales las siguientes anormalidades e irregularidades.

"PRIMERO.- En el número de dicho periódico del día 29 de noviembre del pasado $y$ en su página 5ạ, publico un comentario sobre cuestiones referentes a aumentos y elevaciones de precios de artículos de consumo, a pesar de no ignorar que la publicación de tales comentarios y noticias estaba terminantemente prohibida por mi autoridad, decisión nacida de la indicación que en este 
sentido y por motivos de orden público me fue formulada por el Excmo. Sr. Gobernador Civil de la provincia, salvo la consulta previa y pertinente autorización de esta Delegación Provincial.

"SEGUNDO.- En el número correspondiente al día 15 de febrero, dicho periódico publicó en forma mutilada y fraccionaria la referencia del Consejo de Ministros celebrado el día anterior bajo la presidencia de S.E. el Jefe del Estado, sin que para ello obtuviera autorización de este Organismo, ni tan siquiera celebrase consulta alguna, y sin que para este fraccionamiento pudiera aducir causas motivadas en dificultades técnicas, que le hubieran aconsejado o impedido realizar, como es obligado, la inserción íntegra de la referencia.

"TERCERO.- En el número correspondiente al día 5 de marzo actual, en su -primera plana concede más relevancia tipográfica a una noticia sobre motorismo deportivo celebrado en Baleares, que a los importantes y solemnes actos de carácter nacional y gran trascendencia política que tuvieron lugar el día anterior en esta ciudad con motivo de la conmemoración del XXIV Aniversario de la fusión de F.E. y las J.O.N.S., siendo uno de ellos el 
discurso que pronunció el Excmo. Sr. Ministro Secretario General del Movimiento. Se limita a publicar, a pie de página, una fotografía con un pie $y$ tres titulares, llevando la información a las planas interiores, en las que por cierto, y como prueba del poco cuidado tenido, se han cambiado las lecturas de algunas de las fotografías que se insertan.

„CUARTO.- En el número del día 17 del mismo mes, no ofrece información alguna relativa a la recepción ofrecida en el Palacio de El Pardo por S.E. el Jefe del Estado a los Sres. Directores de Periódicos y Emisoras del Movimiento, noticia que con singular relieve, fue publicada por todos los Diarios Españoles, y naturalmente, los locales.

"QUINTO.- En el número del día 28 de marzo, y a pesar de las indicaciones prohibitivas a que ya se hace referencia en el párrafo primero de este informe, volvió a incluir en su información, sin consulta de esta Delegación noticias referentes a elevaciones de precios, que en aquellos momentos podían contribuir a crear un desagradable clima social, por no reconocerse los esfuerzos del Gobierno en el aspecto planteado. 
"SEXTO.- Con fecha 27 de febrero se ofició a los Directores de todos los Diarios locales en el sentido de la prohibición de publicarse más notas o anuncios en relación con los Mártires de la Tradición que aquellas que se refiriesen a los organizados por el Gobierno o por las Jefaturas Provinciales del Movimiento. Pese a ello en el número del día 8 de marzo, dos notas una enviada por algunos miembros de la Comunión Tradicionalista y seguidamente otra de la misa organizada por la Jefatura Provincial del Movimiento.

"SEPTIMO.- En el número correspondiente al día 19 de marzo, omitió publicar el discurso pronunciado el día anterior en Villagarcía de Arosa por el Excmo. Sr. Ministro Secretario General del Movimiento.

"OCtAvo.- En el número del día 10 de abril y en la sección titulada "Mirador Nacional", se publica un comentario firmado por el Redactor Jefe del Periódico, D. Enrique Santos, titulado “También el Estado debe cumplir sus obligaciones", en el que se vierten afirmaciones que atacan decididamente al mismo, las que son muestra a título de ejemplo, algunas como las de que: "el estado, 
centinela y garantía -se refiere a la Sociedad- incumple sus compromisos, sus obligaciones, sus deberes. Puede parecer anacrónico, incomprensible. Pero es cierto". “...el Estado en el año 1956 encargó con prisa, con suma diligencia, un trabajo que todavía no ha pagado"..."un problema... que se origina por falta de cumplimiento de sus deberes por parte del Estado, de la Administración que tan rigurosamente exige a los demás ciudadanos el exacto cumplimiento de sus deberes".

"Esta Delegación Provincial dio urgente cuenta de estos hechos que pueden ser considerados como de indudable gravedad, a la Dirección General de Prensa, recabando la previa consulta a esta Delegación de cuantos textos o informaciones pretendiera publicar en lo sucesivo el "Diario Regional", facultad que anteriormente tenía delegada el Sr. Cebrián. Esta propuesta fue aceptada por dicho Centro Directivo y dispuesta en oficio del mismo de 16 de abril.

"NOVENO.- En su número correspondiente al día 4 de mayo dejó de publicar la información referente a haberse celebrado la reunión de la Comisión Delegada de Asuntos 
económicos de Gobierno, habida el día anterior en Madrid y presidida por S.E. el Jefe del Estado.

"Todo lo que a los efectos consiguientes tengo el honor de informar a V.S.

ApÉndice 17 : oficio del director general de Prensa al ministro de Información y TuRismo solicitando la destitución de José Luis Cebrián Boné COMO DIRECTOR DE DIARIO REgIONAL, DE FECHA 30 DE SEPTIEMBRE DE 1958.

"Visto el expediente instruido por la Delegación Provincial de este Ministerio en Valladolid, al director del periódico de dicha capital "DIARIO REGIONAL".

"RESULTANDO.- Que con fecha 24 de mayo fue ordenado por el Ilmo. Sr. Delegado Provincial de este Ministerio en Valladolid la iniciación del oportuno expediente a D. José 
Cebrián Boné en su calidad de Director de "DIARIO REGIONAL", ante la forma en que fue presentado en dicho periódico y en su número correspondiente al día 18 de mayo el discurso pronunciado por S.E. el Jefe del Estado en la sesión de las Cortes Españolas del día precedente en la que asimismo fue promulgada la Ley Fundamental del Reino.

"RESULTANDO.- Que con fecha 31 de mayo le fue notificado al interesado el oportuno pliego de cargos con entrega de la copia, al que respondió formulando su pliego de descargos y alegando presuntas razones de orden puramente técnicas y profesional.

"RESULTANDO.- Que el Instructor solicitó del Ilmo. Sr. Delegado Provincial un informe sobre la conducta que como tal Director del periódico ha venido observando el expedientado y el tratamiento periodístico y político que haya podido otorgar con anterioridad al número que nos ocupa a informaciones y noticias referentes a cuestiones importantes del Régimen o referidas a las actividades oficiales de S.E. el Jefe del Estado $y$ a las altas jerarquías del mismo, informe que obra unido a estas actuaciones del que resulta que con inusitada frecuencia ha venido a veces el expedientado concediendo poco relieve 
y pobre valoración a algunas de ellas, incluso ignorando otras que por su importancia intrínseca, como por la personalidad a que se referían, merecieron en todo momento ser tratadas con el relieve y la forma destacada que su valor aconseja, y el conocimiento que tiene como director del periódico de la estimación que ha de otorgarse a las mismas, le obligan.

"RESULTANDO.- Que solicitado informe por esta Dirección General de su Sección de Prensa Nacional sobre las presuntas razones de orden técnico alegadas por el inculpado, la expresada sección informó respecto de las mismas rebatiendo adecuadamente las consideraciones que en tal orden se aducen.

"VISTOS el Decreto de 15 de febrero de 1952; la Ley de Prensa de 22 de abril de 1938; el Decreto de 4 de agosto de 1952 y la Orden de 22 de octubre del mismo año, y demás disposiciones legales, así como los términos que el juramento formulado libre y espontáneamente por el expedientado, como requisito obligado para el ejercicio de la profesión periodística. 
„CONSIDERANDO.- Que de un meditado estudio del número del periódico "DIARIO REGIONAL", correspondiente al día 18 de mayo se advierte una evidente subestimación de la importancia que para la nación española y el porvenir del Estado tenía, tanto en el trascendental discurso pronunciado por la más alta Magistratura de la Nación y en el más solemne y representativo de sus Organos, como por la promulgación de una de sus leyes sustantivas más fundamentales, considerando que desde todo punto de vista, y singularmente desde el periodístico, había de ser más que suficiente a la hora de valorar tal condición, valoración manifiestamente ignorada por el Sr. Cebrián Boné cuando se limita a dedicar a las noticias, una simple cabecera a pie de plana y en una extensión de un diez por ciento de la misma remitiendo el contenido de la información a las planas interiores, sin que frente a esta consideración valorativa de índole política y periodística, puedan prosperar las pretendidas razones exclusivamente de orden técnico y material que ofrece el expedientado en su descargo, ni aún las de la indudable actualidad que suponían las informaciones relativas a los sucesos franceses y argelinos, ya que sin ignorar éstas y aún otorgándolas todo el relieve que por su entidad periodística merecían, pudo perfectamente ya que ello no ha de ser nunca dificultad para un profesional del periodismo, armonizarlas con las referentes a la sesión de Cortes, con el discurso de S.E. el Jefe del Estado y 
promulgación de la Ley Fundamental del Reino, noticia de capital importancia para la nación española, ya que es precisamente al público español al que en primer lugar ha de servir el periódico.

"CONSIDERANDO.- Que los antecedentes que obran en la Delegación Provincial y que han sido aportados a estas actuaciones se advierte que con cierta frecuencia "DIARIO REGIONAL", ha ignorado $y$ en otras ocasiones subestimado, informaciones y noticias, sino de la capital importancia de la que nos ocupa, si indudablemente de trascendencia, informaciones que por lo tanto debían ser recogidas en el periódico, unas, y otras tratadas con el relieve que merecían.

"CONSIDERANDO.- Que según previene el Arto 1 ㅇ de la Ley de Prensa de 22 de abril de 1938, cauce legal por el que se desarrolla su actividad y cometido, la Prensa española ha sido considerada, dados los supuestos transcendentales a los que sirve, como una institución social, y es a estos fines de tipo político y social, a los que por su condición institucional ha de ofrecer su máxima dedicación y debido respeto, exigencia política y legal que en el caso concreto del periodista profesional 
Apéndices

se ve sancionada y elevada en el orden moral por el juramento que como tal periodista ha de prestar para el ejercicio de tal actividad, circunstancia más acusada todavía en el caso de un Director por la necesaria aceptación de su propuesta de nombramiento, por este Ministerio.

"CONSIDERANDO.- Que el Arto 10 en relación con el 2 은 de la Ley de Prensa proclaman que corresponde al Estado la organización, vigilancia y control de la institución nacional de la prensa periódica, mandato que se ve más adelante robustecido en el orden coercitivo por el Arto 19 que previene que serán sancionadas las faltas de desobediencia, resistencia pasiva $y$ en general las de desvío a las normas dictadas por el imperio encarnado actualmente por el Ministerio de Información y Turismo, a través de su Dirección General de Prensa y es evidente, como ya afirmábamos en el primer considerando, que el expedientado ha demostrado manifiesta resistencia pasiva y desvío de las normas y principios que regulan la actividad periodística, pues como tal Director conoce perfectamente aquellas normas $y$ de forma suficiente las orientaciones que con frecuencia recibe a través de la Delegación Provincial de Información y Turismo, sobre el tratamiento que ha de ofrecerse a la difusión de textos o informaciones que se refieran al Jefe del Estado o a las 
manifestaciones y acontecimientos más importantes y sobresalientes del Régimen, todo ello, por otra parte, sin perjuicio de que la preterición manifiesta de acto tan destacado y de relieve tan fundamental como la apertura por el Jefe del Estado de una nueva legislatura, a través de su discurso y la promulgación solemne de los principios fundamentales del Movimiento, puede estimarse incursa en una actitud - si se quiere indirectamente, pero también esta modalidad la prevee (sic) el precepto legaltendente a mermar el prestigio del Régimen (Artículo 18 de la Ley de 22 de Abril de 1938) •

"CONSIDERANDO: Que según el artículo 8ㅇ de la tan citada Ley de Prensa, de todo periódico es responsable el Director y que el artículo 19, en relación con el 20 previene que las faltas cometidas por aquél serán sancionadas en la medida que la infracción revista mayor o menor gravedad, sanciones que oscilan entre la multa; destitución del Director, adjetivada si procede ésta por la cancelación de su nombre en el Registro oficial de Periodistas, hasta la incautación del periódico, sanciones todas ellas que, salvo la primera habrán de ser acordadas por el Excmo. Sr. Ministro del Departamento. 
„CONSIDERANDO: Que las pretendidas razones de orden puramente técnico y profesional, aducidas por el Director incurso en este expediente no son tales, por cuanto no fueron obstáculo para que todo el resto de la Prensa nacional acogiera en sus páginas con el relieve y la preponderancia adecuada tanto de presentación como de titulación, información determinante del expediente a que se refieren estas actuaciones, lo que está denotando, en forma manifiesta que para el Director del DIARIO REGIONAL han prevalecido sobre poderosas y efectivas razones de interés nacional otras supuestas exigencias, de virtualidad alguna para enervar la responsabilidad en que se halla incurso.

"CONSIDERANDO: Que por el Sr. Cebrián Boné no ha sido tenido en cuenta que su nombramiento de Director del DIARIO REGIONAL de Valladolid, si bien tiene su origen en una propuesta de la Empresa propietaria del periódico, precisamente, a tenor de la vigente Ley de 22 de Abril de 1938, requiere su aceptación por parte de este Ministerio para ser efectiva, lo que no ya implícita, sino explícitamente supone la concurrencia en el propuesto de la confianza tanto de la persona física o jurídica proponente como de la autoridad aceptante y el proceder del Sr. Cebrián Boné, fundamentalmente en la confección del número del DIARIO REGIONAL, correspondiente al día 18 
de mayo último, y reiteradamente en números anteriores aunque no de forma tan ostensible como éste, no ha respondido en materia grave a la confianza en el mismo depositada por este Ministerio al aceptar su propuesta de nombramiento, haciéndose, en consecuencia, no merecedor de la misma.

"CONSIDERANDO: Que dada la grave entidad de la infracción cometida por la estimación que el expedientado otorgó a la información referente al discurso de S.E. el Jefe del Estado y promulgación de Ley Fundamental del Reino en el número correspondiente al día 18 de mayo y habida cuenta de los antecedentes de la conducta que se ha venido observando en su actividad directora por el Sr. Don José Luis Cebrián Boné, el Instructor entiende que la sanción no puede ser simplemente corregida por una multa, por importante que ella fuere, sino que ha de transcender en la escala jerárquica punitiva, enmarcándola en el apartado b) de los cuatro que según su gravedad señala el citado artículo 20 de la Ley de Prensa, que prevee (sic ) la destitución del Director responsable de los actos que dan origen a este expediente, por lo que procede elevar las actuaciones practicadas con la presente propuesta de resolución a la consideración superior, del Excmo. Sr. Ministro 
"Esta Dirección General de Prensa, de conformidad con la propuesta de la Delegación Provincial de este Ministerio en Valladolid, es de parecer que procede imponer como sanción a Don José Luis Cebrián Boné, en su calidad de director del "DIARIO REGIONAL" la destitución de su cargo por su manifiesta incapacidad para el ejercicio del mismo.

"V.E. no obstante con su superior criterio resolverá. "Dios guarde a V.E. muchos años. "Madrid, 30 de septiembre de 1958 
ApÉNDice 18: ARTículo PUBLICAdo el 6 DE NOVIEMBRe DE 1964 QUE dio lugar al procesamiento y Consejo de Guerra a Manuel fernández Areal.

«UN PROYECTO REALISTA.

"A uno le parece muy bien ese proyecto francés para reducir, de momento más que de abolir parece que se trata de sustraer sectores determinados de población, el servicio militar obligatorio. Porque uno cree que si la nación no necesita el trabajo militar de los jóvenes del país, es superfluo -además de otras cosas- llamar a los jóvenes a filas y mantenerlos en los cuarteles por mantener una ficción, la de la necesidad de un ejército "en pie de guerra", cuando todo el mundo sabe que en los cuarteles no están permanentemente esos jóvenes realizando tareas militares, sino otras a veces ajenas al servicio de las armas.

"A uno le parece muy bien que los franceses se hayan planteado seriamente la posibilidad de eliminar el servicio militar obligatorio y hasta hayan elaborado un proyecto bien estudiado que puede convertirse en ley 
rápidamente. ¿Para qué mantener cuarteles, periodos largos de vagabundeo por los pasillos de esos cuarteles, horas interminables de una guardia que no sirve para nada (porque no hay nada importante que guardar) y repeticiones de unos movimientos de armas que se saben hasta la saciedad: tiempo uno, tiempo dos, descanso, firmes, derecha, izquierda?

"Sin duda el proyecto va a caer muy bien y sería de desear que tuviese eco en otros países. España, por ejemplo.

"Uno, que es oficial de complemento del Arma de Infantería y ama las virtudes propias de la familia militar, está firmemente convencido, sin embargo, de que en los cuarteles, actualmente, se pierde muchísimo tiempo. Si esta afirmación no fuera exacta, no tendrían explicación esas "enseñanzas para soldado", esas posibilidades de suplir la larga espera sin hacer nada útil por unos estudios y una formación profesional que rendirán mucho al país y que suponen un gran acierto del mando militar superior, inteligentemente consciente de la realidad.

"¿Qué pasaría si España se desprendiese de unos cuantos cuarteles, de esos lóbregos, enormes, destartalados a veces, difíciles de limpiar y de mantener "en perfecto estado de revista", costosos, muchas veces 
vacíos, y acortase -de momento, acortar, pero mucho- el tiempo de servicio militar, de forma que en tres meses un joven español, con un régimen intensivo de campamento, aprendiese el manejo de las armas, las normas de saludo, su poquillo de instrucción en orden cerrado y cuatro cosas más indispensables? Pues que se aprovecharía mucho mejor el tiempo $y$ se gastaría mucho menos dinero en una formación militar que no justifica el permanecimiento en filas actual.

"Hay ya precedentes en el servicio militar de los mineros y la misma IPS O Milicia Universitaria es un ejemplo de cómo facilitar el trabajo civil -aquel que se desempeñará durante más tiempo y con el que se va a servir más directamente al país- de cuantos, en los momentos más decisivos de su vida, se ven obligados a abrir un paréntesis demasiado largo para los tiempos que corren.

"M.F.A." 
ApÉndice 19: ARTículo QUE COMO RÉplica AL ANTERIOR SE PUBLICó EN EL PERIÓdICO EL 8 DE NOVIEMBRE DE 1964, FIRMADO CON TRES ASTERISCOS.

«UNA RESPUESTA

"Con todo gusto publicamos la siguiente aclaración que se nos hace al artículo aparecido en este periódico el pasado día 6, titulado "Un proyecto realista", y firmado M.F.A.

"Es sorprendente la tesis, "pues de algún modo hay que llamarla", que sustenta el autor de "Un proyecto realista", que firma con las siglas M.F.A. No ha comprendido o no ha digerido lo que el ministro francés de los Ejércitos de Tierra, Mar y Aire ha expuesto a los periodistas recientemente, al defender el presupuesto militar de 1965. Francia tiene ahora el servicio obligatorio universal, debido a la creación de una “Force de Frappe" que tendrá armamento nuclear, que le permitirá reducir sus efectivos en hombres $y$, entonces, lo universal del servicio obligatorio lo cubrirá seleccionando a sus soldados; es decir, que introducirá en su legislación lo que ya se ha hecho en España hace años, en que se tienen dispensas en la extensión del servicio de cierto personal técnico que forma la I.P.S. el minero y el de servicios auxiliares. Pero la extensión del servicio no bajará de 
los dieciocho meses en Francia. Igual se puede decir de otros países europeos. Sin embargo, en España, por una excepción entre todas las naciones, el servicio activo del reemplazo sólo dura dieciséis meses.

"Francia ha hecho enormes dispendios para tener el ejército actual. Su presupuesto para la Defensa alcanza, traducido a pesetas, la cantidad de doscientos cuarenta y cuatro mil ochocientos millones de pesetas; el de España es de veinte mil millones. Los gastos para la Defensa, por habitante, en Francia, son de cinco mil noventa y una pesetas, y en España, de seiscientas ochenta y ocho.

"Pero dejemos esto, puesto que el lector sabe bien lo que representan estas cifras y el consiguiente sacrificio del país.

"El autor del "recuadro periodístico" que se cita hace después consideraciones sobre el soldado español, sus misiones $y$ funciones, $y$ pretende tener conocimiento de ello diciendo que es oficial de complemento del Arma de Infantería. Cuesta creerlo. Si sus ideas fueran tan buenas que merecieran ponerlas en práctica, creemos que algún país consciente en el mundo ya la hubiera realizado, pero ninguno lo ha hecho $\mathrm{ni}$ se ve que lo haga en un futuro próximo. 
"La función del Ejército es preparar al pueblo español para hacer frente a cualquier contingencia que se pueda presentar; es formar verdaderos ciudadanos, instruir, educar $y$ mantener unas Unidades con Moral $y$ Disciplina que sean garantía de que nuestro país tiene el respeto que los españoles tenemos derecho a exigir.

"El Ejército trabaja y el Ejército rinde; se hacen anualmente millares de especialistas, se redime a los analfabetos, hay una extensión cultural que da extraordinarios beneficios y se forma al combatiente día a día; también se hace el orden cerrado que vivifica la disciplina, que nada tiene que ver con la estrechez de miras con que se enfoca este aspecto el firmante M.F.A.

"La formación profesional ahora emprendida por el Ejército no tiene más objeto que facilitar a los soldados que se van a licenciar puestos de trabajo que sean de gran rendimiento para el país, al propio tiempo que se beneficia al individuo. Pero esta formación profesional es para los soldados que piden voluntariamente hacerla, renunciando a sus horas de paseo, con una autorización para retrasar su lista de retreta; se les ayuda a convertirse en especialistas o técnicos.

"Lo que no ha captado el autor de "Un proyecto realista", si realmente es un oficial de complemento, es la profunda labor humana que el Ejército realiza y cómo 
aun con medios más bien precarios, puede formar unos soldados que en todo son estos centinelas que, según M.F.A. no tienen nada que guardar, pero que sí guardan nada menos que la tranquilidad y la Paz de España.

"Y para no hacer más larga esta réplica, se pide al señor M.F.A. que lea, pero pidiéndole que sepa leer, el volumen "Ejército", que pronto aparecerá de la publicación "El Gobierno informa" que ha editado el Ministerio de Información y Turismo con motivo de los 25 Años de Paz. Y allí verá la gran misión del Ejército español con todo detalle.

$\|* * *\|$ 